Neoestructuralismo y corrientes

heterodoxas en

América Latina

y el Caribe a inicios

del siglo XXI

ALICIA BÁRCENA ANTONIO PRADO Editores 


\section{Neoestructuralismo y corrientes heterodoxas en América Latina y el Caribe a inicios del siglo XXI}

Alicia Bárcena

Antonio Prado

\section{Editores}

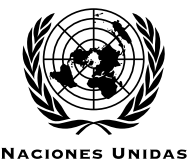

\section{E P 月 L}

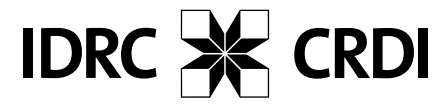

Comisión Económica para América Latina y el Caribe (CEPAL) Santiago de Chile, abril de 2015 


\section{Libros de la CEPAL}

\section{2}

\section{Alicia Bárcena}

Secretaria Ejecutiva

\section{Antonio Prado}

Secretario Ejecutivo Adjunto

\section{Ricardo Pérez}

Director de la División de Publicaciones y Servicios Web

El presente libro fue coordinado por Alicia Bárcena, Secretaria Ejecutiva de la Comisión Económica para América Latina y el Caribe (CEPAL), y Antonio Prado, Secretario Ejecutivo Adjunto. Colaboraron en su preparación Esteban Pérez-Caldentey, Oficial de Asuntos Económicos de la División de Desarrollo Económico; Miguel Torres, Editor Técnico de la Revista CEPAL, y Romain Zivy, Coordinador Adjunto de la Oficina de la Secretaria Ejecutiva.

El documento fue elaborado en el marco del proyecto "Raúl Prebisch y los desafíos del siglo XXI", llevado a cabo por la CEPAL y el Centro Internacional de Investigaciones para el Desarrollo (CIID) (International Development Research Centre (IDRC)) del Canadá durante el período 2011-2013. Los autores agradecen a Federico Burone, Director para América Latina y el Caribe del CIID; Luis Bértola, Profesor de la Universidad de la República del Uruguay y coordinador técnico del proyecto, y Vicente Neira, asistente de investigación del proyecto, así como a todos los participantes en el Simposio sobre Neoestructuralismo y Economía Heterodoxa, que se celebró en la sede de la CEPAL en Santiago, los días 22 y 23 de abril de 2013.

Las opiniones expresadas en este documento son de exclusiva responsabilidad de los autores y pueden no coincidir con las de la Organización.

Publicación de las Naciones Unidas

ISBN: 978-92-1-121879-4 (versión impresa y pdf)

ISBN: 978-92-1-057093-0 (versión ePub)

$\mathrm{N}^{\circ}$ de venta: S.14.II.G.23

LC/G.2633-P/Rev.1

Copyright (C) Naciones Unidas, 2015

Todos los derechos reservados

Impreso en Naciones Unidas, Santiago de Chile

S.15-00293

Esta publicación debe citarse como: Neoestructuralismo y corrientes heterodoxas en América Latina y el Caribe a inicios del siglo XXI, Libros de la CEPAL, N 132 (LC/G.2633-P/Rev.1), Santiago de Chile, Comisión Económica para América Latina y el Caribe (CEPAL), 2015.

La autorización para reproducir total o parcialmente esta obra debe solicitarse al Secretario de la Junta de Publicaciones, Sede de las Naciones Unidas, Nueva York, N.Y. 10017, Estados Unidos. Los Estados miembros y sus instituciones gubernamentales pueden reproducir esta obra sin autorización previa. Solo se les solicita que mencionen la fuente e informen a las Naciones Unidas de tal reproducción. 


\section{Índice}

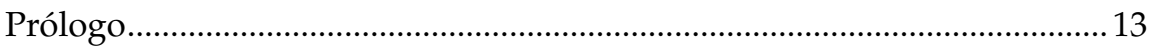

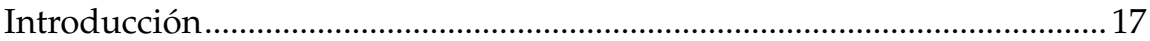

Parte I

Corrientes de pensamiento y contexto regional a inicios del siglo XXI............31

Capítulo I

Una coyuntura propicia para reflexionar sobre los espacios

para el debate y el diálogo entre el (neo)estructuralismo

y las corrientes heterodoxas

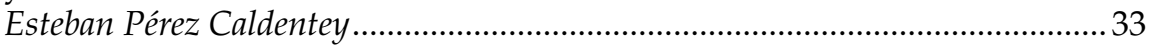

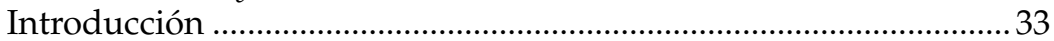

A. La Gran Moderación y los economistas ..........................................35

B. El paradigma económico dominante: sus bases teóricas e implicaciones de política económica .............................................38

C. Las críticas al paradigma económico dominante

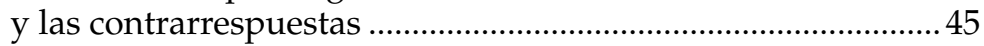

D. La visión de la economía desde el estructuralismo y la heterodoxia

E. El enfoque metodológico del neoestructuralismo

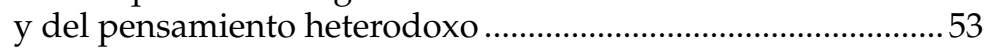

F. El contexto externo: centro-periferia y dinámica.........................57

G. El contexto externo: centro-periferia y restricción externa .............60

H. Cambio estructural, progreso tecnológico e innovación ............67

I. La distribución del ingreso .......................................................... 70 
J. La volatilidad y la inestabilidad..................................................... 71

K. El papel central de la demanda .....................................................73

L. El papel del mercado y del Estado ............................................... 75

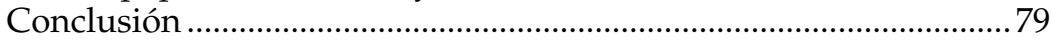

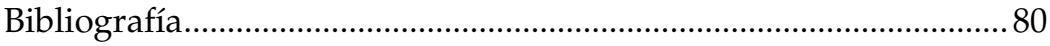

Capítulo II

América Latina frente a la turbulencia económica mundial

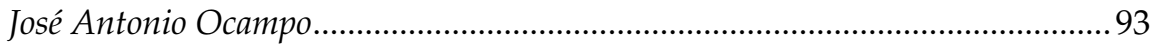

A. Los cambios dramáticos en el entorno internacional..................94

B. Los cambios en el comercio internacional y el rezago tecnológico de la región.....................................................................97

C. El financiamiento externo y los balances

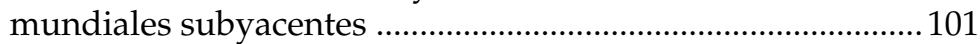

D. ¿Es hora de una nueva estrategia? ............................................106

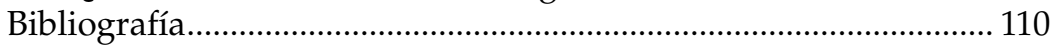

Capítulo III

La reciente internacionalización del régimen del capital

Luiz Gonzaga Belluzzo

Parte II

Macroeconomía para el desarrollo

\section{Capítulo IV}

Neoestructuralismo y macroeconomía para el desarrollo

Ricardo Ffrench-Davis

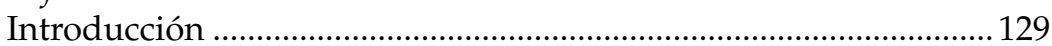

A. El enfoque dominante desde 1990 y sus efectos ........................ 131

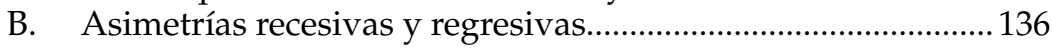

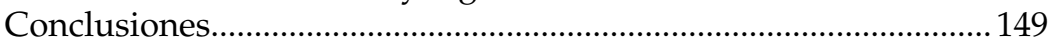

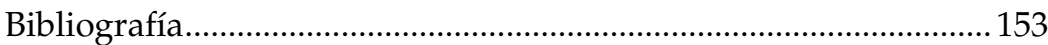

Capítulo V

Macroeconomía para el desarrollo en América Latina y el Caribe:

nuevas consideraciones sobre las políticas anticíclicas

Daniel Titelman, Esteban Pérez Caldentey ....................................................... 155

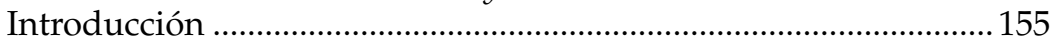

A. El desempeño a largo plazo de América Latina: alta volatilidad y bajo crecimiento................................................158

B. La dominancia de la balanza de pagos ....................................... 162

C. La volatilidad también refleja las características específicas del ciclo económico de América Latina y el Caribe.

D. La relación entre el ciclo y el crecimiento a largo plazo: el canal real (productividad e inversión)

E. La relación entre el ciclo y el crecimiento a largo plazo: el canal financiero. 
F. Redondear la perspectiva del modelo macroeconómico para el desarrollo en cuanto a las políticas anticíclicas

Conclusiones.

Bibliografía.

\section{Capítulo VI}

Hacia una interpretación robinsoniana de la acumulación del capital en América Latina

Juan Alberto Fuentes Knight.

Introducción

A. La teoría del crecimiento de Joan Robinson

B. La acumulación del capital y las edades de crecimiento en América Latina de 1980 a 2012.

Conclusiones.

Bibliografía

Anexo.

Parte III

Cambio estructural y desarrollo productivo

Capítulo VII

Productividad y cambio estructural: el estructuralismo y su diálogo con otras corrientes heterodoxas

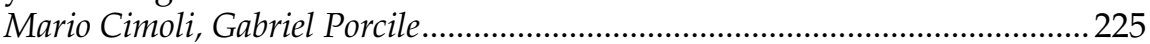

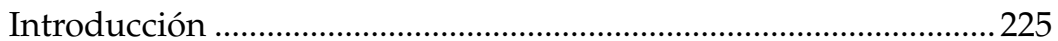

A. Crecimiento económico, especialización y tecnología ..............226

B. Fundamentos microeconómicos del aprendizaje y la convergencia

C. Un ejemplo: la política industrial..............................................2235

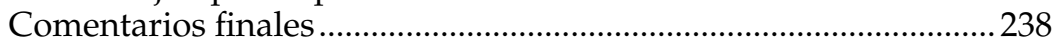

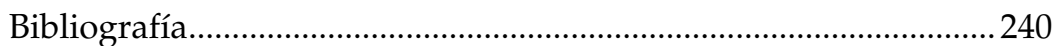

Capítulo VIII

La macro- y la microeconomía del crecimiento basado en los recursos naturales

Introducción

A. Algunas reflexiones sobre las nuevas políticas macroeconómicas

B. Otra asignatura pendiente: la sostenibilidad de los recursos naturales a largo plazo

Reflexiones finales

Bibliografía.

Capítulo IX

Patrones de desarrollo y Estados de bienestar en América Latina

Luis Bértola. 
Introducción

A. Crecimiento económico y recursos naturales: una perspectiva a largo plazo.

B. Crecimiento desigual e interdependiente del centro y la periferia. 264

C. Desarrollo y Estados de bienestar..............................................268

D. Desarrollo y Estado de bienestar en América Latina................2276

Conclusión

Bibliografía. 294

Parte IV

El papel del Estado

Capítulo X

Crecimiento, empleo y equidad: el nuevo papel del Estado

Robert Boyer

Introducción

A. La reducción de las desigualdades en las economías desarrolladas dentro de un régimen de crecimiento alto y estable.

B. El final de la "edad de oro": el éxito de los regímenes dominados por el mercado y sus crisis

C. El surgimiento de un nuevo paradigma sobre el Estado y la política económica

D. El Estado de bienestar y el crecimiento.

E. Las consecuencias de la globalización......

Conclusiones.

Bibliografía.

\section{Capítulo XI}

Transformación del Estado y paradigmas de desarrollo en América Latina

René A. Hernández.

Introducción

A. Sobre los conceptos de Estado y desarrollo: algunas aproximaciones

B. Un acercamiento a los paradigmas de desarrollo latinoamericano

C. Una aproximación al aporte de Prebisch al debate actual ......354

Conclusiones.

Bibliografía

\section{Capítulo XII}

Sobre el Estado, la heterodoxia y el aporte del feminismo

Sonia Montaño $V$.

A. Los aportes del feminismo 
B. El papel del Estado, la democracia y la economía......................370

C. Economía e igualdad ........................................................................373

D. La heterodoxia en la economía y el papel del Estado...............376

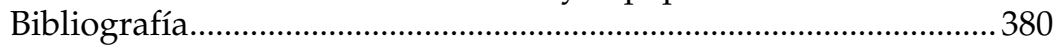

Parte V

Estudios de caso de las grandes economías de la región .383

Capítulo XIII

Desarrollo y macroeconomía: reflexiones a partir del caso mexicano

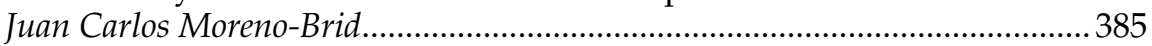

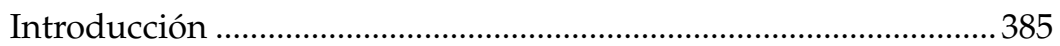

A. Avances, cuestiones pendientes y retrocesos de política macroeconómica en México en los tres últimos decenios ............387

B. Algunas lecciones de la crisis financiera internacional en la aplicación de una política macroeconómica

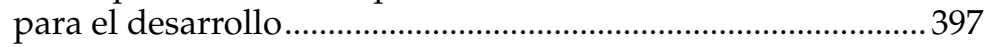

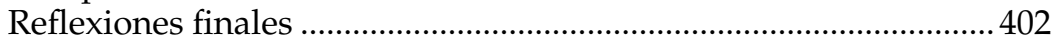

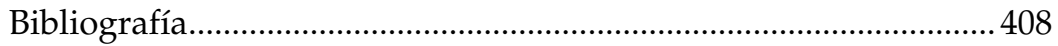

Capítulo XIV

¿Quo vadis, desarrollo brasileño?

Francisco Eduardo Pires de Souza, João Carlos Ferraz …………….................... 411

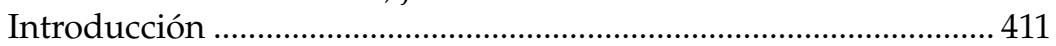

A. Antecedentes: del Plan Real a la bonanza externa ....................413

B. El modelo de crecimiento inclusivo: virtudes y limitaciones..... 415

C. (Primeras señales de) un modelo en gestación ............................421

D. Bases y desafíos de un modelo de desarrollo inclusivo

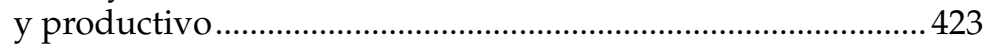

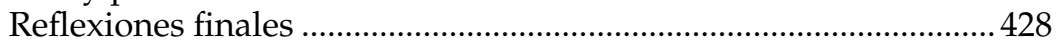

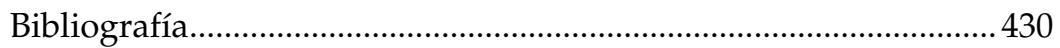

Capítulo XV

Trayectorias de cambio estructural y enfoques de política industrial: una propuesta a partir del caso argentino

Fernando Porta

Introducción

A. Características del desempeño industrial reciente .....................433

B. Limitaciones de la especialización productiva ...........................440

C. Enfoques de política industrial: hacia

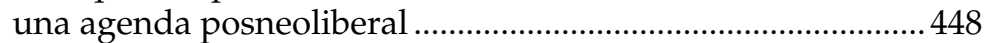

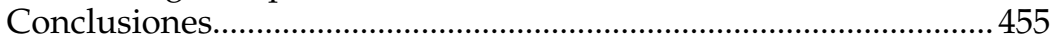

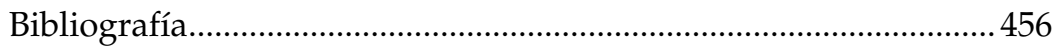

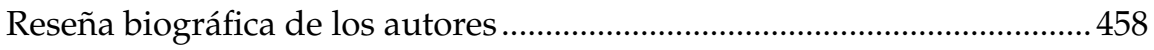

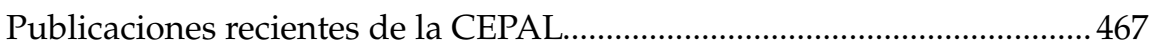




\section{Cuadros}

II.1 Mundo: crecimiento promedio anual de los índices de precios internacionales de los productos básicos, 2000-2013.

II.2 Mundo (países y regiones seleccionados): evolución del saldo de la cuenta corriente de la balanza de pagos como proporción del PIB, 2005-2012.

II.3 Mundo: crecimiento del PIB per cápita, por regiones, 1971-2011

II.4 Mundo: especialización, estructura productiva y crecimiento, 1996-2007

IV.1 América Latina: PIB per cápita respecto del de los

Estados Unidos y del Grupo de los Siete (G7), 1970-2012

V.1 Regiones y agrupaciones seleccionadas: coeficiente de variación de la tasa de crecimiento del PIB per cápita, 1960-2011.

V.2 Regiones y agrupaciones seleccionadas: crecimiento del PIB per cápita, 1971-2011.

V.3 América Latina y el Caribe y subregiones (incluido México): coeficiente de sincronía del ciclo económico con respecto a los Estados Unidos, la zona del euro y China, 1990-2012

V.4 Regiones seleccionadas: duración mediana y amplitud de las fases de expansión y contracción del ciclo económico, 1990-2012.

V.5 América Latina y el Caribe: duración media y amplitud de las fases de expansión y contracción del ciclo económico, 1990-2012.

V.6 Regiones y agrupaciones seleccionadas: duración y amplitud de la fase expansiva del ciclo de productividad laboral, mediante la metodología del ciclo clásico, 1990-2012.

V.7 América Latina (países seleccionados): duración y amplitud de las expansiones y contracciones del ciclo de inversión pública en infraestructura, 1980-2010

V.8 América Latina (países seleccionados): duración y amplitud de las fases de expansión y contracción del ciclo crediticio real en relación con el PIB real, 1990-2012.

VI.1 Rasgos básicos de las edades de crecimiento según Joan Robinson

VI.2 Episodios de alta inflación y cambios en la relación entre los salarios y el PIB

VI.3 Argentina, Brasil, Chile y México: evolución de la inversión, el empleo y la productividad laboral, 1993-2010

VIII.1 Chile: impacto de la tragedia de los comunes en la salmonicultura, 2003-2007.

IX.1 Estructura de la riqueza por regiones, 2005. 
IX.2 Heterogeneidad de la productividad estructural por grupos de países, índice de Gini.

IX.3 Heterogeneidad de la productividad del trabajo en países de América Latina, por grandes sectores, 1991-2006

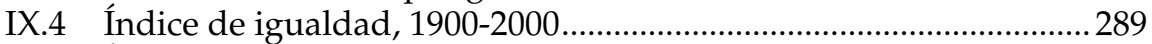

IX.5 Índice Histórico de Desarrollo Humano simple (IHDH) y ajustado por desigualdad (IHDHA), como porcentaje del de los países centrales, 1920-1990

X.1 Estilos de política económica, 1945-2014 _...........................................310

X.2 Factores que aumentaron la probabilidad de una crisis

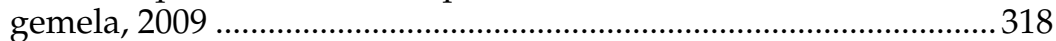

XIV.1 América Latina: términos de intercambio, años seleccionados...........414

XIV.2 Brasil: crecimiento del PIB por el lado de la oferta, 2005-2012 ............. 418

XV.1 Matriz tentativa de objetivos y estrategias de política ...................... 453

\section{Gráficos}

II.1 Crecimiento del comercio y del PIB mundial, 1950-2012 ..................98

II.2 Mundo: evolución de las exportaciones por volumen y por valor, enero de 2006 a julio de 2013

II.3 América Latina: márgenes de riesgo y rendimiento de los bonos, 2003-2013

II.4 América Latina (17 países): apreciación o depreciación real de las monedas, 1990-2011 a 2012 y 2003-2007 a 2012.............. 102

II.5 América Latina (17 países): apreciación o depreciación real de las monedas, 2012-2013

II.6 América Latina: balance en cuenta corriente con respecto al producto interno bruto, 1990-2012

IV.1 América Latina (19 países): volatilidad del PIB, 1977-2012 ............ 134

IV.2 América Latina: relación de los precios de intercambio de los bienes y servicios, 1990-2012.

IV.3 América Latina: evolución del volumen de las exportaciones y las importaciones de bienes FOB, 2003-2012

IV.4 América Latina (19 países): formación bruta de capital, 1970-2012.

V.1 América Latina (20 países): relación entre la volatilidad de la inversión y la tasa de crecimiento del PIB, 1971-2008.

V.2 América Latina y el Caribe: evolución de los coeficientes de correlación móviles entre los ciclos del PIB y las corrientes financieras, y entre los ciclos del PIB y los términos de intercambio con una ventana de cinco años, 1993-2011

V.3 Asia Oriental y el Pacífico y países de ingresos altos: ganancia acumulada media del producto en comparación con el de América Latina y el Caribe, 1990-2012 
V.4 América Latina y el Caribe y Asia Oriental y el Pacífico: tendencia del PIB, 1960-2010

V.5 América Latina: países en los que el ciclo crediticio es un factor endógeno del ciclo del PIB, primer trimestre de 1995 a cuarto trimestre de 2011

VI.1 América Latina: relación entre el crecimiento del PIB per cápita y el crecimiento de la inversión en distintos períodos

VI.2 América Latina: inversión y ahorro interno y externo, 1980-2012

VI.3 América Latina: relación entre el crecimiento del producto por trabajador y del empleo en distintos períodos

VI.4 Argentina, Brasil, Chile y México: evolución del tipo de cambio real efectivo (recíproco) y de la relación entre los salarios y el valor agregado en los sectores transables, 1993-2007

VII.1 Especialización, salarios y crecimiento en el sistema centro-periferia

VII.2 Impacto de la política industrial y tecnológica ……………………....236

VII.3 Países seleccionados: intensidad tecnológica de la estructura productiva, 1990-2008

VII.4 Países seleccionados: productividad relativa, 1990-2008 ………......238

VIII.1 Precio de los productos básicos industriales 244

VIII.2 América Latina: crecimiento anual del PIB y de la demanda agregada, 1990-2004

VIII.3 La apreciación cambiaria antes de la crisis de 2008-2009..................248

VIII.4 América Latina: formación bruta de capital, 1971-2011 …................ 249

VIII.5 Producción salmonícola, 1990-2002 ......................................................253

IX.1 Riqueza total y tipos de riqueza per cápita en siete regiones, 2005

IX.2 América Latina y "Occidente": PIB per cápita en paridades del poder adquisitivo de $1990(x)$ y promedio de años de educación en la población de 15 y más $(y), 1870-1930$

IX.3 América Latina y el Caribe (países seleccionados): rentas capturadas por el Estado como impuestos a la explotación de los recursos naturales, 1970-2010

IX.4 Uruguay: renta de la tierra en relación con el PIB agropecuario y total, 1908-1966

IX.5 Uruguay: precio real de la tierra deflactado por el IPC y estimación de la renta, 1902-2010

XII.1 América Latina (18 países): tasa de actividad económica por sexo, total nacional, rondas de encuestas

XII.2 América Latina (promedio simple 17 países): desigualdad en la distribución de ingresos por quintiles de ingreso, según sexo, zonas urbanas, alrededor de 2012

XII.3 América Latina (7 países): tiempo total destinado al trabajo remunerado y no remunerado por sexo, según país, último dato disponible 
XII.4 América Latina (18 países): índice de feminidad de la pobreza por país y región, alrededor de 2002 y 2012 ............... 378

XII.5 América Latina (promedio simple 18 paísesa): ingreso medio laboral de las mujeres comparado con el de los hombres, según número de años de instrucción, total nacional, alrededor de 2012

XIII.1 México y países seleccionados: PIB real per cápita como proporción del PIB per cápita de los Estados Unidos, 1980-2012.

XIII.2 México: crecimiento económico y balanza comercial como proporción del PIB en períodos seleccionados, 1960-2012

XIV.1 Brasil y América Latina: índice de los términos de intercambio, 2002-2012

XV.1 Argentina: evolución de la producción, el empleo y la productividad media de la industria manufacturera, 1992-2011

XV.2 Argentina: exportaciones por rubro, 1991-2011 .................................. 436

XV.3 Argentina: importaciones totales y su composición según su uso económico, 1991-2011

XV.4 Argentina y Estados Unidos: producto industrial de sectores seleccionados, por trabajador, 1993-2007

XV.5 Argentina: crecimiento de la productividad y comparación con los Estados Unidos, 2000-2010.

XV.6 Argentina: indicadores de innovación y aprendizaje y encadenamientos de las ramas manufactureras, 2005-2007

XV.7 Argentina y Brasil: diferencias entre los indicadores de innovación y aprendizaje y las complementariedades de las ramas manufactureras respecto de Alemania, 2005

XV.8 Argentina: sectores con ventajas comparativas según los indicadores de innovación y aprendizaje, y de encadenamientos, 2005-2007

XV.9 Argentina: sectores con ventajas comparativas potenciales según los indicadores de innovación y aprendizaje y encadenamientos, 2005-2007

\section{Diagramas}

X.1 Transformaciones institucionales en el origen del régimen de crecimiento y la reducción de la desigualdad después de la Segunda Guerra Mundial.

X.2 Tipos de capitalismo y relación entre eficiencia e igualdad, hasta la década de 1970 .

X.3 El cambio de paradigma de la década de 1980:

la desigualdad social como incentivo para el crecimiento 306

X.4 Surgimiento del capitalismo de mercado en un escenario de inestabilidad financiera, 1960-1990 
X.5 Régimen de acumulación con dominación de las finanzas.............309

X.6 Mejora de la eficiencia dinámica mediante algunos sistemas de bienestar............................................................................................ 316

X.7 Complementariedad de los regímenes nacionales de desigualdad y los modelos de desarrollo .......................................319

XV.1 Trayectorias de cambio estructural y acciones de política................ 451

XV.2 Objetivos y estrategias de cambio estructural .................................... 452

\section{Recuadros}

IV.1 Asimetrías recesivas y regresivas ...................................................... 137

IV.2 Coyuntura actual de América Latina................................................. 148 


\section{Prólogo}

Las dos crisis de inicios del presente siglo - la crisis económica y financiera internacional (2008-2009) y la crisis de la zona del euro (2009-2013) - han sido las de mayor envergadura desde la Gran Depresión de los años treinta por su intensidad, impactos económicos y sociales, y duración. Asimismo, estas crisis y sus efectos no solo han puesto nuevamente de manifiesto la incapacidad de la gran mayoría de las instituciones públicas y privadas o de actores del mundo académico para anticiparlas, identificar desequilibrios insostenibles y prevenir los riesgos inherentes al sector financiero, sino también las significativas limitaciones asociadas a la predominancia de una corriente de pensamiento sobre economía y desarrollo y sus políticas de manejo macroeconómico y financiero.

En este contexto, el pensamiento económico convencional que ha dominado de forma casi unilateral en la investigación y enseñanza académica durante los últimos años, así como en la política económica internacional desde hace más de tres décadas, ha sido objeto de fuertes críticas. Se ha constituido en tema de intenso debate por parte de los economistas, académicos y hacedores de políticas, dentro y fuera del paradigma dominante, quienes han venido discutiendo su validez $\mathrm{y}$ coherencia conceptual y empírica.

A finales de los años ochenta e inicios de los noventa se comenzó a desarrollar en la CEPAL una nueva corriente de pensamiento llamada neoestructuralismo. El fracaso de las políticas denominadas paradójicamente de ajuste estructural y las experiencias de desarrollo en el sudeste asiático crearon un entorno favorable para el surgimiento de paradigmas alternativos. En efecto, durante la década de 1980, en el mismo 
momento en que los países latinoamericanos adoptaban programas de ajuste estructural y sufrían un fuerte estancamiento y una de las mayores crisis de la deuda de su historia — período que se denominó la "década perdida"-, las economías asiáticas alcanzaban tasas de crecimiento sin precedentes y lograban mejorar su inserción internacional gracias al menor costo de las exportaciones de productos con mayor contenido tecnológico. Esta experiencia asiática fue muy importante y reveladora, ya que puso en tela de juicio las recomendaciones surgidas bajos los preceptos del Consenso de Washington y su corolario, los programas de ajuste estructural.

La corriente neoestructuralista se presentaba no solo como paradigma alternativo al ajuste neoliberal, sino también como una superación del paradigma estructuralista original en el que se inspiraba. Se trataba de adaptarlo a los nuevos tiempos de apertura y globalización. Para los neoestructuralistas ${ }^{1}$, y los estructuralistas, los principales problemas económicos de América Latina y el Caribe no se deben en lo fundamental a distorsiones inducidas por la política económica o a imperfecciones del mercado, sino que son más bien de carácter solo endógeno y estructural y de origen histórico.

Así, el neoestructuralismo ha impulsado miradas alternativas basadas fundamentalmente en cambios estructurales de la economía necesarios para viabilizar el desarrollo y el crecimiento económico inclusivo, mejorar la inserción comercial externa de los países latinoamericanos, incrementar la generación del empleo productivo, reducir la heterogeneidad estructural y mejorar la distribución del ingreso con la existencia de equilibrios financieros que sustenten estos cambios en la esfera productiva y con un apoyo social y estatal.

En el centro de la nueva estrategia propuesta por los neoestructuralistas se encuentra la acción del Estado en el marco de una renovada ecuación con el mercado y la sociedad. En la CEPAL intentamos completar esta tradición proponiendo preguntas y respuestas en nuestros documentos de posición más recientes: La hora de la igualdad: brechas por cerrar, caminos por abrir (2010), Cambio estructural para la igualdad: una visión integrada del desarrollo (2012) y Pactos para la igualdad: hacia un futuro sostenible (2014).

Estos documentos plantean una visión del desarrollo en la cual la igualdad es el principio ético normativo primordial y el objetivo último, el cambio estructural es el camino y la política, el instrumento. Se destaca también la importancia de establecer pactos en el marco de una

Luiz Carlos Bresser Pereira, Ricardo Bielschowsky, Fernando Fajnzylber, Ricardo Ffrench-Davis, Roberto Frenkel, Jorge Katz, José Antonio Ocampo, Joseph Ramos, Octavio Rodríguez, Jaime Ros, Osvaldo Sunkel y Lance Taylor, entre otros. 
renovada articulación entre el Estado, el mercado y la sociedad. Situar a la igualdad en el centro implica una ruptura con el paradigma económico que ha prevalecido en la región durante al menos tres décadas. Asimismo, pretende generar una visión del desarrollo que integre las dimensiones económica, social y ambiental y contribuir al proceso de formulación e implementación de una agenda para el desarrollo después de 2015 que sea universal y transformadora.

Lejos de ser un conjunto de ideas autocontenidas el (neo)estructuralismo es un sistema abierto que se presta a establecer diálogos con otras tradiciones de pensamiento en economía, como las corrientes heterodoxas. Estas últimas incluyen un conjunto heterogéneo de enfoques que incluyen a los evolucionistas e institucionalistas, la escuela de la regulación, los marxistas y radicales, y los post-Keynesianos. Durante muchos años, estas tradiciones nos han permitido alimentar un análisis crítico del pensamiento y las políticas económicas.

Estos enfoques nos ayudan una vez más a entender mejor los efectos regionales de la crisis económica y financiera iniciada en 2008, la situación de incertidumbre que están atravesando actualmente las economías industrializadas —en particular los países de la Unión Europea-, los cambios de paradigma que se están produciendo a nivel global y la necesidad de políticas alternativas.

Desde estas raíces, el presente libro propone una mirada renovada sobre el neoestructuralismo y las corrientes heterodoxas a inicios del siglo XXI. Una mirada que convoca a algunos de los mejores expertos de las diversas corrientes y permite a la vez abrir un espacio a una nueva generación de investigadores y académicos para expandir las pesquisas y las estrategias de desarrollo de la región.

El libro se divide en cinco partes: corrientes de pensamiento y contexto regional a inicios del siglo XXI; macroeconomía para el desarrollo; cambio estructural y desarrollo productivo, el papel del Estado, y un análisis de casos de las grandes economías de la región.

Este libro ha sido fruto de un esfuerzo más ambicioso de la CEPAL y el Centro Internacional de Investigaciones para el Desarrollo (CIID) (International Development Research Centre (IDRC)) del Canadá, que durante el período 2012-2013 ha impulsado el proyecto titulado "Raúl Prebisch y los desafíos del Siglo XXI". Este proyecto ha permitido rescatar el pensamiento y legado de Raúl Prebisch y otras figuras históricas del pensamiento latinoamericano orientado al desarrollo y analizar su vigencia en el contexto actual de cambios paradigmáticos a nivel global. El proyecto permitió llevar a cabo una serie de actividades de investigación que están plasmadas en su propio sitio web, donde se proporciona 
material multimedia innovador para difundir este conocimiento a las nuevas generaciones en un esfuerzo por maximizar el provecho de las nuevas tecnologías ${ }^{2}$. También se ha buscado promover y apoyar redes de colaboración académica en la región, tanto de enseñanza como de investigación, sobre los grandes temas del desarrollo de América Latina y el Caribe, sus desafíos tradicionales y sus problemáticas emergentes ${ }^{3}$.

Nuestra apuesta es proveer y facilitar espacios de pensamiento alternativo y crítico para que académicos, economistas, políticos e intelectuales latinoamericanos puedan debatir sobre los avances y fundamentos del neoestructuralismo y las corrientes heterodoxas en América Latina y el Caribe y las implicaciones en el diseño, la formulación y la evaluación de políticas públicas.

Entre nuestros propósitos más preciados está el de compartir con las nuevas generaciones de economistas y expertos en ciencias políticas $\mathrm{y}$ sociales los avances teórico-conceptuales del neoestructuralismo y motivarlos a contribuir con su propio pensamiento a la expansión del pensamiento latinoamericano sobre desarrollo.

\author{
Alicia Bárcena \\ Secretaria Ejecutiva \\ Comisión Económica para \\ América Latina y el Caribe (CEPAL)
}

Véase [en línea] prebisch.cepal.org.

REDESENV, Unión de Universidades de América Latina y el Caribe (UDUAL), Asociación de Universidades Grupo Montevideo y Red Prebisch, entre otras. 


\section{Introducción}

Alicia Bárcena y Antonio Prado ${ }^{1}$

El pensamiento económico que ha dominado unilateralmente la enseñanza académica y la política económica desde hace más de cinco décadas ha sido objeto en los últimos años de fuertes críticas y se ha constituido en el centro de un intenso debate entre los economistas que adscriben a dicho pensamiento, como también entre estos y sus opositores. Asistimos a un proceso de discusión intelectual en el que, según la posición que se asuma, se cuestiona o se defiende el paradigma dominante en términos de su validez y coherencia conceptual y empírica. Esta situación, en gran medida, es consecuencia del estallido de las dos crisis de mayor envergadura, intensidad y duración desde la Gran Depresión: la crisis económica y financiera internacional (2008-2009) y la crisis de la zona del euro (2009-2013). La magnitud de los efectos económicos y sociales de estos eventos, sin parangones históricos, ha motivado una acalorada discusión sobre la necesidad de revisar o reformular las políticas requeridas para enfrentarlos, teniendo en cuenta las implicaciones que tendrán en el marco del paradigma dominante. Pero las vulnerabilidades socioeconómicas surgidas de las más recientes crisis también han permitido repensar este conjunto de herramientas de políticas a la luz de enfoques alternativos basados en escuelas heterodoxas del pensamiento económico, como la

Se agradecen los insumos y comentarios de Esteban Pérez Caldentey, Miguel Torres y Romain Zivy. 
evolucionista e institucionalista, la de la regulación y la poskeynesiana, así como los enfoques surgidos del desarrollismo, fundamentalmente del estructuralismo y el neoestructuralismo.

Al igual que la mayoría de las economías emergentes, América Latina y el Caribe ha demostrado cierta resiliencia económica y social para hacer frente a los efectos globales de la crisis financiera y económica de 2008 y 2009. A pesar de que la región registró en promedio una contracción en 2009, pudo recuperarse de manera rápida gracias a condiciones externas favorables y logró, en un principio, retomar niveles de crecimiento económico dinámicos que fueron acompañados no solo de una mejora de los mercados laborales, sino también del mantenimiento de los niveles de gasto social. Asimismo, algunos países de la región, en particular los exportadores de materias primas, lograron incluso implementar políticas y medidas contracíclicas, particularmente en el ámbito fiscal, para mitigar los efectos externos de la crisis. Estas capacidades fueron fruto de una combinación de factores: a nivel interno, la mayoría de los países pudieron mantener posiciones sólidas en sus niveles de deuda pública y privada, registraron inflaciones moderadas acordes con las condiciones internacionales y se beneficiaron - sobre todo los de América del Sur- del llamado superciclo de elevados precios de las materias primas, sostenido en gran medida por la elevada demanda externa procedente de Asia - particularmente de China - e impulsado también por el creciente proceso de financiarización a nivel global. En el ámbito social, es destacable que la región haya logrado a lo largo del período 2002-2013 disminuir significativamente sus niveles de pobreza y, por primera vez en su historia reciente, los niveles de desigualdad.

Hoy en día, el crecimiento y el desarrollo futuros de la región enfrentan nuevos desafíos. A partir de 2011 América Latina y el Caribe registra, en conjunto, una desaceleración paulatina de su ritmo de crecimiento, aunque con su característica heterogeneidad entre países. Las condiciones externas favorables de la década de 2000 pueden haber llegado a su fin, debido en particular a la caída de los precios de las materias primas y la posibilidad de que estos se sitúen en niveles más bajos, al menor dinamismo de la demanda externa, a la disminución del crecimiento del comercio visible desde mediados de 2000 y a los efectos de la progresiva moderación de las medidas de recuperación económica aplicadas por las autoridades estadounidenses. Asimismo, existe el riesgo de una posible reversión de las favorables condiciones de acceso al financiamiento de las cuales se siguen beneficiando las economías de la región. Por otro lado, los niveles de inversión y exportación en la región son insuficientes para dinamizar el crecimiento. En un contexto de crecimiento más modesto y de desaceleración del ciclo, los dilemas (trade-offs) de las políticas macroeconómicas que deberán enfrentar los países de la región serán 
entonces diferentes a los del período anterior y se enfocarán a evitar una reducción más acentuada del crecimiento y la generación de empleo. La región puede padecer problemas de restricción externa, limitados niveles de inversión y las consecuencias de haber mantenido una misma matriz productiva orientada a bienes primarios - la llamada reprimarizacióny de no haber aprovechado completamente los beneficios del auge para impulsar el desarrollo de sectores con mayor contenido de conocimiento. Asimismo, es legítimo plantearse cuán sostenible es mantener hacia la baja los niveles de pobreza y desigualdad sin una senda de crecimiento económico estable y dinámico en el largo plazo. Los dilemas de políticas que plantean estos interrogantes deben ser centrales en el actual debate sobre las corrientes de pensamiento que pueden o no acompañar el período por venir. Estos temas, dilemas y planteamientos de política económica cobrarán mayor fuerza aún si la actual desaceleración que vive la región es más bien de carácter tendencial que coyuntural.

El debate sobre los impactos de las crisis, las limitaciones de las políticas tradicionales para enfrentarlos y la actual situación de incertidumbre que vive la economía mundial es, en parte, un reflejo de las limitantes del paradigma dominante y sus políticas económicas asociadas para solucionar las principales falencias de las economías de libre mercado. Siguiendo el pensamiento de John Maynard Keynes y Raúl Prebisch, estas pueden resumirse en: su incapacidad para asegurar la plena ocupación y crear empleos dignos como norma; su tendencia a generar una arbitraria y desigual distribución de los ingresos y la riqueza, y su propensión hacia la fragilidad financiera y la inestabilidad ${ }^{2}$.

Según estos pensadores, estas falencias son endógenas al funcionamiento tanto de las economías desarrolladas como de aquellas en desarrollo. Constituyen de hecho problemas fundamentales vigentes y no resueltos que nuestra época deberá enfrentar. En el caso de América Latina y el Caribe, estos problemas están asociados a rasgos de carácter estructural que fueron puestos en evidencia hace ya tiempo por el único esfuerzo de creación de un cuerpo de pensamiento teórico sobre política económica que ha surgido en el mundo en desarrollo ${ }^{3}$. Este cuerpo de pensamiento, denominado "estructuralista", sin pretender usar o abusar de sintagmas nominales, identificó el rezago tecnológico, la restricción externa, la desigualdad, la heterogeneidad estructural, la inestabilidad (volatilidad real) y la economía política de las relaciones de dependencia

Véanse J.M. Keynes, The General Theory of Employment, Interest and Money, Nueva York, Harcourt Brace Jovanovitch Publishers, 1936, cap. 24; R. Prebisch, Obras 1919-1949, vol. 4, Buenos Aires, Fundación Raúl Prebisch, págs. 346-361, 301 y 303. Más recientemente, una opinión similar también aparece en Furtado (2003a) y en Minsky, Can "It" Happen Again?, Nueva York, M.E. Sharpe, 1982; y Stabilizing an Unstable Economy, New Haven, Yale University Press, 1986.

3 Esta es una cita casi textual de Celso Furtado (2003, pág. 30). 
y de poder articuladas bajo el binomio centro-periferia, entre otros, como obstáculos estructurales al desarrollo económico y social de la región ${ }^{4}$. Si bien el pensamiento estructuralista es una creación netamente latinoamericana, no se gestó en el aislamiento de las corrientes críticas de su época, sino que absorbió, incorporó y se benefició de un intercambio intelectual con algunos de los economistas heterodoxos más prominentes de este tiempo.

Tras un período de pérdida de visibilidad asociada a la primacía del paradigma dominante y la defensa del lema del Consenso de Washington - estabilización, liberalización y privatización-, el neoestructuralismo recuperó esta tradición y la revitalizó adaptándola a las condiciones más actuales de la región.

El neoestructuralismo, que se desarrolló a partir del documento de la CEPAL Transformación productiva con equidad $(1990)^{5}$, ha mantenido $\mathrm{y}$ profundizado los temas y preocupaciones que constituyen el nudo gordiano del estructuralismo. A la vez, ha ampliado su marco y objeto de análisis y refinado su enfoque metodológico y empírico. Se trata de integrar en el pensamiento estructuralista los cambios que ocurrieron en la región y a nivel internacional a partir de finales de la década de 1980, que incluyen "la apertura comercial, la movilidad internacional de capitales, la privatización y desregulación en un contexto de relaciones más estrechas con el resto del mundo y de mayor integración regional" (Bielschowsky, 2009; véase también Sunkel y Zulueta, 1990, y Ffrench-Davis, 1991 y 2006)6.

El enfoque neoestructuralista integró en su análisis consideraciones sobre temas fiscales, la liquidez y la regulación de la balanza de pagos, incluida la regulación de la cuenta de capitales (Ffrench-Davis, 1999)7.

\footnotetext{
Algunos de estos temas fueron el centro del primer análisis articulado sobre los problemas de desarrollo de América Latina. Véase R. Prebisch, “El desarrollo económico de la América Latina y algunos de sus principales problemas" [en línea] http://prebisch.cepal.org/sites/default/ files/2013/prebisch_el_desarrollo_eco.pdf. Aunque este texto se refiere a América Latina, su análisis es plenamente aplicable al caso de las economías del Caribe.

5 Fernando Fajnzylber jugó un papel central en la concepción del documento Transformación productiva con equidad, Libros de la CEPAL, No 25 (LC/G.1601-P), Santiago de Chile, 1990. Véase al respecto también F. Fajnzylber, "Industrialización en América Latina: de la 'caja negra' al 'casillero vacío'. Comparación de patrones contemporáneos de industrialización", serie Cuadernos de la CEPAL, Nº 60 (LC/G.1534/Rev.1-P), Santiago de Chile, 1990.

6 R. Bielschowsky, "Sesenta años de la CEPAL: estructuralismo y neoestructuralismo", Revista CEPAL, No 97 (LC/G.2400-P), Santiago de Chile, 2009; O. Sunkel y G. Zulueta (1990), "Neoestructuralismo versus neoliberalismo en los años noventa", Revista de la CEPAL, $\mathrm{N}^{\circ}$ 42, Santiago de Chile, 1990, págs. 35-53; R. Ffrench-Davis, "Formación de capital y marco macroeconómico: bases para un enfoque neo estructuralista", El desarrollo desde dentro: Un enfoque neoestructuralista para América Latina, O. Sunkel (comp.), 1991, págs 192-232; R. Ffrench Davis, Reforming Latin America's Economics after Market Fundamentalism, NuevaYork, Palgrave Macmillan, 2006.

7 El libro Macroeconomía, comercio y finanzas para reformar las reformas en América Latina de FfrenchDavis (1999) constituye uno de los desarrollos más completos y acabados de la incorporación de estos temas en el pensamiento neoestructuralista.
} 
A partir de la década de 2000, el neoestructuralismo se articuló alrededor de cuatro grandes áreas: macroeconomía y finanzas, comercio internacional, desarrollo social y sostenibilidad ambiental. Estos temas fueron desarrollados en profundidad en diversas publicaciones institucionales de la CEPAL, entre las que se destacan Globalización y desarrollo (2002) y Desarrollo productivo en economías abiertas (2004) ${ }^{8}$. Últimamente se ha incorporado la temática de la igualdad como eje central de un desarrollo sostenible en lo económico, social y ambiental (La hora de la igualdad: brechas por cerrar, caminos por abrir (2010), Cambio estructural para la igualdad: una visión integrada del desarrollo (2012) y Pactos para la igualdad: hacia un futuro sostenible (2014) $)^{9}$. El neoestructuralismo de la CEPAL ha dado lugar a un programa que es "heterodoxo en materia macroeconómica, desarrollista en cuanto a asignación de recursos e intervención del Estado, universalista en el campo social y conservacionista en materia ambiental" (Bielschowky, 2009).

En consonancia con el enfoque estructuralista tradicional, el neoestructuralismo no se considera a sí mismo como un sistema analítico autocontenido. Además, analiza el comportamiento de los agentes y estructuras económicas y sociales y su interrelación en un contexto histórico y evolutivo (son dinámicos y cambian en el tiempo con el contexto y circunstancias). En este sentido es un sistema de ideas abierto ${ }^{10}$ y que se presta, por consiguiente, a establecer diálogos con otras tradiciones de pensamiento en materia de economía, como la corriente heterodoxa, que al igual que el neoestructuralismo, reconoce las limitaciones del paradigma dominante en las circunstancias actuales y se opone a su monismo metodológico ${ }^{11}$.

La creación de espacios para el diálogo y la colaboración entre las corrientes neoestructuralista y heterodoxa es precisamente el objetivo final de este libro. En él se plantea además que la colaboración intelectual entre ambos enfoques puede desembocar en una agenda de políticas alternativa a la del paradigma dominante.

El presente libro se basa en las presentaciones, discusiones y debates que tuvieron lugar en el marco del seminario Neoestructuralismo y Economía Heterodoxa que la CEPAL organizó en su sede en abril de 2013. En un contexto global de lenta recuperación de la crisis, este seminario ha tenido como meta principal promover la discusión académica y el debate

LC/G.2157(SES.29/3), Santiago de Chile, 2002 y LC/G.2247(SES.30/4), Santiago de Chile, 2004. Véase un análisis sobre la evolución del neoestructuralismo, sus etapas y sus rasgos distintivos en R. Bielschowsky, "Sesenta años de la CEPAL...", op.cit.

10 Véase la definición de sistema abierto en V. Chick, "On open systems", Brazilian Journal of Political Economy, vol. 24, No 1, 2004; S.C. Dow, Economic Methodology: An Inquiry, Nueva York, Oxford University Press, 2002; y Lawson, Reorienting Economics, Nueva York, Routledge, 2003.

11 La corriente heterodoxa incluye un conjunto heterogéneo de enfoques, como los marxistas y radicales, la escuela de la regulación, la poskeynesiana, la institucionalista y la evolucionista. 
en torno a políticas económicas y pensamiento sobre desarrollo aliando las tradiciones estructuralista y neoestructuralista con las diferentes corrientes económicas heterodoxas para analizar los actuales desafíos del desarrollo de América Latina y el Caribe.

Los 15 ensayos incluidos en este volumen están agrupados en cinco partes temáticas:

1. Corrientes de pensamiento y contexto regional a inicios del siglo XXI;

2. Macroeconomía para el desarrollo;

3. Cambio estructural y desarrollo productivo;

4. El papel del Estado, y

5. Análisis de casos de las grandes economías de la región.

Cada una de estas partes y sus respectivos capítulos resumen los hechos y análisis más recientes sobre el desarrollo de América Latina y el Caribe en el nuevo contexto mundial de la poscrisis siguiendo los cánones generales de la tradición estructuralista y neoestructuralista. Una lectura en profundidad de estos trabajos permite resaltar además las similitudes entre la tradición estructuralista y heterodoxa, identificar puntos de vista y denominadores comunes, y establecer vínculos para la investigación futura conjunta.

La primera parte está constituida por tres capítulos. En el primero de ellos, elaborado por Esteban Pérez Caldentey, se presenta lo que constituye el núcleo esencial de este libro: las bases metodológicas y conceptuales para un debate entre las corrientes heterodoxas del pensamiento económico y el (neo)estructuralismo. En sus páginas está contenido el marco apropiado dentro del cual se desarrollan las distintas visiones y temáticas analizadas en los siguientes capítulos. Se inicia con una descripción del contexto que dio origen al actual debate en torno al paradigma dominante y sus falencias, las que quedaron en evidencia con las crisis económicas y financieras de la década de 2000. Luego se caracteriza este paradigma identificando sus especificidades y rasgos fundamentales. Un elemento importante de este ensayo es el análisis de la réplica de los adherentes del paradigma dominante frente a las críticas y cuestionamientos que han enfrentado en este debate. Así, se puede distinguir dentro de la ortodoxia a algunos economistas cuyo principal planteamiento es no innovar y a otros que reducen la enorme magnitud de los problemas en debate meramente a añadir ecuaciones al modelo y proceder a la resolución del sistema reformulado. Frente a esta incapacidad de entendimiento y diálogo, se presenta una tercera alternativa factible basada en potenciar el diálogo entre el pensamiento estructuralista (y el neoestructuralista) y el heterodoxo, buscando los espacios de convergencia entre ambas corrientes. Finalmente, se resumen las principales conclusiones del capítulo. 
En el capítulo II, José Antonio Ocampo nos ofrece su ensayo "América Latina frente a la turbulencia económica mundial". Este texto presenta una visión panorámica del contexto global que enfrenta América Latina a inicios del siglo XXI. Como bien señala Ocampo, se trata de un contexto turbulento, caracterizado por una economía mundial que ha superado la crisis de 2007 y 2008 desencadenada en los Estados Unidos, pero que actualmente enfrenta los avatares de Europa, el posible final del superciclo de precios de productos básicos y la perspectiva de una desaceleración en las economías emergentes. Dentro de este marco, se analiza el campo de acción y la estrategia que deberían adoptar las economías de la región para mantener y acelerar un proceso de crecimiento y desarrollo virtuoso. El capítulo se divide en cuatro secciones, además de una breve introducción que las antecede. En la primera sección se analiza el mundo que enfrentó la región durante el período comprendido entre 2003 y 2007, especialmente la conjunción de factores externos favorables que le permitieron una bonanza de crecimiento basado en productos básicos (remesas, auge del comercio, aumento de los precios de las materias primas exportadas por la región y financiamiento externo). En la segunda sección, el autor analiza los cambios del comercio internacional y el rezago tecnológico que afecta (persistentemente) a la estructura productiva de América Latina. En la sección siguiente se aborda el contexto global y regional en cuanto a financiamiento externo, determinando sus efectos positivos y los efectos colaterales adversos, especialmente en lo que se refiere a la tendencia a la apreciación cambiaria real y la consecuente pérdida de competitividad comercial. A modo de conclusión, en la última sección "¿Es hora de una nueva estrategia?" el autor responde afirmativamente esta pregunta sosteniendo que, frente a la debilidad actual del comercio, las estrategias de crecimiento impulsado por las exportaciones y las políticas ortodoxas que las sustentan han llegado a su fin. El contraargumento es fuertemente estructuralista: hay que transformar la estructura productiva y ampliar los espacios de integración intrarregional, más allá de las dificultades que desde hace mucho obstaculizan y estancan su concreción.

El capítulo III es un ensayo de Luis Gonzaga Belluzzo presentado en la XII Cátedra Raúl Prebisch en abril de 2012. En este documento, Belluzzo revisa en una perspectiva histórica la fase actual por la que atraviesa el proceso de internacionalización del capitalismo. Comprobará el lector que su análisis está dotado de un elevado eclecticismo en términos de enfoques, e incluye formulaciones que van desde los principios del Manifiesto Comunista de Marx y Engels hasta visiones completamente antagónicas como las de Hayek y Friedman. Esta evolución histórica del proceso de internacionalización del capitalismo que nos presenta Belluzzo es también aplicable muy especialmente a las experiencias latinoamericanas, sobre todo al caso del Brasil. 
La segunda parte del libro se compone de tres ensayos enfocados en la macroeconomía y las políticas económicas. El primero de ellos corresponde al capítulo IV, una contribución de Ricardo Ffrench-Davis que se titula "Neoestructuralismo y macroeconomía para el desarrollo". Coherente con su título, este trabajo constituye un esfuerzo orientado a posicionar desde un plano teórico-descriptivo la macroeconomía para el desarrollo, es decir, un conjunto de políticas macrofuncionales dentro de una estrategia de crecimiento con equidad. Dicho conjunto de políticas se enfoca a la necesidad de acelerar el proceso de convergencia entre el PIB efectivo y el potencial, de mantener macroprecios (especialmente el tipo de cambio real) acordes con balances externos sostenibles. Junto con ello, Ffrench-Davis plantea la importancia de considerar el modo en que este conjunto de macropolíticas contribuye a reducir la elevada heterogeneidad estructural que caracteriza a las economías de América Latina y el Caribe. La heterogeneidad estructural y su reducción deben estar en el foco de la macroeconomía para el desarrollo, pues es ella la que, a través de su dispar distribución de productividades a nivel sectorial y territorial, genera las amplias desigualdades salariales que en definitiva son las más determinantes en la conformación de altos, persistentes e intolerables niveles de inequidad en la distribución de ingresos. El autor analiza críticamente, a la luz de sus consecuencias económicas y sociales, el enfoque dominante a partir de los años noventa aplicado en la región, inspirado en el llamado Consenso de Washington. Luego se enfoca en un conjunto de aspectos que denomina asimetrías recesivas y regresivas, analizando con especial atención tres de ellas: i) la brecha recesiva y la formación de capital, ii) la inestabilidad cambiaria y el desarrollo productivo y iii) la generación de empleos de calidad y la inestabilidad de la economía real. Finalmente, presenta las principales conclusiones.

En el capítulo V, elaborado por Esteban Pérez-Caldentey y Daniel Titelman, se aborda también la problemática de la macroeconomía para el desarrollo y se presenta un conjunto de nuevas consideraciones en torno a las políticas anticíclicas. Se plantea que el ciclo y la tendencia son interdependientes y, en consecuencia, las políticas anticíclicas (es decir, las políticas relacionadas con la demanda agregada) no son neutrales en relación con el desempeño de las economías a largo plazo. La manera en que se formulen y apliquen las políticas anticíclicas, incluido el momento de su implementación y el tipo de instrumentos utilizados, conforma y determina, junto con otros factores, la tendencia de crecimiento a largo plazo de las economías. La falta de neutralidad de las políticas anticíclicas se refleja en tres características concretas del ciclo económico de América Latina y el Caribe: i) sus ciclos de expansión son más breves y de menor intensidad en comparación con otras regiones; ii) las fluctuaciones a corto plazo influyen en los resultados a largo plazo por medio de las variables reales y financieras, y iii) el sistema financiero tiende a amplificar las 
fluctuaciones reales, y las recuperaciones reales se producen antes que las recuperaciones del crédito. Del análisis se deduce que las políticas anticíclicas no deben limitarse a encauzar el ciclo a través de las variaciones del nivel de la demanda agregada, sino que deben centrarse además en la composición de la demanda agregada. Por una parte, esto entraña la necesidad de mantener la duración e intensidad de la expansión y evitar el uso de la inversión pública como variable de ajuste durante las fluctuaciones cíclicas. También implica utilizar las políticas macroprudenciales como recurso anticíclico para gestionar la composición y el nivel de la demanda agregada.

El capítulo VI, "Hacia una interpretación robinsoniana de la acumulación del capital en América Latina", fue elaborado por Juan Alberto Fuentes Knight. Como se desprende de su título, el propósito de este texto es, en una primera aproximación, identificar los alcances y limitaciones de la teoría de crecimiento de Joan Robinson a la luz de ciertos rasgos estilizados del crecimiento económico de largo plazo en América Latina. Cabe mencionar que se trata de un esfuerzo teórico y empírico de alta relevancia, por cuanto las políticas macroeconómicas de corto plazo predichas por el keynesianismo han comenzado a revalidarse como una de las consecuencias de la crisis financiera internacional de 2008 y 2009, pero subsiste un déficit en lo que respecta a las políticas macroeconómicas de largo plazo derivadas de los enfoques keynesiano y neokeynesiano, siendo la teoría de Robinson uno de estos casos. Para dar cumplimiento al objetivo del capítulo, Fuentes Knight organiza el texto del siguiente modo. En primer lugar, describe con alto grado de detalle la teoría de crecimiento de Robinson. Esta descripción se sustenta analíticamente mediante un modelo matemático sencillo de cuyas ecuaciones se derivan las principales relaciones entre las variables macroeconómicas involucradas; luego presenta las implicaciones económicas más importantes de este análisis. A continuación, se reseñan las distintas edades de crecimiento constante o variable mediante las cuales Joan Robinson concibió la dinámica del crecimiento: la edad de oro, la edad de oro lánguida, la edad de plomo, la edad de oro restringida, la edad de oro bastarda, la edad de platino galopante y la edad de platino decreciente. Para cada una de estas trayectorias, se describe la relación entre la inversión potencial y la esperada; la relación entre la tasa de crecimiento del producto, el empleo, la población y la productividad, y las relaciones entre ahorro, ganancia, consumo, salarios e inversión. Luego, utilizando datos de largo plazo de las economías de la región, se procede a calibrar el modelo de Robinson. En virtud de este ejercicio, Fuentes identifica una extensa trayectoria de crecimiento centrada en la edad de plomo, es decir, un patrón de desarrollo caracterizado por una insuficiente acumulación de capital, que no permite la generación, asimilación o adaptación de progreso 
técnico y, por lo mismo, conlleva a un estancamiento de la productividad, el empleo y la actividad económica global. Los hechos estilizados de la región sin duda se ajustan perfectamente a esta trayectoria en el período comprendido entre 1980 y 2013, especialmente durante los años ochenta, producto de la recesión generada por la crisis de la deuda. Si bien el autor reconoce subperíodos excepcionales, de diversa duración y caracterizados por trayectorias más virtuosas de crecimiento, una conclusión importante que subyace a su análisis $-\mathrm{y}$ sin duda la contribución mayor de este capítulo- es que la persistente edad de plomo que caracteriza al desarrollo de América Latina y el Caribe durante los últimos cuatro decenios es altamente coherente con los diagnósticos elaborados por los estructuralistas y neoestructuralistas, especialmente desde la CEPAL, en diversos documentos como el "Manifiesto de Prebisch" y la Transformación productiva con equidad, inspirada por Fajnzylber, que en los años recientes se actualizaron y profundizaron en la trilogía de la igualdad.

Prosigue el libro en su tercera parte con otros tres capítulos que tratan temas relativos al cambio estructural y el desarrollo productivo. Esta parte está compuesta por los capítulos VII a IX. En el capítulo VII, preparado por Mario Cimoli y Gabriel Porcile, se presentan de manera sintética las visiones estructuralista, evolucionista y keynesiana acerca del vínculo entre la tecnología, el cambio estructural y el crecimiento económico. El fin último de este análisis es mostrar la convergencia teórica de estas visiones en torno de dicho vínculo. Para ello, los autores exponen sintéticamente un modelo teórico estático que resume los patrones de especialización productiva, salarios de equilibrio y crecimiento económico en un sistema centro-periferia. Los resultados avalan el conocimiento y las evidencias previas que se tiene sobre estas materias, en términos del persistente rezago estructural observado en la región asociado a la escasa diversificación productiva, la lenta difusión del progreso técnico y la ampliación de la brecha productiva interna y externa, con las inevitables consecuencias de baja tasa de productividad, lento crecimiento del producto, desigualdad salarial y, por ende, distribución de ingresos regresiva.

Jorge Katz aborda en el capítulo VIII los aspectos macro y microeconómicos de los procesos de crecimiento basado en recursos naturales, enfocando así su análisis en lo que ha constituido el patrón de desarrollo seguido por la mayoría de las economías de la región en el último decenio. De esta forma, Katz plantea una reflexión sobre los impactos macro y microeconómicos del retorno de la región a las ventajas comparativas basadas en recursos naturales, a las actividades menos intensiva en valor agregado y a las cadenas productivas involucradas con su extracción. Se intenta también determinar de qué modo este patrón de especialización afecta a la estructura productiva, así como a la dotación de los recursos naturales y la sostenibilidad ambiental y ecológica. 
El capítulo IX, redactado por Luis Bértola, se enfoca en la relación entre los patrones de desarrollo y los estados de bienestar. Se profundizan los alcances de este vínculo aplicado al caso de las economías de América Latina. En primer lugar, se identifican las características del desarrollo económico en su acepción moderna y su vinculación o aplicación al caso de las economías intensivas en recursos naturales. Luego se discute la interdependencia entre distintas regiones, haciendo hincapié en la importancia de las heterogeneidades internacionales y sus implicancias para el desarrollo. Seguidamente, se analiza la relación entre el crecimiento económico y el bienestar. Como conclusión principal, se plantea que no es factible concebir los estados de bienestar independientemente de las estructuras productivas. Es imprescindible entonces, según concluye Bértola, tener en consideración esta interrelación simbiótica a la hora de plantear la construcción de un estado de bienestar en la región.

Los capítulos X a XII constituyen la cuarta parte de este volumen. El capítulo X, titulado "Crecimiento, empleo y equidad: el nuevo papel del Estado" corresponde a Robert Boyer. En él se analiza la responsabilidad del Estado, especialmente en este nuevo contexto mundial, caracterizado por fallos evidentes y cada vez más recurrentes de los mecanismos del mercado (que el autor caracteriza como colapsos), para garantizar y articular los tres ejes mayores del desarrollo ya mencionados: el crecimiento, el empleo y la equidad. Para dilucidar esta cuestión, el autor revisa en primer lugar la forma en que los países desarrollados redujeron desigualdades en un escenario de crecimiento económico elevado y estable. Este análisis corresponde sobre todo a las décadas de 1950, 1960 y 1970. Posteriormente, se describe el colapso de esta "edad de oro del capitalismo" y el tránsito hacia los regímenes dominados por el mercado; también se da cuenta de sus sucesivas crisis. Se recorren así las décadas de 1980, 1990, 2000 y los primeros años del decenio en curso. En la tercera sección del capítulo, Boyer plantea las bases de lo que él denomina el nuevo paradigma del Estado y la política económica. Esta sección es una suerte de desmitificación de varias premisas del paradigma dominante, por lo general incuestionables antes de la crisis de 2007 y 2008. En primer lugar, plantea el fracaso de la creencia en la eficiencia y la autorregulación de los mercados financieros, que reivindica y legitima la intervención del Estado en la esfera económica. Se cuestiona también la mentada hipótesis de neutralidad de la política monetaria, a la vez que se realza el papel de la política fiscal como un instrumento eficaz para la reactivación de la demanda efectiva en épocas recesivas. Del mismo modo, el autor revisa y cuestiona otros aspectos del paradigma, como la política de competencia y las políticas de rescate a los sectores productivos y financieros, los efectos adversos de la volatilidad cambiaria y el carácter falaz de la estrategia por goteo del crecimiento económico, es decir, su fracaso. El análisis de Boyer 
continúa enfocándose en las relaciones entre el estado de bienestar y el crecimiento, y luego en las consideraciones que deben tomarse en cuenta con respecto al papel de la globalización. El capítulo finaliza con una síntesis a modo de conclusión.

En el capítulo XI, René Hernández aborda, al igual que Boyer, el proceso de transformación del Estado, pero planteando los paradigmas disponibles para América Latina. En el texto se tratan las nociones centrales del debate sobre la relación entre el Estado y el desarrollo económico, y se presenta especialmente el aporte de la CEPAL a esta literatura. Se esclarecen también los principales paradigmas de desarrollo a los que se ha enfrentado la región; en particular, se estudia la vigencia de las ideas de Prebisch y su contribución al actual debate regional. Finalmente, se exponen los comentarios y reflexiones finales de este ensayo.

El capítulo XII estuvo a cargo de Sonia Montaño y aborda las relaciones entre el Estado, la heterodoxia y las contribuciones del pensamiento feminista a la teoría y praxis del desarrollo. El propósito de la autora es señalar en última instancia cuánto enriquece el pensamiento feminista la calidad de la economía y la política. Para ello, se abordan tres aspectos: el pensamiento crítico en cuanto interpelación de algunos dogmas sobre el Estado y el mercado, la crítica a los supuestos que subyacen a las políticas públicas y las implicaciones del pensamiento heterodoxo en el papel estatal.

En la quinta parte de este libro, dedicada al análisis de las economías regionales de mayor tamaño, se analizan temas particulares de desarrollo en algunas de las áreas tratadas de modo más general en las partes precedentes. Está constituida por tres capítulos, que se detallan a continuación. En el capítulo XIII, Juan Carlos Moreno-Brid nos presenta "Desarrollo y macroeconomía: reflexiones a partir del caso mexicano", trabajo cuyo objetivo es identificar elementos centrales de la estructura económica mexicana que deberían considerarse al elaborar políticas macroeconómicas para el desarrollo. Con este fin, se recurre a la perspectiva neoestructuralista, poniendo énfasis especialmente en la heterogeneidad productiva como determinante de la pauta del crecimiento económico. El autor también analiza de manera crítica las políticas macroeconómicas convencionales que, bajo múltiples enfoques, se han aplicado a raíz de la crisis financiera internacional de 2008 y 2009. A modo de ilustración, Moreno-Brid toma como referencia la política macroeconómica aplicada en México en los últimos 30 años y su relación con el desempeño de la economía mexicana. Sostiene el autor que el magro avance de México en materia de crecimiento y desarrollo en los últimos tres decenios, en un marco de políticas orientadas fundamentalmente a preservar la estabilidad nominal (baja inflación y reducido déficit fiscal) 
y de menor presencia del Estado en la esfera económica, con todo lo que ello ha implicado en la orientación de las políticas macroeconómicas (fiscal, monetaria y cambiaria), comerciales y productivas, constituye un cimiento necesario a la hora de reflexionar en torno a los fundamentos de una política macroeconómica para el desarrollo.

En el capítulo XIV, Francisco Eduardo Pires de Souza y João Carlos Ferraz ofrecen un análisis del proceso de desarrollo del Brasil en el período comprendido entre 2002 y 2012. El análisis comienza con una breve revisión de la situación actual de la economía brasileña, mostrando los impactos que tuvo en ella la bonanza externa de la década de 2000. Luego se discuten las características del modelo implementado en el último decenio, denominado por Pires y Ferraz "de crecimiento inclusivo"; en esta sección del texto se identifican las fortalezas y debilidades de dicho esquema, y se expone una breve discusión en torno al uso dado a las ganancias inesperadas obtenidas de la coyuntura internacional. Prosigue el capítulo con una sección dedicada a evaluar algunos cambios aún en curso, incorporados en la conducción económica del gobierno de la Presidenta Dilma Rousseff. Se argumenta que estos cambios podrían estar señalando el surgimiento de un nuevo modelo orientado a perfeccionar el esquema de crecimiento inclusivo. A continuación, se plantean algunos desafíos que deben enfrentarse para lograr la consolidación de este nuevo modelo. Por último, se presentan las principales conclusiones y se indaga brevemente sobre la posibilidad de que las implicaciones del modelo brasileño sean extrapolables a otras economías de América Latina y el Caribe.

Fernando Porta presenta en el capítulo XV un estudio aplicado a la Argentina en el que se analiza la dinámica del cambio estructural y los distintos enfoques de la política industrial. El autor expone sus argumentos de acuerdo con tres ejes analíticos. En el primero se describe brevemente el desempeño de la economía argentina a partir del cambio de régimen macroeconómico ocurrido en 2002, haciendo hincapié en la evolución observada en el sector industrial. En el segundo, se analiza la dinámica productiva de la Argentina bajo un enfoque neoestructuralista. En tercer lugar, se plantea una propuesta conceptual-metodológica orientada a la formulación de una política industrial inserta en una estrategia de desarrollo inclusivo. 



\section{Parte I}

Corrientes de pensamiento y contexto regional a inicios del siglo XXI 

Capítulo I

\title{
Una coyuntura propicia para reflexionar sobre los espacios para el debate y el diálogo entre el (neo)estructuralismo y las corrientes heterodoxas
}

\author{
Esteban Pérez Caldentey ${ }^{1}$
}

\section{Introducción}

En consonancia con algunos de los más recientes planteamientos sobre el tema, en este trabajo se establece que la crisis financiera mundial de 2007-2009 ha sacudido la forma en que se ha manejado la macroeconomía según el denominado "nuevo consenso" (Blanchard, Dell'Ariccia y Mauro, 2013, pág. 3). Además, se argumenta que esta afirmación puede aplicarse con facilidad al período de la Gran Moderación (1980-2006) y extenderse al conjunto del paradigma dominante en economía, del cual el nuevo consenso no es más que su expresión más moderna.

Casi una década después del estallido de la crisis del mercado de hipotecas de alto riesgo en los Estados Unidos en 2007 y de debates en torno al paradigma dominante, aún no se vislumbran los lineamientos de un planteamiento alternativo. La respuesta a los cuestionamientos

El autor agradece los valiosos comentarios y sugerencias de Ramón Pineda, Antonio Prado, Miguel Torres y Romain Zivy. 
sobre el paradigma dominante oscila entre no cambiar nada y añadir modificaciones, usualmente en el sector financiero, sin alterar la sustancia del marco teórico en cuestión.

No obstante, en cuanto la coyuntura actual constituye un punto de ruptura en la práctica de la ciencia normal (en el sentido de Kuhn, 1996), resulta propicia para empezar a repensar el contenido de la teoría económica y replantear la orientación de las políticas económicas que de ella derivan. Un paso adelante en esta dirección es aunar esfuerzos y abrir espacios para el diálogo y el debate entre corrientes de pensamiento que no forman parte del paradigma dominante y que se han desarrollado en franca oposición a este.

En el caso de América Latina y el Caribe, iniciar esta tarea no requiere devanarse los sesos o intentar reinventar la rueda. La región goza de una larga tradición en teoría económica ligada al estructuralismo y al neoestructuralismo. De hecho, como remarcó Celso Furtado (2003, pág. 30), este constituye el único esfuerzo de creación de un cuerpo de pensamiento teórico sobre política económica que ha surgido en el mundo en desarrollo.

Lejos de ser un conjunto de ideas autocontenido, el estructuralismo o neoestructuralismo es un sistema abierto, que se presta a establecer diálogos con otras tradiciones de pensamiento en economía, como las corrientes heterodoxas. Estas últimas incluyen un conjunto heterogéneo de enfoques que abarcan a los evolucionistas e institucionalistas, a la escuela de la regulación, a los marxistas y radicales, y a los poskeynesianos.

Las corrientes de pensamiento estructuralista-neoestructuralista y heterodoxa identifican, grosso modo, tres falencias básicas en el funcionamiento de las economías de mercado: a) la incapacidad para asegurar la plena ocupación y crear empleos dignos como norma, b) la tendencia a generar una arbitraria y desigual distribución de los ingresos y la riqueza y c) la propensión a la fragilidad financiera y la inestabilidad ${ }^{2}$. Por otra parte, las preocupaciones en el ámbito de la investigación y la política económica son similares: el énfasis en la teorización a partir de la realidad, la concepción del individuo como un animal social e institucional, la autonomía de las instituciones, la percepción de que los individuos enfrentan importantes limitantes para obtener y procesar información, la centralidad de la producción (más que del intercambio) y de la estructura económica, y la importancia del Estado (gobierno) para regular el funcionamiento de los mercados.

Véanse J.M. Keynes (1936, cap. 24) y Prebisch (1993, vol. IV, págs. 301, 303 y 346-361). Más recientemente, también aparece una opinión similar en Furtado (2003a) y en Minsky (1982 y 1986). 
Existen siete áreas temáticas de convergencia entre el neoestructuralismo y el pensamiento heterodoxo: i) el enfoque metodológico, ii) la caracterización del sistema de relaciones económicas internacionales y los temas asociados a esta, incluida la restricción externa, iii) la relación entre distribución del ingreso y acumulación y crecimiento y desarrollo, iv) la volatilidad y la inestabilidad, v) el progreso técnico y la innovación, vi) la relación entre el corto y el largo plazo y vii) el papel del Estado.

$\mathrm{Al}$ inicio de este capítulo se presenta el contexto que dio lugar al actual debate sobre el paradigma dominante y sus limitantes, puestas en evidencia por las crisis económicas y financieras de la década de 2000. Más adelante se caracteriza este paradigma mediante la identificación de sus especificidades y rasgos fundamentales. Posteriormente, se argumenta que las reacciones de los economistas del paradigma dominante ante el debate y las críticas que han surgido en su contra son esencialmente de dos tipos: no modificar nada o simplemente añadir algunos elementos adicionales y revolver. Ante esta compleja situación, en este capítulo se plantea la posibilidad de una tercera alternativa basada en el diálogo entre el pensamiento estructuralista (neoestructuralista) y heterodoxo, y con esta finalidad se detallan los puntos de vista comunes a ambas corrientes.

\section{A. La Gran Moderación y los economistas}

No hay duda de que la crisis financiera mundial (2007-2009) y la crisis de la zona del euro (2009-2013) han sido las más potentes en cuanto a efectos y duración desde la Gran Depresión de 1930. Ambas han dado origen a un intenso debate acerca de la validez conceptual y empírica del paradigma económico dominante.

Con contadas excepciones, los economistas fueron incapaces de intuir o adelantar que las políticas económicas aplicadas en la década previa al estallido de las crisis en los Estados Unidos y en la zona del euro gestarían desequilibrios insostenibles para estas economías, y de manera general para la economía mundial. Menos aún, fueron capaces de predecir ambos eventos o de avizorar su intensidad y duración. En 2007, la Organización de Cooperación y Desarrollo Económicos (OCDE) afirmó que sus predicciones apuntaban a una fuerte creación de puestos de trabajo y disminución del desempleo. De la misma manera, en el mismo año, el Fondo Monetario Internacional (FMI, 2007) manifestó que la expansión global seguía su curso de manera ininterrumpida, lo que permitió al organismo aumentar al alza su predicción de crecimiento de la economía mundial y advertir acerca de los peligros del recalentamiento y de la inflación. Al comienzo de la recesión, gran parte de los economistas 
simplemente descartó la posibilidad de que esta fuera duradera (véanse, entre otros, Posen, 2007a y 2007b; Rogoff, 2008).

La limitada, o más bien nula, capacidad para detectar factores de desequilibrio que podían traducirse en una recesión intensa y duradera responde a la visión de optimismo prevaleciente sobre el estado económico de las economías avanzadas (incluidos los Estados Unidos y la zona del euro), y en general del mundo en su conjunto, con anterioridad a la crisis. Quizás una de las afirmaciones más emblemáticas a este respecto haya sido la del FMI, que en 2006, un año antes de que estallara la crisis financiera mundial, destacó que el estado económico del mundo nunca había sido mejor. Muchos economistas, además, descartaron que los supuestos desbalances globales, la liberalización y desregulación financiera, o el creciente endeudamiento del sector privado en los países desarrollados, pudieran ser una fuente de preocupación, riesgo o fragilidad (Bernanke, 2005; Mussa, 2006; Hausmann y Sturzenegger, 2006; Posen, 2007a; Greenspan, 2005).

En el período previo a estas crisis, gran parte de los economistas y políticos del mundo celebraron la tranquilidad prevaleciente o, de manera más precisa, la Gran Moderación de las economías más avanzadas. El término "Gran Moderación" fue acuñado para reflejar un período histórico, de más de dos décadas de duración (1980-2006), caracterizado por una creciente estabilidad en los precios y en el nivel del PIB (Bernanke, 2005a y 2005b).

La Gran Moderación no solo fue vista como un fenómeno confinado a los países más desarrollados, sino que se extendió, aunque de manera más tardía, al mundo en desarrollo. A partir de la década de 1990, el mundo en desarrollo también experimentó una menor volatilidad real y un menor nivel y volatilidad de la inflación (Coric, 2011; De Gregorio, 2007) ${ }^{3}$. Como región, América Latina y el Caribe redujo la volatilidad real en la década de $2000^{4}$.

El mundo en desarrollo no solo había moderado su volatilidad, sino que además logró elevadas tasas de crecimiento en términos históricos. En el período de mayor crecimiento previo a la crisis (2002-2008), las economías emergentes y en desarrollo se expandieron en conjunto un promedio de entre 4 y 5 puntos porcentuales más que las economías desarrolladas, lo que representó la mayor brecha de crecimiento de la historia entre ambos

Sobre la base de una muestra de 98 países del mundo, desarrollados y en desarrollo, Coric (2011) observa que la volatilidad real se redujo de manera generalizada en la mayoría de los casos a partir de la década de 1980. En virtud de una muestra de 180 países del mundo, Pérez Caldentey y Vernengo muestran que en más del $80 \%$ de los casos, la volatilidad de la inflación se redujo desde mediados de los años noventa.

4 No obstante, del análisis a nivel de cada país se deduce que la reducción de la volatilidad real en América Latina comenzó, en algunos casos, en la década de 1990. 
polos. Esta diferencia de crecimiento permitió, a su vez, reflotar la idea de la convergencia del mundo en desarrollo hacia los estándares de vida de las economías más industrializadas.

Varias regiones del mundo en desarrollo no solo experimentaron en este período previo a la crisis un gran crecimiento - que en el caso de América Latina y el Caribe fue el más elevado en tres décadas-, sino que dicho crecimiento estuvo acompañado de una situación de holgura en el sector externo que resulta inusual si se considera su historia económica ${ }^{5}$. Varias regiones del mundo en desarrollo crecieron intensamente, con un superávit en la cuenta corriente de la balanza de pagos y niveles controlados de inflación y deuda pública. Esto suavizaba el problema de la restricción externa, que ha sido uno de los principales obstáculos para aumentar el crecimiento, incluso en nuestra región.

Finalmente, en el caso de América Latina y el Caribe, un tercer factor que promovió un sentido de optimismo fue la mejora de las condiciones sociales (resumidas en la reducción de la pobreza y la incipiente disminución de la desigualdad), la consolidación de los procesos democráticos y un período caracterizado, con contadas excepciones, por la ausencia de conflictos armados ${ }^{6}$.

La Gran Moderación en el mundo desarrollado y en desarrollo fue vista con beneplácito y celeridad como la consecuencia de un mejor manejo macroeconómico y de la capacidad de las autoridades monetarias y fiscales de manejar a sus anchas el ciclo económico ${ }^{7}$. En el caso de América Latina y el Caribe, la Gran Moderación se interpretó como un resultado exitoso de la aplicación de las políticas del Consenso de Washington, en mayor o menor grado, y de su mantra "estabilizar, liberalizar y privatizar"8.

En virtud de la lógica conceptual del Consenso de Washington, se argumentó que los fundamentos de la región mejoraron en las décadas de 1990 y 2000 gracias a la adecuada implementación del paradigma

5 En el período de expansión más reciente antes de la crisis (2003-2007), América Latina y el Caribe registró una tasa de crecimiento del 3,7\%, muy superior a la contracción registrada en los años ochenta $(-0,8 \%)$. Esta tasa de crecimiento duplicó con creces el magro crecimiento de la década de 1990. Incluso, el desempeño económico del período 2003-2007 fue algo superior al registrado en los años setenta. El ciclo de crecimiento con holgura en el sector externo se refiere a promedios regionales y a las economías más grandes de la región, ya que esto no ocurrió en las economías más pequeñas, incluidas las del Caribe y Centroamérica. Para la región en su conjunto, el período 2003-2007 constituyó un ciclo con características muy particulares. América Latina y el Caribe no ha tenido, en términos regionales, un ciclo expansivo con superávit en la cuenta corriente en más de tres décadas.

6 El número de pobres no indigentes en la región disminuyó de 225 millones a 167 millones entre 2002 y 2011, lo que equivale a una reducción del $44 \%$ al $29 \%$ de la población total (véase CEPAL, 2013).

7 Algunos economistas, como Lucas (2003), afirmaron que la macroeconomía había resuelto su problema central: la prevención de depresiones y crisis.

8 Ocampo (2008 y 2011) y Pérez Caldentey y Vernengo (2010) constituyen una excepción. 
dominante, y que esto se tradujo en un aumento de la tasa de crecimiento y una mejor resistencia a los choques externos adversos (BID, 2008; FMI, 2008; Corbo y Schmidt-Hebbel, 2013; Porcekanski, 2009). Obviamente, no todas las políticas siguieron los dictámenes del mercado como única manera de asignar los recursos y, de hecho, se adoptaron políticas sociales nuevas y el gasto social a nivel regional aumentó del 15\% al 19\% del PIB entre 2000-2001 y 2010-2011 (Cornia y Martorano, 2010).

La complacencia que mostraron los economistas con el estado de la economía mundial en la etapa previa a la crisis, su dificultad para advertir acerca de los desequilibrios nacionales e internacionales que llevaron a la crisis, su escaso poder predictivo y su falta de entendimiento respecto de la naturaleza y los efectos de la crisis han expuesto al paradigma dominante a importantes críticas, tanto desde dentro como desde fuera. Estas críticas incluyen el cuestionamiento de su validez conceptual y empírica.

Llegados a este punto, y antes de analizar con mayor detalle las críticas al paradigma dominante y las contrarrespuestas, es necesario definir y caracterizar lo que se entiende por "paradigma dominante". Esto constituye el objeto de la sección subsiguiente desde la perspectiva del nuevo consenso.

\section{B. El paradigma económico dominante: sus bases teóricas e implicaciones de política económica}

El conjunto de supuestos e ideas que tradicionalmente ha dominado el panorama de la teoría y de la política económica en las últimas seis décadas, el denominado "paradigma económico dominante" (mainstream economics), se desarrolló a partir del análisis de largo plazo. Este fue concebido como una categoría analítica y un marco de referencia para caracterizar, de manera abstracta y coherente, el funcionamiento de las economías de libre mercado, que, pese a no tener mecanismos de coordinación directos, exhiben una regularidad sistemática (Arrow-Debreu, 1954; Hahn, 1981; Friedman, 1974) 9 .

El análisis de largo plazo consiste, por lo general, en especificar posiciones de equilibrio que reflejan esta regularidad sistemática al ser el resultado de todos los tipos de transacciones que pueden llevarse a cabo bajo un régimen de libre competencia. Para efectos prácticos, dichas posiciones de equilibrio han sido caracterizadas en distintos momentos en términos del precio natural o el precio normal de largo plazo (Smith, 1776; Marshall, 1920), la tasa natural de interés (Wicksell, 1898;

El paradigma dominante incluye a los keynesianos de la síntesis neoclásica, los monetaristas, la nueva macroeconomía clásica, los nuevos keynesianos y la escuela austríaca. 
Mankiw, 2010), el PIB potencial o la tasa natural de desempleo (Friedman, 1968; Gali, 2008; Wren-Lewis, 2014).

La particularidad esencial del paradigma económico dominante respecto de otras corrientes de pensamiento es que el largo plazo y, por consiguiente, la regularidad sistemática de las economías de libre mercado, se establece a partir de una estructura analítica que incluye tres categorías independientes de datos: las dotaciones y su distribución, las preferencias y funciones de utilidad, y la tecnología ${ }^{10}$. Puesta así, la teoría permite determinar de manera simultánea las cantidades de bienes y servicios (y el producto) y los precios (precios relativos y nivel de precios). En otras palabras, la teoría que determina las cantidades y el producto es la misma que determina los precios relativos y el nivel de precios (i. e., la teoría del valor es la misma que la teoría de la determinación del producto) (Eatwell, 1983 y 1987; Garegnani, 1990). Esto confiere al pensamiento dominante una coherencia y unidad únicas, con pocos precedentes en la historia del pensamiento económico.

Las posiciones de equilibrio de largo plazo tienen, a la vez, un aspecto positivo y otro normativo. El aspecto positivo se refiere a la descripción de cómo el mecanismo de mercado determina los precios y asigna los recursos.

El aspecto normativo tiene que ver con la evaluación de cuán eficientemente realiza las funciones de determinación de precios y asignación de bienes y servicios, cuando el mercado se considera como parte de un conjunto de los posibles mecanismos de asignación de recursos. El aspecto normativo se resume en la noción de óptimo de Pareto (1906). Este requiere que en una asignación de recursos, estos no se desperdicien, en el sentido de que no existe una manera de reasignar recursos que sea satisfactoria para todos (Debreu, 1959).

El equilibrio competitivo se relaciona con la noción de óptimo de Pareto a través de dos teoremas: i) todo equilibrio competitivo es un óptimo de Pareto y ii) cualquier óptimo de Pareto puede ser representado como el resultado último del mecanismo de intercambio de mercado a través de un sistema de redistribución de ingresos. El segundo teorema permite plantear la posibilidad de intervención externa desde un inicio, ya sea de un gobierno o de un planificador social, en la determinación de un equilibrio competitivo de mercado. De hecho, tomados en conjunto, los dos teoremas implican que las críticas al funcionamiento del mercado se reducen a temas de equidad y no de eficiencia (a menos que existan

10 Obviamente, las preferencias deben ser independientes de las dotaciones y las dotaciones deben poder expresarse con independencia de los precios y de la distribución, y ser apropiadas a la técnica de producción que permite la minimización de los costos. 
fallas de mercado $)^{11}$. Los temas de equidad, además, se pueden resolver mediante la redistribución inicial de los recursos ${ }^{12}$.

Esta visión del largo plazo se constituyó en el núcleo duro y en el auténtico consenso del pensamiento predominante y se analizó de manera estática y dinámica, si bien el análisis dinámico a través de la teoría del crecimiento económico se consolidó como el instrumento por excelencia para el examen a largo plazo (Acemoglu, 2009). La teoría del crecimiento se articula en torno de la noción del estado estable (steady state) (una situación en la que todas las variables consideradas crecen a la misma tasa), sus propiedades y el análisis de la convergencia hacia dicho estado (Solow, 2000, pág. 4). La situación del estado estable, incluida la determinación de los precios de los factores de producción y el nivel de ingreso, es el resultado de la dotación de factores y las condiciones técnicas de producción que operan en un régimen de competencia. Temas tales como la estructura productiva, el cambio estructural o la distribución del ingreso son más bien tangenciales o de importancia secundaria para este enfoque $\mathrm{e}^{13}$.

Los debates que han tenido lugar dentro del paradigma dominante rara vez, por no decir nunca, tocaron las bases teóricas del largo plazo, sino que más bien se centraron en el corto plazo ${ }^{14}$.

11 Las fallas de mercado son inherentes al funcionamiento del mercado e impiden que se llegue a una asignación eficiente de recursos. Se dan en cuatro grandes casos: bienes públicos y externalidades, rendimientos crecientes a escala, monopolio natural y asimetrías de información.

12 No obstante, según la lógica de la teoría, la intervención para redistribuir los recursos y dotaciones ocurre con anterioridad al comienzo de la actividad económica. La redistribución de recursos no distorsiona el funcionamiento del mercado, ya que todos los agentes enfrentan el mismo conjunto de precios y los mismos costos de oportunidad marginales.

13 La preocupación por el cambio estructural constituye una parte importante de las teorías del desarrollo económico y en general de la literatura sobre el tema, como se atestigua en la parte 2 sobre transformación estructural y el capítulo 7 sobre patrones de cambio estructural en Chenery y Srinivasan (1988). En cambio, no tiene lugar en el modelo de crecimiento neoclásico; las actividades económicas son, de hecho, estructuralmente similares y pueden ser agregadas en un sector representativo. Las teorías del crecimiento endógeno, si bien se centran en variables como la productividad y el capital humano, por lo general no tienen en cuenta cambios en la composición del producto y del empleo. Murphy, Shleifer y Vishny (1989), y Hansen y Prescott (2002), y quizás también Lucas (2004), son una excepción a esta observación. Las contribuciones seminales en la teoría del crecimiento del paradigma dominante incluyen a Solow (1956 y 1957), Lucas (1988), Romer (1986 y 1990), Grossman y Helpman (1991), y Aghion y Howitt (1992). Véase el tratamiento del cambio estructural en Ishikawa (1987) para las teorías del desarrollo y en Matsuyama (2008) para los enfoques de crecimiento del paradigma dominante.

14 Entre los debates de mayor notoriedad se incluye el debate de monetaristas y keynesianos sobre los parámetros de las funciones IS-LM, la función de consumo y la velocidad de circulación del dinero (Friedman, 1970; Tobin, 1970), los debates sobre las políticas de estabilización (Modigliani, 1977), los debates sobre la curva de oferta o curva de Phillips (Friedman, 1968; Lucas, 1972b; Sargent y Wallace, 1976) y los debates sobre la rigidez de precios. Los debates más recientes se han focalizado en la política monetaria y en la posibilidad de hacer política monetaria en una economía sin dinero (Woodford, 2003). El debate más importante sobre el largo plazo es el de la controversia sobre la teoría del capital (Harcourt, 1991; Cohen y Harcourt, 2003; Eatwell y Milgate, 1999). 
El corto plazo se especifica solo con referencia al largo plazo y, parafraseando a Samuelson (1947, págs. 36-39), en términos de "restricciones auxiliares" que modifican el principio básico del equilibrio (el principio de Le Chatelier), según el cual, un desplazamiento fuera del equilibrio en una determinada dirección, necesariamente conlleva un movimiento convergente en la dirección opuesta. En la literatura, las posiciones de corto plazo pasaron a identificarse con la existencia de un menú de imperfecciones de mercado $^{15}$. Bajo esta óptica, la superposición de imperfecciones sobre posiciones de equilibrio de largo plazo permitió explicar la ocurrencia de las fluctuaciones económicas y el ciclo, la utilización subóptima de los factores de producción, incluido el desempleo, y del producto y la inflación. Así, por ejemplo, el ciclo no pasa de ser una consecuencia del mal ajuste entre la oferta y la demanda agregadas (Wren-Lewis, 2014).

La existencia de imperfecciones, no obstante, posee una ventaja adicional, ya que estas permiten establecer la racionalidad para la intervención externa en los mercados en el corto plazo y, de manera más precisa, para el uso de las políticas fiscales, y en particular de la política monetaria. De hecho, la capacidad de controlar el nivel de precios y sus fluctuaciones a través del manejo de la tasa de interés radica en la existencia de fricciones monetarias (Woodford, 2003; Gali, 2008).

La relación entre el largo y el corto plazo nunca ha sido fácil. Se trata más bien de una relación distante, tal y como lo atestigua el tratamiento de ambos plazos en la mayoría de los manuales de economía, como dos categorías de análisis separadas, con métodos y enfoques propios y con escasa interrelación. Esta relación también ha dado pie a incoherencias en los fundamentos del propio paradigma y ha sido conflictiva en sendas ocasiones, como lo refleja el debate sobre los microfundamentos y el perenne surgimiento de dicotomías dentro del paradigma dominante ${ }^{16}$.

Eventualmente, la racionalización del funcionamiento del corto plazo sobre la base del comportamiento racional, y en particular del principio de maximización sujeta a restricciones, permitió tender el puente necesario para unificar el corto y el largo plazo bajo una sola teoría. El paradigma dominante pasó a ilustrar el dictamen de los Fundamentos

15 Las imperfecciones de mercado no son lo mismo que las fallas de mercado. Mientras que las fallas de mercado (véase la nota al pie $\mathrm{N}^{\circ} 13$ ) son inherentes al funcionamiento del mercado, las imperfecciones de mercado se imponen sobre la existencia de un equilibrio competitivo. Las imperfecciones más conocidas en la literatura son la rigidez de precios (salarios o tasas de interés), las barreras institucionales que impiden que el mercado asigne recursos de manera eficiente en el corto plazo y la falta de una respuesta apropiada de los agentes a los incentivos de precios (Eatwell, 1987, pág. 727).

16 Véase información sobre microfundamentos en Weintraub (1979), sobre la dicotomía inválida entre el sector real y monetario en Patinkin (1956 y 1987), y sobre cinco neutralidades en el paradigma dominante en Akerloff (2006). 
del Análisis Económico de Samuelson (1947), según el cual, la existencia de analogías entre las características principales de distintas teorías particulares implica que existe una teoría general común subyacente (i. e., la maximización sujeta a restricciones), capaz de incorporar y unificar los puntos específicos de estas teorías particulares.

De esta manera, la misma lógica, el mismo aparato conceptual y, sobre todo, el mismo principio que se venía aplicando a una amplia gama de temas, incluidos no solo los temas económicos per se, sino también los temas ambientales y sociales (como la educación, la protección social, el género y la familia), podía extenderse para cubrir la especificidad del corto plazo y de su relación con el largo plazo ${ }^{17}$. Como señaló Allais (1966, pág. 1156), las sociedades humanas situadas en distintos contextos, en regímenes capitalistas o comunistas, hoy o hace medio siglo, responden a una misma ley: la maximización de la utilidad. Este autor, que recibió el premio Nobel de economía en 1988, también indicó que la similitud del comportamiento debe ser interpretada como correspondiente a la invariabilidad de la sicología humana en el espacio y el tiempo, por los menos en su aspecto colectivo.

Este esfuerzo unificador, basado en la aplicación de la maximización de la utilidad a todo el espectro de la teoría económica, no cambió sustancialmente ni las bases conceptuales, ni las políticas asociadas al largo plazo y al crecimiento económico. Tampoco modificó los lineamientos de las políticas microeconómicas. No obstante, permitió zanjar de manera casi definitiva algunos de los debates más importantes con respecto al corto plazo y de manera más precisa los debates en torno al papel de la demanda agregada y la eficacia de sus principales instrumentos.

Este consenso que unificó el largo y el corto plazo en una misma teoría (también llamado "nuevo consenso" o "nueva síntesis neoclásica") se articula sobre la base de tres ideas ${ }^{18}:$ i) la existencia de niveles "naturales" para el producto y la tasa de interés para caracterizar las posiciones

17 Véase una aplicación de este marco conceptual a distintos aspectos del comportamiento humano y de la actividad económica en Friedman (1962), Coddington (1983), Becker (1978 y 1981) y Lucas (1986 y 1991). La lógica que subyace a estos trabajos fue aplicada en América Latina y el Caribe en las décadas de 1980 y 1990 en temas de educación, salud y pensiones. El tratado sobre la familia de Becker (1981) es sumamente ilustrativo de este enfoque, ya que en él se argumenta, entre otras cosas, que las personas racionales se casan incluso cuando están seguras de encontrar una mejor perspectiva con mayor búsqueda, cuando el costo de la búsqueda adicional excede los beneficios esperados de una mejor perspectiva, y que la aplicación de las ventajas comparativas implica que los hombres se especializarán en el sector del mercado y las mujeres en el sector de los hogares. Como resultado, la tasa salarial de los hombres excederá a la de las mujeres. De la misma manera, la aplicación de este marco al medio ambiente implica que la tasa intertemporal de explotación de los recursos naturales no renovables debe dejarse al mercado, a menos que se demuestre una falla de mercado y que se pueda desarrollar una política correctiva (Solow, 1974; Davidson, 1979).

18 Véase una exposición del nuevo consenso en Blanchard (2008), Woodford (2009) y Gali (2008). 
de largo plazo (Gali, 2008, pág. 186), ii) la introducción de rigideces e imperfecciones microfundamentadas con expectativas racionales y iii) el análisis del corto plazo (ciclo y demanda agregada) como un tema de desviación entre las variables actuales y sus niveles naturales (WrenLewis, 2014) ${ }^{19}$. Las principales implicaciones de este enfoque en términos de política económica se centran en la primacía de la política monetaria a través del manejo de la tasa de interés para administrar el ciclo y, en general, de la demanda agregada, y en la subordinación de la política fiscal a los fines de la política monetaria ${ }^{20}$. Este marco tiene, además, dos propiedades que son fundamentales para su aceptación porque justifican su validez en términos económicos y sociales: a) el carácter contracíclico de la política monetaria y b) la idea de que estabilizar la inflación alrededor de su meta es equivalente a estabilizar el producto real alrededor de su nivel natural o la equivalencia entre la estabilidad nominal y la real ("la coincidencia divina") (Blanchard, 2006; Blanchard y Gali, 2005; Pérez Caldentey y Vernengo, 2013).

A la par del desarrollo de un nuevo consenso en economía, también se gestó un consenso en finanzas, cuyos principios de base no difieren de los del nuevo consenso ${ }^{21}$. El consenso en finanzas se encapsula en cuatro componentes: la hipótesis de mercados eficientes, la relación entre riesgo y retorno, el teorema de Modigliani-Miller y el enfoque de Black-ScholesMerton. El componente más importante es la hipótesis de mercados eficientes porque constituye la base que sustenta y alrededor de la cual se desarrollaron los otros teoremas.

Definida en su forma más fuerte, la hipótesis de mercados eficientes excluye la posibilidad de que sistemas de intercambio tales como el mercado de valores, basados solo en la información actual disponible, tengan beneficios o retornos esperados que excedan el beneficio o retorno

19 El nuevo consenso se identifica con los nuevos keynesianos. La existencia de rigideces los asemeja a la síntesis neoclásica, pero con la ventaja de haberlas microfundamentado y de sustentarlas en el comportamiento racional de los agentes. En esto se parecen a la nueva macroeconomía clásica. Como ellos mismos reconocen, los nuevos keynesianos tienen mucho en común con los monetaristas y podrían perfectamente llamarse "los nuevos monetaristas". Véanse, Mankiw y Romer (1991).

20 Como expresó Blinder (1986), la sabiduría convencional actual sostiene que los cambios discrecionales en la política fiscal hacen poco bien e incluso pueden hacer daño. ¿Por qué ocurre esto? Primero hay que considerar que los rezagos son largos y quizás más largos que una recesión típica. En segundo término, los efectos del instrumento más plausible de la política fiscal, los cambios en los impuestos a los ingresos (o pagos por transferencias), pueden verse debilitados por su uso temporal. Y en tercer lugar, hay un instrumento superior de estabilización que está inmediatamente disponible: la política monetaria.

21 Como señala Fama (2007), no se puede testear modelos de equilibrio sin la eficiencia de mercado porque la gran mayoría de los modelos de equilibrio de mercado parten de la suposición de que los mercados son eficientes. Parten con una versión fuerte de esa hipótesis, de que todo el mundo tiene la información relevante. Los test de eficiencia de mercado son test de equilibrio de mercado, y viceversa, y ambos están indisolublemente unidos. 
de equilibrio (Fama, 1970, pág. 384). La relación entre riesgo y retorno se presume positiva de tal manera que para que un inversionista tenga una mayor tasa de retorno debe estar dispuesto a asumir un mayor nivel de riesgo. El teorema de Modigliani-Miller afirma que, bajo determinadas suposiciones (mercados completos, perfectos y sin gobierno), la forma mediante la cual una empresa financia sus actividades productivas no afecta el costo de capital ni tiene influencia alguna sobre su valor de mercado o sobre las decisiones de producción y consumo de otros agentes económicos. De acuerdo con el enfoque de Black-Scholes-Merton, cualquier cosa podría servir de activo, todo activo tiene un precio y puede ser comercializado, y cualquier riesgo se puede diversificar. Esto sentó las bases para la creación de una espiral de innovación financiera con vistas a crear una utopía de mercados completos y costos de transacción nulos.

Tomados en conjunto, estos teoremas son completamente compatibles y complementarios, y establecen una coherencia y lógica común para las finanzas en el paradigma dominante, que puede explicitarse de la siguiente manera.

Cualquier activo puede comercializarse (ya sea que se trate de activos comunes o de activos más sofisticados, como las opciones y los derivados). En consecuencia, todo activo tiene un precio y una tasa de retorno en un mercado eficiente (teorema de Black-Scholes-Merton e hipótesis de mercados eficientes). En los mercados de activos no hay oportunidades de arbitraje y los precios deben ser iguales al valor presente descontado de los ingresos futuros sobre la vida del activo (hipótesis de mercados eficientes, relación entre riesgo y retorno, Modigliani-Miller, Black-Scholes-Merton). El mejor predictor de los flujos de ingresos futuros son los flujos de ingresos actuales y la tasa de descuento es la tasa libre de riesgo (hipótesis de mercados eficientes, relación entre riesgo y retorno, Modigliani-Miller, Black-Scholes-Merton). Esto es así porque el riesgo de un activo es independiente de cómo este se financie (Modigliani-Miller) $\mathrm{y}$ viene determinado por el riesgo sistemático (relación entre riesgo y retorno). Además, cualquier activo puede reducir su riesgo y tener una tasa de interés libre de riesgo (Black-Scholes-Merton).

Al igual que el nuevo consenso en economía descartó el uso de la política fiscal para manejar el ciclo, dejando a la política monetaria la tarea de administrar la demanda agregada, el consenso en finanzas excluyó las finanzas del ámbito de acción gubernamental. En definitiva, sentó la base -y, de manera más precisa, la "base científica" - para que las fuerzas de mercado se hicieran cargo de las finanzas a nivel nacional, regional y mundial. 


\section{Las críticas al paradigma económico dominante y las contrarrespuestas}

Aunque las críticas han llovido sobre distintos aspectos del paradigma dominante, el grueso se ha centrado en la falta de correspondencia entre los modelos económicos, sus prescripciones de política económica y la realidad del funcionamiento de las economías de mercado, sobre todo a la luz de los cambios en el sistema financiero de las últimas tres décadas ${ }^{22}$. De manera más particular, se critica el excesivo peso de la técnica, de la formalización y de la elegancia matemática en detrimento del realismo y la aplicabilidad de los modelos a las condiciones del mundo real ${ }^{23}$.

Las contrarrespuestas a las críticas no se hicieron esperar y son de dos tipos. Por una parte, un grupo de economistas salió en defensa del enfoque predominante y afirmó la necesidad de reforzar sus aspectos más formales (Sargent, 2010; Lucas, 2009 y 2012; Cochrane, 2009; Fama, 2011; Taylor, 2004). El reciente premio Nobel de economía Eugene Fama (2011) afirmó que la crisis financiera mundial no contradijo la hipótesis eficiente de los mercados financieros, sino que fue una perfecta ilustración de sus principios de base. Para Fama, al igual que para Taylor, la crisis global y financiera es un producto de la regulación gubernamental y el sector financiero es una mera "víctima" de dicha regulación. Como pronostica la hipótesis de mercados eficientes, la crisis generó una mayor volatilidad en los mercados financieros simplemente porque al cambiar tan rápido las noticias y opiniones con respecto al futuro, los agentes incorporaban estos cambios en sus proyecciones (Fama, 2011).

Este grupo de economistas ha defendido el paradigma argumentando que el estallido de la crisis y sus efectos demostraron la necesidad de profundizar la formalización y el uso del instrumental matemático para caracterizar el funcionamiento de las economías de mercado.

Así, por ejemplo, el premio Nobel de economía Sargent (2010) afirmó que mientras más dinámico, incierto y ambiguo sea el contexto económico que se quiere modelar, más mangas hay que arremangarse y aprender y utilizar las matemáticas. De la misma manera, Cochrane (2009) argumentó que el problema es que no tenemos suficiente matemáticas. La matemática

22 En el campo de la teoría, los economistas han señalado algunas deficiencias importantes, como la falta de incorporación del sector bancario y financiero en los análisis (Woodford, 2010; Clarida, 2010; Mishkin 2010; Blanchard, Dell'Ariccia y Mauro (2013), el excesivo peso de la formalización y de la modelística en el análisis económico, la falta de heterogeneidad (Caballero, 2010), la eficiencia de los mercados financieros (Bean y otros, 2010) y el uso indebido de las técnicas cuantitativas (Juselius, 2009).

23 Esta, de hecho, es una antigua disputa que ha vuelto a tomar relevancia como consecuencia de la crisis financiera mundial (Hahn, 1981, pág. 1). Curiosamente, Friedman (1953b, 1974) hizo una crítica similar con respecto al enfoque neowalrasiano de Oscar Lange y también a la manera de enfocar la economía por parte de los economistas que desarrollaron la síntesis neoclásica. 
en economía sirve para mantener diestra la lógica para asegurarse de que el "entonces" sigue al "si suponemos", que frecuentemente no es el caso si solo se escribe prosa. El desafío es cuán difícil es escribir economías artificiales explícitas con estos ingredientes, y de hecho resolverlas, para, de esta manera, saber cómo funcionan.

Esta postura se ha dado con mayor fuerza en el mundo en desarrollo, incluso en América Latina y el Caribe, donde los efectos de la crisis han sido menos intensos y duraderos que en el mundo desarrollado. De hecho, en términos comparativos, no solo los efectos han sido más benignos que en otros episodios de crisis, sino que la recuperación ha sido mucho más rápida (Didier, Hevia y Schmukler, 2012; Corbo y Schmidt-Hebbel, 2013; Álvarez y De Gregorio, 2013).

En la región, los economistas del paradigma dominante argumentan que los fundamentos económicos mejoraron sustancialmente gracias a la exitosa aplicación de las políticas de dicho paradigma. La mejora en los fundamentos derivó, en primer lugar, de los cambios en el régimen macroeconómico y, de manera más precisa, de la conducción de la política fiscal, monetaria y cambiaria.

En el plano fiscal se adoptaron políticas de ortodoxia fiscal, lo que permitió reducir la deuda pública, el ahorro de los ingresos inesperados del aumento de las materias primas y el uso de la política contracíclica en la recesión de 2008-2009. En segundo lugar, el cambio de los regímenes de tipo de cambio fijo a otros con mayor flexibilidad cambiaria permitió evitar las crisis cambiarias recurrentes, amortiguar los choques externos adversos y habilitar la adopción de políticas monetarias independientes. Un tercer elemento de este conjunto de políticas es la independencia del banco central, lo que, a su vez, mantiene la independencia de las políticas monetarias y evita la interferencia del gobierno y la subordinación de la política monetaria a la política fiscal. Esto permitió la reducción significativa de la inflación en América Latina y la mejora de la credibilidad y la reputación de las autoridades monetarias.

Un segundo elemento que explica el desempeño de América Latina y el Caribe es la expansión del sector financiero en términos de la profundidad y diversidad de sus servicios. Aparte de la estabilidad macroeconómica, esto se explica por la liberalización, la desregulación, y la privatización de la banca comercial y el sistema financiero. También en algunos casos se incluye como factor determinante la reforma de los mercados de capitales, lo que impulsó el desarrollo de los mercados de deuda privada y de valores, de los mercados de seguro y de los fondos de pensiones (Henry, 2007, pág. 60). 
Finalmente, la explicación añade a estos dos factores la profundización del proceso de inserción comercial y financiero. La profundización del proceso de apertura comercial redundó en una disminución de las barreras arancelarias y no arancelarias, lo que impulsó el crecimiento del comercio. Por su parte, la apertura financiera permitió la acumulación de activos y pasivos externos, lo que contribuye a una asignación más eficiente de recursos y a mejores garantías frente a los choques nacionales idiosincráticos, y por lo tanto, a un mayor crecimiento y una menor volatilidad del ingreso y de la producción (Henry, 2007, pág. 62) ${ }^{24}$.

En contraposición a esta postura de "no cambiar nada", otros economistas han planteado la necesidad de modificar la teoría económica y en particular la macroeconomía. La opinión más frecuente es que los modelos económicos del nuevo consenso se han diseñado en la dirección correcta, pero se han mantenido a la sombra al sector financiero y deben ser capaces de incorporarlo de manera explícita (véanse Krugman, 2009; Acemogulo, 2009; Lux and Westerhoff, 2009; Akerloff y Schiller, 2009; y Romer, 2013 para el mundo desarrollado, y Calvo, 2010; Mendoza, 2010; y De Gregorio, 2009 para el mundo en desarrollo y América Latina y el Caribe) ${ }^{25}$. En esta línea, el FMI ha planteado la necesidad de reconsiderar algunos de los principios de la macroeconomía convencional y manifestó que la crisis global y financiera de 2008-2009 sacudió el consenso de cómo administrar la política macroeconómica y nos hizo recordar los peligros asociados con desbalances en el sector financiero, mostró las limitaciones de la política monetaria e hizo dudar de algunos de los principios de sus fundamentos intelectuales, y llevó a una reevaluación de qué niveles de deuda pública pueden ser considerados aceptables. Esto condujo a una reconsideración de lo que funcionó y no funcionó, y a un debate acerca de cómo arreglar las cosas desde puntos de vista técnicos a preguntas de diseño institucional más amplias. Cinco años después del comienzo de la crisis, los contornos de un nuevo consenso de la política macroeconómica aún no están claros (Blanchard, Dell'Ariccia, y Mauro, 2013, pág. 3).

No obstante, los pasos que se han dado en esta dirección no alteran la sustancia ni del nuevo consenso ni del paradigma dominante. Se trata de incorporar otra vez algún tipo de imperfección para poder generar

24 Véase en Henry (2007) un análisis detallado de la manera en que, según el modelo de crecimiento neoclásico, la liberalización financiera se traduce en un aumento de los flujos financieros de norte a sur, incrementando de modo permanente el nivel de vida en el sur. El enfoque intertemporal de la balanza de pagos presenta un razonamiento similar (Obstfeld y Rogoff, 1996). Jara, Moreno y Tovar (2008) también enfatizan los aspectos positivos de la acumulación de activos externos y los progresos logrados en el desarrollo de los mercados de deuda internos.

25 Véase también Calvo (2012). De acuerdo con Calvo, la característica definitoria de la macroeconomía del siglo XXI es que el sector financiero puede ser una fuente de choques macroeconómicos de talla mayor. Este era el rasgo distintivo de la macroeconomía a principios del siglo XX. Véase más información en Bernanke, Gertler y Gilchrist (1999) y Borio (2012) han llevado adelante algunas iniciativas para introducir este tipo de factores. 
posiciones y una dinámica de corto plazo que eventualmente tiende a converger o a adaptarse al largo plazo, caracterizado por las fuerzas reales del sistema. En definitiva, se trata de modificar el paradigma dominante para no cambiar nada ${ }^{26}$.

Un auténtico esfuerzo para modificar el nuevo consenso requiere no solo reformular la determinación del corto y largo plazo y su relación, sino también cambiar la microeconomía y repensar de manera general el enfoque de la teoría económica. Tal como se argumentó, la macroeconomía moderna está fundamentada en la microeconomía, y ambas están edificadas sobre la base del mismo principio. En definitiva, los defectos que se atribuyen a la macroeconomía como consecuencia de las crisis recientes y sus efectos revelan, de hecho, la debilidad de los fundamentos microeconómicos del paradigma dominante ${ }^{27}$.

\section{La visión de la economía desde el estructuralismo y la heterodoxia}

En este trabajo se parte de la premisa de que el diagnóstico de "repensar la economía", tanto desde la perspectiva de un mayor equilibrio entre corrientes de pensamiento tradicionales, alternativas y novedosas, como sobre sus formas de enseñanza, es acertado. De hecho, en la historia de las ciencias sociales, y en particular en economía, las nuevas teorías tienden a surgir cuando la ciencia "establecida" o "normal" choca con eventos y anomalías dentro de su propio planteamiento, que esta no es capaz de explicar ni de resolver (Kuhn, 1970) ${ }^{28}$. En la actualidad, el paradigma dominante se encuentra frente a tal disyuntiva: la validez $\mathrm{y}$ coherencia de este enfoque se sustenta fundamentalmente en su capacidad predictiva (Friedman, 1953a y b; Allais, 1966; Lucas, 1988, 2002 y 2012). Se abre entonces una ventana de oportunidades para buscar planteamientos alternativos y esbozar nuevos principios a nivel de la teoría y de la práctica (i. e., de la política económica). Un paso adelante en esta dirección es centrar los esfuerzos en abrir los espacios de debate

\footnotetext{
26 En algunos casos, esto se resume en la introducción de fricciones financieras en la curva de demanda agregada (Woodford, 2010). Un esfuerzo de mayor talla es el de Borio, Disyatat y Juselius (2013), que pretenden introducir factores financieros en la medición del producto potencial (un concepto de oferta), pero parecería que su enfoque se resume más bien a introducir estos factores en la brecha del producto.

27 Calvo (2012) alude a este hecho al admitir que la microeconomía puede tener pies de arcilla.

28 Según Kuhn, el desarrollo de la ciencia en períodos "normales" se guía por la adherencia a un paradigma. La función de un paradigma es presentar problemas y rompecabezas, y proveer herramientas para resolverlos. Una crisis ocurre cuando el paradigma dominante es incapaz de resolver una anomalía. En nuestra opinión, este proceso describe adecuadamente la evolución del paradigma dominante en teoría económica, así como su respuesta a las crisis recientes (Boumans y Davis, 2010). Véase una versión más sofisticada del concepto de ciencia normal en Lakatos (1970).
} 
y diálogo entre las corrientes de pensamiento que se han desarrollado al margen y en oposición al paradigma dominante.

El inicio de esta tarea en el caso particular de América Latina y el Caribe no requiere reinventar la rueda. Los elementos para un planteamiento alternativo sólido ya existen, ya que esta es una de las pocas regiones del mundo en desarrollo que tiene una larga tradición de pensamiento económico propio respecto de sus problemas y desafíos. $\mathrm{Si}$, tal como ha señalado Ocampo (2011), América Latina y el Caribe tiene quizás la institucionalidad regional más extensa y una de las más antiguas entre los países en desarrollo, esto se debe, en parte, a que este proceso es el resultado de un pensamiento nacional y regional de larga data.

No hay duda de que el pensamiento económico más completo que ha surgido en la región es el asociado con el grupo de economistas estructuralistas, que, entre 1940 y 1965, desde la Comisión Económica para América Latina y el Caribe (CEPAL) y el Instituto Superior de Estudos Brasileiros (ISEB), sentó los fundamentos y trabajó en distintos aspectos de la economía del desarrollo. Estos economistas son Celso Furtado (1920-2004), William Arthur Lewis (1915-1991), Raúl Prebisch (1901-1986), Juan Noyola Vásquez (1922-1962), Aníbal Pinto Santa Cruz (1919-1996), Osvaldo Sunkel (1929) e Ignacio Rangel (1914-1994) ${ }^{29}$.

El pensamiento estructuralista se articuló en torno a los siguientes temas, que, con distinto énfasis, constituyeron sus pilares esenciales: las relaciones de poder y dependencia articuladas bajo el binomio centroperiferia, la crítica a la ley de las ventajas comparativas y la predominancia de la restricción externa, el carácter dual del desarrollo económico en distintos niveles (que se revela en fenómenos tales como la heterogeneidad estructural), la existencia de una oferta ilimitada de trabajo (que incide en la distribución del ingreso), una visión del desarrollo como cambio estructural, la necesidad de un desarrollo guiado por el Estado en materia de inversión en infraestructura y desarrollo productivo, la inflación como

29 Entre los economistas que trabajaron en el ISEB se encuentran Hélio Juaguaribe, Guerreiro Ramos, Cândido Mendes de Almeida, Álvaro Vieira Pinto, Roland Corbisier y Nelson Werneck Sodré. Los términos "estructuralista" y "estructuralismo" aparecen a principios de la década de 1960 en el contexto del debate sobre la inflación con la escuela monetarista e inicialmente tuvieron una connotación verbal para equiparar, desde el punto de vista terminológico, a la escuela monetarista y estructuralista (Campos, 1961; Danby, 2005). No obstante, es posible argumentar, como lo hace Mallorquín (1998, pág. 40), que los lineamientos básicos del estructuralismo ya estaban presentes en la década de 1950, en la obra de Furtado (A economia brasileira, 1954) y en el artículo de Noyola (1956). Obviamente, el término "estructuralista" es una categoría analítica y no todos los autores mencionados se autodenominaron estructuralistas. A este respecto, al comenzar a escribir Capitalismo periférico en 1970, Prebisch remarcó: “Yo no sé si después de esta exposición se me llamará estructuralista. Rechazo clasificarme y que me clasifiquen. Pero reconozco que hay que entrar a fondo en el examen estructural del capitalismo" (Prebisch, 1976 citado en Mallorquín, 1998, pág. 36). Véase un desarrollo analítico reciente de la inflación, en línea con el pensamiento estructuralista, en Vera (2013). 
un problema del desarrollo económico, y la necesidad de la inserción regional e internacional para sobreponerse al problema del subdesarrollo ${ }^{30}$.

La evolución del pensamiento de este grupo de economistas se benefició del intercambio intelectual con otros economistas de fuera de la región, cuyo foco de análisis fue el desarrollo económico con puntos de vista y posiciones similares, y que, de una $u$ otra manera, trabajaron con distinto grado de intensidad. Entre los economistas de fuera de la región que trabajaron en América Latina y el Caribe destacan, entre otros: Albert Hirschman (1915-2012), Gunnar Myrdal (1898-1987), Ragnar Nurske (1907-1959), Hans Singer (1910-2006), Paul Rosenstein-Rodan (1902-1985) y Hollis B. Chenery (1918-1994) ${ }^{31}$. Debido a la similitud de posturas entre ambos grupos de profesionales con respecto a temas clave como el comercio internacional, la industrialización y la inflación, y un enfoque metodológico común centrado en la observación empírica, es habitual que este grupo de economistas también se clasifique bajo el paraguas estructuralista.

Las ideas estructuralistas también se desarrollaron sobre la base del pensamiento de economistas pertenecientes a la tradición keynesiana, poskeynesiana y schumpeteriana. En particular, cabe destacar la influencia que tuvieron sobre la escuela estructuralista latinoamericana John Maynard Keynes (1883-1946), Roy Harrod (1900-1978), Nicholas Kaldor (1908-1986), Michael Kalecki (1899-1970) y Joseph Aloys Schumpeter (1883-1950) ${ }^{32}$.

Kaldor fue el que tuvo una mayor cercanía a América Latina y el Caribe, al estructuralismo y a la CEPAL, y cubrió un amplio espectro de temas, incluida la problemática de los países en desarrollo y de América Latina. A instancias de Prebisch, en 1956 Kaldor trabajó como consultor

$30 \quad$ El alguna ocasión Furtado afirmó que la escuela estructuralista latinoamericana explicaba la especificidad del subdesarrollo transformando los parámetros del análisis convencional en variables. Como se verá en el desarrollo de este artículo la escuela estructuralista no solo sustituye los parámetros del análisis convencional por variables sino que incluye variables que el análisis tradicional no contempla y plantea un enfoque novedoso para articular y establecer relaciones entre variables, así como para identificar sus determinantes.

31 Esta clasificación sigue los lineamientos de Pereira (2012b, pág. 348).

32 Love (1996, pág. 155) se refirió a la influencia de Kalecki, Kaldor y Chenery en la teoría de la inflación estructuralista. Comenzó diciendo que Kalecki impresionó a Noyola. Kalecki, Kaldor y Chenery escribieron antes que Sunkel y los dos últimos pasaron algún tiempo en Santiago mientras se desarrollaba la teoría estructuralista. No puede decirse que ellos trajeron el estructuralismo a América Latina, pero puede existir poca duda de que proveyeron un importante estímulo intelectual a su formulación. Ellos constituyeron el eslabón entre el pensamiento estructuralista que había surgido en Gran Bretaña (y en menor grado de los Estados Unidos) y la teoría estructuralista latinoamericana de la inflación. Por su parte, Noyola (1956) cita a Kalecki (1954) y a Aujac (1954). Sunkel (1958) fue quien articuló de manera más apta el enfoque estructuralista de la inflación que sirvió de base para los debates de la década de 1960 al distinguir entre las fuerzas causales de la inflación (factores básicos) y los mecanismos circunstanciales y de propagación. Cabe notar que esta metodología es característica del enfoque estructuralista. De hecho, no es exclusiva del análisis de la inflación y es muy similar a la manera en que Prebisch analizó el origen y la propagación de los ciclos. 
para la CEPAL y preparó el estudio Los problemas económicos de Chile, donde analizaba principalmente el problema de la desigualdad de los ingresos y abogaba por una interpretación estructuralista de la inflación ${ }^{33}$.

En los avances más recientes del pensamiento estructuralista, como el neoestructuralismo (1992-2012), se ha continuado trabajando y profundizando en los temas y las preocupaciones que constituyen el nudo gordiano del estructuralismo. A la vez, se ha ampliado su marco y objeto de análisis y refinado su enfoque metodológico y empírico.

El neoestructuralismo se desarrolló a partir del documento Transformación productiva con equidad (CEPAL, 1990) y del libro compilado por Osvaldo Sunkel, El desarrollo desde dentro: un enfoque neoestructuralista para América Latina $(1991)^{34}$. La elaboración de esta teoría constituye un esfuerzo para integrar al pensamiento estructuralista los cambios que ocurrieron en la región y a nivel internacional desde fines de los años ochenta, que incluyen la apertura comercial, la movilidad internacional de capitales, la privatización y la desregulación en un contexto de relaciones más estrechas con el resto del mundo y de mayor integración regional (Bielchowsky, 2009; Sunkel y Zulueta, 1990) ${ }^{35}$.

En el análisis del enfoque neoestructuralista se integraron consideraciones sobre temas fiscales, la liquidez y la regulación de la balanza de pagos, incluida la regulación de la cuenta de capitales (FfrenchDavis, 1991 ${ }^{36}$. A partir de la década de 2000, el neoestructuralismo se articuló alrededor de cuatro grandes áreas: macroeconomía y finanzas, comercio internacional, desarrollo social y sostenibilidad ambiental.

33 Kaldor se sintió impresionado por los análisis estructuralistas de la inflación desarrollados en la CEPAL, que tendrían su expresión final en los análisis de Noyola y Sunkel (Harrod, 1965; King, 2009, pág. 116). Durante su primera visita a la región, en las charlas que dictó en la Universidad en Chile y en el Brasil, Kaldor desarrolló una serie de conceptos que dominarían su pensamiento - como la causación cumulativa, el progreso técnico, la concentración industrial y los límites al crecimiento industrial - y que son fundamentales para conceptualizar el cambio estructural. Kaldor volvió a América Latina en numerosas ocasiones, y en particular a México, donde abordó los problemas de financiamiento del desarrollo y de una estrategia cambiaria para promover el desarrollo económico.

34 Fernando Fajnzylber jugó un papel central en la concepción de Transformación productiva con equidad (Fajnzylber, 1990). Entre los autores que contribuyeron al libro compilado por Sunkel se destacan Ricardo Ffrench-Davis, Joseph Ramos y Víctor E. Tokman.

35 El pensamiento estructuralista perdió visibilidad en la década de los ochenta con la crisis de la deuda y en parte en la década de los noventa con la primacía del Consenso de Washington. El pensamiento estructuralista tuvo una respuesta débil a la crisis de la deuda, cuya intensidad y duración responden más a factores financieros que a la torpeza e incompetencia de los hacedores de política (Díaz Alejandro, 1984) o a un modelo de desarrollo centrado en un Estado mal administrado e ineficiente. De hecho, la crisis de la deuda fue la primera crisis financiera moderna que experimentó América Latina y su ocurrencia responde a la ausencia de regulación financiera a nivel global.

36 Macroeconomía, comercio y finanzas: reformar las reformas en América Latina (FfrenchDavis, 2006) es una de las obras más completas y acabadas respecto de la incorporación de estos temas en el pensamiento neoestructuralista. 
Estos temas fueron abordados en profundidad en diversas publicaciones institucionales de la CEPAL, entre las que se destacan Globalización y desarrollo (2002) y Desarrollo productivo en economías abiertas (2004). Más recientemente se ha incorporado la temática de la igualdad como eje del desarrollo económico y social (La hora de la igualdad: brechas por cerrar, caminos por abrir (2010), Cambio estructural para la igualdad. Una visión integrada del desarrollo (2012) y Pactos para la igualdad. Hacia un futuro sostenible (2014) $)^{37}$. El neoestructuralismo de la CEPAL ha dado lugar a un programa que es heterodoxo en materia macroeconómica, desarrollista en cuanto a la asignación de recursos y la intervención del Estado, universalista en el campo social y conservacionista en materia ambiental (Bielchowsky, 2009).

El enfoque neoestructuralista guarda una remarcable similitud con el nuevo desarrollismo, que además se caracteriza por su énfasis en incorporar de manera más profunda las ideas de los keynesianos en algunos de los planteamientos del pensamiento estructuralista de base $^{38}$. Se trata de introducir la demanda como determinante esencial del crecimiento económico. Según este, como planteaban Keynes y Kaldor (por lo menos en la última etapa de su vida), el principal obstáculo al crecimiento y al pleno empleo radica en factores asociados a la demanda.

En consonancia con el enfoque estructuralista tradicional, el neoestructuralismo puede caracterizarse, en sus distintas acepciones, como un sistema o conjunto de ideas abierto. Los sistemas abiertos no se consideran autocontenidos y analizan el comportamiento de los agentes y las estructuras económicas y sociales, y su interrelación, en un contexto histórico y evolutivo (son dinámicos y cambian en el tiempo con el contexto y las circunstancias).

Esto implica que en los sistemas abiertos no existe un conocimiento completo ni de todas las variables relevantes ni de sus posibles interrelaciones ${ }^{39}$. También la clasificación entre variables exógenas y endógenas es cambiante. Una variable puede ser exógena en un determinado contexto y endógena en un contexto alternativo. Además, las interrelaciones entre agentes y entre estos y las estructuras económicas

Véase un análisis sobre la evolución del neoestructuralismo, sus etapas y rasgos distintivos en Bielchowsky (2009).

38 Como señala Pereira (2012a), la macroeconomía estructuralista para el desarrollo parte de la suposición de que el principal cuello de botella para el crecimiento y el pleno empleo se encuentra del lado de la demanda. El lado de la oferta es evidentemente esencial. No obstante, los países ya están trabajando para superar estos problemas. El principal problema del desarrollo económico radica en la ausencia de oportunidades de inversión rentables debido a una falta de demanda externa e interna y, en consecuencia, una baja tasa de inversión y ahorro. Véase también Pereira, 2012b).

39 En este sentido, un sistema abierto se asemeja a un sistema complejo. Por contraposición, un sistema cerrado es un sistema completo y esencialmente inalterable (de ideas, doctrinas, cosas, etc.), autocontenido, inalterable e inafectado por fuerzas externas, Chick (2004). 
y sociales son interdependientes y cambiantes en el tiempo ${ }^{40}$. En este sentido, los sistemas abiertos no son deterministas y abren la posibilidad de generar distintos tipos de soluciones a los distintos problemas que pueden enfrentar las economías en su evolución histórica y dinámica.

Puesto que el (neo)estructuralismo constituye un sistema abierto, se abre a establecer diálogos con otras tradiciones de pensamiento en economía, como la corriente heterodoxa, la cual abarca un conjunto heterogéneo de enfoques, incluidos los marxistas y radicales, la escuela de la regulación, los poskeynesianos, los institucionalistas y los evolucionistas. En este capítulo aparece representada la escuela de la regulación, los poskeynesianos, los institucionalistas y los evolucionistas. Los rasgos comunes a la corriente heterodoxa incluyen el énfasis en la teorización a partir de la realidad, la concepción del individuo como un animal social e institucional, la autonomía de las instituciones, la percepción de que los individuos enfrentan importantes limitantes para obtener y procesar información, la centralidad de la producción (más que el intercambio) y de la estructura económica, y la importancia del Estado para regular el funcionamiento de los mercados.

De manera más específica, existen siete áreas temáticas de convergencia entre el neoestructuralismo y el pensamiento heterodoxo: i) el enfoque metodológico, ii) la caracterización del sistema de relaciones económicas internacionales y los temas asociados a esta, incluido el origen y la propagación de los ciclos, la temática del crecimiento de largo plazo y la restricción externa, iii) la relación entre distribución del ingreso, acumulación y crecimiento y desarrollo, iv) la volatilidad e inestabilidad, v) el progreso técnico y la innovación, vi) la relación entre el corto y el largo plazo, y vii) el papel del Estado/gobierno.

\section{E. El enfoque metodológico del neoestructuralismo y del pensamiento heterodoxo}

La teoría estructuralista no se desarrolló sobre la base de hipótesis de comportamientos generales y universales, ni de axiomas predeterminados, como es el caso del paradigma dominante, sino a partir del análisis y estudio de la realidad, y de manera más específica de la realidad latinoamericana. Parafraseando a Love (1994, pág. 395), el estructuralismo fue una práctica antes de ser una política y una política antes de ser una teoría. Prebisch (1986a) dijo que la política económica que proponía trataba de dar justificación teórica a la política de industrialización que ya se estaba siguiendo (sobre todo en los grandes países de América Latina, como el

Véanse Chick (2004), Dow (2002) y Lawson (1997 y 2003). Un ejemplo ilustrativo de un análisis abierto es el concepto de sociología fiscal de Schumpeter (1954). 
Brasil), de alentar a los otros países a seguirla y de proporcionar a todos ellos una estrategia ordenada para su ejecución ${ }^{41}$. De manera aún más explícita Mallorquín expresó en 1998 que en la CEPAL habían empezado a escribir a fines de la década de 1940 y comienzos de la década de 1950, pero que la industrialización había comenzado mucho antes, por lo que no había que atribuir a la CEPAL la influencia en la industrialización, sino todo lo contrario. La teorización vino después. Por su parte, al llegar por primera vez a la CEPAL en 1948 y familiarizarse con el Manifiesto, Furtado percibió que se necesitaba un trabajo de teorización autónomo que partiera de la realidad latinoamericana (Furtado, 2003, pág. 101) ${ }^{42}$.

La teorización a partir de la realidad es también una de las características distintivas de los enfoques heterodoxos y esto los distingue del paradigma dominante. De la misma manera que Keynes (1964, pág. 3) critica a la teoría clásica, los enfoques heterodoxos mantienen que las características del tipo de economías consideradas en el paradigma dominante no son las de la sociedad en la que vivimos, razón por la que resultan desastrosas si intentamos aplicarlas a los hechos reales (Keynes, op. cit). En esta corriente, la teorización a partir de la realidad implica que la historia, la institucionalidad, las estructuras productivas y de mercado, y las relaciones distributivas, a través de todo su espectro productivo y social, juegan un papel central en la determinación del comportamiento y el desempeño de las economías ${ }^{43}$.

Construir el análisis a partir de la realidad entendida como el contexto histórico es reconocer que la realidad no es estática ni inmutable, sino que es cambiante en el tiempo y, lo que es aún más importante, es transmutable. Lejos de representar una observación trivial, en gran parte de los análisis económicos, y en particular en los del paradigma dominante, por lo general se considera que la realidad es inmutable ${ }^{44}$. En el enfoque estructuralista, un caso ilustrativo es la identificación de las presiones básicas y los mecanismos de propagación tanto en el análisis de los ciclos como de la inflación (Sunkel, 1958), que, lejos de ser constantes y constituir un material homogéneo, cambian en el tiempo.

${ }^{41} \quad$ El paréntesis del Brasil es del autor de este artículo y se basa en Furtado (2003).

42 Furtado (1987) agrega que la investigación acerca de las razones del subdesarrollo solo tiene sentido en un contexto histórico, lo que demanda un enfoque teórico distinto.

43 Véanse Taylor (2004) y Davidson (2011).

44 Un ejemplo ilustrativo es la hipótesis de las expectativas racionales, que iguala las expectativas de los agentes económicos con la probabilidad objetiva. Como señala Muth (1961) en su artículo fundacional sobre el tema, la hipótesis se puede parafrasear con más precisión de la siguiente manera: las expectativas (o, de manera más general, la distribución de probabilidad subjetiva) tenderán a estar distribuidas, para el mismo conjunto de información, en torno a la predicción de la teoría (o la distribución de probabilidad objetiva), debido a que las expectativas, por ser predicciones informadas de eventos futuros, son esencialmente las mismas que las predicciones de la teoría económica relevante. Algunos autores argumentan que esto equivale a asumir que todos los agentes son homogéneos. 
De la misma manera, en el nuevo desarrollismo de Pereira se observa que algunas de las tendencias del desarrollo latinoamericano identificadas por los estructuralistas han dejado de operar en la actualidad, por lo que se necesita incorporar en el análisis nuevos hechos estilizados que reflejen la realidad actual. En esta línea, a partir de la evidencia empírica disponible para un período de casi 150 años (1865-2009), Erten y Ocampo (2012) muestran la existencia de cuatro superciclos de precios de materias primas con una duración de entre 30 y 40 años (1894-1932, 1932-1971, 1971-1999 y 2000 hasta el presente).

La mutabilidad y transmutabilidad de la realidad conlleva a una noción del tiempo distinta a la que se aplica tradicionalmente en las ciencias económicas. Por lo general, la mayor parte de los modelos son atemporales o consideran el tiempo solo a partir de una perspectiva lógica; es decir que operan en un contexto de tiempo lógico. Esto implica que pasado, presente y futuro se determinan de manera simultánea; el equilibrio es un concepto mecánico y las posiciones de equilibrio se caracterizan por el uso del estado de equilibrio o steady state ${ }^{45}$.

En contraposición a este concepto, los economistas heterodoxos ubican la noción de tiempo histórico (Robinson, 1980; Lavoie, 1996). El tiempo histórico implica que los eventos y acontecimientos ocurren en una secuencia unidireccional (solo se puede ir hacia adelante). En otras palabras, el tiempo es irreversible y es casi imposible o muy costoso revertir las decisiones de los agentes. Además, las decisiones muchas veces son cruciales (alteran de manera permanente el entorno en que se tomaron, de forma que ese entorno nunca volverá a existir) (Shackle, 1955).

La noción de tiempo histórico prevalente en el pensamiento poskeynesiano también se ubica en el centro del pensamiento de Schumpeter y en el proceso de creación destructiva. Por definición, este se basa en el hecho de que la acción de los empresarios destruye el propio contexto en que se llevó a cabo una innovación. Como señaló el autor, el impulso de los nuevos bienes de consumo, los nuevos métodos de producción y transporte, y las nuevas formas de organización industrial revoluciona incesantemente la estructura económica desde dentro, destruyendo la antigua estructura y creando una nueva (Schumpeter, 1997, pág. 83). En el mundo de la globalización financiera, la innovación financiera también se acoge a una lógica similar.

45 En el modelo de Arrow-Debreu, el de mayor transcendencia para el paradigma dominante, que forma la base de toda la modelización en economía, la introducción del tiempo está intrínsecamente relacionada con temas de certidumbre e incertidumbre. En el modelo básico, todas las transacciones ocurren en un instante en el tiempo. Los agentes (consumidores y productores) tienen perfecto conocimiento del futuro (su papel de consumidores es elegir un plan de consumo confeccionado para todo el futuro) y los mercados futuros son completos. La introducción de la incertidumbre se realiza mediante la noción de mercancía contingente, es decir una mercancía cuya entrega para el intercambio se condiciona a la ocurrencia de eventos (por ejemplo, la entrega de trigo condicionada al buen o mal tiempo). 
Desde un inicio, los economistas estructuralistas se preocuparon de la noción del tiempo como un factor esencial a tener en consideración y distintivo de sus análisis. La introducción del tiempo en la teoría económica fue una de las principales preocupaciones y retos que enfrentó Prebisch antes de hacerse cargo de la CEPAL. Esto lo llevó a desarrollar una teoría de la dinámica económica para la periferia (y para la interrelación entre centro y periferia), contraponiéndola al análisis estático que asegura el aprovechamiento óptimo de los factores de producción y la distribución de los ingresos entre los factores productivos de acuerdo con su respectiva productividad marginal. Toda perturbación del equilibrio del sistema económico tiende a llevarlo a una nueva posición. Si ello no ocurre en la realidad se debe a la intervención de factores ajenos ${ }^{46}$. Esta teoría, que incorpora el tiempo como factor esencial, abarca todos los fenómenos de conjunto de la economía, no solo los de la ocupación y la producción, sino también los de la distribución ${ }^{47}$.

Además, la noción de tiempo que se desprende de los trabajos del enfoque estructuralista y neoestructuralista se asimila al tiempo histórico. Refiriéndose a la teoría del desarrollo, Furtado argumentó que esta se mueve en dos planos: primero, las formulaciones abstractas del mecanismo actual del proceso de crecimiento, basado en modelos con relaciones estables, seguido de su aplicación a realidades históricas (1954, pág. 211; 1964, pág. 1). El papel de la investigación histórica viene del reconocimiento de la irreversibilidad del proceso económico histórico, que hace imposible eliminar el factor tiempo y las diferencias estructurales de las economías en los distintos estadios de desarrollo (Boianavosky, 2008a, pág. 7) ${ }^{48}$.

El reconocimiento del tiempo como histórico implica, por una parte, que los procesos de desarrollo no son lineales en el tiempo. No se trata de una sucesión de etapas o estadios caracterizados por elementos comunes y homogéneos, y políticas similares, como lo conceptualizó en su momento, o como aún se concibe cuando el desarrollo se equipara a aumentos lineales en el nivel de PIB per cápita por encima de un determinado umbral. Furtado (2003, pág. 94) planteó el subdesarrollo no como una etapa por la cual hayan pasado necesariamente las economías que ya alcanzaron un grado superior de desarrollo, sino como una cierta conformación de la

46 Prebisch desarrolló su teoría de la dinámica económica entre 1945 y 1949. Esta está reproducida en Prebisch, (1993, págs. 410-489). Véanse notas a pie de página 121 y 141 en Prebisch (1991, vol. III); y vol. IV pág. 2 (Prebisch, 1993).

47 Prebisch, 1949, pág. 414.

48 Más adelante, Furtado (2003, pág. 88) siguió manteniendo esta postura al expresar que la indagación sobre las causas del atraso solo adquiere pertinencia si es concebida históricamente, lo que exige otro abordaje teórico, y criticó, al igual que lo han hecho Minsky (1986, págs. 4-5) y Davidson (2011), la teoría económica tradicional por su falta de realismo. 
estructura económica derivada de la forma en que se propagó el progreso técnico en el plano internacional (1999, pág. 79) ${ }^{49}$.

De la misma manera, la CEPAL ha planteado que el desarrollo y sus distintas etapas no pueden medirse o evaluarse según un indicador de PIB per cápita, reflejo de la concepción lineal del desarrollo. Más bien, se trata de buscar una conformación más amplia de indicadores, tales como las brechas estructurales (La hora de la igualdad: brechas por cerrar, caminos por abrir, 2010; Los países de renta media. Hacia un enfoque basado en brechas estructurales, 2012). Según este enfoque, no existe un orden preestablecido claro por el cual algunos países tienen las menores o las mayores brechas en el conjunto de los indicadores considerados. El tamaño relativo y la importancia de cada brecha difieren de un país a otro y reflejan distintos cuellos de botella y necesidades. En este sentido, la relevancia de las distintas brechas es distinta en cada país, algunas son muy relevantes para un país y menos para otros, y viceversa.

En segundo lugar, la noción de "tiempo histórico" implica que las decisiones de política económica, tanto en términos de llevar a cabo una acción como de decidir no actuar ante una situación, tienen consecuencias que son difíciles de revertir. La política económica no se reduce a "hacer y deshacer".

\section{F. El contexto externo: centro-periferia y dinámica}

El enfoque metodológico basado en la observación de una realidad cambiante y de una concepción del tiempo histórico llevó a los estructuralistas a reconocer que el desarrollo se enmarcaba en un "sistema [particular] de relaciones internacionales"50. A efectos del análisis, este sistema de relaciones internacionales se caracterizó a partir de la dicotomía entre centro y periferia, que permitió captar la especificidad de los países en desarrollo en relación con los más desarrollados y mostrar las diferencias cualitativas entre las estructuras de los países desarrollados y en desarrollo.

La dicotomía centro-periferia surgió como un esfuerzo analítico por parte de Prebisch para caracterizar la interdependencia de la evolución económica entre países, sus particularidades y, de manera más específica, el acoplamiento de los ciclos económicos de América Latina a los de los países en desarrollo. Prebisch pensaba, como Marx y Schumpeter, que el capitalismo era esencialmente una forma de

\footnotetext{
49 Obviamente esto significa que desarrollo no es sinónimo de reproducir el perfil y los hábitos económicos de los países industrializados (por ejemplo, el perfil de consumo).

50 La expresión es de Prebisch, excepto el texto entre paréntesis recto, que pertenece al autor.
} 
organización económica dinámica y que en su evolución temporal generaba de manera endógena mecanismos para su trayectoria futura. Pero, a la vez, el capitalismo no opera en un solo país, sino que opera de manera conjunta en el mundo, de modo que el acoplamiento se constituía necesariamente en una regla de la evolución económica de los países, incluso los de América Latina. En sus propias palabras (Prebisch, 1993, vol. IV, pág. 224):

"Yo creo que el movimiento cíclico es universal, que hay sólo un movimiento que se va propagando de país en país [...] No hay un ciclo en Estados Unidos [el centro] y un ciclo en cada uno de los países de la periferia. Todo constituye un solo movimiento, pero dividido en fases muy distintas, con características marcadamente diferentes, según se trate del centro cíclico o de la periferia. Por esta última razón, no obstante que el proceso es uno, las manifestaciones de este proceso son distintas, según el lugar en que nos situemos".

Las categorías centro y periferia, lejos de ser estáticas, constituyen un concepto evolutivo que cambia a la par de la economía mundial. Desde la mitad del siglo XIX hasta principios del siglo XX, el centro por excelencia fue Gran Bretaña, y a partir de entonces esa posición fue adoptada por los Estados Unidos. Furtado acuñó la expresión "desplazamiento del centro dinámico" para referirse a la ampliación y diversificación del mercado interno del Brasil en la década de 1930, que le permitió poner en práctica una estrategia para crecer mediante la demanda interna y así contrarrestar el impacto de la Gran Depresión. El crecimiento del Brasil durante el decenio de la Gran Depresión no fue inferior a su promedio histórico (Furtado, 1999, págs. 69-73). En virtud de esta lógica, actualmente China también actúa como centro cíclico, ya que de ese país emana una parte de las fluctuaciones de los precios de las materias primas y los términos de intercambio que han jugado un papel principal en el dinamismo de las economías de América Latina en la última década.

La caracterización más reciente de las interrelaciones entre América Latina y el resto del mundo por parte de autores neoestructuralistas en conceptos tales como la dominancia de la balanza de pagos y el papel atribuido a los flujos financieros o términos de intercambio en el desempeño de la región, y la restricción externa propugnada por los neoestructuralistas y economistas heterodoxos, se desarrollan de manera implícita o explícita en un marco de centro-periferia, tal y como lo concebía Prebisch.

El predominio de la balanza de pagos se refiere a un régimen macroeconómico según el cual la dinámica de corto plazo viene determinada por choques externos, ya sean positivos o negativos. La idea del predominio de la balanza de pagos reconoce la incidencia del comercio internacional en la dinámica de esta balanza a través de los choques de términos de intercambio, 
tal como ocurrió en América Latina y el Caribe en el período 2003-2008. No obstante, atribuye un papel central a la cuenta de capitales y al financiamiento externo en la determinación de las fluctuaciones económicas de los países en desarrollo. En consonancia con la idea de Prebisch de que los ciclos en la periferia están ligados a las condiciones externas, Ocampo señala que la característica dominante de las últimas décadas en América Latina han sido las fuertes fluctuaciones en los gastos y balances privados ligados a los ciclos de financiamiento externo (Ocampo, 2011, pág. 13). De manera similar, Ffrench-Davis atribuye la elevada volatilidad de la demanda agregada en América Latina en las décadas de 1990 y 2000 a factores externos (CEPAL, 2010, pág. 58). Además, señala que aunque en el pasado las fluctuaciones de la demanda agregada respondieron con frecuencia a déficits fiscales financiados mediante emisión monetaria, de manera general se puede afirmar que las oscilaciones más recientes se debieron a choques externos, sobre todo en la cuenta de capitales y los términos de intercambio (Ibid, pág. 61).

El pensamiento heterodoxo también atribuye al sector externo una fuente de impulso de la demanda agregada y de los ciclos. Basándose en Kalecki (1969, págs. 45-58), en la teoría del ciclo de Minsky (1982, págs. 36-44; 1986, págs. 150-151) y en una economía cerrada al resto del mundo y sin gobierno, las decisiones de inversión del sector corporativo no financiero determinan el beneficio esperado a nivel agregado ${ }^{51}$. El beneficio esperado, por su parte, determina la capacidad de autofinanciamiento de las empresas y su estructura de deuda. El beneficio esperado, la estructura de la deuda y el riesgo del prestamista y prestatario determinan, a su vez, el volumen de inversión realizado ${ }^{52}$. En el caso de una economía abierta, aparte de la inversión, el sector externo (y de manera precisa el balance en la cuenta corriente) es otro de los determinantes del beneficio $\mathrm{y}$, por

51 Minsky (1982, pág. 40) sostiene que los beneficios son el flujo de caja que validan o invalidan cualquier estructura de deuda empresarial. El nivel esperado y la estabilidad de los beneficios determina la estructura de deuda que los empresarios, los banqueros y los tenedores últimos de los activos de la economía aceptarán.

52 Dos tipos de riesgo afectan el volumen de la inversión. El primero es el riesgo del empresario o del prestamista, y surge de las dudas en relación con la probabilidad de que efectivamente pueda alcanzar la rentabilidad que espera obtener. Si una persona está arriesgando su propio dinero, este es el único riesgo relevante. No obstante, al existir un sistema de solicitud y otorgamiento de préstamos, hay un segundo tipo de riesgo relevante que podemos llamar "riesgo del prestatario". Este puede ser el resultado del riesgo moral, el incumplimiento voluntario u otro tipo de escape para no cumplir con las obligaciones, o de la posible insuficiencia del margen de seguridad, i. e. el incumplimiento involuntario debido a la decepción de las expectativas (Keynes, 1964, pág. 144; Minsky, 1975, pág. 106). El riesgo del prestatario es subjetivo y nunca aparece en los contratos. Refleja la incertidumbre y los "espíritus animales". El riesgo del prestamista es objetivo y aparece en los contratos financieros de varias formas: mayores tasas de interés, menores plazos de madurez, requisitos de colaterales, restricciones sobre los dividendos, etc. (Minsky, 1975, págs. 109-110; Minsky, 1986, págs. 190-193). Minsky (1975, pág. 114) afirmó que se ha construido una manera de mirar a la inversión, según la cual "la estimación popular" del riesgo del prestamista y del prestatario, que de manera admitida viene influenciada por el desempeño pasado de la economía, actúa como el determinante inmediato de la dinámica de la inversión y, por lo tanto, de la economía. 
consiguiente, contribuye a determinar sus decisiones de inversión y de empleo, así como la estructura de deuda de las empresas. Minsky (1982, pág. 43) remarca que en el caso de una economía pequeña con un sector de gobierno pequeño, que puede perfectamente corresponder al caso de algunos países de América Latina, cualquier aumento súbito del déficit de la cuenta corriente, o disminución del superávit, llevará a un deterioro de los beneficios y a la posibilidad de un deterioro en su estructura financiera.

\section{G. El contexto externo: centro-periferia y restricción externa}

La dicotomía centro-periferia no solo sirve como base analítica para examinar los orígenes, impulsos y mecanismos de propagación de los ciclos, sino también para caracterizar el crecimiento de más largo plazo y sus determinantes. En este sentido, uno de los esfuerzos más importantes, tanto en la tradición heterodoxa como en la estructuralista y neoestructuralista, es ligar el crecimiento de más largo plazo con la restricción externa.

En el pensamiento heterodoxo, el esfuerzo más significativo sin duda es el modelo de crecimiento con restricción de balanza de pagos (Thirlwall, 1979; Mac Combie y Thirlwall, 1994) basado en una versión dinámica del multiplicador del comercio exterior de Roy Harrod. En el estructuralismo, la relación entre crecimiento y restricción externa fue analizada inicialmente por Prebisch (1991) bajo la forma del coeficiente de expansión (alrededor de 1935), que es una versión análoga al multiplicador de Harrod $^{53}$. Los límites que impone el sector externo al crecimiento y el desarrollo de la región constituyen un pilar central del Manifiesto (1949) y de las ideas que de allí derivaron y formaron el pensamiento de la CEPAL y del neoestructuralismo. Una de las manifestaciones más relevantes de la importancia que atribuyeron el estructuralismo y la CEPAL al sector externo fue el concepto del "estrangulamiento externo" derivado de los límites al proceso de industrialización ${ }^{54}$.

En consonancia con su enfoque metodológico, la importancia de la restricción externa fue un fenómeno que se observó en la práctica antes de

Prebisch, 1991, vol. III, págs. 249-298, 301-310, 335-342 y 349-370. El coeficiente de expansión mide la intensidad con que un aumento de la renta, causado por un incremento de las exportaciones o los flujos financieros, produce una mayor expansión de la actividad económica interna. El análisis del multiplicador del comercio exterior de Prebisch es estático, una explicación del cambio de una posición de equilibrio a otra.

54 En un principio, las limitaciones surgieron por la creciente necesidad de importar bienes de capital y bienes intermedios que excedía la capacidad de generar divisas de las exportaciones. En la CEPAL, este problema pasó a ser conocido como el "estrangulamiento externo". Los requisitos crecientes de importación debían ser compensados por un mayor volumen de flujos financieros. Aunque el enfoque estructuralista siempre concibió el desarrollo como un proceso de cambio estructural, también siempre mostró preocupación por los desequilibrios que este proceso podía acarrear y uno de los desequilibrios de base que identificó es el desequilibrio externo. 
que pasara a ser parte del bagaje conceptual de la escuela estructuralista. Martínez sostiene que el pensamiento cepalino sobre la restricción externa se desarrolla, en gran parte, directamente a partir de la experiencia mexicana ${ }^{55}$.

La noción de crecimiento bajo restricción externa pone en el centro del análisis, aunque sea de manera implícita, la organización de las relaciones económicas internacionales bajo la forma de centro-periferia. El desempeño económico de los países en desarrollo (i.e. de los países de la periferia) viene determinado, en gran medida, por la arquitectura financiera internacional. El sistema financiero y monetario actual está anclado a la moneda de reserva de los Estados Unidos y los países que no emiten la moneda de reserva internacional (como los países de la periferia, incluidos los de América Latina y el Caribe) deben adquirir y poder acceder (incluso a través de una política de acumulación de reservas internacionales) a esta moneda que no pueden emitir para poder importar (y desarrollarse) y llevar a cabo transacciones financieras internacionales.

En consecuencia, la política interna de los países de la periferia en gran parte está delimitada y restringida de manera permanente por las condiciones externas. Es en este sentido que los esfuerzos de crecimiento de estas economías se enfrentan a una restricción externa. De manera más específica, los países enfrentan una restricción externa cuando su desempeño (actual y esperado) en los mercados externos y la respuesta de los mercados financieros a este desempeño (actual y esperado) delimitan y restringen su espacio para llevar a cabo políticas internas, incluidas la política, fiscal, cambiaria y monetaria ${ }^{56}$.

55 Esto lo afirma en una entrevista organizada por Carlos Mallorquín en 1997 (Mallorquín, 1998, pág. 147). La CEPAL analizó el problema del desequilibrio externo para el caso de México en (CEPAL, 1957).

56 Esta definición está basada en McCombie y Thirlwall (1999, pág. 49), según los cuales los países enfrentan una restricción externa cuando su desempeño en los mercados externos y la respuesta de los mercados financieros a este desempeño restringen el crecimiento a una tasa por debajo de la cual lo requeriría las condiciones internas. Esta definición presupone que los países crecen a una tasa por debajo de la compatible con el pleno empleo. Por ende, la organización del sistema económico mundial, incluida su arquitectura financiera, tiene un sesgo restrictivo e impide realizar el potencial de crecimiento de los países sujetos a las restricciones externas. Keynes hizo una crítica similar al sistema monetario internacional previo a Bretton Woods (y su Clearing Union consistía justamente en remplazar el sesgo contraccionista por un carácter expansionista (J.M. Keynes, 1980, vol. XXV, pág. 74: "El plan busca la sustitución de presiones expansionistas en vez de contraccionistas en el comercio mundial"). El hecho de no poder realizar la tasa de crecimiento potencial tiene implicaciones para el mercado de trabajo, ya que bajo estas condiciones, los países no pueden absorber la oferta de trabajo, lo que conduce a situaciones de desempleo, subempleo e informalidad. La idea de que los países de la periferia muestran una tendencia a crecer por debajo de su potencial es también un elemento importante del pensamiento de Ffrench-Davis, que se articula alrededor del concepto de brecha recesiva que se explicará con mayor detalle en la sección I.J. Prebisch (1993, vol. IV, pág. 351) pensaba, en una línea similar, que en el esquema clásico, el volumen de producción es regular, se tiende hacia el pleno empleo de los factores productivos y el máximo de producción. En la realidad, no obstante, el crecimiento es ondulatorio, en virtud de la forma en que opera el proceso de acumulación. La producción no se mantiene cerca del óptimo, sino que se acerca y se aleja alternadamente, con un gran desperdicio de factores productivos y, se podría añadir desperdicio de recursos. 
La restricción externa implica que es poco probable que una economía (especialmente de la periferia) pueda mantener un déficit de la cuenta corriente durante un período prolongado de tiempo, a excepción de los países que suelen ser receptores de montos significativos de flujos de inversión extranjera directa o ayuda oficial (McCombie y Thirlwall, 1999). En el largo plazo, los países tienen que mantener en equilibrio su cuenta corriente (CC) o su balanza básica (la cuenta corriente (CC) más los flujos financieros de largo plazo (FF)). Es decir,

$$
\text { (1) } C C-F F=0 \Leftrightarrow P_{d} X+F=P_{f} M E+\mathrm{OCN}
$$

Donde, $C C$ = cuenta corriente; $X$ y $M=$ volumen de exportaciones e importaciones; $E=$ tipo de cambio nominal; $P_{d}$ y $P_{f}=$ precio de las exportaciones expresado en moneda local y precio de las importaciones expresado en moneda extranjera de las importaciones; $O C N=$ valor nominal de los otros componentes de la cuenta corriente.

A partir de esta ecuación (1) se puede expresar la tasa de crecimiento real de una economía en función de los términos de intercambio [1], los cambios en los flujos financieros de largo plazo medidos en términos reales [2] y los cambios exógenos en el nivel de la demanda agregada real externa [3].

$$
\text { (2) } y_{b p c f}=\frac{(1+\theta \psi+\gamma)\left(p_{d}-e-p_{f}\right)}{\xi}+\frac{\eta\left(f-p_{d}\right)}{\xi}+\frac{\pi y_{R M}}{\xi}
$$

Donde las variables incluyen a $y_{b p c f}=$ tasa de variación del crecimiento real de un país de la periferia que es compatible con el equilibrio externo tal y como se definió anteriormente; $p_{d}$ tasa de variación de los precios internos (inflación interna); $p_{f}$ tasa de variación de los precios externos (inflación importada); $\boldsymbol{e}=$ tasa de variación del tipo de cambio nominal; $f$ tasa de variación de los flujos financieros reales; $y_{R M}=$ tasa de variación del crecimiento real del resto del mundo.

Los parámetros comprenden: $\gamma, \psi=$ elasticidades precio de las importaciones y las exportaciones $\gamma, \psi<0$ ); $\xi, \pi=$ elasticidades ingreso de las importaciones y exportaciones; $\theta$ y $\eta=$ proporción de los débitos de la 
cuenta corriente financiados con ingresos derivados de las exportaciones y con flujos financieros, respectivamente ${ }^{57}$.

De acuerdo con (2), la tasa de crecimiento real de un país periférico está positivamente relacionada con el crecimiento de la demanda externa ponderado por la razón de elasticidades de importación y exportación, con el aumento en los términos de intercambio (y negativamente con la apreciación cambiaria ponderada por las elasticidades de precio) y con mayores tasas de crecimiento de los flujos financieros de largo plazo ${ }^{58}$.

Existen cuatro alternativas para que los países puedan flexibilizar la restricción que impone el contexto externo a su crecimiento: i) un aumento permanente en la tasa de crecimiento de la demanda externa, ii) un aumento permanente en la tasa de crecimiento de los flujos financieros de largo plazo, iii) una mejora permanente en los términos de intercambio (tipo de cambio real) y iv) la puesta en marcha de políticas de cambio estructural en los países de la periferia.

La adopción de distintas simplificaciones en relación con (1) permite centrar el foco del análisis en distintas problemáticas relacionadas con estas cuatro alternativas. Por ejemplo, la suposición de que en el largo plazo, las variaciones en el tiempo del tipo de cambio y de los términos de intercambio tienden a anularse, o de que tienden a variar poco, lleva a expresar la tasa de crecimiento compatible con la restricción de la balanza de pagos en función de los flujos financieros y de la demanda agregada del resto del mundo.

$$
\text { (3) } y_{b p c f}=\frac{\eta\left(f-p_{d}\right)}{\xi}+\frac{\pi y_{R M}}{\xi}
$$

En el caso límite en que la cuenta corriente se mantiene en equilibrio en el largo plazo (es decir, cuando $\theta=1 y \eta=0$ ), la tasa de crecimiento compatible con la restricción de la balanza de pagos depende exclusivamente del crecimiento del centro y de las elasticidades ingreso de las exportaciones e importaciones.

57 La tasa de crecimiento de una economía periférica compatible con el equilibrio de la balanza de pagos se deriva de un modelo de tres ecuaciones. La primera expresa la tasa de crecimiento de las importaciones en función del tipo de cambio real y la tasa de crecimiento de la periferia $\left(m_{f}=\psi\left(p^{*}+e-p_{d f}\right)+\xi y_{f}\right)$, la segunda relación expresa la tasa de crecimiento de las exportaciones en función del tipo de cambio real y la tasa de crecimiento del centro $\left.x_{f}=\gamma\left(p_{d f}-p-e\right)+\pi y_{l}\right)$, y la tercera ecuación muestra el equilibrio dinámico de la balanza de pagos $\left(\theta\left(p_{d f}+x\right)+\eta f=p^{*}+m_{f}+e\right)$. La solución se obtiene sustituyendo las ecuaciones de exportación e importación en la condición de equilibrio dinámica y resolviendo esta para la tasa de crecimiento de la periferia.

58 Estos permiten financiar el crecimiento de largo plazo por encima del compatible con una cuenta corriente equilibrada (MacCombie y Thirlwall, 1994). Esto se condice con la postura de la CEPAL respecto de que solo los flujos financieros de largo plazo permiten un mayor crecimiento económico. 


$$
\text { (4) } y_{b p c f}=\frac{\pi y_{R M}}{\xi}
$$

Esta formulación es conocida en la literatura heterodoxa como la Ley de Thirlwall (1979). Según esta ley, que es un caso particular de (1), el crecimiento de largo plazo de la periferia depende de sus elasticidades ingreso de las exportaciones e importaciones.

En sus análisis de la restricción externa, la tradición estructuralista enfatiza el impacto en el crecimiento de largo plazo de las elasticidades precio e ingreso ${ }^{59}$. Este énfasis es particularmente relevante en la caracterización de las estructuras productivas del centro y la periferia. La estructura productiva del centro se caracteriza por ser diversificada y homogénea, mientras que la de la periferia es especializada y heterogénea.

A su vez, una estructura productiva especializada de la periferia significa que una parte sustancial de los recursos productivos se destina a sucesivas ampliaciones del sector primario-exportador, mientras que la demanda de bienes y servicios se satisface, en gran medida, con importaciones (Rodríguez, 1977, pág. 206). Los productos agrícolas tienen una baja elasticidad precio de la demanda porque se utilizan como insumos para un producto o bien final. Por ende, un descenso (aumento) en su precio no se traslada de manera plena al producto final; el precio del insumo es solo un componente del precio del bien final. Además, tienen una baja elasticidad ingreso de la demanda debido a que son considerados (o se aproximan a) bienes inferiores (i. e. la curva de Engel es cóncava). A este factor hay que añadir la superioridad tecnológica del centro en la exportación de manufacturas. Estas dos propiedades de los bienes que exporta e importa la periferia, conjuntamente con la superioridad tecnológica del centro y la estructura de los mercados de bienes y factores, formaron la explicación del deterioro secular de los términos de intercambio ${ }^{60}$.

59 Lo que lleva a pensar en una formulación de la restricción externa tipo sin flujos financieros. Es decir, $y_{b p c f}=\frac{(1+\theta \psi+\gamma)\left(p_{d}-e-p_{f}\right)}{\xi}+\frac{\pi y_{R M}}{\xi}$.

60 Véase una reinterpretación de las tesis sostenidas en 1950 en Prebisch (1991); y Singer (1950, 1987). Según Singer, en 1938 y más adelante en su propuesta de Clearing Union, Keynes también había enfatizado las particularidades y características de los bienes y mercados de la periferia, lo que marca una vez más una convergencia de puntos de vista entre el estructuralismo y la tradición heterodoxa. Es importante notar que el deterioro de los términos de intercambio fue remarcado por Prebisch en 1926 y que en su análisis en el Manifiesto lo asocia directamente con el tema de los ciclos. Como indica (1950, op.cit. pág. 504), no podría comprenderse la razón de ser de este fenómeno (tendencia secular al deterioro de los términos de intercambio), sin relacionarlo con el movimiento cíclico de la economía y la forma en que se manifiesta en los centros y la periferia. Los precios primarios suben con más rapidez que los finales en la creciente (fase de auge del ciclo), pero también descienden más que estos en la menguante (fase de declive del ciclo), de forma que los precios finales [de la industria] van apartándose progresivamente de los precios primarios, a través de los ciclos. La tendencia al deterioro de los términos de intercambio no es un elemento común a todos los pensadores estructuralistas. De hecho, Furtado no mencionó este factor es su análisis histórico del centro y la periferia ni en su estudio clásico sobre el Brasil. Boianovsky (2008, pág. 14) señala que la tesis Prebisch-Singer de una caída secular de los términos de intercambio no jugó un papel relevante en el análisis histórico de la dinámica de crecimiento en el centro y la 
No obstante, el pensamiento estructuralista dio una importancia particular a los efectos ingreso. De hecho, se destacó, tal como lo hace Thirlwall, que el impacto de los efectos precio es insuficiente por sí solo para tener un impacto en el crecimiento de largo plazo. Alfredo Navarrete, en su trabajo pionero sobre el tema de la restricción externa de 1951 en México, Estabilidad de cambios, el ciclo y el desarrollo económico (una investigación sobre los problemas de la balanza de pagos, 1929-1946), concluye que los ajustes que se hagan en el tipo de cambio pueden resultar ineficaces para corregir el desequilibrio externo si existe estancamiento secular en los centros cíclicos.

De la misma manera, en su monografía El falso dilema entre estabilidad monetaria y desarrollo económico (1963, págs. 49-50), Prebisch enfatizó el papel de las elasticidades ingreso en la determinación del crecimiento de la periferia y dijo que el crecimiento de las exportaciones establece un límite máximo al desarrollo de un país periférico. Este límite está dado por la intensidad con que aumenta la demanda de importaciones a medida que crece el ingreso por habitante (i. e., la elasticidad ingreso de la demanda de importaciones). Al subir el ingreso por habitante, tiende a elevarse con más fuerza la demanda de artículos industriales que la demanda de artículos primarios (los países periféricos importan los primeros y exportan los segundos). La situación de los grandes centros industriales es completamente opuesta. A igual tasa de crecimiento de la población, un país periférico no puede crecer espontáneamente al mismo ritmo de los centros comerciales con los que comercia debido a la disparidad de elasticidades, y como la población de los países de la periferia latinoamericana aumenta con una intensidad mucho mayor que la de aquellos centros, este proceso debe ser aún más fuerte ${ }^{61}$.

periferia de Furtado ni en su interpretación teórica del subdesarrollo; estaba ausente de sus dos libros (1954 y 1959) sobre la historia económica brasileña y de su volumen de 1961 sobre desarrollo económico. Véase una apreciación similar en Bielchovsky (1988) y un análisis de las contribuciones de Furtado al pensamiento estructuralista en Bielchovsky (2009).

${ }_{61}$ Dejando de lado el tema del crecimiento de la población, y en línea con la interpretación centroperiferia como una dicotomía analítica y evolucionista, este párrafo es fácilmente aplicable a las relaciones comerciales entre China y América Latina. América Latina exporta a China sobre todo recursos naturales con bajo contenido tecnológico (y baja elasticidad ingreso de las exportaciones), pero importa productos con mayor contenido tecnológico (alta elasticidad de la demanda ingreso de las importaciones). Existe una clara convergencia entre esta caracterización de Prebisch de la restricción externa y la esbozada por el economista poskeynesiano Paul Davidson en varios de sus escritos (1992-2011). En total afinidad con Prebisch (1963), Davidson (1992, págs. 94-95) señala que si las economías menos desarrolladas tienen una ventaja comparativa en las exportaciones de bienes primarios y otros bienes básicos, para los cuales las curvas de Engel sugieren que el mundo menos desarrollado tiene una baja elasticidad ingreso de la demanda, mientras que los países menos desarrollados tienen una elevada elasticidad ingreso de la demanda para los productos manufacturados del mundo desarrollado, los países menos desarrollados están condenados a la pobreza relativa. Si la tasa de crecimiento de la población es mayor en los países menos desarrollados, el futuro de estos países será aún peor. 
La similitud entre el pensamiento heterodoxo y estructuralista se revela en el hecho de que la formulación de la restricción externa conocida como la Ley de Thirlwall es, de hecho, idéntica a la propuesta por Octavio Rodríguez (1977, págs. 235-236) para caracterizar el enfoque cepalino ${ }^{62}$. Vale la pena citar a Rodríguez en su exposición de este concepto:

"Sean y $G_{p}$ y $G_{c}$ las tasas de crecimiento del ingreso de la periferia y del centro, y $E_{p}$ y $E_{c}$ y las respectivas elasticidades-ingreso de la demanda de importaciones. La expresión $G_{p} * E_{p}=G_{c} * E_{c}$ indica qué condición debe cumplir para que el equilibrio externo de ambas economías se mantenga a lo largo del tiempo, bajo el supuesto de que no se producen variaciones en los precios ni movimientos de capital. La expresión alternativa

$$
\text { (5) } G_{p}=\frac{E_{C}}{E_{P}} * G_{C}
$$

Permite describir más fácilmente que si la elasticidad es menos en el centro que en la periferia (si $E_{C}<E_{P}$ ), la preservación del equilibrio externo exige que el ingreso crezca menos en esta que en el primero, y tanto menos cuanto mayor sea la disparidad de elasticidades. Si se excede ese límite tenderá a generarse desequilibrio" ${ }^{63}$.

La Ley de Thirlwall-Rodríguez, al ser un caso particular de la restricción externa (1), no excluye cambios en el largo plazo de los flujos financieros y términos de intercambio (tipo de cambio real). Más bien, hace abstracción de ellos para centrarse en la importancia de las elasticidades ingreso (de exportaciones e importaciones) como determinantes del crecimiento del largo plazo $^{64}$.

Esto tiene dos importantes implicaciones para la teoría y la política económica. En primer lugar, implica que el intercambio entre países no se rige por el axioma de los sustitutos brutos, según el cual, cualquier bien o servicio es un sustituto bruto de cualquier otro. Por ende, la composición de la canasta exportadora y de la producción importa para el crecimiento económico. En segundo término, y derivado de la primera implicación, el aumento del crecimiento requiere un cambio en las elasticidades ingreso o, lo que es equivalente, en la composición de las exportaciones y la producción. Para ponerlo de otra manera, un mayor crecimiento requiere un cambio estructural y para esto es necesario el progreso tecnológico.

\footnotetext{
62 El autor agradece a Gabriel Porcile por haberle señalado el artículo de Rodríguez y su similitud con la Ley de Thirlwall.

63 Si se sustituye $G_{p}$ por $y_{b p c f} ; G_{C}$ por $y_{R M} ; \xi$ por $E_{P}$ y $E_{C}$ por $\pi$, la expresión en (5) es idéntica a la expresión en (4).

64 Moreno-Brid (1998-1999) introdujo en un artículo seminal la posibilidad de un déficit de la cuenta corriente en el modelo de Thirlwall.
} 
Este es precisamente el punto del capítulo VII de Cimoli y Porcile, que establecen una relación funcional entre el cociente de las elasticidades ingreso de la demanda de exportaciones e importaciones ( $\varepsilon_{p} y \varepsilon_{c}$, respectivamente) y una función del grado de diversificación de la estructura productiva periférica $\left(f\left(N^{P}\right)\right)$ tal que

$$
\text { (6) } \frac{y_{b p c p}}{y_{c}}=\frac{\varepsilon_{p}}{\varepsilon_{c}}=f\left(N^{P}\right), f_{1}>0
$$

Un mayor grado de diversificación productiva se traduce en un incremento del cociente de las elasticidades y, por ende, en un aumento de la tasa de crecimiento consistente con la restricción de la balanza de pagos para la periferia $\left(y_{b p c p}\right)^{65}$.

\section{H. Cambio estructural, progreso tecnológico e innovación}

El progreso técnico ha jugado un papel central en el desarrollo del pensamiento estructuralista y neoestructuralista. Según el pensamiento estructuralista tradicional, la propagación desigual del progreso tecnológico explica la conformación histórica de los polos centroperiferia $^{66}$. Las ventajas del progreso técnico se concentran en los centros industriales y se difunden en los propios centros en un período breve, aumentando de esta manera los ingresos de manera generalizada. En la periferia, en cambio, las nuevas técnicas productivas se ponen en práctica

65 En esta formulación, es la tasa de crecimiento del centro. Véase McCombie y Thirlwall (1994), pág. 244. Tal como señala Ocampo (2011), en línea con el pensamiento estructuralista tradicional (véase Furtado, 2003) y más reciente, el crecimiento es concebido como un proceso de cambio estructural. La CEPAL (2012) ha vuelto a recalcar la importancia del cambio estructural como eje central de la igualdad.

66 Como señala Rodríguez (1977, pág. 206), se concibe que centros y periferia se constituyen históricamente a partir de la forma en que el progreso técnico se propaga en la economía mundial. Quizás la interpretación de Furtado (2003, págs. 110-111) con respecto a la evolución del concepto centro-periferia sea más completa, ya que indica que en una presentación sintética de sus trabajos teóricos, Prebisch se refirió a la idea de "un sistema de relaciones internacionales", al que denominó centro-periferia y que fue un subproducto de sus reflexiones sobre las fluctuaciones cíclicas que se dan en la esfera internacional. De esa reflexión en torno a la propagación de los ciclos, le vino la percepción de que el sistema de división internacional del trabajo había surgido para atender prioritariamente los intereses de los países que están al frente del proceso de industrialización. Los países productores y exportadores de materias primas están ligados a ese centro en función de sus recursos naturales, constituyendo una vasta y heterogénea periferia que es incorporada al sistema de diferentes formas y en diversos grados. Esa visión global de la economía capitalista, que permitía identificar en ella una fractura estructural generada por la lenta propagación del progreso técnico y perpetuada por el sistema de división internacional del trabajo, constituye la mayor contribución teórica de Prebisch. Este fue el punto de partida de la teoría del subdesarrollo. 
en los sectores primario-exportadores y en las actividades ligadas a la exportación. Estas actividades pasan a coexistir con sectores rezagados en la penetración de nuevas técnicas y a nivel de productividad del trabajo ${ }^{67}$.

De acuerdo con el pensamiento estructuralista tradicional, pese a que la productividad es mayor en la industria que en la producción de bienes primarios, la relación de precios entre ambos tiende a moverse de forma adversa para la periferia. Esta tendencia, que lejos de ser inmutable puede cambiar según el contexto histórico, se explica por el hecho de que los beneficios de los empresarios y los ingresos de factores productivos tienden a crecer en el centro por encima de su productividad $\mathrm{y}$ en la periferia por debajo. En otras palabras, aunque la productividad es mayor en los centros que en la periferia, los primeros retienen el fruto del progreso técnico de su industria, es decir que no se produce una baja del precio de los bienes finales en sintonía con el aumento de la productividad, mientras que los países de la periferia les han traspasado una parte de su propio progreso tecnológico (Prebisch, 1950, pág. 501).

La explicación de este fenómeno radica en el hecho de que los avances de la acumulación y el progreso técnico que se dan en el centro desembocan en transformaciones de las estructuras sociales que permiten modificar la distribución del ingreso y retener los efectos del progreso técnico (Furtado, 2003, pág. 58 ${ }^{68}$. La explicación más detallada de Prebisch en el Manifiesto (1950) combina, en línea con los lineamientos del pensamiento heterodoxo, los efectos del ciclo (corto plazo) en la tendencia (largo plazo) (Kalecki, 1966) ${ }^{69}$. Según Prebisch, el aumento de los beneficios que se produce como consecuencia del progreso técnico se traduce en períodos de auge y en un incremento de los salarios por la escasez de mano de obra. También se produce un proceso de homogeneización social. En períodos de menor crecimiento y recesión, los asalariados se hallan en una mejor posición para resistir disminuciones en su poder de compra. En la periferia, en cambio, la desorganización característica de las masas obreras en la producción primaria les impide conseguir aumentos de salarios comparables a los de los países industriales. La compresión de los ingresos, ya sean beneficios o salarios, es, pues, menos difícil en la periferia (Prebisch, Ibíd., pág. 505).

El progreso técnico y su desigual distribución no solo conlleva un deterioro en la relación de intercambio en detrimento de la periferia,

67 Como se señaló, esto da lugar a dos tipos de estructuras productivas: i) especializada y heterogénea en la periferia y ii) diversificada y homogénea en el centro.

68 Según Furtado (2003, pág. 97), la presión de las fuerzas sociales ha llevado a que se establecieran sistemas de seguridad social y se definieran políticas de asistencia a las regiones menos desarrolladas.

69 Pérez Caldentey, Titelman y Carvallo (2013) sostienen que el bajo crecimiento tendencial de América Latina y el Caribe en relación con otras regiones se explica, en parte, por ciclos expansivos más cortos y menos intensos. 
sino que además, dada la institucionalidad existente, se constituye en un obstáculo para la mejora de los ingresos reales y del nivel de vida de las poblaciones de la periferia. La respuesta a esta disyuntiva por parte del estructuralismo es tecnificar el proceso de producción en los sectores primarios conjuntamente con un proceso de acumulación y mejoras tecnológicas en la industria ${ }^{70}$. La industrialización o cambio estructural es una manera de captar los frutos del progreso técnico y elevar el nivel de vida de los habitantes de la región.

El progreso técnico ya era un componente central del enfoque estructuralista mucho antes de que fuera descubierto por el paradigma dominante o incluso de que formara parte de los modelos de crecimiento heterodoxos ${ }^{71}$.

Siguiendo esta línea de pensamiento, Ocampo (véase el capítulo II) alerta sobre el importante rezago tecnológico que ha acumulado la región en los últimos años, lo que aumenta su grado de vulnerabilidad ante los cambios de más largo plazo en el contexto externo, tales como el fin del auge de las materias primas y, sobre todo, la disminución significativa del crecimiento del comercio internacional a partir de 2007. Este retraso tecnológico se refleja en el nivel comparativo entre América Latina y el Caribe y otras regiones del mundo en indicadores como la participación de las industrias intensivas en ingeniería como porcentaje de la producción industrial, la investigación y el desarrollo como porcentaje del PIB, y las patentes por millón de habitantes. La evidencia presentada muestra que la participación de las industrias intensivas en ingeniería como porcentaje de la producción industrial se sitúa en el $23 \%$, mientras que esta llega a niveles superiores al $95 \%$ en las economías emergentes de Asia y los países industrializados. De la misma manera, el gasto en investigación y desarrollo como porcentaje del PIB es menor al 0,5\% en América Latina y mayor al 1\% en las economías emergentes de Asia y los países industrializados.

${ }^{70}$ Prebisch declaró que lo que trataba de transmitir era la idea de un equilibrio dinámico entre ambos sectores. Si no hay industrialización en los países en desarrollo, en la periferia, y si hay progreso técnico en la agricultura, la relación de precios de intercambio tenderá al deterioro. La única forma de frenar esa tendencia es la industrialización (Pollock, Kerner y Love, 2006). En el pensamiento estructuralista, el progreso técnico no siempre es independiente de la acumulación, ya que la segunda conlleva el primero. A este respecto, Furtado (1957, pág. 40) escribe que la asimilación de técnicas más avanzadas se realiza usualmente mediante la incorporación de equipo nuevo en el proceso productivo, es decir, a través de la acumulación de capital. Este es el factor esencial del proceso de crecimiento en una economía subdesarrollada.

71 Los artículos seminales del paradigma sobre crecimiento económico donde se incluye el tema del progreso tecnológico datan de mediados de la década de 1950 (Abramovitz, 1956; Solow, 1956; Kaldor, 1957; Robinson 1956). El análisis de Solow se aplica para comparar trayectorias de crecimiento de distintos países, asumiendo que todos tienen la misma tecnología, la misma depreciación de capital, la misma tasa de progreso tecnológico, etc. Habría que esperar hasta la década de 1980 para que el paradigma dominante abordara los problemas asociados a los países en desarrollo (véase Lucas, 2002). 
Finalmente, el número de patentes por millón de habitantes es 60 y 235 veces mayor en Asia emergente y en el mundo desarrollado en relación con América Latina y el Caribe.

\section{La distribución del ingreso}

En las teorías heterodoxas y estructuralistas, el proceso de acumulación (entendido como la razón entre inversión neta y acervo de capital) determina, en última instancia, la distribución del ingreso. En la proposición más simple del pensamiento heterodoxo, el nexo causal es directo. El incentivo para invertir guía la acumulación de capital y por medio de la ecuación de Cambridge, se determina la tasa de beneficios y el salario real (Robinson, 1956, pág. 11; Marglin, 1984, págs. 474-475). Se asume que bajo la existencia de un exceso de capacidad, la acumulación puede generar un patrón de distribución favorable hacia los salarios. En el caso contrario, que ocurre en un contexto de ausencia de exceso de capacidad, un aumento de la acumulación se traduce en un alza de precios. A su vez, el alza de precios disminuye el salario real y aumenta la tasa de ganancia y la participación de los beneficios en el producto.

Las teorías estructuralistas incluyeron un eslabón adicional en la causalidad entre acumulación y distribución del ingreso: la transformación de las estructuras sociales.

Según la teoría estructuralista, históricamente la acumulación de capital mejoró la distribución del ingreso y el nivel de vida general en las economías más desarrolladas porque conllevó una escasez de mano de obra, lo que creó las condiciones para que surgieran presiones sociales que favorecerían la elevación de los salarios reales y la homogenización social (Furtado, 2003, pág. 58). El efecto contrario ocurrió en los países en desarrollo, donde el proceso de acumulación no condujo a una transformación de las estructuras sociales. Más bien, lo que ocurrió fue que la acumulación reforzó las estructuras tradicionales. Esto da lugar a un proceso de causación circular que los pensadores estructuralistas reconocieron desde un principio y que se relaciona con dos conceptos clave también presentes en el neoestructuralismo y que han tomado un lugar preponderante en el pensamiento actual de la CEPAL: la heterogeneidad estructural y la heterogeneidad social.

Furtado (1965, pág. 97) indica que el reforzamiento de las estructuras sociales tradicionales tiende a orientar la aplicación de recursos productivos de una manera que reduce la eficiencia económica y concentra aún más el ingreso en un proceso de causación circular. De modo más general, la ineficiencia económica causa el estancamiento económico. Además, la adopción, por parte de las clases dominantes, de los patrones de consumo de países con un nivel de acumulación muy superior explica 
la gran concentración del ingreso y la persistencia de la heterogeneidad social (Furtado, 1999, págs. 75-76).

Más allá de consideraciones sobre la heterogeneidad estructural y social, la distribución del ingreso también se relaciona con la evolución de las economías en el tiempo. En Minsky, por ejemplo, la distribución del ingreso explica el ciclo y su dinámica (Kalecki, 1969; Minsky, 1982 y 1986). De acuerdo con Kalecki y Minsky, el gasto en inversión determina el beneficio y este, a su vez, determina la capacidad de autofinanciamiento de las empresas y la base sobre la cual estas toman sus decisiones de financiamiento externo (endeudamiento). En la fase de auge de un ciclo, un aumento en el beneficio puede cambiar las decisiones de inversión y de financiamiento externo de las empresas y estas pueden estar dispuestas a asumir un mayor nivel de deuda en relación con sus flujos, lo que genera situaciones de fragilidad financiera (Minsky, 1975, págs. 113-116) ${ }^{72}$.

\section{J. La volatilidad y la inestabilidad}

La volatilidad es uno de los temas de referencia esencial para el trabajo analítico de la CEPAL, para el pensamiento neoestructuralista de las últimas dos décadas (CEPAL, 2002, 2004, 2010, 2012) y para el pensamiento heterodoxo (como se muestra en el apartado anterior).

En consonancia con el enfoque metodológico, el análisis de la volatilidad en América Latina y el Caribe parte de una constatación empírica: a partir de la década de 1980, América Latina y el Caribe no solo ha incrementado su nivel de volatilidad real, sino que se ha caracterizado por ser una de las regiones del mundo con los mayores niveles de volatilidad real. Entre 1960 y 1980, el coeficiente de variación para la región se situó por debajo de 1, mientras que partir de 1980 es sistemáticamente superior a esta cifra.

La volatilidad se explica, en parte, por las características y especificidades de su propio ciclo (Pérez Caldentey, Titelman y Carvallo, 2013). En comparación con otras regiones del mundo desarrolladas y en desarrollo, el ciclo económico de América Latina y el Caribe presenta dos rasgos distintivos. En primer lugar, la región exhibe expansiones que son menos intensas y menos duraderas que en otras regiones del mundo en desarrollo, en particular Asia oriental y Asia y el Pacífico. En segundo término, América Latina y el Caribe muestra, en promedio, contracciones

72 De manera similar, en el pensamiento estructuralista, la estructura social y la distribución han jugado un papel significativo en temas puntuales como el análisis de la inflación. El déficit fiscal que se produce como consecuencia de pugnas redistributivas constituye uno de los mecanismos de propagación que, junto a las presiones básicas, explican la dinámica de la inflación (Noyola 1956; Sunkel, 1958 y 1963; Olivera, 1960). En Furtado también forma parte del análisis inicial la inflación inercial, que este autor denominó inflación neutral (Furtado, 1954 y 1959; Boianovsky, 2009). 
que, en términos de duración y amplitud, tienden a converger con las de otras regiones del mundo desarrollado y en desarrollo. Estas dos características implican que el ciclo completo de expansiones y contracciones tenga una mayor frecuencia en relación con otras regiones (mayor volatilidad) porque tiende a ser más corto y menos intenso.

A su vez, la volatilidad afecta de manera asimétrica a los sectores y productores de la actividad económica y tiende a endogeneizar el PIB tendencial a su movimiento cíclico. Esto se resume en el concepto de brecha recesiva de Ffrench Davis (2010 y el capítulo IV de este libro). Este autor argumenta que, en un período de contracción en el ciclo económico, el PIB efectivo puede estar muy por debajo del PIB tendencial, consistente con un pleno empleo por prolongados plazos, lo que afecta significativamente su evolución futura por los efectos depresivos sobre la inversión productiva, el empleo y la innovación. En los períodos de auge, en cambio, el PIB potencial o la frontera productiva establecen un límite para la recuperación del PIB efectivo. El PIB efectivo puede situarse por encima del PIB potencial solo de manera temporal. Ffrench-Davis denomina brecha recesiva a la brecha entre el producto potencial y el producto efectivo porque, al situarse el PIB actual por debajo del potencial, existe subutilización de capital y trabajo.

Según este autor, la brecha recesiva impacta en la formación de capital y trabajo y, por ende, puede transformar el PIB potencial en una variable endógena. Así, en períodos en que la brecha recesiva es mayor y más prolongada, el PIB potencial es menor. De aquí la importancia de utilizar la política macroeconómica para evitar situaciones de brechas recesivas que puedan dañar la capacidad productiva de una economía y elevar la formación de capital, el empleo sostenible, la innovación y, por ende, el PIB de tendencia.

Este énfasis en la volatilidad de la economía real no es nuevo y fue uno de los temas en que más énfasis puso Prebisch a la hora de caracterizar el funcionamiento de las economías de libre mercado. El autor afirmó que la actividad económica se expande y contrae continuamente en una sucesión interrumpida de las fases de crecimiento de los ingresos, la ocupación y la producción, seguida de fases de decrecimiento, con la consiguiente declinación de la producción y la ocupación. No hay punto de reposo: se asciende para descender y se desciende para volver a ascender. En ese movimiento no hay punto de equilibrio; es una sucesión continua de desequilibrios (Prebisch, 1991, vol. III, pág. 499).

Furtado también destacó el tema de la inestabilidad y expresó que desde cualquier ángulo que la abordemos, la economía industrial capitalista parece condenada a la inestabilidad (2003, pág. 60). De manera similar, la inestabilidad es considerada por el pensamiento heterodoxo (Minsky, 1982, 1986) como una de las principales fallas del capitalismo. 


\section{K. El papel central de la demanda}

El estructuralismo tradicional, tanto de Prebisch como de Furtado y otros pensadores, al igual que las nuevas corrientes estructuralistas y la mayor parte de los economistas, otorga un papel central a la demanda agregada como impulsor y motor de la acumulación, el crecimiento y el bienestar económico y social.

Tanto Prebisch como Furtado argumentaron inicialmente que los países de la periferia, incluidos los de América Latina, podían crecer hacia afuera mediante sus exportaciones o hacia adentro a través de un proceso de industrialización y cambio estructural. Ambos llegaron a la conclusión de que, no obstante la importancia del sector externo, el principal modo de crecer es hacia adentro; el mercado interno es el centro dinámico de la economía (Prebisch, 1950, pág. 496; 1973b, 1973; Furtado, 1999, págs. 69-73; 2003, pág. 54). Cabe notar, sin embargo, que esta prescripción se aplicaba esencialmente a los países de mayor tamaño de la región. Resulta obvio que esto no significa ni cerrar la economía ni adoptar prácticas proteccionistas. Furtado (1999, págs. 102-103) sostiene que solo la ignorancia o la mala fe permitirían confundir esta opinión con una prédica a favor de cerrar la economía.

La idea de crecimiento hacia adentro se asoció al uso de la demanda como instrumento para impulsar el crecimiento económico (Furtado, 1964). Además, el uso de la demanda para estos fines no es ajeno a la historia económica de América Latina y, de hecho, en el caso del Brasil en la década de 1930, precedió a las recomendaciones que más tarde haría Keynes para combatir los efectos de la Gran Depresión. Como señala Furtado en referencia a la política de apoyo para mantener los precios del café a principios de los años treinta (1999, pág. 71), es cierto que nadie advirtió que, al acumular y quemar montañas de café, el Brasil estaba edificando las pirámides que años después Keynes recomendaría como remedio de última instancia para vencer la depresión ${ }^{73}$.

De alguna manera, este enfoque es coherente con uno de los planteamientos básicos de la economía heterodoxa: el denominado "principio de la demanda efectiva". Según este principio, la trayectoria de las economías viene determinada en el corto y el largo plazo por la

73 Como Keynes escribió en su carta al presidente Roosevelt: "El objeto es hacer rodar la pelota" (1933). De ahí que su instrumento preferido ("mi remedio favorito", Clarke, pág. 115) para aumentar la inversión eran las obras públicas financiadas con préstamos. En Los medios para la prosperidad (1933), Keynes argumentó a favor de un programa de obras públicas utilizando la lógica del multiplicador. En condiciones por debajo del pleno empleo, Keynes señaló que este tipo de programas no generaban un déficit fiscal y destacó que es un total error creer que existe un dilema entre los esquemas para aumentar el empleo y los esquemas para equilibrar las cuentas fiscales. Todo lo contrario; es imposible equilibrar el presupuesto si no se aumenta el ingreso nacional, que es más o menos lo mismo que aumentar el desempleo (1980, IX, pág. 347). 
demanda en el sentido de que la producción de bienes y servicios se ajusta a la demanda, y las restricciones por el lado de la demanda priman sobre las restricciones por el lado de la oferta.

El principio de la demanda efectiva tiene una implicación fundamental que los autores de las versiones más recientes del estructuralismo comparten: el hecho de que el largo plazo no puede especificarse con independencia del corto plazo. Pereira (2012b, pág. 2) señala que el componente cíclico de la actividad económica tradicionalmente asociado con variaciones de la demanda agregada en el corto plazo afecta la tendencia de crecimiento de las economías capitalistas en el largo plazo.

Por su parte, Titelman y Pérez Caldentey (véase el capítulo V) sostienen que la dinámica y las características particulares del ciclo en América Latina y el Caribe son relevantes para el corto y el largo plazo. De manera más específica, expansiones más cortas y menos intensas implican que el período de acumulación también sea más corto y menos intenso. La débil naturaleza de las expansiones se refleja en variables estructurales, tales como la productividad y la inversión, que son consideradas determinantes esenciales de la trayectoria de crecimiento de una economía ${ }^{74}$.

Una variable central que vincula el corto y el largo plazo, y que forma parte del análisis central del estructuralismo y neoestructuralismo, así como del pensamiento heterodoxo, es la inversión. En el corto plazo, la inversión es uno de los principales componentes de la demanda agregada y del gasto total, así como un determinante de la utilización de la capacidad instalada. A su vez, en la medida en que la inversión se caracteriza por un elevado grado de irreversibilidad, vincula las decisiones que se toman en el corto plazo con los resultados del mediano y largo plazo, lo que conlleva un proceso de trayectorias dependientes.

La irreversibilidad tiene dos elementos. Por una parte, implica que las decisiones de inversión perduran en el tiempo, ya que las empresas no pueden desinvertir (o lo pueden hacer con un elevado costo o muy gradualmente a través de la depreciación de los activos inmovilizados) y el gasto en inversión se transforma así en un costo irrecuperable ${ }^{75}$.

Por otra parte, la característica de irreversibilidad de la inversión es un importante determinante de la propia decisión de invertir o

74 Schumpeter también compartía la noción de que el corto y el largo plazo están interrelacionados. Como expresó (1939, Vol. 1, pág. v), los ciclos no son como las amígdalas, cosas separables que pueden ser tratadas en sí mismas, sino que son como el latido del corazón, la esencia del organismo que los revela. La interdependencia entre el corto y el largo plazo es una de las características definitorias de la economía heterodoxa (Pereira, 2012b; Arestis y Sawyer, 2009).

75 La noción de irreversibilidad de la inversión puede encontrarse en distintas escuelas de pensamiento (Bertola y Caballero, 1999; Arestis y Sawyer, 2009). 
no invertir. Así, la inversión se vuelve particularmente sensible a las distintas formas de riesgo, tales como la incertidumbre que conlleva la evolución de los precios futuros, los costos operativos que determinan las corrientes de flujos de caja, la incertidumbre de la evolución de los tipos de interés $\mathrm{y}$, en general, la incertidumbre ligada al contexto macroeconómico futuro.

\section{El papel del mercado y del Estado}

Según el pensamiento estructuralista y heterodoxo, los papeles del Estado y del gobierno están indisolublemente ligados al surgimiento y la consolidación de las economías de mercado.

El análisis de la evidencia empírica existente demuestra que en sus estados iniciales, las economías desarrolladas utilizaron una combinación de políticas públicas en la manufactura, el comercio y la tecnología para promover su proceso de crecimiento y desarrollo. Estas involucraron el uso activo de subsidios y aranceles, así como la distribución de derechos de monopolio para estimular el establecimiento de determinados sectores y la supervivencia de las industrias más nuevas. Las políticas públicas también incluyeron el desarrollo de capacidades nacionales mediante la investigación, la educación, el estímulo de la adquisición, el aprendizaje de tecnología extranjera y las prácticas de cooperación público-privada (Chang, 2002 y 2008; Pérez Caldentey, 2008).

Además, la evidencia demuestra que estas estrategias y prácticas también se han extendido como una manera de consolidar la supremacía tecnológica de las grandes potencias industriales actuales. A título de ejemplo, entre 1950 y 1978, el gobierno federal de los Estados Unidos proveyó el 50\% del financiamiento para la investigación y el desarrollo del país. De manera más específica, el gobierno ha dirigido el desarrollo tecnológico y el deseo de innovar en nuevas áreas, como tecnología de la información, biotecnología, energía nuclear y nanotecnología (Phelps, 2013). Los grandes logros tecnológicos de los siglos XX y XXI dudosamente hubiesen podido ver la luz sin un decisivo apoyo gubernamental, incluida la innovación en computadoras de Apple y la magnetorresistencia, las nuevas entidades moleculares (biología) y el nacimiento de Silicon Valley en California (Mazzucato 2013; Janeway, 2012).

No obstante, la experiencia también demuestra que este tipo de estrategias no son exclusivas de los países desarrollados o de las experiencias más exitosas, como las de Asia oriental, sino que también han sido una característica recurrente en la historia de América Latina y el Caribe. Por lo menos desde finales del siglo XIX hasta la crisis de la deuda en la década de 1980, los gobiernos de la región, y en particular los 
de las grandes economías, intervinieron de manera activa en un esfuerzo de consolidación territorial y de promoción del desarrollo de largo plazo de sus economías. El período más destacado de intervención fue, sin lugar a dudas, el de "industrialización guiada por el Estado" (Ocampo, 2004), que se extendió desde finales de la Segunda Guerra Mundial hasta la década de 1960, y en algunas economías incluso hasta principios de los años setenta.

Las políticas de intervención en la región se focalizaron en el desarrollo de infraestructura, en la protección de los sectores exportadores, así como de determinados productos e industrias (y sectores), y en el estímulo a la inmigración del trabajo especializado ${ }^{76}$. Al igual que en el caso de las economías más desarrolladas, en sus inicios, los principales instrumentos utilizados por los gobiernos de la región incluyeron, entre otros, los impuestos a la importación y exportación, las exenciones arancelarias, los controles cuantitativos y una amplia gama de subsidios, el control del tipo de cambio y el crédito barato. A diferencia de los países más industrializados, las economías de América Latina prestaron, con algunas excepciones, poca atención al desarrollo tecnológico y a la educación. En definitiva, y de manera general, las políticas intervencionistas fueron menos efectivas que las aplicadas en los países desarrollados, desbalanceadas en algunos casos y sin la flexibilidad necesaria para adaptarse a una realidad y un contexto cambiantes. Menos aún fueron capaces de promover, como se pensaba, un cambio estructural.

En concordancia con sus principios metodológicos, el estructuralismo no solo reconoció la intervención como un hecho, sino que también planteó sus limitantes. Además, sobre esta base, propuso cambios en la concepción y el alcance de las intervenciones del gobierno. Así fue que la industrialización guiada por el Estado dio paso en la década de 1970 a una estrategia de desarrollo y se centró en la relación entre crecimiento y comercio. Entre sus elementos centrales se incluyó la necesidad de fomentar las exportaciones de materias primas para financiar las importaciones y promover la exportación de manufacturas, que representaban solo el $4 \%$ de las exportaciones totales de bienes en América Latina en promedio para el período 1950-1962 (Pérez Caldentey, Sunkel y Torres, 2012)77.

${ }^{76}$ En este sentido, Baer (2008, pág. 303) considera que la política de subsidios a la inmigración adoptada en el Brasil a finales del siglo XIX actuó como sustituto de una política de inversión en capital humano.

77 Prebisch reconoció a mediados de la década de 1950 las falencias de esta estrategia y fue cuidadoso en hacerla institucionalmente pública en 1961 en el documento Desarrollo económico, planeamiento y cooperación internacional (Prebisch, 1961) Tal y como señaló más de 20 años después, en 1984, los mercados nacionales aislados de la competencia externa, debilitando e incluso destruyendo el incentivo necesario para mejorar la calidad de la producción y reducir los costos bajo el sistema de empresa privada. Esto [la estrategia de industrialización regulada por el Estado] ha sofocado la iniciativa de las empresas en el mercado interno y externo. También volvió a enfatizar las limitaciones de esta estrategia en la última entrevista en la CEPAL cuando afirmó: "En CEPAL sostuvimos desde un principio que la protección 
Siguiendo esta línea, el neoestructuralismo abogó por una renovación en el estilo y la forma de la intervención estatal en relación con los esfuerzos centrados puramente en la industrialización (CEPAL, 1990). En esta etapa, aunque las prioridades de intervención mantuvieron su énfasis en lo sectorial y lo micro, se desplazaron hacia el fortalecimiento de una competitividad basada en la incorporación del progreso tecnológico y hacia el logro de una mayor equidad e igualdad social. En el documento Transformación productiva con equidad se afirma (Ibid, pág. 154) que el estilo de intervención estatal consecuente con la transformación productiva con equidad habrá de ser distinto de aquel que favoreció la industrialización. En la actualidad, las dos tareas cruciales para el Estado consisten en participar en la superación de las carencias acumuladas en los ámbitos de la equidad y de la competitividad internacional (innovación).

Estas líneas de intervención gubernamental son las que han marcado en esta área el pensamiento y la investigación de la corriente neoestructuralista. A este respecto, existe un consenso acerca de que la acumulación de capacidades tecnológicas debe ser el objeto de una política que persiga una transformación productiva. Esto no solo requiere el desarrollo de estructuras exportadoras con mayor contenido tecnológico, sin olvidarse del mercado interno, sino que más bien se trata de potenciar encadenamientos entre el sector externo e interno ${ }^{78}$. En este sentido, tal como se planteaba en el documento Transformación productiva con equidad, una política pública en el ámbito productivo debe ser sectorialmente selectiva en sus iniciativas de desarrollo de la actividad productiva (Ocampo, 2011).

El nuevo desarrollismo plantea puntos muy similares, entre los que se destaca la industrialización orientada al sector exportador, la creación de oportunidades de inversión y la reducción de las desigualdades económicas (Pereira, 2012a y b, pág. 361). Además, tanto el neoestructuralismo como el nuevo desarrollismo otorgan un mayor papel al sector privado en la producción y asignación de bienes y servicios.

era indispensable como instrumento para enfrentar la superioridad técnica y económica de los centros. Desafortunadamente la protección....ha sido extremadamente exagerada, a decir abusiva, y ha sido mantenida en pie durante una largo período de tiempo, careciendo de incentivo para que las industrias reduzcan sus costos de producción" (1986). Otros economistas de tradición estructuralista como Maria da Conceição Tavares y Santiago Macario también reconocieron en la década de los sesenta las limitaciones de la industrialización guiada por el Estado. Véase Pérez Caldentey, Sunkel y Torres (2012).

78 Políticas para la diversificación de la estructura productiva y exportadora, y la promoción de una mayor productividad de las pymes por su capacidad para generar empleo y prestar apoyo a los sectores de productividad intermedia para vincularse de manera más dinámica con empresas más grandes o sectores de mayor liderazgo en productividad. 
A las intervenciones gubernamentales de carácter sectorial y microeconómico, el neoestructuralismo ha añadido un aspecto macroeconómico que no estaba presente en el pensamiento estructuralista: el manejo de la demanda agregada y de sus fluctuaciones cíclicas a través de la política fiscal. Como señala Ocampo (2011, pág. 16), en economías abiertas, la política monetaria encuentra serias dificultades para cumplir su papel anticíclico, especialmente cuando se ha abierto la cuenta de capitales. Por este motivo, el mejor instrumento de manejo anticíclico es, indudablemente, la política fiscal ${ }^{79}$.

En este aspecto, el pensamiento neoestructuralista enlaza con el pensamiento heterodoxo y en particular con el enfoque poskeynesiano que enfatiza esencialmente la intervención gubernamental como un factor macroeconómico centrado en la política fiscal. Según la corriente poskeynesiana, el papel de la política fiscal es acortar la distancia entre la inversión y el ahorro, evitando que el peso recaiga en el nivel de actividad económica. De manera más formal, la restricción presupuestaria del gobierno es igual a

(7) $\mathrm{G}-\mathrm{T}=\mathrm{S}\left(\mathrm{Y}^{\mathrm{e}}\right)-\mathrm{I}\left(\mathrm{Y}^{\mathrm{e}}\right)+\left(\mathrm{M}\left(\mathrm{Y}^{\mathrm{e}}\right)-\mathrm{X}\left(\mathrm{Y}^{*}\right)\right)$

Donde, $\mathrm{G}=$ gasto de gobierno, $\mathrm{T}=$ impuestos, $\mathrm{S}=$ ahorro, $\mathrm{I}=$ inversión, $\mathrm{M}=$ importaciones, $\mathrm{X}=$ exportaciones, $\mathrm{Y}^{*}=$ producto del resto del mundo e $Y^{\mathrm{e}}=$ producto interno (Creel y Sawyer, 2009).

Puesto de esta manera, la restricción fiscal implica que el gasto gubernamental puede absorber el exceso de ahorro (S) sobre (I). En otras palabras, el déficit gubernamental surge cuando hay un exceso de ahorro (S) sobre inversión (I). De la misma manera, se requiere un superávit cuando la inversión (I) excede al ahorro (S). Así, la justificación básica para la política fiscal en este marco es que no existe una tendencia automática hacia la igualdad entre el ahorro y la inversión ${ }^{80}$.

Véase Ffrench-Davis (2010).

Aunque según algunos neoestructuralistas, y en contraposición a la postura postkeynesiana, lo aconsejable es establecer reglas fiscales (Ffrench-Davis, 2010), también se reconoce la dificultad de hacerlo por el hecho de que la tendencia de una variable (i. e. el PIB) puede no ser independiente de su ciclo (Heyman, 2000; Ocampo, 2011; Pérez Caldentey, Titelman y Carvallo, 2013), como ya se indicó. Este también es un punto de intersección entre los pensamientos neoestructuralista y poskeynesiano. 


\section{Conclusión}

En este trabajo se sostiene que los acontecimientos de las últimas tres décadas marcan una ruptura en la práctica de la ciencia normal en economía (el llamado "paradigma dominante"). La validez y justificación de este enfoque se centró, sobre todo, en la capacidad predictiva que estos acontecimientos han puesto en duda. En este sentido, se trata de un momento propicio para explorar nuevas alternativas, tanto desde la perspectiva de un mayor equilibrio entre enfoques tradicionales $y$ novedosos de pensamiento, como sobre sus formas de enseñanza.

América Latina y el Caribe posee una larga y profunda tradición de pensamiento económico. El pensamiento más completo que ha surgido en la región es el ligado al estructuralismo y, en su versión más moderna, al neoestructuralismo. El estructuralismo surgió, en parte, como una reacción al pensamiento ortodoxo en economía debido a su falso sentido de universalidad y su limitada aplicabilidad al mundo real (Prebisch, 1950, pág. 498; Furtado, 2003, págs. 85-87), y, se podría decir, al mundo en desarrollo. El neoestructuralismo constituye un esfuerzo por adaptar las tesis estructuralistas a un contexto cambiante y proponer, a la vez, nuevos temas y pautas para su desarrollo metodológico y la formulación de política económicas.

En cuanto el (neo)estructuralismo es un sistema de ideas abierto, puede beneficiarse con el establecimiento de diálogos y la apertura de espacios de debate con otras tradiciones de pensamiento en economía, como la corriente heterodoxa. La corriente heterodoxa engloba un conjunto heterogéneo de enfoques, incluidos los marxistas y radicales, la escuela de la regulación, los poskeynesianos, los institucionalistas y los evolucionistas.

En este artículo se identifican siete áreas que pueden formar la base para un acercamiento entre ambas tradiciones de pensamiento y para una agenda de política económica cuyo fin sea, como lo plantearon en su momento, y por distintas vías, Keynes y Prebisch, generar un espacio de autonomía para la toma de decisiones que permita enfrentar las tres grandes falencias de las economías de mercado: la incapacidad de generar pleno empleo, la tendencia a la distribución arbitraria del ingreso y la riqueza, y la propensión a la volatilidad y la inestabilidad. 


\section{Bibliografía}

Abramovitz, M. (1956), "Resource and output trends in the United States since 1870", American Economic Review, vol. 46, No 2.

Acemoglu, D. (2009), "The crisis of 2008: structural lessons for and from economics", documento presentado en la reunión de la American Economics Association, San Francisco [en línea] http:/ /economics.mit.edu/ files/3703. (2008), Introduction to Modern Theories of Economic Growth, Princeton, Princeton University Press.Aghion, P. y P. Howitt (1992), “A model of growth through creative destruction", Econometrica, vol. 60.

Akerlof, G. (2006), The Missing Motivation in Macroeconomics [en línea] http://www.aeaweb.org/annual_mtg_papers/2007/0106_1640_0101.pdf

Akerlof, G. y R. Shiller (2009), Animal Spirits: How Human Psychology Drives the Economy, and Why It Matters for Global Capitalism, Princeton, Princeton University Press.

Allais, M. (1966), "A restatement of the quantity theory of money", American Economic Review, vol. 56.

Alvarez, R. y J. De Gregorio (2013), "Why did Latin America and developing countries perform better in the global financial crisis than in the Asian crisis?", documento presentado en la decimocuarta Conferencia anual de investigación Jacques Polak, Washington, D.C., Fondo Monetario Internacional (FMI), 7 y 8 de noviembre [en línea] http://www.imf.org/ external/np/res/seminars/2013/arc/pdf/deg.pdf.

Arestis, Ph. y M. Sawyer (2009), Path Dependency in Macroeconomics, Nueva York, Palgrave MacMillan.

Arrow, K.J. y G. Debreu, (1954), "Existence of an equilibrium for a competitive economy", Econometrica, vol. 22, $\mathrm{N}^{\mathrm{o}} 3$.

Baer, W. (2008), The Brazilian Economy: Growth and Development, Boulder, Co, Lynne Rienner.

Banco Mundial (2011), Latin America and the Caribbean's Long-term Growth. Made in China?, Washington, D.C.

Bean, Ch. y otros (2010), Monetary Policy after the Fall [en línea] http:/ / www.kansascityfed.org/publicat/sympos/2010/2010-08-23-bean.pdf.

Becker, G. (1981), A Treatise on the Family, Cambridge, Harvard University Press. (1978), The Economic Approach to Human Behavior, Chicago, University of Chicago Press.Bernanke, B. (2005), "The global saving glut and the U.S. current account deficit", documento presentado en la Sandridge Lecture, Asociación de Economistas de Virginia, Richmond, Virginia, 10 de marzo.

(2004), "The Great Moderation. Remarks by Governor Ben S. Bernanke", Washington, D.C., 20 de febrero [en línea] http://www.federalreserve.gov/ Boarddocs/Speeches/2004/20040220/. 
Bernanke, B., M. Gertler y S. Gilchrist (1999), “The financial accelerator in a quantitative business cycle framework", Handbook of Macroeconomics, vol. 1, J.B. Taylor y M. Woodford (eds.), Amsterdam, Elsevier. Bertola, G. y R. Caballero (1994), "Irreversibility and aggregate investment", Review of Economic Studies, vol. 61.

BID (Banco Interamericano de Desarrollo) (2008), All that Glitters May Not Be Gold. Assesing Latin America's Recent Economic Performance, Washington, D.C.

Bielschovsky, R. (2010), "Vigência das contribuições de Celso Furtado ao estruturalismo", Revista CEPAL, No especial (LCG.2444-P/P), Santiago de Chile, Comisión Económica para América Latina y el Caribe.

(2009), "Sesenta años de la CEPAL: estructuralismo y neoestructuralismo", Revista CEPAL, No 97 (LC/G.2400-P), Santiago de Chile, Comisión Económica para América Latina y el Caribe (CEPAL), abril.

(1998), "Evolución de las ideas de la CEPAL", Revista CEPAL, $\mathrm{N}^{\mathrm{o}}$ extraordinario (LC/G.2037-P/E), Santiago de Chile, Comisión Económica para América Latina y el Caribe (CEPAL).

Blanchard, Olivier (2008), "The State of macro is good", NBER Working Paper, $\mathrm{N}^{\mathrm{o}} 14259$ [en línea] http://www.nber.org/papers/w14259.pdf. (2006), “Monetary policy; science or art?" [en línea] http:/ / economics.mit.edu/ files/742.Blanchard, O. y J. Gali (2005), "Real wage rigidities and the New Keynesian Model", NBER Working Paper, No 11806, noviembre

Blanchard, O., G. Dell'Ariccia y P.M. Mauro (2013), "Rethinking macro policy II: getting granular", IMF Staff Discussion Note (SDN/13/03), abril [en línea] https: / / www.imf.org/external/pubs/ft/sdn/2013/sdn1303.pdf.

Blinder, A. (1986), "The case against the case against discretionary fiscal policy", The Macroeconomics of Fiscal Policy, R.W. Kopcke (eds.), Cambridge, MIT Press.

Boianovsky, M. (2008a), "A view from the tropics: Celso Furtado and the Theory of Economic Development in the 1950s", Textos para Discussão, N ${ }^{\circ} 247$, Universidade Federal Fluminense [en línea] http://www.uff.br/econ/download/tds/ UFF_TD247.pdf.

(2008b), "Furtado, Celso (1920-2004)", The New Palgrave Dictionary of Economics [en línea] http://www.dictionaryofeconomics.com/article?id= pde2008_F000293.

Borio, C., P. Disyatat y M. Juselius (2013), "Rethinking potential output: embedding information about the financial cycle", BIS Working Paper, N 404.

Borio, C. (2012), "The financial cycle and macroeconomics: what have we learnt?", BIS Working Papers, $\mathrm{N}^{\circ} 395$.

Boumans, M. y J. Davis (2010), Economic Methodology. Understanding Economics as a Science, Nueva York, Palgrave MacMillan.

Caballero, Ricardo J. (2010), "Macroeconomics after the crisis: time to deal with the pretense-of-knowledge syndrome", Journal of Economic Perspectives, vol. $24, \mathrm{~N}^{\circ} 4$.

Calvo, G. (2012), “21st Century Macroeconomics" [en línea] http://vox.lacea.org/ ?q=node $/ 193$. 
(2010), "Financial crises and liquidity shocks. A bank-run perspective" [en línea] http:/ / econ.tulane.edu/seminars/CalvoLiquidityCrisis.pdf.

Campos, R. de O. (1961), "Two views on inflation in Latin America", Latin American Issues, A.O. Hirschman (ed.), Nueva York, The Twentieth Century Fund.

Ceballos, F. y otros (2012), "Respuestas de política a la crisis financiera global: ¿Qué hicieron diferente las economías emergentes?", Revista Estudios Económicos, vol. 24.

CEPAL (Comisión Económica para América Latina y el Caribe) (2014), Pactos para la igualdad: hacia un futuro sostenible (LC/G.2586(SES.35/3)), Santiago de Chile. (2013a), Panorama Social de América Latina, 2013 (LC/G.2580), Santiago de Chile, Publicación de las Naciones Unidas, Nº de venta: S.14.II.G.6.

(2012), Cambio estructural para la igualdad. Una visión integrada del desarrollo (LC/G.2524(SES.34/3)), Santiago de Chile.

(2010), La hora de la igualdad: brechas por cerrar, caminos por abrir (LC/G.2432 (SES.33/3)), Santiago de Chile.

(2004), Desarrollo productivo en economías abiertas (LC/G.2234(SES.30/3)), Santiago de Chile.

(2002), Globalización y desarrollo (LC/G.2157(SES.29/3)), Santiago de Chile.

(1990), Transformación productiva con equidad: la tarea prioritaria del desarrollo de América Latina y el Caribe en los años noventa (LC/G.1601-P), Santiago de Chile.

(1957), El desequilibrio externo en el desarrollo de México económico latinoamericano. El caso de México (E/CN/T2/428), abril.Chang, H.J. (2008), Bad Samaritans: The Myth of Free Trade and the Secret History of Capitalism, Nueva York, Bloomsbury Press.

(2002), Kicking Away the Ladder: Development Strategy in Historical Perspective, Londres, Anthem Press.

Chenery, H y T.N. Srinivasan (eds.) (1988), Handbook of Development Economics, Elsevier Science Publishers.

Chick, V. (2004), “On open systems”, Brazilian Journal of Political Economy, vol. 24, $\mathrm{N}^{\mathrm{o}} 1$ (93), enero-marzo.

Clarida, R. (2010), "What has - and has not - been learned about monetary policy in a low inflation environment? a review of the 2000s" [en línea] http:/ / www.bostonfed.org/economic/conf/conf55/papers/Clarida.pdf.

Cohen, Avi J., y G.C. Harcourt (2003), "Retrospectives: whatever happened to the Cambridge capital theory controversies?", Journal of Economic Perspectives, vol. $17, \mathrm{~N}^{\mathrm{o}} 1$.

Colander, D. y otros (2009), "The financial crisis and the systemic failure of academic economics", Kiel Working Papers, $N^{\circ} 1489$, Kiel Institute for the World Economy, febrero [en línea] http://www.ifw-members.ifw-kiel.de/ publications / the-financial-crisis-and-the-systemic-failure-of-academiceconomics/KWP_1489_ColanderetalFinancial\%20Crisis.pdf.

Cochrane, J.H. (2011), "How did Paul Krugman get it so wrong", Institute of Economic Affairs (IEA) [en línea] http://faculty.chicagobooth.edu/ john.cochrane/research/papers/ecaf_2077.pdf. 
Coddington, A. (1983), "Keynesian economics. The search for the first principles", Journal of Economic Literature, Boston, George Allen and Unwin.

Corbo, V. y K. Schmidt-Hebbel (2013), "La crisis internacional y América Latina”, Monetaria, enero-junio.

Coric, B. (2011), "The global extent of the great moderation", Oxford Bulletin of Economics and Statistics, Departamento de Economía, Universidad de Oxford, vol. $74, \mathrm{~N}^{\mathrm{o}} 4$.

Cornia, G.A. y B. Martorano (2010), "Policies for reducing income inequality: Latin America during the last decade", Social and Economic Policy Working Paper, febrero [en línea] http:/ / www.unicef.org/socialpolicy/files/Postscript_ Formatted_Policies_for_reducing_income_inequality.pdf.

Creel, J. y M. Sawyer (2009), Current Thinking on Fiscal Policy, Nueva York, Palgrave Macmillan.

Danby, C. (2005), "Noyola's institutional approach to inflation", Journal of the History of Economic Thought, vol. 27, $\mathrm{N}^{\circ} 2$.

Davidson, P. (2011), Post Keynesian Macroeconomic Theory, Northhampton, Edward Elgar. (1992), International Money and the Real World, Nueva York, St. Martin's Press. (1979), "Natural resources", A Guide to Post-Keynesian Economics, A.S. Eichner (ed.), Nueva York, M.E. Sharpe. Inc.Debreu, G. (1959), Theory of Value, Nueva York, Wiley.

De Gregorio, J. (2009), “La macroeconomía, los economistas, y la crisis", Documentos de Política Económica, No 33, Santiago de Chile, Banco Central. (2007), "Algunas reflexiones sobre el crecimiento económico en Chile", Documentos de Política Económica, No 20, Santiago de Chile, Banco Central.

Didier, T., C. Hevia y S.L. Schmukler (2012), "How resilient and countercyclical were emerging market economies during the global financial crisis?", Journal of International Money and Finance, vol. 31, $\mathrm{N}^{\circ}$ 8, Elsevier.

Dow, S.C. (2002), Economic Methodology: An Inquiry, Nueva York, Oxford University Press.

Eatwell, J. (1987), "Imperfectionist models", The New Palgrave Dictionary of Economics [en línea] http://www.dictionaryofeconomics.com/article?id= pde1987_X001084.

Eatwell, J. y M. Milgate (1999), "Some deficiencies of Walrasian general intertemporal equilibrium", Value, Distribution and Capital. Essays in Honour of Pirangelo Garegnani, G. Mongiovo y F. Petri, Nueva York, Routledge. (1983), Keynes's Economics and the Theory of Value and Distribution, Oxford, Duckworth.

Erten, B. y J.A Ocampo (2012), "Super-cycles of commodity prices since the mid-nineteenth century", DESA Working Paper, No 110ST/ESA/2012/DWP/110.

Fajnzylber, Fernando (1990), "Industrialización en América Latina: de la 'caja negra' al 'casillero vacío': comparación de patrones contemporáneos de industrialización”, Cuadernos de la CEPAL, No 60 (LC/G.1534/Rev.1-P), Santiago de Chile. Publicación de las Naciones Unidas, $\mathrm{N}^{\mathrm{o}}$ de venta: S.89.II.G.5. 
(1983), La industrialización trunca de América Latina, México, D.F., Editorial Nueva Imagen, S.A.

Fama, E.F. (2011), "Examining the financial crisis with Professor Eugene Fama", Chicago Booth News [en línea] http://www.chicagobooth.edu/news/ 2011-10-28_fama.aspx.

(2007), "Interview with Eugene Fama" [en línea] http:/ / www.minneapolisfed.org/ pubs/region/07-12/fama.cfm.

(1970), "Efficient capital markets: a review of theory and empirical work", The Journal of Finance, vol. 25, No 2.

Ffrench-Davis, R. (2010), "Macroeconomía para el desarrollo: desde el financierismo al productivismo", Revista CEPAL, No 102 (LC/G.2468-P/E), Santiago de Chile, Comisión Económica para América Latina y el Caribe (CEPAL).

(2006), Reforming Latin America's Economics after Market Fundamentalism, Nueva York, Palgrave Macmillan.

(1991), "Formación de capital y marco macroeconómico: bases para un enfoque neo estructuralista", El desarrollo desde dentro: un enfoque neoestructuralista para América Latina, Osvaldo Sunkel (comp.), Lecturas, No 71, México, D.F., Fondo de Cultura Económica.FMI (Fondo Monetario Internacional) (2008), Regional Economic Outlook: Western Hemisphere, Washington, D.C., abril.

(2007), Perspectivas de la economía mundial al día. Actualización de las proyecciones mundiales, julio [en línea] https://www.imf.org/external/pubs/ft/weo/2007/ update/01/pdf/esl/0707s.pdf.

Friedman, M. (1975), Milton Friedman's Monetary Framework. A Debate with His Critics, Robert Gordon (ed.), Chicago, Chicago University Press.

(1968), "The role of monetary policy", The American Economic Review, vol. 58, No 1. (1962), Capitalism and Freedom, Chicago, Chicago University Press.

(1953a), "Lange on price flexibility and employment: a methodological criticism", Essays in Positive Economics, M. Friedman, Chicago, The University of Chicago Press.

(1953b), "The methodology of positive economics", Essays in Positive Economics, M. Friedman, Chicago, The University of Chicago Press.

Furtado, Celso (2003), En busca de un nuevo modelo: reflexiones sobre la crisis contemporánea, México, D.F., Fondo de Cultura Económica (1999), El capitalismo global, México, D.F., Fondo de Cultura Económica.

(1987), "Underdevelopment: to conform or to reform", Pioneers in Development Second Series, G. Meier (ed.), Nueva York, Oxford University Press.

(1978), Prefacio a una nueva economía política, México, Siglo veintiuno editores.

(1965), "Development and stagnation in Latin America: a structuralist approach", Studies in Comparative International Development, vol. 1.

(1964), Development and Underdevelopment. A Structuralist View of the Problems of Developed $\mathcal{E}$ Underdeveloped Countries, Berkeley, University of California Press. (1959), Formação economica do Brasil, Río de Janeiro, Fundo de Cultura. (1957), "Fundamentos da programação económica", Economica Brasileira, vol. 3. (1954), A economia brasileira, Río de Janeiro, Editora a Noite. 
Gali, J. (2008), Monetary Policy, Inflation and the Business Cycle. An Introduction to the New Keynesian Framework, Princeton, Princeton University Press.

Garegnani, P. (1990), "Quantity of capital", Capital Theory, J. Eatwell, M. Milgate y P. Newman (eds), Londres, Macmillan.

Greenspan, Alan (2005), “Remarks by Chairman Alan Greenspan. Economic flexibility. To the National Association for Business Economics Annual Meeting, Chicago, Illinois", 27 de septiembre [en línea] http:/ / www.federalreserve.gov / BoardDocs/Speeches/2005/20050927/default.htm.

Grossman, G.M. y E. Helpman (1991), Innovation and Growth in the Global Economy, Cambridge, Massachusetts, MIT Press.

Hahn, F. (1984), "General equilibrium theory", Equilibrium and Macroeconomics, F.H. Hahn, Cambridge, MIT Press.

Hansen, G. y E. Prescott (2002), "Malthus to Solow", American Economic Review, $\mathrm{N}^{\circ} 92$.

Hansen, L.P. y Th. Sargent (2010), "Wanting robustness in macroeconomics" [en línea] https: / / files.nyu.edu/ts43/public/research/wanting.pdf.

Harcourt, G.C. (1991), Some Cambridge Controversies in the Theory of Capital, Brookfield, Gregg Revivals.

Harrod, R.F. (1965), [Review of] "Essays in economic policy. By N. Kaldor”, Economic Journal, vol. 75.

Hausman, R. y F. Sturzenegger (2006), "Global imbalances or bad accounting? The missing dark matter in the wealth of nations", CID Working Paper, $\mathrm{N}^{\mathrm{O}}$ 127, Harvard University [en línea] http://files.wcfia.harvard.edu/ Haussman_Global.pdf.

Henry, P.B. (2007), "Capital account liberalization: theory, evidence, and speculation", Journal of Economic Literature, vol. 45, N 4, American Economic Association, diciembre.

Heymann, Daniel (2000), “Grandes perturbaciones macroeconómicas, expectativas y respuestas de política”, Revista de la CEPAL, No 70 (LC/G.2095-P), Santiago de Chile, Comisión Económica para América Latina y el Caribe (CEPAL), abril.

Hirschman, Albert O. (1995), A Propensity to Self-Subversion, Cambridge, Harvard University Press.

(1963), "Journeys toward progress", Studies of Economic Policy Making in Latin America, Nueva York, The Twentieth Century Fund.

(1958), The Strategy of Economic Development, New Haven, Yale University Press.

Ishikawa, S. (2008), "Structural change", The New Palgrave Dictionary of Economics [en línea] http://www.dictionaryofeconomics.com/article? id=pde1987_X002096.

Janeway, W.H. (2012), Doing Capitalism in the Innovation Economy: Markets, Speculation and the State, Nueva York, Cambridge University Press.

Jara, A., R. Moreno y C.E. Tovar (2009), "The global crisis and Latin America: financial impact and policy responses", BIS Quarterly Review, junio [en línea] http:/ / www.bis.org/publ/qtrpdf/r_qt0906f.pdf. 
Juselius, Katarina (2010), “Is Beauty Mistaken for Truth?”, Departmento de Economía, Universidad de Copenhague.

Kaldor, N. (1957), "A model of economic growth", Economic Journal, vol. 67.

Kalecki, M. (1969), Theory of Economic Dynamics, Nueva York, Kelley Publishers. (1966), Studies in the Theory of Business Cycles, Nueva York, Basil Blackwell.

Keynes, J. M. (1980), Collected Works, vol. 25, Londres, Macmillan.

(1964), The General Theory of Employment, Interest and Money, Nueva York, Harcourt Brace Jovanovitch Publishers.

(1933), "An open letter to President Roosevelt", New York Times, 31 de diciembre.

King, J.E (2009), Nicholas Kaldor, Nueva York, Palgrave Macmillan.

Krugman, P. (2009), "How did economists get it so wrong?", New York Times, 2 de septiembre [en línea] http://www.nytimes.com/2009/09/06/magazine/ 06Economic-t.html?pagewanted=all\&_r=0.

Kuhn, Thomas (1996), The Structure of Scientific Revolutions, Chicago, University of Chicago Press.

Lakatos, I. (1970), "Falsification and the methodology of scientific research programmes", Criticism and the Growth of Knowledge, Imre Lakatos y Alan Musgrave (eds.), Londres, Cambridge University Press.

Lavoie, M. (1996), Introduction to Post-Keynesian Economics, Nueva York, Palgrave MacMillan.

Lawson, T. (2003), Reorienting Economics, Nueva York, Routledge. (1997), Economics and Reality, Nueva York, Routledge.

Leamer, E. (2007), "Housing and the business cycle", documento presentado en el Simposio "Housing, housing finance and monetary policy", Jackson Hole, Wyoming, 30 de agosto 30 al 1 de septiembre [en línea] http:/ / www.anderson.ucla.edu/Documents/areas/adm/media/leamer_ housing_business_cycle.pdf.

Love, J.L. (1996), Crafting the Third World. Theorizing Underdevelopment in Rumania and Brazil, Stanfrod, Stanford University Press.

(1994), "Economic ideas and ideologies in Latin America since 1930", The Cambridge History of Latin America, vol. 6, N ${ }^{\circ}$ 1, L. Bethel (ed.), Cambridge, Cambridge University Press.

Lucas, R.E. (2012), Economic Dynamics Interviews Robert Lucas on Modern Macroeconomics [en línea] http://www.economicdynamics.org/News271.htm \#interview.

(2009), "In defense of the dismal science", The Economist [en línea] http:/ / www.economist.com/node/14165405.

(2004), "Life earnings and rural-urban migrations", Journal of Political Economy, vol. 112.

(2002), Lectures on Economic Growth, Cambridge, Harvard University Press.

(1991), "Methods and problems in business cycle theory", Studies in Business-Cycle Theory, R.E. Lucas, Jr. Cambridge, The MIT Press.

(1988), "On the mechanics of economic development", Journal of Monetary Economics, vol. 22. 
(1986), "Adaptive behavior and economic theory", Rational Choice. The Contrast between Economics and Psychology, R.M. Hogarth y M.W. Reder, Chicago, Chicago University Press.

(1972a), "Econometric testing of the natural rate hypothesis", The Econometrics of Price Determination, O. Eckstein (ed.,) Washington, D.C., Comité de Gobernadores de la Reserva Federal.

(1972b), "Expectations and the neutrality of money", Journal of Economic Theory, vol. 4, abril.

Lux, Th. y F. Westerhoff(2009), Nature Physics, vol. 5.

Mazzucato, M. (2013), The Entrepreneurial State, Nueva York, Anthem Press.

McCombie, J.S.L. y A.P. Thirlwall (1999), "Growth in an international context: a post Keynesian view", Foundations of International Economics. Post Keynesian Perspectives, J. Deprez y J.T. Harvey (eds.), Nueva York, Routledge.

(1994), Economic Growth and the Balance-of-Payments Constraint, Nueva York, St. Martin's Press.

Mallorquín, C. (1998), Ideas e historia en torno al pensamiento latinoamericano, México, D.F., Plaza y Valdés Editores.

Mankiw, G. (2010), Macroeconomics, Nueva York, Worth Publishers.

Mankiw, G. y D. Romer (1991), New Keynesian Economics, Cambridge, MIT Press.

Marglin, S.A. (1984), Growth, Distribution and Prices, Cambridge, Harvard University Press.

Marshall, A. (1920), Principles of Economics, Londres, Macmillan.

Matsuyama, K. (2008), "Structural change", The New Palgrave Dictionary of Economics [en línea] http:/ / www.dictionaryofeconomics.com/article?id=pde2008_S000440.

Mendoza, E.G. (2010), "Sudden stops, financial crises, and leverage", American Economic Review, vol. 100, No 5, diciembre.

Mishkin, F.S. (2010), "Monetary policy strategy: lessons from the crisis", NBER Working Paper Series, No 16755 [en línea] http:/ / www.nber.org/papers/w16755.

Minsky, H. (1986), Stabilizing an Unstable Economy, New Haven, Yale University Press. (1982), Can "It" Happen Again?, Nueva York, M.E. Sharpe. (1975), John Maynard Keynes, Nueva York, Columbia University Press.

Modigliani, F. (1977), "The monetarist controversy; or, should we forsake stabilization policies?", American Economic Review, vol. 67, No 2, American Economic Association, marzo.

Moreno-Brid. J.C. (1999), “On capital flows and the balance-of-paymentsconstrained growth model", Journal of Post Keynesian Economics, vol. 21, No 2.

Murphy, K., A. Shleifer y R. Vishny (1989), "Income distribution, market size, and industrialization", Quarterly Journal of Economics, vol. 104.

Mussa, M. (2006), "Comments", An Equilibrium Model of "Global Imbalances" and Low Interest Rates, Ricardo Caballero, Emmanuel Farhi y Pierre-Olivier Gourinchas, BIS Working Papers, No 222.

Muth, J. (1961), "Rational expectations and the theory of price movements", Econometrica, vol. 29. 
Navarrete, A. (1951), Estabilidad de cambios, el ciclo y el desarrollo económico: una investigación sobre los problemas de la balanza de pagos de México, 1929-1946, México, D.F., Panamericana.

Noyola, J. (1956), “El desarrollo económico y la inflación en México y otros países latinoamericanos", Investigación Económica, $\mathrm{N}^{\mathrm{o}}$ 4, cuarto semestre.

Obstfeld, M. y K. Rogoff (1996), Foundations of International Macroeconomics, Cambridge, MIT Press.

Ocampo, J.A. (2011), “Macroeconomía para el desarrollo: políticas anticíclicas y transformación productiva", Revista CEPAL, No 104 (LC/G.2498-P/E), Santiago de Chile, Comisión Económica para América Latina y el Caribe (CEPAL). (2008), "Impacto de la crisis financiera mundial sobre América Latina", Revista de la CEPAL, No 97 (LC/G.2400-P), Santiago de Chile, Comisión Económica para América Latina y el Caribe (CEPAL), abril.

(2004), "La América Latina y la economía mundial en el largo siglo XX”, El Trimestre Económico, vol. 71, Nº 4 .

Olivera, J.H. (1960), “La teoría no monetaria de la inflación”, El Trimestre Económico, vol. $28, \mathrm{~N}^{\circ} 4$.

Patinkin, D. (1989), Money, Interest, and Prices, Cambridge, MIT Press. (1987), "Real balances", The New Palgrave Dictionary of Economics, vol. 4, J. Eatwell, M. Milgate y P. Newman (eds), Nueva York, The MacMillan Press.

Pereira, C.B. (2012a), "From old to new developmentalism in Latin America", The Oxford Handbook of Latin American Economics, José Antonio Ocampo y Jaime Ros (eds.), Nueva York, Oxford.

(2012b), "Structuralist macroeconomics and the new developmentalism", Journal of Political Economy, vol. 32, $\mathrm{N}^{\mathrm{o}} 3$, julio-septiembre.

Pérez Caldentey, Esteban (2008), "The concept and evolution of the developmental State", International Journal of Political Economy, vol. 37, № 3.

Pérez Caldentey, Esteban y Matías Vernengo (2013), "Is inflation targeting operative in an open economy setting", Review of Keynesian Economics, vol. 1, No 3 .

(2010), "Back to the future: Latin America's current development strategy", Journal of Post Keynesian Economics, vol. 32, No 4 .

Pérez Caldentey, E., D. Titelman y P. Carvallo (2013), “Weak expansions: a distinctive feature of the business cycle in Latin America and the Caribbean", Working Paper, $\mathrm{N}^{\mathrm{o}} 749$, Levy Economics Institute [en línea] http://www.levyinstitute.org/ pubs/wp_749.pdf.

Pérez Caldentey, E., O. Sunkel y M. Torres (2012), Raúl Prebisch. Un recorrido por las etapas de su pensamiento [en línea] http://prebisch.cepal.org/sites/default/ files/Etapas_pensamiento_Prebisch.pdf.

Phelps. E. (2013), Mass Flourishing: How Grassroots Innovation Created Jobs, Challenge, and Change, Princeton, Princeton University Press.

Pindyck, R. (1990), "Irreversibilty, uncertainty and investment", MIT Working Paper, N ${ }^{o}$ 3137-90-EFA [en línea] http://dspace.mit.edu/bitstream/handle/ 1721.1/2299/SWP-3137-21583472.pdf. 
Pollock, D., D. Kerne y J. Love (2006), “Raúl Prebisch. CEPAL, ortodoxia monetaria e inflación", Suplemento de la Revista BCV, vol. 20, N 1, Caracas, enero-junio [en línea] http:/ / www.bcv.org.ve/Upload/Publicaciones/rbcvs012006.pdf.

Porzecanski, Arturo (2009), "Latin America: the missing financial crisis", serie Estudios y Perspectivas, No 6 (LC/WAS/L.104), Washington, D.C., Oficina de la CEPAL en Washington, D.C., octubre.

Posen A. (2007a), "Don't worry about U.S. mortgages", Welt am Sonntag, 12 de abril. (2007b), "A drag not a crisis", Welt am Sonntag, 27 de septiembre [en línea] http://www.iie.com/publications/opeds/oped.cfm?ResearchID=812.

Prebisch, Raúl (1993), Obras 1919-1949, vol. 4, Buenos Aires, Fundación Raúl Prebisch. (1991), Obras 1919-1948, vols. 1 al 3, Buenos Aires, Fundación Raúl Prebisch.

(1986a), "Cinco etapas en mi pensamiento sobre el desarrollo", Pioneros del desarrollo, Gerald Meier y Dudley Seers (eds.), Madrid, Tecnos.

(1986b), "Notas sobre el intercambio desde el punto de vista periférico", Revista de la CEPAL, N² 28 (LC/G.1392), Santiago de Chile, Comisión Económica para América Latina y el Caribe (CEPAL), abril.

(1963), "El falso dilema entre desarrollo económico y estabilidad monetaria", Boletín Económico de América Latina, vol. 6, Nº 1 .

(1951), "Crecimiento, desequilibrio y disparidades: interpretación del proceso de desarrollo", Estudio Económico de América Latina, 1949 (E/CN.12/164/Rev.1), Nueva York. Publicación de las Naciones Unidas, $N^{\circ}$ de venta: S.51.II.G.1. (1949), El desarrollo económico de la América Latina y algunos de sus principales problemas (E/CN.12/89), Santiago de Chile, Comisión Económica para América Latina y el Caribe (CEPAL).

(1947), Introducción a Keynes, Buenos Aires, Fondo de Cultura Económica.

(1943), La moneda y el ritmo de la actividad económica, inédito.

Robinson, J. (1980), "History versus equilibrium", Collected Economic Papers, vol. 5, Cambridge, MIT Press.

(1956), The Accumulation of Capital, Londres, MacMillan.

Rodríguez, Octavio (1977), "Sobre la concepción del sistema centro-periferia", Revista de la CEPAL, N 3, Santiago de Chile, Comisión Económica para América Latina y el Caribe (CEPAL), abril.

Rogoff, K. (2008), “The world's runaway train", Project Syndicate, julio [en línea] http:/ / www.project-syndicate.org/commentary/the-world-s-runaway-train.

Romer, D. (2013), "Preventing the next catastrophe: where do we stand?", iMFdirect [en línea] http://blog-imfdirect.imf.org/2013/05/03/preventing-the-nextcatastrophe-where-do-we-stand/\#more-6239.

(1990), "Endogenous technological change", Journal of Political Economy, vol. 98. (1986), "Increasing returns and long-run growth", Journal of Political Economy, vol. 94. Samuelson, P. (1983), Foundations of Economic Analysis, Cambridge, Harvard University Press.

Sanders, B. (2009), "Bernanke in his own words", 3 de diciembre [en línea] http:/ / www.sanders.senate.gov/newsroom/recent-business/bernanke-inhis-own-words. 
Sargent, Th. (2010), "Interview with Thomas Sargent", Federal Reserve Bank of Minneapolis, septiembre [en línea] http://www.minneapolisfed.org/ publications_papers /pub_display.cfm?id=4526\&.

Sargent, Th. y N. Wallace (1976), "Rational expectations and the theory of economic policy", Journal of Monetary Economics, vol. 2.

Schumpeter, J.A. (1997), The Theory of Economic Development, New Bunswick, Transactions Publishers.

(1976), Capitalism, Socialism and Democracy, Nueva York, Harper and Row. (1954), History of Economic Analysis, Nueva York, Oxford.

Shackle, G.L.S. (1955), Uncertainty in Economics and Other Reflections, Cambridge, Cambridge University Press.

Singer, H.W. (1987), "Terms of trade and economic development", The New Palgrave Dictionary of Economics [en línea] http://www.dictionaryofeconomics.com/ article?id=pde1987_X002149.

(1950), "The distribution of gains between investing and borrowing countries", American Economic Review, vol. 40, mayo.

Smith, Adam (1776), An Inquiry into the Nature and Causes of the Wealth of Nations, Edwin Cannan, (ed.), Chicago, Chicago University Press.

Solow, R. (2000), Growth Theory: An exposition, Nueva York, Oxford University Press. (1974), "The economics of resources or the resources of economics", American Economic Review, mayo.

(1957), "Technical change and the aggregate production function", Review of Economics and Statistics, vol. 39.

(1956), "A contribution to the theory of economic growth", Quarterly Journal of Economics, vol. 70. Sunkel, O. (1958), "La inflación chilena: un enfoque heterodoxo", El Trimestre Económico, vol. 25, $\mathrm{N}^{\circ} 4$.

(1991), El desarrollo desde dentro: un enfoque neoestructuralista para América Latina, México, D.F., Fondo de Cultura Económica.

Sunkel, O. y G. Zulueta (1990), "Neoestructuralismo versus neoliberalismo en los años noventa", Revista de la CEPAL, $\mathrm{N}^{\circ} 42$, Santiago de Chile, Comisión Económica para América Latina y el Caribe (CEPAL).

Sunkel, O. y P. Paz (1970), Subdesarrollo latinoamericano y la teoría del desarrollo, México, D.F., Siglo Veintiuno.

Taylor, J. (2008), "The financial crisis and the policy responses: an empirical analysis of what went wrong" [en línea] http:/ / www.stanford.edu/ johntayl/ FCPR.pdf.

Taylor, L. (2004), Reconstructing Macroeconomics, Cambridge, MIT Press.

Thirlwall, A.P. (1979), "The balance-of-payments constraint as an explanation of international growth rate differences", Quarterly Review, vol. 32, Roma, Banca Nazionale del Lavoro.

Tobin, J. (1975), "Friedman's theoretical framework", Milton Friedman's Monetary Framework. A Debate with His Critics, Robert Gordon (ed.), Chicago, Chicago University Press. 
Vera, L. (2013), “Inflación estructural redux", Ensayos Económicos, vol. 69, Banco Central de la República Argentina.

Wade, R.H. (2010), "Economist's contribution to the $2^{\text {nd }}$ depression and what they should learn" [en línea] http://inctpped.ie.ufrj.br/spiderweb/pdf_1/ 2_RW_economists_contributions.pdf.

Weintraub, R. (1979), Microfoundations: The Compatibility of Microeconomics and Macroeconomics, Nueva York, Cambridge University Press.

Wicksell, K. (1898), Interest and Prices, Nueva York, Kelley Publishers.

Woodford, M. (2010), "Financial intermediation and macroeconomic analysis", Journal of Economic Perspectives, vol. 24, $\mathrm{N}^{\circ} 4$.

- (2009), "Convergence in macroeconomics. elements of the new synthesis", American Economic Journal, Macroeconomics, vol. 1, $\mathrm{N}^{\mathrm{o}} 1$. (2003), Interest and Prices: Foundations of a Theory of Monetary Policy, Princeton, Princeton University Press.

Wren-Lewis, S. (2014), "Are new Keynesian DSGE models a Faustian bargain?" [en línea] http://mainlymacro.blogspot.com/2014/02/are-new-keynesian-dsgemodels-faustian.html. 



\section{Capítulo II \\ América Latina frente a la turbulencia económica mundial}

José Antonio Ocampo ${ }^{1}$

Quiero agradecer a la CEPAL y al ILPES su invitación a participar en esta conferencia sobre neoestructuralismo, acogiendo, por lo demás, una sugerencia de mi parte. Creo que es oportuna para ampliar la influencia de esta corriente de pensamiento latinoamericano. Más aún, esto resulta muy oportuno, ya que muchas de nuestras ideas han ido conquistando espacios, como se refleja, por ejemplo, en el reconocimiento que hizo el año pasado el Fondo Monetario Internacional al papel de las regulaciones a los flujos de capital, el que ahora otorga el Banco Interamericano de Desarrollo a las políticas de desarrollo productivo activas y el que hizo el Banco Mundial en su reciente informe sobre las clases medias a las virtudes del universalismo en las políticas sociales.

Todas estas son, en fin, victorias de posiciones que esta casa ha defendido, en algunos casos de vieja data, pero que hasta no hace mucho tiempo se descartaron como contrarias a la ortodoxia. Espero que esto sea apenas el comienzo y que nuestro ideario se siga imponiendo en la práctica del pensamiento y de la política económica. Quiero, además,

Esta es la transcripción de la presentación del autor en el seminario sobre neoestructuralismo y economía heterodoxa, realizado en la CEPAL los días 22 y 23 de abril de 2013. Los datos estadísticos para el análisis han sido actualizados, si bien aquí se presentan solo algunos cuadros y gráficos. 
hacer un reconocimiento especial a Osvaldo Sunkel, que nos convocó hace dos décadas a un evento y un libro que fue el origen del concepto de neoestructuralismo.

\section{A. Los cambios dramáticos en el entorno internacional}

Se nos ha pedido que hablemos sobre la crisis y la nueva realidad de la economía internacional. Lo que quiero hacer es analizar cómo esa nueva realidad ha impactado a América Latina. Comienzo anotando que el auge de 2003 a 2007 (hasta mediados de 2008 en algunos países) es el único que ha tenido América Latina en 30 años. Este auge fue el resultado de la coincidencia de una serie de factores externos extraordinarios, como una alineación de los astros que no se va a repetir.

Fue, en primer lugar, un período en el cual la migración latinoamericana hacia los Estados Unidos y España fue cuantiosa y las remesas de trabajadores experimentaron un crecimiento de dos dígitos. Fue, además, el final del gran auge del comercio internacional, que había comenzado a mediados de los años ochenta, el inicio de un superciclo de altos precios de productos básicos y el retorno a costos de financiamiento externo de América Latina similares a los de fines de los años setenta. El único factor negativo para América Latina fue la fuerte competencia de China con México en el mercado de los Estados Unidos y con todos los países de la región en nuestros propios mercados.

La coincidencia de tantos factores favorables provenientes de la economía internacional fue extraordinaria e irrepetible. De hecho, no se puede encontrar otro período de la historia económica de América Latina donde se hayan dado tantos factores positivos tan favorables. Esto sirve de marco para analizar cómo ha cambiado este escenario.

En primer término, desde la crisis de 2007-2008 han desaparecido dos factores. El primero es la migración de mano de obra y el auge de las remesas. En relación con España hay un retorno neto de inmigrantes y la migración a los Estados Unidos está estancada o incluso se ha reducido un poco; más aún, las políticas de migración que se pueden abrir paso en ese país no van a permitir, en principio, nueva migración, sino regularizar una parte de los migrantes irregulares. Como consecuencia de lo anterior, las remesas cayeron en 2009 y no se han recuperado plenamente.

El segundo fenómeno que desapareció con la crisis, y al cual voy a prestar un poco más de atención en mi ensayo, es el auge del comercio 
internacional. A mi juicio, con la crisis terminó un período extraordinario en la historia del comercio internacional, un auge que comenzó a mediados de los años ochenta y que, por su velocidad, fue similar al que se experimentó durante la llamada "edad de oro" de las economías industrializas de la posguerra ${ }^{2}$. El auge más reciente terminó en 2007 (a mediados de 2008, en algunos casos) y no se va a repetir. Este es un hecho que no se reconoce suficientemente.

Con la crisis permanecieron, sin embargo, dos factores favorables: el acceso abundante al financiamiento externo y el auge de precios de productos básicos (véase el cuadro II.1) ${ }^{3}$. Este último puede estar terminando, como consecuencia de la desaceleración de China, que es el factor fundamental que lo alimentó. Así lo revelan, como veremos, la tendencia de los dos últimos años de dichos precios.

Cuadro II.1

Mundo: crecimiento promedio anual de los índices de precios internacionales de los productos básicos, 2000-2013

(En porcentajes; 2010 $=100$ )

\begin{tabular}{lccccc}
\hline Período & Energía & Alimentos & Granos & Metales y minerales & Promedio \\
\hline $2000-2007$ & 17 & 10 & 11 & 14 & 13 \\
\hline $2008-2009$ & -9 & -2 & -4 & -7 & $-5,5$ \\
\hline $2010-2011$ & 16 & 8 & 14 & 3 & 10,25 \\
\hline $2012-2013$ & 0 & -1 & -7 & -3 & $-2,75$ \\
\hline
\end{tabular}

Fuente: Elaboración propia sobre la base de datos de Banco Mundial, Commodity Price Data, "Pink Sheet", 2013.

Tras el auge del financiamiento hay, sin embargo, un factor subyacente que es menos favorable para la región y que se relaciona con la forma como se está reequilibrando la economía internacional después de la crisis. El problema fundamental es la reducción del déficit externo de varias economías, en particular de los Estados Unidos y la periferia europea. Esto obliga a otras economías a moverse en el sentido contrario, hacia cuentas deficitarias, que es precisamente lo que ha acontecido en América Latina (véase el cuadro II.2).

2 En la llamada edad de oro de las economías industrializadas (1950-1973), el PIB de estas se expandió a una tasa del 5,9\%. Posteriormente el crecimiento no llegó a ese nivel ni siquiera durante la "Gran Moderación". En las décadas de 1980, 1990 y 2000 la tasa de crecimiento del PIB fue del 3\%, el 2,5\% y el 1,7\%, respectivamente.

3 El índice promedio de los precios de las materias primas (UNCTAD, 2011) para la energía, los alimentos, granos y metales y minerales se expandió un $13 \%$ entre 2000 y 2007 , se contrajo un $5,5 \%$ durante la crisis financiera global (2008-2009) y logró una rápida recuperación en los dos años que siguieron, registrando una tasa de crecimiento del 10,3\%. 
Cuadro II.2

Mundo (países y regiones seleccionados): evolución del saldo de la cuenta corriente de la balanza de pagos como proporción del PIB, 2005-2012

\begin{tabular}{|c|c|c|c|}
\hline & $2005-2007$ & 2008-2009 & 2010-2012 \\
\hline China & 7,2 & 7,1 & 2,7 \\
\hline India & $-1,1$ & $-2,2$ & $-3,1$ \\
\hline Estados Unidos & $-5,9$ & $-3,8$ & $-3,0$ \\
\hline América Latina & 1,3 & $-0,8$ & $-1,4$ \\
\hline BRICS $^{a}$ & 4,7 & 3,6 & 1,3 \\
\hline OCDE & $-1,5$ & $-1,0$ & $-0,4$ \\
\hline Zona del euro & 0,4 & $-0,2$ & 1,1 \\
\hline
\end{tabular}

Fuente: Elaboración propia, sobre la base datos de Banco Mundial, 2013.

a Incluye el Brasil, la Federación de Rusia, la India, China y Sudáfrica.

La abundancia de financiamiento externo es el mecanismo a través del cual se ha transmitido este efecto. Este fenómeno es lo que la presidenta del Brasil ha llamado el "tsunami de capitales" y el ministro de hacienda de dicho país denominó previamente la "guerra de divisas". Esta es una visión que ha sido respaldada hace pocos meses por los ministros de hacienda de Chile y Colombia y por el gobernador del Banco Central de México.

La forma como el impacto de este reajuste mundial afecta a América Latina es a través de la apreciación de las monedas, que tiene efectos negativos sobre la diversificación productiva, lo que los neoestructuralistas siempre hemos caracterizado como la fuente fundamental del crecimiento económico. El resultado es, por lo tanto, que la región retornó a crecimientos mediocres y, en realidad, si se toma el año 2007 como punto de partida y se agregan las predicciones para 2013, el crecimiento es del 3,0\% anual para América Latina, incluso ligeramente por debajo del promedio desde 1990. Este resultado es mediocre, de hecho uno de los peores del mundo en desarrollo.

En el cuadro II.3 se muestra la tasa de crecimiento del PIB durante el período 1971-2011 para América Latina y el Caribe, Asia Oriental y el Pacífico, Europa y Asia Central, los países de altos ingresos de la Organización de Cooperación y Desarrollo Económicos (OCDE), Oriente Medio y África Septentrional, Asia Meridional y África Subsahariana. En el primer período considerado (1971-1980), América Latina y el Caribe tenía la mayor tasa de crecimiento del mundo en desarrollo, después de Asia Oriental y el Pacífico. En cambio, a partir de los ochenta, América Latina y el Caribe muestra de manera sistemática una de las menores tasas del crecimiento del PIB del mundo en desarrollo. 
Cuadro II.3

Mundo: crecimiento del PIB per cápita, por regiones, 1971-2011

(En porcentajes)

\begin{tabular}{cccccccc}
\hline $\begin{array}{c}\text { Asia } \\
\text { Oriental y } \\
\text { el Pacífico }\end{array}$ & $\begin{array}{c}\text { Europa } \\
\text { y Asia } \\
\text { Central }\end{array}$ & $\begin{array}{c}\text { OCDE } \\
\text { (economías de } \\
\text { altos ingresos) }\end{array}$ & $\begin{array}{c}\text { América } \\
\text { Latina y } \\
\text { el Caribe }\end{array}$ & $\begin{array}{c}\text { Oriente Medio } \\
\text { y África } \\
\text { Septentrional }\end{array}$ & $\begin{array}{c}\text { Asia } \\
\text { Meridional }\end{array}$ & $\begin{array}{c}\text { África } \\
\text { Subsahariana }\end{array}$ \\
\hline $1971-1980$ & 4,5 & $\ldots$ & 2,7 & 3,2 & 2,7 & 0,7 & 0,9 \\
\hline $1981-1990$ & 5,7 & $-1,7$ & 2,7 & $-0,8$ & 0,2 & 3,0 & $-0,9$ \\
\hline $1991-2000$ & 7,1 & $-1,7$ & 1,9 & 1,6 & 1,8 & 3,2 & $-0,3$ \\
\hline $\mathbf{2 0 0 3 - 2 0 0 7}$ & $\mathbf{9 , 3}$ & $\mathbf{7 , 4}$ & $\mathbf{1 , 9}$ & $\mathbf{3 , 7}$ & $\mathbf{3 , 3}$ & $\mathbf{6 , 6}$ & $\mathbf{3 , 0}$ \\
\hline $2001-2011$ & $\mathbf{3} 2$ & 4,7 & 0,9 & 2,2 & 2,6 & 5,3 & 2,1 \\
\hline
\end{tabular}

Fuente: Elaboración propia sobre la base de Banco Mundial, World Development Indicators y Global Finance Development Database (GFDD), 2013.

El período de expansión más reciente (2003-2007), que fue el de mayor crecimiento para América Latina y el Caribe en cuatro décadas, no es una excepción a esta norma. En este período América Latina y el Caribe registró una tasa de crecimiento del 3,7\%, muy superior a la contracción registrada en los años ochenta (del $0,8 \%$ ) y que duplicó con creces el magro crecimiento de los noventa. Incluso, el desempeño económico de 2003-2007 fue algo superior al registrado en los setenta.

No obstante, en términos comparativos América Latina y el Caribe se quedó durante este período a la zaga de otras regiones del mundo en desarrollo y, en particular, de Asia Oriental y el Pacífico (9,3\%), Europa y Asia Central (7,4\%) y Asia Meridional (6,6\%).

\section{B. Los cambios en el comercio internacional y el rezago tecnológico de la región}

Analicemos algunos de estos hechos con mayor detenimiento. En el gráfico II.1 se muestran las principales fases de la historia del comercio internacional después de la Segunda Guerra Mundial. Resaltan cuatro períodos claramente diferenciados. El primero, entre 1950 y 1974, es la edad de oro de crecimiento de los países desarrollados y, especialmente, de los europeos, en la posguerra. El crecimiento del comercio internacional alcanzó durante este período más del $7 \%$ real por año, es decir, los ritmos de expansión más rápidos de la historia económica mundial hasta entonces. El segundo período cubre desde el primer choque petrolero hasta mediados de los años ochenta y se caracterizó por un lento crecimiento, tanto del PIB como del comercio mundial. El tercero se inició a mediados de los años ochenta y terminó 
en 2007. Durante ese período, el PIB mundial a precios de mercado ${ }^{4}$ no se aceleró, pero sí lo hizo el comercio, gracias a la liberalización de muchas economías, la fragmentación de las cadenas de valor y la expansión de la inversión extranjera directa ${ }^{5}$. El comercio internacional volvió a crecer a ritmos superiores al 7\% real por año durante más de dos décadas.

\section{Gráfico II.1 \\ Crecimiento del comercio y del PIB mundial, 1950-2012 \\ (En porcentajes)}

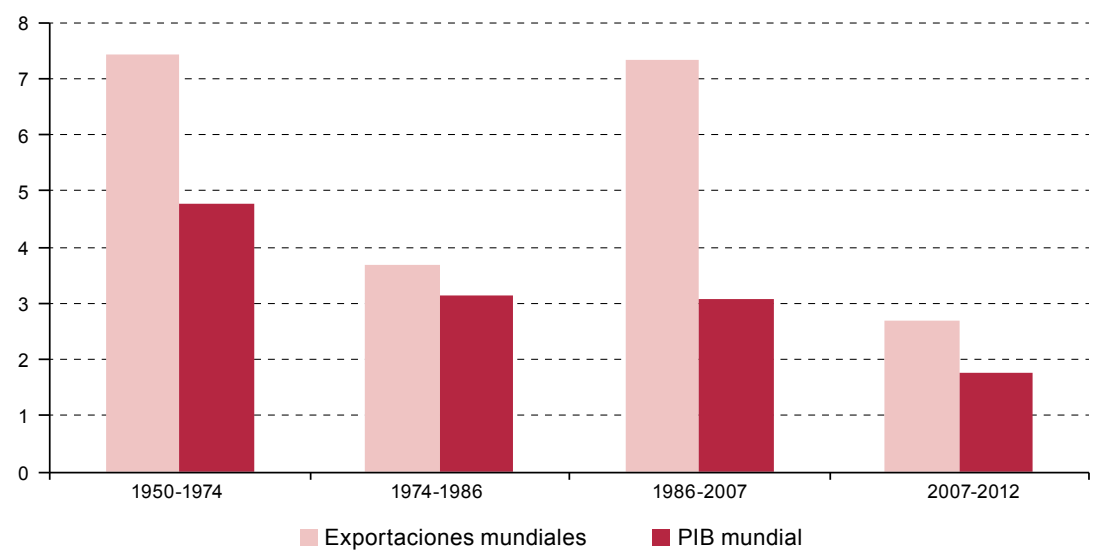

Fuente: Elaboración propia sobre la base de datos de Naciones Unidas hasta 2007 y del Fondo Monetario Internacional (FMI) para los años recientes.

En 2008 se inició un cuarto período, cuyo elemento destacado es el lento crecimiento del comercio internacional, el más bajo de toda la posguerra. Este es el resultado de dos factores: el PIB mundial ha crecido muy poco, pero al mismo tiempo ha disminuido la elasticidad del comercio al PIB, o sea, la relación entre el crecimiento del comercio y el crecimiento del PIB. Durante el período de auge precedente, esa elasticidad había llegado a 2,4, pero se redujo hasta 1,5, un registro similar al que había sido típico en el período 1950-1974. Sobre la base de estos datos podemos hacer unas previsiones simples. Supongamos que la economía mundial vuelve a crecer entre el $2,5 \%$ y el $3 \%$ por año. Con esa elasticidad, el comercio se expandiría hasta un $4 \%$ por año, o sea, 3 puntos porcentuales menos de lo

$4 \quad$ No a precios de paridad, ya que no es posible la comparación de los datos correspondientes con la evolución del comercio

5 Entre los factores que explican el crecimiento del comercio internacional se incluyen las innovaciones tecnológicas en el transporte y las comunicaciones, así como cambios en los métodos de producción que permitieron la creación de nuevos productos, la expansión de la producción y mejoras de eficiencia. Otro factor importante son los cambios en la forma de organización del comercio, como la que se realiza a través de cadenas internacionales de suministro. También hay que destacar la reducción de barreras al comercio y la expansión y globalización financiera (incluida la disminución de las restricciones a los pagos transfronterizos). 
que venía creciendo anteriormente. Este es, reitero, un hecho fundamental que hay que tener presente en una visión y una estrategia de futuro. La implicación más importante para nosotros es que hay que competir en calidad y en tecnología. Esto no es posible con el modelo ortodoxo de crecimiento liderado por exportaciones que América Latina adoptó en los años ochenta y que nos ha puesto en desventaja con aquellos países que han estado promoviendo a fondo sectores exportadores con un mayor contenido tecnológico.

Podría decirse que los ritmos de crecimiento promedio del comercio internacional en años recientes están afectados por la fuerte caída que este experimentó después del colapso del banco de inversión Lehman Brothers en septiembre de 2008. En el gráfico II.2 se muestra, en efecto, la contracción que sufrió el comercio a fines de 2008 y comienzos de 2009, especialmente en valor, así como la fuerte recuperación posterior. Sin embargo, se desaceleró con mucha rapidez y desde comienzos de 2011 el comercio internacional ha tendido a crecer en forma muy lenta, entre el $2 \%$ y el $3 \%$ por año. De hecho, con los datos de base del gráfico, se puede estimar que el crecimiento del comercio entre el primer semestre de 2011 y el primer semestre de 2013 ha sido de un 2,1\% por año, o sea, algo menos de lo que se calcula en el gráfico anterior para el período 2007-2012 en conjunto. La cuestión fundamental es, por lo tanto, que hemos entrado en una nueva era del comercio internacional y que este hecho debe estar en el centro de atención de las políticas económicas de nuestros países.

\section{Gráfico II.2}

Mundo: evolución de las exportaciones por volumen y por valor, enero de $\mathbf{2 0 0 6}$ a julio de $\mathbf{2 0 1 3}$

(Índice $100=$ primer semestre de 2008)

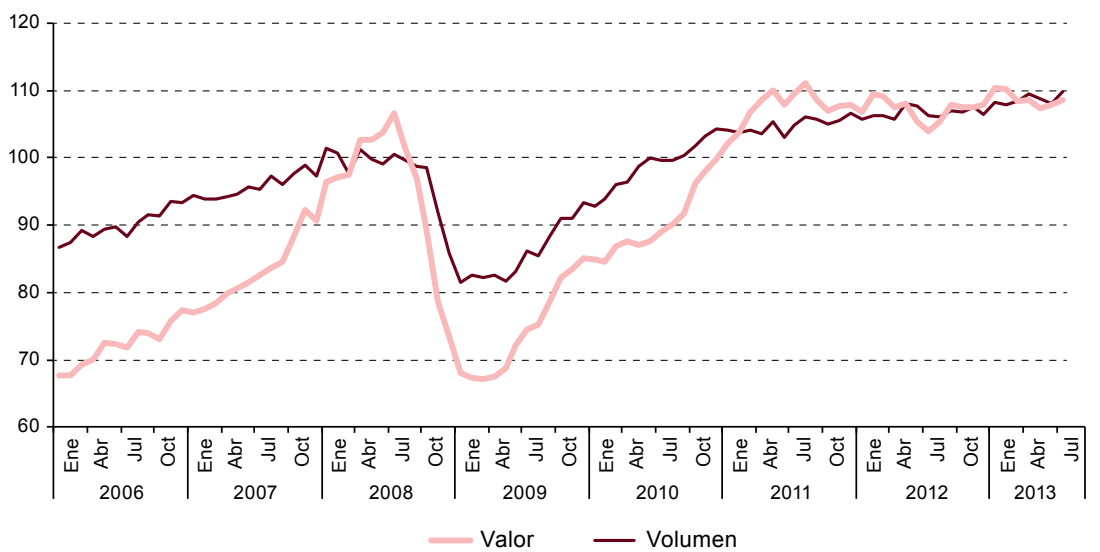

Fuente: Elaboración propia, sobre la base de datos del Netherlands Bureau of Economic Policy Analysis (CPB). 
Un hecho aún más preocupante es el enorme rezago tecnológico que ha acumulado la región, un tema que ha sido analizado con mucha precisión por la División de Desarrollo Productivo de la CEPAL en los últimos años. En el cuadro II.4 se muestran los indicadores de la división para tres dimensiones tecnológicas: participación de las industrias intensivas en ingeniería en el porcentaje de la producción industrial, inversión en investigación y desarrollo como porcentaje del PIB y patentes por millón de habitantes. En los tres casos se comparan los promedios regionales con dos puntos de referencia competitiva: los países desarrollados con estructuras productivas basadas en recursos naturales y los países emergentes de Asia. Los atrasos de los indicadores en relación con ambos son considerables en los dos primeros casos y dramáticos en el tercero.

\section{Cuadro II.4}

Mundo: especialización, estructura productiva y crecimiento, 1996-2007

\begin{tabular}{|c|c|c|c|}
\hline & $\begin{array}{l}\text { Aporte relativo } \\
\text { de las industrias } \\
\text { de ingeniería }{ }^{a}\end{array}$ & $\begin{array}{l}\text { Inversión en } \\
\text { investigación } \\
\text { y desarrollo }^{b}\end{array}$ & Patentes $^{c}$ \\
\hline América Latina & 0,23 & 0,40 & 0,5 \\
\hline $\begin{array}{l}\text { Economías desarrolladas basadas } \\
\text { en recursos naturales }{ }^{d}\end{array}$ & 0,72 & 1,89 & 65,4 \\
\hline Economías emergentes de Asia & 0,99 & 1,21 & 30,5 \\
\hline Economías maduras ${ }^{e}$ & 0,97 & 2,43 & 132,6 \\
\hline
\end{tabular}

Fuente: Mario Cimoli y Gabriel Porcile, "Learning, technological capabilities and structural dynamics", Handbook of Latin American Economics, en José Antonio Ocampo y Jaime Ros (eds.), Nueva York, Oxford University Press, 2011.

a Participación en el valor agregado de la industria (cociente respecto a los Estados Unidos, 2002-2007).

b Como porcentaje del PIB, 1996-2007.

c Acumuladas por millón de habitantes, 1996-2007.

d Con un $40 \%$ o más de las exportaciones basadas en recursos naturales.

e Estados Unidos, Francia, Italia, Japón, Reino Unido y Suecia.

Este es el producto de tres décadas de no haber prestado suficiente atención a la mejoría tecnológica de nuestro aparato productivo y que tiene como contrapartida la tendencia a la desindustrialización. En términos relativos, el coeficiente de industrialización de América Latina llegó, en efecto, a su punto más alto en la segunda mitad los años setenta y desde entonces ha ido retrocediendo, incluso durante el período reciente de crecimiento. La conjunción del menor dinamismo del comercio internacional con este debilitamiento competitivo es preocupante e indica que la reversión de estas tendencias y, en particular, el cambio estructural, debe regresar al centro de la agenda de las políticas económicas de la región. Este es un hecho que ha venido recibiendo atención creciente en los debates latinoamericanos.

Un pequeño paréntesis. Los economistas como Prebisch $-\mathrm{y}$ en general los estructuralistas - argumentaban la necesidad de un cambio estructural. A la vez, una de sus preocupaciones centrales ha sido el efecto 
del proceso del cambio estructural en el sector externo. De hecho, parte del análisis de la restricción externa (por ejemplo, según el concepto de "estrangulamiento externo") se plantea en este contexto.

\section{El financiamiento externo y los balances mundiales subyacentes}

En materia de financiamiento externo, las noticias son mucho más positivas, pero algunos de sus efectos, en particular la tendencia a la revaluación, hacen aún más complejos los problemas de competitividad que afectan a la región. En el gráfico II.3 se ilustran los efectos positivos. El costo del financiamiento externo alcanzó poco antes de la crisis los niveles más bajos desde fines de los años setenta. Una forma de ver esto es que tuvimos casi un cuarto de siglo de alto costo de financiamiento externo, que finalmente desapareció gracias a la mejora de la hoja de balance externo, en particular de una combinación de reducción del endeudamiento externo y aumento de las reservas internacionales.

Gráfico II.3

América Latina: márgenes de riesgo y rendimiento de los bonos, 2003-2013 (En porcentajes)

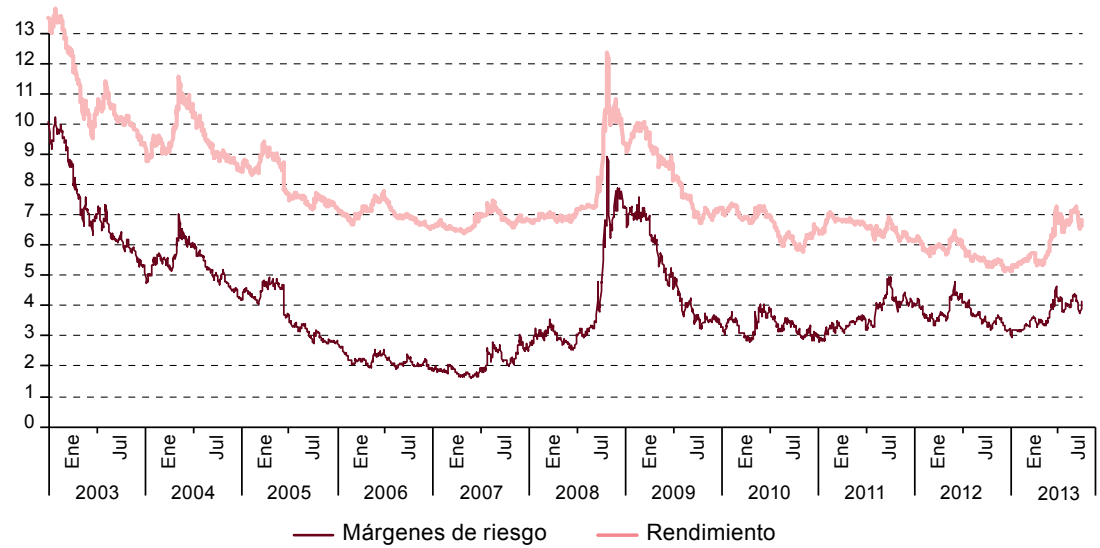

Fuente: Elaboración propia sobre la base de cifras proporcionadas por J.P. Morgan.

Con la crisis tuvimos una reversión temporal de esta tendencia. Sin embargo, el impacto de este choque adverso duró menos de un año, a diferencia de la crisis asiática, que duró seis años, o de la crisis de la deuda, que se prolongó durante ocho años. También ha habido movimientos negativos con posterioridad, que entre 2010 y 2012 estuvieron invariablemente asociados a la crisis europea, en particular a las perturbaciones en los mercados de España e Italia, y en 2013 a las que ha experimentado el mercado 
norteamericano ante los anuncios de la Reserva Federal de que comenzaría a moderar la expansión monetaria. No obstante, pese a estos episodios, el financiamiento externo para América Latina ha continuado siendo el más barato en 30 años. De hecho, si se agregaran los datos de emisiones de bonos en los mercados internacionales, veríamos que el acceso ha sido abundante, muy superior al que había sido típico antes de la crisis.

Hay, por supuesto, diferencias significativas entre países. Para aquellos con mejor acceso a los mercados privados, en particular el Brasil, Chile, Colombia, México y el Perú, el costo del financiamiento fue durante el último semestre de 2012 dos puntos porcentuales más bajo de lo que había sido típico en el primer semestre de 2007, es decir, antes de la crisis financiera de las hipotecas de alto riesgo (o crisis de subprime) en los Estados Unidos. La situación era muy diferente en las economías sin acceso al mercado privado: la Argentina, el Ecuador y Venezuela (República Bolivariana de). Cabe decir que estas últimas han tenido, sin embargo, acceso a una nueva fuente de financiamiento: China.

El aspecto negativo es la tendencia generalizada a la revaluación. En el gráfico II.4 se ilustra este fenómeno. Con base en los datos de la CEPAL, comparo la tasa de cambio real del 2012 con el promedio desde 1990 y con el período 2003-2007. Como se aprecia, la tendencia a la revaluación ha sido generalizada. De hecho, solo hay dos excepciones: México y Nicaragua. No se incluyó la Argentina porque sus datos oficiales no permiten una estimación confiable de estas cifras, aunque ha tenido también un deterioro significativo del tipo de cambio real desde hace tres o cuatro años.

\section{Gráfico II.4}

América Latina (17 países): apreciación o depreciación real de las monedas, 1990-2011 a 2012 y 2003-2007 a 2012

(En porcentajes)

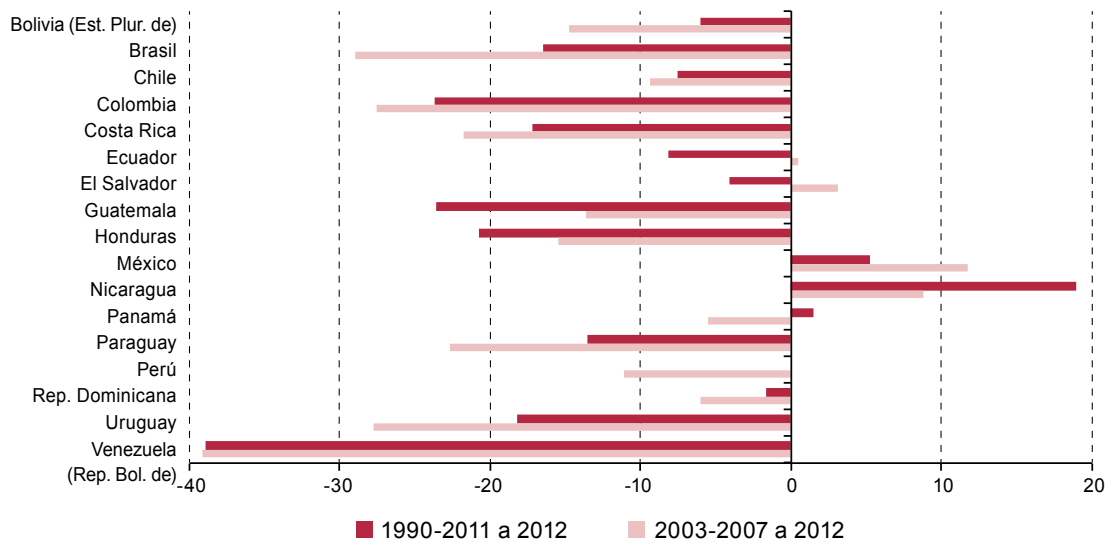

Fuente: Comisión Económica para América Latina y el Caribe (CEPAL). 
Una forma de leer la combinación de mejoras en las hojas de balance externo y acceso al financiamiento con una tendencia a la revaluación es que el riesgo de crisis financiera es limitado, pero ha habido un riesgo creciente de enfermedad holandesa, que de hecho se ha traducido en la agudización de la persistente desindustrialización que ha venido experimentando la región. Así, el financiamiento externo ha tenido como contrapartida el agravamiento del rezago estructural que, de acuerdo con el análisis anterior, es el principal problema de crecimiento que enfrenta la región.

Gráfico II.5

\section{América Latina (17 países): apreciación o depreciación real de las monedas, 2012-2013 a}

(En porcentajes)

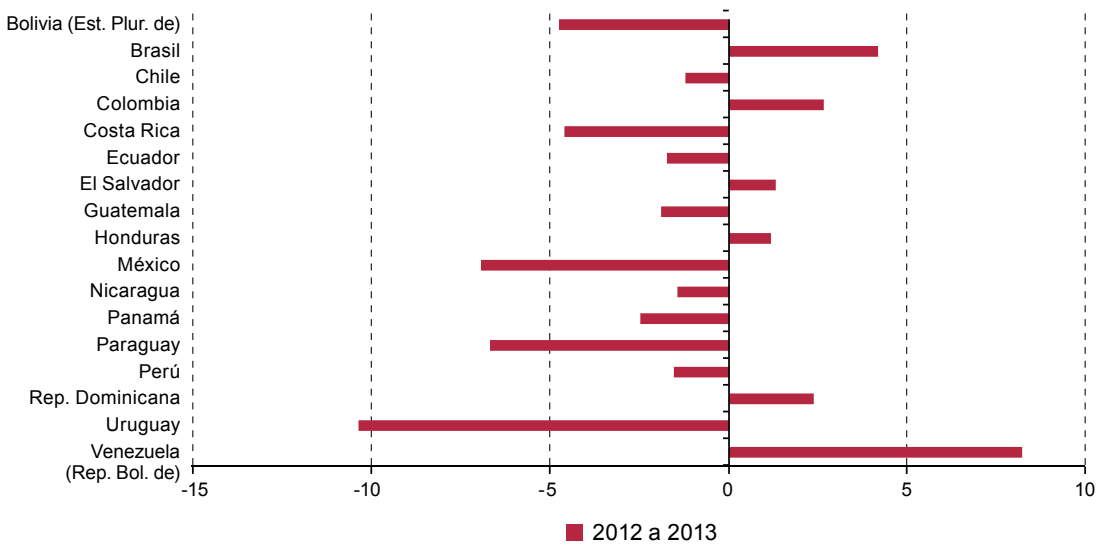

Fuente: Comisión Económica para América Latina y el Caribe (CEPAL).

a Promedios de enero a septiembre de 2012 y de enero a septiembre de 2013.

Dado el actual proceso inverso de depreciación o la disminución de las tendencias a la apreciación se podría indicar que la depreciación en términos reales en la región no ha mejorado la cuenta corriente y, al igual que el ciclo de crecimiento entre 2003 y 2007 se dio con apreciación cambiaria y mejora en la cuenta corriente, el actual ciclo se caracteriza por depreciaciones del tipo de cambio real con tendencias desfavorables en la balanza de pagos.

En esta materia hay también, como ya lo señalé, problemas asociados a la forma como se están produciendo los reajustes en la economía mundial. Hay tres regiones del mundo donde ha habido una mejoría en los balances externos: los países petroleros, que son hoy la principal fuente de superávit del mundo; Europa, que está generando innecesariamente un superávit en cuenta corriente —una situación enteramente diferente a la 
que prevalecía antes de la crisis-, y los Estados Unidos, que corrigió un déficit que sí era innecesariamente excesivo. Obviamente, la contrapartida de estas tendencias es la presión generada sobre otras partes del mundo, en particular sobre China, que ha reducido su superávit externo; el Japón, que lo ha hecho en forma más moderada, y las economías emergentes no petroleras - entre las cuales se incluye el grueso de América Latina- que han venido generado crecientes déficit externos.

Lo que esto indica es que la tendencia al deterioro de la cuenta corriente de la región es parte de un proceso de recomposición de los balances externos de distintas partes del mundo. Se puede decir que esta es una contribución de América Latina al equilibrio de la economía mundial, pero plantea dos problemas diferentes. En primer lugar, como ya se ha ilustrado, ha tornado aún más complejos los problemas estructurales y ha aumentado los riesgos macroeconómicos, pese a la solidez de las hojas de balance externo. La región ha aprendido, en efecto, que los déficits en cuenta corriente son una fuente potencial de crisis de la balanza de pagos. De hecho, las economías emergentes con altos déficits en cuenta corriente, como Turquía y Sudáfrica, se encuentran entre las más vulnerables a una crisis potencial de la balanza de pagos.

Para analizar debidamente este problema en América Latina es necesario, sin embargo, tener en cuenta la evolución de los términos de intercambio como resultado del auge de precios de productos básicos que se inició en 2004. Los países más favorecidos, según los datos de la CEPAL, han sido los que tienen una base exportadora minero-energética: la República Bolivariana de Venezuela, Chile, el Estado Plurinacional de Bolivia, el Perú, Colombia y el Ecuador, en orden descendente que resulta de comparar la mejoría en los términos de intercambio entre 2003 (el año anterior al auge) y 2010 (el año en que culminó la fuerte tendencia ascendente de los precios de productos básicos). Después siguen el Brasil y la Argentina, con una estructura exportadora que depende más de productos agrícolas. Las economías pequeñas tienen casi todas pérdidas por el aumento del precio del petróleo.

El problema más preocupante es que la región está generando déficits en cuenta corriente pese a la mejoría sustancial de los términos de intercambio. Es decir, América Latina está gastando, incluso en exceso, lo obtenido con el auge de los términos de intercambio. Esto se ilustra en el gráfico II.6, que muestra tanto el saldo anual de la cuenta corriente en dólares como una estimación de la cuenta corriente según los términos de intercambio de 2003, es decir, deduciendo del valor de las exportaciones el progreso en el poder de compra que han experimentado por la mejora en los precios relativos con respecto a dicho año. De acuerdo con estos cálculos, en 2012 la región tenía una ganancia de términos de intercambio 
equivalente a 4,5 puntos del PIB y, sin embargo, arrojó un déficit en cuenta corriente. El déficit "potencial" era, por lo tanto, de unos 6 puntos del PIB, más o menos el doble del nivel de 1997-1998.

Gráfico II.6

América Latina: balance en cuenta corriente con respecto al producto interno bruto, 1990-2012 (En porcentajes)

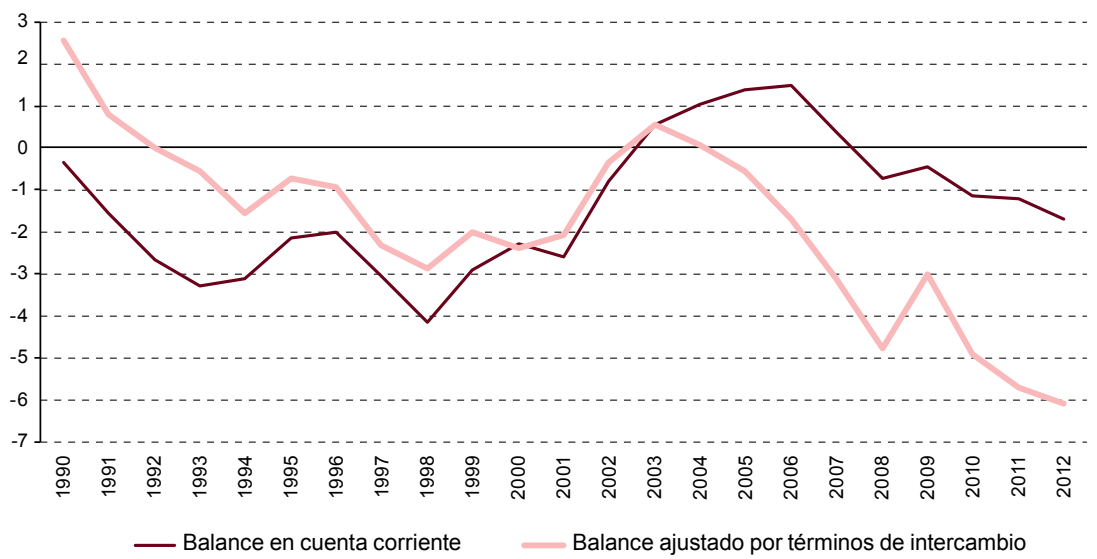

Fuente: Elaboración propia sobre la base de datos de Naciones Unidas hasta 2007 y del Fondo Monetario Internacional (FMI).

La vulnerabilidad frente a una caída de precios de productos básicos es, por lo tanto, elevada. Esa disminución es ya una realidad, pero su magnitud dependerá esencialmente del ritmo de crecimiento de la economía china, cuyo dinamismo es la explicación fundamental de los altos precios de estos productos. Los de los metales han tendido a descender desde 2011 y los agrícolas se han unido a esa tendencia, pero los de los combustibles siguen en niveles muy elevados, jalonados por los serios problemas políticos que afectan al Oriente Medio. La desaceleración de China ya es evidente y la gran pregunta es si sigue la trayectoria de descenso gradual que proyectan las autoridades o experimenta una caída más rápida en razón de los desequilibrios estructurales que enfrenta, en particular el desbalance entre la participación del consumo y la inversión en el PIB.

Mis investigaciones me llevan a pensar que los precios de los productos básicos tienden a experimentar ciclos largos o "superciclos". En particular, en un ensayo que he publicado recientemente encuentro que han experimentado desde fines del siglo XIX tres superciclos completos, de 30 a 40 años, y hemos estado en la fase ascendente de un cuarto. La característica esencial de las fases descendentes es que su intensidad depende del estado de la demanda mundial. Por esa razón, el descenso 
fue acentuado tanto en los años veinte y treinta como en los ochenta y noventa del siglo XX, en tanto que fue mucho más suave después del auge que terminó cuando la Guerra de Corea, porque la economía mundial estaba experimentado entonces un crecimiento rápido. De acuerdo con este patrón histórico, la posibilidad de que se presente un descenso fuerte es alta, dada la debilidad de la economía internacional y, en este caso, la debilidad particular de la economía china.

\section{D. ¿Es hora de una nueva estrategia?}

Eso me lleva pues a la pregunta básica, con la cual quiero concluir: ¿es hora de una nueva estrategia? Mi respuesta es claramente positiva. Con la nueva debilidad del comercio internacional, el espacio para políticas ortodoxas de crecimiento liderado por las exportaciones ha llegado a su fin. Además, a América Latina no le fue particularmente bien con esa estrategia, porque crecer un 3,3\%, cuando el comercio internacional crecía el 7,3\% anual no es un resultado para destacar.

Hay, sin embargo, otras tendencias positivas que permiten pensar en fuentes alternativas de dinamismo, en particular la del mercado interno latinoamericano asociada a las mejorías distributivas, a la reducción de pobreza y al ascenso consecuente de las clases medias. Esa oportunidad se da de dos maneras diferentes. Si pensamos en términos de mercados puramente nacionales, es una oportunidad especialmente para el Brasil. Pero si pensamos en el "mercado interno ampliado" que proporcionan los procesos de integración, es una oportunidad mucho más difundida.

El principal obstáculo en este campo es la crisis política que enfrentan nuestros procesos de integración. De hecho, me atrevo a afirmar que la integración sudamericana está en su peor momento desde los años ochenta. La Comunidad Andina no sale de una profunda crisis y el Mercado Común del Sur (MERCOSUR) enfrenta roces persistentes entre sus principales socios. Los dos flujos comerciales más importantes de América Latina, que son el colombo-venezolano y el argentino-brasileño, están en serios problemas por intervenciones de alguno de sus miembros o por ambos. La explotación de las oportunidades que ofrecen los mercados internos de la región exige, por lo tanto, una renovación firme del compromiso con la integración.

Más allá de la integración, lo que el análisis que he presentado indica es que es esencial adoptar políticas productivas y tecnológicas más activas para hacer un reescalonamiento tecnológico de la estructura productiva y exportadora. Este ha sido uno de los mensajes centrales de la CEPAL desde los años noventa, muy resaltado en el principal documento institucional de 2012, Cambio estructural para la igualdad: una visión integrada del desarrollo. 
Uno de los elementos más importantes es diseñar una estrategia de relacionamiento comercial con China. Esta relación tiene que superar la estructura exportadora decimonónica, en la cual América Latina exporta un puñado de productos básicos e importa una canasta muy diversificada de productos manufacturados con creciente contenido tecnológico. Para expresarlo claramente, China tiene una clara estrategia con América Latina; América Latina carece de ella.

La combinación de una mejor explotación de las oportunidades que ofrece el mercado interno con una política activa de desarrollo productivo orientada a desarrollar sectores con creciente contenido tecnológico es la esencia de la nueva estrategia a la cual debe apuntar la región, obviamente sin dejar nunca de lado la superación del principal problema que hemos heredado de nuestra historia: los altísimos niveles de desigualdad social.

¿Cuáles son las alternativas para una nueva agenda? En términos económicos hay dos alternativas básicas que deberían combinarse en la práctica con un mayor progreso en el diseño de políticas macroeconómicas contracíclicas.

La primera consiste en orientar la mirada hacia las oportunidades que plantean los mercados internos. Obviamente el regreso hacia estrategias de crecimiento "hacia dentro" no es deseable, ni siquiera viable, dadas las significativas transformaciones a las que han dado lugar las reformas de mercado y el proceso de globalización dentro del cual estas se enmarcan. No obstante, dadas las perspectivas de bajo crecimiento del comercio internacional, el mercado interno provee oportunidades que no deberían ser descartadas, incluidos, por ejemplo, el creciente peso de la clase media o la necesidad de reducir los significativos rezagos que la región ha acumulado en infraestructura.

Si bien estas oportunidades pueden explotarse con políticas orientadas únicamente hacia el mercado interno, esta alternativa sería óptima solo para el caso del Brasil. Para el resto de los países, "el mercado doméstico ampliado" generado por un fuerte proceso de integración podría ser una mejor alternativa.

Esto incluye las oportunidades que provee la construcción de una red de infraestructura para la integración, que constituye un campo en el cual los avances han sido limitados -y la experiencia europea muestra que puede beneficiar a todos los países. En consecuencia, para lograr avanzar en esta dirección sería esencial sobreponerse a las tensiones políticas que han acompañado los procesos de integración, en particular en América del Sur.

La segunda alternativa es seguir los lineamientos del incipiente "consenso estructuralista" para desarrollar una integración acorde a las 
oportunidades que ofrece la economía global. Las estrategias ortodoxas de crecimiento a través de las exportaciones que la mayoría de los países han perseguido no han generado tasas elevadas de crecimiento, salvo en algunos períodos, y es probable que generen oportunidades de crecimiento aún más restringidas en un mundo globalizado menos dinámico. Además, el menor dinamismo del comercio internacional impone demandas más estrictas sobre la capacidad de competir. Lo que eso quiere decir es que es necesario definir y establecer una estrategia sólida de desarrollo del sector productivo - o política industrial, si entendemos este término en el sentido amplio que le otorga la literatura internacional, y cuya esfera de acción incluye no solo la manufactura, sino que también integra las oportunidades que provee la base de recursos naturales y el sector servicios. El objetivo esencial de esta estrategia debería ser la mejora tecnológica y, por esta razón, requiere la creación de sistemas de innovación nacional sólidos. Dado el elevado contenido tecnológico del comercio intrarregional, el "mercado doméstico ampliado" provee numerosas oportunidades para desarrollar nuevas actividades económicas con mayores contenidos tecnológicos. Los sistemas de innovación deberían diseñarse también con un componente regional, que puede ser particularmente útil en el caso de las economías más pequeñas.

Una integración más acorde a las oportunidades que ofrece la economía global implica además redefinir las relaciones comerciales con China, que tienen que ir más allá del patrón de intercambio del siglo XIX y principios del XX consistente en intercambiar un puñado de bienes por una miríada de manufacturas. Si esta relación ha de contribuir al pleno desarrollo de América Latina, debería ser una relación de comercio SurSur y de inversión, que permita a América Latina exportar a China un menú más diversificado de bienes y servicios, y a sus empresas de mayor tamaño aprovechar las oportunidades de inversión que ofrece el gigante asiático. Para esto es necesario generar un diálogo más profundo a través de foros comunes de alto nivel, tales como los que proveen el marco para el diálogo entre América Latina y el Caribe y Europa (o, de hecho, para el diálogo chino-africano).

Los avances que se han realizado en las políticas macroeconómicas son significativos, aunque siguen siendo limitados en varios aspectos. El más importante es el escaso progreso en el diseño de políticas macroeconómicas contracíclicas, a excepción de algunos ejemplos tales como el caso de la política fiscal chilena y de una muestra más amplia en el uso de la política monetaria contracíclica.

Un elemento crítico es suavizar los marcados patrones de comportamiento en el tipo de cambio real que caracteriza a la mayor parte de los países (si no a todos). Tipos de cambio competitivos y más estables 
son un ingrediente esencial para la reindustrialización y una mejor integración en la economía global.

En el terreno de las políticas sociales existen dos formas interesantes de abordar los desafíos futuros. La primera es la planteada por la CEPAL (2000 y 2010), consistente en introducir un marco basado en los derechos humanos $\mathrm{y}$, por ende, en el principio de igualdad que lo sustenta, en el centro de un nuevo contrato social.

La segunda es la propuesta por el Banco Mundial (2013), consistente en redefinir el contrato social existente e implícito, de acuerdo con el cual las clases altas y medias esperan una baja carga tributaria que permite al Estado ofrecer una calidad limitada de servicios sociales, y con el que las familias de clase medias optan por servicios fuera del sector público en cuanto se lo permite el aumento de sus ingresos.

El desafío más importante es crear servicios sociales universales de alta calidad y utilizar el sistema fiscal para redistribuir el ingreso de una manera más sólida de lo que ha sido la tónica en el pasado - y no solo a través de un mayor gasto, sino también de una mayor progresividad impositiva.

Ni que decir tiene que una base fiscal más fuerte y amplia es esencial para financiar una estrategia social ambiciosa. El foco explícito de tal estrategia debería centrarse, además, en quebrantar la transmisión intergeneracional de la desigualdad. Un tema principal en el rediseño de la política social es evitar distintas formas de fallas gubernamentales. Y un ingrediente esencial de esta estrategia es el desarrollo de una cultura centrada en el rendimiento de calidad y en una sólida rendición de cuentas. La participación, en distintas formas, de agentes privados con un énfasis solidario (instituciones sin fines de lucro y organizaciones cooperativas, entre otras) puede contribuir a sobreponerse a las fallas de gobierno. Y, además, una política social más ambiciosa debe ser acompañada por crecientes oportunidades económicas que tienen que ser provistas mediante políticas económicas más activas, en particular por una política de mejoras tecnológicas consistentes y continuas de las actividades económicas. 


\section{Bibliografía}

Banco Mundial (2013a), "Commodity Price Data (Pink Sheet)" [en línea] http:/ / econ.worldbank.org/WBSITE/EXTERNAL/EXTDEC/EXTDECPROS PECTS/0,,contentMDK:21574907 menuPK:7859231 pagePK:64165401 piPK:6 4165026 theSitePK:476883,00.html.

(2013b), World Development Indicators [en línea] http://data.worldbank.org/ data-catalog/world-development-indicators.

CEPAL (Comisión Económica para América Latina y el Caribe) (2014a), Estudio Económico de América Latina y el Caribe, 2014 (LC/G.2619-P), Santiago de Chile. Publicación de las Naciones Unidas, $\mathrm{N}^{\mathrm{o}}$ venta: S.14.II.G.3.

(2013), base de datos CEPALSTAT [en línea] http://estadisticas.cepal.org/ cepalstat/WEB_CEPALSTAT/Portada.asp.

Cimoli, M. y G. Porcile (2011), “Learning, technological capabilities and structural dynamics", The Oxford Handbook of Latin American Economics, J.A. Ocampo y J. Ros, Oxford University Press.

CPB (Netherlands Bureau of Economic Policy Analysis) (2015), “Data” [en línea] http://www.cpb.nl/en/data.

Erten, B. y J.A. Ocampo (2013), "Super cycles of commodity prices since the mid-nineteenth century", World Development, vol.44, abril.

FMI (Fondo Monetario Internacional) (2013), “Regional Economic Outlook. Western Hemisphere: time to rebuild policy space", World Economic and Financial Surveys, Washington, D.C., 13 de mayo.

Hausmann, R. (2011), "Structural transformation and economic growth in Latin America", The Oxford Handbook of Latin American Economics, J.A. Ocampo y J. Ros, Oxford University Press.

J.P. Morgan (2014), EMBI [en línea] https:/ / www.jpmorgan.com.

Ocampo, J.A. (2014a), “Latin America's mounting economic challenges”, Issue Brief, Houston, Baker Institute for Public Policy, Rice University, 17 de octubre. (2014b), "Latin America in the midst of the global quicksands", documento preparado para el Programa de las Naciones Unidas para el Desarrollo (PNUD). (2011), “Macroeconomía para el desarrollo: políticas anticíclicas y transformación productiva", Revista CEPAL, N 104 (LC/G.2498-P/E), Santiago de Chile, Comisión Económica para América Latina y el Caribe (CEPAL).

UNCTAD (Conferencia de las Naciones Unidas sobre Comercio y Desarrollo), UNCTADSTAT [en línea] http://unctad.org/en/pages/Statistics.aspx. 


\section{Capítulo III \\ La reciente internacionalización del régimen del capital}

El capitalismo que realmente existe revela su naturaleza más profunda, aquella que Marx y Engels ya desvelan en el Manifiesto Comunista. "La burguesía no puede existir sin revolucionar constantemente los medios de producción y, por consiguiente, las relaciones de producción, y con ello todas las relaciones sociales... Revolución permanente en las condiciones de producción, disturbios ininterrumpidos de todas las condiciones sociales, permanente incertidumbre y agitación es lo que distingue la era burguesa de todas las demás".

Marx y Engels escribieron eso en 1848, antes de que las escaladas industriales de los Estados Unidos, Alemania y el Japón confirmaran sus sospechas sobre el papel de la competencia "universal" en la expansión del régimen del capital. Extasiados ante la potencia revolucionaria y "progresista" del capitalismo en su ímpetu de mercantilización universal, Marx y Engels no previeron el papel crucial de los Estados Nacionales y la lucha interimperialista en la "deformación" de los mercados y las condiciones de la competencia que determinaron la decadencia de Inglaterra. Desde mediados del siglo XIX, las economías rezagadas de Europa y América del Norte fueron las que primero se desarrollaron, en el marco del libre comercio que patrocinaron los intereses de las altas finanzas amparados en la ciudad. Posteriormente, en las tres últimas 
décadas del siglo XIX, sobre todo a partir de la Gran Depresión iniciada en la década de 1870, los rezagados crecieron a la sombra del proteccionismo y las reglas monetarias del patrón oro.

En la segunda mitad del siglo XX, la expansión mundial del capitalismo bajo la hegemonía estadounidense modificó la división internacional del trabajo y el esquema centro-periferia propuesto por la hegemonía inglesa. Desde el siglo XIX, la economía continental norteamericana sustentó el crecimiento en la expansión de su mercado interno y secundariamente en el diversificado modelo de exportaciones. Dotada de un escaso grado de apertura, pero gran productora y exportadora de manufacturas, materias primas y alimentos, la economía de los Estados Unidos encontraba en el comercio exterior un mecanismo de ajuste que facilitaba su expansión acelerada.

El espacio económico internacional posterior a la Segunda Guerra Mundial se construyó a partir del proyecto de integración entre las economías nacionales propuesto por los Estados Unidos y su economía. La hegemonía de dicho país se ejerció mediante la expansión de las grandes corporaciones estadounidenses y sus bancos. Luego de la reconstrucción económica de Europa, la respuesta competitiva de las grandes empresas europeas - la rivalidad entre los sistemas empresariales - promovería la inversión productiva cruzada entre los Estados Unidos y Europa y la primera ronda de industrialización fordista en la periferia. Durante la denominada "era dorada" (19471973), la expansión del comercio internacional supuso, sobre todo, el intercambio de bienes finales de consumo y de capital entre los socios del Atlántico Norte.

La revolución china y de la Guerra de Corea, dieron lugar al estilo de desarrollo asiático. Entrarían en el juego del desarrollo el Japón y, más tarde, la propia Corea y Taiwán, con sus respectivos sistemas empresariales.

"El estilo de desarrollo asiático" fue inaugurado por el Japón, que emergió como potencia económica, ya en los años sesenta, y se propagó hacia Corea y Taiwán, protagonistas de un notable desempeño en las décadas de 1970 y 1980. Los dirigentes y la tecnocracia de estos dos países se inspiraron en el desempeño de su vecino - el Japónque, una década antes, ya en los años cincuenta, gracias a la Guerra de Corea, había conseguido librar su economía de las reformas liberales del General MacArthur.

¿Cuál era, en verdad, el proyecto estadounidense para el Japón? Desarticular los grandes conglomerados, "occidentalizar" la economía, asemejándola al modelo anglosajón de economía de mercado. 
Los asiáticos se valieron, sin duda, de las circunstancias históricas y geopolíticas de la Guerra Fría. La República de Corea y Taiwán se beneficiaron de la condición de puestos avanzados de Occidente, en una zona crítica para el enfrentamiento entre las dos grandes potencias y la competencia entre los dos sistemas.

El éxito del Japón y los tigres asiáticos, como Corea y Taiwán, no se debe tan solo a las "virtudes económicas" de sus modelos. Es obvio que las condiciones geopolíticas también fueron cruciales, ya que ofrecieron la oportunidad para realizar las transformaciones necesarias, no obstante, sin abandonar las prácticas e instituciones que marcaron la administración de sus economías.

Los Estados Unidos hicieron la vista gorda ante el nacionalismo económico que se afirmaba en Asia. Aceptaron las estrategias de crecimiento acelerado que contemplaban políticas industriales proteccionistas y fuertes incentivos a las exportaciones. Siempre en nombre de la libertad, se ignoraron y absolvieron todas las violaciones posibles e imaginables a las buenas reglas del libre mercado. La tolerancia estadounidense incluía la apertura de sus mercados para la invasión, primero, de los productos japoneses y, luego, de los coreanos y taiwaneses.

En la América Latina "desarrollista", este ímpetu de expansión fue acompañado de inestabilidades políticas engendradas en los bastidores de la Guerra Fría y la resistencia de las oligarquías locales todavía comprometidas con las relaciones económicas y de dominación del modelo primario exportador.

El Brasil se valió de políticas nacionales de industrialización que, en el ámbito interno, intentaron promover la "internacionalización" de la economía, o sea, la repartición de tareas entre las corporaciones multinacionales, las empresas estatales y los emprendimientos privados nacionales, los dos últimos encargados de producir los bienes intermedios y materias primas semiprocesadas.

En los 50 años que culminaron en el inicio de la década de 1980, la economía brasileña creció de forma acelerada y sufrió notables transformaciones, pasando del modelo primario exportador a la etapa industrial. El etos del desarrollo surgió de la percepción - de las clases empresariales nacientes, el estamento burocráticomilitar, algunos liderazgos intelectuales y el proletariado en formación- de que el objetivo de acercar al país a las formas de producción y convivencia no podría alcanzarse mediante la simple operación de las fuerzas naturales del mercado.

Sin embargo, es totalmente falso atribuir un papel hegemónico a estas fuerzas calificadas como progresistas en la definición de los rumbos 
del desarrollo. El proyecto de industrialización se fue construyendo a través de alianzas políticas, regionales y de clase que no solo atrajeron los intereses más retrógrados y reaccionarios hacia el bloque desarrollista, sino que también sellaron compromisos con las fuerzas del internacionalismo capitalista.

Esa etapa culminó en la crisis del dólar de 1971 y en la determinación unilateral de la inconvertibilidad de la moneda estadounidense a razón de 35 dólares por onza troy de oro.

La historia de la economía mundial, desde mediados de los años cuarenta, no puede contarse sin comprender las peripecias del dólar en su papel de moneda de liquidación en las transacciones internacionales y de activo de reserva universal. Inmediatamente después de la guerra, bajo la égida de Bretton Woods, el poder del dólar convertible respaldó tres procesos simultáneos: 1) el déficit en la cuenta de capital, producto del aumento de los gastos militares y la inversión directa en el mercado europeo en recuperación, garantizó el abastecimiento de la liquidez necesaria para el crecimiento del comercio mundial; 2) de ahí, la reconstrucción de los sistemas industriales de Europa y el Japón; y 3) la industrialización de muchos países de la periferia, impulsada por la inversión productiva directa y la aplicación de políticas de desarrollo nacional.

Debido a los desequilibrios crecientes de la balanza de pagos estadounidense, se puso fin al sistema de convertibilidad y tasas fijas de Bretton Woods, al imponer la desvinculación del dólar en relación con el oro en 1971 y la introducción de los tipos de cambio flotantes en 1973.

Los libertarios salieron de la tumba, resucitados por los miasmas de la "estanflación" de fines de los años sesenta y comienzos de los setenta. A partir de perspectivas teóricas distintas, los espectros del mercadismo pasaron a rondar el denominado "consenso keynesiano". Para ellos, las proezas de la "era dorada" terminaron siendo un doloroso engaño, que hizo prosperar el famoso populismo económico, una forma perversa de politización a ultranza de la economía. Parafraseando a Eric Hobsbawm, la recomendación de los conservadores era decir "adiós a todo aquello" y emprender con urgencia las reformas necesarias para restablecer el funcionamiento de los verdaderos mecanismos económicos, los únicos aptos la garantizar la libertad del individuo y promover la estabilidad y el crecimiento a largo plazo.

En la visión liberal-conservadora, los propósitos de proteger al ciudadano de los azares y las incertidumbres del mercado terminarían por suscitar efectos contrarios a los buscados. A pesar de las diferencias analíticas y metodológicas, Hayek y Friedmam sostenían que los "años gloriosos" estaban predestinados inexorablemente al fracaso en su insano intento por 
interferir en los movimientos "naturales" de los mercados. Las políticas monetarias acomodadizas, combinadas con pactos "corporativistas" entre las clases sociales y los grupos de interés, redundarían inevitablemente en un bajo dinamismo e inflación crónica y elevada.

Inmediatamente después, los neoclásicos, apoyados en la hipótesis de las expectativas racionales, reforzaron las tropas del reformismo liberal. Dictaron una sentencia condenatoria incluso más dura contra la intervención del Estado, al proclamar la ineficacia de las políticas fiscal y monetaria en su vana pretensión — así decían- de limitar la inestabilidad cíclica y promover el crecimiento de la economía.

Los gobiernos aprenderían posteriormente que los agentes racionales que pueblan los mercados conocen exactamente cuál es la estructura de la economía y, empleando la información disponible, son capaces de prever su probable evolución. No se dejan engañar, ni por un momento, por el viejo truco de estimular la actividad económica con los anabolizantes nominales de la política monetaria lenitiva. Si insisten en esa práctica, políticos y burócratas voluntaristas, en vez de más empleos, conseguirán tan solo más inflación, salvo en la hipótesis improbable de que puedan sorprender y engañar permanentemente a los sagaces agentes privados, implacablemente racionales.

A comienzos de los años ochenta, el grupo de la economía de la oferta decía incluso: la sobrecarga de impuestos sofocaba a los más ricos y desestimulaba el ahorro, lo que comprometía la inversión y, por lo tanto, reducía la oferta de empleos y el ingreso de los más pobres. Las prácticas neocorporativistas - decían ellos- creaban graves deformaciones "microeconómicas", al promover, deliberadamente, intervenciones en el sistema de precios, los tipos de cambio, los intereses y los aranceles. Con el objetivo de inducir la expansión de determinados sectores o de proteger segmentos empresariales amenazados por la competencia, los gobiernos distorsionaban el sistema de precios $\mathrm{y}$, de esa manera, bloqueaban los mercados en su noble e insustituible función de generar información para los agentes económicos. Tales violaciones de las reglas de oro de los mercados competitivos redundaban en una ineficiencia generalizada y en la multiplicación de los grupos "predadores de ingresos", que se amontonaban en los espacios creados por la prodigalidad financiera del Estado.

Como si ello fuera poco, los mercados de trabajo, castigados por la rigidez nominal de los salarios y por reglas políticas hostiles a su buen funcionamiento - como la del salario mínimo- ya no pueden expresar el precio de equilibrio de este factor de producción, por medio de la interacción sin restricciones de las fuerzas de la oferta y la demanda. 
En materia financiera, la teoría de los "mercados eficientes" pretendía enseñar que todas las informaciones pertinentes sobre los "fundamentos" de la economía están permanentemente disponibles para todos los participantes de los mercados que evalúan los títulos de deuda y los derechos de propiedad. La acción racional de los agentes, ante las informaciones existentes, sería capaz de orientar la mejor distribución posible de los recursos entre los diferentes activos. Esa teoría procuraba afirmar que, en condiciones competitivas, no pueden existir estrategias "ganadoras" capaces de propiciar resultados superiores a la media.

El papel del dólar como estándar universal se hizo nuevamente realidad mediante un aumento sin precedentes de las tasas de interés en 1979. El fortalecimiento del dólar, como moneda de reserva y denominación de las transacciones comerciales y financieras, origina las profundas alteraciones en la estructura y la dinámica de la economía mundial. La rehabilitación del patrón dólar dio un nuevo impulso a la redistribución de la capacidad productiva en la economía mundial, estimuló las fusiones y adquisiciones de los años ochenta y amplió los desequilibrios en las balanzas de pagos entre los Estados Unidos, Asia y Europa, así como el avance de la denominada globalización financiera.

Así, después de la crisis de hegemonía y "productividad" de los años setenta del siglo pasado, la "expansión estadounidense" retomó la iniciativa. En estas condiciones, los Estados Unidos fueron capaces de atraer capitales hacia sus mercados y darse el lujo de mantener tasas de interés moderadas. Ese fenómeno se acentuó en los años noventa y propició el surgimiento de tres procesos correlacionados: 1) la abundante entrada de capitales hacia los Estados Unidos, a pesar del déficit en cuenta corriente; 2) la acumulación de reservas en los países asiáticos, como contrapartida de la ampliación de los déficits en cuenta corriente de los Estados Unidos, y 3) la espantosa expansión del crédito y la inflación de activos en las economías centrales.

El "modelo asiático" en su forma actual tiene una relación simbiótica con las transformaciones financieras y orgánicas que originaron las nuevas formas de competencia entre las empresas dominantes de la tríada desarrollada: Estados Unidos, Europa y Japón. El rumbo de la nueva competencia respondió, de hecho, a las políticas liberalizantes de los años ochenta. Y, en su respuesta, el movimiento de las grandes empresas realizó el proyecto de reconfiguración del entorno internacional. La metástasis del sistema empresarial de la tríada desarrollada - particularmente de los Estados Unidos y el Japón- determinó una impresionante modificación de los flujos comerciales. No se trata tan solo de reafirmar la importancia creciente del comercio intraempresas, sino de 
destacar el papel decisivo del "abastecimiento a escala mundial", fenómeno que está presente, sobre todo, en las estrategias de internacionalización de las cadenas productivas que, desde la década de los noventa, beneficiaron a las economías asiáticas, la china en particular.

La nueva competencia engendró simultáneamente: 1) la centralización del control, mediante las olas de fusiones y adquisiciones observadas desde los años ochenta, y 2) la nueva distribución espacial de la producción, o sea, la internacionalización de las cadenas de generación de valor. Centralización del control y descentralización de la producción: ese movimiento de doble cara afectó la naturaleza y la dirección de la inversión directa en nueva capacidad, reconfiguró la división del trabajo entre productores de piezas y componentes y los "montadores" de bienes finales y, como ya se mencionó, alteró las participaciones de los países en los flujos comerciales. El propósito de la competencia entre los grandes bloques de capital es asegurar simultáneamente la diversificación espacial adecuada de la base productiva de las grandes empresas y el "libre" acceso a mercados.

La globalización supone sobre todo la generalización y la intensificación de la competencia protagonizadas por las grandes empresas transnacionales. Las estrategias de localización de la corporación transnacional moderna fueron acompañadas de considerables cambios morfológicos: constitución de empresas en red, que concentraban las funciones de decisión, innovación y subcontratación de las operaciones comerciales, industriales y de servicios en general.

Los cambios en las formas de competencia promovieron el "cuestionamiento" de las estructuras oligopolistas "estabilizadas" que regularon la competencia entre los años cincuenta y ochenta, en la era del "fordismo". De los años cuarenta a setenta del siglo pasado, el patrón de competencia se fundaba en la estabilidad de las estructuras de mercado oligopolizadas y se caracterizaba por la producción estandarizada, tecnología codificada, búsqueda de la integración vertical y aversión a la cooperación.

Los oligopolios se "concentraban", en el caso de productos homogéneos, como la siderurgia, y otros insumos básicos o diferenciados, como los bienes durables de consumo. Esas estructuras oligopolistas estaban "defendidas" por fuertes barreras tecnológicas, financieras y comerciales que dificultaban la entrada de nuevos competidores.

A ese modelo de competencia correspondía una estructura orgánica burocrática, rígidamente jerárquica, fruto de la separación entre propiedad y control, fenómeno que comienza a darse en las tres últimas décadas del siglo XIX. 
Las transformaciones que tuvieron lugar en las últimas décadas originaron fenómenos correlacionados y aparentemente contradictorios: 1) una nueva etapa de "centralización" de la propiedad y del control de los bloques de capital, mediante la escalada de los negocios de fusiones y adquisiciones alentados por la fuerte capitalización de las bolsas de valores en la década de 1980, 1990 y 2000, a pesar de episodios de "ajuste" de precios; 2) la "subcontratación" de las funciones no esenciales para llevar a cabo la actividad principal, lo que profundizó la división social del trabajo y propicia la especialización y los incrementos de productividad.

Las grandes empresas que se lanzan a las incertidumbres de la competencia mundial necesitan cada vez más del apoyo de condiciones institucionales y jurídicas que las habiliten para competir contra los rivales en su propio mercado y en otras regiones. Dependen del apoyo y la influencia política de sus Estados Nacionales para penetrar en terceros mercados (acuerdos de garantía de inversiones y patentes, entre otros), no pueden prescindir del financiamiento público para sus exportaciones en los sectores más dinámicos, no se les deben imponer cargos tributarios excesivos y corren el riesgo de ser desplazadas por la competencia sin el beneficio de los sistemas nacionales de educación y de ciencia y tecnología.

El nuevo paradigma empresarial acentúa excesivamente la importancia de estas ventajas. Entre ellas debemos destacar: la) procesos acumulativos de aprendizaje (aprendizaje práctico en la producción flexible, en el desarrollo de productos); b) economías de escala dinámicas (aumento de volumen vinculado al tiempo y el aprendizaje); c) estructuración de redes electrónicas de intercambio de datos que maximizan la eficiencia a lo largo de las cadenas de agregación de valor (economía de capital de trabajo, sobre todo minimización de existencias, de costos de transporte y almacenamiento); d) nuevas economías de aglomeración (centros de compras y de asistencia técnica y formación de polos de conocimientos técnicos y gerenciales), y e) economías derivadas de la cooperación tecnológica y el desarrollo conjunto de productos y procesos.

Mediante esta concepción de políticas de competitividad se coloca en el centro de las preocupaciones la inducción de las sinergias basadas en el conocimiento y la capacidad de respuesta a la información. El nuevo papel de las políticas estructurales debe centrarse en inducir la cooperación y la coordinación de los actores. No se trata de "escoger vencedores", sino de crear condiciones para que los vencedores aparezcan.

Las transformaciones financieras y orgánicas recientes acompañaron los cambios en la estrategia de localización espacial de las empresas dominantes. Cabe destacar las reorientaciones en la dirección de la inversión extranjera directa y sus consecuencias en la división internacional del trabajo. 
La apertura de la economía a la inversión extranjera - como absorción de tecnología, densificación de cadenas industriales, crecimiento de las exportaciones- dependió fundamentalmente de las políticas nacionales. De entre los países emergentes, creció más y alcanzó incluso mayores niveles de exportaciones quien logró administrar una combinación favorable entre cambio real competitivo y tasas bajas, acompañada de la formación de redes internas entre las empresas integradoras y los proveedores de piezas, componentes, equipamiento y sistemas de logística.

Como ya se mencionó, el cambio en la configuración espacial de la industria fue marcado por un intenso proceso de centralización del capital productivo manufacturero a escala mundial y acompañado por una gran labor de las corporaciones transnacionales para centrar sus estrategias en la "actividad principal".

Las consecuencias de esas transformaciones no son triviales. La centralización del control capitalista en las grandes empresas dio lugar a la "exteriorización" de los segmentos productores de piezas, componentes y bienes finales bajo el comando "inteligente" de la denominada "empresa integradora", responsable de las concepciones estratégicas. Ese movimiento abarató enormemente los costos y aumentó la eficiencia de los sistemas de la producción manufacturera. Cabe destacar que la "economía industrial de la globalización" no habría avanzado sin las innovaciones en las tecnologías de la información y las comunicaciones y sin las importantes transformaciones en la logística, sobre todo en la generalización de los contenedores. Esos factores fueron decisivos para acortar los tiempos de rotación y de circulación del capital productivo.

El mundo presencia un cataclismo en la división internacional del trabajo. Asia se torna en una formidable productora y procesadora de piezas y componentes económicos (sin excluir los bienes finales de consumo y de capital). Se conforma una zona manufacturera, gran importadora de materias primas, que se impulsa en torno de China, reintegrada al circuito capitalista desde las reformas de finales de los años setenta.

Hace casi tres décadas que China ejecuta políticas nacionales de industrialización ajustadas al movimiento de expansión de la economía "mundial". El liderazgo chino percibió que la constitución de la "nueva" economía mundial pasaba por el movimiento de las grandes empresas transnacionales en busca de ventajas competitivas, lo que influyó en el cambio de ruta de los flujos comerciales. Los chinos ajustaron su estrategia nacional de industrialización acelerada a las nuevas realidades de la competencia mundial. 
La experiencia china combina máxima competencia - la utilización del mercado como instrumento de desarrollo- y máximo control. Entendieron perfectamente que los países emergentes no debían "copiar" las políticas liberales recomendadas por el Consenso de Washington. También comprendieron que la "propuesta" estadounidense para la economía mundial incluía oportunidades para su proyecto nacional de desarrollo. Así controlaron las instituciones centrales de la economía competitiva moderna: el sistema de crédito y la política de comercio exterior, incluida la administración del tipo de cambio. Los bancos públicos se utilizaron para dirigir y facilitar la inversión productiva y en infraestructura.

Como es de conocimiento general, China presenta un saldo positivo elevado con los Estados Unidos, pero su déficit va en aumento con el resto de Asia y los demás socios comerciales. El bloque industrializado de Asia, articulado en torno a China, funcionó y todavía funciona como un engranaje de transmisión entre la demanda generada en los países centrales y la oferta de las economías "exportadoras de recursos naturales".

La rápida industrialización de China y los países del sudeste de Asia desplazó una fracción importante de la demanda mundial para los productores de materias primas y alimentos.

Pero el Brasil y América Latina quedaron prácticamente al margen del proceso de reestructuración de las cadenas mundiales de valor. Poco después de su adhesión al Tratado de Libre Comercio de América del Norte (TLCAN), México avanzó en cierta medida en cuanto a su participación en el valor agregado mundial, pero desde comienzos de la década de 2000 perdió rápidamente posición frente a China y sus vecinos asiáticos.

Antes y después de la estabilización de 1994, el Brasil no logró llevar adelante el crecimiento y la diferenciación de su estructura industrial. Antes del Plan Real, la crisis aguda de la balanza de pagos y la amenaza de la hiperinflación alejaron al país de las estrategias de migración y reorganización de las grandes empresas transnacionales. Después de la victoria contra la inflación, la valorización del real, además de reanimar la vulnerabilidad externa, desfavoreció la participación brasileña en las cadenas productivas mundiales, sobre todo en los sectores en que las transformaciones estructurales y tecnológicas mencionadas anteriormente ocurrían con mayor intensidad. Entre los sectores en que nuestro "alejamiento" es más evidente podemos citar: infraestructura de telecomunicaciones, infraestructura de telecomunicaciones móviles, computadoras, computadoras portátiles, televisores con pantalla de plasma y de cristal líquido (LCD), cámaras digitales y componentes electrónicos. 
En los últimos dos años el desempeño de la industria brasileña fue decepcionante. El bienio culminó con una baja de aproximadamente el 2\%: un escaso crecimiento del $0,6 \%$ en 2011 y una caída del $2,7 \%$ en 2012. De esta manera, aunque se cumplan en 2013 las expectativas de un mayor crecimiento de la economía brasileña, en torno al 3,5\%, la industria mantendrá un promedio bastante insatisfactorio en el trienio.

El comportamiento decepcionante de la industria, sobre todo el de la manufacturera, está arraigado a factores externos e internos, pero ninguno de ellos tiene solución a corto plazo.

En el ámbito externo, como se mencionó, las dos últimas décadas presenciaron alteraciones de gran importancia en la distribución espacial de las cadenas manufactureras. Ello no significa que las empresas transnacionales hayan dejado de buscar el mercado brasileño y el MERCOSUR. Pero lo que motiva la inversión es claramente la atracción que ejerce el mercado interno o las perspectivas de una mayor integración del mercado sudamericano. En la mayoría de los casos, el Brasil participa de las cadenas mundiales en la recta final del proceso productivo. Es bueno aclarar que desde nuestro punto de vista, la participación en las cadenas supone una dinámica peculiar entre exportaciones e importaciones: producir para exportar tanto como importar para producir.

Hace mucho tiempo que el Brasil está alejado del movimiento de reestructuración productiva y empresarial que responde al nombre de globalización. Ese alejamiento comienza en la segunda mitad de los años setenta del siglo pasado cuando el Brasil escogió los sectores básicos y tradicionales para promover su proceso de avance industrial. En los últimos cuarenta años, el país realizó contribuciones marginales a la estructura manufacturera con baja capacidad de innovación e integración a las cadenas.

La modernización restringida —en condiciones de sobrevalorización cambiaria y completa ausencia de políticas industriales activas- supuso un aumento brutal de la importación de bienes de capital y el abandono de nuestra propia industria de equipamiento. Esa alta dependencia de las importaciones pasó a ser estructural y se manifiesta en la producción corriente, incluso en condiciones de bajo crecimiento.

En verdad, la década de 1990 se caracteriza por una desindustrialización, entendida como la reducción del coeficiente de valor agregado interno sobre el valor bruto de la producción y como el recorte de puestos de trabajo. Rotos los eslabones interindustriales de las principales cadenas de producción, hoy la estructura industrial brasileña puede compararse a una nebulosa en que sobresalen algunas empresas grandes y medianas en cada sector, cuya estructura de apoyo está 
parcialmente globalizada. De esta manera es posible entender por qué la modernización empresarial de los años noventa redundó en el debilitamiento estructural de la industria manufacturera.

Como ya se mencionó, esto ocurre hace décadas. Las políticas que se basan simplemente en la apertura a las importaciones no pueden considerarse exitosas para la integración de la economía brasileña. Tampoco serán exitosas las políticas basadas en la protección pura y rígida. En las actuales condiciones de evolución de la economía mundial, el Brasil puede y debe ampliar sus acuerdos comerciales, comenzando por la integración regional.

En las negociaciones comerciales, como lo hacen los países emergentes exitosos, es fundamental valorizar la posición del Brasil y de su potencial de importación como forma de impulsar su capacidad exportadora.

Las ventajas de China y de sus socios asiáticos no están aseguradas. El capitalismo no descansa. Tras la crisis de 2008 y sus consecuencias, los países que perdieron posición en la disputa competitiva de la manufactura - sobre todo los Estados Unidos- dan señales de una nueva rueda de innovaciones, aquellas que los sabios que todavía utilizan funciones de producción clasificarían como "ahorradoras de mano de obra".

Marco Annunziata, el economista jefe de General Electric, y Keneth Rogoff preconizan la inminencia de un intenso movimiento de automatización basado en la utilización de redes de "máquinas inteligentes". Nanotecnología, neurociencia, biotecnología, nuevas formas de energía y nuevos materiales forman el conjunto de innovaciones con enorme potencial de revolucionar otra vez las bases técnicas del capitalismo. Todos los métodos que nacen de esa base técnica no pueden más que confirmar su razón interna: son métodos de producción destinados a aumentar la productividad social del trabajo en escala ascendente. Su aplicación continuada torna el trabajo inmediato cada vez más redundante. La autonomización de la estructura técnica significa que la aplicación de la ciencia se vuelve el criterio dominante en el desarrollo de la producción.

El juego de las grandes empresas se juega en el tablero en que la movilidad del capital impone conjuntamente la liberalización del comercio, el control de la difusión del avance técnico (leyes de patentes, entre otros) y el debilitamiento de la capacidad de negociación de los trabajadores. De este modo, las "nuevas" formas de competencia esconden, bajo el velo transparente de la libertad, el aumento brutal de la centralización del capital, la concentración del poder sobre los mercados, la enorme capacidad de ocupar y abandonar territorios y de alterar las condiciones de vida de las poblaciones. 


\section{La macroeconomía de la globalización}

Observada en su configuración macro, la economía se puede concebir como un gran panorama de balances interrelacionados. Los balances de los bancos, las empresas, las familias, los gobiernos y el sector externo registran, en cada momento, los resultados de las decisiones de financiamiento y gasto que toma privadamente cada uno de los participantes del juego del mercado. Las decisiones privadas de gasto apoyadas en el crédito (y, por lo tanto, en el endeudamiento) son las variables independientes que determinan la creación de empleos y, por consiguiente, la formación del ingreso. Así, en la medida en que el pago de salarios y las compras entre las empresas crean el flujo de ingresos globales de la economía, las operaciones de débito y crédito modifican la distribución de la acumulación de derechos sobre la riqueza y, por lo tanto, la situación patrimonial de los protagonistas. En la fase ascendente del ciclo, el flujo de lucros, el ahorro de las familias y los ingresos del gobierno procuran garantizar el servicio y la estabilidad del valor de las deudas y de los costos financieros. Los ahorros derivados del nuevo flujo de ingresos constituyen el financiamiento del sistema bancario y el mercado de capitales. Estos últimos, en su función de intermediarios, promueven la validación del crédito y la liquidez (creación de moneda) "adelantados" originariamente por los bancos para viabilizar los gastos de inversión y consumo.

Iniciada en el segundo semestre de 2007 y acelerada en el infausto episodio de la quiebra de Lehman Brothers, en septiembre de 2008, la crisis ofreció a algunos analistas (como Krugman, Roubini, Michel Aglietta, Martin Wolf y Claudio Borio) la oportunidad de avanzar en la comprensión de las transformaciones ocurridas en las relaciones entre innovaciones financieras, financiamiento de los gastos de consumo de las familias y de inversión de las empresas y generación de ingresos y empleo en la economía globalizada.

El economista Claudio Borio del Banco de Pagos Internacionales (BPI) reveló la verdad que la mayoría de los analistas comprometidos con la banca se esfuerza por esconder al amparo de sus inefables conocimientos. En el origen, desarrollo y configuración del ciclo financiero que culminó en la crisis, se encuentra el flujo bruto de capitales privados, sobre todo los que han formado parte de transacciones entre Europa y los Estados Unidos. Debido a la interpenetración financiera se suscitó la diversificación de los activos a escala mundial y, así, se impuso la "internacionalización" de las carteras de los administradores de la riqueza.

En el ciclo de expansión financiera internacionalizada se combinaron 1) métodos innovadores de "apalancamiento" financiero; 2) la valorización de los activos inmobiliarios; 3) la migración de la producción manufacturera 
hacia los países con bajo costo de mano de obra; 4) la ampliación de las desigualdades; 5) la insignificante evolución de los rendimientos de la población asalariada; 6) la degradación de los sistemas progresivos de tributación.

La lenta evolución de los rendimientos se hizo cómplice de la vertiginosa expansión del crédito para impulsar el consumo de las familias. Amparado en la "extracción de valor" que ofreció el incremento de los precios de los inmuebles, el gasto de los consumidores alcanzó elevadas participaciones en la formación de la demanda final en casi todos los países de las regiones desarrolladas. Mientras tanto, las empresas de los países "consumistas" procuraban intensificar la estrategia de separar en territorios distintos la formación de nueva capacidad y la obtención de los resultados.

En el período de euforia, las grandes empresas desplazaron su manufactura hacia las regiones en que prevalecían bajos salarios, un cambio desvalorizado y una alta productividad. Estadounidenses y europeos corrieron en dirección a Asia y los alemanes, aunque frugales, cambiaron repentinamente de rumbo hacia los vecinos del este. De estas ciudades, exportaron manufacturas baratas para los países y las regiones de origen o de su influencia. Embalados por la expansión de los gastos de las familias, obtuvieron lucros y acumularon efectivo (en general en los paraísos fiscales). El desplazamiento de las empresas estadounidenses generó profundos déficits en cuenta corriente en la economía territorial de la madre patria. Por su lado, los alemanes, a pesar del desplazamiento hacia el este europeo, financiaron los gastos que produjeron los enormes déficits en cuenta corriente de los vecinos de la zona del euro.

El mundo no convergió en el régimen de tasas flotantes. Todo lo contrario: la coexistencia entre regímenes de tipos de cambio flotantes y tasas administradas o fijas se convirtió en la marca registrada de la economía mundial. El número de países que adoptó el "anclaje" al dólar o una canasta de monedas aumentó considerablemente. Después de la crisis asiática, las economías de la región - particularmente China - retomaron las estrategias exportadoras con fuerte acumulación de reservas y medidas sumamente pragmáticas de control de capitales. Ante el aluvión de capitales empleados en el arbitraje con tasas de interés y en la especulación desenfrenada con sus monedas, tanto los países desarrollados como emergentes luchan para evitar la formación de burbujas crediticias e intentan evitar los efectos indeseados y nefastos de la valorización cambiaria.

La entrada de China y otros países emergentes como importantes protagonistas en el comercio internacional de manufacturas promovió un fuerte movimiento deflacionario, lo que contribuyó a la estabilidad de 
precios en el ámbito de la economía mundial. Los precios de los productos básicos permanecieron bajo control hasta el final de la década de 2000. Luego, la situación cambió. Con posterioridad a la crisis, los precios de los productos básicos pasaron a responder elásticamente a los impulsos de la demanda china y, sobre todo, a los excesos de liquidez engendrados por las acciones de los bancos centrales de las economías desarrolladas.

La aceleración de ese componente del gasto en los países emergentes asiáticos compensó con creces la caída de la inversión en la formación de la demanda agregada de los países centrales. El balance mundial registra, por lo tanto, la creación generalizada de capacidad productiva excedente, particularmente en los sectores de alta y media tecnología afectados por la competencia internacional.

Cuando los motores se revirtieron, accionados por la caída de los precios de los inmuebles y la desvalorización de los activos financieros vinculados al consumo, se observó que la deuda de las familias era "excesiva", calculada en función de los flujos previstos de rendimiento y la caída del valor de las residencias. Sofocadas en la abundancia de capacidad a escala mundial, las empresas recortaron todavía más los gastos de capital. Aliviadas de la carga de activos tóxicos gracias a la acción de los bancos centrales, las instituciones financieras acumularon reservas excedentes, pero dudan a la hora de otorgar préstamos incluso a otras instituciones financieras. Entre la caída del ingreso, la ampliación automática de los gastos y el salvataje a los bancos moribundos, los déficits fiscales aumentaron, incrementando el volumen de las carteras de los bancos con la deuda de los gobiernos. Por otro lado, no se observan cambios en los desequilibrios en cuenta corriente de las balanzas de pagos.

En los últimos tres años, las familias con capital negativo y las empresas sobrecargadas de capacidad han acudido a la tranquilidad que ofrece la liquidez y el reequilibrio patrimonial. Los países y las regiones se pelean: unos para revertir los déficits externos, otros para mantener sus superávits. Los gobiernos ensayan políticas de austeridad fiscal. Tales decisiones son "racionales" desde el punto de vista microeconómico y virtuosas bajo la óptica de la gestión de las finanzas internas, pero perversas para el conjunto de la economía. Si todos pretenden reducir gastos, lograr superávits y tornarse líquidos al mismo tiempo, el resultado solo puede ser la caída del ingreso, el empleo y el crecimiento del "peso" de las deudas cuyo "valor" está fijado en términos nominales. Es paradoja del desapalancamiento, también conocido como el infierno de las buenas intenciones, cuyas llamas crepitan en el conocido, pero siempre descuidado territorio de las falacias de composición. Si se interpretan correctamente, las falacias podrían aconsejarnos la necesidad de discernir los fundamentos macroeconómicos de la microeconomía. 

Parte II

Macroeconomía para el desarrollo 

Capítulo IV

\section{Neoestructuralismo y macroeconomía para el desarrollo}

Ricardo Ffrench-Davis ${ }^{1}$

\section{Introducción}

Una de las responsabilidades fundamentales del Estado en la esfera del desarrollo económico y social hace referencia al entorno global en el que se desenvuelven los productores y consumidores de bienes y servicios que operan en la economía nacional; eso es la macroeconomía. Al diseñar el entorno macroeconómico, se deben tener en cuenta dos características básicas: que posibilite el uso pleno de los recursos productivos, con balances internos y externos sostenibles, y que ello guarde coherencia con la formación de nuevas capacidades. Entre otras condiciones, se requiere una evolución de la demanda interna en torno a la capacidad productiva, o el PIB potencial, y que los precios macroeconómicos (en particular, el tipo de cambio) se sitúen en niveles compatibles con una balanza exterior sostenible. Esto es lo que se ha llamado macroeconomía para el desarrollo, que resulta esencial para formular una estrategia de crecimiento con

El autor agradece la colaboración de Felipe Correa y los comentarios de los editores de este libro y de los participantes del seminario sobre Neoestructuralismo y Economía Heterodoxa, realizado por la CEPAL el 22 y 23 de abril de 2013. Sus primeros esbozos sobre neoestructuralismo se encuentran en Ffrench-Davis (1988), elaborados sobre los trabajos pioneros de autores como Aníbal Pinto, Osvaldo Sunkel y Fernando Fajnzylber. 
equidad. El objetivo de este capítulo es examinar los efectos depresores y regresivos que tienen sobre el crecimiento económico y el empleo las políticas macroeconómicas predominantes, inspiradas en el Consenso de Washington o enfoque neoliberal, y delinear los rasgos y efectos centrales de una macroeconomía para el desarrollo; se enfatizan, en particular, las implicancias de la elevada heterogeneidad estructural en diversos tipos de agentes económicos.

La heterogeneidad estructural es un rasgo característico de las economías en desarrollo, como las de la región. Se manifiesta en la notable variación de la productividad entre empresas de diferentes dimensiones y trabajadores con distintas calificaciones, en la diversa capacidad de acción y reacción de los agentes típicos en distintos mercados (como los grandes y pequeños empresarios, los trabajadores de alta y de reducida calificación, los inversionistas productivos generadores de PIB y los inversionistas financieros compradores de activos, o los inversionistas productivos y los consumidores), y en las asimetrías en la capacidad de respuesta de los distintos agentes ante la inestabilidad de la actividad económica y de los precios macroeconómicos.

Si la inestabilidad del entorno macroeconómico es mayor, las asimetrías se intensifican. Ello reviste mucha importancia, ya que las economías de la región se caracterizan por reiteradas expansiones seguidas de situaciones recesivas, lo que conlleva una producción efectiva por debajo de la capacidad productiva del trabajo y el capital, intensos altibajos de los precios macroeconómicos, como el tipo de cambio, falta de liquidez en el mercado crediticio y grandes vaivenes de la balanza exterior. Esta inestabilidad muestra un vínculo estrecho con las fluctuaciones de las corrientes de capital financiero y los precios de las exportaciones primarias.

En el documento La hora de la igualdad: brechas por cerrar, caminos por abrir (CEPAL, 2010) se plantea que la combinación de heterogeneidad e inestabilidad presenta desafíos profundos en la formulación de las políticas públicas: si ello no se tiene en consideración, suele fracasarse no solo en el logro de la igualdad, sino también en el del crecimiento. En efecto, políticas supuestamente "neutrales" suelen producir efectos muy negativos en ambas dimensiones: i) efectos regresivos, que perjudican a las pymes, las producciones incipientes y los trabajadores de menor calificación, y ii) un descenso en la utilización de la capacidad productiva disponible, la formación de capital, la calidad de las exportaciones y el empleo, y la innovación. Por consiguiente, la reducción de la heterogeneidad estructural y de la inestabilidad de la macroeconomía real es determinante para lograr el desarrollo, que, por definición, es inclusivo. 
En consecuencia, las políticas macroeconómicas deben tener en cuenta la heterogeneidad estructural existente para lograr nivelar la capacidad de respuesta de los diversos agentes. Ello es esencial para el desarrollo, que pasa ineludiblemente por la reducción constante de las brechas de productividad, elevando la productividad media y reduciendo su dispersión.

Para alcanzar estas metas es necesario articular y consensuar políticas en varios frentes, entre ellos, las políticas macroeconómicas, sociales y de desarrollo productivo. Desde este enfoque, las políticas macroeconómicas pueden contribuir a transformar las estructuras productivas, introduciendo un sesgo que promueva la igualdad de oportunidades, y a impulsar un dinamismo económico que favorezca la formación de capital, el empleo y la innovación. Este análisis se concentra en la dimensión macroeconómica y su influencia en la equidad, la productividad efectiva y la formación de capital.

Este capítulo se divide en tres secciones, además de esta introducción. En la sección A se presenta una síntesis del desempeño macroeconómico de la región desde 1990. En la sección B se examinan tres tipos de asimetrías que, ante la existencia de inestabilidad en la economía real y heterogeneidad estructural, resultan recesivas y deprimen el desarrollo, debido a sus efectos en la formación de capital, la calidad de la inserción externa y el nivel de empleo y la precariedad laboral. Por último, se formulan las conclusiones.

\section{A. El enfoque dominante desde $\mathbf{1 9 9 0}$ y sus efectos}

En estos años, ha dominado la visión de que el control de la inflación y el equilibrio fiscal bastarían para asegurar el equilibrio macroeconómico. Muchos reformadores pensaban que el logro de esos dos objetivos se facilitaría con un tipo de cambio libre y la apertura plena de la cuenta de capitales, lo que atraería ahorro externo, que se añadiría al ahorro nacional y permitiría financiar un volumen mayor de formación de capital. Al mismo tiempo, ello contribuiría a "importar" estabilidad macroeconómica, ya que limitaría las posibles acciones irresponsables de las autoridades locales. Según ese enfoque, los agentes financieros, con sus votos de confianza o desconfianza a las economías nacionales, pondrían coto a la tendencia de las autoridades nacionales de generar desequilibrios fiscales y monetarios. Además, los flujos de fondos de los mercados financieros determinarían niveles de liquidez, tasas de interés y tipos de cambio de equilibrio. 
Como ingrediente central, se procuró aislar a la gestión monetaria de presiones políticas. Así pues, por lo general, la política monetaria se centró en el control de las metas de inflación. Con frecuencia, la apreciación cambiaria provocada por ingresos de capitales fue recibida con beneplácito, debido a su efecto depresor sobre el índice de precios al consumidor (IPC), sin tener en cuenta su incidencia negativa en la producción de bienes transables y la estabilidad de la economía real.

En consecuencia, en las últimas décadas, en América Latina ha primado un enfoque macroeconómico que otorgaba una clara prioridad a la estabilidad nominal o el nivel de precios y a la disciplina fiscal. Por lo tanto, el diseño y la evaluación de las políticas macroeconómicas se han disociado de la consideración de sus efectos en el empleo y el crecimiento, centrándose excesivamente en el control de la inflación. Este enfoque permitió obtener resultados satisfactorios en el control de la inflación, que, desde la primera mitad de los años noventa, fue de un dígito en la mayoría de los países de la región. No obstante, ello no ha generado un crecimiento sostenido del PIB ni de los ingresos laborales (Ffrench-Davis, 2005).

El ritmo de crecimiento del PIB ha sido decepcionante (Williamson, 2003). Entre 1990 y 2012, se produjo un aumento del PIB de apenas el 3,2\% anual, en comparación con el 5,6\% registrado en la década de 1970. De hecho, la región en su conjunto no ha experimentado un proceso de convergencia que acorte la distancia con el mundo desarrollado. Por ejemplo, en 2008 (el año previo a la llegada del contagio de la crisis mundial), el PIB per cápita de América Latina equivalió al 27\% del ingreso medio de los países del Grupo de los Siete (G7), porcentaje que la región ya había alcanzado a finales de la década de 1980 (véase el cuadro IV.1). Entre 1990 y 1997, período en el que se aplicaron con mayor intensidad en la región las reformas del Consenso de Washington, ambos grupos de países experimentaron un aumento similar del ingreso por habitante. En los años siguientes, hasta 2003, el PIB per cápita disminuyó, influido negativamente por la crisis asiática. A partir de 2004 se experimentó una aceleración notable gracias al efecto positivo de los términos de intercambio, con lo cual en 2008 el PIB per cápita de la región fue levemente superior al 27\% del PIB per cápita del G7, situándose en 2012 en el $29 \%{ }^{2}$. En un extenso período de 23 años, la región recortó solo 2 puntos de los 73 puntos de la brecha que existía en 1989.

El quinquenio 2004-2008 fue el más positivo desde la década de 1970, con un crecimiento promedio del 5,3\% anual. En el período 2009-2012, la mejora relativa de la región se debe más al retroceso de las economías más desarrolladas. 


\section{Cuadro IV.1}

América Latina: PIB per cápita respecto del de los Estados Unidos

y del Grupo de los Siete (G7), 1970-2012

(En porcentajes, sobre la base de dólares en PPA de 2012)

\begin{tabular}{lcc}
\hline Año & América Latina/Estados Unidos & América Latina/G7 \\
\hline 1970 & 26,5 & 32,5 \\
\hline 1980 & 30,3 & 35,6 \\
\hline 1989 & 23,5 & 27,2 \\
\hline 1997 & 23,0 & 26,6 \\
\hline 2008 & 23,3 & 27,4 \\
\hline 2012 & 24,6 & 29,1 \\
\hline
\end{tabular}

Fuente: Para el PIB per cápita en PPA de las tres unidades de 2012: elaboración propia sobre la base de estimaciones del Banco Mundial. Para los años anteriores: estimación sobre la base de las tasas de variación real del PIB per cápita que figuran en los informes del Banco Mundial desde 1970 hasta 2012.

Después del contagio de la crisis mundial de 2008-2009, en 2010-2011 se registraron otras recuperaciones vigorosas $(5,8 \%$ y $4,4 \%$, respectivamente). No obstante, una vez más, al promediar el período de decrecimiento debido al contagio con el período de recuperación posterior, se mantiene una media similar y deficiente. Además, ya en 2012 se había retornado a un 3\%. Ello refleja la debilidad de las políticas microeconómicas (que no se analizan en este estudio) y macroeconómicas.

Por lo general, las etapas de auge (iniciadas en 1990-1991, 1995-1996, 2003-2004 y 2010) han traído consigo desequilibrios macroeconómicos con respecto a los tipos de cambio y el balance externo, así como burbujas en los precios de la bolsa y los créditos al consumo, lo que ha provocado situaciones crecientemente insostenibles y han dado lugar a nuevos ajustes recesivos $^{3}$. Estos desequilibrios (o indicadores de vulnerabilidad) subyacen en la gran inestabilidad que exhibe la evolución del PIB en la mayoría de las economías medianas y grandes de la región, que, por su peso, determinan los promedios ponderados regionales (véase el gráfico IV.1). Es un hecho irrefutable que, en la mayoría de los países de la región, los cambios en la evolución del PIB no responden a abruptas variaciones estructurales o de ámbito microeconómico, sino a cambios cíclicos de variables macroeconómicas asociadas predominantemente al patrón de inserción financiera y comercial.

Hasta 2003, las fluctuaciones de la actividad económica estuvieron asociadas principalmente a las corrientes de capitales. Desde entonces, el auge experimentado, particularmente en América del Sur, ha sido en cierto sentido una excepción parcial, ya que se ha debido a mejoras prolongadas de los términos de intercambio, y no al uso del ahorro externo; en definitiva, se basó más en fondos propios que en

Véase CEPAL (2010) y Ffrench-Davis (2005 y 2010). 
fondos ajenos. Ello le ha conferido una mayor sostenibilidad temporal, junto con la adopción de algunas reformas contracíclicas, como la creación de fondos soberanos estabilizadores. No obstante, la mayoría de los indicadores de vulnerabilidad macroeconómica estuvieron crecientemente presentes hasta 2008 y, en 2010-2012, se ha repetido el proceso de desequilibrio.

\section{Gráfico IV.1}

América Latina (19 países): volatilidad del PIB, 1977-2012

(Tasas anuales de crecimiento, en porcentajes)

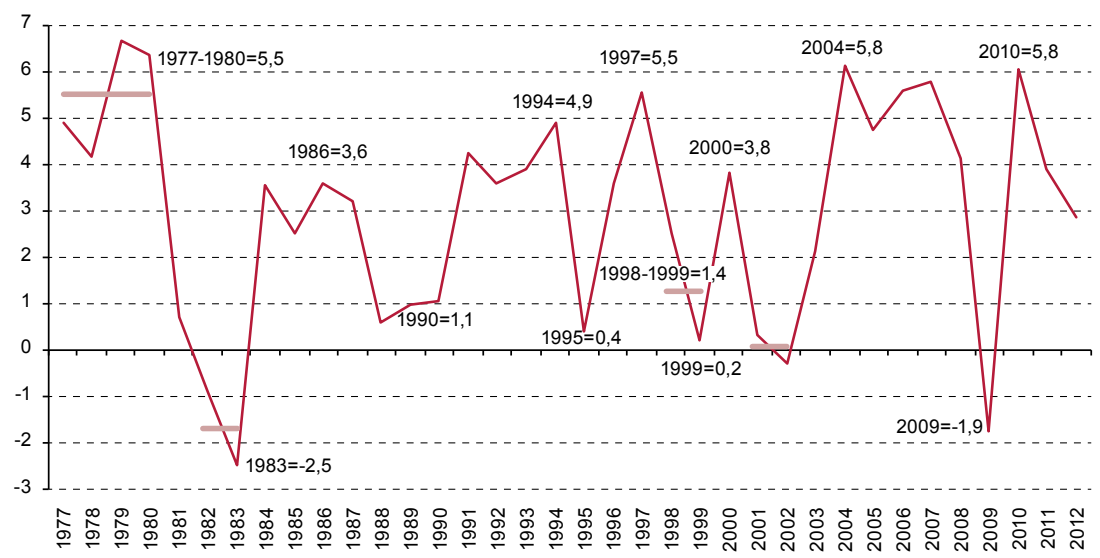

Fuente: Elaboración propia sobre la base de Comisión Económica para América Latina y el Caribe (CEPAL), datos de 19 países.

El indicador más notorio son las persistentes revaluaciones cambiarias y su efecto en las cuentas corrientes. Las revaluaciones han estado asociadas a los precios notablemente elevados de las exportaciones primarias de algunos países de la región, los que determinan fuertes mejoras de los términos de intercambio (véase el gráfico IV.2)4. Mientras esas alzas se mantengan, las revaluaciones parecen sostenibles; sin embargo, van dejando sus huellas distorsionadoras en la calidad de las exportaciones y en la competitividad de las pymes ante las importaciones, cuyo volumen ha crecido un $108 \%$ desde 2003 , en comparación con un aumento del $47 \%$ del volumen de las exportaciones (véase el gráfico IV.3).

\footnotetext{
$4 \quad$ El aumento de cerca del 50\% del índice de términos de intercambio sobrestima el impacto positivo sobre los ingresos por exportación, pues parte del efecto se filtra al exterior mediante las remesas de utilidades de la IED del sector exportador. La filtración fue de alrededor de un tercio en el período reciente de auge. Véase la tendencia de los términos de intercambio en Erten y Ocampo (2012).
} 


\section{Gráfico IV.2 \\ América Latina: relación de los precios de intercambio de los bienes y servicios, 1990-2012 \\ (Índice 1990=100)}

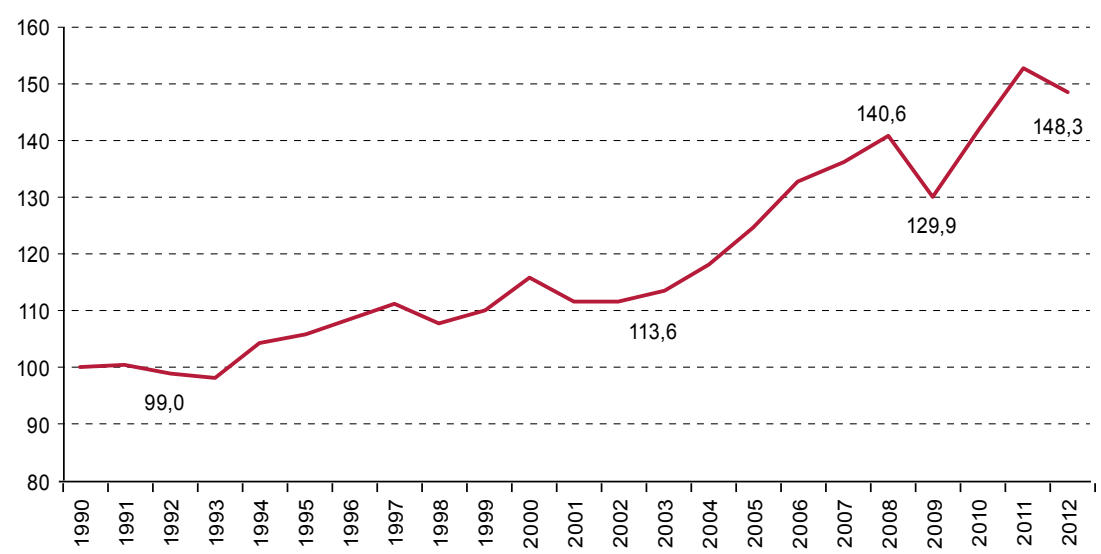

Fuente: Elaboración propia sobre la base de datos de la Comisión Económica para América Latina y el Caribe (CEPAL).

Gráfico IV.3

América Latina: evolución del volumen de las exportaciones y las importaciones de bienes FOB, 2003-2012 (Índice 2003=100)

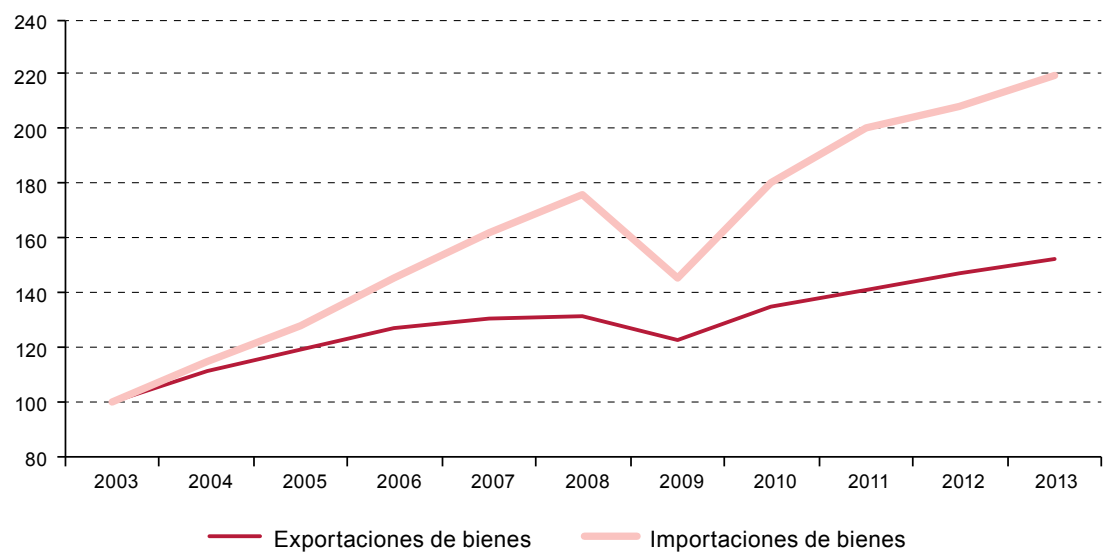

Fuente: Elaboración propia, sobre la base de CEPALSTAT para 2003-2009 y sobre la base de CEPAL, Estudio Económico de América Latina y el Caribe, 2012 para 2010-2012. 
En resumen, paralelamente a los mencionados equilibrios nominales (baja inflación y disciplina fiscal), se observan intensas fluctuaciones de la tasa de crecimiento del PIB, que es el principal indicador de la economía real. En general, en el conjunto de la región, los cambios en la evolución del PIB no responden a abruptas modificaciones estructurales o de ámbito microeconómico, sino a cambios de variables macroeconómicas asociadas predominantemente a variaciones de las corrientes de capital financiero, tanto de entrada como de salida, y de los términos de intercambio. Estos factores, junto con su impacto multiplicado por políticas macroeconómicas pasivas o procíclicas (Kaminsky, Reinhart y Vegh, 2004; Ffrench-Davis, 2010), provocan variaciones sustanciales de la demanda agregada, el tipo de cambio y las expectativas de los agentes económicos. Indudablemente, se trata de variables macroeconómicas que evidencian graves desequilibrios de la economía real, aunque la inflación y las cuentas fiscales estén controladas. Como se documenta en este artículo, esta inestabilidad ha perjudicado decisivamente al crecimiento del PIB y la equidad, debido a su repercusión en la tasa de inversión productiva y en la calidad del empleo.

La enseñanza con respecto a la formulación de las políticas macroeconómicas es que no basta con mantener una tasa de inflación baja y el orden fiscal, ya que ello ha implicado un desequilibrio entre los objetivos. Naturalmente, ambos objetivos son necesarios, pero la manera de lograrlo resulta determinante y, por sí solos, son insuficientes para asegurar la estabilidad y el crecimiento de la economía real. Teniendo en cuenta las circunstancias y la eficacia, hace falta un equilibrio entre los distintos objetivos, así como la consiguiente coordinación de los medios para lograrlos. Es necesario pasar a un enfoque que priorice explícitamente la interrelación de las políticas macroeconómicas con el desarrollo productivo y las repercusiones en materia de igualdad.

\section{B. Asimetrías recesivas y regresivas}

Una característica del desempeño de las economías de la región es la notable repetición de fluctuaciones cíclicas de la actividad económica, con auges pronunciados seguidos de contracciones que suelen ser abruptas; generalmente, este rasgo ha sido más acentuado en las economías medianas y grandes. Esa ciclicidad tiene efectos negativos en la capacidad productiva y su distribución entre los diversos productores del PIB (trabajadores y dueños del capital). La capacidad productiva o PIB potencial pone límite máximo al PIB efectivo obtenible en cada momento del tiempo. Solo un PIB potencial en expansión - cuya evolución depende de los insumos que se le aporten y del entorno macroeconómico que enfrente- da sostenibilidad a un PIB efectivo creciente. 
La ciclicidad ha estado asociada a grandes altibajos de la demanda agregada, del acceso al crédito, los tipos de cambio y la balanza exterior. Dada la existencia de heterogeneidad estructural, la variabilidad afecta de manera diferente a los diversos productores del PIB.

\section{Recuadro IV.1}

\section{Asimetrías recesivas y regresivas}

- En el ciclo económico, frecuentemente, el PIB efectivo no se sitúa alrededor del PIB potencial, sino por debajo. El techo es un máximo, no una media tendencial. Por ello, en general, la inestabilidad no es neutra, sino depresora de la productividad total de los factores (PTF) efectiva y del empleo, y la brecha recesiva (diferencia entre el PIB efectivo y el PIB potencial) hace disminuir la formación bruta de capital.

- La capacidad asignativa del tipo de cambio se resiente y se perjudica al valor agregado de las exportaciones y a la competitividad de las pymes frente a las importaciones.

- El inversionista financiero se puede ajustar instantáneamente a los cambios de expectativas y precios relativos. El inversionista productivo, que es el que genera la formación bruta de capital, cuya asignación de recursos es irreversible, necesita plazos prolongados. La inestabilidad favorece la inversión especulativa en vez de la inversión productiva. Este es un efecto depresivo del crecimiento.

- En el ciclo se reduce la tasa de participación laboral y el empleo de las personas de menor empleabilidad, que son las más pobres, y se eleva la informalidad. Este es un efecto regresivo.

- Un enfoque macroeconómico que descuida la estabilidad de la economía real resulta negativo para el crecimiento y la equidad, dado que combina ambas características: es recesivo y regresivo.

Fuente: Elaboración propia.

La mencionada inestabilidad de la economía real implica que, en contextos recesivos, el PIB efectivo puede estar muy por debajo del PIB potencial durante largos períodos, lo que afectaría su evolución futura, debido a su efecto depresor en la inversión productiva, el empleo y la innovación. En cambio, en los períodos de auge, es evidente que la frontera productiva establece un límite a la recuperación del PIB efectivo; el PIB efectivo solo puede superar al PIB potencial coetáneo durante períodos breves. Naturalmente, durante la recuperación, el PIB efectivo suele crecer más rápidamente que el PIB potencial, pero no se equipara con él mientras no se logre el pleno empleo. La brecha entre ambos es lo que se denomina "brecha recesiva", ya que indica una subutilización del capital y el trabajo disponibles. El hecho de que, en contextos de una marcada inestabilidad, la economía no fluctúe alrededor del PIB potencial, sino que se sitúe en 
un nivel inferior, implica una asimetría que afecta considerablemente al crecimiento económico y su distribución.

Mientras subsista la brecha entre el PIB efectivo y el potencial, persistirán los efectos depresores de la formación de capital, la calidad de la producción de los bienes transables y el mercado laboral, como se expone a continuación. Por consiguiente, para favorecer el crecimiento y la equidad, es muy importante que la actividad económica pueda situarse en un nivel cercano a la frontera productiva, lo que contribuiría a elevarla; esta proximidad no ha sido frecuente ni continuada. En casi todos los años comprendidos entre 1981 y 2012, en el conjunto de la región, han prevalecido brechas recesivas significativas.

\section{Brecha recesiva y formación de capital}

El interrogante que se desprende de la información disponible es por qué la formación bruta de capital ha sido tan reducida en el período en el que predominaron las reformas neoliberales. Una causa fundamental ha sido la existencia de desequilibrios en la economía real, que consistían en brechas significativas entre el PIB efectivo y el potencial. Como se documenta en numerosos antecedentes empíricos, la brecha recesiva entre el PIB efectivo y el potencial (que constituye un desequilibrio macroeconómico esencial) ejerce un efecto marcadamente depresor en la tasa de inversión, que es una variable determinante para el crecimiento económico. De hecho, la experiencia de América Latina muestra una elevada correlación negativa entre la magnitud de la brecha y la tasa de formación de capital (Ffrench-Davis, 2005, pág. 117) ${ }^{5}$. La estrecha asociación que ha existido entre la brecha recesiva y la tasa de inversión en capital fijo en América Latina evidencia uno de los principales efectos dinámicos negativos de la subutilización de los factores productivos.

Esta relación negativa se debe a diversos factores: i) una brecha recesiva implica una subutilización de la capacidad disponible, lo que reduce la productividad efectiva (productividad total de los factores); ii) si las ventas declinan, no se justifica para el empresario una expansión de la capacidad hasta que no prevea que su empresa se acerca a la utilización plena; iii) al disminuir la utilidad, se dispone de menos fondos propios para financiar nuevas inversiones, mientras que se desalienta la disposición a arriesgar fondos o patrimonio a largo plazo, que es lo que requieren las inversiones irreversibles; iv) el correspondiente deterioro de los balances de las empresas suele verse acompañado de una reticencia

Las estimaciones referentes a 1970-2003 de nueve países de América Latina, a los que corresponde la gran mayoría de la población y del PIB regional, se basan en antecedentes de la CEPAL y de Hofman y Tapia (2003). En Ffrench-Davis (2010), se vuelve a analizar este tema, con estimaciones actualizadas de ese estudio que abarcan el período 1970-2009. 
procíclica del mercado de capitales a financiar empresas con falta de liquidez en situaciones recesivas; v) el entorno volátil, generador de incertidumbre, disuade la inversión irreversible; vi) la brecha recesiva y sus fluctuaciones suelen afectar a la calidad de la evaluación de los proyectos y desalentar la innovación productiva, y vii) las intensas fluctuaciones recesivas suelen deprimir los ingresos fiscales, lo que provoca recortes en la inversión pública complementaria de la inversión privada (Easterly y Servén, 2003) ${ }^{6}$.

Así pues, un conjunto de contundentes razones, ligadas a desequilibrios de la macroeconomía real, explican por qué la insuficiente tasa de formación de capital aparece tan asociada a los ciclos económicos. El desempeño deficiente de la formación de capital opaca las tareas que se han estado realizando en la región, de carácter más estructural, para elevar la productividad y reducir la heterogeneidad estructural mediante reformas microeconómicas y mesoeconómicas.

Si se consigue evitar la reaparición recurrente de la brecha recesiva, con una política que logre que la demanda agregada esté cerca del PIB potencial y haya un tipo de cambio real sostenible, se podrá estimular a los posibles inversionistas para que intensifiquen su actividad. El efecto dinámico será mucho mayor si se generan expectativas sólidas entre los actores económicos con respecto a que las políticas públicas mantendrán los equilibrios de la economía real y, además, las autoridades emprenden reformas para completar los mercados de capitales de largo plazo, estimulan la innovación productiva y mejoran la capacitación de la fuerza laboral.

A medida que la brecha recesiva desaparece, muchos emprendedores que habían desactivado proyectos en ciernes intentarán reactivarlos. Ello requiere tiempo, dado el conjunto de elementos necesarios para concretar un proyecto de inversión productiva. Si la brecha solo se elimina durante un período corto, debido a desequilibrios que se han ido gestando durante la recuperación de la actividad económica, muchos posibles inversionistas no tendrán tiempo de concretar su emprendimiento antes de que comience la siguiente recesión. Constituye otra asimetría de los efectos cíclicos, que ayuda a explicar el deficiente desarrollo alcanzado con las políticas neoliberales.

En este sentido, la sostenibilidad del ciclo expansivo es crucial para potenciar la inversión productiva. En el gráfico IV.4 se puede observar que, en los procesos de recuperación, luego de cierto rezago, la formación

El impacto depresor del ciclo sobre la formación bruta de capital fijo se intensifica por el hecho de que la contracción de la inversión suele ser más bien abrupta, en tanto que la recuperación tiende a ser gradual. Esta nueva asimetría arroja una suma de flujos de inversión inferior a la que se obtendría si ambos ajustes fuesen simétricos. 
bruta de capital adquiere velocidad y, al producirse la nueva recesión, esa aceleración se detiene y se revierte. Por lo tanto, cuanto más prolongada sea la cercanía al pleno uso, mayor tenderá a ser la elevación de la tasa de inversión. En consecuencia, es imprescindible que en el período de auge no se gesten desequilibrios en la macroeconomía real, como una apreciación cambiaria creciente, con un alza de la importaciones constantemente mayor que la de las exportaciones, un endeudamiento elevado de los consumidores o una demanda agregada que aumente sistemáticamente más rápido que la capacidad productiva.

\section{Gráfico IV.4}

América Latina (19 países): formación bruta de capital, 1970-2012 ${ }^{\text {a }}$

(En porcentajes del PIB, sobre la base de dólares constantes de 2005)

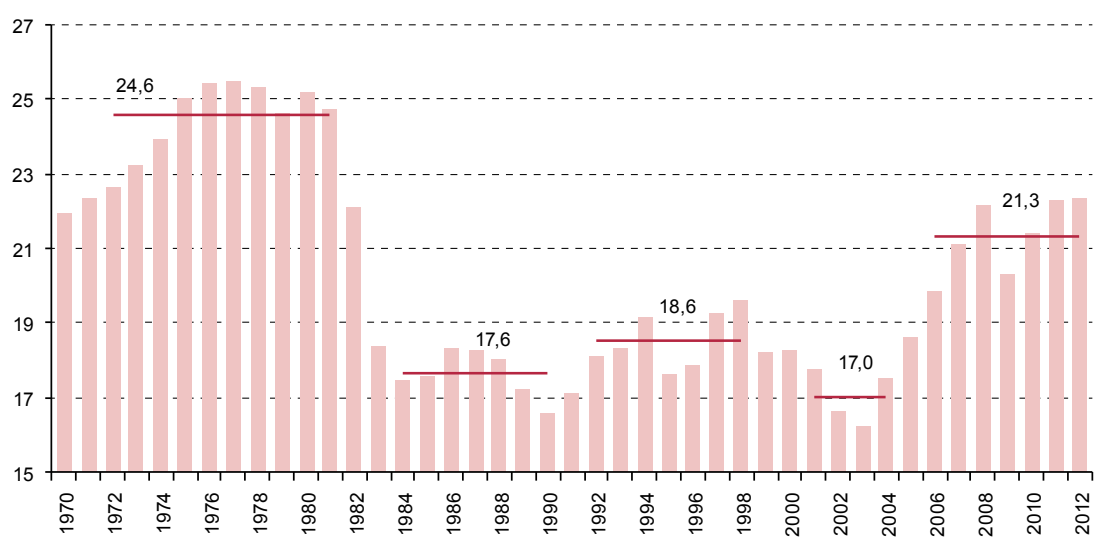

Fuente: Elaboración propia sobre la base de Comisión Económica para América Latina y el Caribe (CEPAL), datos de 19 países.

a Las líneas horizontales indican la tasa media de formación bruta de capital en subperíodos en los que la tasa estaba en expansión (1972-1981, 1992-1998 y 2006-2012) y en situaciones recesivas (1984-1990 y 2001-2004).

Como ya se ha expuesto, desde la década de 1980, ha sido habitual que la economía inicie un proceso de reactivación, alcance a un punto máximo que se aproxima al pleno uso de la capacidad y enseguida transite hacia una nueva recesión. En este tercio de siglo, ha sido poco el tiempo en el que la economía ha presentado un uso elevado de su capacidad productiva. En efecto, los años ochenta se caracterizaron por una brecha recesiva significativa; en 1994 se alcanzó un punto máximo que cayó en 1995; en el curso de 1997-1998 se alcanzó otro pico, seguido por una contracción ya en 1998; en 2003-2004 se inició otro período en alza, que se detuvo por el breve contagio de 2008-2009, y se retornó a un auge en 2010-2012, que se desaceleró en 2013. 
En resumen, en cada situación recesiva, la formación de capital se contrae significativamente y, en los períodos de auge, se suele reactivar de forma gradual y con un rezago, lo que denota otra asimetría relevante. Por consiguiente, se mantiene una brecha que tiene un efecto depresor en la suma de la serie de flujos de inversión correspondientes al proceso de ajuste, aunque al final del ciclo se retorne a un flujo marginal similar al inicial. Lamentablemente, a partir de la década de 1970, la región no ha logrado mantener procesos prolongados de producción cercana al PIB potencial. Lo común ha sido que prevalecieran tasas elevadas de subutilización, debido a la inestabilidad macroeconómica real, generada por flujos de capitales y precios de exportación volátiles, así como por políticas macroeconómicas procíclicas, lo que ha impedido que la formación bruta de capital fijo llegara a entrar en un régimen normalmente elevado.

\section{Inestabilidad cambiaria y desarrollo productivo ${ }^{7}$}

En la macroeconomía para el desarrollo se otorga un papel estratégico al tipo de cambio, como el precio relativo que vincula a la economía nacional con la internacional, que es una variable esencial para la sostenibilidad de los equilibrios macroeconómicos y la asignación de recursos. Se trata de una variable determinante para las decisiones de asignación de recursos productivos y de consumo de los agentes económicos entre los bienes transables y los no transables. Tanto su nivel real medio como su estabilidad son cruciales; la existencia de heterogeneidad estructural y asimetría en las respuestas implica que su inestabilidad tiende a acentuar la intensidad de la heterogeneidad.

Formalmente, algunos países de la región adoptaron un régimen de tipo de cambio libre, con intervenciones esporádicas o excepcionales en ciertos casos. La experiencia de la región muestra que el tipo de cambio real ha exhibido un comportamiento extremadamente procíclico: en la determinación del precio, se ha dado prioridad a la calidad del activo financiero; y el tipo de cambio real ha respondido con más intensidad a las variaciones de la balanza de pagos que a la cuenta corriente. Durante períodos prolongados, el tipo de cambio ha estado determinado por flujos de capitales de corto plazo, operados por especialistas en generar ganancias de capital, en vez de ganancias de productividad, o por variaciones reversibles de los términos de intercambio. Todo ello se mantenía sin tomar en consideración la desalineación de la cuenta corriente. Dado lo prolongado de los procesos de revaluación, que implican una volatilidad de mediano plazo, aparecen efectos estructurales

Véase, por ejemplo, Williamson (2008); Agosin (2007); Rodrik (2008); Eichengreen (2008); Ffrench-Davis (2010), y Ocampo (2011). 
en la asignación de recursos y en los pasivos de los agentes, por ejemplo, desaliento de la adición de valor a las exportaciones de recursos primarios $^{8}$ y productores que se endeudan en moneda extranjera durante los períodos de apreciación cambiaria.

Es cierto que el predominio del régimen de tipo de cambio libre de la década de 2000 evitó crisis cambiarias características de un tipo de cambio nominal fijo. Sin embargo, como contrapartida, la cotización de muchos países de la región pasó a ser extremadamente sensible a los cambios procíclicos de la oferta de fondos externos. De este modo, se incurrió en una contradicción profunda, con consecuencias negativas graves en la asignación de recursos y, en especial, para una acumulación favorable al crecimiento. Con las reformas liberalizadoras de las restricciones cuantitativas y arancelarias de las importaciones, se procuraba un papel protagónico para los rubros transables, lo que suponía que el tipo de cambio adquiriera un papel determinante en la competitividad internacional.

Se suele argumentar que las fluctuaciones cambiarias, tan intensas, se resuelven con operaciones de derivados, esto es, la compra o venta de futuros. Cuando el exportador puede acceder a ellos, son muy eficaces para asegurarse a corto plazo ante las fluctuaciones de los precios y las tasas de interés de las operaciones con la producción presente. Sin embargo, la realidad es que los precios de futuros son bastante similares a los precios de contado (precios spot), y tan fluctuantes unos como los otros. No resultan útiles para evitar los efectos distorsionadores de la inestabilidad a mediano plazo con respecto al desarrollo productivo, esto es, la inversión para aumentar la capacidad productiva.

En este contexto, suele aparecer una nueva asimetría. En los auges cíclicos, cuando las expectativas mejoran y los mercados de capitales se tornan más receptivos hacia los nuevos proyectos, lo que ha sucedido, generalmente, es que el tipo de cambio real se ha empezado a apreciar y se ha creado la expectativa de que se trataba de un proceso perdurable. Naturalmente, ello desalienta la inversión en la producción de rubros transables y la destinada a elevar su valor agregado, lo que no ha evitado que, en ocasiones, esa apreciación fuera bienvenida por las autoridades, en la medida en que las metas en materia de inflación tenían preeminencia sobre el desarrollo exportador, el crecimiento y el empleo sostenible; se trata de casos evidentes de intentar lograr las metas de inflación a expensas

Existen abundantes ejemplos en la literatura ortodoxa en los que se sostiene que el tipo de cambio flexible, libre de intervenciones regulares de la autoridad, es eficaz para enfrentar los riesgos de corto plazo de los períodos contractivos, ignorando masivamente la distorsión de los efectos asignativos de factores irreversibles que provoca durante los auges revaluatorios previos. Véase, por ejemplo, OCDE (2013, págs. 8, 15 y 16). 
del crecimiento. Al mismo tiempo, el volumen de las importaciones solía elevarse mucho más rápido que el de las exportaciones y se deterioraba la cuenta corriente estructural.

En la otra etapa del ciclo, en el período de contracción, predominan importantes devaluaciones cambiarias, lo que tiende a estimular la inversión en bienes transables. Sin embargo, la incertidumbre suele ser intensa y las entidades financieras generalmente restringen el financiamiento de nuevos proyectos. En consecuencia, en el mercado se desaprovechan las oportunidades que ofrece un tipo de cambio depreciado para aumentar la capacidad de producción de bienes transables. El resultado neto tras ambas etapas del ciclo es que la capacidad positiva de asignación del tipo de cambio se debilita y disminuye la producción de bienes transables y su valor agregado.

Evidentemente, la inestabilidad cambiaria distorsiona las evaluaciones de proyectos destinadas a asignar recursos, promueve la inversión especulativa en vez de la inversión productiva, desplaza artificialmente la producción nacional de bienes transables importables (muchos de ellos producidos por pymes) y desalienta que se añada valor agregado a las exportaciones.

Esta grave falla de la política cambiaria constituye un pesado lastre para llevar a cabo una estrategia de desarrollo centrada en las exportaciones, en particular las no tradicionales y con mayor valor agregado. Esas exportaciones son las más propensas a transmitir externalidades y a interactuar con las pymes. La adopción de alguno de los diversos regímenes de flexibilidad administrada del tipo de cambio es un componente esencial del conjunto de variables necesarias para ese logro.

Para ello es fundamental la intervención equilibradora, contracíclica de la autoridad económica, por ejemplo, mediante la compra o venta de moneda extranjera por el banco central, la regulación del nivel y la composición de los flujos, y la utilización de fondos de estabilización de los ingresos de las exportaciones. En las publicaciones de economía y los medios de comunicación, se afirma con frecuencia que cualquier intervención cambiaria implica ir contra "el mercado", y que los logros pretendidos siempre resultan derrotados por "el mercado". Dado que no existe un mercado único, sino diversos mercados, con actores notablemente diferentes, resulta esencial definir cuál es el mercado más pertinente para el logro del desarrollo. Se trata de que la evolución del tipo de cambio real esté acorde con sus fundamentos económicos (principalmente la tendencia de la cuenta corriente y de las productividades según los planteamientos de Balassa y Samuelson), en un mundo donde la moneda extranjera 
es, en parte, un activo financiero con una evolución frecuentemente desligada del desempeño de la cuenta corriente, hasta que los operadores se dan cuenta de que el tipo de cambio real está muy desalineado y lo realinean abruptamente.

Entonces, de lo que se trata, desde un enfoque funcional para el desarrollo, es de lograr que las fuerzas reales del mercado - los productores de exportables y los importadores y productores de importables, que son los actores clave para lograr el desarrollo productivo en lo que respecta a la relación con la economía internacional-, sean las que predominen en la determinación del tipo de cambio, guiada por la autoridad, que debería procurar una evolución sostenible de la cuenta corriente. Para ello, la autoridad puede recurrir a alguna de las variantes de flexibilidad administrada, adecuada a las particularidades de cada país (Williamson, 2008). Ese es "el mercado" que debe imponerse, el de los generadores de una mayor inversión productiva, innovación y productividad, y no el de los operadores a corto plazo y los buscadores de "rentas" (rent-seekers).

En este contexto, resulta fundamental la intervención coherente y selectiva de la cuenta de capitales por parte de la autoridad económica, en combinación con un conjunto de otras políticas macroeconómicas que aseguren la eficacia.

Sin esa regulación, dados los mercados financieros internacionales actuales, no hay espacio para aplicar una macroeconomía para el desarrollo efectiva, con el consiguiente costo tanto en términos de crecimiento económico como de fomento de una mayor igualdad en las estructuras productivas. En una economía en desarrollo, es una grave contradicción aspirar a lograr una economía de mercado eficiente y que las autoridades deleguen en operadores financieros la determinación de precios macroeconómicos tan estratégicos como el tipo de cambio real.

En síntesis, para guardar coherencia con una estrategia de desarrollo en la que la producción de bienes y servicios transables a nivel internacional desempeñe un papel central, hace falta una profunda corrección de la política cambiaria, para fortalecer su calidad como factor con capacidad de asignar recursos productivos e intensificar su vinculación (o los encadenamientos de la producción de transables) con el resto de la economía. Esa mayor vinculación con los segmentos de la economía que no exportan directamente puede contribuir a reducir la heterogeneidad estructural interna, lo que generaría condiciones más igualitarias en el ámbito laboral y entre los empresarios de diversos tamaños. 


\section{Empleos de calidad e inestabilidad de la economía real ${ }^{9}$}

La situación laboral, en particular en economías cuyo nivel de gasto social es modesto (como suelen ser las de América Latina que tienen cargas tributarias bajas), es la variable más determinante en la distribución del ingreso.

A pesar de los progresos logrados en cuanto a la reducción de la pobreza desde los años noventa, todavía no se ha logrado un avance perdurable en la situación laboral, en la que predominen empleos más estables, se disponga de protección social, y los trabajadores disfruten de condiciones de organización y capacidad de negociación. Independientemente de los avances significativos alcanzados durante la recuperación económica y social de 2004-2008, antes del contagio de la crisis financiera mundial todavía predominaba la precariedad laboral, que, naturalmente, se agravó con el contagio. En 2009, al detenerse bruscamente el período de auge, aumentó la pobreza y la precariedad laboral. En lugar de seguir dando paso a empleos más formales, la informalidad recuperó espacio. De 2007 a 2009-2010, aumentó la participación en el empleo de los trabajadores por cuenta propia, "involuntarios" en su mayoría (OIT, 2010, cuadro 2). La recuperación positiva experimentada a partir de 2010 retomó la senda de progreso del período 2004-2008. Ello permitió aumentar el empleo, la formalidad, los ingresos y el PIB efectivo, hasta topar con la limitada capacidad productiva disponible y tener que enfrentar el desafío de elevar la generación de nueva capacidad, ya que esta solo había mejorado levemente.

La generación de más empleo y de mejor calidad es determinante para lograr una reducción progresiva de las intensas desigualdades que se observan en los mercados y las sociedades. Por lo tanto, la política macroeconómica debería prestar una atención explícita a los efectos diferenciados de las diversas políticas en las empresas grandes y pequeñas, la inversión y el consumo, y los trabajadores calificados y de baja calificación. La gradualidad de las políticas y la calidad de la coordinación entre los aspectos monetarios, cambiarios, financieros y fiscales, por ejemplo, influyen sustancialmente en el crecimiento económico y sus efectos distributivos, sobre todo en el nivel y la calidad del empleo.

En la región persiste una brecha social considerable, pues la razón entre el quintil de ingresos más rico y el más pobre de los países

El impacto del entorno macroeconómico y la cuenta de capitales en el nivel y la calidad del empleo se examina en Ffrench-Davis (2012). 
de América Latina duplica con creces la del G7. Así pues, la región sigue siendo muy regresiva en el contexto mundial (Banco Mundial, 2005), lo que está asociado, de manera determinante, a las estructuras productivas. Cabe reiterar que la acusada heterogeneidad estructural entre empresas de diferentes dimensiones y entre trabajadores de distinta calificación implica la existencia de desigualdades en el correspondiente funcionamiento de los mercados ${ }^{10}$. Para crecer vigorosamente es necesario mejorar con mayor rapidez la productividad de los sectores de menores ingresos y, con ello, la empleabilidad de los sectores medios y pobres. En contraposición a la creencia más común del enfoque neoliberal, en la situación actual de América Latina existe un amplio grado de complementariedad entre diversas políticas que contribuirían simultáneamente al crecimiento y a la reducción de la desigualdad en el mercado laboral (Bourguignon y Walton, 2007; Ffrench-Davis, 2014, cap. VII).

La inestabilidad de la demanda interna y del tipo de cambio produce efectos estáticos y dinámicos en el empleo. Un ejemplo de efectos estáticos son los altibajos en la tasa de utilización de la capacidad productiva disponible de trabajo y capital, que, al provocar recurrentemente brechas sustantivas entre la capacidad instalada y el PIB efectivo, generan a su vez brechas entre el pleno empleo y el empleo efectivo. Esas brechas recesivas y la volatilidad de variables tales como el tipo de cambio real han provocado profundos efectos dinámicos, como se ha expuesto arriba, i) en la expansión del acervo de capital nacional, que disminuye, en tanto que la fuerza de trabajo potencial, inexorablemente, sigue elevándose; además, se debilitan las organizaciones laborales y, en situaciones de desempleo creciente, se intensifica la discriminación contra los trabajadores de menor calificación y los empresarios de menor tamaño; ii) en la intensidad del valor agregado que se incorpora a las exportaciones y su interrelación con el resto de la producción interna; iii) en el desarrollo de las pymes, que suelen ser más intensivas en el uso del trabajo y que compiten con las importaciones, y iv) en la formalidad o precariedad del mercado laboral.

Uno de los vínculos que existen entre la inestabilidad de la macroeconomía real y la desigualdad estriba en la extensa heterogeneidad estructural que caracteriza a las economías en desarrollo. Dada la fuerza que aún tiene el enfoque neoliberal, que incluye la idea de la homogeneidad y la "neutralidad" de las políticas al formular las políticas públicas, es fundamental comprender e internalizar la diversa capacidad de acción y

10 Véase un análisis y antecedentes empíricos sobre el intenso grado de heterogeneidad estructural actual en las economías de América Latina y sus implicancias distributivas en Infante (2011). Véase información al respecto sobre Chile en Sunkel (2011). 
reacción de los agentes típicos en distintos mercados. Por lo tanto, hay que tener en cuenta la heterogeneidad entre grandes y pequeños empresarios, trabajadores de alta y de reducida calificación, inversionistas productivos e inversionistas financieros o compradores de activos, e inversionistas productivos y consumidores, así como la elevada movilidad nacional e internacional de los capitales financieros y del trabajo muy calificado, que contrasta con la escasa movilidad del capital físico y de la mano de obra de menor calificación.

Las asimetrías resultantes de esa heterogeneidad se intensifican en situaciones de inestabilidad de la actividad económica y los precios macroeconómicos. Por ejemplo, la distribución del ingreso suele deteriorarse en las recesiones y mejorar en las recuperaciones, pero de manera más gradual en estas que en aquellas, asimetría que provoca efectos regresivos en los balances de los hogares y las empresas. Por otra parte, los esfuerzos que se dedican a las reformas económicas que requieren continuidad y una perspectiva de largo plazo se debilitan. Además, en los períodos de auge de flujos financieros, una parte sustancial se consume, ya que el consumo responde más rápidamente que la inversión productiva cuando hay una oferta de fondos mayor, y el mercado financiero se ha especializado más en financiar el consumo o la compra de activos existentes que en el financiamiento de largo plazo de la inversión productiva. Si ello se acompaña, como ha sido frecuente, de apreciaciones cambiarias, el sesgo se acentúa debido a las crecientes importaciones de bienes de consumo, lo que desvía el "ahorro externo" hacia el "desahorro" nacional.

Así pues, después de un período de auge, quedan elevados pasivos sin una contrapartida de capacidad de pago. El habitual cambio de expectativas, la reversión de los flujos y las devaluaciones abruptas conducen a un ajuste recesivo, con caídas de la demanda interna. A su vez, esta arrastra a la baja a la producción, el empleo y su formalidad y, por lo tanto, los ingresos tributarios. En los últimos años, esta ha sido la dinámica de la región, con una tasa de formación bruta de capital todavía reducida (a pesar de los notables precios de exportación y del ingreso de capitales extranjeros) y un desequilibrio creciente entre el volumen de las exportaciones y las importaciones (véanse el recuadro IV.2 y el gráfico IV.3). Cabe añadir asimismo la débil institucionalidad de la protección social para transferir ingresos en casos de crisis, con un carácter contracíclico y progresivo, ya sea en materia de reinserción, capacitación o compensación de las pérdidas de ingresos (OIT/CEPAL, 2011). 


\section{Recuadro IV.2}

\section{Coyuntura actual de América Latina}

- En 2010-2012, período coyuntural positivo, tras uno similar en 2004-2008, la región se situó en el techo o PIB potencial. El tope en el techo explica el freno del crecimiento del PIB efectivo en 2012.

- Choques de términos de intercambio y financieros elevaron la demanda interna, en un entorno inicial dominado por la restricción externa en 2003. Por ello, tuvieron un fuerte efecto reactivador del PIB, arrastrando a la economía real hasta el techo (positivo) y apreciando el tipo de cambio (negativo). No hay cambio estructural o macroeconómico radical que explique el salto en el crecimiento del PIB; sí lo hacen los choques externos positivos por su efecto sobre el uso de la capacidad disponible.

- Las exportaciones continuaron muy concentradas en los recursos naturales, que tienen bajo valor agregado y precios cíclicamente inestables. En esta época de precios altos, el volumen de las importaciones crece notablemente más rápido que el de las exportaciones.

- La formación bruta de capital se ha elevado y ha alcanzado su mayor nivel desde el Consenso de Washington. Este elemento es muy positivo y se debe al cierre de la brecha recesiva. Sin embargo, la tasa de formación bruta de capital aún es inferior al promedio del decenio anterior a la crisis de la deuda, y el ahorro nacional se ha debilitado (controlando debidamente por el efecto de la relación de intercambio). La región está dependiendo, riesgosamente, de términos de intercambio comercial y flujos financieros transitoriamente muy favorables.

Fuente: Elaboración propia, sobre la base de cifras de la Comisión Económica para América Latina $y$ el Caribe (CEPAL).

Como ya se ha expuesto, la evolución tan cíclica del tipo de cambio real en muchos países ha distorsionado las decisiones en materia de inversión productiva. Durante los auges acompañados de apreciación cambiaria, se suelen generar excesos en la construcción suntuaria y en la comercialización de importaciones, que proveen empleos que no serán sostenibles cuando se corrija un déficit externo que se tornará cada vez más excesivo. Por otra parte, se desplaza artificialmente la producción de bienes transables importables que compiten con las importaciones (muchos de ellos producidos por pymes). Al mismo tiempo, se desalienta la diversificación hacia rubros no tradicionales con un mayor valor agregado y la adición de valor a las exportaciones tradicionales, lo que afecta negativamente al empleo sostenible y su calidad. Así pues, en los períodos de auge, una parte de la creación de empleo es transitoria y, además, se provoca cierta destrucción de empleo permanente.

La inestabilidad de la economía real es asimétrica en lo distributivo e, inevitablemente, implica una subutilización de la productividad potencial, con una producción efectiva y un nivel de empleo menores, así como la expansión del sector informal, en comparación con contextos de mayor 
estabilidad de la economía real. Resulta evidente que tasas más altas de utilización del capital suelen implicar que el nivel medio del empleo sea superior y que la fuerza laboral se combine con un volumen más elevado de capital físico en uso. El consiguiente aumento de la productividad efectiva significa que el bienestar de los trabajadores y los inversionistas (salarios y utilidades del capital) puede mejorar, en virtud de una mayor utilización de la capacidad y del fomento de un círculo virtuoso de mayor inversión, innovación y empleo. Esa es la misión de las políticas macroeconómicas, que deben complementarse con políticas de desarrollo productivo, capacitación y reforma incluyente del mercado de capitales.

En resumen, los profundos ciclos que experimenta la actividad económica, debido a la inestabilidad de la demanda agregada y del tipo de cambio, afectan al nivel de empleo, su formalidad, la naturaleza de los contratos laborales y la evolución de los salarios. La inestabilidad de la macroeconomía real, dada la heterogeneidad estructural vigente en los mercados de la región, tiene un efecto netamente regresivo en la distribución del ingreso y la calidad de los empleos.

\section{Conclusiones}

El entorno macroeconómico provoca diversos efectos en el desarrollo. Entre ellos figuran los efectos: i) en la tasa de inversión; ii) en la intensidad del valor agregado que se genera en las exportaciones y su interrelación con el resto del PIB; iii) en la innovación y su distribución entre distintos sectores de la economía; iv) en el desarrollo de las pymes; v) en la formalidad o precariedad del mercado laboral, y vi) en el presupuesto fiscal. El estilo de las políticas macroeconómicas incide significativamente en todas esas variables.

Los inversionistas productivos y el empleo han estado sujetos a una gran inestabilidad de la macroeconomía real, con elevadas brechas recesivas, en un mercado financiero notoriamente incompleto, sobre todo en el caso del financiamiento de las empresas de menor tamaño. A su vez, la inestabilidad de la economía real ha estado estrechamente asociada a los ciclos de los flujos financieros con el exterior, que, además de exhibir una alta volatilidad procíclica, también tienen una escasa conexión con la inversión productiva. Ha predominado lo que llamamos financierismo en vez del productivismo (Ffrench-Davis, 2010). El motivo principal de ello es la existencia de un mercado financiero internacional dominado por agentes especializados en el corto plazo, cuyo comportamiento suele ser intrínsecamente procíclico y circular al margen del financiamiento de la inversión productiva. Esa deficiencia se agrava por el hecho de que su volatilidad ha provocado crisis financieras y cambiarias en las 
economías emergentes receptoras de esos flujos, cuyos efectos recesivos han desalentado la formación de capital y el empleo. La creciente integración con los mercados financieros internacionales más volátiles, que suele implicar la apertura indiscriminada de la cuenta de capitales, ha favorecido una profundización de la inestabilidad, con un mayor grado de superficialidad del financiamiento. No puede ignorarse un hecho tan evidente como el gran incremento del ahorro financiero y la persistencia de tasas de inversión productiva que todavía son bajas y concentradas.

Como las fluctuaciones no son simétricas alrededor del pleno empleo, sino asimétricas, con un definido sesgo depresor y regresivo, por lo general, las economías de la región han tenido niveles medios de actividad bastante inferiores al pleno empleo, esto es, con considerables brechas recesivas. Ello acarrea un desaliento decisivo a la inversión productiva y un sesgo regresivo, o de inequidad, debido a su impacto negativo en la calidad del empleo y en las empresas más pequeñas. En la medida en que se logre cierta estabilidad de la economía real, y se reduzcan por lo tanto las brechas recesivas, se contribuirá a elevar la formación de capital, el empleo sostenible y el PIB potencial. Estos efectos no son neutros distributivamente, dada la heterogeneidad estructural prevaleciente, pues la existencia de la brecha suele implicar efectos negativos particularmente graves para las pymes, los trabajadores de menor calificación, los sectores informales y aquellos con menor patrimonio en general. La heterogeneidad en cuanto al acceso al financiamiento refuerza las desigualdades en materia de capacidad productiva, en un círculo vicioso que condena a las unidades productivas de menor capital a la vulnerabilidad y a la dificultad para crecer, con el consiguiente aumento de las brechas de ingresos dada la inestabilidad de la macroeconomía real; el sesgo recesivo es también regresivo. Por lo tanto, se trata de formular políticas que permitan potenciar y mantener el ciclo expansivo, evitando las vulnerabilidades que, en cada período de auge, han dado lugar a nuevos ajustes recesivos.

Una reforma de las reformas neoliberales debe priorizar la vinculación del sistema financiero (tanto del mercado financiero nacional como de la cuenta de capitales) al proceso de inversión interna, más que a los mercados financieros externos de corto plazo y especulativos. Resulta imprescindible contribuir a la estabilidad de la demanda interna y de los precios macroeconómicos, como el tipo de cambio.

El desafío de una macroeconomía para el desarrollo es diseñar un conjunto de instrumentos, determinando su dosificación (sobre todo en materia de políticas fiscal, monetaria, cambiaria, del sistema financiero nacional y de la cuenta de capitales), que tenga en cuenta la interrelación entre el corto y el largo plazo, concilie la estabilidad de la economía real con un mayor dinamismo en el crecimiento a largo plazo y contribuya 
a la inclusión social. Para ello es necesario un conjunto de políticas ineludiblemente armonizadas entre sí. No hay lugar para autonomías que entren en contradicción con la coordinación, ni para el predominio de un objetivo a expensas de otros. Es preciso establecer: i) una política fiscal y tributaria que guarde coherencia con el financiamiento del programa de desarrollo social, la inversión pública y las políticas de desarrollo productivo; ii) una demanda agregada que se sitúe a niveles coherentes con el PIB de pleno empleo, y iii) un tipo de cambio sostenible a lo largo del tiempo, en concordancia con el balance de la cuenta corriente. Estas son condiciones básicas de los equilibrios macroeconómicos de la economía real.

En el contexto internacional actual y previsible, para que estas políticas sean viables es necesaria la regulación contracíclica de la cuenta de capitales y el establecimiento de mecanismos estabilizadores de los ingresos de las exportaciones, ya que sus precios son marcadamente cíclicos. La regulación contracíclica de los ingresos y egresos de la cuenta de capitales debe procurar lograr equilibrios sostenibles de la macroeconomía real, es decir, lo opuesto a pretender perpetuar los desequilibrios ${ }^{11}$.

En economías emergentes, como las de los países de América Latina, una regulación contracíclica de la cuenta de capitales, eficaz y eficiente, crearía espacio para aplicar unas políticas monetaria y cambiaria activas y reorganizar el sistema financiero local, a fin de canalizar recursos hacia la inversión productiva, con un sesgo inclusivo, contribuyendo a reducir la heterogeneidad estructural entre los distintos sectores productivos y sociales. Además, la regulación de los flujos de capitales permitiría que hubiera margen para llevar adelante políticas cambiarias y monetarias simultáneamente contracíclicas. Por consiguiente, esa regulación resulta una condición imprescindible para avanzar hacia una macroeconomía para el desarrollo (Ocampo, 2011).

En definitiva, la gradualidad y el alcance integral de la política macroeconómica permitirían que contribuya a reducir la heterogeneidad estructural y su incidencia regresiva, disminuyendo así las desigualdades en materia de ingresos que se generan en los diversos mercados.

Para crecer vigorosamente, es necesario mejorar la productividad de los sectores medios y pobres, dado que se reconoce cada día más que la desigualdad y la pobreza constituyen un lastre para el desarrollo

11 Hay experiencias de controles procíclicos o que intentan perpetuar desequilibrios insostenibles. En contraste, varios países de América Latina han efectuado interesantes esfuerzos de regulación contracíclica (véase, por ejemplo, CEPAL (2010)). Entre ellos destaca la exitosa experiencia de Chile en el primer quinquenio de los años noventa, que ilustra la eficacia que pueden alcanzar las regulaciones contracíclicas de la cuenta de capitales en materia de desarrollo cuando son coherentes e integrales (véanse Ffrench-Davis (2014, cap. VIII) y Magud y Reinhart (2007)). 
económico (Bourguignon y Walton, 2007). Para ello, ocupa un lugar estratégico el diseño de un sistema financiero que contribuya a reducir la gran heterogeneidad estructural de las economías de la región. Esto implica desarrollar vigorosamente el financiamiento de las pymes en diferentes escalas y ámbitos institucionales. La parcialidad (incompletitud) de los actuales mercados de capitales ha sido una barrera infranqueable para que muchas pymes pudieran dar un salto en su desarrollo.

La manera en la que se aborde la reforma de los mercados de capitales nacionales y la conexión con los mercados financieros internacionales representa un desafío crucial para lograr, de manera sostenida, una macroeconomía para el desarrollo y la disminución de la heterogeneidad estructural, con la desigualdad que implica. Es necesario ir generando estructuras productivas que, progresivamente, favorezcan mercados más equitativos, debido a que se van reduciendo las brechas de productividad y de ingresos entre las empresas de diversos tamaños y los trabajadores de diferente origen social y capacitación, gracias a la progresiva disminución de la heterogeneidad estructural. 


\section{Bibliografía}

Agosin, M. R. (2007), "Trade and growth: Why Asia grows faster than in Latin America", Economic Growth with Equity: Challenges for Latin America, R. FfrenchDavis y J.L. Machinea (eds.), Nueva York, Palgrave Macmillan.

Banco Mundial (2005), World Development Report 2006: Equity and Development, Nueva York, Oxford University Press.

Blanchard, O., G. Dell'Ariccia y P. Mauro (2010), "Rethinking macroeconomic policy", IMF Staff Position Note, SPN/10/03, Washington, D.C., Fondo Monetario Internacional, febrero.

Bourguignon, F. y M. Walton (2007), "Is greater equity necessary for higher longterm growth in Latin America?", Economic Growth with Equity; Challenges for Latin America, R. Ffrench-Davis y J.L. Machinea (eds.), Nueva York, Palgrave Macmillan.

CEPAL (Comisión Económica para América Latina y el Caribe) (2010), La hora de la igualdad: brechas por cerrar, caminos por abrir (LC/G.2432(SES.33/3)), Santiago de Chile.

(2012), Cambio estructural para la igualdad: una visión integrada del desarrollo (LC/G.2524(SES.34/3)), Santiago de Chile.

(2013a), Estudio Económico de América Latina y el Caribe 2013 (LC/G.2574-P), Santiago de Chile.

(2013b), Panorama Social de América Latina, 2013 (LC/G.2580), Santiago de Chile.

Easterly, W. y L. Servén (2003), The Limits of Stabilization: Infrastructure, Public Deficits and Growth in Latin America, Stanford, Stanford University Press.

Eichengreen, B. (2008), "The real exchange rate and economic growth", Working Paper $N^{\circ}$ 4, Washington, D.C., Commission on Growth and Development.

Erten, B. y J.A. Ocampo (2012), "Supercycles of commodity prices since the midnineteenth century", World Development, vol. 44.

Ffrench-Davis, R. (2014), Chile entre el neoliberalismo y el crecimiento con equidad, Santiago de Chile, JCSáez Editor, quinta edición.

(2012), "Empleos de calidad y estabilidad macroeconómica real: el rol regresivo de los flujos financieros", Revista Internacional del Trabajo, Ginebra, Organización Internacional del Trabajo (OIT).

(2010), "Macroeconomía para el desarrollo: desde el financierismo al productivismo", Revista CEPAL, N 102 (LC/G.2468-P/E), Santiago de Chile, Comisión Económica para América Latina y el Caribe (CEPAL), diciembre. (2005), Reformas para América Latina: Después del fundamentalismo neoliberal, Buenos Aires, Comisión Económica para América Latina y el Caribe (CEPAL)/ Siglo XXI Editores.

(1988), "Esbozo de un planteamiento neoestructuralista", Revista de la CEPAL No 34, Santiago de Chile, Comisión Económica para América Latina y el Caribe (CEPAL), abril.

Gallagher, K., S. Griffith-Jones y J.A. Ocampo (eds.) (2012), Regulating Global Capital Flows for Long-run Development, Boston, Universidad de Boston.

Hofman, A. y H. Tapia (2003), "Potential output in Latin America: a standard approach for the 1950-2000 period", serie Estudios Estadísticos y Prospectivos, No 25 (LC/L.2042-P), Santiago de Chile, Comisión Económica para América Latina y el Caribe (CEPAL). 
Infante, R. (2011) (coord.), Desarrollo inclusivo en América Latina y el Caribe. Ensayos sobre politicas de convergencia productiva para la igualdad, Libros de la CEPAL, No 112 (LC/G.2500-P), Santiago de Chile, Comisión Económica para América Latina y el Caribe (CEPAL). Publicación de las Naciones Unidas, $\mathrm{N}^{\mathrm{o}}$ de venta: S.11.II.G.56.

Kaminsky, G., C. Reinhart y C. Vegh (2004), "When it rains, it pours: procyclical capital flows and macroeconomic policies", NBER Working Paper, $\mathrm{N}^{\mathrm{o}} 10780$, enero.

Krugman, P. (2011), "How did economists get it so wrong?", New York Times, 6 de septiembre.

Magud, R. y C. Reinhart (2007), "Capital controls: an evaluation", Capital Controls and Capital Flows in Emerging Economies: policies, practices and consequences, S. Edwards (ed.), Chicago, University of Chicago Press.

Ocampo, J. A. (2011), "Macroeconomía para el desarrollo: políticas anticíclicas y transformación productiva", Revista CEPAL, No 104 (LC/G.2498-P/E), Santiago de Chile, Comisión Económica para América Latina y el Caribe (CEPAL), agosto.

Ocampo, J.A. y J. Ros (2011), (eds.), The Oxford Handbook of Latin American Economics, Nueva York, Oxford University Press.

OCDE (Organización de Cooperación y Desarrollo Económicos) (2013), OECD Economic Surveys: CHILE, París.

OIT (Organización Internacional del Trabajo) (2010), Panorama Laboral 2010, América Latina y el Caribe, Lima.

OIT/CEPAL (Organización Internacional del Trabajo/ Comisión Económica para América Latina y el Caribe) (2011), "Políticas contracíclicas para una recuperación sostenida del empleo", Coyuntura laboral en América Latina y el Caribe, Boletín, $\mathrm{N}^{\mathrm{o}}$ 5, Santiago de Chile, junio.

Ostry, J. y otros (2011), "Managing capital inflows: What tools to use?", IMF Staff Discussion Note, No 11-06, Washington, D.C., Fondo Monetario Internacional.

Rajan, R. (2011), Fault Lines: how hidden fractures still threaten the world economy, Princeton, Princeton University Press.

Rodrik, D. (2011), The Globalization Paradox, Nueva York, W.W. Norton. (2008), "The real exchange rate and economic growth", Brookings Papers on Economic Activity, Washington, D.C., Brookings Institution Press.

Sunkel, O. (2011), El presente como historia, Catalonia, Santiago.

Tapia, H. y J.C. Guataqui (2013), "Políticas económicas para el crecimiento", Santiago de Chile, Comisión Económica para América Latina y el Caribe (CEPAL), inédito.

Williamson, J. (2008), “Do development considerations matter for exchange rate policy?", Current Account and External Financing, K. Cowan y S. Edwards (eds.), Santiago de Chile, Banco Central de Chile.

(2003), "Overview: an agenda for restarting growth and reform", After the Washington Consensus: Restarting Growth and Reform in Latin America, P.P Kuczynski y J. Williamson, Institute of International Economics. 
Capítulo V

\section{Macroeconomía para el desarrollo en América Latina y el Caribe: nuevas consideraciones sobre las políticas anticíclicas}

\section{Introducción}

La macroeconomía para el desarrollo en América Latina y el Caribe suele articularse en torno a dos cuestiones: una estrategia activa de desarrollo productivo y diversificación, y una orientación anticíclica de las políticas (Ocampo, 2011; Ffrench-Davis, 2010).

La estrategia del desarrollo productivo tiene como meta, entre otras cosas, aumentar la productividad, fomentar la innovación para dar impulso a la acumulación de capacidad tecnológica y potenciar las oportunidades de la región de exportar bienes y servicios de mayor valor añadido. Por su parte, las políticas anticíclicas son necesarias para

Los autores expresan su agradecimiento a Pablo Carvallo y Manuel Cruz por su valiosa ayuda en la investigación. También agradecen los comentarios que han recibido sobre una versión anterior de este documento, presentada en el Seminario Neoestructuralismo y Economía Heterodoxa (22 y 23 de abril de 2013). 
reducir la acentuada volatilidad macroeconómica que ha caracterizado el desempeño de la región en los tres últimos decenios.

El presente documento se centra en el tema de la macroeconomía anticíclica. Desde la perspectiva del modelo de referencia de la macroeconomía para el desarrollo, la volatilidad es perniciosa para el crecimiento a largo plazo. Hace que se reduzca el horizonte de planificación de los agentes y que aumente el riesgo, desalienta la inversión productiva y distorsiona los precios macroeconómicos, por ejemplo, los tipos de cambio y las tasas de interés reales ${ }^{2}$.

El aumento de la volatilidad se asocia sobre todo con los choques externos de la cuenta de capital y, más recientemente, de los términos de intercambio. Esta dominancia de la balanza de pagos se ha dado en un contexto de mayor apertura financiera, en que los países de la región son vulnerables a los cambios que se operan en las formas y la disponibilidad del financiamiento externo, las fluctuaciones de las tasas de interés (las reducciones de los márgenes de riesgo se acentúan durante los períodos de auge) y los precios determinados por factores externos.

La disminución de la volatilidad equivale a reducir y estabilizar las fluctuaciones de las variables reales y monetarias en torno a sus tendencias a largo plazo. A su vez, esto entraña la necesidad de manejar el nivel de la demanda agregada, mediante políticas monetarias, fiscales y de gestión de las cuentas de capital, para contenerla en la fase ascendente del ciclo y ampliarla en la fase descendente. En la etapa de expansión, las políticas anticíclicas tienen el objetivo de evitar situaciones de gasto interno excesivo y de recalentamiento que se manifiestan en niveles insostenibles de deuda, presiones inflacionarias o desequilibrios en cuenta corriente. A la inversa, durante las contracciones, la expansión de la demanda agregada hace que disminuyan los costos relacionados con los altos niveles de desempleo y vulnerabilidad social.

En este trabajo se argumenta que aunque la volatilidad nominal se ha reducido, la volatilidad real se ha mantenido en niveles elevados y que esto no solo responde al predominio de la balanza de pagos sino a características concretas del ciclo económico de la región. En particular, se demuestra que América Latina y el Caribe registra expansiones menos intensas, en cuanto a duración y alcance, que las de otras regiones $\mathrm{y}$, como resultado, presenta comparativamente un ciclo de mayor frecuencia.

Ffrench-Davis (2010) afirma que la volatilidad influye en el crecimiento económico a largo plazo debido a su efecto sobre la inversión en capital fijo. 
Otra característica fundamental del ciclo que se destaca es que las fluctuaciones a corto plazo tienen su efecto en los resultados a largo plazo y que la relación entre el corto y el largo plazo está determinada por variables reales y financieras. Por una parte, el comportamiento cíclico de las variables reales (productividad e inversión) vinculadas con el desempeño del crecimiento a largo plazo imita la débil fase de expansión del ciclo económico general. Por otra, el comportamiento de los ciclos crediticios demuestra que el sistema financiero actúa como amplificador de las fluctuaciones del PIB durante las expansiones y, en específico, durante las contracciones.

Otro rasgo particular observado en el ciclo económico de América Latina es que las contracciones crediticias duran más que las del PIB. De ello se desprende que el PIB se recupera antes que el crédito y que las fluctuaciones del crédito tienden a ir a la zaga de las del PIB. Las recuperaciones sin reactivación del crédito, junto al comportamiento de las variables reales como la productividad y la inversión, pueden explicar la naturaleza débil de la fase expansiva del ciclo en América Latina.

$\mathrm{Al}$ analizar en conjunto tales datos estilizados de los ciclos, en el presente trabajo se afirma que los conocimientos heredados sobre la macroeconomía para el desarrollo deben desarrollarse más y hacerse explícita la interdependencia entre el ciclo y la tendencia y entre las políticas anticíclicas y la estructura productiva ${ }^{3}$.

Más precisamente, una política anticíclica eficaz debería centrarse en el comportamiento de las variables reales y financieras que vinculan las fluctuaciones a corto plazo con los resultados a largo plazo.

Este análisis tiene dos implicaciones importantes desde el punto de vista de las políticas. En primer lugar, una macroeconomía para el desarrollo debidamente configurada no debería plantear una dicotomía entre las políticas anticíclicas y las de desarrollo productivo, sino que la interrelación entre ambas debería constituir su punto de partida. En segundo lugar, las políticas anticíclicas no deberían centrarse solo en manejar el nivel de la demanda agregada, sino también en afectar su composición.

La interdependencia entre el ciclo y la tendencia fue señalada por primera vez por Kalecki (1968). Véanse además Davidson (2011) y Arestis y Sawyer (2009). Ocampo (2011) y FfrenchDavis (2010) también han analizado las relaciones entre las condiciones macroeconómicas y la estructura productiva, centrándose en el comportamiento de los macroprecios, incluido en especial el tipo de cambio real, que se considera una "variable de trasmisión" clave en las economías de mercado emergentes como las de América Latina y el Caribe. Otro canal de trasmisión es la magnitud de la brecha entre la demanda real y la frontera productiva (FfrenchDavis, 2010). Una mayor utilización de la capacidad (una brecha menor) puede contribuir a un aumento de la productividad media, que a su vez estimularía la creación de nueva capacidad. A la inversa, una brecha recesiva puede implicar una inversión menor, lo que tendría el efecto de deprimir la capacidad productiva de una economía. 
El presente estudio se divide en siete secciones. En las secciones A y B se ofrecen pruebas empíricas que corroboran las dos principales propuestas de la macroeconomía para el desarrollo en relación con América Latina y el Caribe. Una es que la región se ha distinguido por elevados niveles de volatilidad en comparación con sus propios antecedentes y con otras regiones en desarrollo y que la volatilidad se explica por el predominio de la balanza de pagos. En la sección C se afirma que los altos niveles de volatilidad y el exiguo desempeño del crecimiento pueden explicarse también por las características específicas del ciclo económico de América Latina y el Caribe. Las secciones D y E se centran en el mecanismo de trasmisión real y financiero entre el ciclo y la tendencia. En la sección F se examinan las políticas anticíclicas en el contexto del modelo de referencia de la macroeconomía para el desarrollo y se proponen formas de modificarlo. En la última sección se encuentran las consideraciones finales.

\section{A. El desempeño a largo plazo de América Latina: alta volatilidad y bajo crecimiento}

Durante los tres últimos decenios el desempeño de América Latina y el Caribe se ha caracterizado por un creciente nivel de volatilidad en lo que se refiere al comportamiento de la producción y la inversión ${ }^{4}$. Como se muestra a continuación en el cuadro V.1, la volatilidad de la producción medida a partir del coeficiente de variación del PIB, que estuvo por debajo de 1 en las décadas de 1960 y 1970, ha excedido sistemáticamente dicho umbral desde los años ochenta.

En cambio, la volatilidad nominal disminuyó significativamente. La región logró grandes avances en materia de inflación, tanto en lo que se refiere al nivel como a la volatilidad. Entre 1980 y 1989 la inflación promedio se situó en torno al 130\%. Los niveles más elevados se registraron en los países de América del Sur, donde la inflación promedio fue del $270 \%$. El istmo centroamericano registró tasas de inflación significativamente menores con una aceleración inflacionaria entre 1985 y 1989 cercana al 122\%. Hacia la segunda mitad de la década de 1990 la región anotó en promedio una inflación cercana al 14\%, siendo esta mucho más baja en los países del Caribe y el istmo centroamericano. La tendencia a la baja de las tasas de inflación se ha mantenido en el tiempo y entre 2000 y 2012 se situó en un promedio cercano al 6\%. Junto con la disminución de la tasa de inflación, se logró una significativa reducción de la volatilidad de la trayectoria del nivel de precios. No obstante la importancia de este quiebre estructural en la trayectoria de la tasa de inflación, hay que añadir que la reducción de la inflación y de su volatilidad fue un fenómeno regional generalizado. De manera más precisa, la reducción del nivel de la inflación y de su volatilidad se logró con independencia del régimen monetario particular de cada país y de su nivel de inflación inicial. En el período comprendido entre 1982 y 1990, todos los países de América Latina —a excepción de Haití, Honduras y Panamá— tenían tasas de inflación superiores a un dígito. A partir de 1997, la mayoría de los países logró reducir sus tasas de inflación de dos a un dígito. 
Cuadro V.1

Regiones y agrupaciones seleccionadas: coeficiente de variación de la tasa de crecimiento del PIB per cápita, 1960-2011 ${ }^{\text {a }}$

\begin{tabular}{lrrrrrc}
\hline Región o agrupación & $1960-$ & $1970-$ & $1980-$ & $1990-$ & $2000-$ & $2000-$ \\
& 1970 & 1980 & 1990 & 2000 & 2007 & 2011 \\
\hline Asia Oriental y el Pacífico & 2,92 & 0,53 & 0,27 & 0,40 & 0,23 & 0,20 \\
\hline Europa y Asia Central & $\ldots$ & $\ldots$ & $\ldots$ & $-3,17$ & 0,33 & 0,83 \\
\hline América Latina y el Caribe ${ }^{\mathrm{b}}$ & $\mathbf{0 , 7 1}$ & $\mathbf{0 , 3 9}$ & $\mathbf{- 6 , 7 7}$ & $\mathbf{1 , 3 9}$ & $\mathbf{1 , 1 7}$ & $\mathbf{1 , 2 2}$ \\
\hline Oriente Medio y África del Norte & 0,65 & 1,77 & $-15,76$ & 0,88 & 0,54 & 0,47 \\
\hline Asia Meridional & 1,25 & 3,72 & 0,43 & 0,50 & 0,45 & 0,43 \\
\hline África Subsahariana & 0,84 & 1,81 & $-1,98$ & $-3,81$ & 0,58 & 0,62 \\
\hline Mundo & 0,34 & 0,95 & 0,96 & 0,64 & 0,50 & 1,26 \\
\hline $\begin{array}{l}\text { Países de ingresos altos } \\
\begin{array}{l}\text { Organización de Cooperación y } \\
\text { Desarrollo Económicos (OCDE)) }\end{array}\end{array}$ & 0,32 & 0,81 & 0,60 & 0,46 & 0,44 & 1,90 \\
\hline América del Norte & 0,70 & 1,30 & 1,27 & 0,78 & 0,58 & 2,27 \\
\hline
\end{tabular}

Fuente: Elaboración propia sobre la base de Banco Mundial, World Development Indicators y Global Finance, 2013.

El coeficiente de variación es igual a la relación entre la desviación típica $(\sigma)$ de la tasa de crecimiento del PIB per cápita y su media $(x)$. El período 2007-2011 no se incluyó para evitar que el efecto de la crisis mundial (2008-2009) que impactó a América Latina y el Caribe en 2009 (la tasa de crecimiento del PIB se contrajo un 1,9\%) sesgara el promedio de dicho período, ya que el objetivo es mostrar un comportamiento tendencial de la tasa de crecimiento del PIB. Los puntos suspensivos indican que no se dispone de datos.

b La muestra incluye a los 33 países de la región.

Además, con el transcurso del tiempo, no solo ha aumentado la volatilidad, sino que América Latina y el Caribe ha experimentado niveles más altos de volatilidad en comparación con otras regiones del mundo en desarrollo (Titelman, Pérez Caldentey y Mincer, 2008; CEPAL, 2002 y 2012).

El comportamiento de la volatilidad de América Latina y el Caribe contrasta marcadamente con el de otras regiones del mundo que han registrado un declive en la volatilidad a lo largo de todo el período objeto de examen. Un caso emblemático es el de Asia Oriental y el Pacífico, que registró un coeficiente de variación de 2,9 entre 1960 y 1970 y de 0,22 en la década de 2000. De modo similar, África y el Oriente Medio experimentaron un coeficiente por encima de 1 entre 1970 y 1980 y por debajo de 1 en las décadas de 1990 y 2000. Asia Meridional también refleja una tendencia similar.

El aumento de la volatilidad real ha sido perjudicial tanto a corto como a largo plazo. Las pruebas disponibles respecto del período 1971-2008 indican que la volatilidad de la tasa de crecimiento del PIB y la de la inversión presentan una relación inversa. Los respectivos coeficientes de correlación son negativos y significativos, con un nivel de confiabilidad del $95 \%(-0,70$ y $-0,73)$. 


\section{Gráfico V.1}

América Latina (20 países): relación entre la volatilidad de la inversión y la tasa de crecimiento del PIB, 1971-2008 ab
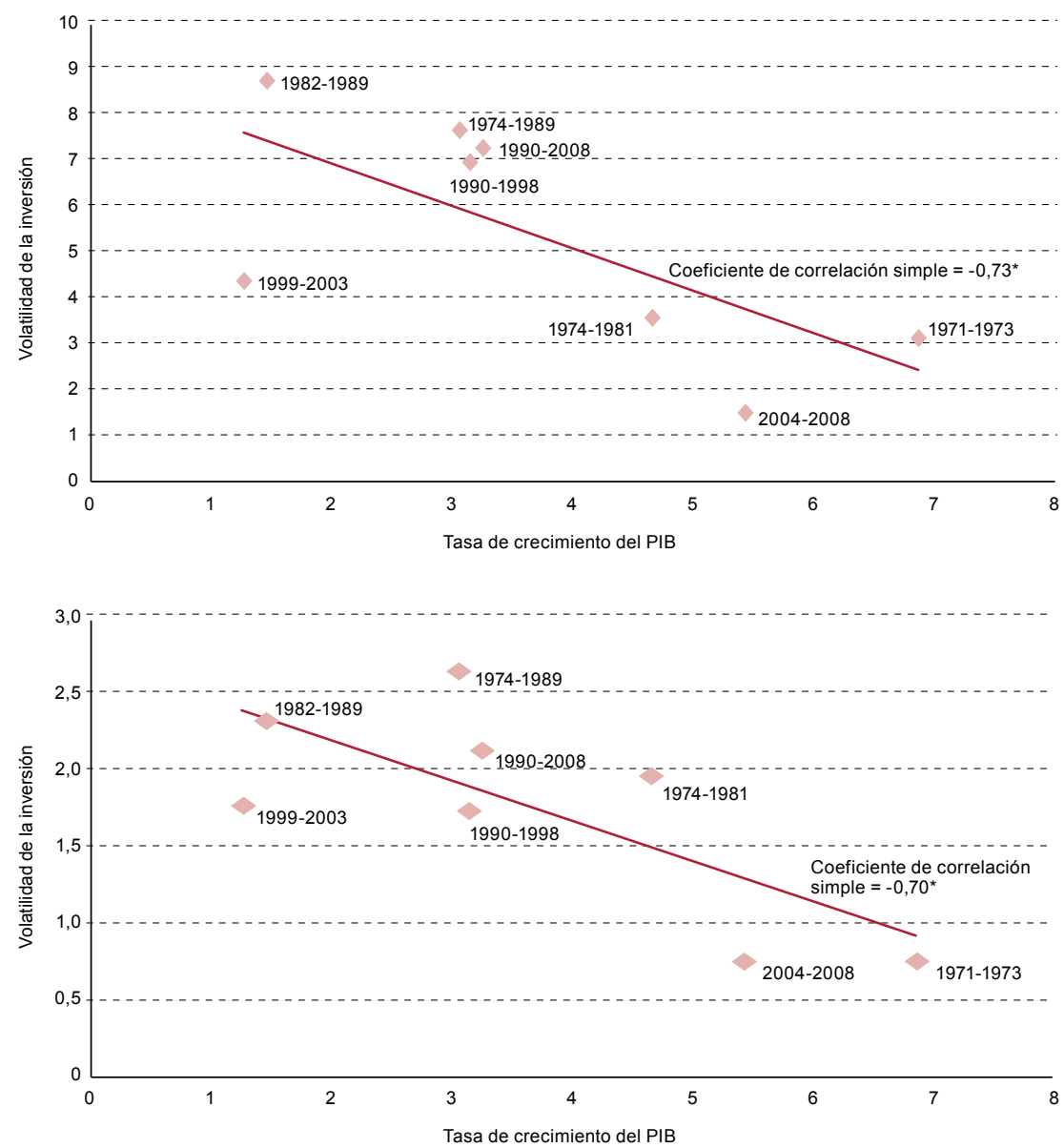

Fuente: Comisión Económica para América Latina y el Caribe (CEPAL), 2012.

a La volatilidad del PIB y la inversión se representan por la desviación típica. El uso alternativo del coeficiente de variación arroja resultados similares. La muestra incluye a los países de América del Sur, Centroamérica, México, Cuba, Haití y la República Dominicana.

b Un asterisco $\left({ }^{*}\right)$ denota un coeficiente significativo con un nivel de confiabilidad del $95 \%$.

Así pues, no es de sorprender que, en parte como resultado del aumento de la volatilidad real a lo largo del tiempo y sus efectos perjudiciales en el crecimiento, América Latina y el Caribe haya experimentado no solo un crecimiento mediocre en promedio, sino un menor crecimiento a largo plazo en relación con otras regiones. En el cuadro V.1 se muestra la evolución del crecimiento del PIB per cápita en América Latina y el Caribe, los países 
miembros de la Organización de Cooperación y Desarrollo Económicos (OCDE) (economías de ingresos altos) y regiones seleccionadas del mundo en desarrollo durante el período 1960-2011.

Las pruebas indican que América Latina y el Caribe tuvo los más altos niveles de crecimiento del PIB per cápita en la década de 1970 en comparación con otras regiones, con la excepción de Asia Oriental y el Pacífico. A partir de entonces, la región ha experimentado una de las más bajas tasas de crecimiento del PIB per cápita en relación con otras regiones en desarrollo durante la mayor parte de los períodos estudiados (1981-1990; 1991-2000; 2001-2009, 2001-2011). Además, el diferencial de crecimiento entre América Latina y el Caribe y otras regiones, como Asia Oriental y el Pacífico, se ha ampliado a lo largo del tiempo (véase el cuadro V.2).

\section{Cuadro V.2}

\section{Regiones y agrupaciones seleccionadas: crecimiento del PIB} per cápita, 1971-2011 a

(En porcentajes)

\begin{tabular}{lccccccc}
\hline & $\begin{array}{c}\text { Asia } \\
\text { Oriental } \\
\text { y el } \\
\text { Pacífico }\end{array}$ & $\begin{array}{c}\text { Europa } \\
\text { y Asia } \\
\text { Central }\end{array}$ & $\begin{array}{c}\text { Países de } \\
\text { ingresos altos } \\
\text { (Organización de } \\
\text { de Cooperación } \\
\text { y Desarrollo } \\
\text { Económicos } \\
\text { (OCDE) }\end{array}$ & $\begin{array}{c}\text { América } \\
\text { Latina y } \\
\text { el Caribe }\end{array}$ & $\begin{array}{c}\text { Oriente } \\
\text { Medio y } \\
\text { África } \\
\text { del Norte }\end{array}$ & $\begin{array}{c}\text { Asia } \\
\text { Meridional }\end{array}$ & $\begin{array}{c}\text { África } \\
\text { Subsahariana }\end{array}$ \\
\hline $1971-1980$ & 4,5 & $\ldots$ & 2,7 & 3,2 & 2,7 & 0,7 & 0,9 \\
\hline $1981-1990$ & 5,7 & $-1,7$ & 2,7 & $-0,8$ & 0,2 & 3,0 & $-0,9$ \\
\hline $1991-2000$ & 7,1 & $-1,7$ & 1,9 & 1,6 & 1,8 & 3,2 & $-0,3$ \\
\hline $\mathbf{2 0 0 3 - 2 0 0 7}$ & $\mathbf{9 , 3}$ & $\mathbf{7 , 4}$ & $\mathbf{1 , 9}$ & $\mathbf{3 , 7}$ & $\mathbf{3 , 3}$ & $\mathbf{6 , 6}$ & $\mathbf{3 , 0}$ \\
\hline $\mathbf{2 0 0 1 - 2 0 1 1}$ & 8,2 & 4,7 & 0,9 & 2,2 & 2,6 & 5,3 & 2,1 \\
\hline
\end{tabular}

Fuente: Elaboración propia sobre la base de Banco Mundial, World Development Indicators y Global Finance, 2013.

a Los puntos suspensivos indican que no se dispone de datos.

El período de expansión más reciente (2003-2007) no constituye una excepción a dicha tendencia observada. En esta etapa, América Latina y el Caribe experimentó las mayores tasas medias de crecimiento en más de tres decenios. La tasa de crecimiento per cápita media regional ascendió al 3,7\%, con lo que no solo superó la de la década perdida de 1980 y la registrada durante la era de las reformas estructurales basadas en el libre mercado (1991-2000) (1,6\%), sino también la de la década de 1970 (3,2\%).

No obstante, en términos comparativos, el desempeño de América Latina y el Caribe no fue en modo alguno excepcional. De hecho, la tasa de crecimiento regional se mantuvo significativamente por debajo de las de Asia Oriental y el Pacífico (9,3\%), Europa y Asia Central (7,4\%) y Asia Meridional (6,6\%). 


\section{B. La dominancia de la balanza de pagos}

Los altos niveles de volatilidad real de América Latina y el Caribe están asociados a una segunda característica de las economías de la región, a saber, la dominancia de la balanza de pagos en un contexto de apertura financiera. La dominancia de la balanza de pagos se define como un sistema macroeconómico en que la dinámica macroeconómica de corto plazo está determinada esencialmente por choques externos financieros y de términos de intercambio positivos o negativos (Ocampo, 2011).

El predominio de la balanza de pagos ha estado asociado tradicionalmente con las perturbaciones de la cuenta de capital y los ciclos. Esto se debe a que los principales choques procíclicos que han afectado a la región, entre ellos, la crisis de la deuda (1981-1984), la crisis mexicana (1995), la crisis asiática (1997), la crisis argentina (2001-2002) y la crisis financiera mundial más reciente (2008-2009), han tenido sus raíces en cambios abruptos de la disponibilidad del financiamiento externo.

Ello se explica en el gráfico V.2, donde se muestra la evolución de los coeficientes de correlación móviles entre el ciclo del PIB y las corrientes financieras, y entre el ciclo del PIB y el de los términos de intercambio entre 1993 y 2011. Como se puede observar en el gráfico, el coeficiente de correlación entre el PIB y el ciclo financiero es estadísticamente significativo a lo largo de la mayor parte del período (es decir, se ubica por encima de la línea de puntos que indica el umbral estadísticamente significativo).

Gráfico V.2

América Latina y el Caribe: evolución de los coeficientes de correlación móviles entre los ciclos del PIB y las corrientes financieras, y entre los ciclos del PIB y los términos de intercambio con una ventana de cinco años, 1993-2011

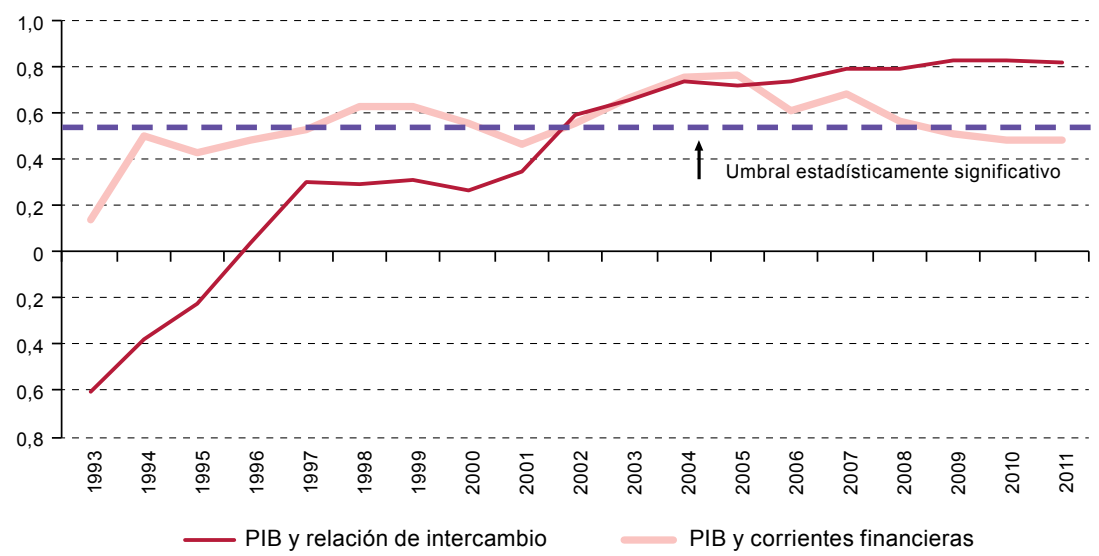

Fuente: Elaboración propia sobre la base de Banco Mundial, World Development Indicators y Global Finance, 2013.

Nota: $\quad$ El umbral estadísticamente significativo se refiere a un nivel de confiabilidad del $95 \%$. 
A ello se añade que, en épocas más recientes y en especial desde la década de 2000, las fluctuaciones de la actividad económica no dependen solamente de la disponibilidad de financiación externa, sino que están estrechamente vinculadas con las fluctuaciones de los precios de los productos básicos y, por lo tanto, con la relación de intercambio. El coeficiente de correlación entre el ciclo del PIB y el de la relación de intercambio no es significativo (con un nivel de confiabilidad del 95\%) durante el período 1993-2001 y se vuelve significativo a partir de entonces, como reflejo de la influencia que han tenido en las economías nacionales de la región el auge de los precios de los productos básicos y la relación de intercambio.

En consecuencia, el predominio de la balanza de pagos responde a que las fluctuaciones regionales y nacionales dependen no solo de los ciclos financieros externos sino también de los ciclos reales (relación de intercambio).

En el cuadro V.3 se presenta evidencia adicional sobre el predominio de la balanza de pagos que se refleja en un coeficiente de sincronía entre el ciclo de América Latina y el de sus subregiones con el de los Estados Unidos, Europa y China. La sincronía entre un país o región (por ejemplo, la región i) y una región de referencia (por ejemplo, los Estados Unidos, Europa y China, o alguno de estos por separado) (región $r$ ) se calcula según la fórmula (Mink, Jacobs y Jakob de Hahn, 2012):

$$
\text { (1) } \varphi(t)=\frac{1}{n} \sum_{i=1}^{n} \frac{g_{i}(t) g_{r}(t)}{\left|g_{i}(t) g_{r}(t)\right|}
$$

donde $g_{i}(t)$ y $g_{r}(t)$ representan las tasas de crecimiento del país o región $i$ y las del país o región $r$, utilizado como referencia. El indicador de sincronía $\varphi$ mide la fracción de tiempo en que, durante un período específico, dicho país o región $i$ se encuentra en la misma fase del ciclo que el país o región $r^{5}$.

Según los datos disponibles sobre el período 1990-2012, América Latina y el Caribe y todas sus subregiones presentan, en general, un alto grado de sincronía con todas las regiones de referencia estudiadas (Estados Unidos, zona del euro y China). Más precisamente, en promedio, el ciclo de América Latina y el Caribe está en sincronía con el de las regiones o países de referencia el 75\% del tiempo (es decir, la

En el caso extremo de que $g_{i}(t) g_{r}(t)>0,\left(g_{i}(t) g_{r}(t)<0\right)$, (para todos los componentes de la sumatoria $\varphi(t)=\frac{1}{n}\left(-\frac{1}{n}\right)$. 
región se encuentra en la misma fase del ciclo que las regiones o países de referencia el $75 \%$ del tiempo).

Por una parte, el mayor grado de sincronía tiene lugar en el período de cuatro años (2003-2007) que precedió la crisis financiera mundial (2008-2009), lo que se debe a que durante dicho período la mayor parte de los países del mundo experimentaron una expansión. Por otra, el menor nivel de sincronía se registró durante la crisis financiera mundial (2008-2009), lo que pone de relieve el impacto diferenciado de la crisis mundial en las diversas regiones y países (véase el cuadro V.3).

\section{Cuadro V.3}

América Latina y el Caribe y subregiones (incluido México): coeficiente de sincronía del ciclo económico con respecto a los Estados Unidos, la zona del euro y China, 1990-2012 ${ }^{\text {a }}$

\begin{tabular}{|c|c|c|c|c|}
\hline & $\begin{array}{c}\text { América Latina } \\
\text { y el Caribe }\end{array}$ & América del Sur & Centroamérica & México \\
\hline \multicolumn{5}{|c|}{ Estados Unidos } \\
\hline $1990-1994$ & 74 & 68 & 85 & 80 \\
\hline 1995-2002 & 73 & 72 & 78 & 75 \\
\hline 2003-2007 & 89 & 99 & 80 & 100 \\
\hline $2008-2009$ & 57 & 45 & 73 & 75 \\
\hline $2010-2012$ & 83 & 92 & 80 & 100 \\
\hline Promedio & 75 & 75 & 79 & 86 \\
\hline \multicolumn{5}{|c|}{ Zona del euro } \\
\hline $1990-1994$ & $\ldots$ & $\ldots$ & $\ldots$ & $\ldots$ \\
\hline 1995-2002 & 73 & 72 & 78 & 75 \\
\hline 2003-2007 & 89 & 99 & 80 & 100 \\
\hline $2008-2009$ & 64 & 58 & 80 & 88 \\
\hline $2010-2012$ & 68 & 74 & 67 & 70 \\
\hline Promedio & 74 & 76 & 76 & 83 \\
\hline \multicolumn{5}{|l|}{ China } \\
\hline 1990-1994 & $\ldots$ & $\ldots$ & $\ldots$ & $\ldots$ \\
\hline 1995-2002 & 69 & 64 & 77 & 77 \\
\hline 2003-2007 & 87 & 87 & 86 & 90 \\
\hline $2008-2009$ & 64 & 68 & 60 & 50 \\
\hline $2010-2012$ & 75 & 76 & 71 & 78 \\
\hline Promedio & 74 & 74 & 74 & 74 \\
\hline
\end{tabular}

Fuente: Comisión Económica para América Latina y el Caribe (CEPAL), 2012.

a Los puntos suspensivos indican que no se dispone de datos.

En general, las pruebas disponibles demuestran que, en lugar de disociarse del ciclo económico de los países desarrollados, América Latina y el Caribe sigue estando muy vinculada a las fluctuaciones de la actividad económica de dichos países. Además, el nivel elevado y cada vez mayor de sincronía entre América Latina y el Caribe y China pone de relieve que el ciclo de la región también se ha vuelto dependiente del de otros países en desarrollo. En el caso de China, esto se explica por su influencia en la determinación de la relación de intercambio de los productos básicos. 
China es un importante consumidor de productos básicos, consistentes en recursos energéticos no renovables, cosechas agrícolas y metales comunes (20\%, 23\% y 40\% de la producción mundial) (Roache, 2012).

\section{La volatilidad también refleja las características específicas del ciclo económico de América Latina y el Caribe}

Los elevados niveles de volatilidad de América Latina y el Caribe se deben no solamente al hecho de que la región depende de su desempeño externo, como lo indica el modelo de referencia de la macroeconomía para el desarrollo, sino también a las características específicas de su ciclo económico.

El ciclo de América Latina y el Caribe presenta dos características distintivas. Por una parte, y de manera más importante, la región suele experimentar expansiones menores en comparación con otras regiones del mundo. Por otra parte, se aprecian contracciones cuya duración y amplitud, por lo general, tienden a converger con las de otros países en desarrollo. Como resultado, el ciclo completo de expansiones y contracciones en América Latina presenta una frecuencia mayor entre todas las regiones consideradas.

Las características particulares del ciclo económico se obtuvieron a partir del enfoque del ciclo clásico ${ }^{6}$. De acuerdo con esta metodología, el ciclo económico puede caracterizarse sobre la base de su duración e intensidad. La duración (D) de una expansión se define como la relación entre el número total de trimestres de expansión y el número total de puntos máximos. Es decir:

\footnotetext{
Según la metodología del ciclo clásico, el ciclo es un conjunto de puntos de inflexión en una serie cronológica que representa el nivel de actividad económica agregada sin tener en consideración las tendencias (Harding y Pagan, 2002a y 2002b; Pagan, 2003). Los puntos de inflexión de la serie se utilizan entonces como base para analizar el ciclo a partir de diversos indicadores como la duración e intensidad de una expansión (del punto mínimo al máximo) y de una contracción (del punto máximo al mínimo) y el grado de coincidencia entre dos series cronológicas dadas. Un elemento fundamental de este enfoque es la determinación de los puntos de inflexión. Estos suelen determinarse mediante el algoritmo de Bry y Boschan (1971), que se creó inicialmente para el procesamiento de datos mensuales y luego fue adaptado a las observaciones trimestrales por Harding y Pagan (2002a, 2002). El algoritmo consiste en definir los valores locales máximos y mínimos de una serie determinada, siguiendo una transformación logarítmica basada en reglas de censura específicas (Bry y Boschan, 1971). Estas reglas incluyen la especificación de dos trimestres como duración mínima para una fase única, y una duración mínima de cinco trimestres para un ciclo completo (Harding y Pagan (2002a, 2002). El punto máximo de la serie $y_{t}$ se encuentra cuando $y_{t}$ es mayor que $y_{t \mp k}$ para $k=1,2$. De modo similar, el punto mínimo de la serie $y_{t}$ se encuentra cuando $y_{t}$ es menor que $y_{t \mp k}$ para $k=1,2$. En el algoritmo se excluye la posibilidad de que ocurran sucesivamente dos puntos mínimos o máximos.
} 


$$
\text { (2) } D=\frac{\sum_{t=1}^{T} S_{t}}{\sum_{t=1}^{T-1}\left(1-S_{t+1}\right) S_{t}}
$$

donde $\mathrm{S}$ es una variable binaria que toma el valor de 1 durante la expansión y de 0 durante la contracción ${ }^{7}$. El numerador de la ecuación (2) $\left(\sum_{t=1}^{T} S_{t}\right)$ denota la duración total de las expansiones, y el denominador $\left.\sum_{t=1}^{T-1}\left(1-S_{t+1}\right) S_{t}\right)$ mide el número de puntos máximos de la serie.

Por su parte, la intensidad o amplitud (A) de la expansión se mide como la relación entre el cambio total de la actividad económica agregada y el número total de puntos máximos. Es decir:

$$
\text { (3) } A=\frac{\sum_{t=1}^{T} S_{t} \Delta Y_{t}}{\sum_{t=1}^{T-1}\left(1-S_{t+1}\right) S_{t}}
$$

donde $Y$ es un parámetro de actividad económica (el PIB en los casos aquí analizados) y el numerador de la ecuación (3) $\left(\sum_{t=1}^{T} S_{t} \Delta Y_{t}\right)$ representa el cambio total en la actividad económica.

Al aplicar la metodología indicada anteriormente a una muestra amplia de 83 países, incluidas 44 economías de mercado emergentes y 39 economías desarrolladas (es decir, economías de ingresos altos) para el período 1998-2012 utilizando datos trimestrales, se obtienen los resultados que figuran a continuación ${ }^{8}$.

En comparación con otras regiones desarrolladas y en desarrollo del mundo, el ciclo económico de expansiones y contracciones de América Latina y el Caribe tiene dos características distintivas. En primer lugar, la región, por regla general, presenta expansiones menores que otras regiones en desarrollo y, en particular, que Asia Oriental y el Pacífico. En segundo

De modo similar, la duración y amplitud de las contracciones se computan mediante la fórmula $c_{i, t}=1-s_{i, t}$

8 La muestra de economías de mercado emergentes está compuesta por 21 países pertenecientes a América Latina y el Caribe, 5 a Asia oriental y el Pacífico, 11 a Europa y Asia Central, 3 al Oriente Medio y África del Norte, 1 a Asia Meridional y 3 a África Subsahariana. La submuestra de economías de ingresos altos incluye países de Europa (23), Asia (4), América del Norte (2), el Caribe (2) y otros. Estos últimos son Chipre, Israel, Macao (China) y Malta. Los países del Caribe son: Barbados, Belice, Granada, Jamaica, República Dominicana, Santa Lucía y Trinidad y Tabago. En comparación con otros análisis sobre el tema, el conjunto de datos utilizado en el presente documento es uno de los más grandes y representativos, a nivel regional y también a nivel subregional de América Latina y el Caribe. En contraste con otros estudios sobre el tema, este incluye la mayoría de los países de América del Sur y Centroamérica, además de economías caribeñas, con lo que se evita introducir un sesgo subregional en los resultados obtenidos. No se disponía de datos de todos los países en relación con el período 1989-2012. En todos los países de la muestra se utilizó el PIB trimestral, con la única excepción de Barbados, en cuyo caso, debido a las limitaciones de los datos, el PIB trimestral se determinó indirectamente a partir de la información sobre las llegadas de turistas. En Barbados, los datos disponibles con carácter anual respecto de las llegadas de turistas y el PIB demuestran que las dos variables presentan un alto grado de coincidencia (incluso en los puntos de inflexión) y de asociación (un coeficiente de correlación muy elevado y significativo). 
lugar, América Latina y el Caribe tiene, en promedio, contracciones que por su duración y amplitud tienden a converger con las de otros países, tanto desarrollados como en desarrollo.

Como resultado, las expansiones menos intensas y las contracciones convergentes implican que el ciclo completo de expansión y contracción tiende a ser más breve y de menor amplitud en América Latina y el Caribe en comparación con otras regiones del mundo. En otras palabras, el ciclo de América Latina y el Caribe presenta una frecuencia más elevada que el de otras regiones.

En lo que se refiere a la duración de la expansión, los datos demuestran que los ciclos de expansión de América Latina y el Caribe abarcan, en promedio, un período de 14 trimestres (tres años y medio) ${ }^{9}$. Con la excepción del Oriente Medio y África del Norte (un año), las expansiones en América Latina y el Caribe son menos duraderas que las del resto de las regiones examinadas y, en particular, que las de Asia Oriental y el Pacífico. En el caso de esta región, las expansiones duran unos ocho años, es decir, casi cinco años más que las de América Latina y el Caribe. En el caso de los países de ingresos altos, la duración de la expansión también es mayor (seis años, o aproximadamente dos años más que en el caso de América Latina y el Caribe) (véase el cuadro V.4).

\section{Cuadro V.4}

Regiones seleccionadas: duración mediana y amplitud de las fases de expansión y contracción del ciclo económico, 1990-2012 ${ }^{\text {a }}$

\begin{tabular}{lccccc}
\hline & \multicolumn{2}{c}{ Contracción } & & \multicolumn{2}{c}{ Expansión } \\
\cline { 2 - 3 } \cline { 6 - 6 } & $\begin{array}{c}\text { Duración } \\
\text { (en trimestres) }\end{array}$ & $\begin{array}{c}\text { Amplitud } \\
\text { (en porcentajes) }\end{array}$ & & $\begin{array}{c}\text { Duración } \\
\text { (en trimestres) }\end{array}$ & $\begin{array}{c}\text { Amplitud } \\
\text { (en porcentajes) }\end{array}$ \\
\hline Asia Oriental y el Pacífico & 3,3 & $-10,6$ & & 32,5 & 39,0 \\
\hline Europa y Asia Central & 3,8 & $-11,6$ & & 25,0 & 43,8 \\
\hline América Latina y el Caribe & $\mathbf{3 , 8}$ & $-\mathbf{4 , 6}$ & & $\mathbf{1 3 , 6}$ & $\mathbf{2 6 , 3}$ \\
\hline Oriente Medio y África del Norte & 7,3 & $-7,0$ & & 3,5 & 15,6 \\
\hline Asia Meridional & $\ldots$ & $\ldots$ & & $\ldots$ & $\ldots$ \\
\hline África Subsahariana & 2,7 & $-7,1$ & & 37,5 & 40,9 \\
\hline Países de ingresos altos & 4,0 & $-4,9$ & & 23,0 & 26,3 \\
\hline
\end{tabular}

Fuente: E. Pérez Caldentey, D. Titelman y P. Carvallo, "Weak expansions: a distinctive feature of the business cycle in Latin America and the Caribbean", Working Paper, N 749, Levy Economics Institute, 2013.

a Los puntos suspensivos indican que no se dispone de datos.

El análisis del ciclo de la expansión más reciente no modifica las conclusiones. En la mayoría de los países de América Latina y el Caribe, la expansión más reciente comenzó a principios de la década de 2000

9 El algoritmo de Bry y Boschan se computó mediante el lenguaje MatLab, con la ayuda de códigos informáticos facilitados por los profesores John Rand y Finn Tarp (de la Universidad de Copenhague). Se utilizó el lenguaje Stata para computar los indicadores de los ciclos. 
y terminó con la crisis financiera mundial (2009). Fue una de las más dilatadas e intensas en más de tres decenios. No obstante, este episodio de expansión es más débil en cuanto a duración y amplitud que el último episodio de expansión que experimentaron otras regiones, en particular, Asia Oriental y el Pacífico (26,5 trimestres y un 29,8\% en el caso de América Latina y el Caribe y 40 trimestres y un 53,9\% en el caso de Asia Oriental y el Pacífico, respectivamente) ${ }^{10}$.

En consonancia con los resultados anteriores, América Latina y el Caribe también exhibe una de las más exiguas ganancias de producto durante la fase expansiva del ciclo. En promedio, América Latina y el Caribe registra, respectivamente, un aumento del $26,3 \%$ del producto. Esto contrasta con la experiencia de la región de referencia, Asia Oriental y el Pacífico, que registra una ganancia de producto equivalente al 39\% (un $48 \%$ más que el de América Latina y el Caribe) (véase el cuadro V.5).

Cuadro V.5

América Latina y el Caribe: duración media y amplitud de las fases de expansión y contracción del ciclo económico, 1990-2012

\begin{tabular}{lccccc}
\hline & \multicolumn{2}{c}{ Contracción } & & \multicolumn{2}{c}{ Expansión } \\
\cline { 2 - 3 } \cline { 5 - 6 } & $\begin{array}{c}\text { Duración } \\
\text { (en trimestres) }\end{array}$ & $\begin{array}{c}\text { Amplitud } \\
\text { (en porcentajes) }\end{array}$ & & $\begin{array}{c}\text { Duración } \\
\text { (en trimestres) }\end{array}$ & $\begin{array}{c}\text { Amplitud } \\
\text { (en porcentajes) }\end{array}$ \\
\hline América Latina y el Caribe & $\mathbf{1 3 , 6}$ & $\mathbf{2 6 , 3}$ & & $\mathbf{3 , 8}$ & $\mathbf{- 4 , 6}$ \\
\hline América del Sur & 15,3 & 27,9 & & 3,6 & $-\mathbf{7 , 1}$ \\
\hline Centroamérica & 25,0 & 27,0 & & 3,5 & $-3,8$ \\
\hline México & 23,0 & 25,6 & & 3,7 & $-7,9$ \\
\hline
\end{tabular}

Fuente: E. Pérez Caldentey, D. Titelman y P. Carvallo, "Weak expansions: a distinctive feature of the business cycle in Latin America and the Caribbean", Working Paper, N ${ }^{\circ} 749$, Levy Economics Institute, 2013.

El desempeño deslucido de las economías de América Latina y el Caribe en relación con otras regiones durante la fase expansiva del ciclo se hace evidente desde la perspectiva del aumento acumulado de la producción. En el gráfico V.3 se muestra el incremento acumulado del producto de Asia Oriental y el Pacífico y de los países de ingresos altos en comparación con el de América Latina y el Caribe. Asia Oriental y el Pacífico tiene un aumento del producto que, según la mayoría de los criterios utilizados, equivale a casi el triple del de América Latina y el Caribe. Por su parte, el aumento del producto del grupo de economías de ingresos altos es un 10\% mayor en comparación con el de América Latina y el Caribe (véase el gráfico V.3).

Estas cifras corresponden a la duración y amplitud de un solo episodio. Se refieren al numerador de las fórmulas de duración y amplitud (las ecuaciones (3) y (4) indicadas anteriormente) y, en ese sentido, no se pueden comparar estrictamente con el resto de los indicadores de los ciclos presentados en el documento. En el caso de Europa y Asia Central, la duración y amplitud del último episodio de expansión también son mayores que las de América Latina y el Caribe $(36,5$ trimestres y $63,2 \%)$. 


\section{Gráfico V.3}

Asia Oriental y el Pacífico y países de ingresos altos: ganancia acumulada media del producto en comparación con el de América Latina y el Caribe, 1990-2012 ${ }^{\text {a }}$

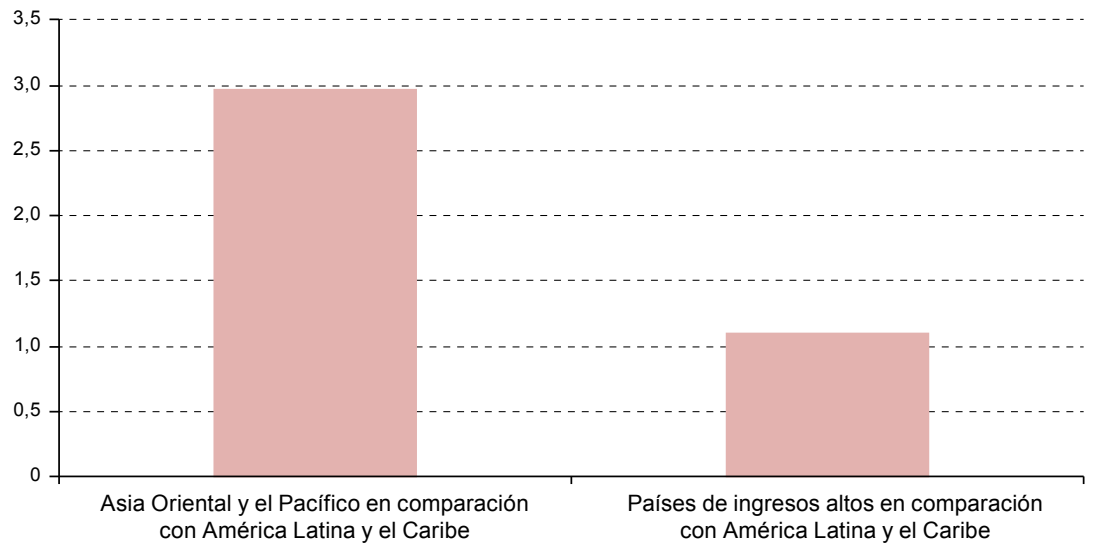

Fuente: E. Pérez Caldentey, D. Titelman y P. Carvallo, "Weak expansions: a distinctive feature of the business cycle in Latin America and the Caribbean", Working Paper, N 749, Levy Economics Institute, 2013.

a Se refiere al promedio de los valores obtenidos a partir del método de Bry y Boschan, el algoritmo de cálculo, el método de Okun y el ciclo de desviaciones respecto del período 1990-2012. El aumento acumulado de la producción se computa como el producto de la amplitud y la duración de la fase de expansión de Asia Oriental y de las economías de ingresos altos en comparación con los de América Latina y el Caribe.

En contraste con los resultados obtenidos respecto de las expansiones, la duración e intensidad de la contracción en el caso de los países de América Latina y el Caribe son similares a las de otras regiones. Con la excepción del Oriente Medio y África del Norte, la duración de las contracciones es inferior a un año: van de 2,7 a 3,8 trimestres (es decir, entre 8 y 11 meses). Las contracciones en el caso de América Latina y el Caribe, Europa y Asia Central, y Asia Oriental y el Pacífico tienen una duración muy similar, de entre 3,3 y 3,8 trimestres (entre 10 y 11 meses).

En consonancia con estos resultados, las contracciones no son más intensas en América Latina y el Caribe que en otras regiones. América Latina y el Caribe presenta la menor amplitud de contracciones entre todas las regiones en desarrollo y desarrolladas. La amplitud media de las contracciones equivale al $4,6 \%$ en el caso de América Latina y el Caribe. Esta se aproxima a la del grupo de países de ingresos altos $(4,9 \%)$ y queda por debajo de la de Asia Oriental y el Pacífico (10,6\%), Europa y Asia Central (11,6\%), el Oriente Medio y África del Norte $(7,0 \%)$ y África Subsahariana $(7,1 \%)$.

Ambos hechos estilizados (expansiones menos intensas y contracciones convergentes) implican que el ciclo completo de América Latina y el Caribe exhibe, en su mayor parte, una duración más breve y 
una amplitud más pequeña en comparación con otras regiones. En otras palabras, el ciclo de América Latina y el Caribe tiene la mayor frecuencia entre todas las regiones.

La duración de un ciclo completo en que se utilice la metodología del ciclo clásico (y, como referencia, el criterio de Bry y Boschan) es de aproximadamente 17 trimestres en el caso de América Latina y el Caribe. Esto es inferior a lo constatado en el caso de los países de ingresos altos (27 trimestres) y en la mayoría de las regiones en desarrollo. En el caso particular de Asia Oriental y el Pacífico, el punto de referencia utilizado en este documento, el ciclo dura 36 trimestres, es decir, casi cinco años más que el de América Latina y el Caribe.

Al mismo tiempo que América Latina exhibe la menor duración de los ciclos, también muestra la menor amplitud en la mayoría de los casos; es decir, presenta la distancia más corta entre el punto más intenso de la contracción y el de la expansión. Si se toma a Asia Oriental y el Pacífico como punto de referencia, la amplitud de su ciclo es un $60 \%$ mayor que la de América Latina y el Caribe.

\section{La relación entre el ciclo y el crecimiento a largo plazo: el canal real (productividad e inversión)}

La dinámica y las características particulares del ciclo económico de América Latina y el Caribe no solo son pertinentes a corto plazo, sino que afectan el desempeño a largo plazo. Desde el punto de vista de este análisis, ello implica que la perspectiva tradicional de la macroeconomía para el desarrollo debe incorporar otra dimensión, a saber, la relación entre las fluctuaciones a corto plazo y el crecimiento a largo plazo, o entre el ciclo y la tendencia.

El hecho de que América Latina y el Caribe presente expansiones de menor duración e intensidad en comparación con otras regiones del mundo también implica que el período de acumulación es más breve e intenso. Asimismo, como se ha señalado anteriormente, la duración más breve de los ciclos implica que el ciclo de América Latina y el Caribe exhibe una frecuencia mayor en relación con el de otras regiones. Tal vez un ciclo de mayor frecuencia es una de las causas que explican el aumento de la volatilidad de la región.

Por otra parte, las características específicas del ciclo también vinculan las fluctuaciones a corto plazo con el desempeño a largo plazo porque estas características se reflejan en variables estructurales (reales) como la productividad y la inversión, que se consideran determinantes fundamentales de la senda de crecimiento a largo plazo de cualquier economía. 
En el cuadro V.6 se muestra la duración y amplitud de la expansión de la productividad laboral de los países de América Latina y el Caribe en comparación con el resto de los países incluidos en la muestra. De conformidad con los resultados anteriores obtenidos por los autores, América Latina y el Caribe tiene, en general, una de las expansiones más breves en cuanto al crecimiento de la productividad.

\section{Cuadro V.6}

Regiones y agrupaciones seleccionadas: duración y amplitud de la fase expansiva del ciclo de productividad laboral, mediante la metodología del ciclo clásico, 1990-2012 a

\begin{tabular}{lc}
\hline & $\begin{array}{c}\text { Duración } \\
\text { (en años) }\end{array}$ \\
\hline Asia Oriental y el Pacífico & 4,3 \\
\hline Europa y Asia Central & 5,5 \\
\hline América Latina y el Caribe & $\mathbf{3 , 8}$ \\
\hline Oriente Medio y África del Norte & 3,3 \\
\hline Asia Meridional & 4,8 \\
\hline África Subsahariana & 2,6 \\
\hline Países de ingresos altos & 6,3 \\
\hline & Amplitud \\
& (en porcentajes) \\
\hline Asia Oriental y el Pacífico & 23,4 \\
\hline Europa y Asia Central & 33,7 \\
\hline América Latina y el Caribe & $\mathbf{1 3 , 6}$ \\
\hline Oriente Medio y África del Norte & 17,2 \\
\hline Asia Meridional & 16,0 \\
\hline África Subsahariana & 8,5 \\
\hline Países de ingresos altos & 17,7 \\
\hline
\end{tabular}

Fuente: E. Pérez Caldentey, D. Titelman y P. Carvallo, "Weak expansions: a distinctive feature of the business cycle in Latin America and the Caribbean", Working Paper, N 749, Levy Economics Institute, 2013.

a Se refiere a la productividad laboral por persona empleada, en dólares de 2011 (convertidos al nivel de precios de 2011 basado en la paridad de poder adquisitivo en dólares EKS de 2005 actualizados). Corresponde a datos anuales.

A ese respecto, conviene destacar las diferencias entre la ganancia acumulada (el producto de la amplitud y la duración) de la productividad entre América Latina y el Caribe y Asia Oriental y el Pacífico. El aumento acumulado de la productividad laboral durante la fase expansiva del ciclo es del $25 \%$ en el caso de América Latina y el Caribe, y el doble de esa cifra (50\%) en el caso de Asia Oriental y el Pacífico.

Junto con el hecho de que América Latina y el Caribe experimenta expansiones menos intensas en comparación con otras regiones $\mathrm{y}$, en particular, con Asia Oriental y el Pacífico, este tipo de prueba podría contribuir a explicar por qué los países de Asia Oriental y el Pacífico han conseguido mantenerse en una senda de crecimiento elevado del PIB a lo largo del tiempo en comparación con América Latina y el Caribe. Esto se muestra en el gráfico V.4, donde se traza la tendencia del PIB durante el período 1960-2010 en ambas regiones. 


\section{Gráfico V.4}

América Latina y el Caribe y Asia Oriental y el Pacífico: tendencia

del PIB, 1960-2010 a

(En escala logarítmica)

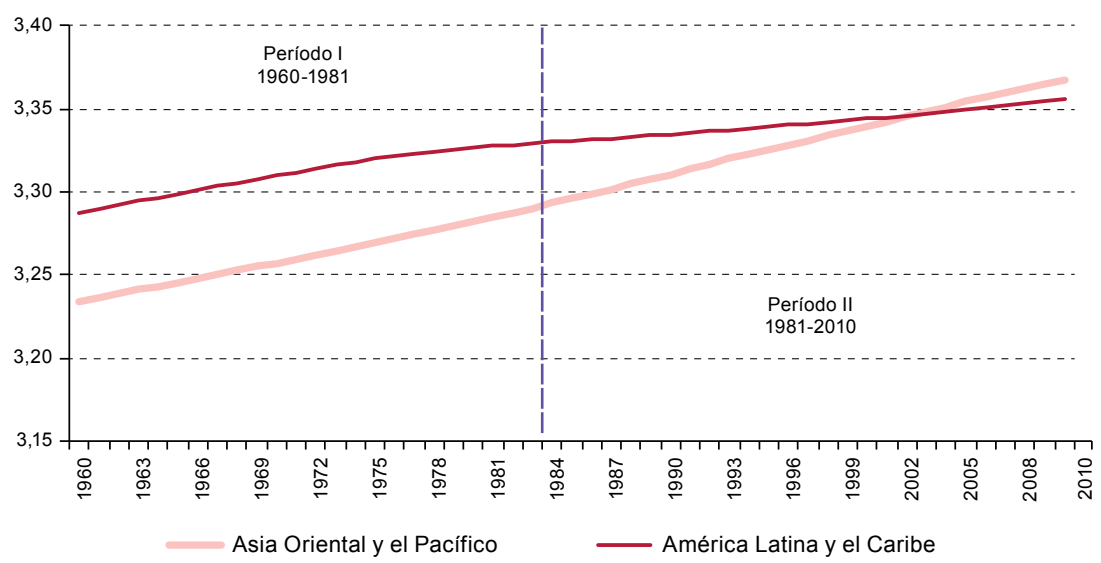

Fuente: Comisión Económica para América Latina y el Caribe (CEPAL), sobre la base de Banco Mundial, World Development Indicators y Global Finance [en línea] http://www.gfmag.com/.

a Los cómputos se realizaron a partir de la metodología del ciclo de desviaciones; corresponden a datos anuales.

Mientras que la región de Asia Oriental y el Pacífico ha conseguido mantener una trayectoria ascendente durante todo el período, América Latina y el Caribe experimenta una ruptura estructural en la década de 1980, lo que muy probablemente se deba a los efectos de la crisis de la deuda, de la que la región no ha conseguido recuperarse en los dos decenios posteriores. A un nivel de análisis más detallado, en el gráfico V.4 se muestra que la tendencia del PIB entre 1960 y principios de los años ochenta (período I) en América Latina y el Caribe es similar a la de Asia Oriental y el Pacífico. Luego, a partir de la década perdida de 1980, tiende a descender y no se recupera en la década de 1990 ni en la de 2000, lo que significa que en este subperíodo las tasas de crecimiento son inferiores a las registradas antes de la crisis de la deuda (período II).

Los efectos a largo plazo de la crisis se perciben en la ruptura estructural de la tendencia del PIB de la región. Al mismo tiempo, el carácter exiguo de las recuperaciones se pone de relieve al comprobar que las políticas económicas implementadas en los dos decenios posteriores a la crisis no consiguieron revertir esos efectos. Incluso en el período 20032007, el de más rápido crecimiento que ha experimentado América Latina y el Caribe en los últimos 30 años, los países de la región, con escasas excepciones, no consiguieron revertir la ruptura estructural ni mejorar la tendencia. Esto difiere de lo ocurrido en Asia: la crisis de 1997, una de las más intensas que ha afectado a los países de Asia Oriental, no modificó el rumbo del PIB tendencial. 
Otro elemento que vincula las fluctuaciones del ciclo con el crecimiento a largo plazo lo define el comportamiento de la inversión pública, que también es claramente asimétrico, pues sus descensos durante las recesiones son mucho más pronunciados que los aumentos durante los períodos de alza. Como se muestra en el cuadro V.7, donde se tienen en cuenta los datos de seis países de la región, la inversión pública en infraestructura se redujo, por término medio, en un $36 \%$ en la fase de contracción del ciclo económico ${ }^{11}$.

\section{Cuadro V.7}

América Latina (países seleccionados): duración y amplitud de las expansiones y contracciones del ciclo de inversión pública en infraestructura, 1980-2010 a

\begin{tabular}{lcccccc}
\hline & \multicolumn{2}{c}{ Expansión } & & \multicolumn{2}{c}{ Contracción } \\
\cline { 2 - 3 } \cline { 6 - 7 } & Duración & Amplitud & & Duración & Amplitud \\
\hline Total & 2,7 & 25,6 & & 2,2 & $-35,6$ \\
\hline Sector de la energía & 1,9 & 34,7 & & 2,0 & $-51,5$ \\
\hline Carreteras y ferrocarriles & 2,1 & 32,3 & & 1,7 & $-33,1$ \\
\hline Telecomunicaciones & 1,8 & 28,1 & & 1,9 & $-58,0$ \\
\hline Agua y saneamiento & 1,6 & 24,2 & & 1,7 & $-23,8$ \\
\hline
\end{tabular}

Fuente: Comisión Económica para América Latina y el Caribe (CEPAL), 2012.

a Se utilizó el algoritmo de Bry y Boschan para determinar los puntos de inflexión, sobre la base de datos anuales.

Las reducciones de la inversión en infraestructura pública tienden a ser más pronunciadas que cualquier aumento durante la fase de recuperación. En los sectores analizados, la contracción es, en promedio, un $40 \%$ superior a la expansión subsiguiente. En los sectores de la energía y las telecomunicaciones, la diferencia entre la disminución de las inversiones durante una contracción y el aumento durante la expansión es mucho mayor (un $35 \%$ de aumento y un $-52 \%$ de disminución en el sector de la energía, y un $28 \%$ y un $-58 \%$ en el sector de las telecomunicaciones, respectivamente). Esa situación tiene efectos negativos sobre la acumulación de capital a lo largo del tiempo.

La contracción de las inversiones puede tener efectos a corto plazo sobre la demanda agregada, pero también influye en la trayectoria a largo plazo de la economía. Esto se debe no solamente a que la inversión pública contribuye al crecimiento de la economía, sino al hecho de que las decisiones de inversión suelen ser irreversibles ("una vez instalado, el capital tiene un valor escaso o nulo, a menos que se use para la producción") y esta característica sirve de vínculo entre las decisiones adoptadas a corto plazo y los resultados a mediano y largo plazo.

${ }_{11}$ La Argentina, el Brasil, Chile, Colombia, México y el Perú, países de donde proviene el 85,5\% del PIB de la región. 
La irreversibilidad puede ser a menudo un factor importante en la decisión de no invertir en la fase descendente del ciclo debido, por ejemplo, a los riesgos cada vez mayores vinculados con el contexto macroeconómico actual y futuro. En ese sentido, una fase descendente del ciclo económico puede asociarse a una escasa acumulación del capital, lo que, a su vez, contribuye aun más a la disminución de las inversiones, y socava no solamente la capacidad de creación de empleo de la economía, sino su potencial de recuperación.

\section{E. La relación entre el ciclo y el crecimiento a largo plazo: el canal financiero}

La dinámica del crecimiento a largo plazo no solo se relaciona con el comportamiento de variables reales como la productividad y la inversión, sino que obedece al comportamiento del crédito y la estabilidad financiera ${ }^{12}$. En este sentido, además del canal real, el canal financiero es otro mecanismo por el que las fluctuaciones cíclicas afectan el rumbo del crecimiento a largo plazo de una economía.

La importancia del canal financiero queda subrayada por el comportamiento asimétrico del crédito al sector privado durante el ciclo. En el cuadro V.8 se muestra la relación entre el ciclo crediticio y el PIB en cuanto a su duración, amplitud y efecto acumulado en países seleccionados de América Latina (a saber, la Argentina, el Brasil, Chile, Colombia, Costa Rica, México, el Paraguay, el Perú, la República Dominicana y Venezuela (República Bolivariana de)) en el período 19902012 sobre la base de datos trimestrales.

2 Según el paradigma dominante de la macroeconomía, los factores financieros no afectan, por lo general, el crecimiento a largo plazo. El teorema de Modigiani-Miller (1958) es un ejemplo de esto porque entraña una total dicotomía entre el valor de mercado de una empresa y su estructura de pasivos. Como indicara Modigliani (1980) pág. viii: “...con mercados que funcionen bien (e impuestos neutrales) e inversionistas racionales que sean capaces de 'revertir' la estructura financiera corporativa, detentando montos positivos o negativos de deuda, el valor de mercado de una empresa (deuda más patrimonio) depende solo de su flujo de ingreso generado por sus activos. De ello se desprende que el valor de la empresa no debería verse afectado por la proporción de deuda en su estructura financiera ni por lo que hará con su rendimiento (abonado como dividendo o reinvertido (con ganancias)". Más recientemente, organizaciones internacionales como el Fondo Monetario Internacional o la OCDE y la Unión Europea han reconocido que las recesiones generadas por factores financieros pueden afectar el PIB potencial. Ello ha llevado a algunos economistas (Borio, Disyatat y Juselius, 2013) a intentar introducir factores financieros en la determinación del PIB potencial. En contraste, un principio fundamental de la economía no tradicional es que la relación entre los factores financieros y el comportamiento de las variables reales es indisoluble (Keynes, 1936; Minsky, 1982, 1986). Los dos van siempre de la mano. 
Por una parte, las pruebas indican que las expansiones del crédito, en promedio, suelen tener una duración paralela similar, pero de mayor intensidad que la del PIB. Por término medio, las expansiones del crédito se prolongan un trimestre más que las del PIB. No obstante, por lo general reflejan una amplitud mayor que las del PIB en un 50\%.

Por otra parte, las contracciones crediticias son, a la vez, un $60 \%$ más prolongadas e intensas que las del PIB. En tanto, la intensidad de las contracciones crediticias excede las del PIB en cinco veces en término medio (cuatro veces si se utiliza la mediana en lugar del promedio) (véase el cuadro V.8).

\section{Cuadro V.8}

América Latina (países seleccionados): duración y amplitud de las fases de expansión y contracción del ciclo crediticio real en relación con el PIB real, 1990-2012 a

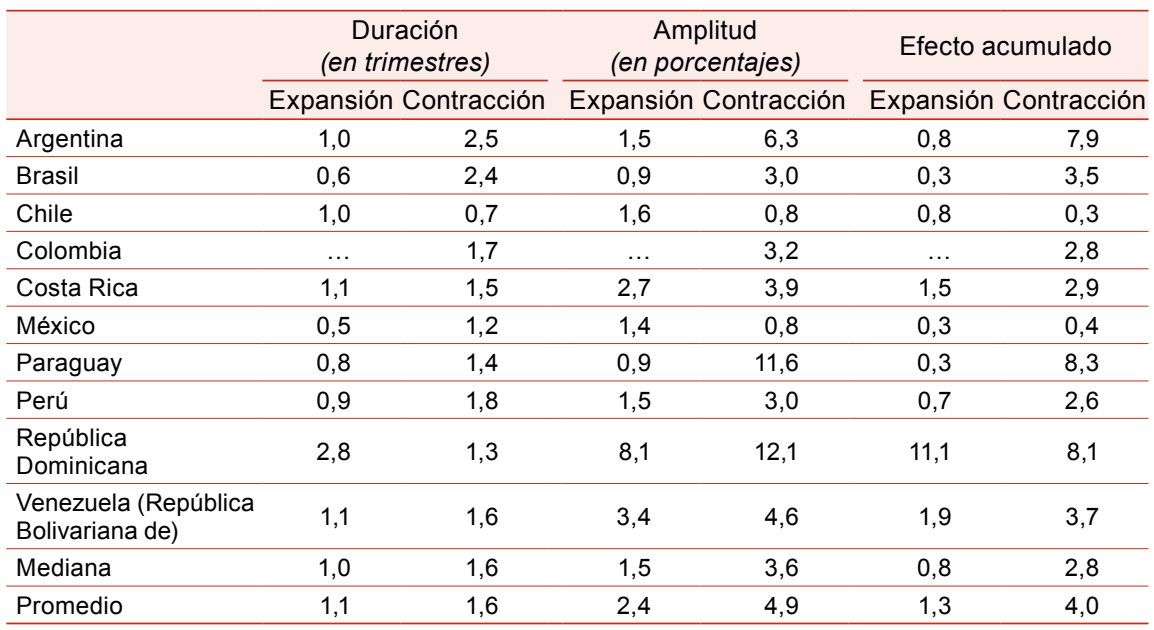

Fuente: Elaboración propia sobre la base de información oficial de los países y Banco Interamericano de Desarrollo (BID), Latin America and the Caribbean Macro Watch Data Tool [en línea] http://www. iadb.org/research/latinmacrowatch/lmw.cfm.

a Los puntos suspensivos indican que no se dispone de datos.

En consecuencia, mientras que el crédito tiende a ir más allá que el PIB en lo que se refiere a la intensidad de las fases de expansión y contracción del ciclo, el efecto es mucho más pronunciado en la de contracción. A esa reacción crediticia desproporcionada en la fase de desaceleración hay que sumar el hecho de que la contracción del crédito tiene una mayor duración ${ }^{13}$.

13 En cuanto a la relación entre los ciclos crediticio y financiero y el crecimiento tendencial del PIB, véanse Borio (2012) y Drehman, Borio y Tsatsaronis (2012). 
Tal asimetría en el comportamiento del crédito (o, dicho de otro modo, el hecho de que las contracciones crediticias no son necesariamente proporcionales a las expansiones crediticias) tiene importantes repercusiones en cuanto a la comprensión del ciclo del PIB y la relación entre las fluctuaciones y las tendencias de más largo plazo.

Una de las repercusiones se deriva de que las contracciones del crédito tienden a ser mucho más pronunciadas que las de la producción. Un modo de interpretar este resultado, en vista de las pruebas mencionadas, es que el sistema financiero tiene el efecto de amplificar las fluctuaciones de las variables reales como las del $\mathrm{PIB}^{14}$. Esta conclusión corrobora la perspectiva del modelo de referencia de la macroeconomía para el desarrollo en el sentido de que el crédito acentúa las fluctuaciones reales (CEPAL, 2002, 2004, 2012).

Una nueva repercusión que aún no se ha tenido en cuenta en la perspectiva del modelo referencia es que, si las contracciones crediticias son más prolongadas que las del PIB, esto significa que las recuperaciones y expansiones del PIB tienen lugar antes que las del crédito. El PIB se recupera y se expande y luego es que se reactiva el crédito ${ }^{15}$. En otras palabras, el crédito es un factor endógeno a la evolución del PIB.

Al menos parcialmente, esto se refleja en que, en el caso de América Latina, las pruebas empíricas disponibles muestran que el comportamiento del PIB precede en el tiempo al comportamiento del crédito. En el gráfico V.5 se indica el porcentaje de países de América Latina en los que existe causalidad de Granger del PIB hacia el crédito en los períodos 1995-2003, 1999-2007, 2001-2009 y 2003-2011. En el primer período estudiado (1995-2003), en el 20\% de los países de la muestra el PIB causa, en el sentido de Granger, el crédito. En el último período (2003-2011), el porcentaje de países donde el crédito fue un factor endógeno aumenta al 70\%.

14 Los resultados obtenidos por los autores presentan cierta similitud con el concepto del acelerador financiero (Bernanke y otros, 1999). Este concepto se basa en la idea de que existe una asimetría de información posterior que da lugar a una prima de financiación externa como reflejo de la diferencia entre los costos de las finanzas internas y externas. En la fase ascendente del ciclo, el aumento de la solvencia crediticia, el patrimonio neto y, en general, de la capacidad de pago, se traducen en una prima menor de financiación externa. Durante las contracciones ocurre lo contrario. Así, la prima externa tiene un comportamiento anticíclico, siendo menor en las expansiones y mayor en las contracciones. En este sentido, la prima de financiación externa puede amplificar en la esfera financiera un choque que afecte las variables reales.

15 Tales resultados son compatibles con el fenómeno del milagro del ave fénix expuesto por Calvo, referente a las recuperaciones sin crédito (Calvo y otros, 2006). 


\section{Gráfico V.5}

América Latina: países en los que el ciclo crediticio es un factor endógeno del ciclo del PIB, primer trimestre de 1995 a cuarto trimestre de $2011^{\text {a }}$

(En porcentajes de países)

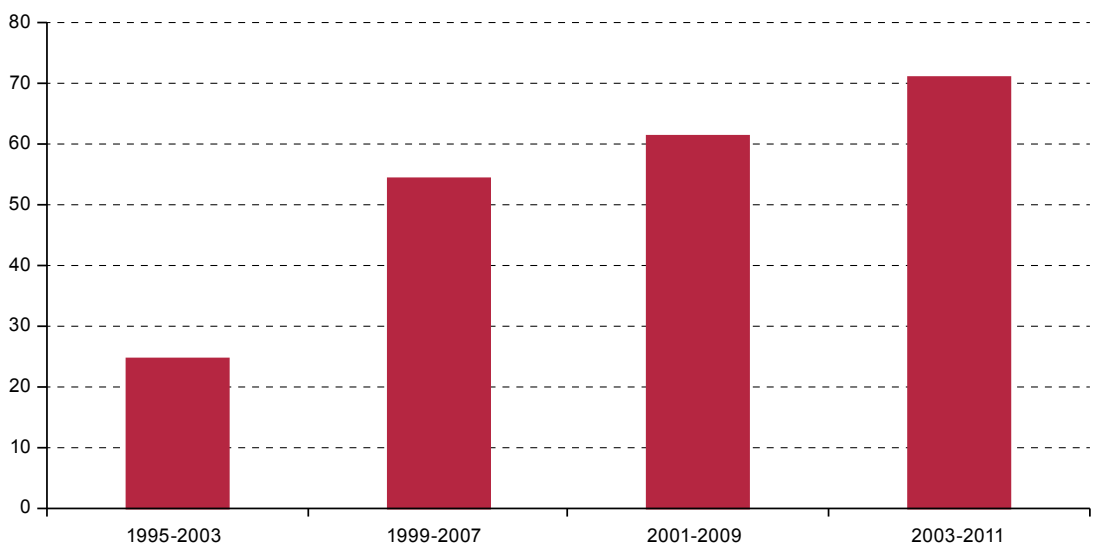

Fuente: Elaboración propia sobre la base de información oficial de los países y Banco Interamericano de Desarrollo (BID), Latin America and the Caribbean Macro Watch Data Tool [en línea] http://www. iadb.org/research/latinmacrowatch/lmw.cfm.

a El porcentaje se estimó a partir del test de causalidad continua de Granger. Los países incluidos en la muestra son: Argentina, Bolivia (Estado Plurinacional de), Brasil, Colombia, Costa Rica, Chile, Ecuador, El Salvador, Honduras, México, Paraguay, Perú, República Dominicana y Uruguay.

Por último, un tercer elemento novedoso es que el crédito se contrae a razón de un múltiplo del PIB y sigue contrayéndose mientras el PIB se expande, lo que implica que el crédito actúa como freno al menos durante una parte de la fase ascendente del ciclo del PIB. Si esto se suma al comportamiento de variables reales como la productividad y la inversión, que se abordaron en la sección anterior, podría explicarse así la fragilidad de la fase de expansión del ciclo en América Latina ${ }^{16}$.

La importancia del canal financiero como mecanismo de trasmisión entre el ciclo y la tendencia constituye un argumento sólido para regular el sistema financiero en su conjunto, o sea, desde la perspectiva macroprudencial, a fin de promover el crecimiento a largo plazo.

16 Tales resultados son coherentes con la anterior constatación de los autores de que la fase expansiva del ciclo se desglosa en dos subfases, de aceleración y desaceleración (la aceleración se define por el crecimiento del PIB a una tasa cada vez mayor o, dicho de otro modo, por una primera y una segunda derivada positiva de la serie de niveles del PIB; la desaceleración se refiere a que el PIB crece a una tasa cada vez menor o, dicho de otro modo, que la primera derivada de la serie de niveles del PIB es positiva, en tanto la segunda es negativa). América Latina y el Caribe tiene una de las tasas de crecimiento más atenuadas, tanto en la subfase de aceleración como de desaceleración en contraste con otras regiones en desarrollo y desarrolladas. La tasa promedio de crecimiento en la fase de aceleración llega al 6,1\% en América Latina y el Caribe, mientras que en otras regiones, como Asia Oriental y el Pacífico, asciende hasta aproximadamente el $7 \%$. De modo similar, América Latina también ha sufrido una fase de desaceleración menos pronunciada que otras regiones, con la excepción de la del Oriente Medio y África del Norte y África Subsahariana (Pérez-Caldentey, Titelman y Carvallo, 2013). 
El objetivo principal de la regulación macroprudencial consiste en conservar la estabilidad del sistema financiero a nivel agregado mediante la reducción del riesgo sistémico al mínimo. A este fin, se debe procurar activamente limitar la acumulación de riesgos financieros y de estructuras financieras frágiles, incluida la prevención de las burbujas de los activos y del crédito (Minsky, 1982 y 1986).

Lo que es más pertinente a este análisis, también implica vigilar las expansiones del crédito y controlar los costos económicos y sociales relacionados con las restricciones crediticias que se producen debido a las contracciones excesivas en el balance general de instituciones financieras que se ven afectadas por una perturbación común (Hanson y otros, 2011), o debido al aumento de la interconectividad (Shin, 2010) ${ }^{17}$. La vigilancia del comportamiento del crédito en el ciclo implica determinar el tipo de vínculos existentes entre el sector real y el financiero, y además, dentro de estos, los que dan lugar a la reacción excesiva del sistema financiero en las fases descendente y ascendente del ciclo. En este sentido, las políticas macroprudenciales pueden verse como un instrumento de carácter anticíclico para gestionar la demanda agregada no solo en cuanto a su nivel, sino a su composición, es decir, en cuanto a las fuentes sectoriales que expanden y contraen la demanda agregada.

\section{F. Redondear la perspectiva del modelo macroeconómico para el desarrollo en cuanto a las políticas anticíclicas}

El reconocimiento de que la volatilidad es un obstáculo importante a la búsqueda de un crecimiento estable y sostenido implica que las políticas macroeconómicas sólidas y orientadas hacia el desarrollo deben basarse en una política anticíclica adecuada.

17 La regulación macroprudencial debe apreciarse como complemento de la regulación microprudencial, cuyo alcance normativo se limita a cada institución financiera por separado. Las normas que rigen la reglamentación financiera internacional son emitidas por el Comité de Basilea de Supervisión Bancaria. El enfoque del Comité de Basilea sobre la reglamentación se centra en los requisitos de capital para cada institución financiera. Dichos requisitos se establecieron inicialmente en el acuerdo de Basilea I (1998). Este acuerdo fue revisado en 2004, lo que dio lugar al Nuevo Acuerdo de Capital de Basilea, o Basilea II. Recientemente, a raíz de la crisis financiera mundial, se estableció un nuevo acuerdo sobre requisitos de capital, conocido como Basilea III. Según el Comité, Basilea III debe comenzar a aplicarse a partir de 2016 y entrar plenamente en funcionamiento antes de 2019. A diferencia de Basilea I y Basilea II, Basilea III aportó algunos elementos macroprudenciales, incluido un amortiguador anticíclico de capital que se debe activar cuando el crédito se expanda más allá de cierto umbral por encima de su tendencia a largo plazo. No obstante, conviene señalar que la lógica en que se basa el amortiguador anticíclico es la de los auges y depresiones, según la cual las crisis del crédito son consecuencia directa de su propio auge. 
Según la perspectiva tradicional de la macroeconomía para el desarrollo, la esencia de las políticas anticíclicas consiste en gestionar el nivel de la demanda agregada mediante políticas monetarias, cambiarias y fiscales encaminadas a nivelar las fluctuaciones de las variables nominales y reales en los ciclos económicos en torno a las tendencias a largo plazo (CEPAL, 2002, 2004).

Bajo esta perspectiva se reconocen las limitaciones del papel de la política monetaria como instrumento de carácter anticíclico en un contexto de predominio de la balanza de pagos y apertura financiera. Además, una mayor estabilidad nominal, que suele ser el objetivo de la política monetaria, no entraña necesariamente una mayor estabilidad real y financiera.

Dadas las limitaciones de la política monetaria, se hace hincapié en la importancia de la política fiscal como instrumento de carácter anticíclico ${ }^{18}$. La política fiscal anticíclica se entiende como una estrategia centrada en aumentar el espacio fiscal en la fase ascendente del ciclo, durante las expansiones, mediante el aumento del ahorro fiscal y la disminución del endeudamiento externo, a fin de "suavizar las restricciones financieras y aliviar las necesidades de ajuste" (CEPAL, 2004).

En consecuencia, los gobiernos deberían prestar particular atención a la gestión de las expansiones a fin de aumentar la capacidad de ahorro de las economías y, de esa manera, ampliar el margen de acción para la gestión anticíclica en la fase descendente del ciclo. Con este fin, se proponen leyes y reglamentaciones en material fiscal que no se basan en metas a corto plazo, sino en variables a largo plazo o estructurales (como la tendencia de crecimiento) ${ }^{19}$.

A fin de ampliar el espacio para las políticas anticíclicas y aumentar su eficacia, es necesario reglamentar las entradas financieras (de capital).

18 Esta perspectiva contrasta mucho con la economía tradicional, según la cual la política monetaria constituye el principal instrumento de estabilización. A la política fiscal se le atribuye cuando más un papel secundario, aunque en algunos círculos del paradigma dominante se reconoce que puede ser útil en una recesión profunda o cuando la política monetaria deja de cumplir su propósito (como sucede cuando las tasas de política monetaria se aproximan a cero (Blinder, 2006)).

19 Por último, la utilización de variables estructurales como referencias para la formulación de la política fiscal permite que los estabilizadores automáticos tengan un mayor espacio para funcionar. La adopción de leyes y reglamentos en materia de responsabilidad fiscal por parte de algunos países latinoamericanos entre 1990 y 2005, como la Argentina (1999 y 2004), el Brasil (2000), Chile (2000), Colombia (2003), el Ecuador (2002 y 2005), Panamá (2002 y 2004), el Perú (2000 y 2002) y Venezuela (República Bolivariana de) (2003) (las fechas citadas entre paréntesis se refieren a la aprobación de las correspondientes leyes o reglamentos de responsabilidad fiscal), se percibe como un paso positivo en la dirección correcta con miras a lograr una "coherencia dinámica en la política fiscal" (CEPAL, 2004). En todos los casos, las leyes de responsabilidad fiscal incluyen metas numéricas respecto del equilibrio fiscal y el establecimiento de normas de transparencia (Brasil, Chile, Colombia, Ecuador, Panamá y Perú) así como la creación de fondos de estabilización a fin de evitar la prociclicidad de las finanzas públicas y contribuir a la mitigación de las fluctuaciones del ciclo económico (Argentina, Chile, Ecuador, Paraguay y Perú). 
El objetivo principal consiste en reducir la volatilidad de las entradas de capital en la fase ascendente del ciclo y reducir el efecto de la expansión sobre la demanda agregada. La regulación de las entradas de capital también tiene el efecto de amortiguar las apreciaciones de los tipos de cambio nominales y reales que tienen lugar en la fase ascendente del ciclo. Por último, también permite dar un mayor margen de maniobra a la política monetaria y fiscal en el ciclo económico.

Dada la relación existente entre las fluctuaciones a corto plazo, el crecimiento a largo plazo y el desarrollo productivo, los análisis y resultados empíricos que se presentan en este documento añaden otra dimensión a la formulación y aplicación de la política macroeconómica anticíclica.

Como se indica en el presente documento, las políticas anticíclicas (es decir, las políticas relacionadas con la demanda agregada) no son neutrales respecto del comportamiento a largo plazo de las economías. La forma en que se conciben y aplican las políticas anticíclicas -incluidos el contexto y tiempo histórico en el que se implementan y el tipo de instrumentos utilizados - se suma a otros factores que configuran y determinan la tendencia de crecimiento de las economías. De este modo, las economías consiguen crecer en forma sostenible a lo largo del tiempo no solo debido a la existencia de políticas adecuadas en materia de innovación, productividad y diversificación, sino a la aplicación de una política anticíclica adecuada y propicia para el crecimiento.

En el caso de América Latina y el Caribe, la interrelación entre el ciclo y la tendencia se refleja en las características específicas del ciclo que no son propicias a la acumulación y al crecimiento elevado. En este sentido, el factor más importante es que América Latina y el Caribe registra expansiones menos intensas que las de otras regiones $y$, en particular, que las de Asia Oriental y el Pacífico.

Las especificidades del ciclo de América Latina y el Caribe se reflejan en el comportamiento de variables como la productividad y la inversión, que están vinculadas con el desempeño a largo plazo. En el caso particular de América Latina y el Caribe, el comportamiento de estas variables refleja el carácter atenuado de sus expansiones. De hecho, el estudio de las particularidades del ciclo, incluidas las expansiones débiles de la producción y la productividad, puede ser fundamental para explicar, al menos en parte, por qué la región no ha logrado mantener un crecimiento sostenido en forma concomitante con otras regiones $y$, en particular, con Asia Oriental y el Pacífico.

Además de las variables reales, hay factores financieros, en particular, el comportamiento del crédito, que desempeñan un papel importante para explicar la fragilidad de las expansiones y su efecto sobre 
el crecimiento a largo plazo. Concretamente, está demostrado que el crédito es un factor endógeno al desempeño del PIB y que el sistema financiero tiende a amplificar las contracciones al obstaculizar la recuperación y servir de freno a la expansión.

La interrelación entre el ciclo y la tendencia tiene tres implicaciones importantes que se deberían tomar en consideración a fin de delinear una macroeconomía para el desarrollo coherente y debidamente configurada.

Una primera implicación importante derivada del análisis es que la macroeconomía para el desarrollo no puede plantear una dicotomía entre ciclos y tendencias o entre el corto o el largo plazo. Las fluctuaciones a corto plazo definitivamente influyen en los resultados a largo plazo.

Una segunda implicación es que las políticas anticíclicas no deberían concentrarse solamente en reducir las fluctuaciones cíclicas. También deberían afrontar el desafío de modificar las características específicas del ciclo que influyen negativamente en el crecimiento y la estructura productiva de los países de la región.

Esto significa que las políticas anticíclicas no solo deben encauzar el ciclo a través de las variaciones del nivel de la demanda agregada. También deben centrarse en la composición de la demanda agregada. Por una parte, esto conlleva la necesidad de mantener la duración e intensidad de la expansión y evitar que se recurra a la inversión pública como variable de ajuste durante las fluctuaciones cíclicas.

Por otra, implica que los países deberían echar mano al conjunto de instrumentos de regulación macroprudencial, más allá de administrar la cuenta de capitales de la balanza de pagos y aplicar regulaciones financieras anticíclicas, para poder manejar el nivel y la composición de la demanda agregada. De hecho, la supervisión del nivel y composición de la demanda requiere diversos instrumentos, que deberían ser específicos para cada contexto y contingencia. Esto entraña una definición y reflexión sobre el tipo de instrumentos que son adecuados en distintos contextos y escenarios.

\section{Conclusiones}

La región de América Latina y el Caribe se caracteriza por elevados niveles de volatilidad con respecto a sus propios antecedentes y a otras regiones del mundo. Los altos niveles de volatilidad están asociados a una dinámica macroeconómica a corto plazo determinada por las perturbaciones reales y financieras externas (es decir, por el predominio de la balanza de pagos).

La volatilidad constituye un importante obstáculo para un crecimiento a largo plazo y estable. Hace que se reduzca el horizonte de 
planificación de los agentes y que aumente el riesgo, desalienta la inversión productiva y distorsiona los principales precios macroeconómicos. En este sentido, una política macroeconómica sólida y orientada al desarrollo debería basarse en una política anticíclica adecuada.

Según la perspectiva tradicional en que se basa la macroeconomía para el desarrollo, las políticas anticíclicas se refieren a la gestión del nivel de la demanda agregada a fin de nivelar las fluctuaciones de las variables reales y monetarias alrededor de sus tendencias a largo plazo.

En el presente documento se afirma que la macroeconomía para el desarrollo debería dar un alcance más amplio y una profundidad mayor a la macroeconomía anticíclica y que esto no solo requiere ir más allá de la volatilidad, sino hacer explícita la relación entre el ciclo y el crecimiento a largo plazo y la estructura productiva.

Este argumento se basa en tres características estilizadas del ciclo económico de América Latina y el Caribe. En primer lugar, los ciclos de expansión son más breves y menos intensos en América Latina y el Caribe en comparación con otras regiones. En segundo lugar, las fluctuaciones a corto plazo influyen en los resultados a largo plazo a partir de variables reales y financieras. En tercer lugar, el sistema financiero tiende a amplificar las fluctuaciones reales y las recuperaciones reales tienen lugar antes que las del crédito.

Este análisis tiene dos implicaciones importantes en lo que se refiere a la formulación de las políticas anticíclicas. En primer lugar, que la macroeconomía para el desarrollo no debería entrañar una dicotomía entre el corto y el largo plazo.

En segundo lugar, que las políticas anticíclicas no deberían centrarse solamente en la gestión del nivel de la demanda agregada, sino en su composición. Esto implica mantener la expansión en el sector real por medio de la inversión y evitar el uso de esta como palanca de ajuste.

También implica utilizar las políticas macroprudenciales como instrumento de carácter anticíclico para gestionar el nivel y la composición de la demanda agregada. 


\section{Bibliografía}

Arestis, Ph. y M. Sawyer, M. (2009), Path Dependency in Macroeconomics, Nueva York, Palgrave MacMillan.

Banco Mundial (2013), World Development Indicators [base de datos].

Bernanke, B.S., M. Gertler y S. Gilchrist (1999), "The financial accelerator in a quantitative business cycle framework", Handbook of Macroeconomics, J.B. Taylor y M. Woodford, (eds.), vol.1, Amsterdam, Elsevier.

BID (Banco Interamericano de Desarrollo), Latin America and the Caribbean Macro Watch Data Tool [en línea] http://www.iadb.org/research/latinmacrowatch/ lmw.cfm.

Blinder, A. (2006), "The case against the case against discretionary fiscal policy", The Macroeconomics of Fiscal Policy, R.W. Kopcke y otros (eds.), Cambridge, MIT Press.

Borio, C. (2012), "The financial cycle and macroeconomics: What have we learnt?", BIS Working Papers, No 395.

Borio, C., P. Disyatat y M. Juselius (2013), "Rethinking potential output: Embedding information about the financial cycle", BIS Working Paper, N 404.

Bry, G. y C. Boschan (1971), Cyclical Analysis of Time Series: Selected Procedures and Computer Programmes, Nueva York, National Bureau of Economic Research (NBER).

Calvo, G., A. Izquierdo y E. Talvi (2006), "Phoenix miracles in emerging markets: Recovery without credit from systemic financial crises", American Economic Review, vol. 96, N².

CEPAL (Comisión Económica para América Latina y el Caribe) (2012), Cambio estructural para la igualdad: Una visión integrada del desarrollo (LC/G.2524(SES.34/3)), Santiago, Chile.

(2004), Desarrollo productivo en economías abiertas (LC/G.2234(SES.30/3)), Santiago de Chile.

(2002), Globalización y desarrollo (LC/G.2157(SES.29/3)), Santiago de Chile.

Davidson, P. (2011), Post Keynesian Macroeconomic Theory, Nueva York, Edward Elgar.

Drehman, M., C. Borio y K. Tsatsaronis (2012), "Characterizing the financial cycle: don't lose sight of the medium term!", BIS Working Papers, N 380.

Ffrench-Davis, R. (2010), "Macroeconomía para el desarrollo: desde el "financierismo" al "productivismo", Revista CEPAL, No 102 (LC/G.2468-P/E), Santiago de Chile, Comisión Económica para América Latina y el Caribe (CEPAL).

(2006), Reforming Latin America's Economics after Market Fundamentalism, NuevaYork, Palgrave Macmillan.

Hanson, S., y otros (2011), "A macroprudential approach to financial regulation", Journal of Economic Perspectives, vol. 25, $\mathrm{N}^{\mathrm{o}} 1$.

Harding, Don y Adrian Pagan (2002a), "A comparison of two business cycle dating methods", Journal of Economic Dynamics and Control, $\mathrm{N}^{\circ} 27$. (2002b), "Dissecting the cycle: a methodological investigation", Journal of Monetary Economics, No 49.

Kalecki, M. (1968), "Trend and business cycles reconsidered", The Economic Journal, vol. $78, \mathrm{~N}^{\circ} 310$.

Keynes, J.M. (1936), Teoría general de la ocupación, el interés y el dinero, México, D.F., Fondo de Cultura Económica [publicado en 2003]. 
(1936) , The General Theory of Employment, Interest and Money, Nueva York, Harcourt Brace Jovanovish Publishers [publicado en 1964].

Mink, M., J. P.A.M. Jacobs y J. de Haan (2012), "Measuring coherence of output gaps with an application to the euro area", Oxford Economic Papers, vol. 64, No 2 , Oxford University Press.

Minsky, H. (1982), Can "It" Happen Again. Essays on Instability and Finance, Nueva York, M.E. Sharpe. (1986), Stabilizing and Unstable Economy, New Haven, Yale University Press.

Modigliani, F. y M. Miller (1958), "The cost of capital, corporation finance and the theory of investment", American Economic Review, vol. 48, № 3 .

Ocampo, J.A. (2011), "Macroeconomía para el desarrollo: políticas anticíclicas y transformación productiva", Revista CEPAL, N 104 (LC/G.2498-P/E), Santiago de Chile, Comisión Económica para América Latina y el Caribe (CEPAL).

Pagan, A. (2003), "Three views of the business cycles and their implications", presentación en SMU, inédito.

Pérez Caldentey, E. y R. Pineda (2011), “Does Latin America lag behind due to shaper recessions and/or slower recoveries?", MPRA Working Paper, $\mathrm{N}^{\mathrm{O}}$ 25036,University Library of Munich [en línea] http://mpra.ub.unimuenchen.de/25036/.

Pérez Caldentey, E., D. Titelman y P. Carvallo (2013) , “Weak expansions: a distinctive feature of the business cycle in Latin America and the Caribbean", Working Paper, $N^{\circ} 749$, Levy Economics Institute [en línea] http:/ /www.levyinstitute. org/pubs/wp_749.pdf.

Roache, S.K. (2012), "China's impact on world commodity markets", IMF Working Paper (WP/12/115), Washington, D.C., Fondo Monetario Internacional (FMI).

Shin, H. S. (2010), "Financial intermediation and the post-crisis financial system", BIS Working Papers, N 304.

Titelman, D., E. Pérez-Caldentey y R. Minzer (2008), “Una comparación de la dinámica e impactos de los choques de términos de intercambio y financieros en América Latina 1980-2006", serie Financiamiento del Desarrollo, N 203 (LC/L.2907-P), Santiago de Chile, Comisión Económica para América Latina y el Caribe (CEPAL). 
Capítulo VI

\section{Hacia una interpretación robinsoniana de la acumulación del capital en América Latina}

Juan Alberto Fuentes Knight ${ }^{1}$

\section{Introducción}

La implementación de políticas macroeconómicas contracíclicas en numerosos países de América Latina como respuesta a la crisis financiera internacional de 2008-2009 (CEPAL, 2012) coincidió con cierto rescate de las políticas macroeconómicas keynesianas centradas en el corto plazo, aunque no ha ocurrido lo mismo en lo que se refiere a la adopción de políticas inspiradas en enfoques keynesianos o poskeynesianos de largo plazo. Ello es particularmente evidente en el caso de los aportes de Joan Robinson. Se considera que la falta de una formalización matemática del modelo original planteado por Robinson —además de la diversidad de formalizaciones efectuadas por numerosos académicos- constituye uno de sus puntos flacos (Skott, 2004) o una de las razones que han atentado contra su utilización (Backhouse, 2003)².

El autor agradece los inestimables comentarios y sugerencias de Esteban Pérez, así como su autorización para incluir en el anexo las ecuaciones que permiten formalizar el modelo de Joan Robinson en términos de relaciones de equilibrio en el corto plazo. También agradece el enorme apoyo de Giannina López y de Nicole Favreau para recopilar y procesar los datos estadísticos utilizados en este trabajo.

2 A pesar de que Joan Robinson no las favorecía, existen formalizaciones matemáticas de su teoría basadas en interpretaciones neoclásicas, por ejemplo las de Harry Johnson (1960) y Findlay (1963), así como interpretaciones marxistas (Harris, 1975) y poskeynesianas, como 
Esta situación contrasta con los modelos poskeynesianos con cierto grado de formalización matemática, como los de Kalecki (1969) y Kaldor (1957).

Sin embargo, también puede argumentarse que la ausencia de un modelo analítico formalizado y cerrado conduce a interpretaciones más amplias de carácter inductivo, sin necesariamente sacrificar el rigor analítico. Así, la identificación de diversas etapas —edades de crecimiento- basadas en relaciones causales y no de equilibrio pueden contribuir a destacar ciertos rasgos del crecimiento económico latinoamericano que la rigidez de otros modelos sin ninguna flexibilidad analítica impide recoger de manera correcta.

A continuación se presentan los componentes básicos de la teoría del crecimiento de Joan Robinson y se presta especial atención a las diversas edades de crecimiento que identificó, sin olvidar que la bibliografía sobre el desarrollo en general no les ha brindado mucha importancia ${ }^{3}$. En la segunda parte se hace un intento por vincular con la teoría de Robinson ciertos hechos estilizados relativos al crecimiento económico latinoamericano del período 1980-2012, recogidos, en particular, en el Estudio Económico de América Latina y el Caribe, 2013. Así se procura, en una primera aproximación, ayudar a identificar los posibles alcances y las limitaciones de la teoría de Robinson a la luz de ciertas características del crecimiento económico de América Latina.

\section{A. La teoría del crecimiento de Joan Robinson}

\section{Condicionantes de la trayectoria del crecimiento}

\section{a) La relación entre la tasa de acumulación del capital y la tasa de ganancia, y entre la inversión potencial y la inversión esperada}

Para Robinson, el deseo de acumular y la inversión representan el motor del crecimiento económico y, a partir de este precepto, plantea dos tipos de relación entre la inversión - $\mathrm{o}$ tasa de acumulación del capital- $\mathrm{y}$ la tasa de ganancias, con dimensiones temporales diferentes. Por una parte, existe una primera función en la que la tasa de ganancia esperada depende de la inversión: se trata de ganancias derivadas de las inversiones. Es decir, son

\footnotetext{
las de Asimakopulos (1991, capítulo 8) y Backhouse (2003), además de una versión basada en estimaciones empíricas (Lovinsky y Gibson, 2004). Aunque J. Robinson expresó la esencia de sus postulados en The Accumulation of Capital (1956), una versión más acabada y clara, como ella misma reconoció, se encuentra parcialmente recogida en su obra posterior Essays in the Theory of Economic Growth (1963). Las primeras reacciones, en parte negativas, a The Accumulation of Capital y las posteriores respuestas de Robinson se encuentran explicadas en el capítulo 8 de Harcourt y Kerr (2009). Véase también una síntesis del pensamiento de Robinson en Asimakopulos (1984) y una evaluación de sus aportes a la tradición poskeynesiana, en Harcourt (2006).

3 Asimakopulos (1969 y 1991, págs. 179-182) y Kurdas (1991) constituyen las excepciones.
} 
las ganancias que se espera obtener de las inversiones ya realizadas, que se convierten en los ahorros de las empresas y que luego se reinvierten. Por ser fuente de futuras inversiones, estas ganancias imponen un límite máximo al futuro proceso de acumulación de capital. Entonces, se podría argumentar que esta relación entre las ganancias y la inversión, que Lavoie (2009, págs. 108-109) concibe como una función del ahorro y donde el centro de atención es la tasa de ganancia esperada $(r)$, también se refleja en una inversión potencial ${ }^{4}$.

Por otra parte, Robinson también propone una segunda función de inversión de causalidad inversa, pues postula que la tasa de ganancia causa o induce cierta tasa de acumulación $(g)$. Ello se refleja en los planes de inversión que, dependiendo de la tasa de ganancia esperada, se concretarán en inversiones futuras y que de manera más difusa dependen también de las condiciones financieras y de los llamados "espíritus animales", es decir, de las expectativas ${ }^{5}$. La inversión asociada a esta función, que Taylor (2011, pág. 182) denomina la función de los espíritus animales, se podría definir como la inversión esperada ${ }^{6}$.

Las dos funciones pueden dar lugar a situaciones de coincidencia o intersección. Ocurre una situación especial — que Robinson califica como la tasa de acumulación deseada y que Asimakopulos (1991, págs. 175-176) denomina la tasa empresarial de crecimiento o de equilibrio- cuando la tasa de ganancia resultante de la inversión (primera función) coincide con la tasa de inversión que supuestamente producirá dicha tasa de ganancia (segunda función). Constituye la trayectoria de crecimiento ideal, correspondiente a la mítica edad de oro del crecimiento postulada por Robinson. En el anexo I se presentan las ecuaciones que, en condiciones de equilibrio en el corto plazo y con la capacidad instalada, permiten explicar el modelo de Robinson. Sin embargo, pueden evaluarse otras trayectorias de crecimiento, que no necesariamente involucran comparaciones de distintos puntos de equilibrio y que dependen de la relación entre ambos tipos de funciones.

4 Este no es un concepto utilizado por Robinson, pero se lo aprovecha en este trabajo con fines heurísticos.

5 La siguiente cita de Robinson (1963, págs. 37 y 38) ilustra con claridad sus ideas sobre el tema: El capitalismo desarrolla un espíritu de emulación. Sin la pulsión competitiva que lo lleva a crecer, el moderno capitalismo empresarial no podría florecer. Al mismo tiempo, el crecimiento está sujeto a costos y riesgos intrínsecos que lo mantienen acotado dentro de ciertos límites. Para explicar el origen de la propensión a acumular - ya sea poco o mucho-, se deben indagar las características históricas, políticas y psicológicas de la economía en cuestión; pero este tipo de modelo no facilitará nuestra investigación. No obstante, parece razonablemente plausible aseverar que, dadas las características generales de una economía, para sostener una mayor tasa de acumulación se requiere un mayor nivel de ganancias, porque ofrece más probabilidades de éxito y porque facilita el acceso a fuentes de financiamiento. Por ende, a los fines de nuestro modelo, los "espíritus animales" de las empresas se pueden expresar como una función entre el crecimiento del capital productivo deseado y las ganancias esperadas.

6 Tampoco es un concepto utilizado por Robinson. 
La primera función de la inversión de Joan Robinson hace depender la tasa de ganancias de la inversión. En particular, el aporte de Kalecki sostiene que en una economía cerrada donde los trabajadores no ahorran, las ganancias $(P)$ pueden desagregarse, por un lado, en las ganancias consumidas $(C g)$ y, por el otro, en las ganancias invertidas $(I)$, es decir que $P=C g+I$. Al establecer relaciones de causalidad entre estas variables, Kalecki argumentó que era más probable que las decisiones previas relativas al consumo y la inversión determinaran las ganancias futuras (Lavoie, 2009, pág. 86), planteamiento que Robinson reformuló como "las ganancias esperadas resultantes de la inversión", y que puede expresarse con la siguiente ecuación:

(1) $P=\frac{P I}{1-\left(1-S_{P}\right) \beta}$

Se mantiene así una relación positiva entre la inversión bruta (I) y el consumo de las ganancias, en el sentido de que un mayor nivel de consumo e inversión produce mayores ganancias. La propensión de los empresarios a consumir puede expresarse como $\left(1-S_{p}\right) \beta$, donde $\beta$ representa la proporción de las ganancias distribuidas en forma de intereses y dividendos, $\left(1-S_{p}\right)$ es la propensión a consumir las ganancias y $S_{P}$ equivale a la propensión a ahorrar estas ganancias retenidas, pero canalizadas en inversiones? 7 . La expresión $1-\left(1-S_{p}\right) \beta$ constituye, entonces, la propensión a ahorrar las ganancias brutas, que dependen tanto de la proporción de ganancias distribuidas $(\beta)$ como de la proporción de ganancias ahorradas $\left(S_{P}\right)^{8}$.

Una alternativa que diversos autores han utilizado para expresar esta relación de manera más general —denominada la ecuación de Cambridge- es la siguiente:

(2) $r=g / s$

7 En el modelo más sencillo se supone que solamente ahorran los rentistas, que reciben utilidades e intereses, mientras que los trabajadores consumen todos sus ingresos. No obstante, es posible realizar ejercicios más complejos que incluyan el ahorro de los trabajadores y mantengan los mismos resultados siempre que los rentistas tengan una mayor propensión a ahorrar que los trabajadores (Asimakopulos, 1969).

8 Esto se deriva de la ecuación $S=P-C g$, donde las ganancias consumidas $(C g)$ pueden expresarse como $\left(1-S_{P}\right) \beta P$. Por ende, se obtiene $S=P-\left(1-S_{P}\right) \beta P$, fórmula equivalente a $S=P\left(1-\left(1-S_{P}\right) \beta\right)$, a partir de la cual se llega a la ecuación (1). Aquí Robinson presupone la existencia de una economía capitalista competitiva, cerrada y sin gobierno. En el libro Exercises of Economic Analysis (1961) se presenta una primera expresión de la relación entre las ganancias, el ahorro y la inversión. Algunos antecedentes de esta teoría se pueden consultar en Kalecki (1969, capítulos 4 y 9), que plantea que los planes de inversión de las empresas dependen de sus ahorros previos y de las ganancias esperadas. A su vez, los ahorros de las empresas son una proporción de las ganancias producidas por las inversiones en el pasado, mientras que las ganancias esperadas dependen tanto de las inversiones actuales como pasadas (Lavoie, 2009, pág. 86). Robinson sostiene que, a diferencia de Kalecki, su enfoque de la inversión se basa en el crecimiento económico deseado, similar al que Harrod denomina crecimiento garantizado (warranted), más que en el capital deseado (Robinson, 1963, pág. 87). 
Aquí $r$ representa la tasa de ganancia y equivale a $\mathrm{P} / \mathrm{K}$ (donde $\mathrm{K}$ es el capital), $g$ es la tasa de acumulación de capital (equivalente a I/K), y $s$ representa la propensión a ahorrar'.

En términos más precisos, esto significa que una menor propensión a consumir o una mayor propensión a ahorrar daría lugar a una menor tasa de ganancia resultante de una determinada tasa de acumulación de capital ${ }^{10}$. Al combinar esta función (la inversión potencial) con la otra función que hace depender la inversión de la tasa de ganancia esperada, de expectativas y de condiciones financieras (la inversión esperada), se deduce que un mayor consumo o un menor ahorro estarían asociados a una mayor inversión. Estos argumentos corresponden a la idea planteada por Robinson como la paradoja fundamental de proyectar el análisis keynesiano en el largo plazo (Robinson, 1963, pág. 60), puesto que va en contra de la tesis neoclásica de que un mayor ahorro genera mayores inversiones.

Sin embargo, Robinson (pág. 61) también reconoce la posible existencia de una relación de doble vía entre la acumulación de capital y el ahorro, postulado que no se ve necesariamente reflejado en las ecuaciones más sencillas que han procurado explicar su modelo. Entonces, resulta que así como una menor propensión al ahorro estaría asociada a una mayor tasa de acumulación de capital, una mayor tasa de acumulación también pueden traer aparejada una mayor propensión a ahorrar, pues obligaría a reinvertir las ganancias en vez de distribuirlas como dividendos o intereses, que serían consumidos.

Este sería un ejemplo de cómo la dinámica de la inversión conduce a un ajuste y a un aumento del ahorro y de cómo la segunda función (la inversión esperada), que hace depender la tasa de acumulación de la tasa de ganancia y que está sujeta a inciertos espíritus animales, puede alterar la primera función, centrada en la relación entre la inversión, la ganancia y el ahorro (la inversión potencial, expresada como $r=g / s$ ). También ejemplifica cómo el proceso de acumulación de capital (con una inversión esperada mayor a la potencial) puede modificar la distribución del ingreso de manera indirecta, en este caso por la vía del consumo postergado de quienes reciben dividendos o intereses. Esta idea refleja una perspectiva keynesiana de la relación entre la inversión y el ahorro: la equivalencia ex post entre el ahorro y la inversión implicaría la necesidad de ajustes previos para que la inversión esperada pudiera ser cubierta por suficiente ahorro.

Ante la intención de acelerar la acumulación de capital, se podría concebir una situación equivalente mediante una caída del consumo y de

La equivalencia entre las dos ecuaciones se logra al dividir ambos miembros de la ecuación por K y expresar el denominador de la parte derecha de (1) como $s$.

10 En las versiones más sencillas de este enfoque solamente ahorran los capitalistas; por ende, lo que no llegan a consumir determina el patrón de ahorro de la economía en su conjunto. 
los salarios reales de los trabajadores por la vía de la inflación con el fin de producir las ganancias adicionales que se deben reinvertir. Lo mismo puede ocurrir si aumenta o disminuye el consumo de las ganancias, que podría compensarse con una reducción o un incremento de los salarios reales. Robinson argumenta que la búsqueda de menores salarios reales podría verse frustrada ante la existencia de sindicatos que defiendan el poder de compra de los trabajadores mediante un aumento inflacionario de los salarios nominales, medida que constituye una barrera inflacionaria que impediría aumentar la tasa de ganancias (Robinson, 1963, págs. 58-59). En general, no solo es posible ajustar la distribución de los ingresos entre los trabajadores y los demás integrantes de la población para facilitar o impedir la acumulación de capital, sino que también se puede modificar la propensión a consumir o a ahorrar las ganancias (en el modelo más sencillo donde los trabajadores consumen todos sus ingresos).

\section{b) La relación entre el crecimiento del producto, el empleo y el progreso técnico}

Más allá de la situación de equilibrio en el corto plazo durante el cual está dada la capacidad instalada y el progreso técnico calificado se considera neutral, a diferencia de la teoría del crecimiento de Harrod, en el enfoque de Robinson el proceso de acumulación puede afectar la naturaleza del progreso técnico, sin que sea exógeno ${ }^{11}$. Es fomentado por la competencia y la relativa escasez o abundancia de mano de obra puede estimular la adopción de técnicas de producción más o menos mecanizadas, aunque no de manera mecánica o determinista. Esto se torna particularmente evidente cuando se reconoce la existencia de innovaciones que se dan de manera autónoma (Robinson, 1963, págs. 36 y 51-52).

A su vez, la naturaleza del progreso técnico se refleja en la evolución de la productividad laboral que, junto con el crecimiento del empleo, determinan el crecimiento del producto, tal como se observa en la siguiente ecuación, donde representa el crecimiento del producto, es el crecimiento de la productividad y equivale al crecimiento del empleo:

(3) $g_{y}=g_{d}+g_{l}$

Asimismo, la evolución del progreso técnico y el crecimiento de la población - la oferta de mano de obra $(n)$ - determinan la tasa de crecimiento posible, a diferencia de la tasa de crecimiento deseado o de equilibrio planteada anteriormente. Así, mientras que en la situación ideal de crecimiento deseado cabe esperar que se mantenga una situación de pleno empleo mediante un

11 En este contexto, el progreso técnico mejora la relación entre el producto y el empleo sin alterar la relación entre el capital y el producto, la cual resultaría neutral según la definición de progreso técnico de Harrod (Asimakopulos, 1969). 
desarrollo que asegure la equivalencia entre el crecimiento del empleo y el crecimiento de la población (en edad de trabajar), con lo cual, otras trayectorias darían lugar a situaciones diversas con puntos de partida (desempleo) diferentes. Esta idea se puede expresar con la siguiente fórmula ${ }^{12}$ :

(4) $g_{u}=n-\left(g_{y}-g_{d}\right)$

En este caso, el cambio en la tasa de desempleo $\left(g_{u}\right)$ depende de la brecha entre el crecimiento de la población en edad de trabajar $(n)$ y la generación de empleo $\left(g_{l}\right)$, que, a su vez, depende de la diferencia entre el crecimiento del producto y el de la productividad laboral $\left(g_{y}-g_{d}\right)$, obtenida de la ecuación (3). La existencia de desempleo en el largo plazo es una de las características del análisis de Robinson que lo distingue de otros enfoques poskeynesianos, como el de Kaldor.

\section{c) Las estructuras institucionales: las relaciones (antagónicas) entre las clases y su incidencia en la distribución del ingreso}

Robinson incluye en su modelo aspectos institucionales atinentes a las relaciones entre los trabajadores y los capitalistas. También plantea tanto situaciones de armonía en algunos escenarios, sin incidencia sindical alguna, como situaciones de conflicto o negociación donde existen organizaciones obreras capaces de incidir en la fijación de los salarios. En particular, Robinson aborda dos tipos de situaciones que pueden repercutir en las variaciones salariales y traer aparejadas consecuencias para la tasa de acumulación de capital (Asimakopulos, 1976). La primera se da cuando existe una demanda laboral excedentaria que, al conducir a aumentos salariales, restringe la tasa de crecimiento, aspecto que se puede compensar en parte mediante una creciente mecanización e incorporación de innovaciones técnicas, lo cual aumentaría la tasa de crecimiento posible de la economía ${ }^{13}$.

La segunda situación ocurre cuando el incremento de la tasa de acumulación (o del consumo de las ganancias) ejerce presión para bajar los salarios reales a niveles que los trabajadores no están dispuestos a aceptar y que en presencia de un poder sindical daría lugar a la barrera inflacionaria explicada en las secciones anteriores. Puede surgir una variante de esta situación cuando el salario real está a un nivel apenas tolerable que no puede reducirse más, por lo que también impone límites a la tasa de acumulación, aunque no necesariamente por la vía de la barrera

Véase una explicación similar en Backhouse (2003).

13 En un contexto donde la inversión esperada es mayor a la potencial —es decir, caracterizada por la prevalencia de un aguerrido instinto animal-, Robinson supone que el ajuste entre la inversión actual y el ahorro pasado se cubre mediante los créditos del sistema bancario. En una economía que se acerca al pleno empleo y donde aumentan la oferta de crédito, la inflación y la tasa de interés, una tasa de interés real más alta puede restringir el proceso de acumulación (Backhouse, 2003; Robinson, 1971, pág. 74). 
inflacionaria. Esta variante difiere de aquella donde la causalidad es inversa, en el sentido de que la acotada tasa de acumulación mantiene el nivel de vida al mínimo (Robinson, 1963, pág. 59).

\section{Las edades de crecimiento}

\section{a) Las edades de crecimiento constante o variable}

Aunque la teoría de Robinson tomó como línea de partida el análisis comparativo de puntos de equilibrio en el corto plazo - reflejados en una caracterización del crecimiento que postula una edad de oro donde se cumplen diversas condiciones ideales-, reviste particular utilidad su explicación sobre las trayectorias alternativas. Estas incorporan variaciones de la edad de oro, además de las edades de platino, que no se basan en la comparación de puntos de equilibrio, sino en procesos de cambio más análogos a situaciones hipotéticas. Además, Robinson clasifica las edades de acuerdo con su tasa de crecimiento, que sería constante en las edades de oro, y creciente o decreciente en las de platino. Las edades de oro se inscriben en la tradición poskeynesiana, representada sobre todo por Kaldor y Pasinetti, y se centran en trayectorias de tasas constantes de crecimiento, mientras que las de platino abren perspectivas - aunque incipientes- para modelos donde los desequilibrios son mayores. Los rasgos básicos de estas edades se resumen en el cuadro VI.1 y se describen a continuación.

\section{Cuadro VI.1}

Rasgos básicos de las edades de crecimiento según Joan Robinson

\begin{tabular}{|c|c|c|c|c|c|}
\hline Edad & $\begin{array}{l}\text { Condiciones } \\
\text { iniciales }\end{array}$ & $\begin{array}{l}\text { Relación } \\
\text { entre inversión } \\
\text { potencial (A) } \\
\text { y esperada (I) }\end{array}$ & $\begin{array}{l}\text { Relación entre } \\
\text { crecimiento del } \\
\text { producto }\left(g_{\gamma}\right) \text {, } \\
\text { empleo, }\left(g_{l}\right) \\
\text { población }(n) \text { y } \\
\text { productividad }\left(g_{d}\right)\end{array}$ & $\begin{array}{l}\text { Ahorro, } \\
\text { ganancia, } \\
\text { consumo, } \\
\text { salarios e } \\
\text { inversión }\end{array}$ & Comentarios \\
\hline $\begin{array}{l}\text { Edad } \\
\text { de oro }\end{array}$ & $\begin{array}{l}\text { Pleno empleo. } \\
\text { Armonía } \\
\text { laboral. }\end{array}$ & $\mathrm{I}=\mathrm{A}$ & $\begin{array}{l}g_{y}=g_{d}+g_{l} \\
g_{1}=n\end{array}$ & $\begin{array}{l}\text { La mayor } \\
\text { inversión está } \\
\text { asociada a un } \\
\text { menor ahorro } \\
\text { (paradoja } \\
\text { keynesiana) y un } \\
\text { mayor margen } \\
\text { de ganancia. }\end{array}$ & $\begin{array}{l}\text { Persiste el } \\
\text { equilibrio. }\end{array}$ \\
\hline $\begin{array}{l}\text { Edad } \\
\text { de oro } \\
\text { lánguida }\end{array}$ & $\begin{array}{l}\text { Existe } \\
\text { desempleo. } \\
\text { Armonía } \\
\text { laboral. }\end{array}$ & $\mathrm{I} \leq \mathrm{A}$ & $\begin{array}{l}g_{y}=g_{d}+g_{l} \\
g_{l}>n, \text { con lo cual } \\
\text { se reduce el } \\
\text { desempleo }\end{array}$ & $\begin{array}{l}\text { La redistribución } \\
\text { de los rentistas a } \\
\text { los desempleados } \\
\text { podría aumentar } \\
\text { la inversión } \\
\text { y el empleo. }\end{array}$ & $\begin{array}{l}\text { Persiste el } \\
\text { equilibrio, pero } \\
\text { con desempleo. }\end{array}$ \\
\hline $\begin{array}{l}\text { Edad } \\
\text { de plomo }\end{array}$ & $\begin{array}{l}\text { Existe } \\
\text { desempleo. }\end{array}$ & $\begin{array}{l}\mathrm{I}<\mathrm{A} \\
\text { Espíritus } \\
\text { animales } \\
\text { débiles. }\end{array}$ & $\begin{array}{l}g_{y}=g_{l} \\
\text { Ya que } g_{d}=0 \\
g_{l}<n \text {, con lo cual el } \\
\text { desempleo aumenta. }\end{array}$ & & $\begin{array}{l}\text { La población }(n) \\
\text { se ajusta } \\
\text { al empleo }\left(g_{1}\right) \text {, } \\
\text { pero los salarios } \\
\text { no aumentan. }\end{array}$ \\
\hline
\end{tabular}


Cuadro Vl.1(conclusión)

\begin{tabular}{|c|c|c|c|c|c|}
\hline Edad & $\begin{array}{l}\text { Condiciones } \\
\text { iniciales }\end{array}$ & $\begin{array}{l}\text { Relación } \\
\text { entre inversión } \\
\text { potencial (A) } \\
\text { y esperada (I) }\end{array}$ & $\begin{array}{l}\text { Relación entre } \\
\text { crecimiento del } \\
\text { producto }\left(g_{\gamma}\right) \text {, } \\
\text { empleo, }\left(g_{l}\right) \\
\text { población }(n) \text { y } \\
\text { productividad }\left(g_{d}\right)\end{array}$ & $\begin{array}{l}\text { Ahorro, } \\
\text { ganancia, } \\
\text { consumo, } \\
\text { salarios e } \\
\text { inversión }\end{array}$ & Comentarios \\
\hline $\begin{array}{l}\text { Edad } \\
\text { de oro } \\
\text { restringida }\end{array}$ & Pleno empleo. & $\begin{array}{l}\text { I }>\text { A } \\
\text { Fuertes } \\
\text { espíritus } \\
\text { animales. }\end{array}$ & $\begin{array}{l}g_{y}=g_{l}+g_{d} \\
g_{l>} n\end{array}$ & $\begin{array}{l}\text { Una situación } \\
\text { de mayor ahorro } \\
\text { podría conducir } \\
\text { a que I = A, } \\
\text { mediante una } \\
\text { I menor. }\end{array}$ & $\begin{array}{l}\text { El ajuste hacia } \\
g_{l}=n \text { se da } \\
\text { mediante } \\
\text { la suba } \\
\text { (improbable) de } \\
\text { la tasa de interés } \\
\text { o mediante } \\
\text { un acuerdo } \\
\text { empresarial } \\
\text { destinado a } \\
\text { reducir las } \\
\text { presiones } \\
\text { salariales. } \\
\text { Inestabilidad en } \\
\text { el corto plazo. }\end{array}$ \\
\hline $\begin{array}{l}\text { Edad } \\
\text { de oro } \\
\text { bastarda }\end{array}$ & $\begin{array}{l}\text { Existe } \\
\text { desempleo. } \\
\text { Existe } \\
\text { antagonismo } \\
\text { entre las } \\
\text { clases y } \\
\text { poder sindical. }\end{array}$ & $\mathrm{I}>\mathrm{A}$ & $\begin{array}{l}g_{y}=g_{l}+g_{d} \\
g_{l \gtrless} n \\
\text { Puede existir una } \\
\text { tendencia a que el } \\
\text { desempleo crezca } \\
\text { o mengüe el valor } \\
\text { de } g_{y}\end{array}$ & $\begin{array}{l}\text { Un menor } \\
\text { (mayor) } \\
\text { consumo } \\
\text { (ahorro) podría } \\
\text { compensar } \\
\text { los mayores } \\
\text { salarios. }\end{array}$ & $\begin{array}{l}\text { La presión por } \\
\text { aumentar los } \\
\text { salarios de parte } \\
\text { de los sindicatos } \\
\text { conduce a una } \\
\text { mayor inflación } \\
\text { (barrera de } \\
\text { inflación) que } \\
\text { restringe la } \\
\text { acumulación. }\end{array}$ \\
\hline $\begin{array}{l}\text { Edad } \\
\text { de platino } \\
\text { galopante }\end{array}$ & $\begin{array}{l}\text { Existe } \\
\text { desempleo. } \\
\text { Problemas con } \\
\text { la composición } \\
\text { del capital: } \\
\text { bienes } \\
\text { de capital } \\
\text { insuficientes } \\
\text { para producir } \\
\text { otros bienes } \\
\text { de capital. } \\
\text { Existe poder } \\
\text { sindical y } \\
\text { antagonismo. }\end{array}$ & $\begin{array}{l}\text { I }>\text { A } \\
\text { Fuertes } \\
\text { espíritus } \\
\text { animales. }\end{array}$ & $\begin{array}{l}g_{y}=g_{l}+g_{d} \\
g_{l>} n\end{array}$ & $\begin{array}{l}\text { Una mayor } \\
\text { inversión está } \\
\text { asociada a } \\
\text { una mayor } \\
\text { proporción } \\
\text { de ganancias } \\
\text { y una menor } \\
\text { proporción } \\
\text { de salarios. }\end{array}$ & $\begin{array}{l}\text { El ajuste puede } \\
\text { deberse a } \\
\text { barreras de } \\
\text { inflación, } \\
\text { el pleno empleo } \\
\text { o porque se } \\
\text { llega a la } \\
\text { proporción } \\
\text { adecuada } \\
\text { de capital. }\end{array}$ \\
\hline $\begin{array}{l}\text { Edad } \\
\text { de platino } \\
\text { incipiente }\end{array}$ & $\begin{array}{l}\text { Pleno empleo } \\
\text { Problemas con } \\
\text { la composición } \\
\text { del capital: } \\
\text { exceso de } \\
\text { inversiones en } \\
\text { la producción } \\
\text { de bienes } \\
\text { de capital } \\
\text { destinados a la } \\
\text { elaboración de } \\
\text { otros bienes } \\
\text { de capital. }\end{array}$ & $\mathrm{I}>\mathrm{A}$ & $\begin{array}{l}g_{y}=g_{l}+g_{d} \\
g_{l>} n\end{array}$ & & $\begin{array}{l}\text { El ajuste puede } \\
\text { conducir a una } \\
\text { edad de oro } \\
\text { restringida, pero } \\
\text { con mayores } \\
\text { posibilidades } \\
\text { de desequilibrio. }\end{array}$ \\
\hline
\end{tabular}

Fuente: Joan Robinson, Essays in the Theory of Economic Growth, Londres, Macmillan, 1963; Athanasios Asimakopulos, Keynes's General Theory and Accumulation, Cambridge, Cambridge University Press, 1991; y "A Robinsonian growth model in one-sector notation", Australian Economic Papers, № 8, 1969. 


\section{i) La edad de oro}

La trayectoria inicial de referencia de Robinson es la edad de oro, no por su pretendida validez, sino porque pone de relieve las condiciones que tendrían que darse para lograr una tasa de crecimiento alta y estable en condiciones de pleno empleo. En esta edad, que Robinson considera mítica, el aumento de la inversión esperada (asociada a los espíritus animales) coincide con el de la inversión posible (resultante de las ganancias). El capital tiene la composición adecuada para ajustarse a la tasa de equilibrio de la acumulación deseada, derivada de la coincidencia entre la inversión posible y la inversión esperada. Ello da lugar a una trayectoria de crecimiento del producto donde, a partir de una situación de pleno empleo, el crecimiento de la ocupación coincide con el crecimiento de la población (n) $\mathrm{y}$, basados en un supuesto de progreso técnico neutro, los salarios reales aumentan en la misma proporción que la productividad laboral, la tasa de ganancia permanece constante y prevalece la armonía laboral. La flexibilidad de los precios, surgidos de mercados competitivos, permite que se ajuste la demanda para impedir un aumento de la capacidad instalada no utilizada, que crece al mismo ritmo que la economía ${ }^{14}$.

\section{ii) La edad de oro lánguida}

En la edad de oro lánguida, la inversión esperada y la inversión potencial tienden a coincidir y se mantiene una tasa de crecimiento constante, pero el punto de partida se caracteriza por la existencia de desempleo, que distingue esta edad de la de oro propiamente dicha. No obstante, el desempleo no está asociado a una insuficiente demanda agregada - desempleo keynesiano-, sino que tendría una naturaleza que Robinson califica como crónica y que sería el resultado de un crecimiento restringido de la capacidad productiva en el pasado (Robinson, 1961, pág. 102). En esta edad, el crecimiento del producto continúa dependiendo de la productividad laboral y del aumento del empleo, impulsados por la acumulación de capital y, en la medida en que el crecimiento del empleo sea mayor al crecimiento de la población, habrá una tendencia a que el desempleo mengüe y tienda hacia el pleno empleo. Ocurrirá lo contrario si el proceso de acumulación conlleva una tasa de crecimiento del empleo menor al crecimiento de la población, con lo cual descenderá el nivel de empleo.

Robinson identifica tres reacciones que pueden conducir a una merma del desempleo: una mayor tasa de acumulación, una menor mecanización y la transferencia voluntaria (puesto que supone que no existe gobierno) de los recursos de los rentistas a las familias de los desempleados (Robinson,

14 Ello supone una situación de competencia. El modelo de Robinson también puede ajustarse ante la existencia de una competencia imperfecta, con diferentes grados de utilización de la capacidad instalada, tal como se explica en las próximas secciones. 
1961, págs. 102-103). No encuentra razones particulares para que en una economía capitalista se dé espontáneamente el primer proceso donde sube la tasa de acumulación. Tampoco halla motivos de optimismo respecto del segundo tipo de reacción: argumenta que, si bien pueden existir incentivos para reducir el grado de mecanización debido a la baja salarial causada por el desempleo, el cambio en el uso de las técnicas que ello involucra puede resultar tan problemático para las empresas como invertir en técnicas de producción superiores. Además, sería extraño que este cambio ocurriera en un contexto que pone de manifiesto la existencia de empresas poco ágiles incapaces de asegurar el crecimiento potencial de la economía.

Robinson parece tener una apreciación más favorable del tercer tipo de reacción, que equivale a una política fiscal de redistribución de ingresos. Al transferir recursos de quienes tienen una menor propensión a consumir (rentistas) a otros sectores con una mayor propensión (familias de desempleados), la demanda agregada experimentaría un alza y traería aparejados dos efectos: aumentaría los precios - lo que reduciría los salarios reales de los trabajadores-, pero también constituiría un incentivo para atraer inversiones y, a su vez, ayudaría a combatir el desempleo (Robinson, 1961, pág. 104).

\section{iii) La edad de plomo}

Un resultado más drástico se alcanza en la edad de plomo - una variación perversa de la edad de oro lánguida-, que ilustra el efecto combinado del desempleo y de la ausencia de progreso técnico, originados en una insuficiente acumulación de capital. En este caso la inversión esperada, asociada a los espíritus animales, está por debajo de la inversión posible, probablemente como resultado de una clase empresarial poco dinámica o que enfrenta expectativas muy inciertas ${ }^{15}$. La acotada acumulación de capital no favorece la incorporación de avances técnicos, con lo cual la productividad laboral no aumenta y el empleo crece a un ritmo lento, menor que la tasa de crecimiento de la población. En estas circunstancias, se contraen el mercado laboral y los salarios debido a una oferta laboral excedentaria, por lo que Robinson plantea, desde una óptica maltusiana, que en esta trayectoria la tasa de crecimiento de la población se tendría que ajustar a la tasa de crecimiento del empleo ${ }^{16}$.

15 En la obra Exercise in Economic Analysis (1961, pág. 107), Robinson plantea que la causa del laxismo observado en las empresas tal vez se deba a que los riesgos son demasiado grandes, que resulta difícil obtener financiamiento o que los empresarios han dejado de esforzarse por alcanzar la competitividad y que ahora llevan adelante una política destinada a vivir y dejar vivir.

16 Una interpretación menos radical del ajuste demográfico sería que ocurriera por la vía de la emigración. Véase en Galor (2011, págs. 9-17) una caracterización muy precisa, basada en hechos históricos, de un crecimiento con ajustes poblacionales, que permiten considerarla una etapa de crecimiento maltusiano similar a la edad de plomo postulada por Robinson. 


\section{iv) La edad de oro restringida}

La edad de oro restringida es el resultado de un proceso de acumulación en que la inversión esperada es mayor a la posible, con expectativas -o espíritus animales- que favorecen un nivel de inversión superior al que resulta factible (una tasa de acumulación que lleva a un crecimiento del empleo mayor a la tasa de crecimiento de la población). Surgen entonces fuerzas que continuamente tienden a reducir la acumulación de capital a un nivel congruente con la expansión que permite el crecimiento del empleo, a partir de una situación donde ya se ha alcanzado el pleno empleo.

Según Robinson, existen dos posibles fuentes que restringen la tasa de acumulación para contribuir a la convergencia de la tasa esperada y la tasa posible de acumulación de capital. Por una parte, es posible que la tasa de interés suba en un contexto donde se incrementa la demanda de crédito y la inflación, a raíz de los aumentos salariales causados por la creciente demanda de puestos de trabajo ante una situación de pleno empleo. En este caso, la tasa de interés tendría que subir hasta llegar a frenar la inversión, aunque Robinson expresa un profundo escepticismo sobre la posibilidad de que la política monetaria pueda controlar la inversión mediante las tasas de interés, sobre todo en contextos donde la política monetaria está condicionada por la balanza de pagos y los tipos de cambio (Robinson, 1963, pág. 43) ${ }^{17}$.

La otra forma de lograr una convergencia entre la inversión potencial y la inversión esperada radica en una decisión colectiva de las empresas, que podrían ejercer un monopsonio en el mercado laboral para disminuir la tasa de acumulación y evitar así competir por más trabajadores - por la vía de los incrementos salariales - ante la posible amenaza de que suban los salarios. Esta situación estimularía las inversiones en técnicas de producción más mecanizadas, que restringirían la tasa de ganancia hasta bajar la tasa de acumulación de capital, aunque también aumentarían la tasa de crecimiento posible de la economía (Asimakopulos, 1976). De lo contrario, cada empresa podría realizar inversiones y subutilizar su capacidad instalada, lo que también haría menguar su tasa de ganancia y, luego, el crecimiento de las inversiones. Cualquiera de estas condicionantes podría causar tensiones y una probable trayectoria de inestabilidad en el corto plazo (Robinson, 1963, págs. 55-56).

Sin intervención de gobierno, el aumento del crédito sería endógeno (sin una oferta monetaria dada, como suponen los enfoques monetarios ortodoxos), pero se adecuaría para facilitar el proceso de acumulación con tasas de interés suficientemente bajas y así no propiciar el surgimiento de hiperinflaciones. Robinson reconoce que se trata de un proceso incierto que no está exento de errores. Véase este enfoque en particular en Backhouse (2003). 


\section{v) La edad de oro bastarda}

Una variante de la edad de oro restringida es la edad de oro bastarda, que ilustra cómo los salarios reales altos, no asociados a una escasez de mano de obra, restringen el proceso de acumulación. El punto de partida es una situación donde el desempleo coincide con un panorama institucional caracterizado por sindicatos capaces de evitar que los salarios reales se desplomen por debajo del nivel inferior requerido para asegurar una elevada tasa de acumulación de capital y una mayor creación de empleo. Esta capacidad sindical se reflejaría en salarios monetarios crecientes, por lo que el proceso de acumulación se toparía con una barrera de inflación, traducida en una restricción financiera. Aunque la tasa de acumulación sea menor a la que podría alcanzarse sin esta barrera, la tasa de empleo igualmente podría crecer y, según sea superior o inferior al crecimiento de la población, tal vez contribuiría a reducir el desempleo.

Las expectativas de creciente inflación y mayores salarios pueden fomentar aun más la inflación por dos vías que propiciarían un incremento del gasto. La primera es que, ante las expectativas de mayores precios, se intensificará la propensión de los rentistas a consumir sus ganancias, sobre todo mediante la compra de bienes duraderos, y la segunda sostiene que quizá se aceleren los planes de inversión, dadas las expectativas de mayores salarios (Robinson, 1963, pág. 72).

Robinson postula dos variantes de la edad de oro bastarda: una con elevados niveles salariales gracias a la acción sindical y una edad de oro bastarda de bajo nivel, en la que el salario real que restringe el proceso de acumulación se encuentra en el mínimo tolerable. Robinson agrega, por ejemplo, que ante estos salarios característicos de un nivel de subsistencia, un alza en el precio de los alimentos puede obligar a los empleadores a ofrecer mayores salarios monetarios para garantizar la supervivencia de sus trabajadores (pág. 70). Esta variante de la edad de oro bastarda de bajo nivel se asemeja a la edad de plomo en el sentido de que en la primera el nivel mínimo de vida restringe el proceso de acumulación, mientras que en la de plomo el proceso de acumulación mantiene el nivel de vida a un mínimo (Robinson, 1963, pág. 59).

Se podría atenuar el efecto negativo de los salarios en la tasa de acumulación mediante una menor propensión al consumo de las ganancias (o, en otras palabras, una mayor propensión al ahorro). Ello compensaría la menor tasa de ganancias que resulta de salarios mayores y entonces favorecería una mayor tasa de acumulación del capital y una mayor disminución del desempleo.

\section{vi) La edad de platino galopante}

La edad de platino galopante se caracteriza por espíritus animales muy favorable que acelera la tasa de acumulación, coyuntura que exacerba la brecha 
entre la inversión esperada y la inversión posible y que se debe a un problema en la composición del capita ${ }^{18}$. A diferencia de la inversión destinada a producir bienes de consumo, la inversión no basta para elaborar suficientes bienes de capital que permitan manufacturar otros bienes del mismo tipo (Robinson, 1963, pág. 56), lo cual trae aparejado un crecimiento menor al que se obtendría con un proceso continuo de ajuste que garantizara que la composición de los bienes de capital producidos fuera la adecuada ${ }^{19}$. Además y a diferencia de la edad de oro restringida, la inversión potencial se ajusta a la esperada, con un aumento de la tasa de ganancias y una reducción del salario real, y con una mayor tasa de crecimiento del empleo, factores que posibilitan producir más bienes de capital destinados a la manufactura de otros bienes del mismo tipo. Esta trayectoria de crecimiento podría detenerse cuando se alcance el pleno empleo o los salarios reales se eleven demasiado (barrera de inflación), o bien podría continuar hasta que la proporción de bienes de capital entre el sector de consumo y el de inversión llegue a la proporción requerida para lograr el nivel deseado de acumulación. Esto ilustra una vez más cómo la conjunción de ciertas condiciones iniciales - pleno empleo o desempleo, acuerdos institucionales y la composición de la producción de bienes de capital- puede dar lugar a escenarios diferentes de los de la edad de oro.

\section{vii) La edad de platino incipiente}

La edad de platino incipiente se diferencia de la galopante por el hecho de que ha habido inversiones excesivas en la producción de bienes de capital con el objeto de elaborar otros bienes de esta clase, porque se alcanzó el pleno empleo, y porque la tasa de acumulación llegó al tope máximo y ya se está desacelerando, aun cuando la tasa de inversión esperada siga siendo mayor a la posible. En estas condiciones, la tasa de crecimiento de la población (mano de obra disponible) es menor a la tasa de crecimiento del empleo demandado por el sector productor de bienes de capital. Al igual que en el caso de la edad de oro restringida, Robinson introduce la posibilidad de subir la tasa de interés para reducir la tasa de acumulación, lo que disminuye la tasa de ganancias y permite concebir una nueva trayectoria de ajuste. Esta situación incluye el traspaso de los trabajadores del sector productor de bienes de capital al de bienes de consumo, una mecanización creciente que permite mantener tasas de ganancia y salarios reales constantes, y una merma gradual de la tasa de acumulación hasta alcanzar un escenario similar al de la edad de oro restringida, pero con la amenaza de posibles desequilibrios de corto plazo.

18 Asimakopulos (1969) prefiere simplificar el modelo de crecimiento de Robinson y acotarlo solamente a un sector, sin distinguir entre un sector de bienes de capital que produce bienes de consumo y otro que produce bienes de capital. Así, supone que en las edades de platino el capital está sujeto a restricciones físicas que tal vez limitan la inversión. Asimakopulos (1991, pág. 182) retoma el análisis de dos sectores pertinentes.

19 Esto entraña mantener determinada relación entre los bienes de capital a partir de los cuales se manufacturan otros bienes de capital y aquellos utilizados para producir bienes de consumo (Robinson, 1963, pág. 56). 


\section{Algunas ampliaciones de la teoría de Robinson}

La extensión del enfoque de Robinson a fin de analizar la acumulación y el crecimiento en América Latina se puede facilitar mediante algunas ampliaciones, especialmente para tomar en cuenta la importancia del sector externo. Lovinsky y Gibson (2004) lo hicieron combinando el enfoque de Robinson con la teoría keynesiana para economías abiertas, método que les permitió integrar el ahorro externo que cubre el déficit de la cuenta corriente con el déficit del sector público y el pago de los intereses que supone la creación de deuda pública. Como resultado y después de cierto procesamiento matemático, ajustaron la ecuación de Cambridge para que tome en cuenta los efectos del ahorro externo, el déficit del sector público y los intereses asociados al pago de la deuda. Por consiguiente, la ecuación (2) adquiere el siguiente formato:

(5) $g=s \bar{r}+\left(s j+p^{*}-p\right) q u$

En esta ecuación, $g$ es la tasa de acumulación y $s$ constituye la propensión a ahorrar, mientras que $\bar{r}$ representa las ganancias después del pago de impuestos; $j$, los intereses pagados a los tenedores de deuda pública; $p^{*}$, el coeficiente de ahorro externo (como una proporción del producto); $p$, el déficit del sector público; $u$, el grado de utilización de la capacidad instalada - definida por la relación entre el producto actual y el producto potencial (Q) - ; y q, la razón entre $\mathrm{Q}$ y el capital (K). Al multiplicar $q$ por $u$, queda fuera $Q$, con lo cual el segundo término de la ecuación se convierte en la proporción de ahorro neto adicional resultante de la cuenta corriente (ahorro externo), ajustado por el déficit fiscal y el pago de intereses, $y$ multiplicado por $\mathrm{X} / \mathrm{K}$ (el producto generado por unidad de capital).

Ello básicamente significa que el ahorro externo puede sumarse al ahorro nacional y que su efecto aumentará o disminuirá dependiendo del menor o mayor déficit fiscal. Al expresar la misma ecuación en términos de las ganancias $(r)$ como una variable dependiente, esta tendrá una relación (paradójicamente) negativa con el ahorro (interno y externo) y positiva con el déficit fiscal, lo que resulta congruente con la proyección de la teoría keynesiana a largo plazo.

Si se interpreta el enfoque de Robinson sobre la base de esta ampliación, se concluye que la versión ajustada de la primera función de la inversión o inversión potencial tendría que combinarse con la inversión esperada - dependiente de los rendimientos esperados-, las condiciones financieras y las expectativas (espíritus animales). Al introducir el ahorro externo como una variable, al menos parcialmente dependiente del flujo de inversión extranjera directa en la medida en que se financia con recursos externos, también se ejemplifica un caso en que el ahorro (externo) responde a la inversión (externa). 
Otra ampliación del enfoque de Robinson, abordada en sus últimos escritos, consiste en incluir el grado de utilización de la capacidad instalada como una variable que afecta la inversión y el crecimiento, idea luego adoptada en el modelo de Lovinsky y Gibson (2004) y formalizada por Asimakopulos (1969 y 1970). En su modelo básico y en sus hipótesis de crecimiento, Robinson presupone que los mercados de bienes de consumo son competitivos; por ende, los precios se ajustan para asegurar un pleno uso de la capacidad instalada, aun cuando reconoce que en condiciones de competencia imperfecta la existencia de precios más altos puede crear situaciones donde no se utilice la capacidad, lo cual conllevaría un menor nivel de inversión (Robinson, 1961, págs. 105-107).

En sus últimos escritos, Robinson amplió el alcance de este tema, congruente con el enfoque de Kalecki orientado a fijar una prima por encima de los precios que prevalecen en un mercado competitivo, la que varía de la mano del poder monopólico de las empresas. Dado que esta prima incide en los precios y en el grado de utilización de la capacidad instalada, ejerce repercusiones adicionales en el empleo y la inversión, tal como explica Asimakopulos (1970 y 1977).

Por una parte, se puede incrementar la prima como un mecanismo compensatorio frente a las presiones sindicales por una suba salarial, lo cual puede dar lugar a la barrera inflacionaria. Por otra parte y a diferencia de la situación donde existen mercados competitivos y los precios se ajustan para asegurar un pleno uso de la capacidad instalada, en mercados imperfectos el empleo se ajusta de acuerdo con el nivel de la demanda efectiva. Aunque puede suponerse que en mercados imperfectos en general existe una capacidad no utilizada, es posible conjeturar diferentes trayectorias de crecimiento dependiendo del supuesto que se adopte, por ejemplo la posibilidad de que, a causa de inversiones acotadas, las empresas decidan disminuir sus precios bajando la prima, medida que aumentaría el empleo y reduciría la proporción de ganancias en el producto (Asimakopulos, 1970). Esto pone una vez más de manifiesto que el enfoque robinsoniano no involucra un modelo analítico cerrado, sino abierto a diferentes posibilidades.

\section{B. La acumulación del capital y las edades de crecimiento en América Latina de 1980 a 2012}

\section{La relación entre la acumulación de capital, el crecimiento y el ahorro en América Latina}

En congruencia con su orientación keynesiana, Joan Robinson asigna a la inversión un papel fundamental como motor del crecimiento. Ello se puede evaluar en cinco períodos de crecimiento económico en América Latina 
definidos sobre la base de criterios que toman en cuenta los ciclos económicos de la región y, en particular, los principales choques de origen externo sufridos durante estas tres décadas: i) el período 1982-1989, marcado por la crisis de la deuda; ii) el período 1990-1997, signado por la inestabilidad financiera y la crisis asiática de 1997-1998; iii) el período 1997/1998-2002 — considerado por algunos observadores el sexenio perdido después del choque causado por la crisis asiática-, que culmina con la crisis argentina de 2001-2002, iv) el período iniciado en 2003, marcado por el auge de los precios de las materias primas exportadas por la región, salvo durante 2008-2009, y v) el período 2009-2012 a raíz de la crisis financiera global, que marca el comienzo de cierta desaceleración del crecimiento en la región. Si se parte del enfoque de Robinson y de esta periodización, se pueden aprovechar los trabajos de Jiménez y Manuelito (2012 y 2013) y de la CEPAL (2012 y 2013) e identificar varios rasgos que caracterizan las inversiones realizadas en América Latina entre 1980 y 2012.

En primer lugar, en América Latina la inversión total ha seguido una trayectoria cambiante, con niveles especialmente bajos durante la década de 1980 como resultado de la crisis de la deuda y la recesión de la economía mundial, y experimentó cierto repunte en las etapas subsiguientes, aunque con diferencias entre los países. Cayó de manera sostenida durante la primera mitad de la década de 1980 y alcanzó el 17,7\% del PIB entre 1980 y 1989. Durante los años noventa, cuando numerosos países de la región sufrieron una fuerte inestabilidad financiera pero tuvieron acceso al ahorro y las inversiones externas, la inversión logró recuperarse en cierta medida (alcanzó el 19,0\% del PIB) y creció en la década de 2000, sobre todo entre 2003 y 2010 (cuando llegó al 20,4\% del PIB), aunque con patrones muy heterogéneos entre los países durante esta última etapa.

En segundo lugar, en la región ha existido una estrecha relación entre el crecimiento de la inversión y el del PIB (Ffrench-Davis, 2005, págs. 109-112), lo cual se condice con el enfoque poskeynesiano en general. Cuando se estima el coeficiente de correlación entre la tasa de crecimiento de la inversión y la del PIB per cápita, se observa una correlación significativa y positiva en todos los períodos analizados, representada por las líneas de regresión simple del gráfico VI.120.

Además de esta correlación, el desplazamiento hacia arriba de las líneas que corresponden a cada período indica que, con el transcurso del tiempo, el crecimiento de la inversión coincide con mayores tasas de crecimiento del PIB per cápita (véase el gráfico VI.1).

${ }^{20}$ Aunque la inversión forma parte del PIB, la evolución de cada componente de este tiene una dinámica propia, siendo la inversión la variable más volátil. Por ende, el coeficiente de correlación entre ambas variables fluctúa entre los distintos períodos, por ejemplo: 0,7 (1982-1989), 0,53 (1990-1997), 0,83 (1998-2002), 0,7 (2003-2008) y 0,63 (2009-2012). En todos los períodos analizados, la significancia estadística alcanza un 99\%, excepto en 1990-1997, cuando el nivel de confianza disminuye al $98 \%$. 


\section{Gráfico VI.1}

\section{América Latina: relación entre el crecimiento del PIB per cápita y el crecimiento de la inversión en distintos períodos}

(En tasas de crecimiento)

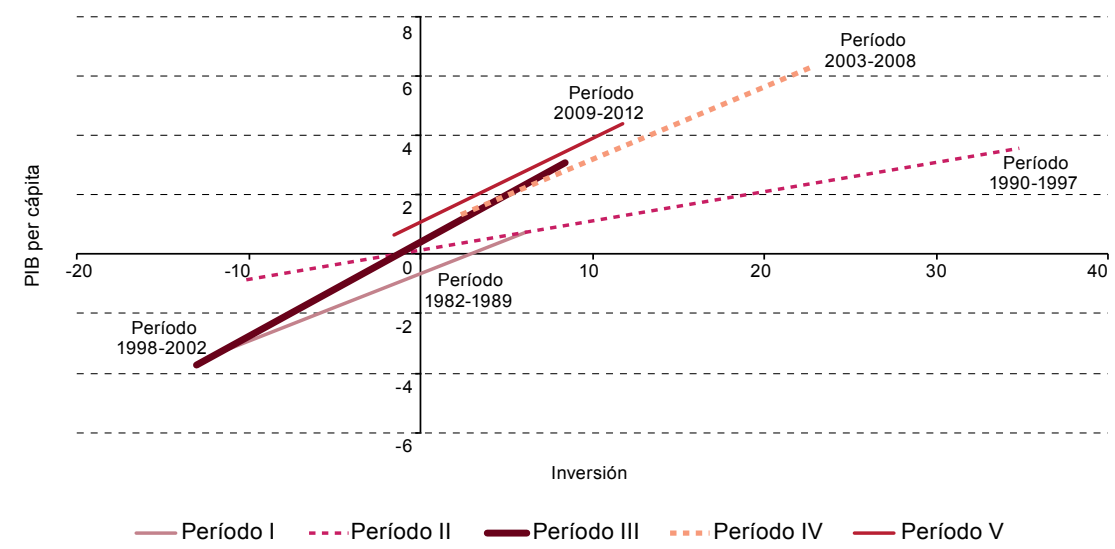

Fuente: Comisión Económica para América Latina y el Caribe (CEPAL), sobre la base de cifras oficiales.

Algunas estimaciones de las relaciones de causalidad entre la inversión y el PIB (evaluadas con el método de Grange) sugieren que las dos variables se afectan de manera recíproca, aun cuando sea mayor el número de países donde el crecimiento del PIB en general haya precedido al crecimiento de la inversión (Jiménez y Manuelito, 2013; CEPAL, 2013, págs. 122-126). En algunos países, como en el Brasil y parcialmente en México, la relación de causalidad ha pasado de la inversión al PIB, mientras que en otros (Chile, Colombia, Nicaragua y el Uruguay) ha seguido el sentido inverso y en varios países (la Argentina, Costa Rica y Panamá) la relación ha sido bidireccional. Estos resultados sugieren que las oscilaciones en la tasa de acumulación de capital han guardado un vínculo estrecho con los cambios en las presiones de la demanda agregada, tanto de origen interno como externo. También sugieren que, al contribuir al pleno uso de la capacidad instalada, la demanda agregada y su gestión por la vía de políticas contracíclicas resultan fundamentales para asegurar una tasa de acumulación de capital alta y relativamente estable.

En tercer lugar y vinculado al punto anterior, en varios países de América Latina se observan indicios de una relación positiva entre el crecimiento de la inversión y el grado de utilización de la capacidad instalada, medida por la brecha del producto. En particular, entre 1990 y 2010 se registraron coeficientes elevados y significativos de correlación entre ambas variables en América Latina y, en especial, en la Argentina, Chile, Colombia, Guatemala, México, el Panamá, el Paraguay y el Uruguay, mientras que fueron algo menores pero igualmente significativos en los 
casos del Brasil y el Perú (CEPAL, 2013, cuadro II.4, pág. 119). Esto indicaría un posible efecto acelerador, en la medida en que pueden concebirse como expectativas de crecimiento - asociadas al crecimiento de la demanda agregada- que impulsan el dinamismo de la inversión. Al mismo tiempo, existe cierta evidencia de que el desempeño mediocre de la productividad laboral de la región se debe en parte a una limitada utilización de la capacidad instalada en varios países (Aravena y Fuentes, 2013).

En cuarto lugar, los espíritus animales - reflejados en la voluntad empresarial de aumentar el ritmo de acumulación de capital en América Latina, aun cuando hayan sufrido cambios según la etapa y el contexto de cada país - no parecen haber sido muy fuertes, en particular frente a los de otros países. La inversión fue significativamente inferior a la de otras regiones de rápido crecimiento, sobre todo en comparación con Asia o, incluso, con Oriente Medio y África Septentrional. En China y la India, la inversión — definida como la formación bruta de capital—alcanzó en 2012 cifras por encima del 40\% del PIB y en Oriente Medio y África Septentrional osciló entre el 25\% y el 30\%, mientras que en América Latina alcanzó un promedio algo superior al $20 \%{ }^{21}$.

Por último, la evolución de la relación entre el ahorro y las inversiones (véase el gráfico VI.2) tiende a confirmar la importancia de la dinámica de estas últimas como una determinante del ahorro, sin que un mayor grado de ahorro necesariamente produzca más inversiones, incluso cuando se trata de una relación compleja e interdependiente donde el ajuste del ahorro a la inversión no es automático y puede condicionar la inversión ${ }^{22}$. Así, la virtual desaparición del ahorro externo en América Latina durante la década de 1980 como consecuencia de la crisis de la deuda, momento en que la inversión fue significativamente menor que en etapas previas y posteriores, puso de manifiesto la existencia de profundas restricciones externas que trajeron aparejado un menor nivel de inversión.

21 Puesto que la decisión de invertir determina las ganancias que se reinvertirán (ganancias ahorradas), se puede plantear como hipótesis que la inversión se ve restringida por el elevado nivel de consumo y la marcada propensión exhibidos por los estratos empresariales de mayores ingresos, en comparación con los de los mismos grupos empresariales de otras regiones del mundo. Sería lo opuesto al efecto positivo que la mayor propensión a consumir de los trabajadores o de la población en general puede ejercer en la demanda agregada.

22 No obstante la necesaria equivalencia contable ex post de la inversión y el ahorro, Asimakopulos (1984) explica que Robinson identificó en Keynes una deficiencia acerca del manejo del tiempo relacionado con el ajuste del ahorro a la inversión: si bien este ajuste se podía realizar mediante cambios en el multiplicador (específicamente en la propensión al consumo) efectuados por la inversión, resultaba difícil concebirlo como un ajuste simultáneo al efectuarse el cambio en la inversión. Esto significaba que en la práctica no se daba simultáneamente la equivalencia entre la tasa de la inversión y del ahorro. Al plantear que las ganancias empresariales se destinan a la inversión o al consumo, Kalecki adopta un enfoque más simple y claro, pues plantea que la decisión de invertir determina qué porcentaje de las ganancias se dedica al consumo y qué parte (el resto, es decir las ganancias ahorradas) se destina a la inversión. Al decidir cuánto invierten y consumen, los empresarios también determinan sus ganancias (futuras) (Lavoie, 2009, pág. 86; Kalecki, 1969, capítulos 4 y 9). 


\section{Gráfico VI.2}

América Latina: inversión y ahorro interno y externo, 1980-2012

(En porcentajes del PIB)

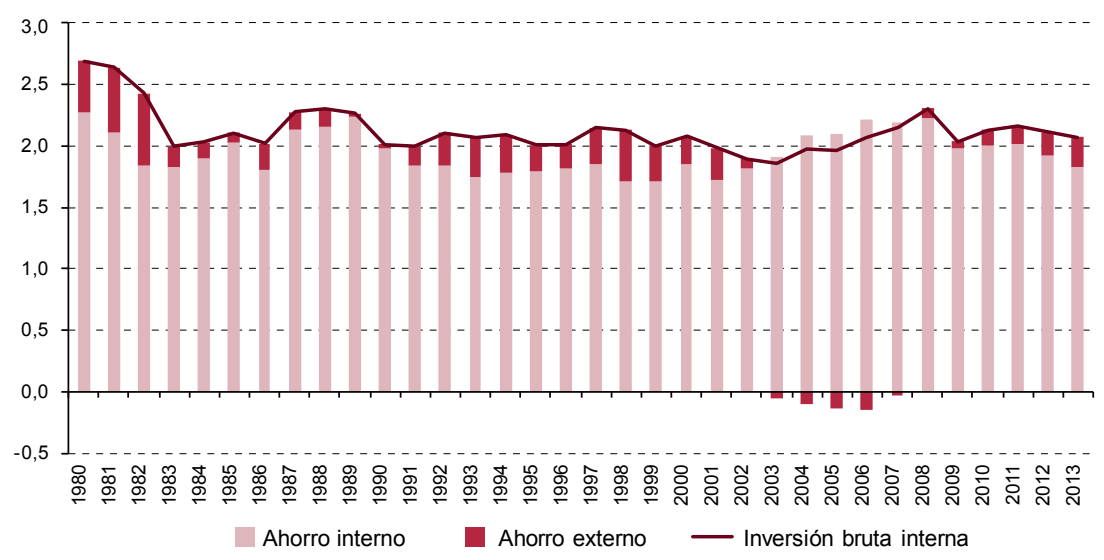

Fuente: Comisión Económica para América Latina y el Caribe (CEPAL), sobre la base de cifras oficiales.

El pronunciado aumento del ahorro externo durante la década de 1990 debilitó de manera progresiva dicha restricción, lo que favoreció la inversión, pero tampoco entrañó un crecimiento equivalente de la inversión. Por una parte, fue el resultado de un marcado aumento de la inversión extranjera directa, sobre todo a partir de 1995, que puso de manifiesto la existencia de una nueva dinámica en que la inversión (externa) producía ahorro (externo), pero también de flujos de capital de corto plazo que no se reflejaron en un fortalecimiento de la capacidad productiva de los países de destino. Por otra parte, todo parece indicar que, si bien el ahorro externo total estuvo en alza, un porcentaje considerable del ahorro interno se acomodó al ahorro externo y fue sustituido por este sin redundar en mayores inversiones, que se mantuvieron en torno al 20\% del PIB (véase el gráfico VI.2).

Uthoff y Titelman (1998), en particular, detectaron en el período 1972-1993 una relación negativa de sustitución entre el ahorro externo e interno, y comprendieron que esta relación revestía especial solidez cuando los flujos de capital estaban por encima de su tendencia. Concluyeron que al superar esta tendencia, los ingresos de capital provocaban una apreciación del tipo de cambio y el alza del valor de los activos internos, por lo cual aumentaba el consumo privado y se reducía el ahorro nacional. Además, hallaron que la inversión ejercía un efecto positivo en el ahorro.

A partir de 2003, el ahorro interno experimentó un crecimiento significativo como una proporción del PIB, debido a un aumento del ingreso nacional ocasionado por una mejora sustancial de los precios de las materias primas exportadas por los países de América del Sur. Sin embargo, aunque la inversión se expandió, no lo hizo en la misma proporción que el ahorro, sino 
que entre 2003 y 2007 hubo una salida de ahorro de los países de la región. De nuevo, ello puede interpretarse como un mayor nivel de ahorro - ahora nacional-que sustituyó al ahorro externo y que no dio lugar necesariamente a un incremento equivalente de la inversión. También reflejaría cómo la inversión determinó el nivel de ahorro que aprovechaba cada país ${ }^{23}$.

El hecho de que se subutilizara el ahorro interno disponible - parte del cual se destinó al ahorro exterior- con el objeto de cubrir inversiones entre 2003 y 2008 apunta, con ciertos matices, a espíritus animales que todavía no aprovecharon al máximo las posibilidades de inversión (la inversión potencial reflejada en la ecuación de Cambridge) de cada país ${ }^{24}$. Esta situación sugiere que la ecuación de Cambridge, incluso ajustada para tomar en cuenta el ahorro interno y externo y el balance fiscal, no alcanza a dar cuenta de la inversión, pero también sugiere que la segunda función de la inversión (esperada o impulsada por espíritus animales) de Robinson, aun cuando resulte poco precisa, ayuda a explicar lo ocurrido.

\section{La edad de plomo del crecimiento en América Latina}

Al analizar a la luz del enfoque de Robinson cómo evolucionaron la inversión, el empleo y la productividad, se observa que durante algún momento entre 1980 y 1989 la mayoría de los países de la región se caracterizaron por una trayectoria de crecimiento cercana a la edad de plomo postulada por la académica británica. En este período, la insuficiente acumulación de capital implica que no hay progreso técnico, con lo cual se estanca el crecimiento de la productividad en la medida que se da un crecimiento equivalente del producto y del empleo. En la década de 1980, resulta evidente la limitada acumulación de capital, pero esta se tradujo en una menor productividad laboral y no solo en su estancamiento, lo que significa que se trató de una etapa incluso más extrema que la edad de plomo de Robinson. Ello se debió a las peculiaridades del mercado laboral, a raíz de las cuales la menor tasa de acumulación y del producto $\left(g_{y}\right)$ coincidió con una tasa de crecimiento del empleo $\left(g_{l}\right)$ relativamente menor que no equivalió a la tasa de crecimiento del producto, tal como postula la edad de plomo $\left(g_{l}>g_{y}\right.$ en vez de $\left.g_{y}=g_{l}\right)$.

${ }^{23}$ Además, también justifica orientar políticas, especialmente relativas a la gestión de la cuenta de capitales, para que la inversión se cubra con ahorros nacionales en lugar de ahorro externo, que está sujeto a mayores fluctuaciones y coloca a los países en una situación de mayor vulnerabilidad, sobre todo en la medida en que se cubra el déficit de la cuenta corriente con capitales de corto plazo susceptibles de salidas súbitas en momentos de incertidumbre (Bresser-Pereira, 2012).

24 Esta idea puede matizarse en la medida en que los ahorros en el exterior se concretaron en inversiones directas de los países latinoamericanos en otros países de la región o del mundo. El mayor ahorro nacional representa la contraparte de una cuenta corriente superavitaria - reflejo de un mayor incremento del valor de las exportaciones que de las importaciones-que, a su vez, dio lugar a un aumento significativo del ingreso bruto nacional disponible (que toma en cuenta el efecto de los términos de intercambio), superior al crecimiento del PIB (que se calcula a precios constantes). 
En particular, el empleo tuvo una tasa de crecimiento positivo y se observó un incremento significativo del autoempleo debido a una débil demanda de empleo asalariado, lo cual caracterizó varios episodios de crisis o desaceleración en la región (Weller y Kaldewei, 2013). Por consiguiente, durante los años ochenta la productividad laboral promedio se contrajo en todos los países, salvo Colombia.

Aunque el crecimiento del autoempleo amortiguó en parte los efectos de las crisis, lo que se manifiesta es el hecho de que la tasa de desempleo reportada por los países no refleja necesariamente las dinámicas del subempleo o el desempleo disfrazado, que pueden aumentar en momentos de recesión. En la mayoría de los países hubo una suba pronunciada de esta tasa durante los años ochenta, sobre todo durante el primer quinquenio. En general, las condiciones de vida sufrieron un fuerte deterioro, traducido en una mayor pobreza y en un ajuste maltusiano que en varios países adoptó la forma de un mayor flujo emigratorio. A grandes rasgos, la trayectoria seguida por el crecimiento durante la década de 1980 presenta, entonces, las características de la edad de plomo.

En el gráfico VI.3, se puede observar que la línea que relaciona mediante una regresión simple la evolución del PIB por trabajador ocupado con el crecimiento de la ocupación durante 1982-1989 reviste suma elocuencia: si bien se observa un crecimiento del empleo, el incremento del PIB por persona ocupada (productividad laboral) resulta negativo. Si además se incluyeran los puntos de intersección correspondientes a cada país, solamente Colombia gozaría de un aumento positivo de la productividad laboral.

\section{Gráfico VI.3}

América Latina: relación entre el crecimiento del producto por trabajador y del empleo en distintos períodos

(En tasas de crecimiento)

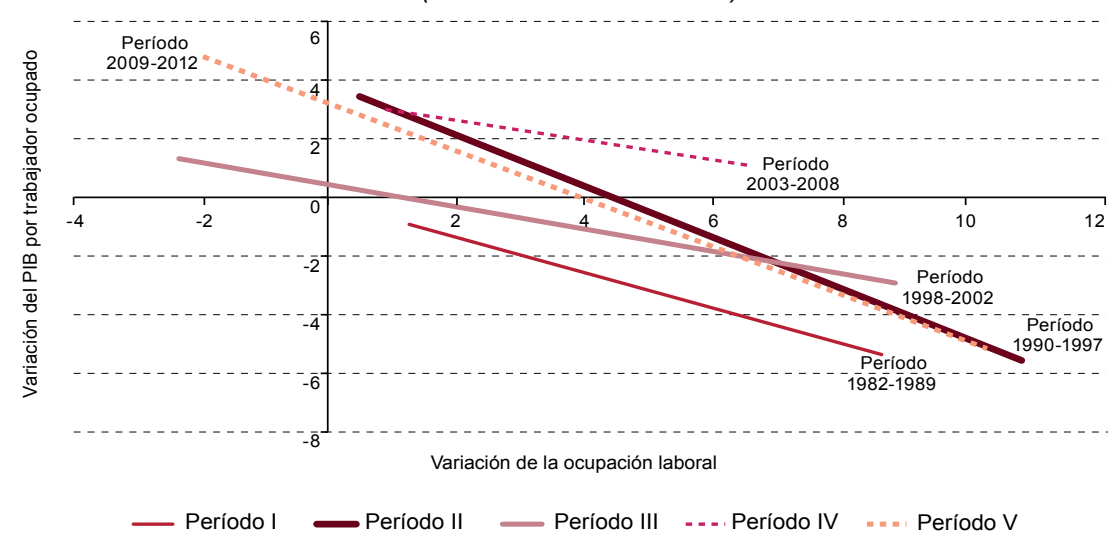

Fuente: Comisión Económica para América Latina y el Caribe (CEPAL), sobre la base de cifras oficiales. 
La evolución negativa de la productividad persistió en varios países durante las etapas siguientes (1990-1997 y 1998-2002). En este contexto tendió a prevalecer un mayor aumento del empleo, lo cual sugiere que aun cuando la inversión se haya recuperado al menos en parte y que esta haya ocupado más mano de obra, el proceso de acumulación no estuvo acompañado por suficientes medidas destinadas a lograr una incorporación sostenida de avances técnicos para crear empleo de creciente productividad, y que un porcentaje considerable de los puestos de trabajo se continuó originando del lado de la oferta de la mano de obra bajo la forma de trabajadores informales por cuenta propia en lugar de asalariados empleados por el mercado laboral formal. Así, los países que aparecen en ambos períodos posteriores a la década de 1980, con una menor productividad, incluyen al Ecuador, Venezuela (República Bolivariana de) y el Perú, aunque en las décadas siguientes se aprecia un creciente número de países donde aumentó la productividad, lo que revela que el fantasma de las edades de plomo se fue desvaneciendo.

\section{Posibles episodios de barreras de inflación}

La extrema volatilidad financiera experimentada entre 1990 y 2002, junto con la inestabilidad del crecimiento y de la inversión, dificulta asociar lo ocurrido durante este período en América Latina con las edades postuladas por Robinson que, como parte de la lógica de su modelo, dan cuenta de mayores o menores tasas de crecimiento constante o de aceleraciones o desaceleraciones prolongadas. Además, al haberse centrado en el análisis de una economía capitalista cerrada, Robinson no introduce en su modelo el análisis de los flujos financieros y del tipo de cambio. Aunque sí analiza cómo inciden los choques externos o las situaciones de inestabilidad en el crecimiento, estas consideraciones no están directamente incorporadas en las edades de crecimiento que propuso, por lo que integrar plenamente estos temas a su modelo fundamental y a sus variaciones (edades) constituye una asignatura pendiente.

Entre 1990 y 2002 América Latina recuperó en parte la inversión y la productividad, pero ello se dio en un contexto de profunda inestabilidad financiera regional e internacional que perjudicó a la mayoría de los países de la región y, en especial, a los más grandes (la Argentina, el Brasil y México). Durante esta etapa, el proceso de acumulación de capital en la región presenta algunos de los rasgos descritos por Robinson, además de otros asociados más directamente a los ingresos de capital y a auges financieros en condiciones de apertura y de desregulación con tipos de cambio fijos.

Como han explicado Frenkel y Repetti (2009), en la mayoría de las crisis financieras de este período se recurrió a la liberalización financiera 
y a un tipo de cambio poco flexible que introducía un margen de ganancia especulativo destinado a estimular el ingreso de capitales y así incrementar la liquidez, el crédito y la demanda agregada. Se daba inicio a un auge financiero, en términos similares a los contemplados por H. Minsky (1986), que terminaba de manera súbita cuando se generalizaba la percepción de que resultaba imposible sostener el consiguiente aumento del déficit de la cuenta corriente financiado por capital de corto plazo. Se manifestaban entonces problemas de iliquidez o insolvencia financiera, se depreciaba el tipo de cambio, aumentaba la inflación, y se contraían la demanda agregada, los salarios reales y el crecimiento económico ${ }^{25}$.

En este contexto de inestabilidad financiera se produjeron varios episodios que comparten algunos de los rasgos de las barreras de inflación planteados por Robinson, cuya posible ocurrencia la economista británica asoció a pugnas distributivas en presencia de organizaciones sindicales que, al impedir una reducción de los salarios reales, daban lugar a una retroalimentación entre el alza de los precios y las subas salariales, que luego restringía el proceso de acumulación de capital. En el cuadro VI.2 se presentan datos que permiten concluir que varios procesos inflacionarios profundos estuvieron acompañados de una merma significativa de la participación de los salarios en el PIB, mientras que en estos episodios no resultó habitual la situación contraria - contracciones repentinas de la participación del excedente de explotación dentro del PIB ${ }^{26}$.

Sin embargo, no es posible hallar un claro vínculo entre los procesos redistributivos asociados a la inflación y los cambios en el ritmo de acumulación de capital en los países afectados. En varios casos, la inversión continuó en alza, mientras que se dieron algunos episodios caracterizados por una menor inversión, como en la Argentina entre 2000 y 2004 y en el Perú entre 1989 y 1992, pero estas situaciones en general no parecen vinculadas a pugnas distributivas sino a los grandes desequilibrios financieros típicos de estas economías durante estas etapas. Ello no niega la posibilidad de que algunas pugnas distributivas hayan contribuido a ejercer presiones inflacionarias y a introducir cambios en la relación entre las cuotas salariales y el excedente de explotación en

25 Resulta significativo que entre 1990 y 2002 los países menos integrados a los mercados financieros, como los centroamericanos, hayan crecido más que el resto de América Latina (con la excepción de Chile), situación que se vio reforzada por un aumento de las remesas. Este aumento tuvo repercusiones repercusiones similares en el ingreso nacional a las que trajo aparejada en la década siguiente la mejora de los términos de intercambio en América del Sur, sobre todo entre los países exportadores de minerales y de hidrocarburos.

26 Se requeriría un análisis más exhaustivo de cada caso para determinar en qué situaciones los desequilibrios financieros fueron alimentados por pugnas distributivas con participación sindical y en cuáles fueron la consecuencia directa de marcados desequilibrios financieros combinados con cambios extremos en los precios relativos - asociados a variaciones cambiarias-, sin que mediaran de manera explícita pugnas distributivas con participación sindical. 
el PIB. Por ejemplo, a fines de los años ochenta y a principios de los años noventa se observaron en el Brasil cambios en las cuotas, relativamente considerables y en ambos sentidos, y, en comparación con años anteriores, una consecuente y pronunciada merma del coeficiente de inversión, pero su análisis debe enmarcarse dentro de contextos más amplios de inestabilidad institucional y financiera ${ }^{27} 28$.

\section{Cuadro VI.2}

Episodios de alta inflación y cambios en la relación entre los salarios y el PIB (En tasas de crecimiento)

\begin{tabular}{lcccc}
\hline $\begin{array}{l}\text { Barreras } \\
\text { de inflación }\end{array}$ & Período & $\begin{array}{c}\text { Tasa de inflación } \\
\text { (base 2005=100) }\end{array}$ & $\begin{array}{c}\text { Cambio en la } \\
\text { relación entre } \\
\text { los salarios } \\
\text { y el PIB }\end{array}$ & $\begin{array}{c}\text { Cambio en la } \\
\text { relación entre } \\
\text { la inversión } \\
\text { y el PIB }\end{array}$ \\
\hline Argentina & $2000-2004$ & 12,7 & $-5,1$ & $-4,5$ \\
\hline Brasil & $1991-1995$ & 1099,6 & $-1,0$ & 4,4 \\
\hline Colombia & $1989-1994$ & 26,3 & 0,8 & 6,4 \\
\hline Honduras & $1990-1994$ & 19,7 & $-2,5$ & 8,3 \\
\hline México & $1993-1998$ & 20,4 & $-1,0$ & 5,3 \\
\hline Perú & $1989-1992$ & 2501,2 & $-12,0$ & $-1,6$ \\
\hline Uruguay & $2001-2005$ & 10,3 & $-3,4$ & 7,9 \\
\hline
\end{tabular}

Fuente: Comisión Económica para América Latina y el Caribe (CEPAL), sobre la base de cifras oficiales.

En este contexto, los desequilibrios cambiarios desempeñaron un papel fundamental: en particular, las profundas devaluaciones, como las de la Argentina (2002), el Brasil (1998), Chile (1997-2000) y México (1994), coincidieron con una marcada caída de la participación de los salarios en el valor agregado total de estos sectores. Ello reviste especial validez en el caso de los sectores transables, como cabría esperar por su mayor relación con las exportaciones y las importaciones directamente vinculadas con los tipos de cambio (véase el gráfico VI.4) ${ }^{29}$. Más tarde, cuando se dieron

27 En el Brasil, los salarios pasaron de representar el 45\% del total del PIB en 1990 al 42\% en 1991, el $44 \%$ en 1992, el 45\% en 1993 y el 40\% en 1994.

28 Lavoie hace hincapié en que este tema fue planteado por varios teóricos poskeynesianos, como Kalecki y Kaldor, pero apunta que la inflación es el resultado de instituciones ineficientes, incluidas las que enmarcan negociaciones entre trabajadores y empleadores (Lavoie, 2009, págs. 129-130).

29 Existe una correlación estadísticamente significativa entre la evolución del tipo de cambio y la proporción de las remuneraciones en el valor agregado en los sectores transables de la Argentina, el Brasil y Chile. El coeficiente de correlación es de 0,7976 en la Argentina (donde $p=0,004$ ), 0,6702 en el Brasil $(p=0,171)$ y 0,4475 en Chile $(p=0,0717)$. No obstante, este coeficiente no tuvo significancia estadística en el caso de México. 
apreciaciones reales, no se recuperaron necesariamente las proporciones de los salarios dentro del valor agregado que existían - antes de la depreciación o la devaluación-sobre todo en Chile y México ${ }^{30}$.

\section{Gráfico VI.4}

\section{Argentina, Brasil, Chile y México: evolución del tipo de cambio real efectivo (recíproco) y de la relación entre los salarios y el valor agregado en los sectores transables, 1993-2007} (Año base=100)

A. Argentina: $1993=100$

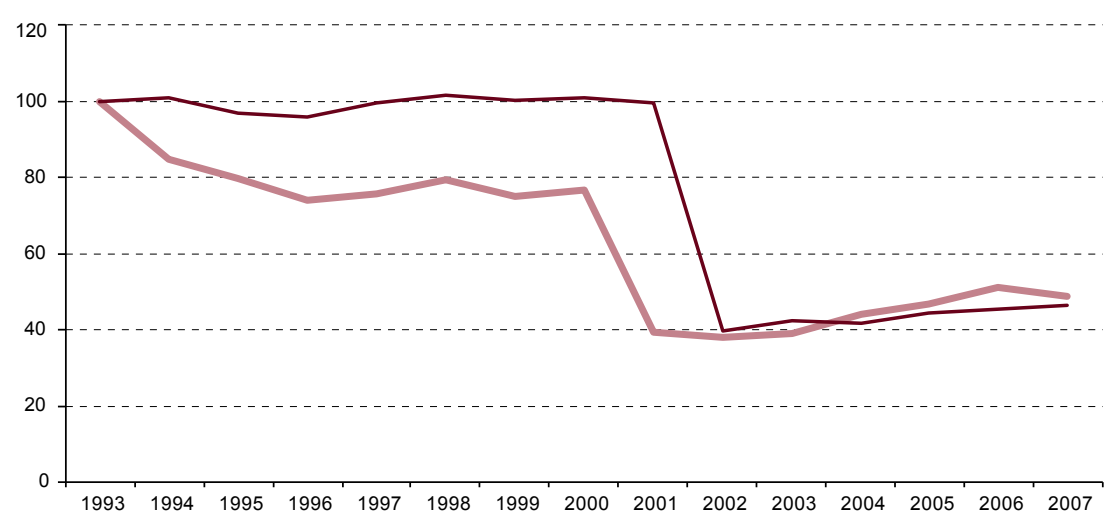

B. Brasil: $1996=100$

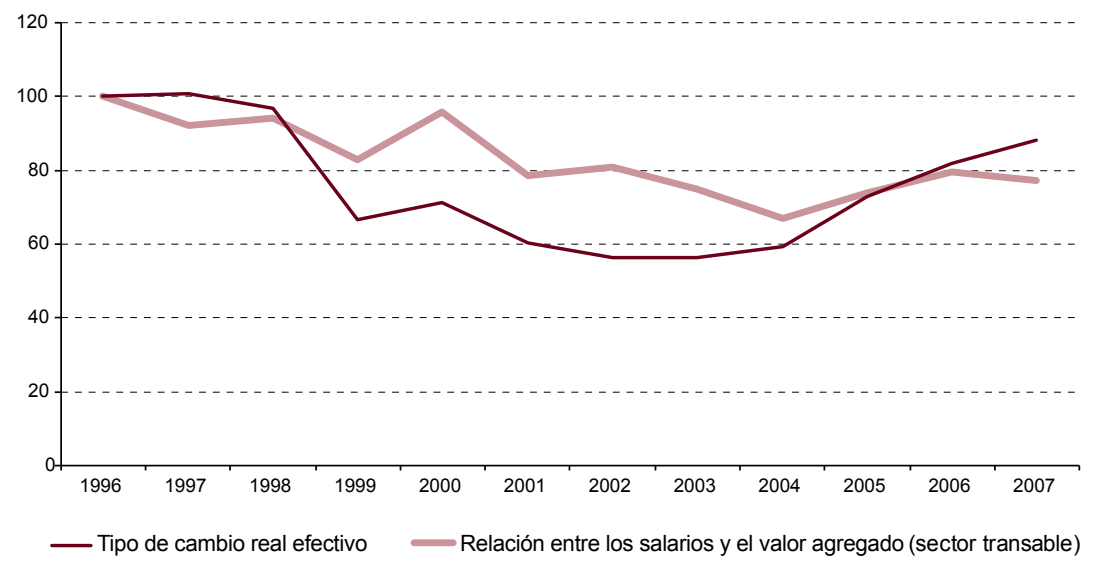

30 Una hipótesis postularía que ante procesos de apreciación real del tipo de cambio, se crearía una situación semejante a una ilusión monetaria, debido al mayor poder adquisitivo de la moneda frente a otras, que se reflejaría en las importaciones adquiridas ante condiciones (precios) más favorables. 
Gráfico VI.4 (conclusión)

C. Chile: $1993-100$

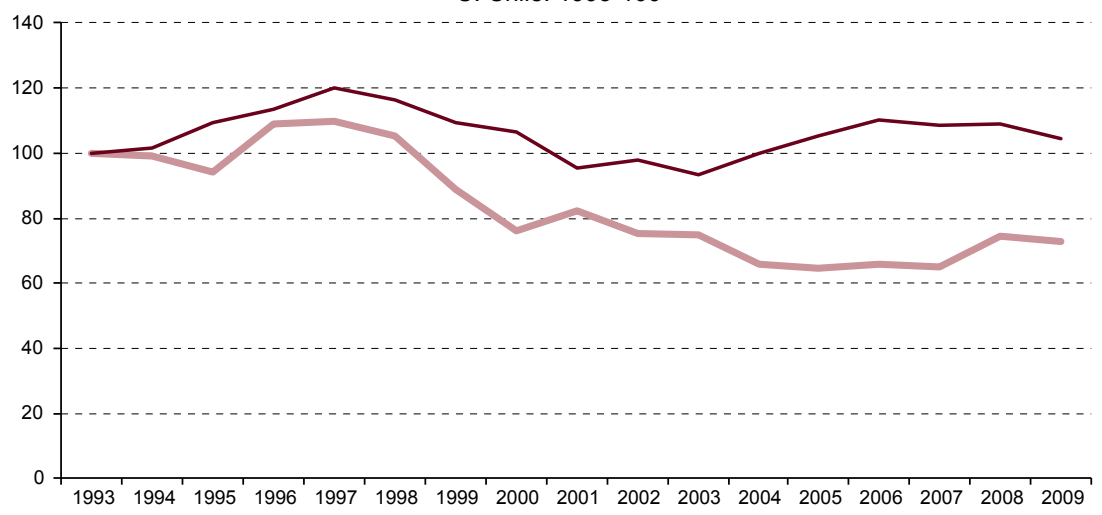

D. México: $1993=100$

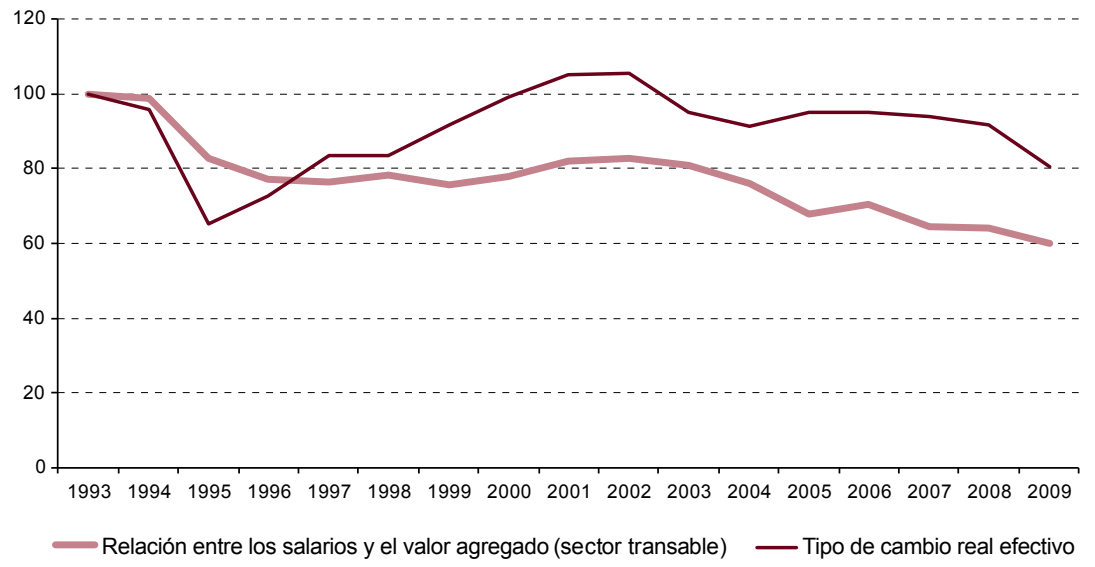

Fuente: Comisión Económica para América Latina y el Caribe (CEPAL), sobre la base de datos del proyecto LA-KLEMS [en línea] http://www.worldklems.net/.

En general, la inestabilidad financiera experimentada entre 1990 y 2002 por varios países de América Latina fue contraria a un proceso dinámico de acumulación de capital en la región, a pesar de cierta recuperación de las inversiones privadas y de la gradual erosión de las restricciones externas. Aunque muchos de los rasgos de su crecimiento se apartan de las edades formuladas por Robinson, hay cierta similitud con una edad bastarda en aquellos países donde la desregulación financiera, tal vez estimulada por las pugnas redistributivas en algunos casos, propició un auge del crédito, los precios y los salarios que frenó la acumulación de capital e impidió aproximarse al pleno empleo. 
No obstante, sufrieron menos sobresaltos otros países sin pugna distributiva explícita, que no padecieron las consecuencias de la inestabilidad de los mercados financieros, porque no estaban integrados a estos - como los centroamericanos y la República Dominicana- o porque pudieron liberar gradualmente o regular sus sistemas financieros (Stallings y Studart, 2006, págs. 43-44), como Colombia y Chile. Pocas fueron las naciones - como Chile y la República Dominicana- que sortearon las vicisitudes financieras al tiempo que experimentaron una fuerte tasa de acumulación de capital que llevó a una creación dinámica de empleo entre 1990 y 1997. Ello permite concebirlas como economías que transitaban una trayectoria semejante a una edad de oro, aunque lánguida, pues no se logró el pleno empleo, situación que devino particularmente evidente tras la crisis asiática de 1997-1998. Ahora bien, la falta de incorporación de variables relativas al sector financiero y a la evolución del tipo de cambio en el modelo de Robinson limita la validez de sus aportes para explicar lo ocurrido en América Latina entre 1990 y 2002.

Por otra parte, durante los períodos 1990-1997 y 1998-2002 en América Latina se alcanzaron avances progresivos gracias a la adopción de tipos de cambio más flexibles, la regulación de los sistemas financieros y flujos crecientes de inversión extranjera directa que disminuyeron la volatilidad de la cuenta de capitales, así como ajustes fiscales y políticas monetarias que lograron controlar la inflación. Todas estas medidas contribuyeron a evitar las peores consecuencias de la recesión y de la virtual suspensión de los flujos de capital de corto plazo ocasionadas por la crisis asiática de 1997-1998, si bien dieron lugar a lo que se ha calificado como el quinquenio perdido (1997/1998 y 2002). Sin embargo y pese a la merma de la tasa de crecimiento y de un menor ritmo de acumulación de capital, que parecería reflejar los débiles espíritus animales característicos de América Latina, se fortalecieron las bases macroeconómicas para entrar en una nueva etapa de precios más estables y un mayor crecimiento.

\section{Las edades de platino y los cambios en la composición de las inversiones}

Después de la década de 1980, la productividad comenzó a mejorar en numerosos países, situación representada en el gráfico VI.3, donde las líneas tienden a desplazarse hacia arriba, hacia el área que corresponde a variables con crecimiento de signo positivo lo que refleja una mayor productividad en cada nivel de empleo ${ }^{31}$. Los ritmos cambiantes y los altibajos de los incrementos también son significativos. Si se comparan los

31 El coeficiente de correlación entre el crecimiento del PIB a raíz del nivel de ocupación y la tasa de crecimiento del empleo fue de -0,52 entre 1982 y 1989, con una significancia estadística del 97\%, y de -0,85 entre 1990 y 1997 (con un nivel de confianza del 99\%), mientras que alcanzó -0,48 en el período 1998-2002 (con una significancia del 96\%), -0,38 en 2003-2008 (con una significancia de apenas el 85\%) y de -0,71 en 2009-2012 (con una significancia del 99\%). 
períodos seleccionados, se observa que en América Latina se registraron dos aumentos considerables de la productividad laboral: uno ocurrido entre los períodos 1980-1989 y 1990-1997 —desde una situación en la que el crecimiento de la productividad era negativo (la edad de plomo de la década de 1980) hasta el siguiente período de inestabilidad financiera, pero con un repunte de cierta significancia (1990-1997) —, y otro que transcurrió entre 1998-2002, período que sufrió los duros embates de la crisis asiática, y 2003-2008, años favorecidos por el auge de los precios de las materias primas. Como se verá más adelante, esta podría calificarse como una variación de la edad de platino galopante según el enfoque de Robinson.

Sin embargo, en materia de productividad también hubo retrocesos parciales, que reflejaron los procesos de desaceleración y de menor acumulación de capital de los períodos 1998-2002 y 2009-2012: uno tras la crisis asiática y el otro después de la crisis financiera mundial. Además, durante estos períodos de crisis y ajuste se ensanchó la brecha entre el desempeño de los países con un mayor crecimiento de la productividad y el de las demás economías. En cambio, esta dispersión fue más limitada en los momentos de mayor progreso y, sobre todo, durante 2003-2008.

Así, a partir de 2003 la mayor parte de los países de América Latina experimentaron una aceleración en su crecimiento, en especial aquellos con mayor capacidad para aprovechar las subas de los precios de las materias primas causadas por el auge de la demanda china. En los gráficos VI.1 y VI.3 se observa que en esta etapa el mayor ritmo de acumulación de capital favoreció un aumento del producto, del empleo y de la productividad. Las expectativas favorables contribuyeron a que la inversión esperada se aproximara a la inversión potencial, lo cual se reflejó en un aumento significativo de la tasa de crecimiento de la acumulación de capital y del coeficiente de inversión en el PIB, aun si la inversión real parece haberse mantenido por debajo de la inversión potencial.

Esta aceleración de la acumulación de capital entre 2003 y 2008 puede asociarse con rasgos de lo que Robinson define como la edad de platino galopante, pero con tres diferencias: los espíritus animales, la evolución de los salarios reales y la composición del capital. La primera, ya analizada, se refiere a los síntomas de los débiles espíritus animales de los empresarios de la región.

La segunda diferencia radica en que, si bien el enfoque de Robinson postula que la aceleración del proceso de acumulación puede detenerse por un problema en la composición del capital que, al no producir suficientes bienes de capital para elaborar otros bienes del mismo tipo no se ha adaptado a la nueva dinámica, los países de la región parecen haber tenido mayor flexibilidad para afrontar este problema, pues al ser economías abiertas podían importarlos, incluso en el caso de los bienes de capital favorecidos 
por tipos de cambio apreciados ${ }^{32}$. Esto también significa que en ausencia de un sector productor de bienes de capital restringido y ante la abundancia de ahorros externos, los requisitos de acumulación no plantearon las tensiones entre los salarios y el consumo de ganancias que se postulan en esta edad, por lo que los salarios reales menguaron entre 2003 y 2008.

Por otra parte, una interpretación más amplia de este enfoque permite analizar sus apreciaciones sobre la base de la composición del capital, ya sea porque el capital resulta insuficiente, sobre todo después de al menos dos décadas de inversiones acotadas, o a raíz de la insuficiencia de cierto tipo de inversión ${ }^{33}$. En particular, los cambios en la composición de las inversiones explican en parte cómo evolucionaron entre 1980 y 2012. Durante la década de 1980 la inversión pública sufrió una merma pronunciada debido a la puesta en marcha de programas de estabilización y ajuste, a causa de los cuales se intensificaron en numerosos países los rezagos existentes en materia de infraestructura. No se logró recuperar por completo la inversión pública durante los años noventa, si bien este déficit se compensó en forma parcial en esta etapa gracias a un incremento de la inversión privada, conformada en parte por inversiones extranjeras directas en las que se aprovecharon los procesos de apertura y privatización impulsados durante estos años. Solamente después de 2003 aumentó la inversión, debido tanto al incremento de la inversión pública como a los (mayores) aumentos de la inversión privada, en un contexto marcado por el auge de los precios de las materias primas que fortaleció las finanzas públicas y amplió el ingreso bruto disponible y el ahorro público y privado en la mayoría de los países (Jiménez y Manuelito, 2013).

Ciertos rasgos de la composición de las inversiones sugieren efectos diferenciados en el crecimiento económico y la productividad. La inversión en maquinaria y equipo, que tiene la mayor correlación con el crecimiento del PIB que el resto de las categorías de inversión, mostró más fluctuaciones que las inversiones en el sector de la construcción, el cual mantuvo una trayectoria relativamente estable de crecimiento en torno al 10\% del PIB y explica en buena parte las variaciones de la inversión privada.

A su vez, la evidencia disponible para cuatro países de América Latina (la Argentina, el Brasil, Chile y México) permite extraer tres conclusiones sobre las posibles repercusiones de la apreciación cambiaria - o de los precios relativos en general- en la composición de las inversiones (véase el cuadro VI.3) ${ }^{34}$. En primer lugar, la inversión en el sector no transable

32 En otras etapas, sobre todo durante el período en que predominó la sustitución de importaciones y durante la década de 1980, la restricción externa se reflejó, por ejemplo, en una insuficiente capacidad para importar bienes de capital.

33 Dado el aparente crecimiento excedentario de las inversiones, en comparación con el crecimiento del consumo, durante el período 2010-2013 China pareció atravesar una edad de platino incipiente.

34 Esta información forma parte del banco de datos del proyecto LA-KLEMS [en línea] http:/ / www. worldklems.net/, en el que la CEPAL actúa como secretaría técnica (CEPAL, 2013, págs. 139-141). 
aumentó a un ritmo más acelerado que en el sector transable entre 1993 y 2010, y sobre todo entre 2003 y 2010, cuando en varios de estos países se combinó la mejora de los términos de intercambio con el ingreso de capitales y la apreciación cambiaria ${ }^{35}$.

\section{Cuadro VI.3}

Argentina, Brasil, Chile y México: evolución de la inversión, el empleo y la productividad laboral, 1993-2010

(En tasas de crecimiento anual promedio)

\begin{tabular}{|c|c|c|c|c|c|c|c|c|c|}
\hline \multirow{2}{*}{$\begin{array}{l}\text { Variación } \\
\text { por período }\end{array}$} & & \multicolumn{4}{|c|}{ Sector Transable } & \multicolumn{4}{|c|}{ Sector No Transable } \\
\hline & & $\begin{array}{l}1993- \\
1996\end{array}$ & $\begin{array}{l}1997- \\
2002\end{array}$ & $\begin{array}{l}2003- \\
2010\end{array}$ & $\begin{array}{l}1993- \\
2010\end{array}$ & $\begin{array}{l}1993- \\
1996\end{array}$ & $\begin{array}{l}1997- \\
2002\end{array}$ & $\begin{array}{l}2003- \\
2010\end{array}$ & $\begin{array}{l}1993- \\
2010\end{array}$ \\
\hline \multicolumn{10}{|c|}{$\begin{array}{l}\text { Formación bruta de capital fijo en maquinaria y equipo } \\
\text { y en construcción }\end{array}$} \\
\hline & Argentina & 7,01 & $-7,89$ & 16,02 & 3,84 & 0,46 & $-9,52$ & 29,79 & 6,66 \\
\hline & Brasil & 0,02 & 1,96 & 5,98 & 3,83 & $-0,67$ & 1,09 & 8,08 & 4,46 \\
\hline & Chile & 13,25 & 3,80 & 9,30 & 8,50 & 16,05 & 2,75 & 12,71 & 10,16 \\
\hline & México & 0,01 & 4,93 & 3,56 & 3,80 & $-2,16$ & 7,27 & 5,74 & 4,98 \\
\hline & Promedio & 5,07 & 0,70 & 8,71 & 4,99 & 3,42 & 0,40 & 14,08 & 6,56 \\
\hline \multicolumn{10}{|c|}{ Horas hombre } \\
\hline & Argentina & $-3,32$ & $-2,63$ & 1,73 & $-0,92$ & $-1,30$ & 0,28 & 8,34 & 2,80 \\
\hline & Brasil & & 1,25 & 0,91 & 1,07 & 2,29 & 2,83 & 2,95 & 2,84 \\
\hline & Chile & $-0,23$ & $-1,29$ & $-0,64$ & $-0,54$ & 3,68 & 1,95 & 1,87 & 2,48 \\
\hline & México & 0,76 & $-0,17$ & $-0,92$ & $-0,13$ & 1,43 & 2,86 & 2,13 & 2,42 \\
\hline & Promedio & $-0,93$ & $-0,71$ & 0,27 & $-0,13$ & 1,52 & 1,98 & 3,82 & 2,64 \\
\hline \multicolumn{10}{|c|}{ Valor agregado } \\
\hline & Argentina & 2,43 & $-1,86$ & 5,87 & 2,33 & 3,20 & $-0,57$ & 7,72 & 3,77 \\
\hline & Brasil & 0,79 & 1,76 & 3,11 & 2,42 & 2,33 & 2,16 & 4,09 & 3,20 \\
\hline & Chile & 6,08 & 3,08 & 1,90 & 3,65 & 7,05 & 3,49 & 5,16 & 5,27 \\
\hline & México & 2,67 & 2,82 & $-0,94$ & 1,36 & 0,87 & 3,90 & 1,86 & 2,56 \\
\hline & Promedio & 2,99 & 1,45 & 2,49 & 2,44 & 3,36 & 2,25 & 4,71 & 3,70 \\
\hline \multicolumn{10}{|c|}{ Productividad laboral } \\
\hline & Argentina & 5,45 & 0,88 & 6,44 & 4,02 & 5,84 & $-0,67$ & 0,38 & 1,05 \\
\hline & Brasil & & 1,00 & 1,32 & 1,17 & 0,03 & $-0,56$ & 1,16 & 0,28 \\
\hline & Chile & 6,34 & 4,53 & 2,95 & 4,47 & 3,30 & 1,51 & 2,93 & 2,63 \\
\hline & México & 1,90 & 3,08 & $-0,05$ & 1,51 & $-0,59$ & 1,11 & $-0,27$ & 0,16 \\
\hline & Promedio & 4,56 & 2,37 & 2,66 & 2,79 & 2,15 & 0,35 & 1,05 & 1,03 \\
\hline \multicolumn{10}{|l|}{ Relación I/L } \\
\hline & Argentina & 9,89 & $-5,56$ & 9,70 & 3,20 & 2,80 & $-10,70$ & 20,26 & 3,25 \\
\hline & Brasil & & 0,83 & 5,12 & 3,14 & $-2,89$ & $-1,70$ & 7,24 & 2,33 \\
\hline & Chile & 13,57 & 4,97 & 10,16 & 9,09 & 11,99 & 0,72 & 10,57 & 7,45 \\
\hline & México & $-1,02$ & 5,10 & 4,47 & 3,86 & $-3,94$ & 4,26 & 3,51 & 2,38 \\
\hline & Promedio & 7,48 & 1,33 & 7,36 & 4,82 & 1,99 & $-1,86$ & 10,39 & 3,85 \\
\hline
\end{tabular}

Fuente: Comisión Económica para América Latina y el Caribe (CEPAL), sobre la base de datos del proyecto LA-KLEMS [en línea] http://www.worldklems.net/.

35 Para propósitos estadísticos se definieron como transables los sectores agropecuario, industrial y minero, mientras que los demás se clasificaron como no transables. 
En segundo lugar, el aporte de la inversión a la creciente productividad laboral tendió a ser mayor en el caso de los sectores transables, como lo demuestra la coincidencia de los aumentos de la inversión y de la productividad laboral en Chile (en todos los períodos) y en la Argentina (1993-1996 y 2003-2010), o la coincidencia de variaciones limitadas de la productividad asociadas a menores incrementos de la inversión, como se observa también en el caso de la Argentina (1997-2002) y México (1993-1996 y 2003-2010), en particular. Contrasta con ello el aporte de la inversión a la productividad laboral en el caso de los sectores no transables, donde, con excepción de Chile, no salta a la vista en el caso de la Argentina, el Brasil o México.

En tercer lugar y relacionado con el párrafo anterior, la creación de empleo (expresada en el cuadro por el número de horas hombre trabajadas) por parte del sector transable en la Argentina, Chile y México fue negativa durante el período 1993-2010 en su conjunto, mientras que en el Brasil el aumento resultó relativamente modesto (al igual que en la Argentina en 2003-2010). Esta situación contrasta con lo ocurrido en el sector no transable, donde la creación de empleo registró tasas positivas y significativas en los cuatro países durante este período en general y en cada uno de los subperíodos analizados ${ }^{36}$. Es probable que esta mayor demanda de empleo en el sector no transable en la región, no necesariamente de alta calificación aunque sí con una proporción creciente de empleo asalariado, dé cuenta de las mejoras en los salarios reales durante esta época ${ }^{37}$.

En general, la limitada eficacia de las inversiones en el sector no transable, traducida en inversiones considerables, un incremento significativo de las horas trabajadas y un aumento modesto de su productividad, probablemente refleje tanto las propias condiciones heterogéneas del sector como la naturaleza del mercado laboral de cada país. En el caso de Chile, puede plantearse como hipótesis que un mercado con menor desempleo y subempleo, aun en el sector no transable, conduce a un menor aumento de las horas trabajadas y a un mayor incremento de la productividad laboral que en el caso de los otros países ${ }^{38}$. En el otro extremo se halla México, donde pese a cierto auge de la inversión en el sector no transable, disminuye la productividad al tiempo que el número de horas trabajadas va en alza.

\footnotetext{
México constituye la única excepción entre 1993-1996.

37 Véase en Weller y Kaldewei (2013) el gráfico 16, donde se pone en evidencia el mayor crecimiento del empleo en sectores no transables, así como el gráfico 4, donde se refleja el aumento del empleo asalariado y la reducción del trabajo por cuenta propia, sobre todo entre 2003 y 2007.

38 Palma (2013), quien halló pruebas de una desindustrialización en varios países de América del Sur -medida en términos de empleo-, argumenta que un mercado laboral más restringido favoreció la productividad de Chile.
} 
Así, la existencia de un sector no transable heterogéneo de baja productividad, alto empleo y montos mayores de inversión contrasta con un sector transable que es el destino de las inversiones que, al incorporar innovaciones técnicas, aumentan la productividad laboral, crean escaso o nulo empleo adicional y son objeto de montos de inversión relativamente acotados. Este peligro ya se había observado durante los años noventa a raíz del auge de los ingresos de capital externo, que causó un alza del tipo de cambio. Si bien este efecto propiciaba la inversión, pues bajaba el precio en moneda nacional de los bienes de capital importados, también favorecía las inversiones en los sectores no transables (Agosín, 1998) y habría vuelto a manifestarse después de 2003.

En consonancia con las ampliaciones que ya se han realizado y algunas iniciativas similares adoptadas para otros enfoques poskeynesianos (Pérez Caldentey y Vernengo, 2013), estas explicaciones sugieren la necesidad de enriquecer el enfoque de Robinson para tomar también en consideración la cuenta de capital, el tipo de cambio y dos sectores alternativos a los que abordó en sus trabajos - los bienes de capital y de consumo-, que podrían ser los sectores transables y no transables, para articularlos con el efecto del tipo de cambio y de los precios relativos en general. Además de incorporar las variables de ahorro externo y déficit fiscal (Lovinsky y Gibson, 2004) en el modelo básico de Robinson, ello también permitiría, en la medida en que también se adaptara el contenido de las edades, mejorar la explicación de las trayectorias más recientes de crecimiento en la región.

Cabría preguntarse, por ejemplo, si no se podría incorporar una edad de cobre que involucrara los procesos de aceleración y desaceleración de la acumulación de capital asociados a los precios de las materias primas exportadas o al ingreso de remesas o de capitales de corto plazo. En este escenario, los tipos de cambio se aprecian en la fase de auge y favorecen la inversión y el empleo asalariado en los sectores no transables -amén de la inversión en recursos naturales-, con lo cual se desincentiva la diversificación productiva y la incorporación acelerada de avances técnicos, aunque aumenten los salarios reales, y se introducen desequilibrios potenciales que luego pueden tornar dificultoso ajustarse a una etapa de desaceleración que el mismo modelo puede incluir.

\section{Conclusiones}

La teoría del crecimiento de Joan Robinson resulta orientadora, pues coloca a la acumulación de capital en el foco del proceso de crecimiento económico, y sus dos funciones de inversión - una que proyecta los rendimientos esperados sobre la base de las inversiones pasadas y otra 
que define la inversión futura sobre todo como un factor que depende de ciertas expectativas (espíritus animales) - revisten utilidad para analizar el proceso de acumulación de capital en América Latina. Los escenarios - edades de crecimiento-, basados en relaciones causales más que en relaciones de equilibrio, también proporcionan marcos para analizar el proceso de crecimiento, y el hecho de que aborden el progreso técnico como un proceso endógeno y el desempleo como un resultado posible de su modelo ofrece mayor pertinencia. También contribuyen a esta riqueza la naturaleza flexible y la apertura analítica de su modelo, que facilita aproximarse al tema del crecimiento desde una perspectiva inductiva, sin que esté completamente predeterminada por un conjunto de relaciones entre variables rígidas definidas a priori.

Ahora bien, el hecho de que la teoría original de Robinson no incorpore un modelo de crecimiento de una economía abierta al comercio exterior y a las relaciones financieras internacionales limita el alcance de sus aportes, tanto en relación con el modelo básico como en lo atinente a las edades de crecimiento. Es posible encontrar analogías entre la edad de plomo y la etapa vivida por América Latina durante la década perdida de 1980, así como entre eventuales barreras de inflación y lo que algunos países con elevada inflación experimentaron durante los años noventa, o entre una edad de oro lánguida y el crecimiento de un número reducido de países en 1990-1997. También es posible identificar rasgos compartidos por la edad de platino galopante y la etapa de gran crecimiento experimentado por un grupo mayor de países como resultado del auge del precio de los recursos naturales entre 2003 y 2008. Sin embargo, el modelo de Robinson y sus edades requieren ampliaciones y adaptaciones para ayudar a entender más cabalmente los rasgos básicos del crecimiento en la región.

Algunas ampliaciones ya realizadas incorporan el efecto del ahorro externo y del balance fiscal al modelo básico de Robinson, pero la exclusión de aspectos financieros, sobre todo la cuenta financiera de la balanza de pagos y el tipo de cambio, como variables fundamentales para articular lo ocurrido en el sector externo con el proceso de acumulación de capital, limita en gran medida sus posibilidades de efectuar mayores aportes que permitan comprender mejor el crecimiento en la región. Tanto en el modelo básico de Robinson como en la teoría de las edades de crecimiento convendría incluir estas variables y sustituir la incorporación tradicional de dos sectores - producción de bienes de capital y de bienes de consumo- por categorías alternativas, como el sector transable y el no transable. Este podría ser un aporte beneficioso para entender el proceso de acumulación de capital y de crecimiento en América Latina. 


\section{Bibliografía}

Agosín, M. (1998), “Entradas de capital y desempeño de la inversión: Chile en los noventa", Flujos de capital e inversión productiva: lecciones para América Latina, R. Ffrench-Davis y H. Reisen (eds.), París, Organización de Cooperación y Desarrollo Económicos (OCDE).

Aravena, Claudio y Juan Alberto Fuentes (2013), "El desempeño mediocre de la productividad laboral en América Latina: una interpretación neoclásica", serie Macroeconomía del Desarrollo, N 140 (LC/L.3725), Santiago de Chile, Comisión Económica para América Latina y el Caribe (CEPAL).

Asimakopulos, Athanasios (1991), Keynes's General Theory and Accumulation, Cambridge, Cambridge University Press.

(1984), "Joan Robinson and economic theory", PSL Quarterly Review, vol. 37, $\mathrm{N}^{\mathrm{o}} 15$, Banca Nazionale del Lavoro.

(1977), "Post-Keynesian growth theory", Modern Economic Thought, S. Weintraub, University of Pennsylvania Press.

(1970), "A Robinsonian growth model in one sector notation -an ammendment", Australian Economic Papers, No 9.

(1969), "A Robinsonian growth model in one-sector notation", Australian Economic Papers, $\mathrm{N}^{\mathrm{o}} 8$.

Backhouse, R.E. (2003), "Concentric circles of limits to the rate of accumulation: an interpretation of Joan Robinson's theory of economic dynamics", Review of Political Economy, vol. 15, $\mathrm{N}^{\mathrm{o}} 3$.

Bresser-Pereira, L.C. (2012), Structuralist Macroeconomics and the New Developmentalism, São Paulo, Fundación Getulio Vargas.

CEPAL (Comisión Económica para América Latina y el Caribe) (2013), Estudio Económico de América Latina y el Caribe, 2013 (LC/G.2574-P), Santiago de Chile, agosto. Publicación de las Naciones Unidas, Nº venta: S.13.II.G.3.

(2012), Estudio Económico de América Latina y el Caribe, 2012 (LC/G.2546-P), Santiago de Chile. Publicación de las Naciones Unidas, $\mathrm{N}^{\circ}$ de venta: S.12.II.G.3.

Ffrench-Davis, Ricardo (2005), Reformas para América Latina después del fundamentalismo neoliberal, Buenos Aires, Siglo XX editores.

Findlay, R. (1963), "The Robinsonian model of accumulation", Economica, vol. 30, $\mathrm{N}^{\mathrm{o}} 117$, febrero.

Frenkel, R. y M. Repetti (2009), “A developing country view of the current global crisis: what should not be forgotten and what should be done", Cambridge Journal of Economics, vol. 33.

Galor, O. (2012), Unified Growth Theory, Princeton University Press.

Harcourt, Geoffrey (2006), The Structure of Post-Keynesian Economics. The Core Contributions of the Pioneers, Cambridge University Press.

Harcourt, Geoffrey y Prue Kerr (2009), Joan Robinson, Palgrave Macmillan.

Harris, D.J. (1975), "The theory of economic growth: a critique and reformulation", The American Economic Review, vol. 65, N²

Jiménez, Luis Felipe y Sandra Manuelito (2013), “Rasgos estilizados de la relación entre inversión y crecimiento en América Latina y el Caribe, 1980- 2012", serie Macroeconomía del Desarrollo, N 136 (LC/L.3704), Santiago de Chile, Comisión Económica para América Latina y el Caribe (CEPAL). 
(2012), “La inversión y el ahorro en América Latina: nuevos rasgos estilizados, requerimientos para el crecimiento y elementos de una estrategia para fortalecer su financiamiento", serie Macroeconomía del Desarrollo, No 129 (LC/L.3603), Santiago de Chile, Comisión Económica para América Latina y el Caribe (CEPAL).

Johnson, Harry (1960), “A simple Joan Robinson model of accumulation with one technique", Osaka Economic Papers, Nº 9.

Kaldor, N. (1957), "A model of economic growth", Economic Journal, No 67.

Kalecki, M. (1969), Theory of Economic Dynamics. An Essay on Cyclical and Long-Run Changes in Capitalist Economy, Nueva York, Augustus M. Kelley.

Kurdas, C. (1991), "Robinson's dark room: investment in post-Keynesian growth theory", The Joan Robinson Legacy, I.H. Rima (ed.), Nueva York, M.E. Sharp.

Lavoie, M. (2009), Introduction to Post-Keynesian Economics, Nueva York, Palgrave, Macmillan.

Lovinsky, J. y B. Gibson, (2004), “A Robinson model for Argentina”, Joan Robinson's Economics. A Centennial Celebration, B. Gibson (ed.), Edward Elgar.

Minsky, H. (1986), Stabilizing an Unstable Economy, New Haven, Connecticut, Yale University Press.

Palma, G. (2013) "Desindustrialización, desindustrialización 'prematura' y un nuevo concepto de síndrome holandés", Radiografía crítica al "modelo chileno": balance y propuestas, Gonzalo Martner y Eugenio Rivera (eds.) Santiago de Chile, LOM Ediciones.

Pérez Caldentey, E. y M. Vernengo (2013), “Wage and profit-led growth: the limits to Neo-Kaleckian models and a Kaldorian proposal", Working Paper, No 775, Levy Economics Institute of Bard College.

Robinson, Joan (1971), Economic Heresies: Some Old Fashioned Questions in Economic Theory, Nueva York, Basic Books.

(1963), Essays in the Theory of Economic Growth, Londres, Macmillan.

(1961), Exercises in Economic Analysis, Londres, Macmillan. (1956), The Accumulation of Capital, Londres, Macmillan.

Skott, P. (2004), "Mythical ages and methodological strictures 'Joan Robinson's contributions to the theory of economic growth", Working Paper, No 2004-09, Amherst, University of Massachusetts.

Stallings, B. y R. Studart (2006), Finance for Development. Latin America in Comparative Perspective, Washington D.C., Brookings Institution.

Taylor, L. (2011), Maynard's Revenge. The Collapse of Free Market Macroeconomics, Cambridge, Massachusetts, Harvard University Press.

Uthoff, A. y D. Titelman (1998), “La relación entre el ahorro externo y el ahorro nacional en contextos de liberalización financiera", Flujos de capital e inversión productiva: lecciones para América Latina, R. Ffrench-Davis y H. Reisen (eds.), París, Organización de Cooperación y Desarrollo Económicos (OCDE).

Weller, Jürgen y Cornelia Kaldewei (2013), "Empleo, crecimiento sostenible e igualdad", serie Macroeconomía del Desarrollo, No 145 (LC/L.3743), Santiago de Chile, Comisión Económica para América Latina y el Caribe (CEPAL). 


\section{Anexo}

\section{El modelo de Joan Robinson expresado algebraicamente ${ }^{39}$}

En el modelo de Joan Robinson restringido a las relaciones de equilibrio en el corto plazo se definen los ingresos provenientes de los salarios de los trabajadores y las ganancias de los capitalistas de la siguiente manera:

(1) $Y=W+P$

Donde $Y$ es el ingreso; $W$, los salarios; y $P$, las ganancias.

La tasa de ahorro, por su parte, depende de la participación de los salarios y las ganancias en el ingreso, por lo que el ahorro bruto estará dado por el ahorro bruto de los capitalistas $\left(S_{P}\right)$ y el de los empleados $\left(S_{W}\right)$.

Y el ahorro está compuesto por cada uno de los tipos de ingresos:

(2) $S=S_{W}+S_{P}$

Aquí $S_{W}$ es lo ahorrado de los salarios y $S_{P}$ representa lo ahorrado de las ganancias.

Por lo tanto:

(3) $S_{W}=S_{W} W ; S_{P}=S_{P} P$

$s_{W}$, es la propensión a ahorrar los salarios y $s_{p^{\prime}}$ la propensión a ahorrar las ganancias.

La teoría keynesiana supone como condición de equilibrio que la tasa de ahorro debe ser igual a la tasa de inversión:

(4) $I=S$

Al descomponer el ahorro se obtiene:

(5) $I=S_{W}+S_{P}=s_{W} W+s_{P} P$

(6) $I=S_{W}+S_{P}=S_{W}(Y-P)+S_{P} P$

Al dividir (6) por el capital (K), se obtiene la ecuación de acumulación de capital denotada por I/K:

(7) $\frac{I}{K}=\frac{S_{W}(Y-P)}{K}+\frac{S_{P} P}{K}$

Elaborado por Esteban Pérez, aunque en el caso de las últimas dos ecuaciones también se toma en cuenta a Kurdas (1991) y Backhouse (2003). 
Al reordenar algebraicamente se obtiene la siguiente fórmula:

(8) $\frac{P}{K}=\frac{I / K}{S_{P}+\left(\frac{1-P / Y}{\frac{P}{Y}}\right) S_{W}}$

De (8) obtenemos la tasa de ganancia de la economía, la que está dada por:

(9) $r=\frac{g}{S_{P}+\left(\frac{1-m}{m}\right) S_{W}} ; r=\frac{P}{K}, m=\frac{P}{Y}, g=\frac{I}{K}$

Aquí $r$ es la tasa de ganancia, $m$ representa la ganancia sobre el ingreso y $g$, la tasa de acumulación de capital.

Así, finalmente se obtiene:

(10) $r=\frac{g}{s}$

Donde $s$ es la propensión a ahorrar.

La tasa de acumulación puede representarse de la siguiente manera, aunque existe menor acuerdo sobre su representación e, incluso la propia Robinson, expresó serias dudas acerca de la posibilidad de hacerlo de manera precisa. Una de las opciones es esta:

(11) $g^{*}=y(r-i)\left(y^{\prime}>0, y^{\prime \prime}>0\right)$

Donde $g^{*}$ es la tasa de acumulación deseada y constituye una función creciente de la tasa de ganancia, e $i$ representa la tasa de interés real.

Otra forma de representar la tasa de acumulación consiste en tomar en cuenta la tasa de ganancia deseada, que está muy cerca de la ganancia realizada, donde la inversión deseada del período $t$ se define sobre la base de la tasa de ganancia realizada en el período anterior. De esta forma, la función de inversión podría también representarse como:

(12) $K_{t}^{*}=f\left(r_{t-1}\right)$ donde $f^{\prime}>0$ 
Parte III

Cambio estructural y desarrollo productivo 

Capítulo VII

\section{Productividad y cambio estructural: el estructuralismo y su diálogo con otras corrientes heterodoxas}

Mario Cimoli

Gabriel Porcile

\section{Introducción}

Cuando se rinde tributo a autores relevantes en economía, se puede enfatizar el hecho de que fueron los primeros en detectar o sistematizar ideas avanzadas para su época que encontraron confirmación con el pasar del tiempo; o se puede mostrar que propusieron una agenda de investigación que ha sobrevivido y todavía influye en la agenda contemporánea. Ambos tipos de homenaje podrían prestarse a autores como Prebisch, Furtado y Fajnzylber, aun cuando una proporción no menor de los economistas no tengan plena conciencia de cuánto han contribuido a la teoría del desarrollo. En este capítulo se opta por otra forma de reconocimiento de la tradición estructuralista, que es la de combinarla con otras corrientes de pensamiento y buscar sus puntos de convergencia y mutua fertilización. Las ideas de ciertos autores y escuelas se combinan y complementan con armonía; ello ocurre porque lograron identificar dimensiones centrales del comportamiento de la economía. La facilidad con que se combinan sus ideas es fruto de su profundidad y relevancia. 
En este capítulo se discuten convergencias entre las tradiciones estructuralista, evolucionista y keynesiana. Para ello se presenta un modelo sencillo en que las dinámicas tecnológica y de la demanda efectiva interactúan para definir trayectorias de convergencia o divergencia con los países desarrollados. El foco recae sobre la evolución conjunta de la innovación y difusión de tecnología (enfatizada por los evolucionistas), la estructura productiva (enfatizada por los estructuralistas) y la demanda efectiva (enfatizada por los keynesianos). El modelo se presenta mediante el uso de instrumental gráfico, resumiendo las ecuaciones que involucran sus principales resultados; una presentación formal y más completa del modelo se encuentra en Cimoli y Porcile (2013). Una advertencia es necesaria: este es un ensayo sobre convergencias teóricas y se concentra en algunas de las contribuciones de las escuelas mencionadas. No se pretende, ni sería posible, abarcar el conjunto de ellas. Con el fin de presentar el modelo, determinar sus principales resultados teóricos y mostrar sus implicaciones de política más relevantes, los contenidos de este capítulo se han organizado en cuatro secciones aparte de esta introducción. En la sección A se aborda el vínculo entre crecimiento, especialización y tecnología. En la sección B se presentan los fundamentos microeconómicos del aprendizaje y la convergencia, y en la sección $C$ se expone una aplicación del modelo enfocado en la política industrial. Por último, a modo de conclusión, se presentan algunos comentarios finales.

\section{A. Crecimiento económico, especialización y tecnología}

El punto de partida de los estructuralistas es el estrecho vínculo que existe entre cambios en la estructura productiva y absorción de tecnología. El "manifiesto" de Prebisch atribuye a la difusión lenta y desigual del progreso técnico a escala internacional una responsabilidad clave en la emergencia y reproducción de un centro y una periferia ${ }^{1}$. Para que un país tenga una estructura productiva diversificada y con un peso importante de sectores intensivos en conocimientos, debe ser capaz de aprender, de ser (por lo menos) un "seguidor" eficiente y evitar el aumento del rezago tecnológico. Al mismo tiempo, una estructura productiva con un peso importante de sectores más intensivos en conocimientos genera externalidades y estímulos que alimentan el aprendizaje y los aumentos de productividad. El análisis gráfico siguiente permite mostrar cómo interactúan las diferentes variables (tecnología, especialización, crecimiento, empleo y distribución) (véase el gráfico VII.1). Las contribuciones de distintas escuelas de pensamiento ayudan a comprender la articulación entre dichas variables y su movimiento.

Véanse Rodríguez (1980 y 2007) y Bielshowsky (2009). 


\section{Gráfico VII.1}

Especialización, salarios y crecimiento en el sistema centro-periferia ${ }^{a}$

A

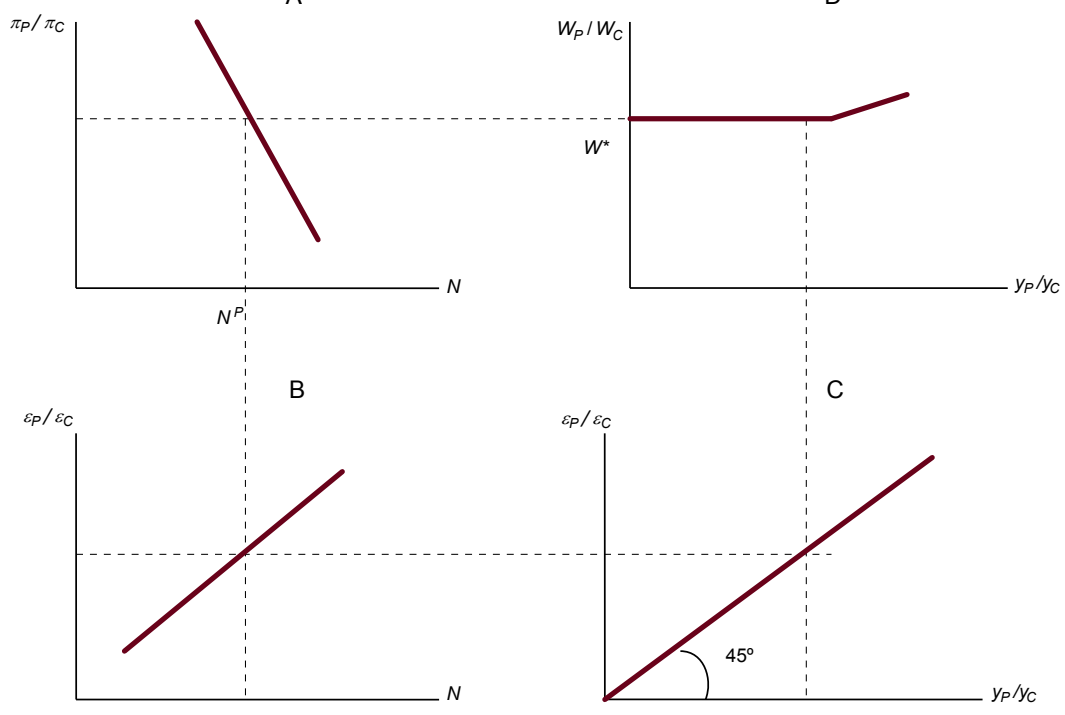

Fuente: Elaboración propia.

a Cuadrante A: brecha tecnológica y productividades relativas entre periferia y centro $\left(\pi_{\mathrm{P}} / \pi_{\mathrm{C}}\right)$ como función de la diversificación de la estructura productiva hacia sectores más intensivos en tecnología $(N)$; cuadrante B: elasticidades ingreso de la demanda de exportaciones e importaciones de la periferia $\left(\varepsilon_{\mathrm{p}} / \varepsilon_{\mathrm{c}}\right)$ como función de $\mathrm{N}$; cuadrante C: crecimiento económico relativo entre periferia y centro $\left(y_{\mathrm{p}} / y_{\mathrm{C}}\right)$ con equilibrio externo; cuadrante D: respuesta del salario relativo $\left(W_{\mathrm{P}} / W_{\mathrm{C}}\right)$ entre periferia y centro a las tasa de crecimiento relativa.

\section{Cuadrante A: brecha tecnológica y productividad relativa}

El modelo se basa en el supuesto de que la producción solo usa trabajo y tecnología, que la distribución de capacidades tecnológicas es asimétrica entre países y que existe un conjunto muy grande de bienes que puede representarse como un continuo de bienes con distintos niveles de productividad del trabajo.

El primer cuadrante (cuadrante A del gráfico VII.1) representa la relación entre estructura productiva, tecnología y productividad. En el eje de las abscisas se representa el número de sectores de la economía ordenados según una clasificación decreciente de productividad del trabajo en la periferia, en comparación con la productividad del trabajo en el centro. El sector $N=1$ es aquel en que la razón entre productividad del trabajo en la periferia $\left(\pi_{\mathrm{p}}\right)$ y productividad del trabajo en el centro $\left(\pi_{\mathrm{C}}\right)$ es más alta; en otras palabras, el primer sector es aquel en que la periferia tiene su mayor ventaja comparativa $\left(\pi_{\mathrm{P}} / \pi_{\mathrm{C}}\right)$, la que disminuye a medida que $N$ aumenta $^{2}$.

2 Véanse Dornbusch, Fischer y Samuelson (1977), Cimoli (1988) y Dosi, Pavitt y Soete (1990). Un modelo en que se recogen plenamente las interacciones entre lo micro y lo macro se presenta en Ciarli y otros (2010). Véase también Katz (1997). 
La productividad relativa de la periferia en cada sector depende de dos factores: i) la brecha tecnológica entre el centro y la periferia, esto es, el grado de superioridad tecnológica del centro, captado por la distancia de la periferia con relación a la frontera tecnológica, y ii) la intensidad tecnológica en la producción de cada uno de los bienes. El supuesto adoptado es que la productividad relativa de la periferia es (para una misma brecha) menor en los bienes más intensivos en tecnología. Por esa razón, a medida que aumenta $N$ y disminuyen las ventajas comparativas de la periferia, también aumenta la intensidad o complejidad tecnológica de los bienes producidos.

¿En qué sectores o bienes se especializa la periferia en el comercio internacional? El precio de los bienes se define como una función del costo unitario de producción, que a su vez depende de la relación entre el valor del salario y la productividad. La periferia podrá producir en forma competitiva todos aquellos bienes en que el costo unitario del salario sea menor que en el centro, o sea los bienes que satisfacen $\left(W_{P} / \pi_{P}^{N}\right)<\left(W_{C} / \pi_{C}^{N}\right)$, donde $W_{P}$ y $W_{C}$ son los salarios en la periferia y el centro, respectivamente, del mismo modo que $\pi_{P}^{N}$ y $\pi_{C}^{N}$ representan las productividades del trabajo de ambos polos en el sector o bien $N$. La periferia producirá en condiciones competitivas hasta el bien $N=N^{P}$, para el que se verifica que el salario relativo $\left(W_{P} / W_{C}\right)$ es igual a la productividad relativa $\left(\pi_{P} / \pi_{C}\right)$. Por lo tanto, el patrón de especialización de la periferia queda definido por los bienes comprendidos entre $N=1$ y $N=N^{P}$, mientras que el centro producirá los bienes a partir de $N=N^{P}$. El bien correspondiente a $N^{P}$ será producido en los dos polos, ya que en ambos el costo de producción es el mismo.

La determinación del patrón de especialización de los polos puede observarse en el cuadrante A del gráfico VII.1. Dado el salario relativo de equilibrio (representado en el cuadrante $\mathrm{D}$ como $W^{*}$ ) y dada la curva de productividades relativas, se obtiene fácilmente el grado de diversificación de la periferia en equilibrio $\left(N^{P}\right)$. El centro produce bienes con valores de $N$ más elevados. Como estos bienes son más intensivos en conocimientos, la estructura productiva del centro tendrá mayor complejidad que la de la periferia ${ }^{4}$.

\section{Cuadrantes B y C: especialización y crecimiento}

En el cuadrante B se representa la relación entre diversificación productiva y la razón entre la elasticidad ingreso de la demanda de exportaciones $\left(\varepsilon_{p}\right)$ e importaciones $\left(\varepsilon_{C}\right)$ en la periferia. La razón entre las elasticidades depende positivamente de la diversificación productiva

Esta es la visión original del sistema centro-periferia, en que las diferencias de productividad entre los polos se explican principalmente por diferencias en las capacidades tecnológicas.

4 Véase CEPAL (2007) y Hausmann e Hidalgo (2010). 
hacia sectores de mayor intensidad tecnológica. Esta relación entre tecnología y elasticidades depende de dos factores.

El primero de ellos es que un patrón de especialización con un mayor peso de los sectores más intensivos en tecnología (un valor más alto de $N$ ) permite al país generar más innovaciones o imitar con más rapidez las que surgen en la economía mundial. Esto a su vez abre las puertas de los mercados de más rápido crecimiento o hace posible ampliar la participación en los mercados externo e interno. El segundo factor es que la demanda de bienes de alta tecnología responde más fuertemente a los aumentos del ingreso que la demanda de productos básicos (commodities) o de bienes de baja tecnología. Si bien la llamada lotería de productos básicos (commodity lottery) puede explicar ciclos breves de bonanza exportadora en los países altamente especializados en bienes primarios, en general, tanto por el lado de la oferta (entendida como la capacidad de aprovechar las oportunidades en mercados en crecimiento o evitar pérdidas de participación) como por el lado de la demanda (referida a los patrones de consumo, que se vuelcan hacia bienes de mayor intensidad tecnológica a medida que aumenta el ingreso), la elasticidad ingreso de la demanda de exportaciones del país aumenta a medida que este se especializa en bienes más intensivos en tecnología 5 .

Los autores estructuralistas y la tradición keynesiana en teoría del crecimiento enfatizan que la tasa de crecimiento con equilibrio externo de la periferia depende de la relación entre las elasticidades ingreso de la demanda de exportaciones e importaciones ${ }^{6}$, como se expresa en la siguiente ecuación:

(1) $y_{p}=\frac{\varepsilon_{p}}{\varepsilon_{c}} y_{c}$

Con ciertos supuestos ${ }^{7}$, la ecuación 1 proporciona la tasa de crecimiento del producto de largo plazo con equilibrio externo en los dos polos del sistema: $y_{P}$ es la tasa de crecimiento de la periferia, $y_{C}$ la tasa de crecimiento del centro y $\left(\varepsilon_{P} / \varepsilon_{c}\right)$ la razón entre las elasticidades. Estas tasas son compatibles con el equilibrio externo porque garantizan que la

Véanse Araujo y Lima (2007); Blecker (2011); Botta (2009); Cimoli y Porcile (2011); Dosi, Pavitt y Soete (1990); CEPAL (2007 y 2012); Gouvea y Lima (2010).

6 Véanse McCombie y Thirlwall (1997) y Moreno-Brid (2003). Una revisión amplia del tema se encuentra en Thirlwall (2011).

7 La validez de esta relación requiere un tipo de cambio real constante y que no haya endeudamiento líquido en el largo plazo. El tipo de cambio real puede desempeñar un papel importante en el largo plazo al afectar el grado de diversificación de la estructura, un tema que no se aborda en este trabajo. Sobre este aspecto, véanse Bresser (2008), Freund y Pierola (2008), Eichengreen (2008), Frenkel y Rapetti (2011), McMillan y Rodrik (2011) y Cimoli y otros (2012). La ecuación también requiere que no haya pleno empleo, de tal forma que la oferta de trabajo siempre se ajuste a los estímulos de la demanda. Más detalles pueden encontrarse en Cimoli y Porcile (2013). 
tasa de crecimiento de las exportaciones de la periferia $\left(\varepsilon_{P} y_{C}\right)$ será igual a la tasa de crecimiento de sus importaciones $\left(\varepsilon_{C} y_{p}\right)$. Recordando que la razón entre las elasticidades es una función del grado de diversificación de la estructura productiva periférica, la ecuación 1 puede escribirse como:

(2) $y_{p}=f\left(N^{P}\right) y_{c}, f^{\prime}\left(N^{P}\right)>0$

La forma funcional de $f\left(N^{P}\right)$ es una cuestión empírica; por simplicidad, se asumirá una especificación lineal a lo largo del trabajo. Su curvatura depende del impacto de la mayor complejidad productiva y del cambio de la especialización sobre la participación del país en los distintos mercados. De la ecuación 1 se obtiene la tasa relativa de crecimiento entre centro y periferia, que será exactamente igual a la relación entre las elasticidades ingreso de las exportaciones y las importaciones de la periferia, función de $N^{P}$.

$$
\text { (3) } \frac{y_{p}}{y_{c}}=\frac{\varepsilon_{p}}{\varepsilon_{c}}=f\left(N^{P}\right)
$$

La igualdad anterior se representa en el cuadrante $C$, donde por medio de una línea trazada en un ángulo de $45^{\circ}$ se transforma la relación entre las elasticidades ingreso de las exportaciones de la periferia y del centro, en una relación entre las tasas de crecimiento de equilibrio de las dos economías. La causalidad teórica va desde las elasticidades hacia el crecimiento, mientras que las elasticidades dependen del progreso técnico y de los patrones de demanda.

La periferia podría crecer durante cierto tiempo a una tasa superior a la definida por la razón entre las elasticidades, pero ello está asociado a un aumento de la deuda externa (las importaciones se incrementan más que las exportaciones en el tiempo). Surge así la posibilidad de ciclos de expansión y recesión asociados a ciclos de endeudamiento y a la posterior remesa de divisas por concepto de pago de la deuda (políticas de rápida alternancia de expansión y contracción (stop and go) observadas con frecuencia en la historia económica de la región (véanse Ffrench-Davis y Ocampo (2001) y Ocampo y otros (2009)). En el largo plazo, en tanto, a pesar de las fluctuaciones, la tendencia de las tasas de crecimiento será a mantenerse próximas a la definida por la condición de equilibrio externo.

\section{Salarios, empleo y subempleo}

El cuadrante D permite encontrar el nivel del salario relativo de equilibrio a partir de la dinámica del crecimiento y el empleo. La tasa de crecimiento de la demanda de trabajo en la periferia depende de la tasa de crecimiento económico menos la tasa de aumento de la productividad del trabajo. En la 
medida en que el crecimiento de la demanda de trabajo supere el aumento de la oferta de trabajo (dado por la tasa de crecimiento de la población), habrá una reducción del subempleo y de la heterogeneidad estructural, definida por las grandes diferencias de la productividad del trabajo entre sectores y dentro de los sectores, en la periferia. Esto ocurre porque una proporción de los trabajadores será gradualmente retirada del sector del empleo de subsistencia para situarse en los sectores de mayor productividad. A la inversa, si los estímulos de demanda proporcionados por la relación de elasticidades son muy débiles, debido a una especialización muy concentrada en bienes con baja elasticidad ingreso de la demanda, el subempleo podría aumentar. En casos en que el progreso técnico tiene como principal resultado la racionalización de los procesos productivos y la reducción de costos, sin la paralela expansión del producto, los aumentos de productividad no se traducen en mayor crecimiento, sino en más desempleo, subempleo o ambos.

Por ello, para evaluar correctamente el impacto de los aumentos de productividad y del progreso técnico sobre el empleo y el subempleo, es necesario tomar en cuenta sus impactos sobre las elasticidades y sobre la demanda agregada. La reducción de la heterogeneidad estructural requiere tasas de crecimiento del producto acordes con la productividad, que garanticen la creación de empleos en los estratos de mayor productividad, reduciendo el peso de la informalidad y el subempleo (Infante y Sunkel, 2009).

En el cuadrante D se observa que el salario relativo entre periferia y centro responde positivamente a tasas mayores de crecimiento en la periferia, que generan un aumento de la demanda de trabajo. La respuesta del salario relativo es lenta al principio, debido a la amplia reserva de trabajadores en las actividades de subsistencia o informalidad de baja productividad. Pero a medida que el crecimiento periférico se acelera, es factible esperar que el mercado de trabajo se incline gradualmente a favor de los trabajadores. Cuando ello ocurre, no solo el nivel de empleo, sino también el de salarios, muestra una reacción positiva en la periferia. La parte ascendente de la curva de salarios relativos indica el mayor dinamismo del mercado de trabajo de la periferia, cuando esta se diversifica.

El peso de la heterogeneidad y las tasas más bajas de crecimiento del empleo en la periferia en comparación con el centro implican que el salario relativo tenderá a ser más bajo en la primera. Este es un factor adicional que eleva la desigualdad en la economía periférica. Es verdad que el diferencial de salarios podría aumentar la competitividad de dicha economía, lo que a su vez podría favorecer su diversificación. Pero si las diferencias de productividad entre los polos son muy marcadas, la respuesta de la diversificación frente a los menores salarios será 
muy pequeña ${ }^{8}$. Este efecto corresponde al concepto de competitividad espuria de Fajnzylber (1990): la periferia se vuelve más competitiva por aceptar salarios menores, pero ello no tiene efectos significativos sobre el aprendizaje. La competitividad auténtica se origina en una reducción de la brecha tecnológica y de la brecha de productividades, y en ese caso el salario relativo aumenta en respuesta al cambio estructural en la periferia sobre la base de la incorporación de progreso técnico.

Los cambios en los precios relativos afectan la estructura productiva y por ese medio el crecimiento de largo plazo. El nivel de los precios relativos incide en el patrón exportador y puede por eso elevar (o reducir) la tasa de crecimiento. Más aún, puede ocurrir que una apreciación cambiaria genere una pérdida de sectores que no es posible recuperar por medio de una depreciación. En este caso habría un efecto de histéresis (se destruyen sectores que después no se recuperan, aun cuando el tipo de cambio se eleve otra vez). Estos efectos pueden ser importantes, pero su análisis escapa a los objetivos de este trabajo.

\section{B. Fundamentos microeconómicos del aprendizaje y la convergencia}

En el análisis anterior fue posible mostrar cómo las diferentes variables (tecnología, especialización, crecimiento, empleo y heterogeneidad) se combinan en una situación hipotética de crecimiento con equilibrio externo. Pero es necesario discutir qué tipo de dinámica microeconómica sostiene tal resultado, lo que se hará en esta sección. Cuando se desarrollaban los trabajos pioneros de la CEPAL, no se contaba con una teoría microeconómica en que se pudiera fundamentar de forma rigurosa la divergencia observada a nivel macroeconómico. Esta teoría microeconómica la proporciona la economía evolucionista, que desde mediados de la década de 1970 ha avanzado en la comprensión de la dinámica tecnológica y de construcción de capacidades.

¿Por qué el progreso técnico no se difunde en la periferia como en el centro? Entender la dinámica asimétrica de la innovación y la generación de empleos entre centro y periferia, y en el interior de la estructura periférica, es clave para entender la persistencia de la extrema desigualdad que caracteriza la región. En esta sección se discute qué fuerzas acentúan o diluyen la polarización a partir de la microeconomía

En términos gráficos, si el declive de la curva de productividades relativas es muy marcado, una gran caída del salario relativo solo produce un leve cambio en el patrón de especialización. 
evolucionista (de inspiración schumpeteriana), que representa un complemento natural a la macroeconomía estructuralista-keynesiana9.

En clara oposición a los supuestos de la teoría del crecimiento dominante hasta mediados de los años ochenta, para los evolucionistas el progreso técnico no era un bien libre y mucho menos exógeno, dado por "Dios y los ingenieros", según la conocida frase de Joan Robinson. Su visión sobre el proceso de aprendizaje puede resumirse en los siguientes aspectos:

- El aprendizaje es localizado y las empresas aprenden en el entorno de las competencias y capacidades tecnológicas existentes.

- El aprendizaje posee un fuerte componente tácito, de modo que en muchos casos la tecnología no puede ser copiada o transferida en forma codificada (mediante manuales o instrucciones, por ejemplo), sino que la experiencia en la producción es crucial.

- El progreso técnico tiene marcados elementos de dependencia de la trayectoria (path-dependency), lo que implica que la sombra del pasado se proyecta en la evolución futura de las capacidades.

- Los aspectos anteriores sugieren que los procesos de innovación y difusión de tecnología deben concebirse como estrechamente vinculados, ya que no hay difusión sin el esfuerzo de las empresas rezagadas por adaptar y mejorar la tecnología extranjera a la luz de las condiciones específicas de sus mercados y capacidades. De hecho, la difusión viene acompañada por una secuencia de innovaciones menores que, si bien en forma individual tienen un impacto muy pequeño, a lo largo de varios años generan aumentos significativos de productividad y competitividad internacional.

- Los casos exitosos de convergencia o reducción de la brecha (catching up) se caracterizan, precisamente, por el esfuerzo continuado en que la tecnología extranjera se usa como una base para el aprendizaje local, y no como un sustituto.

- En el aprendizaje hay elementos de retornos crecientes muy marcados, que explican fenómenos de acumulación de capacidades, por un lado, y de rezago creciente, por otro. Las empresas que innovan en cierto período son las que tienen más

Véanse Dosi (1988), Cimoli y Dosi (1995), Katz (1997) y Cimoli, Dosi y Stiglitz (2008). En los trabajos pioneros de la CEPAL de los años cincuenta, se suponía implícitamente que la industrialización bastaría para inducir la absorción de tecnología y el cierre de la brecha. Junto con la protección a la industria, se estaría protegiendo el proceso de aprendizaje. La visión de Steindl (1952 y 1976, pág. 133), según la cual el progreso técnico acompaña "como una sombra" a la acumulación de capital, podría describir en forma aproximada la idea sobre la relación entre industria y tecnología que predominaba en la época. 
probabilidad de innovar en el período siguiente. Los retornos crecientes se asocian a distintos tipos de complementariedades entre activos productivos y tecnológicos, y a varias formas de sinergia a nivel meso y macroeconómico. Estas sinergias pueden generar ciclos virtuosos de aprendizaje, inversión y crecimiento.

- El argumento anterior extiende así la llamada ley de VerdoornKaldor - según la cual los aumentos de producción inducen aumentos de productividad-para abarcar la influencia de una amplia gama de procesos de aprendizaje. Dichos procesos fueron identificados y analizados por la literatura neoschumpeteriana y entre ellos se destacan no solo el aprendizaje por experiencia o por la práctica (learning by doing), sino también el aprendizaje por uso (learning by using), el aprendizaje por interacción (learning by interacting) y el aprendizaje por exportación (learning by exporting), entre otros ${ }^{10}$.

- El progreso técnico emerge de un proceso de interacción, de prueba $\mathrm{y}$ error $\mathrm{y}$ de intercambio de informaciones en que participan un conjunto amplio y heterogéneo de agentes, muchas veces con objetivos diferentes, reglas y estructuras organizacionales muy diversas (por ejemplo, empresas, universidades y centros de investigación). La existencia de un marco institucional adecuado, formal o informal, que coordine la interacción de esos agentes e induzca comportamientos cooperativos a favor de la innovación y la difusión, es clave para determinar la intensidad del progreso técnico.

- No hay una trayectoria predeterminada para el progreso técnico: su propio carácter tácito, idiosincrático, específico a una cierta realidad, hace que distintas trayectorias y bifurcaciones sean posibles. Más aún, el diseño institucional y de las políticas industrial y tecnológica (incluida la política de educación) puede afectar fuertemente su rumbo, de modo que hay espacios para que la sociedad tome decisiones estratégicas sobre cuáles son los senderos deseables.

El conjunto de factores descritos define la tasa de innovación y difusión a escala internacional, y la de cada país en particular, a partir de las características de sus estructuras productivas y de sus configuraciones institucionales. Dichos factores son los que en última instancia están en la base de la acumulación de capacidades tecnológicas a lo largo del tiempo. Diversos autores (Freeman, 1987; Nelson, 1991; Metcalfe, 2001)

10 Véanse León-Ledesma (2002) y Arthur (1989 y 1994). 
acuñaron la expresión "sistema nacional de innovación" para referirse a las distintas formas en que el marco institucional (incluidas las políticas tecnológica e industrial, así como la política macroeconómica) y la estructura productiva se combinan en cada país para definir la intensidad y dirección de la innovación. La diversidad de combinaciones posibles es parte importante de los distintos estilos de desarrollo que se observan en los diferentes países y períodos históricos.

La discusión anterior permite mirar hacia el lado de la oferta y la microeconomía de una forma muy distinta a la convencional. El progreso técnico no se refleja en cambios de funciones de producción bien definidas, sino en trayectorias de aprendizaje que se materializan en la acumulación de capacidades tecnológicas. En particular, el papel de las políticas públicas no es lograr mayor flexibilidad en los mercados o la neutralidad de estímulos, sino construir instituciones que posibiliten mecanismos estables de coordinación de largo plazo entre los distintos agentes que estimulen las inversiones en innovación y difusión de tecnología. Estas instituciones complementan el sistema de precios, en algunos casos, y en otros generan las distorsiones necesarias para escapar de situaciones de dependencia de la trayectoria.

\section{Un ejemplo: la política industrial}

En esta sección se utiliza el marco analítico esbozado previamente para analizar el impacto de las políticas destinadas a promover el aprendizaje y el cambio estructural.

En el gráfico VII.2 se muestra el efecto de la adopción de una política industrial y tecnológica activa que hace posible un proceso de convergencia tecnológica, es decir, de reducción de la brecha tecnológica y de productividad con las economías líderes. Se observa que el efecto de una política de este tipo es mover hacia la derecha la curva de productividades relativas en el cuadrante 2A. Como consecuencia, se produce un cambio en el patrón de especialización (de X a Z). El país ha aumentado la complejidad de su estructura productiva y capta en mayor medida los impulsos dinámicos que provienen de la demanda efectiva global. En otras palabras, hay un cambio en las elasticidades ingreso de las exportaciones e importaciones (cuadrante 2B), junto con el cambio en el patrón de especialización. Esto realimenta y fortalece el crecimiento (cuadrante 2C), el aprendizaje y el cambio estructural. Los rendimientos crecientes a escala entran en la historia por medio del círculo virtuoso generado por la interacción entre el aumento de la productividad, la diversificación, el crecimiento y el impacto de este último sobre la productividad (Verdoorn-Kaldor). 


\section{Gráfico VII.2}

Impacto de la política industrial y tecnológica ${ }^{a}$

$2 \mathrm{~A}$

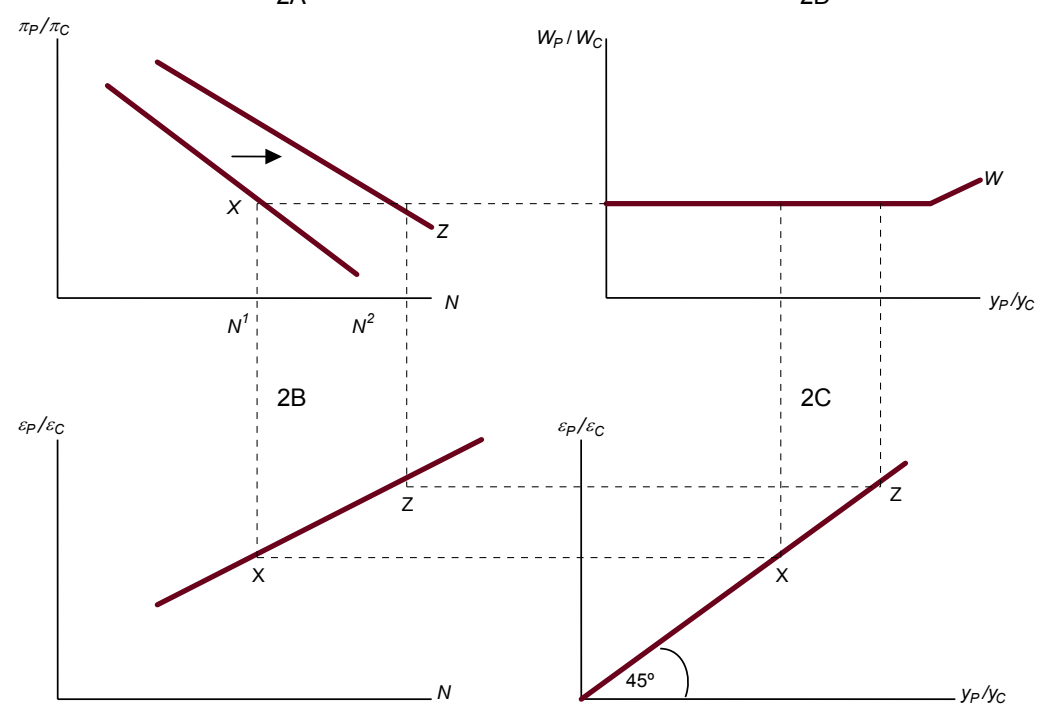

Fuente: Elaboración propia.

a Cuadrante 2A: productividades relativas entre centro y periferia, donde $\pi_{P}$ es la productividad de la periferia y $\pi_{C}$ es la productividad del centro; cuadrante 2B: elasticidades ingreso de las exportaciones e importaciones como función del grado de diversificación de la estructura; cuadrante 2C: relación entre patrón de especialización y crecimiento con estabilidad en la cuenta corriente; cuadrante 2D: salarios relativos entre centro y periferia como función del crecimiento económico.

Al mismo tiempo, la nueva configuración del patrón productivo trae aparejado un cambio en la configuración de la estructura del empleo. El cambio estructural permite absorber en empleos de mayor productividad a más trabajadores, que antes estaban en el subempleo. Si bien en el ejemplo se supone que no hubo cambios en los salarios relativos entre centro y periferia (cuadrante 2D), la caída del subempleo transforma el más rápido crecimiento en una mejor distribución.

La previsión del modelo estructuralista, con sus distintas vinculaciones con las escuelas schumpeteriana y keynesiana, es que aquellos países que aplican políticas industriales y tecnológicas más activas consiguen, al mismo tiempo, transformar su base productiva y reducir las diferencias de productividad que los separan de los países líderes. El cambio estructural y la reducción de brechas van juntos. Esto es precisamente lo que puede observarse en los gráficos VII.3 y VII.4, apreciados en forma complementaria. Allí se muestra la evolución conjunta de una proxy del cambio estructural, el índice de participación relativa (IPR, que refleja el peso relativo de las ingenierías en las 
manufacturas, en comparación con su peso en las manufacturas en un país avanzado ${ }^{11}$, y de la productividad relativa del trabajo, que es una proxy de la brecha tecnológica. El país avanzado que se toma como referencia es los Estados Unidos, pero podría ser cualquier país próximo a la frontera tecnológica. Se comparan la Argentina, el Brasil y la República de Corea entre 1990 y 2008. Se seleccionaron la Argentina y el Brasil por el hecho de que cuentan con una industria relativamente avanzada en la región. Los resultados que se observan son válidos también para los países más pequeños, donde la intensidad del cambio estructural es aún débil en comparación con la de países de mayor tamaño. La duración y consistencia de las políticas industrial y tecnológica en la República de Corea ha sido ya ampliamente documentada (véanse por ejemplo los trabajos clásicos de Amsden (1989) y Chang (2002), mientras que en la Argentina y el Brasil estas políticas han sufrido fuertes discontinuidades (Bell, 2006; Peres, 2010). Una comparación con un mayor número de países, fuera y dentro de la región, puede encontrarse en CEPAL (2012).

\section{Gráfico VII.3}

Países seleccionados: intensidad tecnológica de la estructura productiva, 1990-2008 a

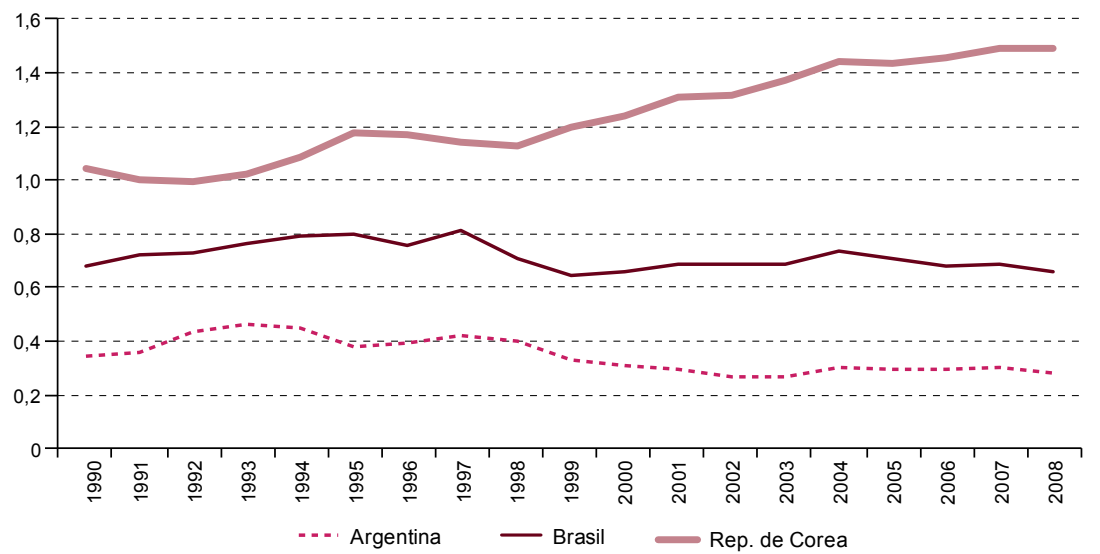

Fuente: Elaboración propia.

a La intensidad tecnológica está expresada mediante el índice de participación relativa (IPR), que corresponde a la participación de las actividades de ingeniería en el valor agregado manufacturero del país dividida por la participación de las actividades de ingeniería en el valor agregado manufacturero de un país avanzado (en este caso, los Estados Unidos).

11 Todos los indicadores de cambio estructural usados en la literatura tienen limitaciones importantes, y el IPR no es la excepción a esta regla. De todas formas, los resultados que se muestran en el gráfico VII.3 no cambian cuando se usan indicadores alternativos, como el índice de complejidad económica o los gastos en I+D como porcentaje del PIB. 
Gráfico VII.4

Países seleccionados: productividad relativa, 1990-2008 ${ }^{a}$

(Estados Unidos $=100$ )

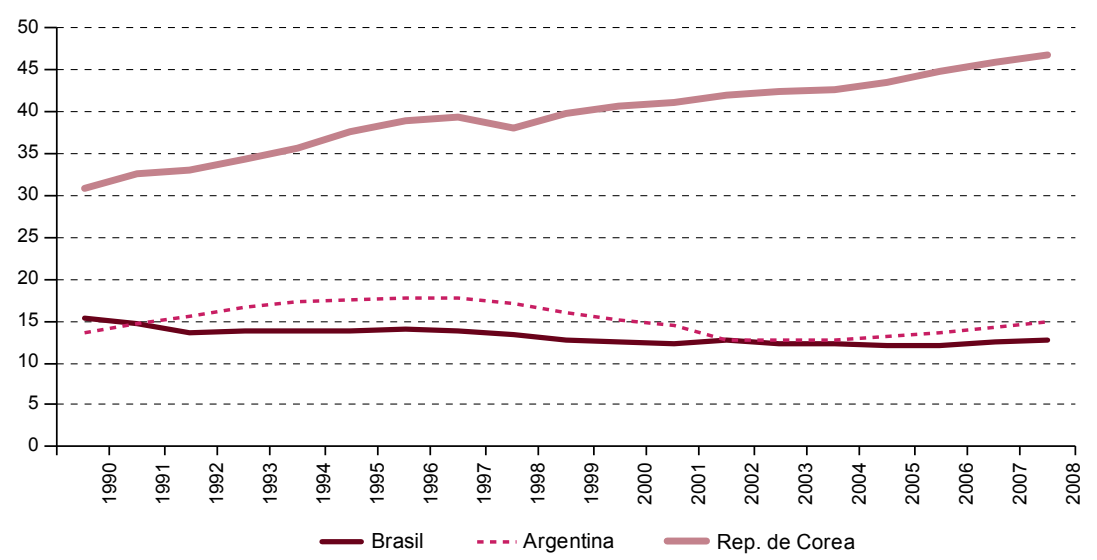

Fuente: Elaboración propia.

a La productividad relativa es la productividad del trabajo del país dividida por la productividad del trabajo de un país en la frontera tecnológica (en este caso, los Estados Unidos).

Se observa que en la República de Corea la brecha con la frontera tecnológica se reduce al mismo tiempo que la estructura productiva se torna cada vez más densa desde el punto de vista tecnológico. Por el contrario, en los dos países latinoamericanos seleccionados para el ejercicio comparativo hay una tendencia al estancamiento o a moverse en el sentido opuesto: pérdida de complejidad, de productividad relativa y de crecimiento. La dinámica que subyace a este comportamiento, como se mencionó, es la considerable diferencia de intensidad y dirección de sus políticas industriales y tecnológicas.

\section{Comentarios finales}

La teoría estructuralista del desarrollo busca identificar las razones por las que las desigualdades en productividad, crecimiento e ingresos por habitante se mantienen o se amplían a lo largo del tiempo, tanto en la economía internacional como dentro de las economías rezagadas. Esta teoría sugiere que dichas tendencias son resultado de la evolución conjunta de las estructuras productivas y el aprendizaje tecnológico. La reproducción de esas tendencias se sostiene por los diversos mecanismos acumulativos de construcción de capacidades, estudiados por la teoría evolucionista. Debido a la importancia de estos mecanismos, para escapar de las trampas del bajo crecimiento y el bajo aprendizaje se requiere la 
acción de la política industrial y, en particular, el fortalecimiento del sistema nacional de innovación. Los impactos del cambio estructural sobre el crecimiento y el empleo son mediados por sus efectos sobre la demanda efectiva — como ha sido propuesto por la tradición keynesiana y por el multiplicador dinámico de Harrod-y, más específicamente, sobre la tasa de crecimiento compatible con la estabilidad de la relación entre el déficit en cuenta corriente y el PIB.

La reproducción de las asimetrías productivas se asocia también a la evolución de variables que están más allá de lo tecnológico. Existen dinámicas sociales y políticas que afectan el ambiente institucional y los incentivos al aprendizaje, y que refuerzan los mecanismos acumulativos del cambio técnico. Si bien la dinámica social no es abordada en este trabajo, debe resaltarse que no existe nada de inevitable o inmutable en la divergencia de los países menos desarrollados. Las políticas no son completamente endógenas a la estructura. Más que por la figura de un juego de ajedrez, en que cada pieza solo puede ejecutar movimientos rígidamente predeterminados, la idea de desarrollo se representa mejor por la imagen de Borges del jardín de los senderos que se bifurcan: hay trayectorias diversas que se van descubriendo y revelando a partir de decisiones estratégicas, que requieren de cierta creatividad e invención a cada momento. Es necesario recuperar la percepción de que existen estilos de desarrollo y que la sociedad puede ejercer su capacidad de escoger entre futuros alternativos. Sin duda, en cada paso se enfrentan restricciones específicas, tanto en el plano tecnológico como en el de la estructura productiva y social. Las decisiones estratégicas son precisamente las que se toman con el objetivo de ir superando de manera gradual las restricciones en el tiempo, en lugar de confirmarlas y reforzarlas. La política industrial de las próximas décadas debe tener como eje central la absorción y la acumulación de capacidades en los nuevos paradigmas, así como la construcción de instituciones para la adaptación y la generación de innovaciones incrementales, y aun de innovaciones mayores, en dichos paradigmas. Tener o no capacidades en las nuevas tecnologías define quién será competitivo en qué ramas y quién tendrá o no un lugar en la futura división internacional del trabajo. 


\section{Bibliografía}

Amsden, A. (1989), Asia's Next Giant: South Korea and Late Industrialization, Nueva York, Oxford University Press.

Araujo, R.A. y G.T. Lima (2007) "A structural economic dynamics approach to balance of payments constrained growth", Cambridge Journal of Economics, vol. 31, N 5 .

Arthur, B. (1994), Increasing Returns and Path-Dependency in Economics, Michigan University Press/Ann Arbor.

(1989), "Competing technologies, increasing returns and lock-in by historical events", Economic Journal, vol. 99, N 1.

Bell, M. (2006), "Time and technological learning in industrializing countries: how long does it take? how fast is it moving (if at all)?", International Journal of Technology Management, vol. 36, N $\mathrm{N}^{\mathrm{o}}$ 1-3.

Bértola, L. y J.A. Ocampo (2010), Desarrollo, vaivenes y desigualdad: Una historia económica de América Latina desde la independencia, Madrid, Secretaría General Iberoamericana (SEGIB).

Bielschowsky, R. (2009), "Sesenta años de la CEPAL: estructuralismo y neoestructuralismo", Revista CEPAL, N 97 (LC/G.2400-P), Santiago de Chile, Comisión Económica para América Latina y el Caribe (CEPAL), abril.

Blecker, R.A. (2011), “Long-run growth in open economies: export-led cumulative causation or a balance-of-payments constraint?", Handbook of Post-Keynesian Economics, G. Harcourt y P. Kriesler (eds.), Oxford, Oxford University Press.

Botta, A. (2009), "A structuralist North-South model on structural change, economic growth and catching up", Structural Change and Economic Dynamics, vol. 20.

Bresser-Pereira, Luiz Carlos (2008), "Dutch disease and its neutralization: a Ricardian approach", Brazilian Journal of Political Economy,vol. 28, $\mathrm{N}^{\mathrm{o}} 1$, enero.

Chang, H.J (2002), Kicking Away the Ladder: Policies and Institutions for Economic Policy in Historical Perspective, Londres, Anthem Books.

CEPAL (Comisión Económica para América Latina y el Caribe) (2012), Cambio estructural para la igualdad. Una visión integrada del desarrollo(LC/G.2524(SES.34/3)), Santiago de Chile. (2007), "Progreso técnico y cambio estructural en América Latina", Documentos de Proyecto, $\mathrm{N}^{\mathrm{o}} 136$ (LC/W.136), Santiago de Chile.

Ciarli, T. y otros (2010), "The effect of consumption and production structure on growth and distribution. A micro to macro model", Metroeconomica, vol. 61, No 1 .

Cimoli, M. (1988), “Technological gaps and institutional asymmetries in a North-South Model with a continuum of goods", Metroeconomica, vol. 39, No. 3.

Cimoli, M. y G. Dosi (1995), “Technological paradigms, patterns of learning and development: an introductory roadmap", Journal of Evolutionary Economics, Heidelberg, Springer-Verlag Heidelberg.

Cimoli, M. y G. Porcile (2013), “Technology, structural change and BOP-constrained growth: a structuralist toolbox", Cambridge Journal of Economics.

(2011), "Learning, technological capabilities and structural dynamics", The Oxford Handbook of Latin American Economics, J.A. Ocampo y J. Ros, Oxford University Press.

Cimoli, M., G. Dosi y J.E. Stiglitz (2008), "The political economy of capabilities accumulation: the past and future of policies for industrial development. A preface", LEM Papers Series, No 2008/15, Pisa, Laboratory of Economics and Management (LEM), Sant'Anna School of Advanced Studies. 
Cimoli, M., G. Porcile y S. Rovira (2010), "Structural change and the BOP constraint: why did Latin America fail to converge?", Cambridge Journal of Economics, vol. 34, $\mathrm{N}^{\mathrm{o}} 2$.

Cimoli, M., S. Fleitas y G. Porcile (2012), "Technological intensity of the export structure and the real exchange rate", Economics of Innovation and New Technology, vol. $22, \mathrm{~N}^{\circ} 4$.

Dornbusch, R., S. Fischer y P. Samuelson (1977), "Comparative advantage, trade, and payments in a Ricardian Model with a continuum of goods", American Economic Review, vol. 67, $\mathrm{N}^{\circ} 5$.

Dosi, G. (1988), "Sources, procedures and microeconomic effects of Innovation", Journal of Economic Literature, vol. 26, $\mathrm{N}^{\circ} 3$.

Dosi, G., K. Pavitt y L. Soete (1990), The Economics of Technical Change and International Trade, Brighton, Wheatsheaf.

Eichengreen, B. (2008), "The real exchange rate and growth", Working Paper $\mathrm{N}^{\circ} 4$, Commission on Growth and Development.

Fajnzylber, Fernando (1990), “Industrialización en América Latina: de la 'caja negra' al 'casillero vacío': comparación de patrones contemporáneos de industrialización", serie Cuadernos de la CEPAL, No 60 (LC/G.1534/Rev.1-P), Santiago de Chile. Publicación de las Naciones Unidas, $\mathrm{N}^{\circ}$ de venta: S.89.II.G.5.

Freeman, C. (1995), "The national system of innovation in historical perspective", Cambridge Journal of Economics, vol. 19, $\mathrm{N}^{\circ} 1$. (1987), Technology Policy and Economic Performance: Lessons from Japan, Londres, Francis Pinter.

Ffrench-Davis, Ricardo y José Antonio Ocampo (2001), "La globalización de la volatilidad financiera", Crisis financieras en países 'exitosos', Ricardo Ffrench-Davis (ed.), Santiago de Chile, McGraw-Hill/Comisión Económica para América Latina y el Caribe (CEPAL).

Frenkel, R. y M. Rapetti (2011), "A concise history of exchange rate regimes in Latin America", The Oxford Handbook of Latin American Economics, J.A. Ocampo y J. Ros, Oxford University Press.

Freund, C. y M.D. Pierola (2008), "Export surges: the power of a competitive currency", Policy Research Working Paper, $\mathrm{N}^{\circ} 4750$, octubre.

Gouvea, R.R. y G.T. Lima (2010), "Structural change, balance of payments constraint and economic growth: evidence from the multi-sectoral Thirlwall's Law", Journal of Post Keynesian Economics, vol. 33, № 1, octubre.

Hausmann, R. y C.A. Hidalgo (2010), "Country diversification, product ubiquity, and economic divergence", CID Working Paper, $\mathrm{N}^{\circ}$ 201, Center for International Development, Universidad de Harvard.

Infante, R. y O. Sunkel (2009), "Chile: hacia un desarrollo inclusivo", Revista de la CEPAL, No 97 (LC/G.2400-P), Santiago de Chile, Comisión Económica para América Latina y el Caribe (CEPAL), abril.

Katz, J. (1997), "Structural reforms, the sources and nature of technical change and the functioning of the national systems of innovation: the case of Latin America", documento presentado en el simposio STEPI sobre innovación y competitividad de las economías de reciente industrialización, Seúl, mayo.

León-Ledesma, M.A. (2002), “Accumulation, innovation and catching-up: an extended cumulative growth model", Cambridge Journal of Economics, vol. 26. 
McCombie, J.S.L y A.P. Thirlwall (1997), “The dynamic Harrod trade multiplier and the demand-oriented approach to economic growth: an evaluation", International Review of Applied Economics, vol.11, $\mathrm{N}^{\mathrm{o}} 1$.

McMillan, M. y D. Rodrik (2011), “Globalization, Structural Change and Productivity Growth", Organización Internacional del Trabajo (OIT)/Organización Mundial del Comercio (OMC), febrero.

Metcalfe, J.S. (2001), "Institutions and progress", Industrial and Corporate Change, vol.10, $\mathrm{N}^{\mathrm{o}} 3$, Oxford University Press, septiembre.

Moreno-Brid, J. (2003), "Capital flows, interest payments and the balance-ofpayments constrained growth model: a theoretical and empirical analysis", Metroeconomica, vol. 54, $\mathrm{N}^{\mathrm{o}} 2-3$.

Narula, R. (2004), “Understanding absorptive capacities in an innovation systems context: consequences for economic and employment growth", DRUID Working Paper, $\mathrm{N}^{\mathrm{o}}$ 04-02, diciembre.

Nelson, Joan M. (1991), “Organized labor, politics, and labor market flexibility in developing countries", World Bank Research Observer, vol. 6, N 1.

Ocampo, J.A., C. Rada y L. Taylor (2009), Growth and Policy in Developing Countries: A Structuralist Approach, Oxford University Press.

Pacheco-Lopez, P. y A.P. Thirlwall (2006), "Trade liberalization, the income elasticity of demand for imports and economic growth in Latin America", Journal of Post-Keynesian Economics, vol. 29, $\mathrm{N}^{\mathrm{o}} 1$.

Palma, J.G. (2011), "Why has productivity growth stagnated in most Latin American countries since the neoliberal reforms?", Cambridge Working Papers in Economics, $\mathrm{N}^{\mathrm{o}} 1030$, julio.

Peres, Wilson (2010), "The (slow) return of industrial policies in Latin America and the Caribbean", The Political Economy of Capabilities Accumulation: the Past and Future of Policies for Industrial Development, M. Cimoli, G. Dosi y J.E. Stiglitz (eds.), Oxford University Press.

Prebisch, R. (1949), El desarrollo económico de América Latina y su principales problemas, Nueva York.

Rodríguez, O. (2007), El estructuralismo latinoamericano, México, D.F, Siglo XXI. (1980), La teoría del subdesarrollo de la CEPAL, México, D.F, Siglo XXI. (1977), "Sobre la concepción del sistema centro-periferia", Revista de la CEPAL, $N^{\circ}$ 3, Santiago de Chile, Comisión Económica para América Latina y el Caribe (CEPAL), abril.

Stallings, B. y W. Peres (2000), Growth, Employment and Equity: The Impact of Economic Reforms in Latin America and the Caribbean, Washington, D.C., Brookings Institution Press.

Steindl, Josef (1952), Maturity and Stagnation in American Capitalism, Nueva York, Oxford.

Thirlwall, A. (2011), "Balance of payments constrained growth models: history and overview", School of Economics Discussion Paper, $\mathrm{N}^{\circ} 1111$, Universidad de Kent, mayo.

Vera, L.A. (2006), "The balance-of-payments constrained growth model: a north-south approach", Journal of Post-Keynesian Economics, vol. 29, No 1.

Verspagen, B. (1993), Uneven Growth between Interdependent Economies: An Evolutionary View of Technology Gaps, Trade and Growth, Avebury, Ashgate Publisher.

Wade, R. (1990), Governing the Market: Economic Theory and the Role of Government in East Asian Industrialisation, Princeton, Princeton University Press. 
Capítulo VIII

\section{La macro- y la microeconomía del crecimiento basado en los recursos naturales ${ }^{1}$}

Jorge Katz

\section{Introducción}

Tras el magro comportamiento registrado en la década de 1980, traducido en pronunciadas caídas del PIB posteriores a la moratoria mexicana de 1982, una fuerte contracción del empleo y de la equidad social, y considerables episodios de destrucción de la capacidad productiva y tecnológica nacional - resultantes de la manera irreflexiva en que distintos gobiernos llevaron a cabo la apertura y la desregulación de la economía siguiendo los dictados del Consenso de Washington-, los países de América Latina experimentaron un heterogéneo pero alentador repunte a partir de los años noventa y durante la primera década del tercer milenio.

Dicha recuperación se vio impulsada en buena medida por el crecimiento de las exportaciones, la mejora de los términos de intercambio y una significativa transformación estructural que permitió

El presente trabajo está basado en la presentación que el autor efectuó en el Seminario sobre neoestructuralismo y economía heterodoxa, llevado a cabo en Santiago de Chile por la Comisión Económica para América Latina y el Caribe (CEPAL) el 22 y 23 de abril de 2013. El autor agradece la invitación a participar en el seminario, así como los comentarios recibidos, tanto en la reunión como posteriormente en forma anónima. Las opiniones vertidas en este trabajo son de entera responsabilidad del autor y en nada comprometen a los organismos mencionados. 
que nuevos sectores (muchos de ellos fabricantes de productos básicos industriales de uso difundido, como petróleo y gas, minerales, celulosa y papel, soja y sus derivados, y también flores y alimentos de distinto tipo) se expandieran a tasas de dos dígitos durante períodos relativamente prolongados, lo cual redundó en un incremento del empleo, mejoras salariales y mayores ingresos fiscales.

El auge de la demanda de dichos productos básicos industriales por parte de China, la India y otros países asiáticos, junto con el consecuente aumento de sus precios, explica en gran medida lo ocurrido (véase el gráfico VIII.1).

\section{Gráfico VIII.1}

\section{Precio de los productos básicos industriales}

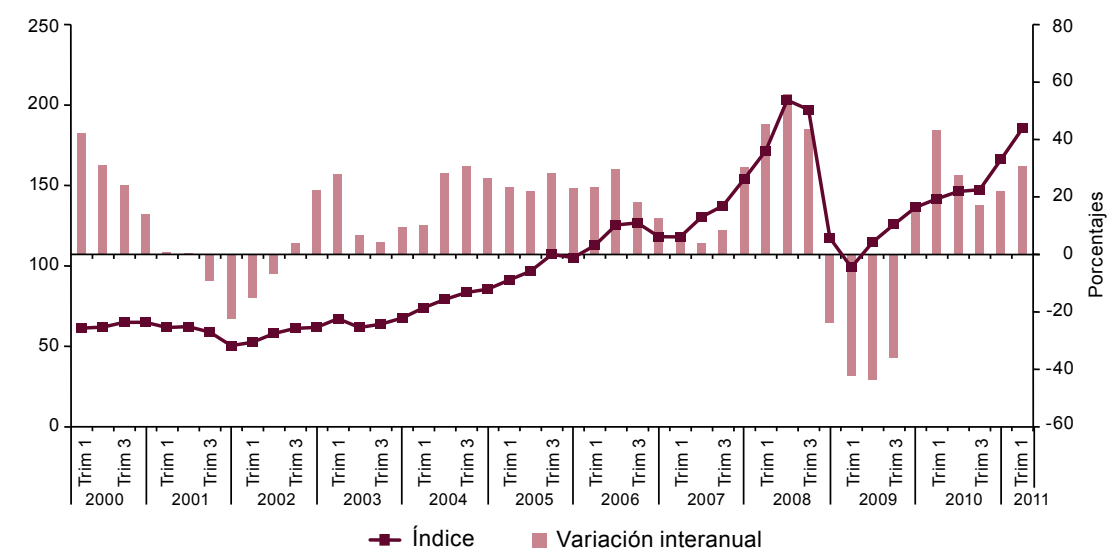

Fuente: Elaboración propia.

El proceso estuvo asociado a la apertura de nuevas plantas fabriles en los sectores mencionados, que aportaron tecnologías modernas y niveles de productividad cercanos a la frontera técnica internacional. Ello trajo aparejado el surgimiento de comunidades empresariales y profesionales, nuevas instituciones sectoriales y novedosas formas de organización y comportamientos de los mercados, en el marco de una profunda transformación de la estructura productiva. Lo ocurrido refleja un episodio coevolutivo de cambios tecnológicos, nuevos estilos de organización industrial y la transformación de las instituciones de apoyo en distintas esferas de la vida comunitaria.

Al mismo tiempo, también experimentaron un pronunciado cambio estructural, tecnológico e institucional los sectores dedicados a los servicios, como el bancario, las telecomunicaciones y la industria financiera. La brecha entre las firmas de alta y de baja productividad de cada sector se ha ensanchado considerablemente; por ende, los cálculos 
agregados de la productividad total de los factores y la contabilidad convencional del crecimiento ocultan una profunda heterogeneidad estructural que los torna poco convincentes.

Hasta el momento, este vasto proceso no ha sido objeto de suficientes estudios. Se podría sostener sin temor a equívocos que surgieron distintas formas de capitalismo en la región, algunas más exitosas que otras pero, sin excepción, diferentes del modelo de organización social y económica de la posguerra, en el que el Estado adoptaba un papel primordial, por lo que guiaba el proceso de crecimiento y daba incentivos especiales a la producción de manufacturas para el mercado nacional. Esta vez son los productos básicos industriales de uso difundido, por un lado, y los servicios, por el otro, los que han tomado el papel protagónico como motores del crecimiento, a diferencia de la manufactura, que desempeñó dicha función décadas atrás.

Con este trabajo se apunta a reflexionar acerca de algunos aspectos macro- y microeconómicos de esta nueva fase del desarrollo latinoamericano y acerca de las nuevas preguntas que se plantearán de cara al futuro.

Pese a que resulta indiscutible que diversos núcleos sociales viven en la actualidad mejor que en el pasado, no todo lo que se percibe resulta auspicioso y alentador. Si bien es cierto que una fracción del PIB -mayor o menor dependiendo del país en cuestión - se ubica hoy mucho más cerca de la frontera internacional de la productividad y que los empresarios y operarios empleados por dichos sectores productivos reciben remuneraciones significativamente más altas que el promedio nacional, se observa también una mayor concentración del ingreso en el decil más alto de la comunidad y una brecha más amplia entre pobres y ricos. La brecha relativa entre la media del quintil más alto y del más bajo es de 20 a 25 veces, por lo que a todas luces resulta más amplia que la observada, por ejemplo, en los países europeos, donde este coeficiente ronda valores de 6 a 8 veces.

Destaca la aparición de una nueva clase media, cuyo tamaño varía entre los países, pero que reúne entre 30 y 40 millones de personas solo en el Brasil, y es también numerosa en Bolivia (Estado Plurinacional de), Chile, Colombia y México. Esta nueva clase media reclama hoy una mayor y mejor provisión de bienes públicos, como salud, educación y seguridad social. Los movimientos de protesta observados en diversos países de la región constituyen un claro reflejo de este hecho.

Esta emergente clase media se concentra en el tercer y el cuarto quintil de la distribución y está hoy fuertemente endeudada con el sistema bancario, a raíz de su avidez por acceder a una vivienda, bienes de consumo duraderos y vehículos a un ritmo vertiginoso. Exhibe signos 
de fragilidad a largo plazo que no se pueden pasar por alto en la medida en que la escasa transparencia con que funcionan los mercados de crédito puede llevar a burbujas riesgosas en los mercados inmobiliarios y de créditos de consumo, tal como ya ocurrió en diversos países desarrollados. Se está transitando hacia una nueva sociedad de masas cuya estructura y comportamiento no deberían quedar solo al arbitrio del mercado sin un adecuado proceso de monitoreo por parte de la autoridad pública. Se requiere mayor transparencia informativa y control precautorio ex ante, así como una aplicación más rigurosa de las normas sobre competencia, que hasta el momento exhiben signos de gran debilidad. Esta situación constituye un gran punto flaco del nuevo modelo de capitalismo que en la actualidad se está consolidando en los países de la región.

Asimismo, es cierto que junto a los signos positivos también ha crecido la exclusión social, la marginación y la falta de empleabilidad de grandes segmentos poblacionales que por diversos motivos - escasez de bienes públicos, mal funcionamiento de los mercados de crédito, falta de acervos iniciales de capital humano- han ido quedando marginados del sistema y constituyen una prueba fehaciente de que las reglas puras del mercado no bastan para lograr un desarrollo con equidad e inclusión social. Estos núcleos excluidos —eufemísticamente tachados de "terroristas" por la ideología dominante- engrosan los grupos que viven de actividades ilícitas ante su incapacidad para integrarse al cuadro social. Toda esta coyuntura reclama una reflexión más profunda acerca del tipo de instituciones y formas de organización social que se desean alcanzar en el futuro.

Al avanzar por esta senda, las economías latinoamericanas experimentaron un claro retorno a sus ventajas comparativas tradicionales y abandonaron el sendero de desarrollo de la posguerra. Han vuelto a dar prioridad a sus recursos naturales de alta calidad así como a su mano de obra barata y poco calificada. En otras palabras, han dejado de lado la meta de lograr la convergencia con la frontera tecnológica universal y se han concentrado en sostener la estabilidad financiera a corto plazo y el equilibrio de los principios fundamentales.

En este vasto episodio de destrucción creativa experimentado por la región tras haber abierto, privatizado y desregulado su actividad económica, como lo aconsejaba el ideario del Consenso de Washington, prevaleció —además de una mano de obra barata de baja calificación profesional - la abundancia relativa de gas y petróleo, de bosques con ciclos de maduración más breves que los del hemisferio norte, de tierras agrícolas y riqueza pecuaria de calidad insuperable, y de franjas costeras y lacustres capaces de albergar la mejor acuicultura del mundo.

Los elementos que marcan la dirección del proceso al que se dio inicio radican en los programas de política pública inspirados en reglas puras de mercado y en regímenes de política macroeconómica que 
otorgan prioridad tanto al control de la inflación como al equilibrio de los fundamentos de corto plazo en lugar de estar abocados a la convergencia con el mundo desarrollado y al cierre de la brecha de productividad relativa con los países maduros.

Las ideas que abogan por un Estado subsidiario, la neutralidad de la acción gubernamental y el libre juego del mercado en la determinación del sendero de crecimiento de la economía han prevalecido por sobre las enseñanzas que brinda la historia: los ejemplos más notorios de convergencia - tanto del siglo XIX como los casos más recientes de la República de Corea y de China en la actualidad- han tenido lugar en un marco donde el Estado desempeña un papel proactivo al diseñar, financiar y regular el crecimiento, la provisión de bienes públicos y la distribución de los beneficios del desarrollo entre los miembros de la sociedad.

Este trabajo tiene como objeto presentar una reflexión acerca de las repercusiones macro- y microeconómicas de este retorno a las ventajas comparativas naturales, a las actividades menos intensivas en valor agregado y a las cadenas productivas que explotan los ricos recursos naturales de la región. Se analizan también los efectos que todos estos factores ejercen en la estructura productiva, por un lado, y en el uso de los recursos naturales y la sostenibilidad ambiental y ecológica, por el otro. Estas cuestiones se debaten en la bibliografía pertinente con el exótico nombre de enfermedad holandesa, en lo atinente a los aspectos macroeconómicos, y como la tragedia de los comunes en lo relativo a la microeconomía. Sin embargo, en este trabajo se hará referencia a ambos aspectos. Por fuerza, se pintará el cuadro con brocha gruesa, ya que ambos temas trascienden los límites de un escrito de esta índole y porque en otros documentos del libro también se abordan de una u otra forma distintos aspectos de estos temas.

\section{A. Algunas reflexiones sobre las nuevas políticas macroeconómicas}

En la bibliografía de la última década se exponen con claridad las principales preocupaciones de los macroeconomistas latinoamericanos, como la enorme volatilidad macroeconómica que exhiben los países de la región (véase el gráfico VIII.2). Ella afecta incluso a aquellos países que parecen ser objeto de una administración muy cautelosa y prolija en lo que hace al balance fiscal estructural y a la apertura de la cuenta de capitales (en un contexto en el que las autoridades de los países desarrollados han mantenido tasas de interés cercanas a cero en un intento por revitalizar sus alicaídas economías). Al mismo tiempo se ha admitido la necesidad de cierto grado (no menor) de apreciación cambiaria con miras a mantener acotada la inflación (véase el gráfico VIII.3). 


\section{Gráfico VIII.2}

América Latina: crecimiento anual del PIB y de la demanda agregada, 1990-2004 (En porcentajes)

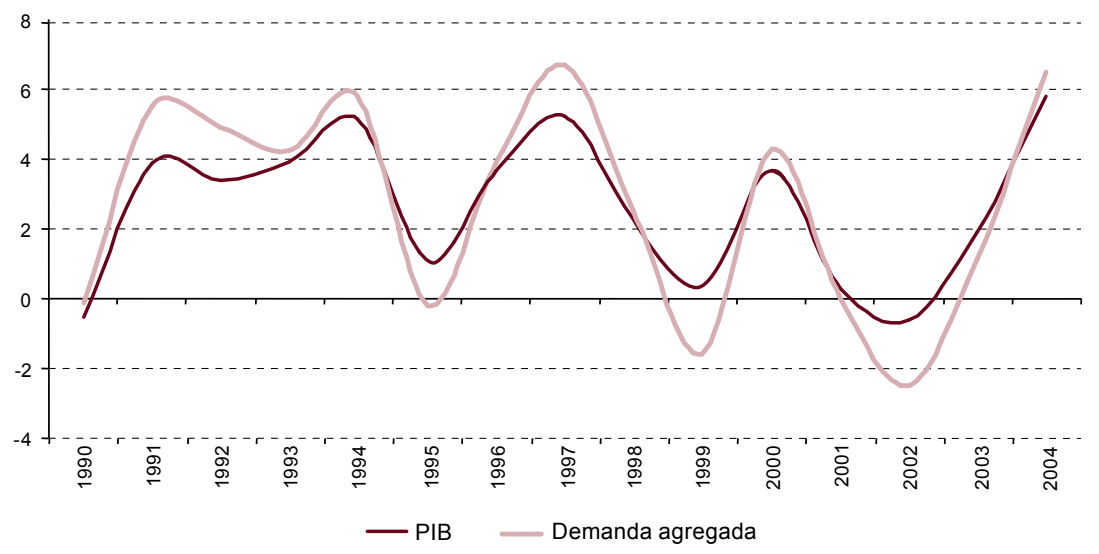

Fuente: Ricardo French Davis, Entre el neoliberalismo y el crecimiento con equidad, Santiago de Chile, LOM Ediciones, 2005.

Gráfico VIII.3

La apreciación cambiaria antes de la crisis de 2008-2009

(En porcentajes)

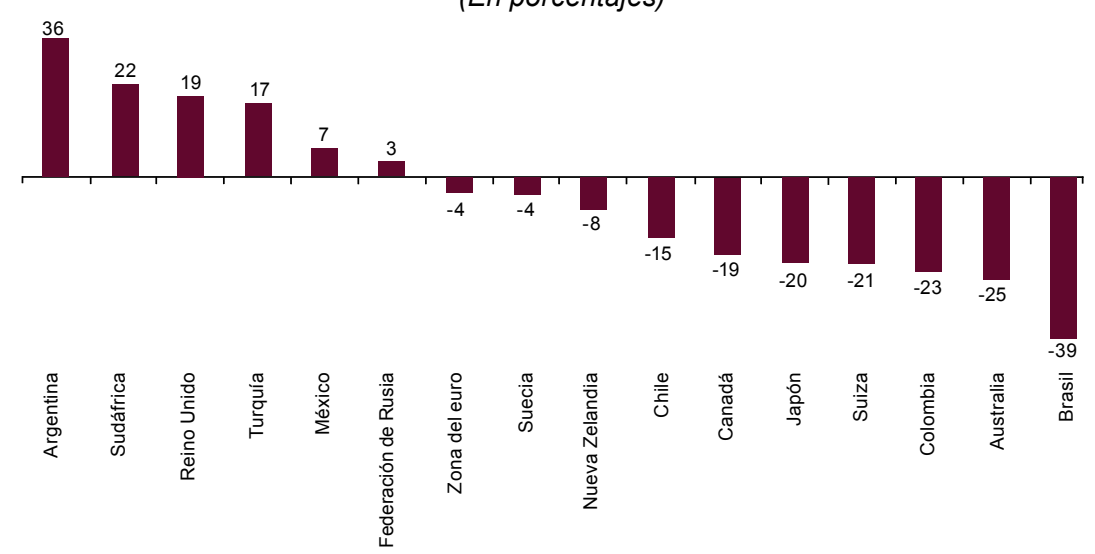

Fuente: Elaboración propia.

A los países de la región les ha resultado difícil digerir el impacto conjunto de: i) la volatilidad macroeconómica, que afecta el instinto animal de los empresarios y favorece las conductas defensivas, lo cual acorta el horizonte de planificación de las compañías y atenta contra la inversión y el gasto en investigación y desarrollo; ii) la apreciación cambiaria, y iii) los elevados precios internacionales de los productos básicos industriales de uso difundido. Observamos que la respuesta ha 
sido una caída generalizada de la tasa de formación de capital, que exhibe niveles inferiores a los de los años setenta y que, pese a su recuperación parcial durante la década de 1990, nunca volvió a tener el vigor que gozó 20 años atrás (véase el gráfico VIII.4). Los gastos en investigación y desarrollo nunca alcanzaron las expectativas de quienes esperaban que la desregulación de los mercados, la mayor competencia y la apertura externa los llevara a niveles similares a los de los países desarrollados — entre el $2 \%$ y el $4 \%$ del PIB.

Gráfico VIII.4

América Latina: formación bruta de capital, 1971-2011

(En porcentajes del PIB)

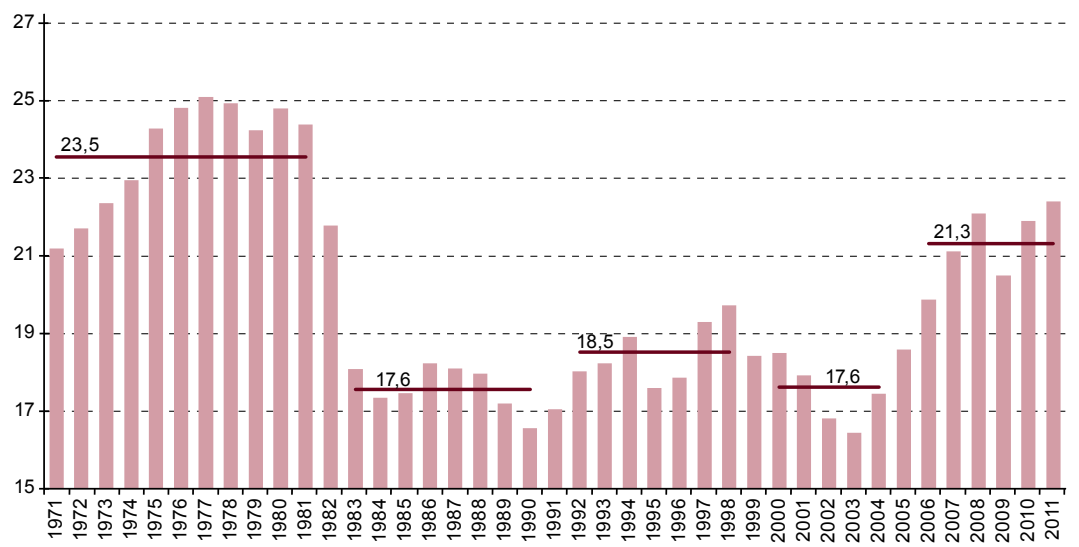

Fuente: Ricardo French Davis, Entre el neoliberalismo y el crecimiento con equidad, Santiago de Chile, LOM Ediciones, 2005.

Por su parte, la apreciación cambiaria propició, por un lado, la mercantilización (commoditization) del patrón productivo y de las exportaciones y, por el otro, una tendencia cada vez más marcada a importar maquinaria y bienes de consumo duradero en lugar de producirlos internamente. Las fábricas locales han avanzado hacia un mayor contenido unitario de importaciones y reducido el uso de componentes intermedios de producción nacional. El creciente saldo negativo del balance comercial externo, incluso en áreas muy volcadas hacia la exportación (vehículos, por ejemplo), constituye un indicador fehaciente de esta realidad. Las pymes nacionales productoras de componentes intermedios han perdido terreno de la mano del aumento de los insumos importados. La estructura productiva y las exportaciones fueron perdiendo diversidad y complejidad; la actividad productiva tendió a concentrarse en bienes no comerciables y en escasas ramas de productos básicos que en general hacen un uso muy intensivo del capital 
$\mathrm{y}$, por ende, suelen cubrir los tramos con un menor valor agregado interno y con una aplicación menos intensiva del conocimiento en cada cadena productiva. Esto jugó en contra de la creación de empleos de alta calidad y bien remunerados. El mercado laboral creció de la mano de la economía, sobre todo, en el sector de los servicios personales de bajo valor agregado, sin formas adecuadas de protección social y con altas tasas de rotación entre las tareas.

Salvo en áreas muy puntuales, los sistemas nacionales de innovación no registran grandes avances a lo largo de esta etapa, siendo la importación de máquinas y la adopción de licencias internacionales las fuentes principales del proceso de modernización que exhiben diversos núcleos del aparato productivo.

Lo ocurrido resulta del marco teórico que llevó a que sucesivas generaciones de economistas latinoamericanos definieran como objetivo fundamental de la política macroeconómica el sostener el equilibrio financiero de corto plazo como base de su programa de política macroeconómica. El modelo Mundell-Fleming — que constituye la extensión a una economía abierta del modelo IS-LM (o modelo de Hicks-Hansen) - presenta un algoritmo agregado en el que la estructura del aparato productivo y su heterogeneidad, expresada por las distancias que exhiben diferentes industrias respecto de la frontera internacional de productividad, no son tomadas en cuenta y, por lo tanto, no son parte de las preocupaciones centrales de la acción de gobierno. La mayor afluencia de divisas debida a la exportación de productos básicos lleva a la apreciación cambiaria y desincentiva la producción nacional de bienes más intensivos en ingeniería y en conocimientos técnicos locales. Es dicho marco teórico el que inspira hoy en día buena parte de la formulación y puesta en práctica de las políticas macroeconómicas en la región.

Si la heterogeneidad estructural es muy marcada, el tipo de cambio no resulta el instrumento más adecuado para inducir a aquellas ramas productivas relativamente más alejadas de la frontera internacional de la productividad a invertir en nueva capacidad instalada y en investigación y desarrollo para competir con las importaciones (Rapetti, 2011). En estos casos, la apreciación cambiaria, que no afecta a los sectores más eficaces de la economía que producen productos básicos industriales (industrial commodities), impide la convergencia de industrias que, si bien están contemporáneamente alejadas de la frontera internacional de productividad, podrían en el mediano plazo lograr competitividad en los mercados mundiales tras una fase de aprendizaje. El Japón jamás habría devenido en el eficiente productor de automóviles que es hoy en día si en la década de 1950 se hubiera concentrado en la seda y en las industrias textiles que por ese entonces constituían sus ventajas comparativas naturales. Lo 
mismo puede decirse de la República de Corea durante los años ochenta (Kim, 1997). Sin embargo, resulta evidente que en dichos casos el papel de un Estado que alentaba la creación de nuevas formas de competitividad en la economía no se limitó solo al manejo del tipo de cambio.

Es más, tal como han argumentado diversos economistas en años recientes, si la apreciación cambiaria y la falta de incentivos se mantienen por lapsos relativamente largos, bien pueden crearse situaciones irreversibles en las que la alta propensión a importar y el escaso instinto animal de los empresarios se perpetúen en el tiempo y reflejen el desaliento causado por una política macroeconómica poco propicia para el desarrollo industrial (Frenkel y Rapetti, 2011). Una apreciación cambiaria del $30 \%$ o el $40 \%$ sin duda destruye toda posibilidad de que un incremento de la productividad del orden del 3\% o el $4 \%$ anual constituya incentivo suficiente como para competir con firmas del exterior. La importación se transforma así en el sustituto más directo al que recurren los empresarios locales.

A juicio del autor, esta visión es la que ha inspirado buena parte del manejo de la política macroeconómica en América Latina en el curso de la última década. Ello refleja la prioridad que los gobiernos de la región otorgan a metas de baja inflación y a principios fundamentales de equilibrio financiero de corto plazo capaces de garantizar la credibilidad en la escena internacional y, con ello, el acceso a la inversión extranjera directa, y que posterguen el debate sobre estrategias de desarrollo productivo y tecnológico de largo plazo que permitirían la convergencia con la frontera internacional de productividad. Queda entonces sin responder la pregunta de cómo se puede alcanzar una macroeconomía bien administrada que logre bajos niveles de inflación y un tipo de cambio alto y estable, que incentive las exportaciones de mayor valor agregado nacional y que incluya formas de política industrial que tomen en cuenta la alta heterogeneidad estructural del aparato productivo y la dificultad que este enfrenta para aumentar la productividad e incorporar innovaciones tecnológicas de origen nacional.

La gran asignatura pendiente que la ortodoxia económica dominante ha dejado sin responder es cómo formular e implementar intervenciones fiscales, monetarias y cambiarias que, junto a políticas industriales y de desarrollo productivo, permitan avanzar hacia el objetivo de cerrar la brecha relativa de productividad con el mundo desarrollado. La historia económica de los últimos 50 años brinda ejemplos de gran riqueza respecto de cómo conciliar las políticas macro- y microeconómicas para crear ciclos de elevado crecimiento sostenido. Baste con mencionar los casos de la República de Corea y la provincia china de Taiwán, o también el caso de Finlandia que, ante la caída y desaparición de la Unión 
de Repúblicas Socialistas Soviéticas (URSS) —su principal comprador de productos forestales-, decidió efectuar un giro significativo hacia los sectores intensivos en conocimiento y embarcarse en un proceso de convergencia productiva con la frontera tecnológica universal. En lugar de extraer enseñanzas de estos ejemplos, la política macroeconómica de la región dio prioridad al equilibrio de los fundamentos de corto plazo y dejó pendiente la convergencia con la frontera productiva internacional. También hizo a un lado la búsqueda de mayor equidad e inclusión social mediante un mayor valor agregado nacional en la estructura productiva. La lucha contra la pobreza se basa en programas asistenciales y subsidios fiscales en lugar de políticas de desarrollo productivo, que redundarían en mejores puestos de trabajo y mayor inclusión social.

\section{B. Otra asignatura pendiente: la sostenibilidad de los recursos naturales a largo plazo}

Corresponde ahora abordar los aspectos microeconómicos de un crecimiento basado en los recursos naturales. Una mayor demanda externa de productos básicos industriales de uso difundido induce una mayor explotación de los recursos naturales nacionales (gas y petróleo, celulosa y papel, soja y sus derivados, entre otros). Esto abre una extensa lista de nuevas preguntas de índole microeconómica relacionadas con la sostenibilidad ambiental, la gobernanza de mercados basados en la explotación de recursos de uso compartido, y el origen y la naturaleza del cambio tecnológico en los sectores de los productos básicos industriales. ¿Puede el crecimiento basado en los recursos naturales dar lugar a la sostenibilidad ambiental, una mayor profundidad tecnológica nacional y una inclusión social más amplia? ¿Qué nuevas instituciones necesita un modelo basado en los recursos naturales para garantizar la consecución de dicho objetivo? Estos son interrogantes ya planteados hace tiempo por Raúl Prebisch en el seno de la CEPAL, que ahora vuelven a recobrar fuerza ante la relevancia que adquirieron en épocas recientes las exportaciones de productos básicos industriales manufacturados a partir de recursos naturales (Prebisch, 1980).

La experiencia de los países escandinavos, así como de los Estados Unidos y el Canadá en el siglo XIX, sugiere que ello es posible, pero que requiere de un proceso coevolutivo entre la economía, las instituciones y el medio ambiente que no resulta sencillo de alcanzar (Lundvall y Edquist, 1993). Este constituye un eje central del debate latinoamericano actual. A efectos de examinarlo en detalle, en este trabajo se utilizará como ejemplo la salmonicultura chilena durante las últimas dos décadas, que describe tanto un caso de éxito - gran ritmo expansivo y convergencia en volúmenes de producción con los principales países del mundo- 
como de claro fracaso, pues no se pudo desarrollar al mismo tiempo una acción colectiva (capital social) y capacidades tecnológicas propias que le permitieran evitar la tragedia de los comunes que el país sufrió en 2008-2009. Los rasgos sobresalientes de este proceso se describen en el gráfico VIII.5 y en el cuadro VIII.1.

Gráfico VIII.5

Producción salmonícola, 1990-2002

(En miles de toneladas)

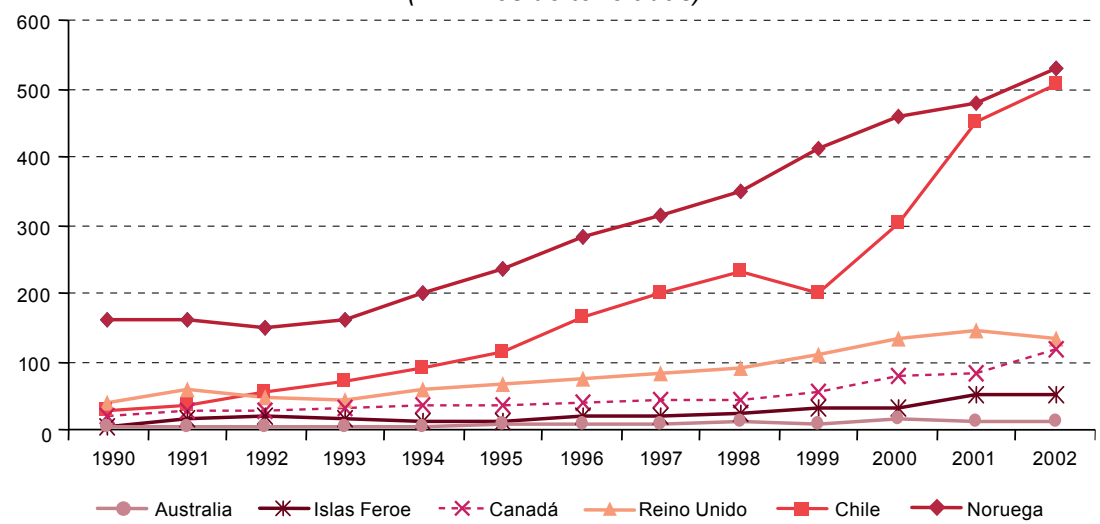

Fuente: Elaboración propia.

Cuadro VIII.1

Chile: impacto de la tragedia de los comunes en la salmonicultura, 2003-2007

\begin{tabular}{lrrrrr}
\hline & 2003 & 2004 & 2005 & 2006 & 2007 \\
\hline Kilogramos de salmón del Atlántico & 71856 & 76968 & 82838 & 102015 & \\
\hline Kilogramos de alevines & 3,71 & 3,66 & 3,57 & 3,34 & 3,14 \\
\hline Kilogramos de huevas & 1,30 & 1,28 & 1,25 & 1,17 & 1,10 \\
\hline Peso promedio en planta & 4444 & 4558 & 4342 & 4219 & 4130 \\
\hline Factor de conversión económica & 1,36 & 1,40 & 1,38 & 1,42 & 1,52 \\
\hline Factor de conversión biológica & 1,24 & 1,27 & 1,28 & 1,30 & 1,34 \\
\hline Días para la cosecha & 487 & 497 & 484 & 488 & 543 \\
\hline
\end{tabular}

Fuente: Elaboración propia

Los precios internacionales de los productos básicos industriales experimentaron una suba significativa durante la década de 2000 (véase el gráfico VIII.1). Su actual caída ha llevado a muchos economistas a afirmar que el reciente ciclo expansivo habría llegado a su fin, como ya ocurrió otras veces en el pasado. Sin embargo, ello exige cierta reflexión ${ }^{2}$.

2 El hecho de que sea China, gracias a su enorme territorio y su fuerte ritmo de crecimiento, quien impulsa el proceso al que se hace referencia abre dudas acerca de su posible continuidad (o no) en el futuro. Esta es la primera vez en la historia de la humanidad que un país de 1.500 millones de habitantes, relativamente pobre y dirigido por la burocracia del Partido Comunista, intenta construir las instituciones del capitalismo y brindar a su población niveles de bienestar similares 
Más allá de lo anterior, lo cierto es que en la otra punta de las cadenas productivas en las que China demanda más productos básicos industriales y alimentos de manera voraz, se encuentran los países latinoamericanos, que utilizan con mayor intensidad sus recursos naturales para satisfacer dichas demandas. Entonces surge una pregunta: ¿cómo afectará esta situación la sostenibilidad ambiental a largo plazo, la capacidad tecnológica nacional requerida para cumplir adecuadamente dicho papel, la gobernanza de estos sectores que suelen basarse en recursos compartidos y traen aparejadas consecuencias de gran magnitud para la biosfera, y el compromiso intergeneracional de mantener el valor de estos recursos para las generaciones venideras.

Un uso más intensivo de los recursos naturales presupone una mayor explotación de los que ya se aprovechaban y la incorporación de nuevas áreas productivas en otras latitudes. Producir más haciendo un uso más intenso de los recursos naturales no equivale a producir más manufacturas. Cada geografía presenta una mirada específica de factores ecológicos y formas de organización social asociadas a la explotación del recurso, por lo que no resulta válido aplicar aquí la metáfora del agente representativo de la microeconomía convencional. Cada sitio constituye un caso en sí mismo, pues la ecología y la organización social que rodean a la explotación del recurso son específicas de ese territorio y esa comunidad, aun cuando se trate de regiones próximas y de características ecológicas similares (Ostrom, 2000 y Cardenas, 2009).

Asimismo, los recursos naturales tienen también rasgos de bien público, esto es, son muchas veces bienes de uso compartido, donde el modelo convencional de mercado no funciona adecuadamente. Cuando dos empresas cultivan salmones en la misma bahía o lago, no hay forma de impedir la transmisión horizontal de enfermedades, patógenos o depredadores marinos, por ejemplo. Aquello que perjudique a un centro de cultivo poco después afectará al otro que comparte la misma bahía o franja costera. Y lo mismo sucede con la propagación de plagas en la industria agrícola y frutícola, y en los demás sectores afines. Al entrar al mundo de los recursos naturales, se ingresa a modelos de gobernanza de los mercados en los que la acción colectiva, la reciprocidad y la confianza - el capital social expresado en instituciones de cooperación proactivasrevisten mayor importancia que las meras señales de precios que guían la maximización individual del productor independiente típica del

a los de los países desarrollados. En estos momentos hay decenas de nuevas ciudades en plena construcción, se dan movimientos masivos de población en el interior del país y el aparato industrial sigue creciendo a una velocidad vertiginosa a raíz del enorme potencial del mercado interno. Es cierto que los salarios aumentaron en fechas recientes, lo cual resulta difícil de explicar en un país con un exceso de población deseosa de entrar al mundo urbano. Todo esto muestra lo poco que sabemos acerca del caso de China y sobre si su expansión habrá de continuar en el futuro (y a qué tasas). China no se rige por reglas convencionales de mercado, razón por la que resulta en extremo difícil imaginar su futuro desde una visión contrafáctica de una economía de mercado. 
modelo convencional de mercado. Es precisamente la tensión entre uno y otro enfoque lo que ha llevado a los expertos a referirse a la tragedia de los comunes como una manera expresiva de graficar el hecho de que la maximización individual de los beneficios lleva a la sobreexplotación de los recursos y al fracaso colectivo (véase el cuadro VIII.1). Sin embargo, el fracaso colectivo no es la única opción posible, como han demostrado E. Ostrom, E. Cardenas y otros autores al probar que en muchas circunstancias los usuarios del recurso dan origen a formas de acción colectiva, instituciones y mecanismos solidarios destinados a preservarlo. En numerosas ocasiones, resulta beneficioso contar con un marco jurídico y reglamentario sólido $-\mathrm{y}$ con su debida implementación- a fin de apoyar e inducir la acción colectiva y los mecanismos de cooperación.

Cuando el objetivo consiste en lograr un crecimiento basado en los recursos naturales, no solo despierta preocupaciones su sobreexplotación. Todavía no se dispone de suficientes conocimientos sobre el comportamiento de la ecología como para saber a ciencia cierta cuál es el costo de oportunidad que un mayor uso de los recursos naturales traerá aparejado para la biodiversidad, la erosión de los suelos, la desertificación, el efecto invernadero, el cambio climático y los recursos hídricos. Tanto el mundo neoclásico - que aborda estos asuntos en términos de impuestos y externalidadescomo el evolucionista — que construyó sus metáforas de comportamiento microeconómico sobre la base de la experiencia de sectores industriales- han logrado avances limitados en lo que respecta a comprender la complejidad del vínculo entre la economía y la ecología. Resulta imperioso llevar a cabo más investigaciones sobre la llamada capacidad de carga de los recursos naturales en distintos puntos geográficos. La diversidad institucional y de reglas del juego con que diferentes regiones, países y culturas explotan los recursos naturales es en extremo variada, por lo que no resulta sencillo formular teorías universales. Sí se sabe que la acción colectiva, la reciprocidad y la confianza desempeñan un papel crucial en la preservación a largo plazo de los recursos y la sostenibilidad ambiental. Se ha llegado a suponer - erróneamente- que por tratarse de sectores que elaboran productos básicos, no hay gran necesidad de llevar adelante actividades de investigación y desarrollo, cuando en realidad la sostenibilidad ambiental y sanitaria a largo plazo plantea la necesidad de contar con muchísimos conocimientos sobre biología, genética, sanidad animal y medioambiente que recién hoy en día se comienza a percibir (Katz, Iizuka y Muñoz, 2011).

La ecología, la genética y la biología tienen reglas de comportamiento que apenas se llega a comprender. El espacio que aquí se abre para revalorizar los vínculos entre las empresas y las universidades en estos campos es realmente insospechado. Lo mismo puede decirse, por ejemplo, de la explotación minera por vía bacteriana o de la desalinización del agua marina, temas que en las próximas décadas deberían ser objeto de investigaciones para continuar apuntando a un crecimiento basado en los recursos naturales. 
El tema no acaba aquí. Un uso más intensivo de los recursos naturales plantea nuevos interrogantes relativos al costo de oportunidad de los servicios ambientales y su utilización alternativa en distintas actividades productivas, así como entre diferentes sectores de la comunidad, por ejemplo en el caso de los pueblos originarios, que han adoptado como hábitat zonas de gran riqueza petrolera, bosques naturales o la franja costera de distritos lacustres o marítimos. Surgen así preguntas sobre los derechos de propiedad, los precios virtuales de los servicios ambientales, las regalías y los cánones pagaderos por su uso, y el papel y la participación de las comunidades locales en la explotación del recurso. En los países de la región, la coevolución de las actividades de desarrollo productivo y las instituciones de apoyo y de reglamentación encargadas de velar por estos asuntos adolecen de una gran fragilidad, que en el futuro deberá ser objeto de un análisis minucioso (Iizuka y Katz, 2013). Dicha coevolución entre las instituciones, los cambios tecnológicos y el desarrollo del aparato productivo de industrias basadas en los recursos naturales constituyen un campo de pensamiento que los economistas evolucionistas latinoamericanos casi no han abordado hasta el presente. La óptica nelsoniana de la coevolución entre la estructura productiva y las instituciones abre un amplio espacio para teorizar sobre los vínculos entre la economía, la organización social, la biosfera y la ecología. ¿Cuáles son las instituciones y las diversas formas de organización productiva de estos sectores que repercuten $-\mathrm{y}$ de qué manera- en la biosfera y la ecología? ¿Y cómo cambian y evolucionan conforme avanzan la explotación de los recursos y la consiguiente ampliación de la frontera agrícola, minera y acuícola?

El crecimiento basado en los recursos naturales no debe verse como una meta antagónica del desarrollo de la industria. La experiencia del mundo escandinavo muestra cómo la industria de maquinarias para los sectores lácteos o forestales, las ramas de agroquímicos, las vacunas y los fertilizantes, los productores de equipos de transporte e infraestructura portuaria, entre otros, han acompañado el crecimiento de los sectores primarios. La vieja disyuntiva entre el sector agropecuario y la industria parece superada cuando se mira al mundo desde esta perspectiva. Sin embargo, el cuadro institucional y de gobernanza de los sectores basados en recursos de uso compartido reclama una institucionalidad y un conjunto de reglas de juego que no son las del mundo industrial, y en este plano resta mucho por hacer.

No obstante, lo que sí resulta obvio es que las fuerzas de mercado gozan de poca ductilidad para llevar al aparato productivo por este camino. Hay demasiadas incertidumbres, fallas de mercado, falta de capacidades iniciales, escasez de bienes públicos de diversos tipos, fragilidad en los vínculos entre el pensamiento agregado y la realidad del ámbito local, así como un entendimiento acotado de los temas referidos a los pueblos originarios, que hacen que transitar este camino desde la lógica de los 
mercados constituya una alternativa poco factible. Es el Estado el que deberá ofrecer los incentivos y crear las instituciones para que el desarrollo basado en los recursos naturales resulte sostenible desde el punto de vista ambiental y sea más equitativo con el entorno local. Son muchos los bienes públicos que se necesitan a lo largo de la cadena productiva de cada uno de estos sectores. Se requiere brindar respaldo a la investigación y llevar adelante un desarrollo que permita determinar la carga óptima aceptable de los recursos en sus distintos puntos de explotación, así como asistencia financiera para instalar nueva capacidad productiva en las pymes locales, y apoyo jurídico y logístico para abrir nuevos mercados internacionales. Crecer basado en los recursos naturales supone no solo instrumentar programas de gobernanza y regulación de los sectores productivos con reglas de juego distintas a las del ámbito manufacturero, sino también una adecuada provisión de bienes públicos e instituciones de apoyo en toda la cadena productiva. Esta meta entraña una estrategia nacional a largo plazo que trascienda los límites de una única gestión de gobierno e incluya una decisión en la que toda la comunidad esté involucrada.

\section{Reflexiones finales}

En este trabajo se ha planteado que en el futuro América Latina deberá hacer frente a nuevos dilemas de política pública, tanto de índole macroeconómica como microeconómica, dado el creciente peso que los productos básicos industriales y la producción de alimentos han adquirido en años recientes para la estructura productiva y las exportaciones. La expansión de la frontera agrícola, minera, acuícola y frutícola abre nuevas preguntas relacionadas, por un lado, con la enfermedad holandesa y, por el otro, con la tragedia de los comunes, que las autoridades encargadas de formular la política económica en la región deberán abordar con realismo - aunque sin gran teoría que los apoye - para alcanzar tanto la estabilidad de los fundamentos macroeconómicos como el cierre de la brecha tecnológica y de productividad con los países desarrollados y la sostenibilidad medioambiental, sin perder de vista la equidad y la inclusión social. Cada una de estas esferas de la política económica es importante en sí misma y todas deben recibir una adecuada atención. El peligro de una visión parcializada de estas distintas esferas conlleva la posibilidad de una mayor inflación y un deterioro de las cuentas fiscales si no se respetan adecuadamente los equilibrios macroeconómicos; una pérdida relativa del terreno ganado en los mercados mundiales si se deja de lado el desarrollo productivo y tecnológico; un deterioro medioambiental si se descuida la institucionalidad y la aplicación de normas de respeto ambiental, y una pérdida de gobernabilidad democrática si el crecimiento sigue concentrando la riqueza en los tramos más altos de la sociedad y la escasez de bienes públicos acentúa la exclusión social. 
En los últimos tiempos, la región se ha posicionado como una gran fuente de abastecimiento de productos básicos industriales y alimentos a las potencias asiáticas en rápida expansión, lo que abre una gran oportunidad de cara al futuro. Pero hasta el momento, las estrategias de política se han concentrado solo en sostener la estabilidad macroeconómica a corto plazo, sin prestar demasiada atención a las restantes esferas. La brecha relativa de productividad, el deterioro medioambiental y el reclamo por mayor equidad e inclusión social continúan relativamente desatendidos en el marco de una visible complacencia por el buen desempeño de los agregados macroeconómicos. En otras palabras, las nuevas oportunidades que el cambio en la economía mundial trajo aparejado para América Latina no se aprovecharon lo suficiente como para avanzar en otras direcciones hacia la convergencia con la frontera tecnológica mundial, la sostenibilidad medioambiental y el respeto del pacto intergeneracional en pos de sostener el valor de los recursos naturales, al tiempo que se fortalece la equidad y la inclusión social. Una mirada heterodoxa, esencialmente neoestructuralista, muestra con nitidez los flancos débiles que se deberán abordar en el futuro. 


\section{Bibliografía}

Bernat, Gonzalo y Jorge Katz (2013), “Macroeconomic adjustment and structural change: the experience of Argentina, Brazil and Chile in 2000-2010", Journal of Economies and Institutions.

Cardenas, J.E. (2009), Dilemas de lo colectivo. Instituciones, pobreza y cooperación en el manejo local de los recursos de uso común, Bogotá, Centro de Estudios sobre Desarrollo Económico (CEDE), Universidad de Los Andes.

Ffrench Davies, Ricardo (2005), Entre el neoliberalismo y el crecimiento con equidad, Santiago de Chile, LOM Ediciones.

Frenkel, R. y M. Rapetti (2011), "Fragilidad externa o desindustrialización: cuál es la principal amenaza para América Latina en la próxima década?", serie Macroeconomía del Desarrollo, N ${ }^{\circ} 116$ (LC/L.3423), Santiago de Chile, Comisión Económica para América Latina y el Caribe (CEPAL), noviembre.

Iizuka, M. y J. Katz (2013), “Globalization, sustainability and the role of institution", inédito.

Katz, J., M. Iizuka y S. Muñoz (2011), “Creciendo en base a recursos naturales, 'tragedia de los comunes' y el futuro de la industria salmonera chilena", serie Desarrollo Productivo, $\mathrm{N}^{\mathrm{o}} 191$ (LC/L.3307-P), Santiago de Chile, Comisión Económica para América Latina y el Caribe (CEPAL), abril.

Kim, L. (1997), Imitation to Innovation. The Dynamics of Korea'S Technological Leadership, Harvard Business School.

Lundvall, B.A. y Ch. Edquist (1993), "Comparing the Danish and Swedish systems of innovation", National Innovation systems, A comparative Analysis, R. Nelson (ed.), Oxford University Press.

Nelson, R. (1994), "The co-evolution of technology, industrial structure and supporting institutions", Industry and Corporate Change, vol. 3, $\mathrm{N}^{\mathrm{o}} 1$.

Ostrom, E. (2000), El gobierno de los bienes comunes. La evolución de las instituciones de acción colectiva, Mexico, D.F., Fondo de Cultura Economica (FCE).

Prebisch, R. (1980), "Bioesfera y desarrollo", Revista de la CEPAL, No 12, Santiago de Chile, Comisión Económica para América Latina (CEPAL), diciembre.

Rapetti, M. (2011), "Macroeconomic policy coordination in a competitive real exchange rate strategy for development", Working Paper, N 2011-09, Amherst, University of Massachusetts. 

Capítulo IX

\section{Patrones de desarrollo y Estados de bienestar en América Latina}

Luis Bértola

\section{Introducción}

Este capítulo se centra en el estudio de la relación entre, por una parte, los patrones de desarrollo de las economías latinoamericanas, sobre todo las que lo han basado en la amplia disponibilidad de recursos naturales y, por otra, los Estados de bienestar. Se intenta precisar los desafíos específicos que enfrenta el desarrollo económico moderno en las economías latinoamericanas $\mathrm{y}$, en especial, la forma en que surgen las demandas sociales en el marco de crecientes conquistas democráticas, articuladas con estructuras productivas muy diferentes a las que sustentaron el Estado de bienestar en las economías hoy desarrolladas.

Se aborda en primer lugar el llamado desarrollo económico moderno y su relación con los recursos naturales, tratando de arrojar luz sobre la forma en que, recurrentemente, la disponibilidad de recursos naturales ha impuesto restricciones al desarrollo y en que la sociedad moderna ha ido eliminando esas restricciones. La intención es poner en perspectiva histórica el debate actual sobre los límites ambientales del crecimiento. 
También se analiza la interdependencia entre distintas regiones, con especial atención a la importancia de las heterogeneidades internacionales y sus implicancias para el desarrollo. La idea es demostrar cómo la existencia de grandes asimetrías internacionales impone demandas específicas al desarrollo de regiones atrasadas, que no solamente deben combatir las causas de su retraso, sino que han de hacerlo en un entorno de gran competencia con países más avanzados.

Por último, se abordan las demandas de bienestar que surgen del proceso de desarrollo y la forma en que se entrelazan los conceptos de Estado de bienestar y estructura productiva, con particular énfasis en los desafíos que ello impone a economías cuyas estructuras productivas son muy heterogéneas, volátiles y con amplios sectores informales. Es imperativo realizar un esfuerzo de conceptualización específico para los países latinoamericanos y emprender con creatividad la enorme tarea de enfrentar, al mismo tiempo, los desafíos de crecimiento y la convergencia, la estabilidad económica, el desarrollo del Estado de bienestar y la explotación de los recursos naturales sin poner en peligro la sostenibilidad ambiental.

\section{A. Crecimiento económico y recursos naturales: una perspectiva a largo plazo}

El llamado crecimiento económico moderno ha representado un enorme salto en las tasas de desarrollo. Las últimas 15 generaciones a lo largo de los últimos 300 años generaron una dinámica tal, que cada una de ellas produjo cambios probablemente más importantes que lo acumulado durante cualquier milenio anterior, si no durante toda la historia de la humanidad.

Todavía en el siglo XIX era muy difícil incorporar a los enfoques teóricos y a las visiones ideológicas la magnitud de los cambios que venían ocurriendo y que se habrían de profundizar. Se debatían muchas teorías sociales y económicas que consideraban las importantes limitaciones al crecimiento económico. La idea de un estadio final, de alcanzar un estado estacionario en el proceso económico, estaba siempre presente, como un concepto persistente del fin de la historia. Así, a pesar de las grandes confrontaciones metodológicas que hubo, por ejemplo, entre David Ricardo y Robert Malthus, ambos estaban dominados por la concepción de la escasez y los límites del crecimiento. Malthus veía en la escasez de recursos la explicación de la entrada recurrente en escena de los factores positivos, que restablecerían el equilibrio al hacer que la cantidad de habitantes fuera compatible con los recursos naturales existentes. De manera similar, Ricardo veía en la escasez de los recursos naturales, y en la apropiación de la renta derivada de ellos por clases sociales que no generaban acumulación de capital, la explicación de un estado estacionario, cuya llegada se podría evitar o 
postergar si se combatía la apropiación de rentas por esos sectores. Incluso la teoría neoclásica, que domina la ciencia económica hasta nuestros días, se basa en una firme concepción de la escasez de recursos y no ha contribuido de manera importante a la comprensión de la dinámica del cambio tecnológico.

A pesar de todo lo anterior, desde las revoluciones agrarias que se produjeron hasta la expansión de las relaciones capitalistas en el campo, y pasando por la Revolución Industrial y las sucesivas revoluciones tecnológicas y de transportes, la oferta de recursos no ha hecho más que aumentar. Mientras la población mundial pasó de 438 millones en el año 1500 a 6.700 millones en 2008 y el ingreso per cápita tuvo un aumento similar, la producción económica total se multiplicó 205 veces.

Es difícil exagerar el significado de estos logros. Es indudable que muchas de las necesidades que hubo que satisfacer en esos siglos fueron resultado de la expansión de lo que se podría llamar "la frontera", es decir, la extracción de recursos o la producción de nuevos recursos renovables sobre la base del aumento de la superficie en explotación. Pero no puede caber la menor duda de que una parte muy importante de ese crecimiento estuvo explicada por la enorme capacidad del hombre de aprender, innovar y desarrollar ciencia y tecnología, para superar los desafíos que se le presentaban. Aun en el caso de expandir la frontera y hacer económicamente viable la explotación de nuevas regiones, el cambio tecnológico y la innovación fueron una premisa.

En particular, en lo que refiere a la producción de alimentos, es importante tener en cuenta que el sector agrario siempre ha sido capaz de dar respuesta a las demandas que se le han presentado. Mientras que en los últimos 200 años la población mundial se ha multiplicado en casi siete veces, la producción de alimentos se multiplicó en más de diez. La desnutrición que aún presentan millones de personas no se debe a la falta de alimentos, sino a su deficiente distribución, además de la mala distribución del ingreso y la existencia de conflictos bélicos de diverso tipo. Es más, podría decirse que en estos momentos hay una sobreproducción de alimentos (Federico, 2005). Todo ello se ha logrado con una población agraria que, en términos relativos, se ha reducido constantemente. En torno a 1950, la población agraria mundial era del 75\% del total; en 1993, del 54\%, y en 2011, del 48\%. Según datos del Banco Mundial, entre 1993 y 2011, la producción total de alimentos aumentó en un $59 \%$, mientras que la población mundial aumentó en un $26 \%$.

Es indudable que esa revolución y ansia de crecimiento ocurrida en los últimos siglos generó, y sigue generando, una gran cantidad de resultados perversos y destructivos. Al tiempo que se expandió la frontera, se exploró y conquistó el subsuelo y se produjo un crecimiento intensivo, también se consumieron sin mesura los recursos no renovables, se contaminó la atmósfera, se degradaron territorios, se expulsó a la 
población agraria hacia ciudades donde no siempre encontraba mejores oportunidades laborales, o hacia territorios peor dotados para la actividad agraria. De esa manera, no solamente se destruyeron recursos que ya no estarán disponibles para las generaciones futuras, sino que se han alterado y transformado recursos de la biosfera que serán muy difíciles de recuperar. Por otra parte, se han creado situaciones de marginalidad y desarraigo que tendrán efectos negativos duraderos en muchas generaciones por venir, porque estas afectaciones ambientales tienen un impacto marcadamente diferenciado, no solamente entre países, sino entre los distintos estamentos sociales dentro de cada país, siendo por lo general los sectores más pobres los más damnificados. En consecuencia, se trata de un patrón que no será sostenible en el futuro si se desea mantener los niveles actuales de desarrollo $\mathrm{y}$, sobre todo, si se pretende que las regiones más desfavorecidas accedan al mismo nivel de bienestar que las más favorecidas.

De todos modos, sería injusto valorar el legado que esas 15 generaciones dejan a la posteridad exclusivamente en términos de los problemas mencionados. Al mismo tiempo, dejaron a sus descendientes un enorme caudal de conocimiento que puede aprovecharse para resolver los desafíos del desarrollo en el futuro. Hay razones para pensar que las capacidades humanas podrán, una vez más, salvar obstáculos que antes se creían infranqueables.

\section{B. Crecimiento desigual e interdependiente del centro y la periferia}

Casi todas las regiones y sociedades del mundo se han beneficiado de este crecimiento, pero lo han hecho de manera muy diversa. También han contribuido a él en diferente proporción y han sufrido las consecuencias de los excesos y el mal direccionamiento del desarrollo. Más aun, esos diferentes desempeños, lejos de ser simplemente trayectorias paralelas, han conformado un todo sistémico, desigual y con impactos asimétricos.

América Latina muestra una tendencia muy clara a la divergencia con los niveles de producto interno bruto (PIB) per cápita del mundo desarrollado. Debido al carácter volátil y marcadamente cíclico del crecimiento latinoamericano, esa tendencia por momentos se diluye, pero a largo plazo está muy bien definida. El ciclo de acortamiento de distancias que se vive en la actualidad tiene antecedentes similares en coyunturas anteriores.

Mucho se ha debatido acerca de si el crecimiento del centro ha sido posible gracias al acceso a los recursos de la periferia y si la demanda de recursos por parte del centro inhibió, promovió o condicionó el desarrollo de la periferia. Incluso se ha polemizado sobre si ese desarrollo se alcanzó a expensas del desarrollo de la periferia. 
La respuesta es compleja, pero podría afirmarse que, como en tantos otros planos, los impactos han sido asimétricos. Ya Paul Bairoch (1975) sostenía que las importaciones de materias primas desde la periferia no habían sido totalmente determinantes de la Revolución Industrial. Sin duda contribuyeron, o ampliaron las posibilidades, pero no fueron los verdaderos determinantes de que ese proceso tuviera lugar y avanzara. Más bien al contrario, el desarrollo del centro sí fue decisivo para la periferia y las dinámicas de los países centrales pautaron decididamente los desempeños de los periféricos. De ahí surge el concepto de "dependencia" en sus múltiples formas, unas más acentuadas que otras.

Las teorías dependentistas más pertinaces, al estilo de las de Gunder Frank, no han podido resistir el paso del tiempo ni los cambios históricos. No es cierto que la acumulación en el centro haya dado lugar a una desacumulación permanente en la periferia. La mayor parte de los países ha experimentado un proceso de desarrollo, que si bien no se compara con el del centro, está lejos de ser un desempeño deficiente. Esa no ha sido la realidad de América Latina, y mucho menos de China, la India y otros países, que han experimentado un rápido crecimiento económico, acompañado de mejoras en los niveles de educación y expectativa de vida al nacer. Además, algunos de los supuestos en que se basan esas teorías han fracasado rotundamente. Por ejemplo, se ha demostrado que romper con el capitalismo y realizar transformaciones socialistas no es un camino al desarrollo económico y social, y tampoco supuso la construcción de sociedades más democráticas.

Lo que sí puede constatarse es que existe una tendencia universal en el proceso de desarrollo económico: la de una participación creciente de la inversión de capital físico en relación al uso de los recursos naturales. A su vez, ese capital físico ha ido de la mano de una acumulación creciente de capital humano y de conocimiento organizativo, social e institucional. El Banco Mundial ha tratado de agrupar esos componentes con los conceptos de capital natural (es decir, la disponibilidad de recursos naturales), el capital físico (el conjunto de maquinarias, construcciones e infraestructura) y el capital intangible, que alude a diferentes formas del conocimiento e innovaciones sociales. A lo largo del proceso de desarrollo, la estructura del capital no es neutra. Esa tendencia obedece a una creciente inversión en maquinaria y equipamiento, que trae consigo mayores niveles de conocimiento tecnológico y, a la vez, genera mayores economías de escala, un componente central del aumento de la productividad. Por su parte, el capital intangible condensa un conjunto de aprendizajes de diverso tipo que potencian tanto el cambio tecnológico como las capacidades institucionales y organizacionales y perfilan las bases de la competitividad internacional. Los países que tienen los mayores niveles de ingreso per cápita son los que han avanzado más rápidamente en el cambio de la estructura del capital, primero con el aumento del capital físico en relación 
al natural, y luego con el aumento del capital intangible en relación a los otros dos (véase el gráfico IX.1). A su vez, en el cuadro IX.1 se presenta esa estructura por regiones, lo que pone de relieve la precariedad del desarrollo latinoamericano, que solamente supera a África en esa trayectoria.

Gráfico IX.1

Riqueza total y tipos de riqueza per cápita en siete regiones, 2005 (En dólares)

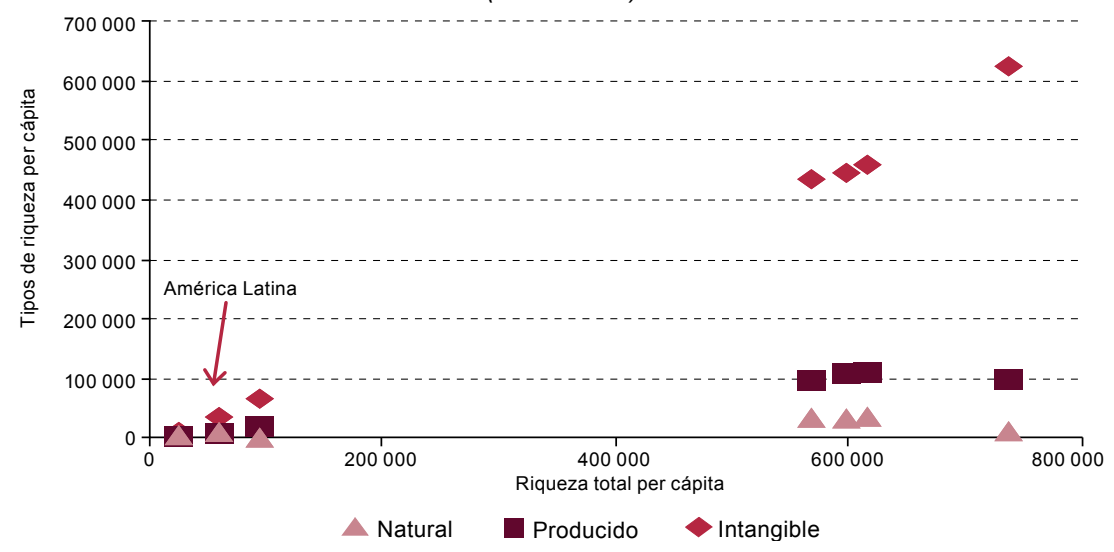

Fuente: Elaboración propia, sobre la base de datos del Banco Mundial, 2012.

Cuadro IX.1

Estructura de la riqueza por regiones, 2005

(En dólares)

\begin{tabular}{|c|c|c|c|c|c|c|}
\hline & $\begin{array}{c}\text { Riqueza } \\
\text { total }\end{array}$ & $\begin{array}{c}\text { Riqueza } \\
\text { total }\end{array}$ & $\begin{array}{c}\text { Capital } \\
\text { intangible }\end{array}$ & $\begin{array}{l}\text { Activos } \\
\text { externos } \\
\text { netos }\end{array}$ & $\begin{array}{l}\text { Capital } \\
\text { producido }\end{array}$ & $\begin{array}{l}\text { Capital } \\
\text { natural }\end{array}$ \\
\hline Países de África seleccionados ${ }^{a}$ & 23324 & 100 & 54 & -2 & 17 & 31 \\
\hline América Latina y el Caribe & 57809 & 100 & 65 & -3 & 16 & 22 \\
\hline China, India y República de Corea & 92651 & 100 & 74 & -1 & 24 & 3 \\
\hline España, Grecia, Italia y Portugal & 595210 & 100 & 75 & 0 & 18 & 6 \\
\hline Australia, Canadá y Nueva Zelandia & 565255 & 100 & 77 & -1 & 18 & 6 \\
\hline Dinamarca, Finlandia, Noruega y Suecia & 613205 & 100 & 75 & 0 & 18 & 6 \\
\hline \multirow[t]{2}{*}{ Estados Unidos } & 734195 & 100 & 85 & -1 & 14 & 2 \\
\hline & $\begin{array}{l}\text { Riqueza } \\
\text { tangible }\end{array}$ & $\begin{array}{l}\text { Riqueza } \\
\text { tangible }\end{array}$ & & & & \\
\hline Países de África seleccionados ${ }^{a}$ & 10830 & 100 & & -4 & 37 & 66 \\
\hline América Latina y el Caribe & 20278 & 100 & & -8 & 46 & 62 \\
\hline China, India y República de Corea & 24306 & 100 & & -4 & 91 & 13 \\
\hline España, Grecia, Italia y Portugal & 147137 & 100 & & 1 & 75 & 24 \\
\hline Australia, Canadá y Nueva Zelandia & 127826 & 100 & & -6 & 77 & 29 \\
\hline Dinamarca, Finlandia, Noruega y Suecia & 151466 & 100 & & 1 & 74 & 25 \\
\hline Estados Unidos & 106949 & 100 & & -6 & 94 & 13 \\
\hline
\end{tabular}

Fuente: Elaboración propia, sobre la base de datos del Banco Mundial, 2012.

a Congo, Côte d'Ivoire, Kenya, Nigeria, República Democrática del Congo, Senegal, Sudáfrica, Zambia, Zimbabwe. 
Una manera de ver esas estructuras es en el ámbito de la educación, donde América Latina muestra una situación contradictoria. Por un lado, como fruto de importantes esfuerzos, se han producido mejoras significativas en el nivel educativo medio pero, por otro, esos esfuerzos resultan insuficientes a la hora de realizar comparaciones internacionales. América Latina pasó de un promedio de 1,5 años de educación a principios del siglo XX a 7,1 años a fines del siglo XX. Entretanto, Alemania, los Estados Unidos, Francia y el Reino Unido tenían en conjunto un promedio 12,5 años (Bértola, Hernández y Siniscalchi, 2011).

América Latina ha mostrado una particularidad muy importante de su patrón de desarrollo: en relación con cada nivel de ingreso per cápita, el nivel educativo es menor que en otras regiones. En otras palabras, la región presenta un peor desempeño educativo $\mathrm{y}$, al mismo tiempo, parece obtener mayor desempeño económico con menor nivel de educación. Las principales ideas que se han manejado como explicaciones de este fenómeno tienen que ver con las estructuras sociales y las relaciones de poder.

\section{Gráfico IX.2}

América Latina y "Occidente": PIB per cápita en paridades del poder adquisitivo de $1990(x)$ y promedio de años de educación en la población de 15 y más $(y), 1870-1930$

(En años y dólares)

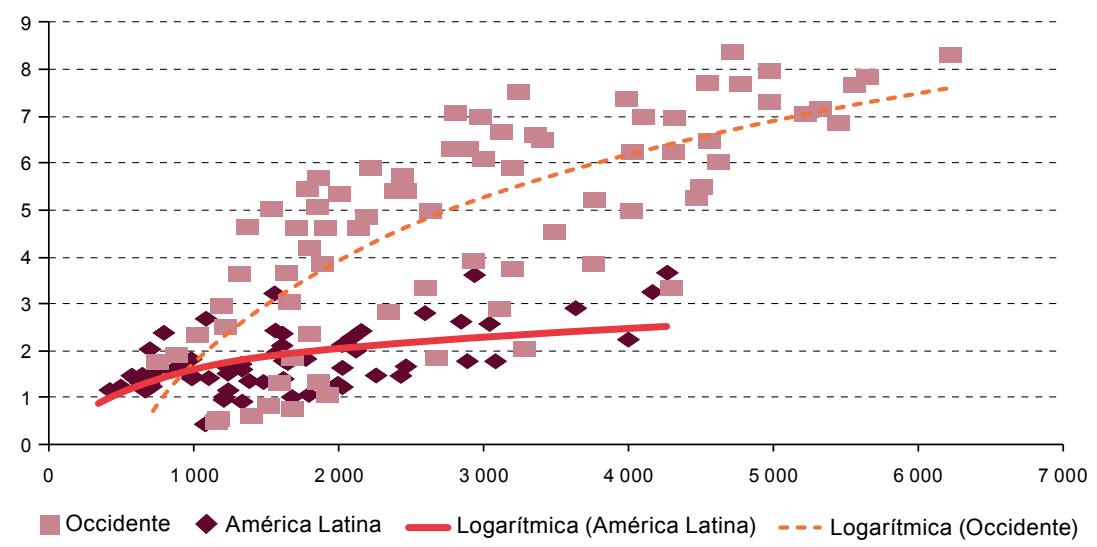

Fuente: Elaboración propia, sobre la base de L. Bértola, M. Hernández y S. Siniscalchi, "Un índice histórico de desarrollo humano de América Latina y algunos países de otras regiones: metodología, fuentes y bases de datos", Documentos de Trabajo, № 28, Programa de Historia Económica, Montevideo, Facultad de Ciencias Sociales, Universidad de la República, 2012.

Existe una amplia gama de enfoques que hacen énfasis en las estructuras sociales para explicar por qué los niveles educativos de América Latina son inferiores a los de otras regiones, en relación con cada nivel de ingreso. Sin embargo, hay otra manera complementaria de explicar 
estos fenómenos. ¿Cómo es posible que una población produzca más de lo que se esperaría en función de su capital humano? La respuesta es que la producción está dominada por una elevada participación de los recursos naturales. La trayectoria tradicional latinoamericana de exportación de bienes primarios, que tienen relativamente poco valor agregado pero son capaces de generar rentas, sería el factor fundamental en que se basa el alto ingreso per cápita en relación a los niveles de formación de capital humano, expresados en el nivel educativo.

Esta característica fue un importante punto de partida en el desarrollo de muchos países, como los propios Estados Unidos y los países escandinavos y de Australasia. Sin embargo, teniendo en cuenta los estudios antes mencionados, es válido concluir que los recursos naturales también pueden transformarse en un inhibidor del cambio si quienes los controlan también detentan el poder político y si la orientación del patrón productivo es hacia la extracción de renta de recursos naturales antes que hacia la capacidad de innovación basada en el desarrollo del capital humano y el cambio estructural de la producción.

No existe una causalidad sencilla entre disponibilidad de recursos naturales y nivel educativo. El vínculo entre ambos aspectos siempre estará mediado por el conjunto de relaciones sociales predominantes, en términos de poder económico y político. Por ejemplo, los países más meridionales de América del Sur, si bien poseen abundantes recursos naturales en relación a su población, lograron atraer inmigrantes y desarrollar niveles salariales y de gasto social mayores que otras regiones donde la dotación de recursos naturales per cápita no era tan elevada. Cuando la dotación de recursos naturales alta se combina con una gran concentración de su propiedad y la existencia de grandes masas de población de bajo nivel de instrucción y escaso poder político, debido en parte a la discriminación racial y cultural, el retraso educativo puede ser aun mayor (Bértola y Ocampo, 2012). En definitiva, la maldición de los recursos naturales no es un resultado inexorable en los países que disponen de ellos en abundancia. Lo decisivo son las estructuras económicas, sociales y políticas que se construyen durante su apropiación y explotación.

\section{Desarrollo y Estados de bienestar}

Los Estados de bienestar han surgido a partir de un proceso de drásticos cambios estructurales, que primero se caracterizó por la industrialización y luego por la expansión de los servicios. Entre las transformaciones radicales ocurridas en ese proceso figuran los cambios de la localización de la población, de la estructura de las familias, de la división del trabajo en el seno de los grupos familiares, de la distribución del tiempo dedicado 
al ocio, la educación y el trabajo, y de la estructura del consumo y la forma de consumir. También se produce un cambio radical en la estructura de riesgos, lo que impone a las sociedades la organización de su cobertura.

Estos cambios se produjeron a escala global. Es muy importante tener presente que los Estados de bienestar no se construyeron solamente para dar respuesta a fenómenos internos de las distintas sociedades. Los Estados de bienestar comienzan a desarrollarse durante la llamada primera globalización, en medio de un gran cambio estructural y de una gran restructuración de recursos entre distintas partes del planeta. El modelo bismarckiano, además de hacer frente a las amenazas de los movimientos obreros y comunistas, respondía a la necesidad de retener mano de obra calificada que, de lo contrario, emigraría a los Estados Unidos u otras economías de nuevo asentamiento. Los Estados de bienestar buscaban, por otra parte, dar garantías a los trabajadores en un contexto de gran inseguridad laboral, con una economía en transformación y sometida a intensas fluctuaciones. Esas tendencias se producían en los países de emigración, como Alemania y los países escandinavos, pero también en los de inmigración, como la propia Australia, el Canadá e incluso países latinoamericanos, como el Uruguay. De ahí que sea necesario destacar, una vez más, la importancia de la dimensión internacional (Huberman, 2012; Lloyd, 2013).

Sin embargo, no fue sino en la posguerra de la Segunda Guerra Mundial que los Estados de bienestar alcanzaron su pleno desarrollo en los países más avanzados. Los trabajos de Esping-Andersen han devenido en clásicos y son referentes inevitables para el estudio del tema. Su clasificación primaria en tres mundos de "capitalismo de bienestar" (Esping-Andersen, 1990) y su ampliación, revisión y discusión de más "variedades de capitalismo de bienestar" (Esping-Andersen, 1999) merecen ser examinadas en detalle.

Los tres mundos del capitalismo de bienestar (el liberal, el corporativo y el socialdemócrata) se distinguen entre sí por la forma en que enfrentan la cobertura de riesgos similares, con diferentes conformaciones de la tríada mercado-familia-Estado. Entre otras variables clave para el análisis, está el papel del mercado en la cobertura de riesgos. En ese sentido, el capitalismo de bienestar liberal asigna al Estado un rol marginal, consistente en socorrer en casos extremos a una población extremadamente vulnerable, que no puede valerse por sí misma y que por la mera dependencia de esos servicios se encuentra en una posición de mayor marginalidad social. En ese régimen, la mayoría de los individuos o familias se valen de sus propios ingresos para obtener en el mercado la cobertura de servicios de salud y jubilación que necesitan. A diferencia de ese modelo, los otros dos buscan hacer frente a dichos riesgos mediante 
soluciones de tipo colectivo, social y estatal. En los sistemas de bienestar corporativo, desarrollados durante la posguerra en la edad de oro del capitalismo, la cobertura de riesgos se produce en el marco de un mercado de trabajo muy segmentado en distintos sectores económicos, con formas específicas de organización y con un acceso muy diferenciado a la cobertura de riesgos y su calidad. Sobre la base de una economía fordista, cada gremio tiene una forma de organización específica y diferenciada. A su vez, los beneficios se aplican al conjunto de una estructura familiar acotada, con un jefe de hogar perceptor de ingresos, predominantemente masculino, y con una presencia femenina relativamente alta en el hogar, donde la mujer desempeña un papel central. El tercer modelo, el socialdemócrata, se basaba en una amplia cobertura universal por parte del Estado, a la que se accedía con independencia de la posición que ocupara cada individuo en el mercado de trabajo, con niveles de calidad muy superiores al de las prestaciones del sistema marginal del capitalismo liberal. Este sistema supone una importante carga tributaria, que se hace posible gracias a la amplia participación de la mujer en el mercado de trabajo y a los diversos servicios públicos que se prestan en el marco de esa estructura del mercado de trabajo.

Así pues, el desarrollo de esos Estados de bienestar ha tenido rasgos comunes y diferenciados. Es necesario explicar la dinámica mediante la que se fueron conformando y diferenciando los distintos modelos. Si bien algunas características del proceso son comunes, es importante explicar las diferencias. Difícilmente puedan encontrarse determinantes únicos de las diferentes modalidades. Se han esgrimido diversos elementos: las características de los movimientos campesinos, el impacto de las distintas religiones, las diferentes formas de organización de los movimientos obreros y los partidos políticos, los variados caminos para la conformación del Estado moderno a partir de los distintos senderos que ha recorrido la revolución burguesa, las particulares formas de inserción internacional y el tamaño de los países, entre otros.

La comprensión de la génesis de esos Estados de bienestar es sumamente importante ya que, a diferencia de lo que muchos han afirmado en el marco de la globalización, las economías y sociedades no avanzaron hacia un patrón único de organización social, sino que las variedades de capitalismo perduraron en las diferentes formas de afrontar la crisis de los Estados de bienestar y en su posterior desarrollo.

Esping-Andersen (1999) hace algunas afirmaciones que bien merecen un análisis profundo. Una de sus conclusiones cuestionables es que, si bien las crisis de los modelos de bienestar reinantes hasta los años ochenta se debían a problemas internos de dichos modelos, la crisis que se evidencia a partir de los años ochenta y noventa es de carácter 
exógeno. El autor la atribuye a la globalización (que altera los márgenes para el desarrollo de políticas fiscales y monetarias autónomas e impone la flexibilización de los mercados laborales) y a los cambios demográficos, tanto en lo que se refiere a la estructura y estabilidad de las familias, como al envejecimiento de la población, que transforma la estructura de riesgos (Esping-Andersen, 1999, pág. 3).

Por otra parte, sostiene que a los capitalismos de bienestar se les presenta el gran dilema de elegir entre sociedades de pleno empleo, pero con una creciente desigualdad económica entre trabajadores calificados y no calificados, y sociedades con alto nivel de desempleo. Lo que resulta interesante es la afirmación de que esa presión no se debe tanto a la globalización y al surgimiento de países en desarrollo que producen bienes industriales con costos salariales mucho más bajos, sino principalmente a los efectos de una orientación del cambio tecnológico endógeno de los países desarrollados, que tiende a reducir la demanda de empleo no calificado y a depender de las capacidades de generación de empleo calificado, especialmente en el sector de los servicios.

Con ese enfoque, Esping-Andersen aspira a soslayar la aparente contradicción entre globalización y Estado de bienestar, ya que el propio origen de esos fenómenos, sobre todo en economías pequeñas y abiertas, se ha debido a la necesidad de dar estabilidad a una población y una economía sumamente expuestas a los vaivenes de los mercados internacionales.

Esos dos grupos de afirmaciones parecen contradecirse de cierto modo, lo que tal vez se deba a aspectos conceptuales que son fundamentales a los efectos de este trabajo. Está claro que EspingAndersen cree firmemente que los Estados de bienestar guardan relación con una estructura productiva específica, con niveles de productividad determinados y en contextos de importantes cambios tecnológicos. Sin embargo, diríase que la caracterización de los mundos de bienestar se volvió poco a poco tan precisa y absorbente, que se fue transformando en una discusión autocontenida, en la que perdió peso el vínculo entre el modelo de bienestar y los sustentos de la estructura productiva. Esto puede traer graves consecuencias desde el punto de vista del análisis.

Como dijo Esping-Andersen (1999, pág. 3): “(...) la crisis contemporánea difiere sustancialmente de las precedentes. Hasta ahora, la crisis era invariablemente endógena al Estado de bienestar, que hacía las cosas incorrectamente o generaba consecuencias no deseadas. En contraste, la crisis actual es en esencia una manifestación de las conmociones exógenas que ponen en peligro la viabilidad a largo plazo del Estado de bienestar. La nueva economía global (...) hace que las estructuras políticas vean menoscabado su uso discrecional de la política fiscal y monetaria, 
entraña una mayor flexibilidad en materia de empleo y salarios y, sobre todo, condena al desempleo a los trabajadores menos calificados si no se reducen los salarios y las prestaciones sociales. El envejecimiento de las poblaciones significa que se deben volver a analizar los compromisos con la seguridad social. La inestabilidad de la familia implica (...) que se está erosionando la capacidad tradicional de los hogares de cuidar de sus integrantes y (...) los riesgos de la pobreza son cada vez mayores (...) esos riesgos exógenos dan pie a situaciones dolorosas en lo que se refiere a las políticas...". Más adelante en el mismo trabajo, añadió: "La 'verdadera' crisis de los regímenes contemporáneos de bienestar se debe a la desvinculación existente entre la construcción institucional actual y el cambio exógeno" (Esping-Andersen, 1999, pág. 5).

Como bien dice Esping-Andersen, el período de entreguerras, con sus tendencias autárquicas y nacionalistas, fue excepcional en la historia de los últimos 150 años. Lo cierto es que los modelos de bienestar se construyeron con determinantes económicos y sociales propios de ese período. Pero tal vez lo más importante sea que, así como el inicio de los modelos de bienestar se remonta al período de la primera globalización, según el análisis de Huberman, la conformación de los Estados de bienestar se produce en el marco de las respuestas nacionales a la caída del sistema del patrón oro y a la crisis de la primera globalización. Por lo tanto, entender que la globalización representa una conmoción externa que afecta a los modelos de bienestar permite de cierto modo desconectar a los Estados de bienestar de su entorno productivo. La globalización fue una salida a una crisis de las economías desarrolladas, cuyo modelo de bienestar era un componente más del complejo andamiaje económicosocial. La globalización es una respuesta a la crisis del fordismo, de la que los Estados de bienestar eran una parte, no del todo funcional, pero sí claramente integrada.

También se presta a debate la segunda afirmación de EspingAndersen. Es muy persuasivo y válido su argumento de que el cambio tecnológico endógeno es una fuerza dinámica que genera desempleo, especialmente para los menos calificados. No obstante, ahora que han transcurrido 15 años más de desarrollo asiático, se puede afirmar que la producción industrial en masa proveniente de Asia ha representado para los mercados europeos o norteamericanos una amenaza mayor de lo que supuso Esping-Andersen. Entre otras cosas, no tuvo en cuenta la forma en que Asia ha sustituido a los Estados Unidos y Europa en importantes rubros de exportación destinados a terceros mercados, lo que ha hecho menguar la dinámica exportadora y la generación de empleo de los países más desarrollados. Por otra parte, ese fenómeno de deslocalización ya se había iniciado mucho antes de la crisis de los años ochenta y noventa. En la propia Escandinavia se sufrían las 
consecuencias, por ejemplo, de la competencia asiática frente a los astilleros suecos, que fue estudiada por Bohlin (1989).

Es igualmente discutible que los cambios demográficos, como el cambio de las características de los hogares y el envejecimiento de la población, sean ajenos a la dinámica de los Estados de bienestar. Solo se puede llegar a esa conclusión si se los desvincula de su entorno socioproductivo. La estructura familiar tiene mucho que ver con la estructura de riesgos y las oportunidades del mercado laboral. También depende de los servicios que presta la sociedad para enfrentar los riesgos. Obviamente, la expectativa de vida al nacer guarda una estrecha relación con el crecimiento económico, y este con la dinámica productiva. En síntesis, el desarrollo económico moderno presenta tendencias generales que involucran al Estado de bienestar y generan sus propias dinámicas de transformación, que difícilmente puedan considerarse exógenas.

En ese sentido, aunque no se concentran específicamente en los estudios del Estado de bienestar, los enfoques regulacionistas ofrecen un marco conceptual más abarcador y fructífero, en que los Estados de bienestar y las regularidades para la reproducción de los diferentes sectores sociales se articulan con un régimen de acumulación más amplio, que comprende la división técnica y social del trabajo, la dimensión temporal de las modalidades de acumulación de capital, las regularidades para la reproducción de los diferentes componentes de la demanda y las modalidades de inserción en la economía internacional.

Al igual que en los enfoques de Esping-Andersen, los regulacionistas, ubicados dentro de la corriente de los sistemas sociales de producción según Hall y Soskice (2001), se resisten a considerar que exista una tendencia a la igualación y convergencia de todas las sociedades modernas en un patrón único de organización social. Por una parte, Esping-Andersen sostiene que, al enfrentar esas conmociones externas, las distintas variantes del bienestar mantienen sus características constitutivas más básicas. Por otra, en los enfoques basados en la regulación se considera que los complejos entramados estructurales e institucionales presentan inercias y dependencia de la trayectoria, por lo que la idea de un capitalismo único no tiene cabida.

A ese tipo de enfoques, según los cuales existen y persisten diversos patrones de desarrollo, se suman los enfoques sobre las variedades de capitalismo (Hall y Soskice 2001). Se trata de marcos teóricos pensados para el estudio de los países desarrollados. Si bien esto no les resta validez, como se verá, primero deberían someterse a un intenso proceso de adaptación para ser aplicables a la realidad latinoamericana. 
El enfoque de las variedades de capitalismo está centrado en el papel fundamental de las empresas en el proceso competitivo, de cambio tecnológico y de construcción social. Se analizan cinco elementos, sobre la base de Hall y Soskice (2001):

i) las relaciones industriales son el ámbito en que se desenvuelve la negociación de los salarios y de las condiciones de trabajo, vinculadas y con un impacto en la productividad;

ii) el entrenamiento vocacional y la educación determinan la competitividad de las empresas;

iii) las formas de gobernanza de la empresa constituyen un complejo entramado de relaciones entre accionistas, gerentes, empresas familiares, grupos económicos diversificados, grupos económicos verticalmente integrados, entre otros;

iv) las relaciones entre empresas son un componente fundamental del relacionamiento con clientes y proveedores, pues influyen en los niveles de productividad, eficiencia y competitividad, y

v) la coordinación de los propios empleados de las empresas constituyen un elemento central de las estrategias cooperativas y la trasmisión de información.

Con el estudio de esos cinco componentes, se estilizan dos tipos de capitalismo: las economías liberales de mercado y las economías coordinadas de mercado. El análisis parte de los conceptos de instituciones y organizaciones desarrollados por North (1990), en los que se resalta la importancia de las instituciones tácitas, informales, con un importante componente de entorno cultural, que determinan la conducta de los agentes.

A partir del entramado de instituciones y organizaciones, se construye una matriz de infraestructura institucional que determina la estrategia corporativa. Su conformación no se basa solamente en la competencia en los mercados y la jerarquía dentro de las empresas, sino en dar un gran peso a los componentes de la cooperación y la confianza. A su vez, las instituciones no son el resultado de una selección por parte de empresas específicas, sino que constituyen un problema considerable de coordinación de segundo orden: "[L]as empresas situadas dentro de cualquier economía política deben lidiar con un conjunto de instituciones coordinadoras cuya naturaleza no está completamente bajo su control" (Hall y Soskice, 2001, pág. 13). Se produce de esta manera una especie de amalgamiento institucional, donde distintas instituciones se refuerzan y condicionan mutuamente. Así, incluso entre las economías coordinadas de mercado se aprecian diferencias, como las que distinguen a los complejos grupos japoneses de gran diversidad sectorial y el modelo alemán, de gran estructuración sectorial e integración vertical. 
Al seguir ese enfoque se llega a conclusiones similares a las de la escuela de la regulación en cuanto a los límites de la globalización como unificadora de modelos de desarrollo. Los países se distinguen por sus particulares patrones de desarrollo basados en ventajas comparativas institucionales. Los diferentes países se suman a la globalización y entran en unidades políticas mayores, como la Unión Europea, pero lo hacen bajo la condición de que no se cuestione su modelo competitivo basado en su matriz institucional, aunque eso no quiere decir que las matrices institucionales no se transformen y evolucionen. Lo cierto es que un país no trataría de destruir sus bases institucionales de competitividad al incorporarse a procesos de internacionalización.

Un concepto central de los enfoques de las variedades de capitalismo, es que existe una correspondencia muy directa entre los tipos de economía política que se desarrollan y los tipos de Estados de bienestar que se construyen. Ese aspecto se mencionó anteriormente en la crítica a Esping-Andersen y el enfoque de las variedades de capitalismo lo encara con claridad. Los Estados de bienestar forman parte de la matriz de ventajas comparativas institucionales y reflejan la actitud de los actores clave en dicho proceso.

El Estado de bienestar no es un conjunto autónomo de arreglos institucionales, sino que está íntimamente ligado a la escena económicosocial en general. La pregunta que se plantea recurrentemente es si los Estados de bienestar fueron una expresión de un período muy particular de la economía mundial dominado por estrategias keynesianas en el marco de Estados nacionales relativamente autónomos, o si reflejan ideales políticos y sociales que pueden ser instrumentados en cualquier época, si esa fuera la preferencia de la ciudadanía. Según Lloyd, los escenarios futuros son inciertos. Pueden presentarse dos escenarios negativos para los Estados de bienestar: o bien la propia lógica de los mercados sustituye a la mayoría de las instituciones existentes en la provisión de bienes públicos, que serían administrados por técnicos en el marco de ciertas regulaciones y en posición de dependencia frente a los intereses capitalistas, o bien se produce un marcado descenso de la confianza en las propias instituciones del Estado, al punto de que este se retire de esas funciones, a favor de intereses privados. Las posibles tendencias de renacimiento de los Estados de bienestar pueden encontrar respaldo en las oportunidades que ofrece la sociedad del conocimiento, el predominio de los impulsos sociobiológicos hacia la cooperación y la solidaridad, la construcción de una democracia trasnacional, el avance del desarrollo económico y la consolidación de demandas sociales con la presencia de nuevos sectores emergentes a nivel global (Lloyd, 2013). 
Una conclusión posible es que los Estados de bienestar no se pueden comprender fuera de un contexto general de determinantes económicos y sociales y que, por otra parte, al parecer su futuro no será el resultado ineludible del desarrollo económico moderno, sino que está abierto, es incierto y depende tanto de determinantes económicos como de los valores que desarrollen y las opciones que adopten las distintas sociedades y la comunidad global. En consecuencia, al hablar sobre el devenir del Estado de bienestar en América Latina no se puede presuponer que su desarrollo forme parte de una tendencia universal e irreversible.

\section{Desarrollo y Estado de bienestar en América Latina}

Como se ha expuesto abundantemente, la estructura productiva latinoamericana mantiene características muy específicas. Se trata de economías que han tenido un escaso desarrollo industrial y una desindustrialización precoz en relación al nivel del PIB per cápita, en las que las exportaciones primarias tienen un peso sobredimensionado y la estructura de importación gira sobre todo en torno a los bienes de alto contenido tecnológico, en los que América Latina tiene un déficit manifiesto. A largo plazo, esto ha supuesto una tendencia al déficit de la balanza comercial como freno al crecimiento ya que, a medida que aumenta el ingreso, se incrementa el consumo de bienes de mayor contenido tecnológico. El cambio tecnológico se produce más aceleradamente allí donde la demanda se expande y, a su vez, la demanda se expande cuando se producen cambios tecnológicos radicales que alteran las pautas de consumo. No importa cuánto se incrementen las exportaciones, pues lo relevante es el ritmo de aumento de las importaciones que conlleva el crecimiento del ingreso.

Esa tendencia de América Latina no es lineal. Como ya se ha ilustrado elocuentemente, ese proceso tiene un marcado componente cíclico. Sus ciclos guardan relación con una gran cantidad de factores, como la volatilidad financiera, la creación y destrucción tecnológica, los vaivenes políticos de la economía internacional, la aparición recurrente de nuevos centros expansivos, el agotamiento y descubrimiento de recursos naturales, entre otros. Así, la industrialización europea y la primera globalización dieron lugar a un ciclo largo y fluctuante de aumento de los términos de intercambio y expansión de la demanda de bienes primarios producidos por América Latina, que potenció las relaciones de elasticidad-ingreso de la demanda de exportaciones e importaciones, permitiendo a América Latina emprender un proceso de acortamiento relativo de distancias. La desaceleración del crecimiento mundial 
en el período de entreguerras forzó a América Latina a reformular su inserción internacional y tratar de potenciar su desarrollo hacia adentro a partir de cambios radicales de su estructura productiva, que le permitieron diversificar significativamente sus capacidades, aunque sin lograr un acortamiento sustantivo de la distancia con los países líderes. De manera desigual, algunos países apropiaron tecnología madura y lograron acortar distancias en algunas ramas industriales estratégicas, pero fueron muy contadas las oportunidades en que la región logró construir y desarrollar modelos de desarrollo productivo que la situaran en la frontera del cambio tecnológico.

Así, en las sucesivas olas de cambio tecnológico, los esfuerzos latinoamericanos fueron quedando rezagados, especialmente cuando a partir de los años ochenta se optó en general por volcarse a una estrategia de inserción internacional que volvía a apostar a la inserción internacional basada en la explotación de ventajas comparativas estáticas. La dinámica de las últimas décadas ha vuelto nuevamente a estar poderosamente dominada por grandes fluctuaciones cíclicas. El actual ciclo expansivo, impulsado por el aumento de la demanda asiática de bienes primarios y por las bajísimas tasas de interés que se pagan en el mundo desarrollado, han provocado una importante afluencia de capitales a América Latina, dispuestos a invertir a tasas de ganancia relativamente bajas, que muchas veces son posibles debido a la situación de precios de los productos básicos a nivel internacional.

Aunque el futuro sea incierto y sea muy difícil vaticinar cuánto durará este escenario expansivo, parece claro que en la mayoría de los casos no está conduciendo a una profunda transformación de las estructuras productivas que revierta la particular forma de inserción de América Latina en la economía mundial. Ante esa situación, es fundamental diagnosticar acertadamente las características de la estructura productiva para entender qué variedad de capitalismo es la que tiene esta región, cuáles son sus desafíos y amenazas, cuáles son las formas de economía política que predominan y cuáles son las formas que pueden asumir los Estados de bienestar y las políticas sociales. Este diagnóstico parece ser decisivo para la formulación y desarrollo de la matriz de ventajas comparativas institucionales y para comprender cuáles son los actores clave en dicho proceso.

Si se hiciera un mínimo análisis de los cinco componentes centrales de las variedades de capitalismo en el complejo organizativo-institucional de América Latina, y más allá de las grandes diferencias que luego se abordarán, se podría señalar lo siguiente:

i) Las relaciones industriales son el ámbito de negociación de los salarios y de las condiciones de trabajo, e influyen en la productividad. Puede destacarse la alta informalidad del sistema 
productivo latinoamericano, con una gran heterogeneidad estructural, amplios sectores no insertados en los sistemas de negociación salarial, así como salarios que, en relación a los países desarrollados, representan una parte muy pequeña de la demanda efectiva y del mercado interno, ya que el grueso de las exportaciones se basa en ventajas de acceso a materias primas con escaso valor agregado. Existen sectores más formales sujetos a diferentes pautas de negociación salarial y productividad pero, dado que los aumentos de productividad muchas veces tienden a ser exógenos a las empresas, por estar asociados con la inversión extranjera o incluidos en los bienes de capital, las pautas de la negociación salarial a menudo no están vinculadas estrictamente a cambios en la productividad endógenos del proceso productivo.

ii) El entrenamiento vocacional y la educación son ámbitos que determinan la competitividad de las empresas. En ese plano, la demanda limitada de mano de obra de alta calificación ha llevado a los sistemas educativos latinoamericanos a estar muy desconectados de los sistemas productivos y a exhibir, como ya se ha mostrado, niveles comparativos bajos. Desde otro punto de vista, puede sostenerse que los niveles de PIB per cápita son superiores a los que corresponden a los niveles educativos de la región.

iii) Las formas de gobernanza de la empresa constituyen un complejo entramado de relaciones entre accionistas, gerentes, empresas familiares, grupos económicos diversificados, grupos económicos verticalmente integrados y otros. En el caso latinoamericano, este sistema muestra gran fragilidad debido a la heterogeneidad estructural ya mencionada. Las grandes empresas vinculadas a la exportación tienen estructuras más sofisticadas y por lo general están asociadas al capital extranjero, al igual que la mayoría de las grandes empresas de servicios modernos. En algunos países, la producción estatal ha sobrevivido a las reformas de mercado de los años ochenta y noventa, con importantes núcleos de acumulación y articulación con el tejido productivo. El tejido empresarial está dominado numéricamente por empresas pequeñas y medianas, de muy poca capacidad de generación de innovación, con niveles de productividad muy por debajo de la media.

iv) Las relaciones entre firmas constituyen un componente central del relacionamiento con clientes y proveedores y determinan 
niveles de productividad, eficiencia y competitividad. Con la excepción de algunas empresas estatales y núcleos endógenos, la estructura productiva es sencilla, de escasa profundidad e interacción y con los núcleos más dinámicos subordinados a las cadenas internacionales de valor. El océano de pequeñas y medianas empresas se mantiene muy aislado de las interacciones dinámicas con el resto del tejido productivo del país.

v) Finalmente, la coordinación de los propios empleados de las empresas constituye un elemento central en las estrategias cooperativas y en la trasmisión de información. En ese plano, las grandes empresas internacionales transfieren sus prácticas de origen y las grandes empresas públicas mantienen dinámicas específicas relativamente poco conocidas y estudiadas. En todo caso, parece ser muy difícil codificar esas prácticas en América Latina.

Todos estos aspectos están contenidos en dos elementos centrales de la formación institucional-organizativa de la economía latinoamericana: la heterogeneidad estructural y las características de su capital.

Es posible pensar que las bases competitivas de una sociedad tienen relación con el tipo de capital predominante. Este, a su vez, determina las trayectorias del cambio tecnológico y de la organización social. Ya se ha analizado cuán importante sigue siendo el capital natural en América Latina y cuán poco desarrollado está todavía el llamado capital intangible.

Por otra parte, la estructura productiva de América Latina se reafirma como la de mayor heterogeneidad en la perspectiva comparada internacional. Como se indica en el cuadro IX.2, América Latina muestra un Gini de desigualdad del PIB por ocupado entre grandes sectores que más que duplica el de la mayoría de las otras regiones. A su vez, en el cuadro IX.2 se muestra la gran volatilidad de la heterogeneidad de América Latina. Es la región que presenta más variaciones en la heterogeneidad del producto por ocupado, vista en relación con la forma en que el concepto de productividad se ve afectado por cambios radicales en el nivel de actividad económica y por la propia volatilidad del PBI antes anotada, lo que a su vez guarda relación con la volatilidad de la demanda y los precios de los principales bienes de exportación. En otras palabras, si se compararan los parámetros de productividad usando distintos años de base, los resultados serían claramente cambiantes, pero no por efecto de cambios y dinámicas tecnológicas sectoriales, sino principalmente por el impacto de los precios. 
Cuadro IX.2

Heterogeneidad de la productividad estructural por grupos de países, índice de Gini

\begin{tabular}{|c|c|c|c|c|c|c|}
\hline Grupo & & 1991 & 1996 & 2001 & 2006 & Promedio \\
\hline 1. América Latina ${ }^{a}$ & 1 & 0,455 & 0,406 & 0,478 & 0,448 & 0,447 \\
\hline 2. Principales países de Europa ${ }^{b}$ & 2 & 0,168 & 0,191 & 0,158 & 0,180 & 0,174 \\
\hline 3. Asia ${ }^{\mathrm{C}}$ & 3 & 0,318 & 0,314 & 0,332 & 0,281 & 0,311 \\
\hline 4. Escandinavia ${ }^{d}$ & 4 & 0,198 & 0,220 & 0,234 & 0,259 & 0,228 \\
\hline 5. LATPER ${ }^{e}$ & 5 & 0,229 & 0,218 & 0,217 & 0,209 & 0,218 \\
\hline 6. Nuevo asentamiento ${ }^{f}$ & 6 & 0,269 & 0,278 & 0,286 & 0,286 & 0,280 \\
\hline 7. Estados Unidos & 7 & 0,211 & 0,211 & 0,221 & 0,233 & 0,219 \\
\hline 8. Toda Europa & 8 & 0,188 & 0,208 & 0,188 & 0,203 & 0,197 \\
\hline Grupo & \multicolumn{6}{|c|}{ Variación en puntos porcentuales } \\
\hline 1. América Latina ${ }^{a}$ & $-4,8$ & 7,1 & $-3,0$ & & & \\
\hline 2. Principales países de Europa ${ }^{b}$ & 2,3 & $-3,3$ & 2,2 & & & \\
\hline 3. Asia ${ }^{\mathrm{C}}$ & $-0,4$ & 1,8 & $-5,1$ & & & \\
\hline 4. Escandinavia ${ }^{d}$ & 2,2 & 1,4 & 2,5 & & & \\
\hline 5. LATPER $^{e}$ & $-1,1$ & $-0,1$ & $-0,8$ & & & \\
\hline 6. Nuevo asentamiento ${ }^{f}$ & 0,9 & 0,8 & 0,0 & & & \\
\hline 7. Estados Unidos & 0,0 & 1,0 & 1,2 & & & \\
\hline 8. Toda Europa & 2,0 & $-2,0$ & 1,5 & & & \\
\hline
\end{tabular}

Fuente: L. Bértola, "Informe de proyecto", Santiago de Chile, Comisión Económica para América Latina y el Caribe (CEPAL), 2012, inédito.

a Argentina, Brasil, Chile, Colombia, Costa Rica, Ecuador, México, Perú, Uruguay y Venezuela (República Bolivariana de).

b Alemania, Bélgica, Francia, Países Bajos, Reino Unido y Suiza.

c República de Corea y Japón.

d Dinamarca, Finlandia, Noruega, Suecia.

e España, Italia y Portugal.

f Australia, Canadá y Nueva Zelandia.

Podría argumentarse que esa alta heterogeneidad latinoamericana se debe principalmente a las diferencias entre los países que componen el grupo. En realidad está firmemente enraizada en las estructuras domésticas de cada uno de ellos, como se muestra en el cuadro IX.3. Prácticamente ninguno, ni siquiera los menos desiguales, logran alcanzar los niveles de otras regiones del mundo.

\section{Cuadro IX.3}

Heterogeneidad de la productividad del trabajo en países de América Latina, por grandes sectores, 1991-2006

\begin{tabular}{lccccc}
\hline & 1991 & 1996 & 2001 & 2006 & Promedio \\
\hline Costa Rica & 0,277 & 0,244 & 0,224 & 0,205 & 0,238 \\
\hline Argentina & 0,279 & 0,276 & 0,291 & 0,308 & 0,289 \\
\hline Uruguay & 0,311 & 0,310 & 0,335 & 0,302 & 0,314 \\
\hline Brasil & 0,353 & 0,290 & 0,338 & 0,355 & 0,334 \\
\hline Perú & 0,393 & 0,288 & 0,266 & 0,464 & 0,353 \\
\hline Colombia & 0,371 & 0,334 & 0,352 & 0,378 & 0,359 \\
\hline Ecuador & 0,394 & 0,374 & 0,322 & 0,417 & 0,377 \\
\hline Chile & 0,405 & 0,372 & 0,396 & 0,452 & 0,406 \\
\hline México & 0,467 & 0,478 & 0,402 & 0,404 & 0,438 \\
\hline Venezuela (República & 0,408 & 0,478 & 0,399 & 0,475 & 0,440 \\
\hline
\end{tabular}

Fuente: L. Bértola, "Informe de proyecto", Santiago de Chile, Comisión Económica para América Latina y el Caribe (CEPAL), 2012, inédito. 
Esa elevada heterogeneidad de la estructura productiva más o menos formalizada se refuerza debido a las características del mercado de trabajo informal y constituye un gran freno a los procesos de integración de las estructuras productivas en redes más densas de formación de valor e interacción entre empresas. Esas características contribuyen a mantener la heterogeneidad de la estructura que reposa en las ventajas comparativas derivadas del acceso a los recursos naturales y dificultan la incorporación de otras formas de capital que, a su vez, son las que sustentan la inserción dinámica en el comercio mundial y transforman el tejido institucional-organizativo.

Esas características del entramado productivo de América Latina han constituido uno de los grandes desafíos de los enfoques regulacionistas que, basados en los conceptos de régimen de acumulación y modos de desarrollo, como una conjugación de elementos estructurales e institucionales para dar espacio a regularidades que permitan mantener un proceso de acumulación estable, han tenido serias dificultades para establecer un marco explicativo aceptable del desarrollo de las economías latinoamericanas. Diversos enfoques que analizan la configuración de diferentes ciclos endógenos de estas economías se encuentran con potentes exogeneidades que dificultan las caracterizaciones. De ahí que se hayan aventurado muchas definiciones con nombres exóticos, como el de fordismo tropical.

Esas dificultades deberían servir de acicate para realizar diagnósticos creativos y evitar la aplicación de modelos analíticos pensados y apoyados en realidades históricas muy diferentes, como es la de los países desarrollados (Bizberg y Thèret, 2012).

Una forma de aproximarse a las dinámicas del desarrollo latinoamericano consiste en identificar cinco posibles fuentes de crecimiento económico y definir las fuerzas sociales y económicas que lo sustentan, las formas en que se articulan y el predominio de unas u otras en el régimen de crecimiento. En los modelos evolucionistas de convergencia $\mathrm{y}$ divergencia se mencionan tres de esas formas de crecimiento.

i) El crecimiento kaldoriano inducido por la expansión de la demanda que promueve la especialización y la ampliación de la escala de producción, con sus correspondientes impulsos al aumento de productividad. Este crecimiento se puede combinar con otro, más keynesiano, en el sentido de que las políticas internas de expansión de la demanda pueden tener este efecto dinámico sobre el conjunto de la economía al emplear recursos humanos no plenamente ocupados e inducir aumentos de las escalas de producción o del uso de la capacidad instalada. No obstante, puede sostenerse que el componente kaldoriano es el que predomina a largo plazo, en el sentido del impacto de la expansión de la demanda sobre las economías de escala y las nuevas inversiones. 
ii) El crecimiento schumpeteriano, fruto de los esfuerzos innovadores producidos por la acumulación de conocimiento científico-tecnológico y su aplicación al surgimiento de nuevos productos y procesos. Este crecimiento está muy vinculado a las actividades de investigación dentro y fuera de las empresas, en el sistema científico-tecnológico de un país.

iii) A las dos fuentes anteriores de crecimiento y aumento de la productividad se suma, en el caso de los países periféricos o con atraso relativo, el crecimiento proveniente de la transferencia internacional de tecnología, que, a su vez, dependerá del tamaño de la brecha tecnológica y de las capacidades sociales internas para poder apropiarse de las oportunidades conexas y adoptar tecnología exógena. A grandes rasgos puede decirse que, cuanto más grande sea la brecha, mayor será el potencial de crecimiento sobre la base de este componente, pero la posibilidad de alcanzar un nivel equiparable está muy limitada por la capacidad interna y las diferencias estructurales existentes entre los países de origen y destino de la tecnología. Esos intentos de recuperar el terreno perdido como estrategia de desarrollo tienen grandes limitaciones, ya que no permiten más que un proceso de convergencia condicional, que muchas veces puede quedar bloqueado antes de comenzar siquiera a aproximarse al nivel de desarrollo de los líderes, si el proceso no se articula con los modelos kaldoriano o schumpeteriano, y si estos dos no están firmemente arraigados en las condiciones específicas del país.

iv) En el caso de las economías que cuentan con abundantes recursos naturales, se presenta recurrentemente el crecimiento inducido por la renta, entendido como un proceso que se basa en la captación de un diferencial de precios en el mercado internacional, que no depende de una valorización del recurso por la vía del cambio tecnológico sino por su monopolio en condiciones de extrema expansión de la demanda sin un correlato en la oferta. Ese crecimiento rentista tiende a estar sujeto a una gran volatilidad, pues el cambio tecnológico puede contribuir al descubrimiento de nuevas reservas o al aumento de la productividad de los bienes reproducibles. Ese proceso se ve estimulado por coyunturas en que se generan rentas muy elevadas que hacen posibles nuevas inversiones, si es que no existe un monopolio absoluto del recurso. En todo caso, las formas en que se generan y apropian esas rentas varían marcadamente según las características del sector de que se trate y las estructuras de la propiedad, del mercado internacional y de las redes de comercialización y transporte, entre otras. Ese tipo de crecimiento rentista se solapa con la dinámica kaldoriana. 
v) Por último, América Latina ha conocido episodios de crecimiento económico inducido por la expansión financiera. Ese tipo de crecimiento suele ser efímero y conduce rápidamente a una forma particular de "enfermedad holandesa", tal vez la peor de todas, pues no se basa en el desarrollo de ningún sector productivo propiamente dicho.

Esas distintas formas de crecimiento económico tienen implicancias dinámicas muy diversas y se asocian a diferentes actores con distintas conductas y culturas económicas y políticas. Puede argumentarse que la tendencia divergente a largo plazo y la volatilidad de la economía latinoamericana han estado muy vinculadas al predominio del crecimiento basado en el patrón rentista y financiero, en cuyas etapas de auge se ha logrado algunas veces poner en marcha modelos de crecimiento basados en la recuperación del terreno perdido, y en los que permanentemente han aparecido actividades de tipo kaldoriano y schumpeteriano, pero sin llegar a transformarse en patrones dominantes de crecimiento.

Es importante señalar que esas modalidades de crecimiento no se asocian a distintos sectores económicos, sino que se pueden solapar o complementar con el mismo sector. Por ejemplo, el sector petrolero puede experimentar una dinámica schumpeteriana si el desarrollo de nuevas tecnologías permite acceder de manera eficiente a profundidades que antes no se consideraban económicas y a procesar materias primas que antes eran imposibles de explotar. Sin embargo, ese sector también puede generar crecimiento a partir del aumento de los precios y la producción debido a un aumento importante de la demanda sin un incremento proporcional de la oferta o porque los productores tienen un control monopólico y oligopólico del mercado. En ese caso, la fuente de los ingresos no es principalmente una actividad innovadora. De la misma manera, el producto primario puede aumentarse por la vía extensiva y es posible conseguir un aumento de los precios mediante restricciones de la oferta (entre otros ejemplos típicos, cabe mencionar el caucho natural, el guano, los nitratos y el café en sus etapas tempranas). El crecimiento también puede deberse a innovaciones importantes en nuevas semillas o bienes de capital (arados, tractores, cosechadoras, sistemas de riego, entre otros).

Es importante señalar que los crecimientos rentistas e inducidos por los flujos de capital no son intrínsecamente dañinos o perversos, pero tienen una marcada propensión a serlo si no logran articularse con actividades de tipo más dinámico y si se transforman en la vía de desarrollo por excelencia. Más aun, ese tipo de crecimiento, de no ir acompañado por otras transformaciones, tiende a ser fuertemente concentrador de los ingresos, ya sea debido al control de los recursos naturales, o a la propia concentración de las actividades financieras. 
Se plantea entonces, en términos de economía política, la pregunta clave de cuál es la dinámica que explica ese crecimiento volátil y rezagado y que impide el fortalecimiento de los sectores, que a largo plazo, deberían liderar el proceso de cambio.

Hay que empezar por ubicar el componente de la renta de los recursos naturales no reproducibles. El gráfico IX.4 contiene información que es necesario reprocesar para que realmente refleje el concepto de renta aquí utilizado. Más allá de esa necesidad, la información es suficientemente elocuente en diversos sentidos. En primer lugar, no puede decirse que las marcadas fluctuaciones sean movimientos de tipo schumpeteriano, o sea, que los aumentos de los niveles de las rentas provengan principalmente de conmociones de la demanda o de grandes componentes especulativos. En otras palabras, parece indudable que en estos casos existe un importante componente de generación de rentas. En segundo lugar, es notable el marcado componente cíclico en la participación de estas rentas en el producto. Más aun, el componente parece ser claramente procíclico, es decir, no se trata de que la participación de las rentas aumente porque caiga el resto del PIB, sino que la caída de las rentas es la que explica la reducción del PIB. En tercer lugar, la importancia de este tipo de rentas es mucho mayor en los países mineros y petroleros, obviamente, y menor en países que tienen una amplia base agrícola, como la Argentina y el Brasil.

No se cuenta con información igualmente amplia en el caso de las economías de base agraria. Solamente a los efectos de mostrar el tipo de cálculo que se puede llegar a realizar, se muestran dos ejemplos de una economía pequeña y de base agropecuaria, como la uruguaya que, según el gráfico IX.3, parecería tener un bajo nivel de renta.

\section{Gráfico IX.3}

América Latina y el Caribe (países seleccionados): rentas capturadas por el Estado como impuestos a la explotación de los recursos naturales, 1970-2010 (En porcentajes del PIB)

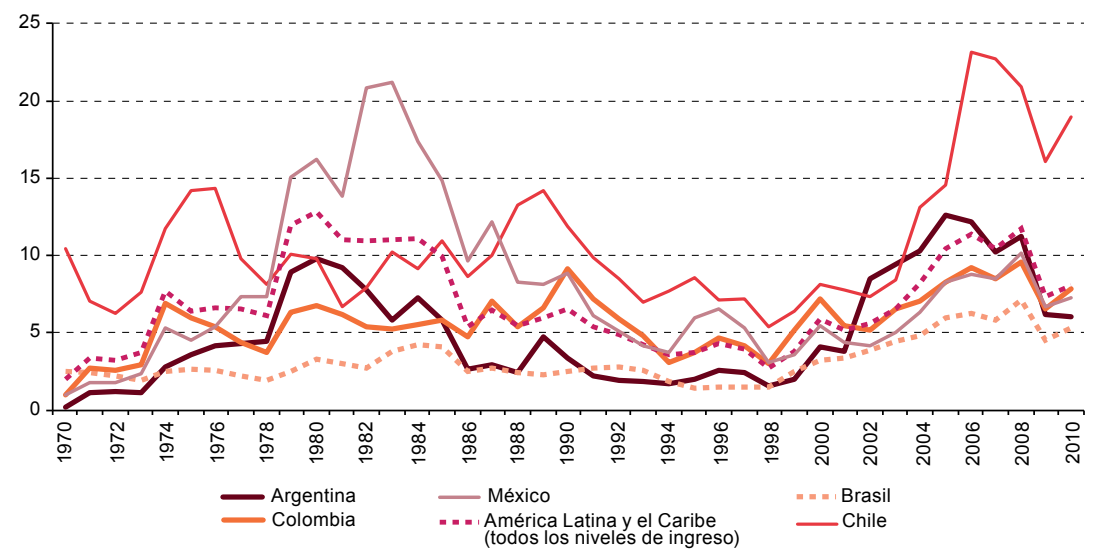

Fuente: Comisión Económica para América Latina y el Caribe (CEPAL). 
En el gráfico IX.4 se muestran las tendencias del período 1908-1966 en lo referente a la generación de rentas agrarias y su participación en el PIB. En la línea punteada azul de arriba se indica la participación del componente de renta (basado en la propiedad del recurso natural, en relación al total del valor agregado del sector). La serie presenta fluctuaciones marcadas que coinciden muy bien con los movimientos de los términos de intercambio, en especial su pronunciado descenso hacia el final de los años cincuenta e inicios de los sesenta. En la línea inferior, roja y sin puntos, se muestran fluctuaciones similares pero con una tendencia más permanente a una menor participación de la renta agraria en el PIB. Esto puede enmarcarse en los cambios introducidos en el modelo de crecimiento, a favor, predominantemente, de una estrategia de tratar de alcanzar un nivel tecnológico equiparable, mediante la industrialización y agriculturización de la economía, en desmedro de la ganadería tradicional, que ha sido la principal fuente de captación de rentas. La combinación de la industrialización, en buena medida basada en la transferencia de rentas agrarias a ese sector, y la caída de los términos de intercambio, hizo que las rentas agrarias casi desaparecieran del modelo.

\section{Gráfico IX.4}

Uruguay: renta de la tierra en relación con el PIB agropecuario y total, 1908-1966

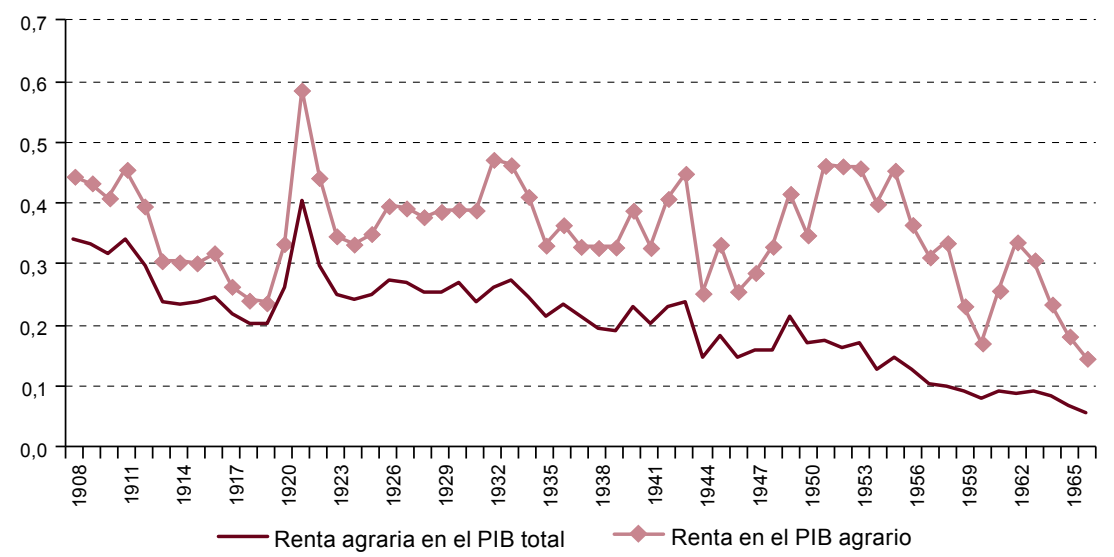

Fuente: Elaboración propia sobre la base de L. Bértola, "A 50 años de la curva de Kuznets: crecimiento económico y distribución del ingreso en Uruguay y otras economías de nuevo asentamiento desde 1870", Investigaciones en Historia Económica, № 3, 2005.

En el gráfico IX.5 se presenta otra perspectiva de estos fenómenos. La curva punteada roja de arriba muestra un índice del precio de la tierra deflactado por el índice de precios al consumidor (IPC), en tanto la serie inferior, azul y sin puntos, muestra la misma serie pero deflactada, además, por un índice de aumento de la productividad de la tierra, ya que se podría suponer que el precio de la tierra refleja en parte un proceso schumpeteriano 
de valoración de ese capital debido a diferentes tipos de innovaciones. Como resultado de esa deflactación, quedan las fluctuaciones del precio de la tierra que reflejan una valoración circunstancial y rentista del bien. En relación con el período de superposición con las series anteriores, esa serie presenta muchas coincidencias en sus fluctuaciones. No obstante, al extenderse hasta la actualidad, muestra tendencias con muchos quiebres y potentes fluctuaciones. Los períodos inflacionarios parecen haber afectado la valoración del bien, en un proceso muy coincidente con el deterioro de los términos de intercambio, en parte impulsado por el precio del petróleo, rubro en que el Uruguay es importador absoluto. En ese contexto, el sector agrario sufrió una verdadera crisis, que llevó a sus representantes a utilizar consignas del tipo "rentabilidad o muerte". Sin embargo, a partir de la estabilización de los precios y la valorización de los bienes agrarios en la última década y media, se ha producido una marcada creación de renta agraria, que supera con creces los importantes aumentos de la productividad del sector, impulsados por su potencialidad, y por la introducción de grandes cambios estructurales en su producción. Por primera vez en la historia del Uruguay la producción agrícola ha superado a la ganadera. En síntesis, durante las últimas décadas ha habido dos movimientos de interés. Por un lado, la generación de una gran renta del recurso natural y por otro, un importante estímulo al incremento de la productividad agraria, fruto de la incorporación de diversas innovaciones y del cambio estructural hacia sectores más intensivos en inversión y conocimiento. Obviamente, cabe preguntarse qué sustentación pueden tener esas tendencias a largo plazo.

\section{Gráfico IX.5}

Uruguay: precio real de la tierra deflactado por el IPC y estimación de la renta, 1902-2010

(En índices, base 1913=100)

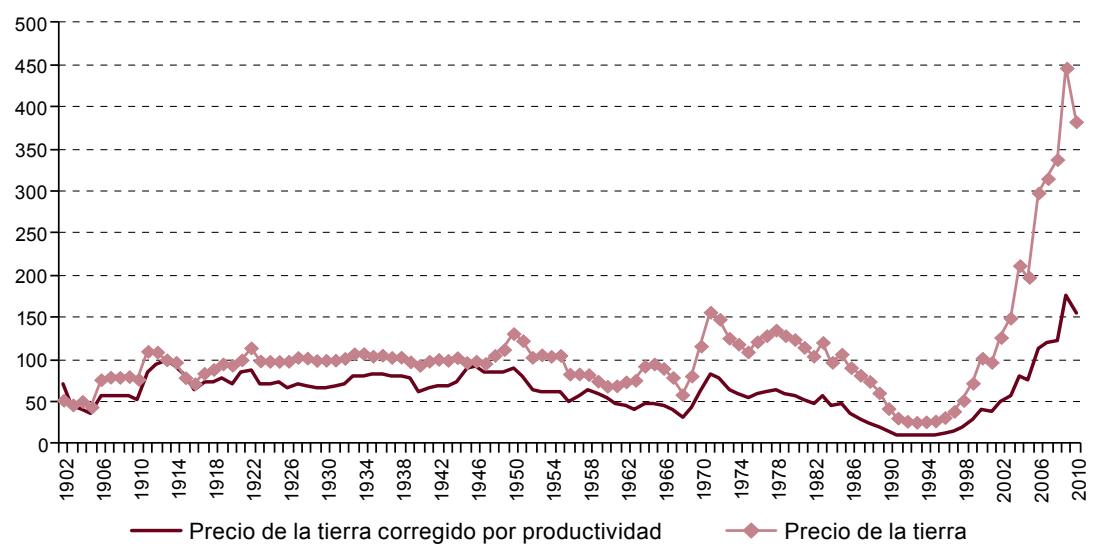

Fuente: L. Bértola, “Informe de proyecto", Santiago de Chile, Comisión Económica para América Latina y el Caribe (CEPAL), 2012, inédito. 
En síntesis, aun con diferencias marcadas y lógicas específicas, la generación de rentas de los recursos naturales es un proceso común a los bienes no reproducibles y a la producción agropecuaria. Ambos sectores están sujetos a la generación de rentas de dimensiones importantes en relación al PIB y experimentan fluctuaciones similares en estas rentas, que son claramente procíclicas en relación al movimiento del PIB.

Cuando los recursos naturales se valorizan, atraen a muchos inversores que buscan apropiarse de esas fuentes de rentas, lo que tiende a concentrar su apropiación. No obstante, esa gran volatilidad hace que dichos procesos tengan lugar en contextos institucionales débiles, por lo que los Estados pocas veces están capacitados para imponer condiciones a quienes explotan los recursos. Así, además de procesos de apropiación de bienes y rentas, se produce un uso no regulado de esos recursos, con grandes consecuencias ambientales y sociales. Si se suman los efectos del cambio climático, el resultado es un marcado aumento de las desigualdades de ingreso y de las condiciones de vida, por el impacto de esa expansión en el medio ambiente y en los recursos naturales compartidos, y por el desplazamiento de los sectores más pobres a zonas más marginales, erosionadas y con menor acceso a servicios y bienes públicos.

Es fundamental entender la economía política de la ausencia o presencia del cambio estructural y del patrón de desarrollo y sus arreglos institucionales. Si el sistema político y social está organizado en torno a la captura de rentas del sector primario y a la defensa de los logros obtenidos en ese ámbito, esto puede explicar en gran medida el escaso respaldo que se brinda a estrategias de desarrollo de tipo keynesiano, schumpeteriano e incluso de recuperación del terreno perdido. A su vez, los aspectos ambientales suelen considerarse asuntos postergables en comparación con la necesidad de satisfacer necesidades más inmediatas de la población.

Es necesario hacer una tipología de casos de recursos desde el punto de vista de la apropiabilidad, la reproducción, las características tecnológicas, el acceso, las formas predominantes de propiedad y sus impactos ambientales y distributivos. También sería importante ponderar en términos económicos, sociales y políticos el desarrollo de otros sectores en comparación con las economías rentistas. Por ejemplo, las economías domésticas y de autoconsumo, la expansión del sector industrial y la expansión de las funciones públicas y de servicios terminan por conformar escenarios sociales y económicos muy variados, con diversos potenciales y resultados en términos de economía política. Se impone la necesidad de realizar un mapeo de las estructuras económicas y sociales, que refleje los conceptos ya estudiados de heterogeneidad estructural en el producto y el empleo, y ampliar esos análisis al campo de la economía política. 
Estos procesos se dan en el marco de una tendencia a largo plazo de profundización de la vida democrática. Como en muchos otros aspectos, la tendencia a la expansión del sistema democrático no ha sido lineal, sino que ha estado surcada por un sinfín de episodios autoritarios. Afortunadamente, en esta última década se ha experimentado en América Latina una nueva ola de democratización (al estilo de Huntington), de modo que por primera vez en la historia casi la totalidad de los gobiernos de América Latina son democráticos. Aparte de su valor intrínseco, esa situación es determinante desde el punto de vista de las luchas por la apropiación, distribución y utilización de las rentas. La lógica de reproducción de los sistemas políticos en contextos de democracia es muy particular y ha sido estudiada en detalle por la nueva economía política, con insistencia en el concepto del votante medio. Lo que no se ha hecho en la bibliografía es establecer el nexo entre esas lógicas y el impacto sobre las diferentes estrategias y patrones de crecimiento económico en contextos de sociedades con rentas elevadas y volátiles y gran heterogeneidad estructural. $\mathrm{O}$, para utilizar los términos de las teorías de las variedades de capitalismo, habría que determinar cómo se articula la ampliación democrática en América Latina con los diferentes entornos organizativos e institucionales de las empresas y el Estado.

Las ambigüedades del desarrollo de América Latina, sus avances y debilidades en el plano del desarrollo humano y los desafíos para los Estados de bienestar resaltan de manera elocuente en los cuadros IX.4 y IX.5. En ellos se indican, con respecto a una muestra de países de diferentes regiones, los avances en el plano de la equidad de los componentes del índice de desarrollo humano (IDH) y en el desarrollo humano corregido por equidad.

En el cuadro IX.4 se puede apreciar que todas las regiones del mundo han mejorado sustantivamente los índices de igualdad. Como es de suponer, los países escandinavos van al frente, seguidos por los países centrales, España e Italia y los de nuevo asentamiento. Por un amplio margen, los países latinoamericanos presentan los más bajos niveles de igualdad y contribuyen de manera decisiva al aumento de las diferencias entre las regiones. Como puede observarse en el cuadro IX.5, cuando se corrige el IDH en función del componente de desigualdad, la posición relativa de los países latinoamericanos se deteriora significativamente. 
Cuadro IX.4

Índice de igualdad, 1900-2000

\begin{tabular}{lccccc}
\hline Cono Sur & Centro & $\begin{array}{c}\text { Nuevo } \\
\text { asentamiento }\end{array}$ & $\begin{array}{c}\text { España } \\
\text { e Italia }\end{array}$ & Escandinavia \\
\hline 1900 & & 0,559 & 0,403 & \\
\hline 1910 & & 0,606 & 0,396 & \\
\hline 1920 & 0,576 & 0,653 & 0,490 & 0,528 \\
\hline 1930 & 0,641 & 0,711 & 0,548 & 0,562 \\
\hline 1940 & 0,344 & 0,682 & 0,726 & 0,567 & 0,670 \\
\hline 1950 & 0,369 & 0,768 & 0,785 & 0,661 & 0,767 \\
\hline 1960 & 0,361 & 0,789 & 0,803 & 0,727 & 0,830 \\
\hline 1970 & 0,408 & 0,794 & 0,836 & 0,752 & 0,890 \\
\hline 1980 & 0,428 & 0,768 & 0,798 & 0,794 & 0,887 \\
\hline 1990 & 0,419 & & 0,777 & 0,773 & \\
\hline 2000 & 0 & & 0,689 & 0,587 & \\
\hline
\end{tabular}

Fuente: L. Bértola y otros, "A century of human development and inequality: a comparative perspective", Documentos de Trabajo, Programa de Historia Económica, Montevideo, Facultad de Ciencias Sociales, Universidad de la República, 2012.

\section{Cuadro IX.5}

Índice Histórico de Desarrollo Humano simple (IHDH) y ajustado por desigualdad (IHDHA), como porcentaje del de los países centrales, 1920-1990

\begin{tabular}{|c|c|c|c|c|c|c|c|c|}
\hline & \multicolumn{2}{|c|}{ Cono Sur } & \multicolumn{2}{|c|}{$\begin{array}{c}\text { Nuevo } \\
\text { asentamiento }\end{array}$} & \multicolumn{2}{|c|}{ España e Italia } & \multicolumn{2}{|c|}{ Escandinavia } \\
\hline & $\mathrm{IHDH}$ & IHDHA & IHDH & IHDHA & $\mathrm{IHDH}$ & IHDHA & IHDH & IHDHA \\
\hline 1920 & & & 105 & 120 & 57 & 49 & 70 & 64 \\
\hline 1930 & & & 101 & 112 & 42 & 35 & 77 & 67 \\
\hline 1940 & & & 109 & 115 & 46 & 38 & 82 & 81 \\
\hline 1950 & 30 & 14 & 99 & 90 & 42 & 33 & 80 & 81 \\
\hline 1960 & 39 & 19 & 95 & 97 & 56 & 49 & 89 & 96 \\
\hline 1970 & 34 & 16 & 97 & 98 & 65 & 60 & 94 & 103 \\
\hline 1980 & 26 & 14 & 96 & 101 & 67 & 64 & 92 & 103 \\
\hline 1990 & 36 & 20 & 97 & 100 & 74 & 77 & 95 & 109 \\
\hline
\end{tabular}

Fuente: L. Bértola y J.A. Ocampo, The Economic Development of Latin America since Independence, Oxford University Press, 2012.

$\mathrm{Al}$ abordar el debate sobre las características del Estado de bienestar en América Latina, y partiendo de las descripciones de Esping-Andersen, Filgueira (1997) afirma correctamente que la tradición latinoamericana se enmarca predominantemente en el Estado de bienestar conservador. La región ha desarrollado sus modelos de bienestar a partir de una expansión progresiva de beneficios a distintos grupos profesionales, empezando por la burocracia del Estado, en especial la militar, y ampliando los beneficios progresivamente a distintos grupos profesionales, con marcadas diferencias en las prestaciones. El sistema se basa en un sector formal donde el hombre es el perceptor de ingresos principal y a través de él llegan los beneficios al resto de la familia, o sea, a la población en 
general. El Estado de bienestar latinoamericano se ha desarrollado en distintas etapas, con un inicio en economías más abiertas y expuestas a las migraciones internacionales, en consonancia con el surgimiento de los Estados de bienestar en los países desarrollados y en otras economías de nuevo asentamiento (Huberman, 2012; Lloyd, 2011).

Filgueira (1997), a su vez, hace una afirmación más tajante, que va en línea con el punto de vista de este trabajo: en sentido estricto, en América Latina no existen Estados de bienestar, sino Estados sociales. Además, con acierto, intenta caracterizar los regímenes latinoamericanos no simplemente en términos de su nivel de maduración, al estilo de MesaLago, como si fueran etapas de un continuo universal, sino tratando de identificar distintas particularidades estructurales del funcionamiento de los estados sociales latinoamericanos. De ese modo, se determinó que los sistemas existentes hacia los años setenta eran de universalismo estratificado (Argentina, Chile y Uruguay), o sistemas duales (Brasil y México), o sistemas excluyentes (Bolivia (Estado Plurinacional de), Ecuador y la mayoría de las repúblicas centroamericanas).

Como se ha argumentado a lo largo de este trabajo, las características de los Estados de bienestar no pueden desvincularse de las características más generales de la estructura productiva, pues conforman un conjunto de interacciones interdependientes. La inexistencia de Estados de bienestar es la contracara de la inexistencia de economías desarrolladas, no solamente porque haya una relación cuantitativa entre el nivel de ingreso per cápita y el gasto público social sino, en un sentido más amplio, por la forma en que el sistema de bienestar se articula con lo que en la teoría de las variedades de capitalismo se conoce como matriz comparativa institucional.

El examen sistemático de esas interacciones es clave, no solamente en aras de caracterizar las distintas estructuras sino en el sentido más ambicioso de poder diseñar y promover caminos hacia la superación de las limitaciones del desarrollo. Con ese propósito, es necesario definir los actores, organizaciones y arreglos institucionales que permitan transformar las bases de la ventaja comparativa institucional.

Esas formas de Estados de bienestar en América Latina tienen una obvia relación con la mayor desigualdad de la región si se compara con otras. Existen muy amplios grupos de la población latinoamericana que está al margen de los servicios que prestan los Estados de bienestar, por pertenecer a sectores escasamente formalizados, tener trabajos precarios, desarrollar actividades de subsistencia en zonas marginales, realizar actividades de alta estacionalidad, protagonizar procesos migratorios internos y habitar zonas donde la propia presencia del Estado es marginal, no solamente en materia de políticas sociales, sino en cuanto al suministro de bienes públicos, incluida la seguridad. 
La situación de los sectores marginados se deteriora aun más si se añade el impacto de los fenómenos medioambientales a los factores que ya se han estudiado exhaustivamente sobre las características de la desigualdad y las tendencias regresivas del gasto social. La propia expansión democrática, que es resultado del aumento de la participación política universal, pero también de la capacidad de presión corporativa de diferentes grupos, hace que los sectores más marginados queden expuestos a los daños ambientales sin mayor involucramiento de amplios sectores de la sociedad democrática.

\section{Conclusión}

América Latina se encuentra en la actualidad en una coyuntura económica extremadamente favorable, por lo que en términos generales ha podido exhibir altas tasas de crecimiento económico, reducción de la pobreza y, en muchos casos, una importante reducción de la desigualdad.

Sin embargo, esos logros no se deben a la elección y conformación de una senda de desarrollo. En todo caso, el patrón actual de crecimiento tropieza con un amplio conjunto de desafíos, cuya solución puede ser decisiva para el desempeño a largo plazo.

América Latina se ve en la necesidad de mostrar avances en cinco ejes principalmente. Casi todos están relacionados y es muy difícil definir las jerarquías y prioridades entre ellos:

i) El eje de la transformación productiva. Se trata de encontrar la forma de mantener la dinámica exportadora de los sectores más competitivos, junto a la imperiosa necesidad de potenciar nuevos sectores exportadores, lo que será imposible sin una transformación profunda del conjunto del tejido productivo, a fin de reducir marcadamente la heterogeneidad estructural. Esos objetivos requieren una gran cantidad de recursos de la sociedad en lo que respecta al desarrollo de instrumentos y capacidades para las políticas industriales.

ii) El eje de las transformaciones sociales, la erradicación de la indigencia, la máxima reducción de la pobreza, la reducción de las alarmantes desigualdades sociales. Estas políticas requieren muchos recursos, con la ventaja de que, a largo plazo, se pueden transformar en fuentes de dinámica económica y social por la vía de la formación de capital humano y de diversas capacidades. La universalidad de las prestaciones sociales, especialmente el acceso a la educación y a seguros de desempleo y accidentes 
laborales, así como de las políticas que permiten una amplia integración de la mujer al mercado de trabajo formal, son objetivos centrales de las políticas de desarrollo.

iii) La sostenibilidad ambiental se ha transformado en una piedra angular de cualquier política. No se trata de compensar económicamente el deterioro ambiental, sino de frenarlo y revertirlo, y en especial, revertir sus impactos en los sectores más vulnerables. En ese sentido, las políticas ambientales están indisolublemente ligadas a las políticas sociales.

iv) Los procesos de desarrollo económico y social no siempre han ido de la mano de la democracia política. Sin embargo, a la larga, la continuidad del desarrollo tiene mayores probabilidades de mantenerse en regímenes democráticos. Por otra parte, la convivencia democrática es un valor que supera, probablemente con amplio margen, otros tipos de aspiraciones. El gran dilema de la región es cómo lograr construir, en democracia, un sistema creíble y eficiente de captación y gestión de recursos que le permita avanzar hacia las metas de transformación productiva, equidad y sostenibilidad ambiental. América Latina debe aumentar significativamente la movilización social de los excedentes económicos y orientarlos a la satisfacción de esos tres tipos de necesidades. Esa es la clave del proceso. El gran desafío consiste en convencer a los interesados y crear los equilibrios políticos necesarios, al mismo tiempo que se trata de buscar soluciones a la volatilidad económica. El carácter volátil y cíclico de la economía ha conducido al desarrollo de instrumentos procíclicos y, lo que es aun más peligroso, a la conformación de equilibrios sociales y políticos de escasa sostenibilidad temporal. Según las experiencias acumuladas en otras partes del mundo, el desarrollo de los Estados de bienestar no es un proceso irreversible. La propia experiencia latinoamericana así lo testimonia. El sistema político debe resistirse a la tentación de construir escenarios cortoplacistas de bienestar y políticas sociales. El sistema político democrático puede tender trampas peligrosas a la estabilidad y sostenibilidad de las políticas. A largo plazo, si no se producen logros sustantivos en la transformación de la estructura productiva y la capacidad de competencia internacional, y si las políticas sociales no están articuladas con esa "matriz de competitividad institucional", es posible 
que el bienestar sea efímero. Por ese motivo, las políticas, que deben tener un horizonte de largo plazo y resistir presiones corporativas y tentaciones populistas, requieren un Estado creíble y confiable, con crédito moral y solvencia técnica.

v) El quinto ámbito decisivo es el internacional. Se ha insistido en ese aspecto a lo largo del trabajo y no puede pasarse por alto en la construcción de una amplia gamas de políticas de exploración y expansión hacia mercados y rubros tradicionales. Se deben estudiar nuevos productos y mercados, concediendo un papel estratégico a los procesos de integración regional. Estos deben tener una clara dirección política, como forma de construir peso y poder político regional con miras a la participación en negociaciones internacionales. En ese ámbito es que se gestan las oportunidades productivas y comerciales, y donde se deben disputar los procesos de regulación internacional, no solamente del comercio y la soberanía, sino del acceso al conocimiento y la protección del medio ambiente.

El camino del desarrollo y el bienestar no le ha resultado fácil a América Latina y no está garantizado que lo sea en el futuro. La región debe cifrar sus esperanzas en la potenciación de sus capacidades, en su integración social, su armonía con su entorno natural, la elaboración de mejores formas de convivencia política y social y el fortalecimiento de su posición internacional, en un marco de respeto y tolerancia. 


\section{Bibliografía}

Bairoch, P. (1975), Revolución industrial y subdesarrollo, México, D.F., Siglo XXI.

Bértola, L. (2012), "Informe de proyecto", Santiago de Chile, Comisión Económica para América Latina y el Caribe (CEPAL), inédito.

(2011), "Institutions and the historical roots of Latin American divergence" The Oxford Handbook of Latin American Economics, J.A. Ocampo y J. Ros (eds.), Oxford, Oxford University Press.

(2005), “A 50 años de la curva de Kuznets: crecimiento económico y distribución del ingreso en Uruguay y otras economías de nuevo asentamiento desde 1870", Investigaciones en Historia Económica, $\mathrm{N}^{\mathrm{o}} 3$.

Bértola, L. y J.A. Ocampo (2012), The Economic Development of Latin America since Independence, Oxford University Press.

Bértola, L. y G. Porcile (2006), “Convergence, trade and industrial policy: Argentina, Brazil and Uruguay in the International economy, 1900-1980", Revista de Historia Económica-Journal of Iberian and Latin American Economic History, $\mathrm{N}^{\mathrm{o}} 1$.

Bértola, L., M. Hernández y S. Siniscalchi, S. (2012), "Un índice histórico de desarrollo humano de América Latina y algunos países de otras regiones: metodología, fuentes y bases de datos", Documentos de Trabajo, $\mathrm{N}^{\mathrm{o}} 28$, Programa de Historia Económica, Montevideo, Facultad de Ciencias Sociales, Universidad de la República.

Bértola, L. y otros (2012a), “Relative performance, structural change and technological capabilities in Latin America in historical perspective", Beyond the Global Crisis: Structural Adjustments and Regional Integration in Europe and Latin America, L. F. Punzo, C.A. Feijo y M. Puchet Anyul (eds.), Routledge Studies in the Modern World Economy.

Bértola, L. y otros (2012b), "A century of human development and inequality: a comparative perspective", Documentos de Trabajo, Programa de Historia Económica, Montevideo, Facultad de Ciencias Sociales, Universidad de la República.

Bizberg I. y B. Thèret (2012), "La diversidad de los capitalismos latinoamericanos: los casos de Argentina, Brasil y México", Notas de la Regulación, Nº 61.

Bohlin J. (1989), Svensk varvsindustri 1920-1975: lönsamhet, finansiering och arbetsmarknad, Göteborg.

Bourguignon, F. y Ch. Morrison (2002), "Inequality among world citizens", American Economic Review, vol. 92, No 4 .

Cimoli, M. y G. Porcile (2011), “Learning, technological capabilities and structural dynamics", The Oxford Handbook of Latin American Economics, José Antonio Ocampo y Jaime Ros (eds.), Nueva York, Oxford University Press.

Cimoli, M. Y otros (2005), "Cambio estructural, heterogeneidad productiva y tecnología en América Latina", Heterogeneidad estructural, asimetrías tecnológicas y crecimiento en América Latina, M. Cimoli (ed.), Santiago de Chile, Comisión Económica para América Latina y el Caribe (CEPAL)/Banco Interamericano de Desarrollo (BID).

Esping-Andersen, G. (1999), The Social Foundations of Postindustrial Economies, Oxford University Press.

(1990), The Three Worlds of Welfare Capitalism, Cambridge, Polity Press.

Federico, G. (2005), Feeding the World. An Economic History of Agriculture, 1800-2000, Princeton University Press. 
Filgueira, F. (1997), "Tipos de welfare y reformas sociales en América Latina: Eficiencia, residualismo y ciudadanía estratificada", documento elaborado para el proyecto "Social Policy and Social Citizenship in Central America", Social Science Research Council.

Filgueira, F. y otros (2006), "Universalismo básico: una alternativa posible y necesaria para mejorar las condiciones de vida", Universalismo básico: Una nueva política social para América Latina, C.G. Molina, (ed.), Washington, D. C., Banco Interamericano de Desarrollo (BID)/Planeta.

Frankema, E. (2009), Has Latin America Always Been Unequal?: A Comparative Study of Asset and Income Inequality in the Long Twentieth Century, Boston, Brill.

Hall, P. y D. Soskice (2001), "Varieties of Capitalism", The Industrial Foundations of Comparative Advantage, Oxford University Press.

Huberman, M. (2012), Odd Couple. International Trade and Labor Standards in History, Yale University Press.

Lloyd, C. (2013), "Welfare State and capitalist crisis", Retrenchment or Renewal: Welfare States in Times of Economic Crisis, G. Jonsson y K. Steffanson (eds.), Nordwel Studies in Historical Welfare State Research, No 6, Helsinki, Helsinki University. (2011), "The history and future of social democratic welfare capitalism", Beyond Welfare State Models, P. Kettunen y K. Peterson (eds.), Edward Elgar, Cheltenham.

López-Guzmán Guzmán, Tomás, G. Millán Vázquez de la Torre y S. Sánchez Cañizares (2007), "Financiación autonómica e incidencia fiscal de los tributos ecológicos: una reflexión en torno al principio de 'quien contamina, paga'", Revista de Estudios Regionales, N 78.

Mesa-Lago, C. (1978), Social Security in Latin America: Pressure Groups, Stratification, and Inequality, Pittsburgh, University of Pittsburgh Press.

Milanovic, B. (2011), The Haves and the Have-nots. A Brief Idiosyncratic History of Global Inequality, Nueva York, Basic Books.

PNUD (Programa de las Naciones Unidas para el Desarrollo) (2011), Informe sobre Desarrollo Humano 2011. Sostenibilidad y equidad, Nueva York, Oxford University Press.

PNUMA (Programa de las Naciones Unidas para el Medio Ambiente) (2011), "Hacia una economía verde. Guía para el desarrollo sostenible y la erradicación de la pobreza. Síntesis para los encargados de la formulación de políticas" [en línea] www.unep.org/greeneconomy.

Pommeranz, K. (2000), The Great Divergence. China, Europe and the Making of the Modern World Economy, Princeton, Princeton University Press.

Prados de la Escosura, L. (2010), "Improving human development: a lon-run view", CEPR Discussion Paper, $\mathrm{N}^{\circ} 7982$.

Reimers, F. (2006), "Education and social progress", The Cambridge Economic History of Latin America, en V. Bulmer-Thomas, J. Coatsworth y R. Cortés Conde (eds.), Nueva York, Cambridge University Press.

Reinert, E. (2007), How Rich Countries Got Rich... and Why Poor Countries Stay Poor, Londres, Constable. 



\section{Parte IV \\ El papel del Estado}





\section{Capítulo X \\ Crecimiento, empleo y equidad: el nuevo papel del Estado}

Robert Boyer

\section{Introducción}

Las reflexiones sobre el papel del Estado tras el colapso de la creencia en la omnipotencia de los mecanismos del mercado se derivan de dos observaciones. En primer lugar, llama la atención el surgimiento en América Latina hace una década del tema del crecimiento con equidad, mientras que en el resto del mundo, por el contrario, se registraba un aumento de la desigualdad. La segunda observación es que, ante una crisis sistémica, hay una incertidumbre radical del análisis, de modo que, como afirma Joseph Schumpeter, si los modelos fracasan, significa que la teoría macroeconómica es errónea, por lo que es necesario adoptar una visión que inspire una nueva concepción del desarrollo y del Estado. En el presente ensayo se trata el tema del crecimiento, el empleo, la igualdad, y el nuevo papel del Estado. Más precisamente, se analiza la reorganización del rol del Estado con el objetivo de propiciar un mecanismo por el cual se reduzcan permanentemente las desigualdades, bajo un régimen de crecimiento sostenible a largo plazo.

A fin de explicar cómo se concibió un régimen de este tipo, en la sección A se resume la evolución de los modelos económicos desde 
la Segunda Guerra Mundial en Europa y los Estados Unidos. Tras un período de gran éxito, el sistema socioeconómico entró en crisis en la década de 1970, lo que legitimó el regreso de la teoría de los mercados autorregulados y eficientes, que también entraron en crisis (véase la sección B). Posteriormente, con el fracaso del fundamentalismo de mercado, se abre una nueva etapa que puede conducir a un paradigma de la rehabilitación de la función del Estado a través de una política económica pragmática, teniendo en cuenta las lecciones del pasado. En la búsqueda de un sistema socioeconómico que incorpore una meta de justicia social, es importante aclarar los vínculos entre los diversos componentes del sistema de protección social, no solo con el bienestar de la población, sino también con las formas institucionales que conforman el régimen de crecimiento. Sin embargo, estas políticas no pueden ser una simple reproducción de las utilizadas por los países desarrollados después de la Segunda Guerra Mundial. En efecto, la apertura internacional en todos los ámbitos - el comercio, la inversión directa, el capital financiero y la propiedad intelectual- ha creado un grado de interdependencia sin precedentes de las políticas económicas en la búsqueda de regímenes de crecimiento sostenibles en términos de desigualdad social y ambiental.

\section{A. La reducción de las desigualdades en las economías desarrolladas dentro de un régimen de crecimiento alto y estable}

\section{La década de 1950: el equilibrio entre la eficiencia económica y la justicia social}

A mediados de los años sesenta, uno de los libros más importantes de introducción a la economía era Economics, de Paul Samuelson (1948). Desde el primer capítulo, se insistía en la necesidad de optar entre la equidad y la eficiencia: de un lado se hallaba la antigua Unión Soviética y del otro los Estados Unidos. Según el autor, a mayor igualdad, se registraba un menor desempeño de la economía. Esta oposición resultaba sorprendente a quienes conocían el caso de Francia, donde se observaba un alto crecimiento - superior al de los Estados Unidos- y una reducción de la desigualdad. Esta coexistencia no podía concebirse en la teoría. Por una parte, la teoría de la regulación fue elaborada para interpretar este régimen, aparentemente paradójico, que llamamos fordista (Aglietta, 1982; Boyer, 1986), en el cual los obreros gozan de un alto crecimiento de los salarios y una extensión de la cobertura 
social que permiten una compresión de la jerarquía de los ingresos, mientras que la tasa de ganancia permanece bastante estable y genera un alto nivel de inversión productiva y de la productividad llegándose casi al pleno empleo. En la teoría neoclásica, que solo estudia los equilibrios estáticos, esta conjunción extremadamente favorable no puede existir, pero si se analizan los procesos de institucionalización de las economías, se puede suponer la aparición de nuevos modelos de crecimiento, que no son regímenes naturales, sino construcciones sociales logradas por medio de políticas originales. Así nació la teoría de la regulación. Interpretar retrospectivamente este proceso ayudaría a entender lo que está ocurriendo o podría ocurrir en América Latina y evaluar las posibilidades de éxito del proyecto de crecimiento con equidad (CEPAL, 2012a).

\section{La sorprendente década de 1960: una simbiosis entre la reducción de la desigualdad y el crecimiento}

El fin de la inestabilidad y la tendencia al estancamiento observados entre las dos guerras mundiales se deben a la complementariedad entre un conjunto de transformaciones estructurales y de las principales instituciones económicas, ninguna de las cuales por sí sola habría sido una causa determinante (véase el diagrama X.1).

\section{Diagrama X.1}

Transformaciones institucionales en el origen del régimen de crecimiento y la reducción de la desigualdad después de la Segunda Guerra Mundial

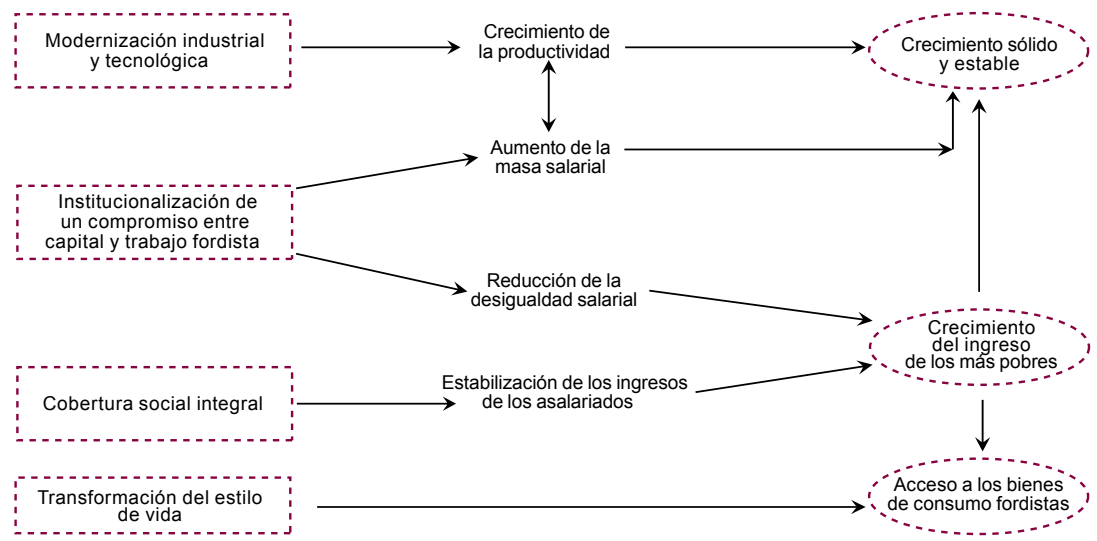

Fuente: Elaboración propia. 
En este modelo se considera una capacidad productiva muy alta, porque entre las dos guerras mundiales se produjeron varias innovaciones, como la cadena de producción en masa, y el retraso se compensó con una altísima inversión en la implementación de las nuevas técnicas, de tal modo que al comienzo de la instauración del sistema existía una enorme capacidad de progresión de la productividad que se distribuía entre los salarios, las utilidades y la baja de los precios relativos de los nuevos bienes de producción industrial.

Pero la novedad mayor fue un compromiso con los asalariados para que la producción en masa sintonizara con el consumo en masa, gracias a la indexación de los salarios nominales en función de la inflación y la productividad de la economía, lo que no existía anteriormente, cuando el producto era absorbido por las capas sociales de mayor ingreso y con mayor poder adquisitivo, era exportado a las colonias o simplemente vendido al resto del mundo. Esta invención crucial deriva de la idea de que el mercado interno debe sincronizarse con los avances tecnológicos, y esta nueva visión dio lugar a tres cambios institucionales, que se enumeran a continuación.

En primer lugar, se favoreció el acceso a la educación. Por ejemplo, en los Estados Unidos, la ley de reajuste a los militares (denominada G.I. Bill) propició un acceso casi gratuito a la educación de los soldados que combatieron en la Segunda Guerra Mundial; en Francia, el acceso a la educación fue consecuencia de la democratización, mientras que en los países socialdemócratas se homogeneizó la calificación del capital humano (André y Delorme, 1983).

El segundo cambio fue el establecimiento de una tributación personal muy progresiva: en los Estados Unidos, al final de los años cincuenta, la tasa marginal por el sector más rico de la población era del $83,5 \%$, muy elevada con respecto al impuesto de tasa prácticamente uniforme que hoy reduce radicalmente la redistribución del ingreso hacia los más pobres (Piketty, 2013). Claramente se observaba una aceptación social de la redistribución a nivel nacional.

Por último, con el incremento del gasto social se produjo una desconexión del acceso a la salud, la formación profesional, las prestaciones familiares y la vivienda con respecto a los mecanismos puros de mercado: algunos países avanzaron en el concepto de desmercantilización de la relación laboral y, especialmente en el norte de Europa, surgió un capitalismo de bienestar (Pedersen, 2008).

De hecho, se modificó totalmente el régimen socioeconómico mediante una intensa construcción institucional, de modo que no se trató simplemente de una recuperación de los daños y retrasos asociados con la Gran Depresión y la Segunda Guerra Mundial, sino que casi todos los sectores políticos y los gobiernos, independientemente de sus orientaciones ideológicas, percibieron el surgimiento de una nueva era del capitalismo. En 
Francia, por ejemplo, el presidente liberal Giscard d'Estaing declaró su admiración por las sociedades socialdemócratas. Los democratacristianos y los socialdemócratas europeos tenían una visión muy similar de la integración económica. En los Estados Unidos, Alfred Sloan, alto dirigente de General Motors, se consideraba la parte más elevada de la jerarquía salarial, y los demócratas y republicanos compartían la misma concepción y práctica de la política económica keynesiana, lo que puede considerarse el cuarto cambio clave después de los años cincuenta. Estos hechos marcan un profundo contraste con el capitalismo contemporáneo, donde los directores generales de los bancos de inversión están en la cúspide del escalafón salarial, y ya no se ven a sí mismos como empleados. Es esencial comprender cabalmente las condiciones sociales de semejantes regímenes: no fue solo la invención de una ingeniería social en busca de un óptimo de Pareto, sino un complejo proceso que se originó tras la guerra con consecuencias que pocos anticiparon. Por último, prácticamente se alcanzó el pleno empleo y, en ese entendido, los asalariados tenían un gran poder de negociación, a diferencia de lo que se observa hoy: en Francia, con más del $10 \%$ de desempleo y más de 5 millones de desocupados, el poder de negociación de los asalariados no es tan grande, de modo que triunfan las estrategias de flexibilización salarial.

\section{Diversidad de compromisos sociopolíticos nacionales y pluralidad del capitalismo}

Claramente, hubo amplias diferencias en la implementación de este modelo abstracto según las trayectorias nacionales. La investigación estadística dejó al descubierto la existencia simultánea de al menos cuatro formas de capitalismo en las economías de la Organización de Cooperación y Desarrollo Económicos (OCDE), que se describen a continuación (Amable, Boyer y Barré, 2008; Amable, 2003).

El capitalismo de mercado o liberal se caracteriza por un amplio uso de mecanismos de mercado, regulados por organismos para asegurar su correcto funcionamiento. En la configuración del escenario posterior a la Segunda Guerra Mundial, los convenios colectivos en las ramas motrices y la distribución de incrementos salariales en otros sectores clave de la economía - debido a la existencia de un empleo casi pleno, alcanzado gracias a políticas monetarias y fiscales activas, inspiradas en la teoría keynesianaexplican la restauración del crecimiento y una reducción significativa de las desigualdades. Este es el modelo estadounidense o británico.

La segunda configuración, la del modelo socialdemócrata, se define como la negociación permanente de nuevos compromisos sociales en la cual todos los actores económicos tienen voz y poder de decisión sobre el cambio institucional. Además, como el sentido de solidaridad nacional se expresa mediante una amplia cobertura social, de tipo universal, esta configuración resultó ser la más eficaz para conciliar la justicia social y la eficiencia 
económica, incluso más allá de las crisis financieras, tras la apertura al capital internacional. Los países nórdicos pertenecen a este modelo.

El tercer modelo es el del capitalismo impulsado por el Estado, sea el gobierno central (en el caso de Francia) o las provincias (en el caso alemán). En esta configuración, el gran sector público de ayer, hoy caracterizado por múltiples intervenciones y elevadas transferencias sociales instrumentadas por medio de la fiscalidad y la seguridad social, permite una importante redistribución del ingreso nacional, la que promueve la actividad del mercado interno (Francia) o la creación de empleo en los sectores de exportación (Alemania). En ambos casos, se conciliaron el crecimiento y el mantenimiento de la desigualdad reducida, por lo menos hasta la década de 1970.

Por último, el capitalismo mesocorporativista está organizado en torno a grandes grupos que abarcan una amplia variedad de industrias en las que, mediante un compromiso inicial, se asegura la estabilidad del empleo de los trabajadores cuyas habilidades son esenciales para la producción, en una jerarquía salarial limitada por el hecho de que los líderes de los grandes grupos se forman dentro de sus confines. Esta es otra manera de garantizar la complementariedad entre la desigualdad reducida y el desempeño económico; este compromiso inicial marca el camino en el Japón y la República de Corea. Tradicionalmente, la mayor parte de la seguridad social dentro de los grupos mencionados estaba garantizada, pero la crisis de este modelo y el estancamiento a largo plazo resultante condujeron a una intervención cada vez más amplia del Estado en términos de política social.

\section{El "trilema" de la capacidad de respuesta a las condiciones del mercado, la eficiencia dinámica y la justicia social}

Tradicionalmente, de Paul Samuelson a los teóricos de los ciclos económicos reales, el capitalismo se clasifica según la relación entre la eficiencia estática - es decir, la habilidad de reaccionar ante alteraciones de la productividad o la confianza, a crisis cambiarias o a caídas del comercio mundial- y la justicia social. ¿Pero cuál fue la razón del éxito del fordismo? En primer lugar, la atenuación de los ciclos; luego, principalmente su capacidad para conciliar la modernización, la mejora general del nivel de vida y la moderación de las desigualdades.

No fue un simple proceso de convergencia para volver a las configuraciones anteriores, sino el resultado de compromisos sociopolíticos nuevos, que dieron sentido y legitimidad a un intenso constructivismo institucional. En esta dinámica, primero fue el capitalismo socialdemocrático y después el capitalismo con fuerte intervención del Estado los que obtuvieron mejores resultados en el logro de la complementariedad entre la eficiencia dinámica y una mayor justicia social (véase el diagrama X.2). Cabe recordar que a fines de la década de 1960, varios expertos estadounidenses concurrieron a Francia para observar el milagro francés y tratar de obtener algunas lecciones para su propio país. 
Diagrama X.2

Tipos de capitalismo y relación entre eficiencia e igualdad, hasta la década de $\mathbf{1 9 7 0}$

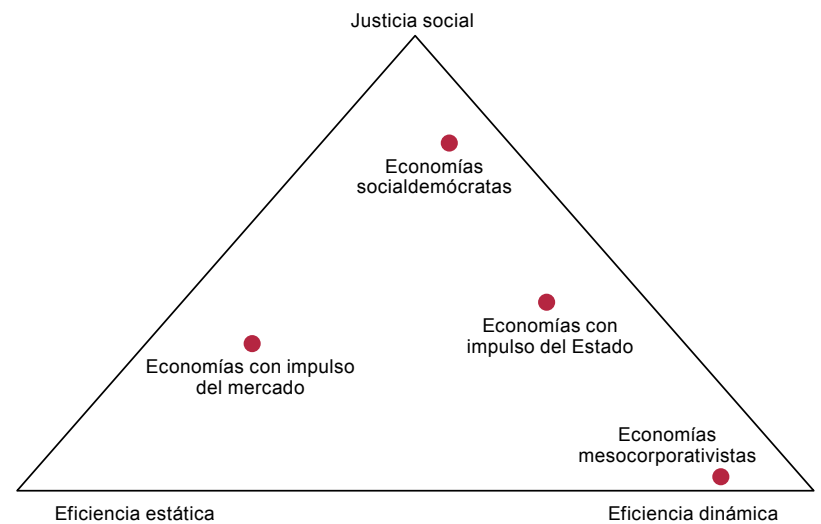

Fuente: Elaboración propia.

\section{B. El final de la "edad de oro": el éxito de los regímenes dominados por el mercado y sus crisis}

\section{La década de 1980: una contrarrevolución conservadora}

En los años ochenta surgió una revolución que empezó con las ideas y que probablemente no habría sido tan exitosa sin el agotamiento y la posterior crisis abierta del modelo previo de los países de la OCDE.

En primer lugar, la progresión de la productividad total de los factores en los Estados Unidos era nula, de tal modo que siguieron vigentes las instituciones encargadas de repartir el ingreso, pero el crecimiento se estancó y afloraron conflictos distributivos que generaron inflación y desempleo.

En segundo lugar, hubo una ola de internacionalización que destruyó los compromisos previos. Anteriormente, en el fordismo, existía una complementariedad entre los capitalistas y los asalariados, pero cuando una economía sigue expandiendo sus exportaciones hasta un determinado umbral, ocurre una desconexión entre los intereses de los empresarios y los de los asalariados: lo que no se puede vender a nivel nacional, se vende al exterior y los salarios pasan a ser un costo y no una contribución a la demanda interna. Por ejemplo, la industria alemana no vendía un gran volumen al sector interno, pero estaba vendiendo al resto del mundo: así se rompió la relación entre capital y trabajo a nivel nacional.

Finalmente, la globalización financiera exacerbó este proceso de desconexión entre el espacio económico y el espacio político, porque los 
dueños del capital podían retirar su dinero de una institución o centro financiero y colocarlo en cualquier otro, lo que desagregaba la base material del crecimiento con consumo y producción en masa dentro del territorio nacional.

De tal modo, emergió de manera endógena una nueva ideología, intelectualmente compartida por los gobiernos conservadores y socialistas, que postulaba que el mercado era muy superior al Estado en la asignación de recursos y que las desigualdades favorecían los incentivos del mercado, dada la importancia en términos de eficiencia de que los talentos reciban una remuneración elevada: "el ganador se lleva todo" se transformó en la consigna del capitalismo moderno. En consecuencia, se observó un retorno sorprendente a la macroeconomía clásica, en la cual las desigualdades son positivas porque incitan al trabajo; un estado de bienestar mínimo permite que los trabajadores acepten concesiones salariales; es muy favorable que haya ricos porque generarán ahorros $\mathrm{y}$, según la teoría prekeynesiana, van a invertir esos ahorros $\mathrm{y}$, cuando los inviertan, los pobres tendrán más empleos. Asimismo, es necesario que los innovadores reciban altas remuneraciones para que crezca la economía (véase el diagrama X.3).

\section{Diagrama X.3}

El cambio de paradigma de la década de 1980: la desigualdad social como incentivo para el crecimiento

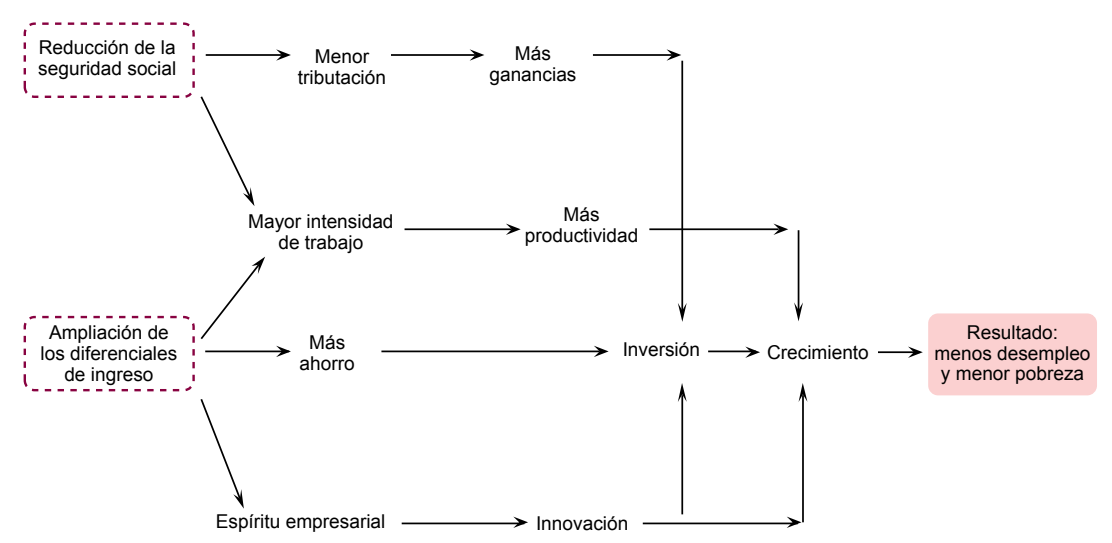

Fuente: Elaboración propia.

En el diagrama X.3 puede observarse la magnitud del cambio del paradigma central de la economía, que actuará como catalizador y justificación de las modificaciones de las leyes, los sistemas de remuneración y la gestión de las políticas económicas, cuyo objetivo es ahora no perturbar las economías mercado, que se suponen estructuralmente estables. 


\section{La década de 1990: el fracaso de todas las alternativas al capitalismo de mercado}

Para que este paradigma — que en sí resultó ser bastante extremo- se asentara, fue necesario que fracasaran las diversas alternativas que surgieron como una extensión de una institucionalización que tuviera en cuenta el cambio del contexto internacional y tecnológico.

En primer lugar, en la primera mitad de la década de 1980, el gobierno socialista francés trató de responder a la recesión mundial con el crecimiento del gasto público, pero el aumento de los déficits públicos y externos dio origen rápidamente a un plan de austeridad que tuvo un impacto duradero en la política económica de Francia y otros países. Este hecho fue interpretado como la derrota del keynesianismo en el nuevo contexto de la economía mundial. Desde entonces dejó de considerarse el capitalismo francés como una alternativa al capitalismo estadounidense.

Un segundo episodio condujo a una reevaluación del capitalismo socialdemócrata: la globalización de las finanzas generó una crisis bancaria y económica del modelo sueco que dio lugar a una reforma de la cobertura de la seguridad social hacia la privatización de muchos servicios, como la salud, y la reducción de la proporción del gasto público respecto del PIB. Esta mercantilización afectó al modelo socialdemócrata, aunque mantuvo una especificidad significativa.

El colapso del sistema soviético es aún más grave. De hecho, cuando se derrumba el más serio competidor del capitalismo, libera la presión ejercida sobre las reformas en favor de los trabajadores y de los ciudadanos de los varios tipos de capitalismo. Solo queda el sistema capitalista que toma el nombre de economía de mercado, y la democracia es su complemento necesario en el ámbito político. Algunos analistas afirmaron que el colapso de la Unión Soviética marcó el fin de una era.

En los años ochenta, el capitalismo mesocorporativista del Japón parecía amenazar la superioridad del capitalismo de mercado estadounidense. Pero la apertura a los flujos de capitales internacionales generó una burbuja bursátil y la crisis de las hipotecas de alto riesgo, que finalmente anuló el dinamismo del crecimiento. A continuación hubo dos décadas perdidas de estancamiento casi total que destruyeron el prestigio y el atractivo del capitalismo japonés. Solo la política económica del primer ministro Shinzo Abe ("abenomics") abrió un nuevo período.

Por último, en la década de 1990, período glorioso de la economía estadounidense, parece triunfar un nuevo tipo de capitalismo: el del mercado financiero, que se convierte en la única referencia para la comparación de prácticas internacionales (benchmarking) (Fukuyama, 1992). 


\section{El período 1990-2006: el triunfo del capitalismo financiero}

El triunfo del capitalismo dominado por las finanzas se debió a las deficiencias de las alternativas mencionadas arriba, en el sentido de que la innovación financiera es el corazón del capitalismo moderno; asimismo, se observó un cambio radical en los distintos tipos de capitalismo; todos se enfocaban en la privatización del bienestar, la reducción de la recaudación y la apertura internacional para alcanzar el modelo de eficiencia estática. De hecho, ante una alta volatilidad, poco importa la eficiencia dinámica: se debe reaccionar rápidamente y, en ese aspecto, el capitalismo de mercado es el más eficaz. De este modo, en caso de propiciar la volatilidad, el modelo capitalista se convierte en un círculo virtuoso para la economía que sigue su ejemplo y en un círculo vicioso para el resto, por lo que todos los países intentaron imitar la estrategia estadounidense.

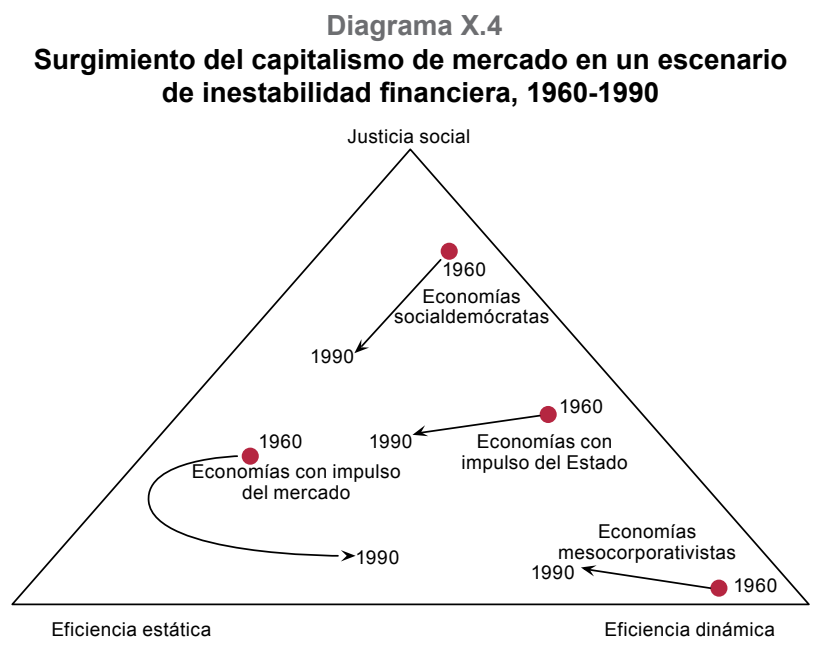

Fuente: Elaboración propia.

En primer lugar, es necesario destacar que resultaba paradójico instaurar un régimen económico impulsado por las finanzas, dado que en el modelo fordista dominaba la lógica de creación del valor agregado. En el modelo liderado por las finanzas se anticipa la riqueza futura, medida en términos de la bolsa de valores, la que desencadena el proceso de inversión, producción y demanda. Las expectativas y la confianza en las finanzas determinan la posibilidad del régimen. Una simulación de este régimen con un modelo relativamente sencillo (Boyer, 2000) determinó que en los años noventa las condiciones de estabilidad estaban satisfechas de antemano en la economía estadounidense. Por una parte, se otorgó 
gran importancia al patrimonio financiero de los hogares, que representa una amplia fracción del ingreso disponible, y que incluye la tenencia de acciones y obligaciones directas o indirectas, mediada por los fondos de pensiones (véase el diagrama X.5). Para el ciudadano estadounidense, este modelo parecía dar inicio a un período de prosperidad sin esfuerzo y sin límite: ante la perspectiva de riqueza, una persona podía solicitar un crédito, con el que adquiría una propiedad, utilizar esa propiedad como garantía para comprar un vehículo y con el valor del vehículo conseguir un crédito para sus vacaciones. Así, el circuito macroeconómico parecía cerrarse sin inconvenientes.

Diagrama X.5

Régimen de acumulación con dominación de las finanzas

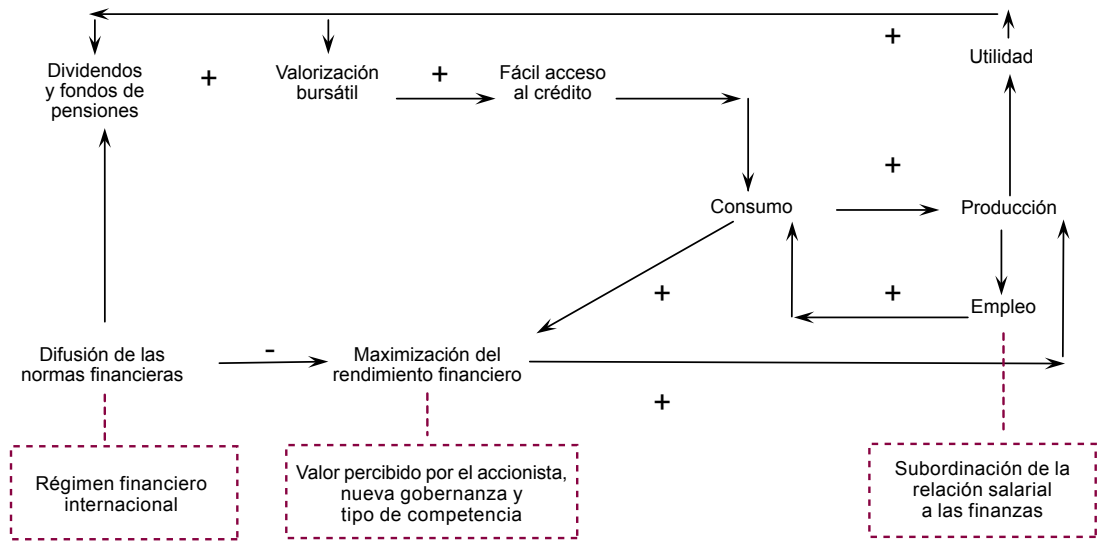

Fuente: Elaboración propia.

De esta manera, puede explicarse que desde la década de 2000 un gran número de macroeconomistas europeos aconsejaron a sus respectivos gobiernos la adopción del método estadounidense, según el cual el crédito y las finanzas son los instrumentos clave de la actividad económica. Estas pretensiones son altamente ingenuas, en tanto las estructuras económicas de los Estados Unidos son bastantes peculiares y, solo el Reino Unido se asemeja a la configuración de ese país. En efecto, para los demás países, especialmente Alemania, Francia y el Japón, la lógica productiva de la creación de valor de las empresas no financieras es mucho más importante que el valor financiero y la financierización. De esta manera, la apertura a la financiación y la innovación ha contribuido al deterioro del crecimiento y la estabilidad en estas tres economías, debido a la incompatibilidad con otras formas institucionales construidas en torno a la búsqueda de la competitividad y el desempeño industrial. 


\section{El período 2007-2008: el fracaso de la liberalización y la globalización financiera}

Respecto de los países cuyo régimen de crecimiento se regía por las finanzas, la relajación de los criterios de selección en la concesión de crédito y la titularización masiva de préstamos de mala calidad en los Estados Unidos originó una crisis estructural. De hecho, la falta de control sobre las innovaciones financieras creó una burbuja especulativa casi sin precedentes que fue contaminando por completo la economía nacional e internacional (Boyer, 2013a). Se logró evitar una depresión equivalente a la de 1930 mediante la adopción de una acción masiva, rompiendo con la ortodoxia que regía con anterioridad en la política económica. El banco central proporcionó liquidez a los bancos insolventes y los gobiernos aceptaron la ampliación del déficit público (véase el cuadro X.1). Ese fue el precio que se debió pagar para obtener una modesta recuperación, que no fue muy prolongada, dado que la economía estadounidense había perdido su motor ligado al crecimiento del crédito, y las exportaciones, el consumo y la inversión productiva no tomaron su lugar.

Cuadro X.1

Estilos de política económica, 1945-2014

\begin{tabular}{|c|c|c|c|}
\hline $\begin{array}{r}\begin{array}{r}\text { Períodos y regímenes } \\
\text { de crecimiento }\end{array} \\
\text { Características }\end{array}$ & $\begin{array}{c}\text { 1945-1971 } \\
\text { Producción y consumo } \\
\text { en masa }\end{array}$ & $\begin{array}{c}\text { 1972-2007 } \\
\text { Internacionalización } \\
\text { y financierización }\end{array}$ & $\begin{array}{l}\text { 2007-presente } \\
\text { Nuevo desarrollismo } \\
\text { y rol del Estado }\end{array}$ \\
\hline \multicolumn{4}{|l|}{ Visión general } \\
\hline $\begin{array}{l}\text { 1.Conceptualización } \\
\text { de la economía }\end{array}$ & $\begin{array}{l}\text { Inestabilidad estructural } \\
\text { que requiere de } \\
\text { intervenciones } \\
\text { del Estado }\end{array}$ & $\begin{array}{l}\text { Un conjunto } \\
\text { de mercados } \\
\text { autorregulados }\end{array}$ & $\begin{array}{l}\text { El Estado como garante } \\
\text { de la estabilidad } \\
\text { financiera e impulsor } \\
\text { del desarrollo }\end{array}$ \\
\hline 2.Teoría dominante & $\begin{array}{l}\text { Macroeconomía } \\
\text { keynesiana }\end{array}$ & Nueva teoría clásica & $\begin{array}{l}\text { Nuevas teorías } \\
\text { del desarrollo } \\
\text { (CEPAL, China) }\end{array}$ \\
\hline $\begin{array}{l}\text { 3.Tipo de compromiso } \\
\text { sociopolítico }\end{array}$ & $\begin{array}{l}\text { Compromiso entre } \\
\text { capital y trabajo }\end{array}$ & $\begin{array}{l}\text { Dominación de las } \\
\text { finanzas }\end{array}$ & $\begin{array}{l}\text { Nuevo trato con } \\
\text { los ciudadanos }\end{array}$ \\
\hline \multicolumn{4}{|l|}{ Política económica } \\
\hline 4.Política monetaria & $\begin{array}{l}\text { Optimización del } \\
\text { equilibrio entre el } \\
\text { empleo y la inflación }\end{array}$ & $\begin{array}{l}\text { Estabilización de } \\
\text { una baja inflación y } \\
\text { luego impulso a las } \\
\text { finanzas }\end{array}$ & $\begin{array}{l}\text { Retorno del prestamista } \\
\text { de última instancia, no } \\
\text { neutralidad del crédito } \\
\text { y de la moneda }\end{array}$ \\
\hline $\begin{array}{l}\text { 5.Gasto público } \\
\text { y sistema fiscal }\end{array}$ & $\begin{array}{l}\text { Estabilizadores } \\
\text { automáticos }\end{array}$ & $\begin{array}{l}\text { Gasto público } \\
\text { procíclico }\end{array}$ & $\begin{array}{l}\text { En las depresiones, } \\
\text { altos multiplicadores, } \\
\text { no neutralidad ricardiana }\end{array}$ \\
\hline 6.Política de ingresos & $\begin{array}{l}\text { Convenios colectivos, } \\
\text { salario mínimo, } \\
\text { impuestos progresivos }\end{array}$ & $\begin{array}{l}\text { Individualización y } \\
\text { descentralización, } \\
\text { sistema de tasa fija }\end{array}$ & $\begin{array}{l}\text { Lucha contra las } \\
\text { desigualdades, } \\
\text { establecimiento de } \\
\text { normas financieras }\end{array}$ \\
\hline 7.Política de la competencia & $\begin{array}{l}\text { Limitada hacia una } \\
\text { serie de oligopolios } \\
\text { nacionales }\end{array}$ & $\begin{array}{l}\text { Apertura a la } \\
\text { competencia } \\
\text { internacional y } \\
\text { surgimiento de } \\
\text { oligopolios mundiales }\end{array}$ & $\begin{array}{l}\text { Suavización de la política } \\
\text { contra la concentración } \\
\text { del capital }\end{array}$ \\
\hline $\begin{array}{l}\text { 8.Política comercial } \\
\text { y tipo de cambio }\end{array}$ & $\begin{array}{l}\text { Lenta apertura } \\
\text { internacional, régimen } \\
\text { de tipo de cambio fijo } \\
\text { pero ajustable }\end{array}$ & $\begin{array}{l}\text { Generalización de } \\
\text { regímenes de tipos } \\
\text { de cambio flexibles, } \\
\text { con excepción de la } \\
\text { zona del euro }\end{array}$ & $\begin{array}{l}\text { Control del tipo de } \\
\text { cambio real para } \\
\text { favorecer el desarrollo } \\
\text { interno }\end{array}$ \\
\hline
\end{tabular}

Fuente: Elaboración propia. 
No se trató solo de una burbuja, sino también de la respuesta a la crisis de la nueva economía y a la liberalización financiera, que se había traducido en la década de 1980 en especulación inmobiliaria y en la crisis de las sociedades de ahorro y préstamos, más limitada y localizada dado que las innovaciones en materia de finanzas aún no eran masivas. Fue claramente una crisis estructural del régimen de acumulación con dominación de las finanzas. Dada la centralidad de los Estados Unidos en la intermediación financiera internacional, la ruptura de la confianza en la estabilidad de su sistema bancario se reflejó inmediatamente en la caída del crédito en el comercio internacional, el bloqueo de las decisiones de inversión y la caída masiva de la producción en casi todos los países. También entró en crisis el sistema de relaciones internacionales, que no tenía reglas ni instrumentos para controlar la propagación del exceso de crédito, en especial hacia las economías emergentes.

Este fue el segundo fracaso de la liberalización financiera. Se suponía que la apertura de la cuenta de capital estabilizaría la evolución del tipo de cambio y favorecería una mejor asignación de capital entre los países desarrollados y en desarrollo. No obstante, se observó precisamente lo contrario: estalló una "guerra" cambiaria y el ahorro de los países emergentes financió el consumo de los países ricos.

\section{Desde 2009 hasta el presente: la crisis estructural de todos los regímenes de crecimiento}

La crisis más grave se observó en los países que confiaban en las virtudes de la liberalización financiera, dejando la iniciativa a los actores privados: Estados Unidos, Inglaterra, Irlanda e Islandia. Ellos debieron recurrir a políticas más heterodoxas, es decir, una ruptura total con respecto a lo que recomendaba anteriormente la teoría en vigor e implementaban el banco central y el ministerio de hacienda (Boyer, 2011d). Algunos analistas anticiparon una posible repetición de la década perdida del Japón: un estancamiento de mediano plazo con riesgo de deflación.

Por otra parte, la recesión de 2008 y 2009 fue particularmente grave en los países que habían basado su crecimiento en las exportaciones y el dinamismo de la innovación: Alemania, el Japón o la República de Corea. Los gobiernos y la opinión pública notaron luego la fragilidad de su modelo de desarrollo y su extrema dependencia de la evolución mundial, hasta el punto de considerar la posibilidad de una transición a un sistema basado en el desarrollo del mercado interno y, especialmente, del consumo.

En la primera fase de la crisis producida por la quiebra de Lehman Brothers, China parece escapar de la serie de recesiones que afectan a otros países. De hecho, gracias al control del crédito y del tipo de cambio 
y a un ambicioso programa de infraestructura pública, la economía china creció solo un poco más lentamente que en el pasado (Boyer, 2011a y b). Sin embargo, el período 2010-2013 marca una bifurcación porque el incremento del comercio internacional se desacelera y el modelo basado en la inversión productiva y el sector inmobiliario tiende a agotarse. Esta fue una oportunidad para reorientar las políticas en torno a la transición hacia el mercado interno y la satisfacción de las necesidades sociales y ambientales, resultantes de la fase de crecimiento acelerado.

La Unión Europea se enfrenta a una crisis diferente: en una primera fase, la magnitud de los estabilizadores automáticos limita las consecuencias de la crisis, pero los déficits públicos en 2010 motivaron la preocupación de los mercados financieros internacionales y de las autoridades de Bruselas, en un grado suficiente para provocar un retorno a las políticas de austeridad, incluso antes de que estuviera asegurada la recuperación económica (Boyer, 2012b). Durante este proceso, aparece una de las debilidades estructurales que había sido subestimada por los iniciadores del euro: la heterogeneidad de la especialización y los modos de regulación de los países de la zona del euro muestran el carácter incompleto y las inconsistencias de las instituciones de la Unión Europea. De este modo, la crisis financiera se convierte en una crisis económica que lleva a una crisis política de la integración europea (Boyer, 2013b).

\section{El surgimiento de un nuevo paradigma sobre el Estado y la política económica}

Por último, es conveniente rescatar algunas enseñanzas del análisis sobre la reevaluación de la concepción del Estado, sus objetivos e instrumentos. Las siguientes propuestas son el resultado de dos consideraciones extraídas del análisis anterior. Por una parte, se debe prestar atención a las lecciones de la historia con el fin de corregir los errores que conducen a las grandes crisis económicas. Por otra parte, no necesariamente se necesita la misma política para cualquier país y en cualquier momento, ya que esta debe ser compatible o coherente con el modo de desarrollo y el tipo de regulación que caracteriza a cada economía nacional.

\section{El fracaso de la creencia en la eficiencia y la autorregulación de los mercados financieros otorga una nueva legitimidad a la intervención del Estado}

Los mercados financieros hacen una mala asignación del capital, como lo demuestra la sucesión de burbujas financieras ocurridas en los Estados Unidos (la crisis de las sociedades de ahorro y préstamos de la década de 1980, la nueva economía y la crisis de las hipotecas de alto riesgo), 
en el Japón (la burbuja accionaria y de bienes raíces de 1980), Asia (la crisis cambiaria, bursátil e inmobiliaria de 1997) y la Unión Europea (la crisis inmobiliaria en España, Irlanda e Islandia de la década de 2000). Por lo tanto, es necesario reinventar una forma de planeación, ya que las grandes empresas siguen planificando sus actividades a nivel nacional e internacional, mientras que el Estado sigue las pautas del mercado, es decir, las consecuencias de las decisiones estratégicas de las multinacionales. Este modelo difiere de la visión keynesiana, según la cual el Estado establece las reglas del juego y hace converger las expectativas en torno a una senda de crecimiento en la que todos los actores participan en la toma de decisiones y, con el tiempo, el capital privado y social pasa al dominio del Estado y las empresas se ajustan a ello. Hoy vivimos un período en el cual Morgan Stanley o Goldman Sachs deciden si el régimen de Grecia es viable o no. Esta es claramente una cuestión de soberanía nacional y de usurpación del poder económico surgido de la deliberación democrática; en definitiva, el modo de respetar las decisiones de los ciudadanos constituye un gran dilema.

\section{El colapso de la hipótesis de neutralidad de la política monetaria}

Desde el mundo académico, la victoria de la nueva economía clásica había convencido finalmente a los bancos centrales y a los gobiernos de que la política monetaria debía limitarse a contener la inflación dentro de límites estrictos para que, en el mediano y largo plazo, esta no tuviera impactos en la actividad real a nivel macroeconómico. Así pues, dejaron de realizarse importantes cambios debido a la liberalización y proliferación de instrumentos financieros con un aumento equivalente de liquidez monetaria, que fueron la causa directa de la sucesión de burbujas financieras. Estos aceleraron el crecimiento en una primera instancia, para luego sumir a las economías modernas en una gran crisis sistémica. Del mismo modo, los bancos centrales provocaron una crisis al incrementar la refinanciación de los bancos con la esperanza de que pudieran expandir el crédito y, por tanto, la inversión y el consumo. En Europa, por ejemplo, el mecanismo de transmisión de la política monetaria a la economía real ha caído en una trampa de liquidez; el hecho de que la política monetaria tenga sus límites no significa que el dinero sea neutral.

Para evitar la repetición de tales episodios, es esencial rediseñar la política monetaria y reconocer que contribuye a determinar el nivel de actividad, pero que no es suficiente para garantizar la estabilidad financiera (Boyer, Dehove y Plihon, 2004). Es importante contar con otros instrumentos, como una supervisión macroprudencial, además de la reforma de los métodos microprudenciales mencionados. 


\section{En una coyuntura de depresión, el gasto público vuelve a ser una herramienta eficaz de acción sobre la demanda efectiva}

En una coyuntura de depresión, es muy útil poder actuar sobre la demanda efectiva, a diferencia de lo que propone la teoría de neutralidad ricardiana dominante, que proporciona multiplicadores nulos o negativos. Sin embargo, como el FMI finalmente reconoció y ha demostrado, en períodos de depresión los multiplicadores son muy altos, lo que significa que la política fiscal funciona con mayor eficacia que la política monetaria y puede evitar un colapso, si bien encuentra limites en la estimulación de una recuperación, como lo demuestra el largo período de estancamiento del Japón desde la década de 1990. El claro efecto recesivo de las políticas de austeridad en Europa después de 2011 es otra evidencia empírica de la magnitud de los multiplicadores keynesianos y del carácter erróneo de la equivalencia ricardiana cuando la economía está lejos del pleno empleo (Boyer, 2012b).

\section{El absolutismo de la política de competencia se mitiga, especialmente para rescatar a grandes bancos y empresas manufactureras}

En el pasado se pensaba que la política de competencia era la única herramienta para propiciar la innovación y el crecimiento. Este no fue el caso en la Unión Europea: las economías del sur no han alcanzado los niveles de gasto en investigación y desarrollo del norte, y la magnitud de la liberalización económica y financiera tampoco ha liberado a América Latina de su dependencia de la exportación de materias primas y la debilidad de sus sistemas de innovación.

Por una parte, la competencia es el corazón y el motor del capitalismo, pero, sin un fuerte control colectivo - como Marx había previsto y lo confirma la historia económica-, se convierte en un proceso que recurrentemente genera oligopolios o monopolios. Por otra parte, ¿cuál es la salida de la crisis de Lehman Brothers? La concentración sin precedentes de las entidades financieras "muy grandes para quebrar" (too big to fail) o "demasiado conectadas para quebrar" (too connected to fail). Existe una clara contradicción entre la ideología neoclásica, según la cual la competencia entre pequeñas unidades regula el sistema, y las transformaciones observadas.

\section{Las evoluciones erráticas de los tipos de cambio manifiestan los límites de la globalización financiera: los gobiernos deben tener una política cambiaria}

En la economía contemporánea, de una alta movilidad del capital y enorme volumen de las transacciones financieras en el comercio internacional, el tipo de cambio deriva del proceso de ecualización de la tasa de rendimiento del capital móvil. Este tipo de cambio no guarda ninguna conexión a corto 
o mediano plazo con el tipo de cambio real que propiciará la inserción internacional de la economía de cada país, es decir que hay una nueva concepción del régimen de cambio (Bresser-Pereira, 2009). Por tanto, es importante definir uno o más instrumentos para volver a establecer un tipo de cambio que permita una integración viable en la economía mundial gracias a la capacidad de recuperación de un sistema de producción capaz de apoyar las exportaciones y equilibrar la balanza de pagos (Boyer, 2011c). Durante mucho tiempo, el FMI afirmó que cualquier perturbación del equilibrio del mercado cambiario socava la asignación eficiente del capital. Recientemente, admitió que, de una forma $\mathrm{u}$ otra, los controles de capital podrían ser eficaces para reducir la inestabilidad provocada por cambios repentinos de los flujos de capital internos y externos, al menos parcialmente y de forma temporal.

\section{Ante el fracaso de la estrategia por goteo, el sistema fiscal debe incorporar una mayor progresividad con respecto al nivel de ingreso}

La idea de que una economía se desarrolla cuando hay grupos de altos ingresos ha fracasado: si así fuera, América Latina estaría muy desarrollada. Si bien en México vive la persona más rica del mundo, no se puede inferir que ese país vaya a desarrollarse, ya que, dada la alta movilidad del capital y la ausencia de un sistema fiscal progresivo, no es posible remediar la desigualdad de la distribución del ingreso. En consecuencia, dejó de considerarse que un sistema de tasa fija sea el ideal y algunos países como el Brasil exploraron un aumento de la redistribución del ingreso y, de hecho, lograron reducir la desigualdad (Boschi, 2009). Los estudios históricos en el largo plazo muestran que la progresividad del impuesto sobre la renta y la naturaleza de la carga fiscal sobre la transmisión de la herencia tuvieron un papel importante en la reducción de las desigualdades económicas y sociales después de la Segunda Guerra Mundial. Por el contrario, la adopción de una tasa tributaria uniforme y una reducción de la tributación del capital han tenido un impacto decisivo en el crecimiento de la desigualdad desde la década de 1980 (Piketty, 2013).

\section{El Estado de bienestar y el crecimiento}

Las representaciones ideológicas y teóricas de bienestar tienen un impacto en las reformas que se efectúan en varios países. Los sistemas inspirados por Beveridge imponen costos crecientes en materia de trabajo y deterioran la competitividad y el empleo, lo que se presenta como una justificación de recortes sociales. Del mismo modo, los sistemas de Bismarck se enfrentan a la rebelión fiscal de las clases medias y la erosión de sus bases imponibles debido a la alta movilidad del capital financiero. La seguridad social es analizada como un costo puro sin ninguna contribución positiva ni 
significativa. Esta visión basada en una simple contabilidad reduccionista deja de lado totalmente el hecho de que el aumento de la seguridad social promueve el bienestar, por lo general reduce la desigualdad y puede ser también el catalizador de la eficiencia económica dinámica. Esta trilogía fue señalada por primera vez para interpretar el «milagro holandés» (Visser y Hemerijck, 1997) (véase el diagrama X.6).

\section{Diagrama X.6}

Mejora de la eficiencia dinámica mediante algunos sistemas de bienestar

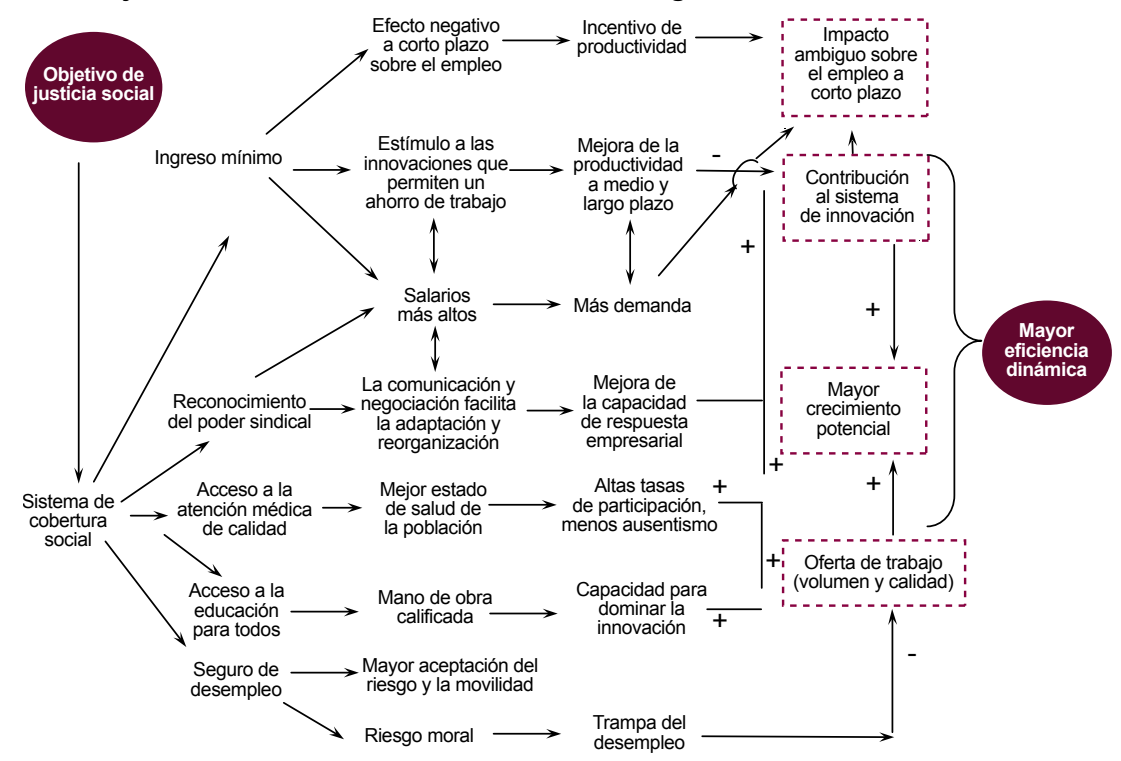

Fuente: Elaboración propia.

\section{La inversión en educación y salud aumenta el bienestar}

Educar significa nutrir a ciudadanos informados que pueden tomar decisiones; un sistema de salud eficaz permite una vida más larga sin enfermedades graves; las prestaciones por desempleo y el salario mínimo reducen la pobreza entre los asalariados; en consecuencia, aumenta el bienestar, aunque esta contribución no se mide con los actuales métodos de cálculo de las cuentas nacionales.

Cuando la provisión de educación, salud y seguro contra los riesgos económicos se organiza colectivamente y es financiada por las contribuciones de toda la sociedad, los sistemas de bienestar y fiscales ejercen un impacto redistributivo claro y constituyen herramientas para reducir las desigualdades. En cambio, la individualización de los contratos de seguros, la descentralización de muchos de los componentes de la asistencia social y el auge de los fondos de pensiones originan trayectorias divergentes entre individuos con características iniciales muy similares. 


\section{Los sistemas de bienestar: conciliación de la teoría de Keynes con la de Schumpeter}

Los impactos del estado de bienestar en la economía son numerosos y pueden contribuir a la innovación, el crecimiento y el desempeño económico. Una política dinámica de aumentos del salario mínimo puede afectar transitoriamente a las empresas menos productivas, pero es un incentivo para las innovaciones orientadas al ahorro en concepto de mano de obra y el aumento a largo plazo de la productividad. Por otra parte, en las sociedades de asalariados, los salarios son factores determinantes del consumo y la demanda global y, por lo tanto, pueden compensar el sesgo del cambio tecnológico hacia el ahorro de mano de obra con la coevolución de la demanda.

En cierto sentido, las concepciones de Schumpeter y Keynes son más complementarias que opuestas (Dosi, 2008). Los gastos de salud contribuyen a un mejor bienestar, menos ausentismo y una mayor esperanza de vida, lo que a su vez posibilita un mayor retorno de la inversión en educación y formación. La educación para la mayoría de la población, concebida como la adquisición de la capacidad para aprender a resolver los problemas, aporta un ingrediente clave para el dinamismo de los sistemas nacionales de innovación. Los países nórdicos han llevado un paso adelante las sugerencias derivadas del modelo mencionado del "milagro holandés" y recurrentemente ajustan la complementariedad entre sus sistemas de protección social y de innovación (Boyer, 2014).

Ambas teorías proponen una actualización similar de las prestaciones por desempleo: no generan ninguna "trampa de desempleo", sino una tasa de reemplazo generosa que se complementa con una política activa de formación con el fin de reasignar los recursos humanos necesarios para la extinción de los sectores obsoletos y el crecimiento rápido de los sectores de alta productividad. Por lo tanto, fuera de los países nórdicos, los fundamentos para un Estado del bienestar universal en simbiosis con el sistema nacional de innovación han sido abandonados en favor de un enfoque de simple reducción de costos, sin tener en cuenta los efectos adversos sobre el bienestar de la población, la capacidad productiva a largo plazo y la capacidad de innovar y explorar una mejora de la especialización internacional (Amable, Boyer y Barré, 2008).

\section{E. Las consecuencias de la globalización}

El análisis macroeconómico efectuado más arriba, aunque atractivo, adolece de un defecto importante: se basa en los supuestos de que las economías nacionales están implícitamente cerradas y de que los factores reales determinan la financiación. Estos supuestos son obsoletos en el mundo actual. 


\section{El gran peligro de la globalización financiera}

Podría suponerse que el carácter espectacular de la crisis asiática de 1997 sería un ejemplo para los demás países que sucumbieron a los encantos de la globalización financiera y el incremento acelerado de los créditos en moneda externa, en este caso el dólar. En efecto, los capitales son atraídos por las economías emergentes, de las cuales huyen cuando se producen acontecimientos desfavorables. En ese caso, de manera simultánea estallan crisis bancarias y cambiarias. Las primeras ocurren porque el crecimiento del crédito es mayor que la absorción de la economía y provoca burbujas especulativas, inmobiliarias y bursátiles. La incapacidad de pagar los créditos en moneda extranjera precipita una desconfianza generalizada sobre la moneda nacional. Todos los estudios sobre las crisis financieras convergen hacia un diagnóstico casi unánime: es altamente peligroso abrir la cuenta de capital y permitir que los agentes internos se endeuden en moneda extranjera, sin tener que extremar precaución respecto de la reglamentación y la vigilancia prudencial (Boyer, Dehove y Plihon, 2004).

Hacia la segunda mitad de la década de 2000, una serie de países que recientemente se habían insertado en el sistema internacional adoptaron la misma estrategia aventurada que los países asiáticos en la década de 1990. Se trata principalmente de los países de Europa del Este que se incorporaron progresivamente a la Unión Europea. De manera imprudente, Bulgaria, Estonia, Hungría y Letonia registraron un gran incremento de los créditos con relación al PIB y aceptaron un endeudamiento en moneda extranjera (euros) (véase el cuadro X.2). Mientras que las instituciones financieras internacionales intentaban diversificar sus carteras e inducir inversiones directas, las autoridades nacionales se mostraban satisfechas por el dinamismo de sus economías.

Cuadro X.2

Factores que aumentaron la probabilidad de una crisis gemela, 2009

\begin{tabular}{lccc}
\hline & $\begin{array}{c}\text { Préstamos en divisas } \\
\text { (en porcentajes del total) }\end{array}$ & $\begin{array}{c}\text { Créditos en moneda } \\
\text { extranjera } \\
\text { (en porcentajes del PIB) }\end{array}$ & $\begin{array}{c}\text { Crédito de corto plazo } \\
\text { (menos de 1 año) } \\
\text { (en porcentajes) }\end{array}$ \\
\hline República de Corea & 9,5 & 119,0 & - \\
\hline India & 1,4 & 81,0 & - \\
\hline Brasil & 2,0 & 61,0 & - \\
\hline República Checa & 8,0 & 97,3 & 5,8 \\
\hline Polonia & 24,0 & 58,3 & 18,2 \\
\hline Hungría & 55,0 & 106,7 & 13,2 \\
\hline Eslovaquia & 35,0 & 107,2 & 28,2 \\
\hline Bulgaria & 53,0 & 90,3 & 19,6 \\
\hline Rumania & 54,0 & 66,7 & 14,8 \\
\hline Lituania & 61,0 & 94,7 & 25,7 \\
\hline Estonia & 82,0 & 161,0 & 33,6 \\
\hline Letonia & 86,0 & 134,2 & 9,1 \\
\hline Turquía & 29,0 & 23,8 & 10,2 \\
\hline Ucrania & 49,0 & 31,3 & \\
\hline
\end{tabular}

Fuente: Elaboración propia sobre la base de Fondo Monetario Internacional (FMI). 
La crisis de los Estados Unidos se difundió progresivamente al resto del mundo y se produjo una reversión de la dirección de los flujos de capitales hacia los grandes centros financieros, aunque estos se encontraban en crisis, dado que se suponía que proporcionarían más garantías que las economías emergentes. Por consiguiente, se puede señalar que se asiste al resurgimiento de las crisis financieras duales en los países globalizados. Al parecer, la crisis asiática solo aportó lecciones a los países que afectó y no tuvo gran impacto en el aprendizaje de las economías emergentes en general. Hay un contraste entre la experiencia de la República de Corea y el Brasil, y los países de Europa del Este: los primeros conocieron varias crisis profundas, mientras que los segundos no.

\section{Pros y contras de la creciente interdependencia de las economías}

Si no existe un patrón único en los modelos de desarrollo y los regímenes de desigualdad ¿cómo explicar su persistencia? En Boyer (2014) se ha demostrado que progresivamente se está formando un sistema bastante coherente o al menos compatible a nivel mundial (véase el diagrama X.7).

\section{Diagrama X.7}

Complementariedad de los regímenes nacionales de desigualdad y los modelos de desarrollo

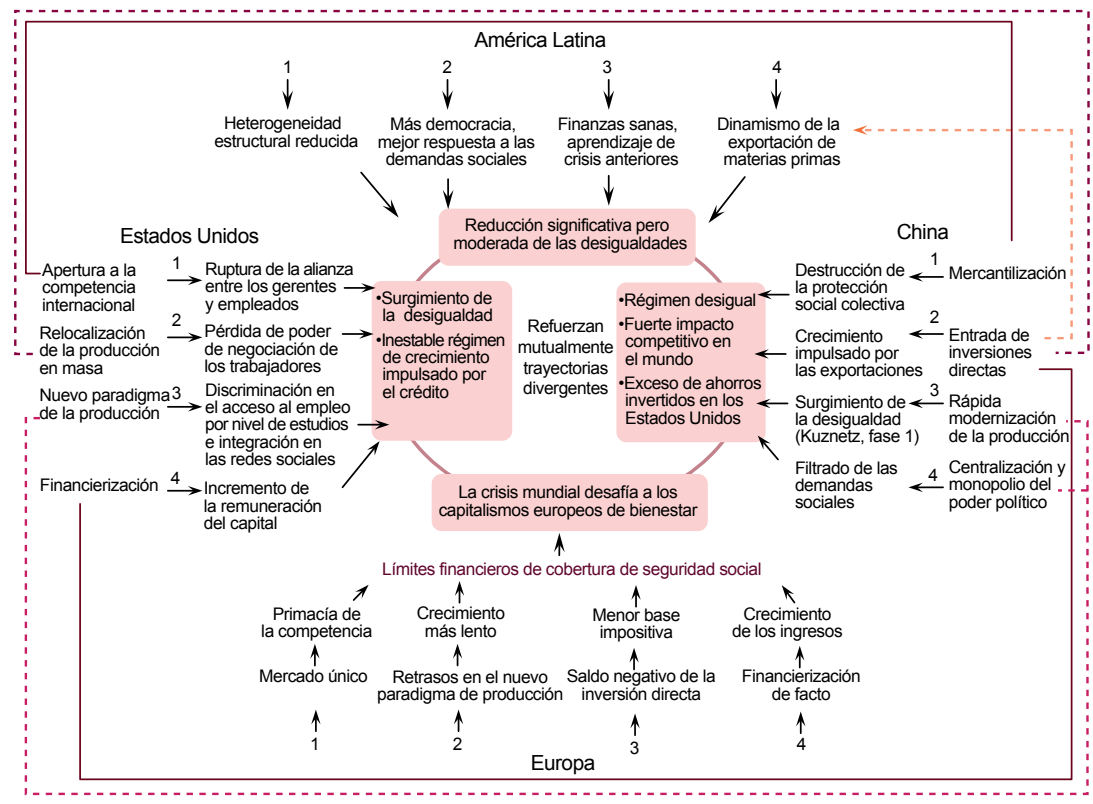

Fuente: Elaboración propia. 
El incremento de los ingresos en la etapa de crecimiento liderado por las finanzas en los Estados Unidos fue paralelo al crecimiento de la desigualdad generada por la rápida modernización productiva en China. Esta no es la única coevolución de la economía mundial.

En efecto, la crisis del euro y la amenaza a los sistemas de bienestar extendidos y de defensa de la solidaridad social son la consecuencia de la presión conjunta de la rápida puesta al día de la mayoría de las industrias chinas y las recurrentes crisis financieras mundiales generadas por la promoción, por parte de los Estados Unidos, de la liberalización y la globalización del comercio, el capital y las finanzas.

La paradoja latinoamericana, un descenso atípico de la desigualdad económica a partir de una extrema polarización social, también se explica por su especialización complementaria a la de China y los Estados Unidos, la capacidad de aprender de las últimas crisis financieras y la transición hacia la democracia, como también al hecho de dar finalmente una respuesta positiva a las demandas de protección social.

Los desequilibrios macroeconómicos generados por el aumento de la desigualdad dentro de cada economía nacional son simétricos en los Estados Unidos y en China; en consecuencia, solo los movimientos de compensación del comercio y las finanzas internacionales permiten la viabilidad de regímenes socioeconómicos que no podrían mantenerse dentro de fronteras cerradas: un abundante crédito para sostener el estilo de vida ante un ingreso real promedio estancado en los Estados Unidos; el exceso de capacidad industrial debido a la contracción de la participación del trabajo en China, y la baja tasa de ahorro de los hogares estadounidenses frente al elevado ahorro en China, en parte canalizado nuevamente al sistema financiero de los Estados Unidos. Así, la internacionalización de la producción, el capital y las finanzas hace que los regímenes de desigualdad contrastados parezcan compatibles y viables, porque tuvieron lugar en modelos de desarrollo complementarios. Por otra parte, esto explica las opuestas evoluciones en materia de la desigualdad: se observa una menor desigualdad entre los países, ya que la globalización permite una variedad de regímenes de crecimiento dominados por las finanzas — los impulsados por las exportaciones y la innovación, y los construidos sobre la renta de materias primas-, pero cada uno de ellos potencia las desigualdades de los individuos dentro del mismo Estado-nación. 


\section{Conclusiones}

La desigualdad creciente se convirtió en la década de 2010 en uno de los principales retos para la mayoría de los países. Este fenómeno pone en peligro la cohesión social, erosiona la legitimidad de la política y, en última instancia, pone en peligro la resiliencia de la economía. Por tanto, debemos cuestionar la premisa de la nueva teoría clásica según la cual la desigualdad sería el vector de un régimen de crecimiento emergente. Esta se basa en la idea de que la desigualdad es necesaria para fomentar el esfuerzo de los trabajadores, estimular la inversión y promover la innovación como fuente de crecimiento y creación de empleo.

En este contexto, la búsqueda de sistemas socioeconómicos alternativos podría basarse en la experiencia de los Estados Unidos y Europa tras la Segunda Guerra Mundial: una estricta supervisión del mercado y una fuerte intervención pública a la vez redujeron las desigualdades y promovieron un crecimiento rápido y relativamente estable. Sin embargo, estas experiencias no pueden extrapolarse como tales debido a los cambios del mundo moderno causados por la internacionalización de la producción, el nuevo modelo productivo y el poder de la globalización financiera. Por el contrario, parece importante movilizar el marco conceptual que los economistas de los países socialdemócratas han desarrollado para mostrar las condiciones necesarias para que una extensa seguridad social permita compatibilizar e incluso complementar la eficiencia económica con la justicia social. Este enfoque puede adaptarse a las condiciones específicas de América Latina en la actualidad.

Los objetivos e instrumentos de la política económica varían de acuerdo con el sistema socioeconómico. En consecuencia, sería peligroso continuar aplicando las políticas que condujeron a la sucesión de crisis derivadas de una descuidada liberalización, especialmente de las finanzas, o volver a las políticas posteriores a la Segunda Guerra Mundial sin actualizarlas. ¿Cuáles podrían ser los principios de una política para el siglo XXI y el desarrollo? En primer lugar, es necesario reconocer que la estabilización de la inflación por medio de una política monetaria prudente no garantiza la estabilidad financiera, sino que es imprescindible regular las finanzas. Fuera del pleno empleo, el desempleo es involuntario, por lo que las políticas monetaria y fiscal pueden afectar el nivel de actividad. En los casos de depresión, el gasto público recupera su eficacia en la reducción del desempleo. La determinación del tipo de cambio no puede ser delegada a los movimientos de entrada y salida de capitales a corto plazo, ya que debe permitir la inserción de la economía nacional en el sistema internacional mediante un modelo de producción eficiente. Por último, si el juego de 
la política no permite una reinstitucionalización de la distribución del ingreso, se requiere una tributación progresiva de la renta y el capital.

El mundo atravesó un período de grandes transformaciones de las economías, las sociedades y las relaciones internacionales, pero las grandes teorías heredadas del pasado solo las analizan de manera imperfecta. A largo plazo, el capitalismo y sus teorías deberían cambiar en conjunto. Sin embargo, casi todos los economistas basan sus análisis en teorías que están desactualizadas - la neoclásica está atrasada un siglo, la keynesiana 50 años y la regulacionista una década-, por lo que deben ser prudentes al evaluar y juzgar la coyuntura económica actual y al asesorar a los políticos. Por esta razón, se propone en el presente artículo una visión global que pueda plasmarse en teorías, luego en modelos abstractos y finalmente en modelos aplicados, los que serían útiles para tomar decisiones en términos de política económica, social y estrategias de largo plazo. El mundo contemporáneo ha experimentado un cambio tan profundo que las teorías del pasado han perdido vigencia. Es de esperar que se abra un período de grandes teorizaciones, equivalente a la década de 1930. 


\section{Bibliografía}

Aglietta, Michel (1982), A Theory of Capitalist Regulation: The US Experience, Nueva York, Schocken Books.

Amable, Bruno (2003), The Diversity of Modern Capitalism, Oxford, Oxford University Press.

Amable, Bruno, Robert Boyer y Rémi Barré (2008), Los sistemas de innovación en la era de la globalización, Madrid, Miño y Davila.

André, Christine (2003), "Ten European systems of social protection: an ambiguous convergence", European Social Security and Global Politics, Danny Pieters (ed.), Londres, Kluwer Academic Publishers.

André, Christine y Robert Delorme (1983), "Matériaux pour une comparaison internationale des dépenses publiques", Statistiques et Etudes Financières, № 350. (1982) L'état et l'économie, París, Seuil.

Artus Patrick (2009), "Le problème essentiel pour la régulation financière et pour le système monétaire international: la finance procyclique", Flash économie, $\mathrm{N}^{\circ} 155$, París, Natixis, 3 de abril.

Bizberg, Ilan y Theret Bruno (2012), "La diversité des capitalismes latino-américains: les cas de l'Argentine, du Brésil et du Mexique", Revue de la régulation, $\mathrm{N}^{\circ} 11$ [en línea] http:/ / regulation.revues.org.

Boschi, Renato (2009), "Estado desarrollista en Brasil: crisis, continuidad, incertidumbres", documento de trabajo, Instituto Universitario de Investigación de Río de Janeiro (IUPERJ), inédito.

Boyer, Robert (2014), "Is more equality possible in Latin America?", A Challenge in a World of Contrasted but Interdependent Inequality Regimes, Berlín. (2013a), "Financial innovations, growth and crisis. The subprime collapse in perspective", Crises of Global Economies and the Future of Capitalism. Reviving Marxian Crisis Theory, Yagi Kiichiro y otros (eds.), Routledge, Abingdon.

(2013b), "Origins and ways out of the euro crisis: supranational institution building in the era of global finance", Contributions to Political Economy, vol. 32, 7 de junio [en línea] http:/ / cpe.oxfordjournals.org.

(2012a), "Diversité et évolution des capitalismes en Amérique latine. De la régulation économique au politique", Revue de la régulation, vol. 11 [en línea] http:/ / regulation.revues.org/9720.

(2012b), "The four fallacies of contemporary austerity policies: the lost Keynesian legacy", Cambridge Journal of Economics, vol. 36.

(2011a), "A new epoch but still diversity within and between capitalism. China in comparative perspective", Capitalist Diversity and Diversity within Capitalism, Christel Lane y Geoffrey T. Wood (eds.), Routledge, Abingdon. (2011b), Diversity and Transformations of Asian Capitalisms, Hiroyasu Uemura y Akinori Isogai (eds.), Londres, Routledge.

(2011c), "Aprender de las crisis financieras. Cómo organizar sistemas financieros domésticos desarrollistas?", Las instituciones financieras y el crecimiento económico en el contexto de la dominación del capital financiero, Noemi Levy Orlik y Teresa López González (coords.), México, D.F., Universidad Nacional Autónoma de México (UNAM). (2011d), Les financiers détruiront-ils le capitalisme ?, París, Economica. (2004) "Du 'consensus de Washington' à la 'proposition de São Paulo'?", Mondialisation et compétition: pourquoi certains pays émergents réussissent et d'autres non, Luiz Carlos Bresser-Pereira, París, La Découverte. (2000), "Is a finance-led growth regime a viable alternative to Fordism? A preliminary analysis", Economy and Society, vol. 29, $\mathrm{N}^{\circ} 1$, febrero. 
Boyer, R. (1986a), La théorie de la régulation: une analyse critique, París, la Decouverte.

Boyer, Robert e Yves Saillard (eds.) (2001), Regulation Theory: The State of Art, Londres, Routledge.

Boyer, Robert, Mario Dehove y Dominique Plihon (2004), "Les crises financières", Rapport du CAE, $\mathrm{N}^{\circ}$ 50, París, La documentation Française.

Bresser-Pereira, Luiz Carlos (2009), Pourquoi certains pays émergents réussissent et d'autres non, París, La Découverte.

Campbell John, John Hall y Ove K. Pedersen (2008), National Identity and the Varieties of Capitalism. The Danish Experience, Copenhague, DJOF publishing.

CEPAL (Comisión Económica para América Latina y el Caribe) (2012a), Cambio estructural para la igualdad. Una visión integrada del desarrollo(LC/G.2524(SES.34/3)), Santiago de Chile. (2012b), Panorama de la Inserción Internacional de América Latina y el Caribe, 2011-2012 (LC/G.2547-P), Santiago de Chile, octubre. Publicación de las Naciones Unidas, $\mathrm{N}^{\mathrm{o}}$ de venta: S.12.II.G.5.

Dosi, Giovanni (2008), "Schumpeter meeting Keynes: a policy friendly model of endogenous growth and business cycles", LEM Paper Series, $\mathrm{N}^{\circ} 21$, Santa Ana School of Economics.

Duflo, Esther (2011), "Balancing growth with equity: the view from development", documento presentado en el Simposio Jackson Hall 2011, Wyoming, 1 de agosto.

Fukuyama, Francis (1992), The End of History and The Last Man, Nueva York, Free Press.

Galbraith, James K. (2012), Inequality and Instability. A Study of the World Economy Just before the Great Crisis, Oxford, Oxford University Press.

Harada, Yuji y Hironori Tohyama (2012), “Asian capitalisms: institutional configurations and firm heterogeneity", Diversity and transformations of Asian Capitalisms, Boyer Robert, Hiroyasu Uemura y Akinori Isogai (eds.), Londres, Routledge.

Jiménez, Juan Pablo e Isabel López Azcúnaga (2012), “¿Disminución de la desigualdad en América Latina? El rol de la política fiscal", Working Paper Series, $\mathrm{N}^{\circ}$ 33, Berlín, desiguALdades.net/Frei Universität.

Lavinas, Lena (2012), "Brasil, de la reducción de la pobreza al compromiso de erradicar la miseria", Revista CIDOB d'Afers Internacionals, № 97-98, abril.

López Gallardo, Julio (2005), "Income distribution in Latin America. Theoretical considerations and Mexico's experience", Economie Appliquée, vol. 58, N³.

Milanovic, Branko (2012), "Global income inequality by the numbers: in history and now", Policy Research Paper, N 6259, Banco Mundial, noviembre.

(2007), "Globalization and inequality", Global Inequality, Held David y Ayse Kaya, Cambridge, Polity Press.Pedersen, Ove (2008), "Corporatism and beyond: the negotiated economy", National Identity and the Varieties of Capitalism. The Danish Experience, John Campbell, John Hall y Ove K. Pedersen, Copenhague, DJOF publishing.

Piketty, Thomas (2013), Le capital au XIXe siècle, París, Seuil.

Prebisch, Raúl (1981), Capitalismo periférico, crisis y transformación, México, D.F., Fondo de Cultura Económica.

Samuelson, Paul A. (1948), Economics: An Introductory Analysis, McGraw-Hill.

Stiglitz, Joseph E. (2012), The Price of Inequality. How Today's Divided Society Endangers our Future, Londres, WW. Norton \& Company.

Telo, Carlos (2012), Sobre la desigualdad en México, México, D.F., Facultad de Economía, Universidad Nacional Autónoma de México (UNAM).

UNRISD (Instituto de Investigaciones de las Naciones Unidas para el Desarrollo Social) (2010), Combating Poverty and Inequality. Structural Change, Social Policy and Politics, Ginebra. Visser, J. y A. Hemerijck (1997), 'A Dutch Miracle' - Job Growth, Welfare Reform and Corporatism in the Netherlands, Amsterdam University Press. 
Capítulo XI

\section{Transformación del Estado y paradigmas de desarrollo en América Latina}

René A. Hernández

\section{Introducción}

En el presente ensayo se esboza la relación entre los retos asociados a la transformación del Estado y la evolución de los diferentes paradigmas y estrategias de desarrollo que se han aplicado en América Latina. Se intenta desmitificar el falso dilema de las concepciones que contraponen de forma excluyente la función del Estado con el papel del mercado en la actividad económica. En particular, se trata de esclarecer si, como sugiere O'Donnell (2008a), cualquier paradigma de desarrollo y estrategia conexa suponen decidir y adoptar una postura sobre los límites del Estado y la política pública. Además, se procura rescatar un elemento que parece esencial en la cosmovisión de la ideas de Prebisch para nuestros días, y en especial para América Latina, a saber, su concepción balanceada entre las medidas intervencionistas y el respeto al mercado, junto con su elevado pragmatismo, siempre centrados en la necesidad de mantener la mirada atenta al cambiante orden internacional o al desarrollo del mundo en general. 
Se debe advertir que en el presente ensayo no se intenta presentar una historia formal de los paradigmas de desarrollo de la región ni realizar un análisis epistemológico del desarrollo latinoamericano en la historia del pensamiento económico. Como señala Ocampo (2008), no existe una historia del pensamiento económico latinoamericano propiamente dicha. Sí se desea presentar algunas ideas interpretativas entre los distintos paradigmas de desarrollo y el papel del Estado y vincular en cada línea de interpretación el pensamiento de Prebisch y su relevancia para el debate posdesarrollista actual ${ }^{1}$.

El texto se divide en cinco partes, además de la introducción. En la segunda parte se examinan los conceptos centrales del debate entre Estado y desarrollo económico y se vinculan con los textos principales de la Comisión Económica para América Latina y el Caribe (CEPAL) sobre el tema. En la tercera parte se repasan los principales paradigmas y los elementos fundamentales de su caracterización. En la cuarta parte se incorpora la vigencia de las ideas de Prebisch y su influencia en el pensamiento económico latinoamericano. En la última parte se exponen los comentarios y reflexiones finales.

\section{A. Sobre los conceptos de Estado y desarrollo: algunas aproximaciones}

La relación entre Estado y desarrollo puede llegar a establecerse al menos de dos maneras. La primera se basa en un enfoque de economía política, a partir de una postura teórica o histórica. La segunda se fundamenta en alguna de las teorías del Estado, como la teoría orgánica, la contractualista, la institucionalista, la marxista original, la de Gramsci y Poulantzas o la weberiana. Al estudiar el desarrollo se puede seguir un camino similar, es decir, asumir una postura teórica o histórica y recurrir a alguna de las teorías clásicas, neoclásicas, estructuralistas, neoestructuralistas o evolucionistas del crecimiento económico y el desarrollo.

En el presente ensayo se adopta una teoría institucionalista para justificar la intervención estatal en un contexto de cambio estructural. Se establecen proposiciones estilizadas y se plantean definiciones y

\footnotetext{
Como referencia, se recomienda consultar los textos clásicos de Bulmer-Thomas (2011) sobre historia económica de América Latina, a Sunkel y Paz (1970), Thorp (1998), o el reciente texto de Bértola y Ocampo (2013) sobre el desarrollo económico latinoamericano desde los procesos de independencia. Sobre la evolución del pensamiento de la CEPAL y el estructuralismo latinoamericano, no se pueden pasar por alto a Rodríguez (2006), Rosenthal (2004), Bielschowsky (1998a, 1998b y 2010) o Love (1994), por nombrar algunos de los más sobresalientes. En cuanto a la renovación del pensamiento de la CEPAL desde los años ochenta, llamado también "neoestructuralismo", véase la recopilación de Sunkel (1991), Ffrench-Davis (2005), Ocampo y Ros (2011), Ocampo (2008), Stallings y Peres (2000) y Fajnzylber (1993).
} 
aclaraciones conceptuales que, a su vez, permiten establecer el vínculo entre Estado y desarrollo. Posteriormente se revisan los aportes centrales de la CEPAL en esa esfera por medio de algunos de sus textos institucionales y, por último, se rescatan las ideas de Prebisch sobre la temática para llegar a una aproximación de la vigencia de sus ideas en el debate contemporáneo.

\section{Sobre el concepto de Estado: proposiciones básicas}

La primera proposición del presente ensayo consiste en reconocer que el Estado y su economía política son variables determinantes del desarrollo económico y social. La dimensión política se incluye debido al supuesto básico de que hay un interés común y compartido por todos (el bien común). Las soluciones propuestas al dilema Estado-mercado y al reto del desarrollo han sido diversas, desde la izquierda populista hasta la izquierda progresista, y desde la centroderecha pragmática hasta la derecha neoliberal y la centroizquierda moderna. Todos los cambios de paradigmas de los siglos XX y XXI se han enmarcado en el eje de acumulación capitalista mundial y explican, en buena medida, los vaivenes del desarrollo económico y social de la región.

El mercado equilibrado y eficiente de los neoclásicos ha sido cuestionado desde la Gran Depresión de los años treinta, luego con la crisis de la deuda de los años ochenta y, más recientemente, a raíz de la crisis financiera internacional de 2008. Ahora, incluso los neoliberales más vehementes aceptan como inevitables algunas formas de intervención estatal, debido no solo a la presencia de externalidades, sino a la ubicuidad de los mercados incompletos, la información asimétrica y el incipiente desarrollo institucional ${ }^{2}$. El falso dilema entre Estado y mercado debe descartarse a favor de la relación correcta de estudio: el papel del Estado en el mercado.

La segunda proposición se refiere a que el Estado en su concepción más amplia es una construcción institucional y, por ende, una variable explicativa fundamental de por qué unos países son más ricos que otros (Chang, 2003). Para abordar ese tema, no solo es preciso adoptar una teoría del Estado, sino hacerlo a partir de un análisis de la dinámica institucional y una teoría del cambio institucional. Ello implica dar el paso para

\footnotetext{
El elemento central de la polémica del neoliberalismo sobre este tema se relaciona con el "Estado de bienestar" por el supuesto debilitamiento de las instituciones que ocurriría como resultado de prácticas clientelistas que llevarían a la postre al totalitarismo o, como lo llamó Hayek, a un "camino de servidumbre". Asimismo, Milton Friedman señala en Free to Choose que "la libertad económica es un requisito esencial de la libertad política. Al permitir que las personas cooperen entre sí sin la coacción de un centro decisorio, la libertad económica reduce el área sobre la que se ejerce el poder político. Además, al descentralizar el poder económico, el sistema de mercado compensa cualquier concentración de poder político que pudiera producirse. La combinación de poder político y económico en las mismas manos es una fórmula segura para llegar a la tiranía".
} 
redefinir lo público y construir o reconstruir instituciones cimentadas en el bien general y en algo distinto a la sumatoria de intereses particulares. Sobre ese aspecto, North (1990) señala: "Quiero atribuir un papel mucho más fundamental a las instituciones en las sociedades; son el determinante subyacente del desempeño de las economías. Si queremos construir una teoría dinámica del cambio (algo que falta en la corriente principal de la economía y que fue tratado muy imperfectamente en la teoría marxista), debe construirse un modelo de cambio institucional".

El reconocimiento del rol del Estado en el proceso de desarrollo se ha dado a medida que se ha redescubierto el papel de las instituciones en el desempeño económico de las naciones. Los trabajos seminales de O. Williamson (1985), The Economic Institutions of Capitalism, y de D. North (1990), Institutions, Institutional Change and Economic Performance, se constituyen en referencias fundamentales al poner en duda el supuesto de que las instituciones se generan de manera espontánea y son un subproducto del crecimiento económico cuando, en realidad, las mejoras institucionales son las precondiciones esenciales y determinantes del crecimiento. Más recientemente, Rodrik (2002, 2004, 2007), Chang (2003) y Acemoglu y Robinson (2012) han llegado a aproximaciones similares y argumentan que las instituciones son la principal variable explicativa de por qué unas naciones son más ricas que otras y por qué algunas fracasan en su búsqueda de mayor bienestar, crecimiento y desarrollo económico.

La teoría institucionalista ha ido ganando terreno $y$ se ha consolidado como una alternativa interpretativa del papel del Estado en el proceso de desarrollo. En particular, señala que el éxito de una economía depende de un conjunto de instituciones, entre las que figura el mercado. Además, reconoce que las instituciones que no son de mercado, como las redes empresariales, los sindicatos y las empresas transnacionales, los sistemas nacionales de innovación, las políticas industriales y el corporativismo social son elementos clave de esa amplia matriz. La intervención estatal se justifica en un contexto de cambio estructural que implica, a su vez, transformaciones profundas de la estructura productiva, la tecnología y las instituciones. El Estado desempeña dos funciones en la facilitación de este cambio estructural: i) proveer una visión de futuro a largo plazo y de construcción de nuevas instituciones, y ii) mediar en la resolución de los conflictos que surgen a menudo durante el proceso de cambio estructural (Chang, 2003).

La tercera proposición es que el Estado en América Latina tiende a ser social-liberal y cada vez más democrático, con diversas interpretaciones del capitalismo globalizado y una integración comercial y regional creciente. La dimensión social responde a que los Estados siguen y seguirán asumiendo la responsabilidad en cuanto a la protección 
de derechos sociales como la salud, la educación y la previsión social. Por ejemplo, después de la crisis de 2008, los planes adoptados por la gran mayoría de los países de la región tuvieron como ejes de acción la atención a los sectores vulnerables, la mitigación de la caída del empleo y la restitución del entramado productivo, con miras a frenar una posible erosión de los logros alcanzados en la década anterior en materia de lucha contra la pobreza y reducción de la desigualdad del ingreso.

La dimensión liberal del Estado en América Latina se aprecia en la forma de llevar a cabo las funciones del Estado, que se realizan de manera más competitiva, con mayor transparencia y mejores mecanismos de rendición de cuentas, evitando el monopolio de la burocracia estatal en las partidas presupuestarias de educación, salud e infraestructura. El Estado social-liberal no sustituye el mercado, sino que lo complementa (Bresser Pereira, 1998).

Por esas razones, en lugar de enfocarse en aspectos normativos sobre cuál debería ser la función "correcta" del Estado según las distintas vertientes del conservadurismo y el liberalismo social, o del neoliberalismo y algunas formas de radicalismo, resulta mucho más interesante indagar sobre las razones subyacentes que explican por qué algunos Estados tienen una propensión más desarrollista que otros. En última instancia, lo que se espera de cualquier Estado es que sea aceptablemente efectivo, legítimo, representativo, capaz de concertar pactos políticos, económicos y sociales de alcance nacional, socialmente responsable, capaz de construir visiones de largo plazo y, sobre todo, capaz de mantener la gobernabilidad y gobernación con una fuerte vocación desarrollista ${ }^{3}$.

Antes de avanzar en el análisis de la relación entre Estado y desarrollo económico es necesario hacer algunas aclaraciones y definiciones importantes y, al mismo tiempo, contextualizarlas en América Latina y el Caribe $^{4}$. Gran parte de la región cuenta hoy con regímenes y gobiernos democráticos, que presentan diferentes grados de madurez y eficiencia $\mathrm{y}$, a la vez, adolecen de importantes fallas y limitaciones. En la práctica latinoamericana, no existe el "Estado óptimo" o "Estado prototipo" ni un modelo político único y dominante. En ese contexto político es que deben desarrollarse los debates sobre paradigmas, estrategias y modelos de desarrollo, sobre procesos y cambios democráticos y, fundamentalmente, sobre el papel y los límites del Estado (O’Donnell, 2008a).

Bresser Pereira (1998) sostiene que existe gobernabilidad cuando el gobierno tiene una legitimidad asegurada por instituciones políticas capaces de representar e intermediar intereses sectoriales legítimos, y que existe gobernación cuando el Estado tiene capacidad financiera y administrativa para ejercer las políticas decididas por el gobierno.

4 Véase en ILPES (1995) la mejor colección de ensayos sobre reforma y modernización del Estado de esa década. 
O'Donnell (2008a) define el régimen democrático como "la realización regular e institucionalizada de elecciones libres, institucionalizadas y razonablemente competitivas, así como la vigencia de algunas libertades 'políticas', tales como las de opinión, expresión, asociación, movimiento, acceso a medios periodísticos no monopolizados y similares. En estas esferas se ejercen dos derechos fundamentales: uno, votar libremente en la elección de quienes habrán de ocupar posiciones en la cúpula del Estado (los gobiernos), y otro, si así se desea intentar, ser electo o electa para ocupar los respectivos cargos".

Además, O'Donnell (2008a) define el Estado como un conjunto de instituciones y de relaciones sociales (la mayor parte sancionadas y respaldadas por el sistema legal de ese Estado) que normalmente penetra y controla el territorio y los habitantes que se pretende delimitar geográficamente. Esas instituciones tienen como último recurso, para hacer efectivas las decisiones que toman, la supremacía en el control de los medios de coerción física que algunas agencias especializadas del mismo Estado normalmente ejercen sobre aquel territorio ${ }^{5}$.

En el caso latinoamericano, los Estados han surgido a partir de procesos históricos muy diferentes entre sí. Tales diferencias no pueden ser ignoradas y en gran medida explican la adopción y adecuación de distintos "estilos de desarrollo", ritmos dispares en sus procesos de desarrollo democrático, progresos desiguales en el plano institucional y avances diferenciados en la lucha contra la pobreza y la desigualdad ${ }^{6}$.

Por otra parte, los Estados son entidades cambiantes y dinámicas, que se adaptan y transforman ante el entorno nacional e internacional. Logran progresos pero también sufren retrocesos. No son inmutables $\mathrm{y}$, en última instancia, son organizaciones sociales conformadas por instituciones que pueden llegar a ser débiles o fuertemente constituidas y

\footnotetext{
5 Nótese que esta definición de corte weberiano se refiere a lo que el Estado es, y no a la amplísima gama de definiciones sobre lo que hace o debe hacer. El análisis no es solamente sobre el Estado, sino sobre Estados que son o se autoproclaman nacionales. Siguiendo a O'Donnell (2008b), la nación no precede al Estado, sino que este se esfuerza por crearla. Define la nación como "un arco de solidaridades, una construcción política e ideacional que postula la existencia de un 'nosotros' que entraña un reclamo de lealtad por encima y más allá de otras entidades e intereses y que, si ya no lo tiene, frecuentemente busca asentarse o definirse en un territorio delimitado por un Estado".

6 Aníbal Pinto (2008) define el "estilo de desarrollo" como el modo en que, "dentro de un determinado sistema, se organizan y asignan los recursos humanos y materiales con el objeto de resolver los interrogantes sobre qué, para quiénes y cómo producir los bienes y servicios". Específicamente, distingue dos conjuntos de rasgos: i) los que componen la base estructural de la organización productiva, en especial la estructura sectorial del producto y del empleo, los diversos estratos tecnológicos y el tipo de relacionamiento externo predominante, y ii) los elementos dinámicos del sistema, que se revelan a partir del análisis del nivel y composición de la demanda y de sus antecedentes, es decir, el nivel y la distribución del ingreso. Según ese concepto, ambos conjuntos de rasgos están íntimamente vinculados por medio de un círculo de causalidad acumulativa (Cardoso y Faletto, 1979; Cardoso, Prebisch y Green, 1982).
} 
enraizadas en el constructo social. En ese sentido, cualquier generalización sobre el Estado resulta aventurada y cualquier prescripción, demasiado simplista (O’Donnell, 2008b).

Según esa definición, el Estado puede explicarse a partir de cuatro dimensiones. En primer lugar, podría verse como un conjunto de burocracias, compuesta por organizaciones complejas que tienen legalmente asignadas responsabilidades tendientes a resguardar $\mathrm{o}$ proteger algún aspecto del interés público general7. En segundo lugar, podría ser un sistema legal compuesto por reglas legalmente establecidas y sancionadas que inciden en las relaciones y contratos sociales. En tercer lugar, podría considerarse una unidad de identidad colectiva para los habitantes de su territorio, es decir un Estado desde la perspectiva de su pueblo. Por último, el Estado puede ser un decantador o tamiz que regula el espacio y frontera del territorio, la población y el mercado que delimita. En síntesis, la definición se refiere a la eficiencia de las burocracias estatales, la efectividad del sistema legal, el papel del Estado como eje de identidad y su condición de tamiz para regular el espacio y el territorio ( $\mathrm{O}^{\prime}$ Donnell, 2008a, 2008b).

El cambio de paradigma al que se enfrenta América Latina desde hace algunos años, como todos los cambios de su tipo, no es tan perceptible ni reconocido, debido al rezago de las instituciones del Estado en lo que respecta a acoger o concretar los cambios en las formas de "ser y hacer" las cosas. La necesidad transformativa surge porque las evidentes mutaciones de la sociedad aún no tienen suficiente correlato con los cambios en las instituciones, y tampoco se aplican respuestas integrales a las problemáticas sociales, económicas y ambientales. La globalización, la profunda revolución tecnológica y los recientes paradigmas tecnoeconómicos, el avance científico, pero también la presión sobre el medio ambiente, los cambios demográficos, las migraciones, los desastres naturales, el cambio climático y las disparidades territoriales, son algunas de las dimensiones que están experimentando cambios y representan algunas de las brechas más importantes en la actualidad, sin que todavía existan ni se hayan consolidado las instituciones capaces de afrontar $\mathrm{u}$ orientar esas transformaciones. En consecuencia, las demandas de mayor igualdad, más oportunidades para un mayor número de personas, mejor y mayor participación en las decisiones políticas, mayor transparencia, entre otras, siguen tan vigentes como antes en la agenda pública.

En ese contexto, la burocracia se define como "un conjunto de relaciones sociales de comando y obediencia que está jerárquicamente pautado por reglas formales y explícitas, vigentes en el seno de una organización compleja" (O'Donnell, 2008b). 
La caracterización sobre la situación actual de los Estados de América Latina es que enfrentan un gran déficit y son reflejo de las profundas contradicciones, la heterogeneidad estructural, la larga historia de desigualdades e inequidades, las convulsas trayectorias políticas y las reformas fiscales inconclusas que han caracterizado a la región. Son Estados que carecen de suficiente credibilidad en su papel de proveedores de bienes públicos, recaudadores fiscales, garantes de la protección social y promotores de la productividad y el empleo. Sin embargo, desde la ciudadanía misma surge un creciente clamor que exige un papel cada vez más central para el Estado (CEPAL, 2010).

La ecuación Estado-mercado que prevalece desde hace tres décadas se ha mostrado incapaz de responder a los desafíos globales de hoy y de mañana. Por lo tanto, se plantea el reto de colocar al Estado en el lugar que le corresponde de cara al futuro. El debate debe centrarse en el propio modelo y orientación del desarrollo, en el sujeto y fin último del desarrollo y en los medios para alcanzarlo.

\section{Sobre el concepto de desarrollo y las formas de pensar en el tema}

Existen básicamente dos formas de concebir el desarrollo. La primera y más intuitiva es como un cambio en las condiciones de vida de las personas, junto con los procesos necesarios para lograrlo. A esto se asocian los conceptos de progreso, prosperidad y bienestar ${ }^{8}$. El papel de los actores, instituciones y organismos en este proceso es lo que se denomina visión estratégica del desarrollo. En ese sentido, el desarrollo se ve como el resultado de un proceso en que intervienen actores, organismos y medios para alcanzar un conjunto de metas previamente establecidas. Según la narrativa de Hirschman (1980), una estrategia de desarrollo debe buscar "más que la combinación eficaz de recursos escasos, la potenciación y utilización de las capacidades ocultas y diseminadas en la sociedad, en un esfuerzo colectivo encauzado por el desarrollo".

La segunda forma de aproximarse al concepto de desarrollo es más cercana a la idea weberiana de la historia del cambio social y no lo concibe como el resultado de una estrategia, política o acción pública deliberada, sino del funcionamiento de un sistema compuesto por su estructura institucional y social (Veltmeyer, 2010). De hecho, cualquier "desarrollo" puede definirse a partir de sus factores estratégicos o estructurales, y cualquier política pública, independiente de su origen o concepción, tiene una dimensión estratégica y otra estructural.

Nótese que el concepto de desarrollo no ha sido el mismo a lo largo del tiempo, como se verá más adelante (Veltmeyer, 2010). Véase una exposición notable sobre factores estructurales y modalidades del desarrollo en los ensayos clásicos de Aníbal Pinto (1973). 
La idea de libertad o "desarrollo como libertad" en la formulación de Sen (1999) se basó en la filosofía del liberalismo social y puede verse como la fusión de las ideas de progreso, igualdad y libertad. En ese contexto, el desarrollo se entiende sobre todo como un asunto de libertad que amplía las opciones disponibles para los individuos y los estimula a aprovechar sus oportunidades, es decir, como el proceso de expansión de las libertades reales de que goza un pueblo. El papel del Estado consiste en nivelar el campo de juego, reformar las instituciones, asegurar una mayor inclusión social y elevar las capacidades del capital humano con miras al aprovechamiento de las oportunidades, por ejemplo, las de educación.

En el primer Informe sobre Desarrollo Humano del Programa de las Naciones Unidas para el Desarrollo (PNUD) se define el "desarrollo humano sostenible" como el proceso de ampliar las habilidades y las opciones de las personas de manera que sean capaces de satisfacer sus propias necesidades.

En América Latina, y en el marco de las corrientes estructuralistas, el desarrollo consistía en la incorporación del progreso técnico y su difusión en el aparato productivo y social con el fin de alterar la estructura productiva, como parte de un proceso acumulativo de largo aliento. Ese proceso incluía capacidades, organización del Estado, capital, tecnología y sinergias y complementariedades entre lo público y lo privado?. El desarrollo se daba en un espacio y tiempo y, como señaló hace más de dos décadas el profesor Sunkel (1991), el único desarrollo posible es "desde dentro", es decir, se trata ante todo de un proceso endógeno que no se puede importar.

En términos estructurales, siguiendo la tipología de Veltmeyer (2010), el proceso de desarrollo como "cambio a largo plazo" en la evolución a gran escala de las sociedades se ha conceptualizado y periodizado sobre la base de tres "metateorías". La primera se centra en la transformación de la sociedad y la economía agrarias en un sistema industrial, cuyo proceso, en términos genéricos, podría considerarse de "industrialización". En ese contexto, es posible ubicar a los países en tres categorías, según su grado de evolución: i) preindustrial (agrario); ii) en proceso de industrialización, e iii) industrializado. Uno de los supuestos fundamentales de esta metateoría es que el nivel de mejoramiento socioeconómico sería una consecuencia de ese cambio de la estructura de producción económica.

En sus textos de los años cincuenta, Prebisch señala que la estructura productiva está compuesta por los sectores productores de bienes, mientras que a la estructura económica se añaden la infraestructura física y los sectores de servicios (incluso los que presta el gobierno). Por consiguiente, según la narrativa de Prebisch, las características de la estructura productiva condicionan las de la estructura económica. 
La segunda metateoría concibe el proceso de desarrollo en términos de una transformación fundamental de la estructura de valores que sostiene la estructura institucional del sistema. De esta manera, las sociedades pueden caracterizarse como tradicionales, modernizantes o modernas. La evolución del sistema, o la transformación de un sistema en otro, puede concebirse como la transición de una sociedad de tipo tradicional (orientada hacia valores de tipo comunitario, de ayuda mutua y solidaridad) a un sistema moderno orientado hacia un individualismo en que las personas buscan alcanzar determinada posición, en lugar de actuar en función de las necesidades de la sociedad.

La tercera metateoría es la del desarrollo capitalista, es decir, la transformación de una sociedad y una economía precapitalista en un sistema capitalista. Según esa concepción, el cambio fundamental es consecuencia de un proceso de transformación social, es decir, de una sociedad de productores agrícolas a pequeña escala (campesinos y pequeños agricultores) en un proletariado, definido según los conceptos marxistas como una clase social que carece de medios de producción, por lo que se ve obligada a intercambiar su fuerza de trabajo por un salario para vivir.

Las tres metateorías del desarrollo basadas en el cambio a largo plazo (industrialización, modernización y desarrollo capitalista) bien podrían interpretarse como tres dimensiones o puntos de partida diferentes del mismo proceso, es decir, la "gran transformación" según la narrativa de Karl Polanyi (1944), donde la economía de mercado y el Estado no deben entenderse como elementos o instituciones separadas, sino como una creación humana de carácter conjunto que Polanyi denomina sociedad de mercado. Este proceso ha tomado varios siglos y sigue ocurriendo en el mundo en desarrollo.

\section{El Estado y el desarrollo en los documentos de la Comisión Económica para América Latina y el Caribe}

No se pretende hacer una reseña de todos los documentos institucionales de la CEPAL sobre la relación sobre Estado y desarrollo, pues resulta innecesario para los fines planteados. Se busca más bien destacar los documentos que, por su importancia y pertinencia, marcaron un antes y un después en el debate sobre el papel del Estado en el desarrollo latinoamericano ${ }^{10}$. La intención es aprovechar la oportunidad en exhibir la vitalidad y actualidad de las ideas de Prebisch en el marco del debate contemporáneo sobre el papel del Estado en el desarrollo.

10 La mejor exposición sobre el pensamiento económico de la CEPAL se encuentra en Bielschowsky (1998b, 2010), Rodríguez (2006), Rosenthal $(1998,2004)$ y Love (1994). Véanse además, sobre el pensamiento de Prebisch, Dosman (2006, 2010), Pérez Caldentey, Sunkel y Torres (2013), Love (1980), Rodríguez (2001) e Iglesias (2003). 
El pensamiento de la CEPAL se caracteriza por aplicar un método histórico-estructural y desarrollar tres ejes analíticos que han permanecido a lo largo de su producción intelectual: i) el análisis de la inserción internacional; ii) el análisis de las condicionantes estructurales internas del crecimiento y del progreso técnico, así como de las relaciones entre ellos y el empleo y la distribución del ingreso, y iii) el análisis de las posibilidades de acción estatal ${ }^{11}$.

El primer documento es sin duda "El desarrollo económico de América Latina y sus principales problemas" (Prebisch, 1949), considerado por Albert Hirschman como el manifiesto latinoamericano. Fue la obra que sentó las bases teóricas y conceptuales de un modelo de subdesarrollo liderado por el Estado y esbozado por Prebisch a partir de una crítica a la teoría del comercio internacional (Pérez Caldentey, Sunkel y Torres, 2013).

El genio del "manifiesto" fue la capacidad de moldear una síntesis única y convincente por medio del examen de los principales determinantes de la actividad económica de los países en desarrollo. Se propone el concepto de "centro-periferia" de la economía mundial para explicar la dinámica y estructura de la desigualdad mundial. El desarrollo, según Prebisch, implicaba adoptar una postura y, en consecuencia, el "manifiesto" se pronunciaba por un Estado activo donde la industrialización de la periferia no era un fin en sí mismo, sino el medio por el que los países en desarrollo podían acceder a los beneficios del progreso técnico y de esa manera, elevar progresivamente el nivel de vida de sus habitantes. Esa perspectiva de industrialización se contraponía a la doctrina dominante de las ventajas comparativas y presentaba una opción para América Latina desde América Latina (Dosman, 2001; Rodríguez, 2001; Bielschowsky, 2010).

Puesto que no se esperaba que ese proceso se diera de forma espontánea (debido a las limitaciones de capital extranjero o nacional), se inferiría que solamente lo podría generar y liderar el único agente de la periferia capaz de hacerlo de forma deliberada con el fin de alterar la estructura productiva de las economías periféricas: el Estado. La implicación práctica en las décadas siguientes fue el amplio uso de la capacidad del Estado para liderar el proceso de desarrollo industrial, así como promover la planificación y la inversión para generar un crecimiento

11 Según Bielschowsky (2010), el método histórico-estructural está “dedicado al examen de las especificidades productivas sociales, institucionales y de inserción internacional de los países de América Latina y el Caribe, en su carácter de 'periféricos', examinadas en contraposición con las características de las economías 'centrales', y observadas desde la perspectiva prioritaria de su transformación a mediano y largo plazo". Por su parte, Sunkel y Paz (1970) señalan que "el análisis relativo a la limitada aplicabilidad en el tiempo de las leyes económicas sugiere la necesidad de establecer hipótesis significativas para situaciones históricas concretas; en otras palabras, se reconoce la historicidad del objeto de la ciencia económica". 
más acorde con la función de preferencia social de las economías periféricas (Glade, 2003).

El segundo documento, bajo el título Crecimiento, desequilibrio y disparidades: interpretación del proceso de desarrollo económico, es una obra de cinco capítulos que conformó la primera parte del Estudio Económico de América Latina, 1949 (CEPAL, 1951). Ese documento reflejaba muchas de las ideas vertidas en la misma época por los pioneros de la teoría del desarrollo Nurske, Lewis, Myrdal y A. Rosenstein-Rodan, entre otros, quienes definieron junto con Prebisch lo que muchos años después Krugman llamó la "alta teoría del desarrollo".

Además de su crítica al esquema de inserción internacional y a la generación de vulnerabilidad externa en la periferia, Prebisch aborda en esos dos textos seminales los ingredientes esenciales de la escuela estructuralista latinoamericana, a saber: i) las condiciones iniciales de la estructura interna que, por su condición de subdesarrollo, dificultaba la industrialización y difusión del progreso técnico en la periferia, y ii) la validez de la intervención estatal debido a la complejidad inherente de dichas estructuras en el proceso de desarrollo (Bielschowsky, 1998a y 1998b; Rodríguez, 2006; Pérez Caldentey, Sunkel y Torres, 2013).

Como señalan Pérez Caldentey, Sunkel y Torres (2013): “Convencido de la imperiosa necesidad de crear un conjunto de ideas coherente para analizar y pensar de manera específica los fenómenos de América Latina, Prebisch construyó un pensamiento propio a partir de una visión del desarrollo económico y de la inserción internacional de la región; en otros términos, mediante un acto creativo, intuitivo e inductivo que precede y también es condición previa a la investigación analítica, Prebisch concibe intelectualmente la dinámica del proceso de desarrollo en la región".

Las propuestas de los textos mencionados adquieren madurez en los años siguientes y se consolidan en "Hacia una dinámica política de desarrollo para América Latina" (1963) y "El proceso de desarrollo industrial en América Latina" (1966). El elemento central de esos dos textos fue la elaboración analítica más amplia que recibió el papel del Estado en el proceso de desarrollo y sobre todo en su planificación. Uno de los avances importantes de esos documentos fue el posicionamiento de la empresa privada en la matriz social, el análisis sobre las políticas de redistribución y las reformas necesarias de los regímenes imperantes de tenencia de la tierra. Es de destacar que se apartaron del precepto ingenuo de intervención estatal y reconocieron tempranamente las limitaciones del Estado en determinadas circunstancias, debido a que ciertas intervenciones estatales podían dar lugar a distorsiones que incidirían en sentido contrario y de forma perversa en el proceso de desarrollo (Glade, 1993). 
En la década de 1970, los textos "Cambio y desarrollo" (1970) y "Empresas públicas: su significación presente y su potencial en el desarrollo" del Boletín Económico para América Latina (1971), fueron trascendentales porque delinearon de manera sistemática los procesos de intervención estatal mediante empresas estatales o públicas y enunciaron ampliamente la relación de dichos procesos con las fallas de mercado y las externalidades. Si bien se realizaron importantes contribuciones en el plano microeconómico y en la formulación de políticas públicas, aún no estaban demarcados los vínculos con el progreso técnico y la distribución del ingreso, con todos los mecanismos de transmisión, y faltaba elaborar una propuesta más acabada del proceso de transformación productiva.

Posteriormente, Fernando Fajnzylber, en La industrialización trunca de América Latina (1983) y Transformación productiva con equidad (1990), analizó cuatro elementos fundamentales. El primero se refiere a la estrategia de industrialización por medio de la exportación de productos industriales y los consecuentes efectos dinámicos en términos de creación de empleo, aumento de productividad y crecimiento de los salarios reales. Es decir, la consecución de una competitividad "auténtica" (basada en la incorporación de progreso técnico) en lugar de "espuria" (apoyada en la caída del ingreso real), propiciando una transformación productiva dinámica que conlleve una estrategia de crecimiento con equidad. En ese sentido, como señala Rodrik (2005), la exportación de productos industriales con procesamiento local contribuía a difundir la lógica industrial y de paso confirmaba la aseveración de Prebisch en el sentido de que la estructura económica es importante y lo que los países producen y exportan es un factor determinante en su desempeño económico.

El segundo aspecto, al referirse al desempeño de los tigres asiáticos, es que en esos países la política industrial y comercial se basó en un componente importante de sustitución de importaciones. En el tercer aspecto, relacionado con el papel del Estado, destacó su carácter no neutral y su vinculación y complementariedad con el sector empresarial. El último aspecto se refiere al contexto internacional en que operaron las experiencias industrializadoras de los tigres asiáticos.

A partir de la propuesta sobre transformación productiva formulada en 1990, la CEPAL continuó profundizando en el tema con el fin de extender los planteamientos del documento original. En el marco de ese esfuerzo se elaboran los documentos Equidad y transformación productiva: un enfoque integrado y Población, equidad y transformación productiva (CEPAL, 1992a y 1992b).

En 1995, el Instituto Latinoamericano y del Caribe de Planificación Económica y Social (ILPES) publica el texto Reforma y modernización del Estado y destaca que lo importante es la calidad y selectividad de las 
intervenciones del Estado, no solo la magnitud del aparato burocrático. De esa manera, se plantea el debate entre los límites de lo público y lo privado. Con ese esfuerzo, el ILPES hace un aporte sobresaliente y pionero al concluir que no existe un prototipo de Estado ni soluciones uniformes para el conjunto, las comunidades o los territorios dentro del mismo país, y propone tres grupos de funciones públicas emergentes de la reforma del Estado: i) tareas clásicas del gobierno: provisión de bienes públicos; administración de desequilibrios macroeconómicos y acumulación de capital social, físico y humano; ii) armonización, mediante la regulación gubernamental, de los intereses particulares frente a los intereses públicos y concertación de pactos y acuerdos al respecto, y iii) gestión estratégica y papel anticipador del Estado al construir visiones de futuro y de largo plazo con el fin de orientar la dinámica del proceso de desarrollo.

En el año 2000, la publicación Equidad, desarrollo y ciudadanía aborda de forma integral la multidimensionalidad del desarrollo y plantea nuevas formas de enfocar lo público, desde la perspectiva del Estado y a partir de una mayor promoción de la ciudadanía y la cohesión social. Comienza con un análisis del legado de los años noventa y luego ofrece una visión global sobre temas relativos a la equidad: i) los principios de la política social y la lucha contra la pobreza; ii) el desarrollo educativo, el empleo y la seguridad social; iii) el gasto público social, y iv) las metas en materia de cobertura de servicios sociales. Además, trata temas económicos, vistos desde sus dimensiones sociales y de desarrollo sostenible. Aborda con notable fluidez la estabilidad y el crecimiento económico, el desarrollo productivo y los problemas específicos de las economías más pequeñas, la regulación de servicios públicos y la consolidación de los espacios para el desarrollo sostenible. Por otra parte, contiene las reflexiones más destacadas del período, sobre ciudadanía y cohesión social.

Finalmente, en la etapa más reciente, en 2010, se publica La hora de la igualdad: brechas por cerrar, caminos por abrir, donde se plantea que la igualdad de derechos es el marco normativo que sirve de base para propiciar pactos sociales que ofrezcan más oportunidades a quienes menos tienen. Propugna un pacto fiscal que contemple una estructura y una carga tributaria con mayor efecto redistributivo, capaz de fortalecer el papel del Estado y la política pública a fin de garantizar umbrales de bienestar. El texto plantea un conjunto de políticas económicas con visión de largo plazo en el ámbito productivo, laboral, territorial y social, que no solo promuevan la igualdad de oportunidades, sino la reducción de las brechas en materia de logros efectivos, lo que constituye el pilar de la agenda de la igualdad.

El documento se identifica plenamente con la idea de que la igualdad social y un dinamismo económico que transformen la estructura 
productiva no están contrapuestos entre sí y el gran desafío es encontrar las sinergias entre ambos elementos. Sugiere que hay que crecer para igualar e igualar para crecer. A largo plazo, los conceptos de igualdad, crecimiento económico y sostenibilidad ambiental deben apoyarse y reforzarse mutuamente. En consecuencia, se propone crecer con menos heterogeneidad estructural y más desarrollo productivo, e igualar mediante la potenciación de las capacidades humanas y la movilización de energías del Estado. Se busca revertir las profundas disparidades territoriales mediante la construcción de sociedades más integradas en torno a dinámicas productivas, con sinergias sociales y territoriales positivas, así como reforzar la protección de las personas mediante el mejoramiento de los mercados laborales, las capacidades de las finanzas y la gestión pública.

En 2012, la publicación de Cambio estructural para la igualdad: Una visión integrada del desarrollo perfecciona los postulados de La hora de la igualdad. Parte del hecho de que, en un contexto mundial particularmente complejo, América Latina y el Caribe requiere, con más fuerza que nunca, perseverar en tres direcciones para alcanzar el necesario desarrollo: i) el cambio estructural que permita avanzar hacia sectores más intensivos en conocimiento; ii) la convergencia para reducir las brechas internas y externas de ingresos y productividad, y iii) la igualdad de derechos.

Lo anterior supone tres grandes retos: i) lograr un crecimiento sostenido a tasas elevadas, suficientes para cerrar las brechas estructurales y generar empleos de calidad; ii) cambiar los patrones de consumo y producción en el contexto de una verdadera revolución tecnológica con sostenibilidad ambiental, y iii) garantizar la igualdad sobre la base de una estructura productiva más convergente, con protección social universal y construcción de capacidades.

La superación de esos tres desafíos entraña el regreso de la política y del Estado, que recupera su papel en la promoción de la inversión y el crecimiento, la redistribución y la regulación, con vistas al cambio estructural para la igualdad, mediante la aplicación de políticas industriales, macroeconómicas, sociales y laborales.

Finalmente, con Pactos para la igualdad: hacia un futuro sostenible (2014) se completa la trilogía y se trazan las nociones fundamentales para definir las prioridades de la agenda para el desarrollo regional después de 2015. En este documento, reviste especial importancia el pacto social debido a la encrucijada que enfrenta la región ante los pronósticos de un crecimiento económico más moderado y el debilitamiento de los principales motores de crecimiento, y al contexto de economía política asociado a reformas postergadas en materia de salud, educación, inversión en infraestructura, materia fiscal y protección social. De este modo, la revisión de la ecuación 
Estado-mercado-sociedad cobra más relevancia y actualidad ya que se requiere pasar del cortoplacismo de las políticas de gobierno a las visiones de largo plazo de las políticas de Estado.

\section{B. Un acercamiento a los paradigmas de desarrollo latinoamericano}

En este apartado se presentan, en forma estilizada, los rasgos esenciales de los principales paradigmas de desarrollo en América Latina. No es una descripción exhaustiva ni mucho menos formal de la evolución epistemológica del pensamiento latinoamericano. Tampoco es una descripción de un paradigma exacto, ya que a lo largo del desarrollo de la región después de los procesos de independencia se pueden observar notables diferencias entre países en cuanto a la forma, intensidad, ritmo, alcance, gradualidad y secuencia con que han aplicado los elementos básicos y dominantes de cada paradigma.

La realidad es siempre mucho más compleja y difícil de afrontar y, en rigor, los países han adoptado paradigmas con modalidades y mecanismos disímiles, han formulado políticas similares que han llevado a resultados diferentes y algunos de los preceptos centrales no se han aplicado necesariamente de forma uniforme, consistente y sistemática, debido a que los contextos y los puntos de partida de cada país han sido distintos. En consecuencia, como se menciona en la introducción, se trata de presentar grandes líneas interpretativas entre las ideas, la práctica y los procesos de desarrollo, al mismo tiempo que se define la relevancia del pensamiento de Prebisch ${ }^{12}$. Conviene señalar que ese esfuerzo interpretativo tampoco se presta a simplificaciones burdas, pues cada paradigma en el proceso de desarrollo latinoamericano guarda su propia identidad, complejidad y especificidad histórico-estructural. Sin embargo, con fines de exposición, cada uno se presenta a partir de sus rasgos más esenciales.

\section{El punto de partida: ¿desarrollo o subdesarrollo latinoamericano?}

En América Latina, el debate sobre los diferentes paradigmas de desarrollo (o subdesarrollo) se relaciona directamente con el proceso de acumulación capitalista, en el que tanto las corrientes estructuralistas como las de la teoría de la dependencia sustentaron conceptualmente su formulación.

Un elemento del "Prebisch esencial", como lo llama Dosman, que parece crucial para nuestros días y en especial para América Latina, es

Una presentación mucho más elaborada de los paradigmas de desarrollo latinoamericano se encuentra en Ocampo (2008), Bértola y Ocampo (2013) y Love (1994). 
su concepción balanceada y su elevado pragmatismo. Por balanceado ha de entenderse, entre otras cosas: i) un mayor papel del Estado, pero sin llegar a un Estado omnipresente (igual que a fines de los años noventa); ii) sustitución de importaciones, pero no a cualquier costo; iii) políticas monetarias más activas y favorables al crecimiento, aunque no a costa de la inflación; iv) controles de cambios y de movimiento de capitales, pero dependiendo del momento de aplicación y la intensidad, y v) la discusión con el Norte, sin llegar a la ruptura.

En ese aspecto, es oportuno rescatar uno de los tres mensajes centrales de Prebisch, relacionado con la conformación de visiones del orden mundial acordes a los intereses de los países del centro. Según la narrativa de Prebisch existe un "pensamiento céntrico" que racionaliza el sistema internacional, desde la teoría clásica del comercio internacional hasta la teoría de las expectativas racionales o del nuevo comercio internacional, desde el libre cambio hasta el Consenso de Washington.

En el contexto de ese pensamiento hegemónico centrista, el proceso de desarrollo latinoamericano, como se verá más adelante, ha estado irremediablemente atado a su articulación con el comercio y la economía internacional, a las instituciones y grupos de poder dominantes y al desarrollo de las fuerzas productivas. El resultado ha sido la profunda heterogeneidad estructural y la consecuente diversidad de políticas económicas adoptadas a lo largo de su historia ${ }^{13}$ (Ferrer, 2010).

De lo anterior se desprenden los otros dos mensajes de Prebisch, basados en la aseveración de que la transformación de la estructura productiva es posible en la medida en que la periferia sea capaz de desarrollar una relación simétrica no subordinada con los centros hegemónicos del poder mundial ${ }^{14}$. Asimismo, el desarrollo no es posible sin un cambio estructural profundo, sin modificar la orientación y fuerza del Estado, y sin un cambio en la estructura productiva que incorpore actividades cercanas a la frontera del conocimiento. Todas esas aseveraciones parecen confirmarse hoy en día; la evidencia más contundente se encuentra en la experiencias recientes de crecimiento e industrialización de los tigres asiáticos y, en las últimas décadas, de China y la India (Ferrer, 2010).

13 De ahí surge la idea generalizada de que el mercado es el medio más eficiente de asignar recursos. La globalización es tan avasalladora que cualquier intento de la periferia por construir un proyecto nacional de desarrollo está destinado al fracaso.

14 Incluso en la etapa exportadora, Prebisch y el pensamiento estructuralista nunca propugnaron una visión autárquica del comercio o del desarrollo. De hecho, Prebisch siempre apuntó a redefinir la articulación de América Latina con los flujos de intercambio internacional y la economía mundial, no a aislarse de ellos. En ese sentido, el "manifiesto" nunca fue anticomercio, antiagricultura ni proindustrialización a ciegas. Prebisch cuestionó el mercado como el gran igualador, pero reiteró la necesidad de mantener el continuo equilibrio entre las medidas intervencionistas y el respeto al mercado, con la mirada atenta al orden internacional (Ocampo, 2008). 
El análisis histórico y teórico sobre desarrollo o subdesarrollo en América Latina difícilmente puede agotarse en un solo ensayo (Bértola y Ocampo, 2013; Altimir y otros, 2008; Ocampo y Ros, 2011). Sin embargo, a manera de síntesis, Prebisch entendió que el subdesarrollo no puede identificarse como un simple "estado de atraso" y lo visualizó como un patrón de funcionamiento y de evolución específica de ciertas economías, a partir de tres conceptos clave.

El primero se refiere a la heterogeneidad estructural como característica destacada de las economías periféricas. La heterogeneidad estructural se caracteriza, ante todo, por la existencia de actividades o ramas de la producción en que la productividad media del trabajo es normal, por ser relativamente próxima a la que permiten las técnicas disponibles o relativamente similar a la que prevalece en los grandes centros industriales (generan empleo). En segundo lugar, la heterogeneidad se refiere a la existencia simultánea de actividades tecnológicamente rezagadas, con niveles de productividad muy reducidos (generan subempleo). Es decir, la coexistencia de empleo y subempleo (de fuerza de trabajo de alta y baja productividad) constituye la expresión directamente visible de la heterogeneidad estructural: el subempleo tiende a perdurar y el subempleo estructural se transforma de rural en urbano.

El segundo se refiere a la especialización productiva. En sus orígenes, la especialización de la estructura productiva de la periferia se relacionó con el extenso período en que su crecimiento dependió de la exportación de alimentos y materias primas. Cuando la industria se convirtió espontáneamente en la fuente principal de dinamismo, la especialización inicial en exportaciones de productos primarios condicionó el nuevo patrón de desarrollo. De esa manera, la industrialización evoluciona de lo simple a lo complejo y el patrón de desenvolvimiento industrial peculiar de la periferia implica el mantenimiento del carácter especializado de su estructura productiva. En consecuencia, el nivel de complementariedad intersectorial y de integración vertical de la producción que va alcanzando la periferia resulta exiguo o incipiente.

El último tiene que ver con el desarrollo desigual. Se refiere, ante todo, al carácter variable y bipolar del desarrollo del sistema centroperiferia, que guarda relación con las peculiaridades estructurales descritas y resulta desigual porque los ingresos medios (por persona ocupada o per cápita), tienden a diferenciarse entre sus dos polos. El deterioro secular de la relación de precios de intercambio y la diferenciación de ingresos, así como el comportamiento dispar de la productividad del trabajo, implican una debilidad de las economías periféricas, vinculada con su capacidad de alcanzar y mantener ritmos de acumulación elevados. 
Por su parte, Sunkel y Paz (1970) observan que el subdesarrollo no se puede entender como si fuera un momento en evolución continua (enfoque del desarrollo como crecimiento) ni discontinua (enfoque del desarrollo como sucesión de etapas) de una sociedad económica, política y culturalmente aislada y autónoma. Por el contrario, basados en la observación histórica sistemática, postulan que el subdesarrollo es parte del proceso histórico global de desarrollo, que tanto el subdesarrollo como el desarrollo son dos caras de un mismo proceso histórico universal y ambos son históricamente simultáneos. Están vinculados funcionalmente, es decir, interactúan y se condicionan mutuamente y su expresión geográfica concreta se observa en dos grandes dualismos: por una parte, la división del mundo entre los Estados nacionales industriales (avanzados, desarrollados, centrales), y los Estados nacionales subdesarrollados (atrasados, pobres, periféricos y dependientes). Por la otra, la división dentro de los Estados nacionales en áreas, grupos sociales y actividades avanzadas y modernas y en áreas, grupos y actividades atrasadas, primitivas y dependientes.

El desarrollo y el subdesarrollo pueden comprenderse como estructuras parciales, pero interdependientes, que conforman un sistema único. La característica principal que las diferencia es que la estructura desarrollada, en virtud de su capacidad endógena de crecimiento, es la dominante y la subdesarrollada, dado el carácter inducido de su dinámica, es dependiente. Esto se aplica tanto entre países como dentro de un país.

Lo anterior supone una reorientación y redefinición de la política de desarrollo tanto en lo interno como en las relaciones internacionales. Para que sean eficaces y permanentes los reordenamientos de esta naturaleza, solo pueden basarse en la participación social, política y cultural activa de nuevos grupos sociales antes excluidos o marginados. Esa participación debe hacerse presente tanto en la formulación de los objetivos de la sociedad como en la tarea de alcanzarlos. Se trata de procesos en que nuevos grupos sociales, que fueron objeto del desarrollo, pasan a ser sujetos de este (Sunkel y Paz, 1970).

En la esfera económica, las causas de la riqueza de unos países y la pobreza de otros, y del crecimiento acelerado de unos y lento de otros, siempre han sido objeto de investigación, pero tras la Segunda Guerra Mundial fue que surgieron varias interpretaciones sobre el tema. La teoría formal del crecimiento económico (sustentada en el modelo neoclásico de Solow y en los "nuevos" modelos de crecimiento endógeno de Romer) pasó a formar parte de la macroeconomía y de la corriente dominante de la teoría económica. En contraste, el estudio de los países pobres se enmarcó en la temática del desarrollo económico. El crecimiento de la productividad formó parte de la organización industrial. Por su parte, el estudio de cómo los países ricos alcanzaron su prosperidad actual se integró en la historia económica. 
En las dos últimas décadas, el crecimiento económico ha resurgido como un campo independiente y la teoría del desarrollo no está muerta, como sugiere Krugman en su artículo "The fall and rise of development economics", ya que se han logrado avances notables en la modelización de sus ideas centrales y en la comprensión de que en la dinámica de desarrollo no solo importa la acumulación de factores, sino la reasignación productiva, que es la fuente del cambio técnico, el aprovechamiento de externalidades, las mejoras en la coordinación para superar las indivisibilidades y las complementariedades de la inversión y la posible existencia de equilibrios múltiples con sendas dispares de evolución que influyen en el resultado final.

\section{El "desarrollo hacia afuera"}

El paradigma de la era de las exportaciones o de "desarrollo hacia afuera" estuvo asociado al auge primario-exportador y al concepto de progreso. Este último se concebía como el resultado del proceso de integración de los países latinoamericanos a la economía mundial como productores de materias primas. Ese período abarcó desde 1870 hasta 1929 y terminó con la Gran Depresión (Ocampo, 2008; Cárdenas, Ocampo y Thorp, 2003).

En cuanto al desempeño económico del último siglo, Bértola y Ocampo (2013) lo caracterizan como un período de fluctuaciones notables: entre 1870 y 1980, en contextos muy diferentes y con algunas fluctuaciones, América Latina mejoró su posición en relación a la media mundial, lo que contrasta con la caída, hasta mediados del siglo XX, del 'resto del mundo' (excluyendo a Occidente ampliado y a América Latina). Además, la participación de América Latina en la producción mundial se amplió continuamente: del 2,9\% en 1870 al 5,6\% en 1929 y el 9,8\% en 1980. Sin embargo, la región no pudo acortar distancias con Occidente. La brecha entre América Latina y Occidente se mantuvo relativamente estable a lo largo de ese período e incluso tendió a cierto aumento durante algunos subperíodos, sobre todo entre 1950 y 1973, cuando las economías occidentales batieron sus récords históricos de crecimiento durante la denominada "edad de oro" del capitalismo, al tiempo que la región experimentó una explosión demográfica y se dificultó el crecimiento de las economías regionales líderes. En términos más detallados, la brecha se amplió en relación con las economías de nuevo asentamiento, pero se redujo en relación con la Europa industrializada hasta 1929, y lo opuesto aconteció después de la Segunda Guerra Mundial.

Durante la vigencia de este paradigma en la segunda mitad del siglo XIX, los principales problemas del desarrollo económico consistieron en establecer un sistema de transporte moderno, facilitar el acceso directo de los exportadores a los recursos naturales y movilizar mano de obra 
hacia los sectores modernos. Como resultado de esos factores, América Latina expandió significativamente sus exportaciones y el crecimiento económico asociado a dicha expansión atrajo un flujo considerable de capitales y de nuevas inmigraciones europeas al continente. Un elemento distintivo de esa fase fue que, a pesar del papel preponderante de las exportaciones, ello no significó que los sectores exportadores absorbieran una proporción importante de la fuerza de trabajo ni que llegaran a tener una participación elevada del PIB, ya que las exportaciones se sustentaron en la extracción de recursos naturales que no se estaban explotando.

En el plano social, el progreso fue desigual, ya que se amplió la brecha entre los países más ricos y más pobres de la región y, a la vez, se profundizó significativamente la desigualdad dentro de cada país. Además, el desarrollo exportador generó, de forma diferenciada entre países, mayor diversificación de las estructuras económicas nacionales y cierto desarrollo de la industria manufacturera, de las infraestructuras de comunicaciones y transportes y de los servicios financieros, acompañado de un proceso de urbanización. Fue en ese período que América Latina amplió la brecha con otras regiones no desarrolladas y algunos países de la región, como la Argentina y el Uruguay, alcanzaron niveles de ingresos similares o mayores a los países ricos de esa época (Bértola y Ocampo, 2013).

Debido a profundos desequilibrios en la economía mundial y al sistema monetario internacional se produce la Gran Depresión de los años treinta y, con ella, el fin de la era de las exportaciones o del "desarrollo hacia afuera", dando espacio al advenimiento del nuevo paradigma de industrialización dirigida por el Estado.

\section{La industrialización dirigida por el Estado}

El crecimiento liderado por las exportaciones llegó a su fin por diversas razones, principalmente debido a la Gran Depresión, al colapso del patrón oro, a las fluctuaciones del comercio mundial y a los embates de la Segunda Guerra Mundial. En América Latina, todo ello sentó las bases para iniciar la transición hacia un nuevo modelo de desarrollo que se distinguió por adoptar la industrialización como motor del desarrollo, promover la intervención estatal en diferentes ámbitos de la actividad económica y desarrollar una fuerte orientación al mercado interno. Conforme al precepto de la CEPAL, se trataba de un patrón de "desarrollo hacia adentro" o, como se conoce internacional y secularmente, de "industrialización por sustitución de importaciones".

Por razones puramente analíticas, pero también de exposición, aquí se prefiere utilizar el término "industrialización dirigida por el Estado" en lugar de industrialización por sustitución de importaciones. 
Según la narrativa de Cárdenas, Ocampo y Thorp (2003), la sustitución de importaciones no fue ni el elemento más destacado del modelo a lo largo del tiempo, ni una característica compartida por todos los países desde fines de la Segunda Guerra Mundial hasta la década de 1970, período durante el que se aplicó ese modelo de desarrollo. En la práctica, el proceso constó de distintas etapas, diversidad en la aplicación de instrumentos y énfasis bastante diferenciados. En algunas economías pequeñas de la región, la industrialización no sustituyó por completo el modelo de exportaciones de productos primarios y dio lugar a esquemas mixtos que combinaban la sustitución con la promoción de exportaciones (Rosenthal, 1998, 2004).

Las ideas de industrialización fueron adquiriendo un creciente impulso, no solo en América Latina sino en el resto de mundo, y permearon de manera profunda en la región desde los años treinta hasta bien entrados los años setenta, en gran parte debido a la influencia de las ideas de desarrollo provenientes de Europa central, la experiencia exitosa de planificación económica y del Estado de bienestar del Reino Unido, las ideas keynesianas de una política macroeconómica de pleno empleo $\mathrm{y}$ activamente intervencionista $\mathrm{y}$, sin duda, por la fuerte influencia de los primeros pioneros del desarrollo: Rosenstein-Rodan, Arthur Lewis, Gunnar Myrdal, Ragnar Nurske y, por supuesto, Raúl Prebisch (Singer, 1998).

Fue en ese contexto histórico que cobró plena vigencia el modelo de industrialización dirigida por el Estado y tanto el desarrollo económico como la industrialización se convirtieron en términos equivalentes. Se fue tomando conciencia sobre el papel de la intervención estatal en la asignación de recursos para la inversión pública en industrias consideradas "estratégicas", como las de energía, siderurgia, minería y petroquímica ${ }^{15}$.

Si bien se reconocen al menos cuatro etapas por las que atravesó este paradigma a lo largo del tiempo, al menos está claro que, en las fases más tempranas, la implementación de las políticas y la aplicación de instrumentos del modelo se desenvolvieron más bien por prueba $\mathrm{y}$ error y por aproximaciones sucesivas que por un modelo teórico claramente concebido ${ }^{16}$. Como señaló magistralmente Joseph Love (1994),

15 La planificación normativa, racionalista, indicativa y tradicional fue el instrumento por excelencia para llevar a cabo la intervención estatal. Tuvo su apogeo en la década de 1960. El Instituto Latinoamericano y del Caribe de Planificación Económica y Social (ILPES) de la CEPAL fue el bastión teórico-conceptual más prominente que tuvo la región durante los años sesenta y setenta y antes del repliegue de la planificación en los años ochenta.

16 La primera etapa se caracterizó por la expansión de las exportaciones heredada del modelo anterior. La segunda tuvo un carácter más pragmático al apoyar sectores considerados estratégicos (energía, petróleo), aplicar instrumentos combinados de política y promover la creación de bancos de desarrollo. La tercera fue la fase "clásica" y se caracterizó por la tendencia a racionalizar la protección mediante la integración comercial regional. La última fase constituyó la etapa madura y fue el período del modelo mixto de sustitución de importaciones y promoción de exportaciones (Ocampo, 2008). 
la industrialización de América Latina fue un hecho antes que fuera una política y una política antes que una teoría ${ }^{17}$. La CEPAL proporcionó racionalidad y fundamento conceptual y analítico a un proceso en pleno desarrollo y generalizado en toda la región, dotándolo a la vez de un sentido de identidad regional ${ }^{18}$. El manejo de la balanza de pagos y el uso de la protección arancelaria como instrumentos de desarrollo se constituyeron en los componentes centrales de una fuerte intervención estatal, basada en las asimetrías existentes entre el "centro" y la "periferia"19.

Desde fines de los años cincuenta, y como lo han documento ampliamente Bielschowsky (2010), Rodríguez (2006), Bértola y Ocampo (2013), Cárdenas y otros (2003) y Rosenthal (1998, 2004), la propia CEPAL criticó los excesos de la sustitución de importaciones y de las intervenciones estatales y propuso un modelo "mixto" de racionalización de las importaciones con política activas de promoción de exportaciones y mayor integración regional. En ese período también se acentuaron las críticas al modelo de industrialización desde fuera de la CEPAL, especialmente las provenientes de las instituciones de Bretton Woods y de los círculos académicos, donde se encontraban figuras como Jacob Viner y M. W. Corden, por nombrar algunas.

Desde una visión amplia del proceso con un horizonte temporal de largo plazo, se puede afirmar que, a pesar de sus limitaciones prácticas, su sesgo antiexportador y los excesos de la intervención estatal y la protección arancelaria, el modelo de industrialización dirigida por el Estado fue sobresaliente y exitoso al menos durante los tres decenios posteriores a la Segunda Guerra Mundial, pues permitió que la región alcanzara una tasa media de crecimiento del PIB del 5,5\% anual entre 1950-1980 (2,7\% per cápita). El sector manufacturero fue el motor de crecimiento en la región, con una participación del 27\% del PIB en 1973 (Cárdenas, Ocampo y Thorp, 2003).

Es importante además señalar que el modelo tuvo repercusiones tanto en el ámbito económico como el social, institucional y productivo, antes que se pusieran de manifiesto sus limitaciones de orden práctico. Los

Citado en Ocampo (2008).

18 La CEPAL sustentó la defensa de la industrialización a partir de una teoría de la acumulación del capital, más que de una teoría de la eficiencia económica (Ocampo, 2008).

19 Conviene señalar que Prebisch $(1970,1973)$ advirtió sobre los riesgos de una protección excesiva y señaló que la solución no era sostener una protección arancelaria que aislara a los países de la economía internacional, sino replantear la división internacional del trabajo para que los países de la región se beneficiaran del cambio técnico, directamente asociado a la industrialización. Sin embargo, el "modelo" de sustitución de importaciones de la CEPAL fue, por un lado, encasillado con ese nombre, y por otro, banalizado por algunos de sus rasgos, en particular su orientación al sector interno, su carácter dirigista y su inclinación fuertemente proteccionista. Nuevamente, en la práctica, los países perpetuaron el uso del modelo y de sus instrumentos más allá de lo justificado por las circunstancias imperantes (Rosenthal, 1998). 
resultados del modelo no fueron los mismos en todos los países ni a lo largo del tiempo, y el avance de la industrialización dependió del tamaño de sus economías y de los arreglos internos de carácter social y político encaminados a lograr la expansión del mercado interno y enfrentar el firme rechazo de los sectores exportadores tradicionales (Bértola y Ocampo, 2013). Por ejemplo, el crecimiento del PIB no fue uniforme entre los distintos países y mostró cierta convergencia entre la Argentina, Chile y el Uruguay. La productividad laboral aumentó y permitió salarios reales más elevados. El desarrollo institucional en sentido amplio fue notable y permitió no solo la creación de instituciones estatales, empresas e industrias estratégicas, sino la elaboración de normas y reglas que orientaran el rol del Estado y de los agentes económicos. La industrialización fue sinónimo de desarrollo mediante la transmisión del progreso técnico a la estructura productiva. El medio e instrumento fue la planificación, que permitía materializar la intervención estatal.

Al respecto, Ocampo (2008) destaca que "en las postrimerías de la Segunda Guerra Mundial las economías de todas las regiones no se enfrentaban a una opción entre intervención del Estado y libre empresa, sino a distintas modalidades de intervención del Estado. La intervención estatal y la planeación eran consideradas en el mundo entero como las únicas alternativas a la desorganización de los mercados que había caracterizado a las décadas precedentes. El elemento distintivo de la nueva etapa es que, en la elección entre distintas modalidades de intervención, América Latina no optó por una mayor sino por una menor intervención, es decir por esquemas de organización económica en los que la empresa privada seguía desempeñando un papel preponderante... En este sentido, el éxito de un modelo de industrialización condujo al desarrollo de una economía mixta mucho más cercana a la de Europa occidental que a los modelos socialistas que proliferaron después de la Segunda Guerra Mundial en gran parte del mundo".

Las limitaciones y contradicciones internas del modelo de industrialización dirigida por el Estado, especialmente el sesgo antiexportador y antirrural, los excesos de la sustitución de importaciones y factores externos como la crisis de la deuda, la crisis del Estado benefactor en los países industrializados y la caída del muro de Berlín y del comunismo, sentaron las bases del inicio del fin del modelo "orientado hacia adentro". Al mismo tiempo, fuera de América Latina, los preceptos poskeynesianos sufrían los ataques frontales del conservadurismo y del liberalismo de la escuela de Chicago, así como del ala progresista (los llamados economistas radicales). De esa manera, se gestaban las condiciones y elementos clave del próximo paradigma, con una tendencia evidente a promover la liberalización del comercio y la integración económica y financiera mundial, y a depositar más confianza en el 
mercado como mejor forma de asignar los recursos, relegando el papel del Estado a una función marginal y subsidiaria. De la misma forma que en los años treinta se dio inicio a la industrialización dirigida por el Estado con un mayor protagonismo estatal, la crisis de la deuda dio espacio al modelo de economías abiertas orientadas por principios de mercado, de donde se derivó lo que luego se conocería como el Consenso de Washington ${ }^{20}$.

\section{Las reformas estructurales y de mercado}

La transición hacia el nuevo paradigma de reformas estructurales y de mercado a fines de los años setenta y principios de los ochenta fue mucho más rápida que en el caso del paradigma de industrialización dirigida por el Estado y, a diferencia de este último, en el modelo de reformas de mercado, la teoría antecedió a la práctica y ambas se radicalizaron e ideologizaron, alcanzando desde una ortodoxia convencional lo que algunos denominaron el "fundamentalismo de mercado" o "fundamentalismo liberal" (Ffrench-Davis, 2005; Bértola y Ocampo, 2013; Kozul-Wright y Rayment, 2008).

Según la línea argumentativa de Bértola y Ocampo (2013), para describir el paradigma plasmado en el Consenso de Washington, se prefiere el término "reformas de mercado" al de "neoliberal", ya que este último no describe a cabalidad la intensidad de aplicación de las reformas, ni las diferencias notables de gradualidad y secuencia adoptadas en los distintos países. Por ejemplo, hubo divergencias en el campo de las políticas cambiarias, en los programas antiinflacionarios e incluso en la liberalización de la cuenta de capital, que en algunos países se desarrolló de manera simultánea con la liberalización de la cuenta corriente y, en otros casos, se hizo de forma consecutiva ${ }^{21}$ (Ffrench-Davis, 2005; Stallings y Peres, 2000).

El elemento descriptivo principal de ese paradigma simplificado en el Consenso de Washington fue la liberalización de las fuerzas del mercado mediante un sistema basado en permitir que los precios alcanzaran su debido nivel (getting the prices right). Las diez reformas contenidas en el decálogo fueron las siguientes: i) disciplina presupuestal; ii) redefinición de las prioridades del gasto público y reorientación a favor de la inversión

20 John Williamson ha manifestado en diferentes ocasiones que lamenta haber utilizado el término "Consenso de Washington", en primer lugar, porque no fue concebido en Washington y, en segundo lugar, porque no revela un consenso. La caracterización del modelo "neoliberal" no es exacta y hay considerables diferencias en la forma, intensidad, ritmo, gradualidad y secuencia de la aplicación de los distintos instrumentos de política (Williamson, 1990).

21 Las reformas de mercado como tal (reducir la participación del Estado en la actividad económica y liberalizar los mercados) coincidieron con las políticas de estabilización macroeconómica (corregir déficits externos y fiscales y establecer el control inflacionario). Su separación es esencial a efectos analíticos y su coincidencia temporal ha generado confusión en diversos análisis del proceso de reformas (Bértola y Ocampo, 2013). 
en infraestructura física, de educación y de salud; iii) reforma fiscal con base amplia de contribuyentes, reglas sencillas y porcentajes moderados de impuestos marginales; iv) desregulación financiera y liberalización de las tasas de interés; v) tipo de cambio competitivo que promoviera un crecimiento de las exportaciones; vi) liberalización del comercio exterior mediante una reducción acentuada de los aranceles; vii) liberalización de la inversión extranjera directa; viii) privatización de las empresas públicas; ix) desregulación de los mercados, y x) garantía de derechos de propiedad.

En las décadas de 1980 y 1990, muchos países adoptaron paulatinamente las prescripciones de política antes enumeradas. La cronología de las reformas fue diversa, como lo han documentado Morley y otros (1999), señalando que hubo dos fases de las reformas. La primera se desarrolló en los años setenta, fue muy disímil entre distintos países y experimentó un repliegue durante la crisis de la deuda. La segunda fue mucho más acelerada y se generalizó especialmente con la liberalización comercial y la desregulación financiera.

Con el paso del tiempo, los límites del modelo se volvieron evidentes: en el plano macroeconómico se logró de cierto modo controlar la inflación (en ocasiones a costa de una sobrevaloración del tipo de cambio) y se mejoró la situación fiscal, pero el crecimiento económico desde 1990 hasta 2008 (representativo del período de reformas) fue del 3,4\% anual, casi dos puntos porcentuales inferior al 5,5\% registrado en el período 1950-1980. Si se incluyen los años de la crisis financiera internacional (2009 y 2010), la tasa de crecimiento se reduce al 3,1\% (Bértola y Ocampo, 2013).

Ante la situación anterior, la economía ortodoxa no cuestionó las limitaciones y sesgos del modelo, sino que recurrió a las fallas de implementación, a las carencias de derechos de propiedad y a las debilidades institucionales para explicar los resultados del proceso de reformas ${ }^{22}$. Tal y como señalara elocuentemente Chang (2005): “En la literatura ortodoxa sobre instituciones y desarrollo, los derechos de propiedad juegan el rol más importante. Dicha literatura afirma que, las 'buenas' políticas, basadas en teorías 'correctas', recomendadas por economistas ortodoxos, no han funcionado porque muchas de las economías en desarrollo y en transición carecen de un sistema de derechos de propiedad seguro y claramente definido. Según este punto de vista, en ausencia de una garantía apropiada para los frutos de sus sacrificios, la gente no invierte, cualesquiera sean las políticas con respecto a equilibrios macroeconómicos, comercio, regulaciones industriales".

22 Rodrik $(2002,2004)$ ha resaltado la importancia de las instituciones en el desarrollo económico, especialmente las que protegen los derechos de propiedad (denominadas creadoras de mercado). Sin embargo, para el desarrollo económico a largo plazo se requieren además instituciones de reglamentación, estabilización y legitimación de los mercados. 
Fue así que se recurrió a una "segunda generación" de reformas (o de reformas de las reformas) con el propósito de superar las fallas de implementación y las debilidades institucionales de la primera ronda. Entre ellas figuraron la lucha contra la corrupción, la liberalización del mercado de trabajo, la adhesión a la normativa de la Organización Mundial del Comercio (OMC), la adopción de una mayor regulación financiera, la apertura de la cuenta de capital, la autonomía de la bancos centrales, la aplicación de metas de inflación y la adopción de regímenes cambiarios fijos o flotantes. En el plano social, las más importantes fueron la construcción de redes de protección social y la reducción de la pobreza absoluta.

En la práctica, como ya se mencionó, los países siguieron diferentes trayectorias y se acogieron al Consenso de Washington con diferentes grados de sumisión y, sobre todo, de agresividad o cautela en la implementación de las reformas. Estas tuvieron resultados muy limitados en los promedios regionales agregados, pero tuvieron diferente intensidad entre los países. Sin embargo, puede aducirse que dichas políticas acentuaron la heterogeneidad estructural, lo que se refleja en tasas de crecimiento altas y bajas entre los países, sectores de alta y baja productividad, brechas entre empresas pequeñas y grandes, y diferencias de ingreso notables entre los que tienen educación y el resto de la población (Stallings y Peres, 2000). En el ámbito social y durante la década perdida, los efectos sociales fueron regresivos en materia de pobreza y distribución del ingreso. La pobreza aumentó del $40,5 \%$ al 48,3\% debido al deterioro de los salarios reales, a la contracción del empleo formal y a la inflación imperante del período. La distribución del ingreso se deterioró, ya que los ajustes fiscales aplicados durante el período terminaron socavando el gasto público social (Bértola y Ocampo, 2013, pág. 257). Los efectos de las reformas estructurales sobre las variables sociales y sobre la distribución de ingreso en particular siguen siendo objeto de debate. Sin duda, generaron ganadores y perdedores y su resultado neto fue diferenciado de país a país (Ganuza y otros, 2004, 2001).

Como señala Ffrench-Davis (2008): “Uno de los rasgos distintivos del neoliberalismo es su globalismo; esto es, su desconocimiento de los problemas de carácter sectorial, de la heterogeneidad de las estructuras productivas y del acceso al poder de diferentes sectores, de la significación de las segmentaciones de los mercados, y de la dificultad para transmitir información hacia los agentes económicos de manera que estos contribuyan a la concreción de los objetivos de las reformas. En fin, subestima la presencia frecuente de procesos de ajuste desestabilizadores y de rezagos y sobreajustes (overshooting), y el carácter incompleto de mercados e instituciones en las economías en desarrollo". La existencia de estos elementos constituye un obstáculo insalvable para que las políticas 
económicas globales 'neutras' o indirectas, por sí solas, resulten eficaces en las naciones emergentes o en proceso de transformación.

A principios de la década de 1990 y ante el fracaso de las políticas llamadas paradójicamente de "ajuste estructural" y las experiencias exitosas de desarrollo en el sureste asiático, se generó un entorno propicio para el surgimiento de paradigmas alternativos y heterodoxos. En efecto, durante los años ochenta, cuando los países latinoamericanos adoptaban programas de ajuste estructural y sufrían los embates del estancamiento y de la deuda, las economías emergentes asiáticas alcanzaban tasas de crecimiento sin precedente y lograban mejorar su inserción internacional gracias a sus exportaciones de productos con mayor contenido tecnológico, al desarrollo de capacidades tecnológicas y a políticas deliberadas de los Estados para alterar la estructura de incentivos y el vector de producción de sus economías. Esta experiencia asiática fue muy reveladora, ya que ponía en tela de juicio las recomendaciones surgidas bajo los preceptos del Consenso de Washington y sus programas de ajuste estructural (Guillén Romo, 2010).

A finales de los años ochenta e inicios de los noventa, se comenzó a desarrollar en la CEPAL una nueva corriente de pensamiento llamada "neoestructuralista" (Sunkel, 1991; Bielschowsky, 1998b). El documento Transformación productiva con equidad (CEPAL, 1990) es un fiel reflejo de la renovación de este pensamiento y una pieza fundamental de la evolución del pensamiento de ese organismo internacional.

Tres hechos estilizados destacan en este contexto. En primer lugar, mientras los defensores del ajuste estructural propugnaban el retiro del Estado, los países asiáticos se pronunciaban por una mayor regulación e intervención estatal. En segundo lugar, mientras que en los planes de ajuste estructural se exaltaba la inserción internacional sobre la base del principio de las ventajas comparativas estáticas, es decir, la exportación de productos intensivos en trabajo, los países asiáticos construían su competitividad a partir de una inserción dinámica en las nuevas tecnologías y de la creación de ventajas comparativas dinámicas. En tercer lugar, en el momento en que los defensores del Consenso de Washington aconsejaban a las economías latinoamericanas reorientar su actividad hacia los mercados externos, las economías asiáticas mantenían relaciones dinámicas estrechas entre las actividades vinculadas al mercado interno, el mercado regional y las actividades exportadoras. En esas condiciones, la experiencia asiática constituyó un auténtico ejemplo de lo contrario a las prácticas imperantes en materia de política económica en América Latina (Ocampo y Ros, 2011).

Debido a lo anterior, suele sostenerse que la corriente neoestructuralista se presentó no solo como el paradigma alternativo al modelo de reforma de mercado, sino como una superación del paradigma estructuralista original en que se inspiró. Se trata, como sugiere 
Ferrer (2013a, 2013b), de adaptarlo a los nuevos tiempos de apertura y globalización. Para los neoestructuralistas, lo principales problemas económicos de América Latina no se deben en lo fundamental a distorsiones inducidas por la política económica, sino que son más bien de carácter endógeno, estructural y de origen histórico (Guillén Romo, 2007).

Los neoestructuralistas destacan tres hechos característicos de las economías latinoamericanas a finales de los años ochenta: i) la presencia de un modelo de inserción externa que condujo a una especialización empobrecedora; ii) el predominio de un modelo productivo desarticulado, vulnerable, muy heterogéneo, concentrador del progreso técnico e incapaz de absorber de manera productiva el aumento de la mano de obra, y iii) la persistencia de una distribución del ingreso muy concentrada y excluyente, que muestra la incapacidad del sistema de disminuir la pobreza. En consecuencia, el neoestructuralismo busca la transformación productiva con equidad, que se basa en cambios estructurales de la economía que permiten el desarrollo y crecimiento económico con equidad, con la existencia de equilibrios financieros que sustenten esos cambios en la esfera productiva y con un apoyo social y estatal (Lustig, 1998; Ocampo, 2008; CEPAL, 1990, 2010, 2012).

El neoestructuralismo surgió como un enfoque teórico alternativo al modelo de reforma estructural y de mercado. En sus inicios, intentó buscar soluciones menos regresivas frente a los problemas inflacionarios y de desequilibrio comercial, por medio de los planes de estabilización y de ajuste heterodoxos de los ochenta. Se trataba, por tanto, de un enfoque de corto plazo que había surgido en medio de la crisis de la deuda de los años ochenta. Tal y como señalan Fontaine y Lanzarotti (2001), "en un medio ambiente intelectual hostil a cualquier consideración de orden estructural, el corto plazo era la única vía de entrada al debate".

Sin embargo, a medida que fracasaban los planes de ajuste ortodoxos de los neoliberales y heterodoxos de los inicios del neoestructuralismo, este comenzó a remitirse cada vez más al pensamiento original de la CEPAL. Ello no impidió que los neoestructuralistas procedieran a una revisión crítica de ese pensamiento, con el fin de superar algunas de sus principales insuficiencias y limitaciones. Por ejemplo: i) una confianza excesiva en los beneficios de la intervención estatal, dejando de lado los problemas de corrupción, captura del Estado, burocracia y poca eficacia del sector público; ii) un pesimismo exagerado y muy prolongado frente a los mercados externos, y iii) una subestimación de los aspectos monetarios y financieros, que conduce a una política económica a corto plazo muy poco rigurosa (Sunkel, 1991; Guillén Romo, 2007).

Respecto a este último punto, Ffrench-Davis (1991) sostiene que el estructuralismo se caracteriza por dos insuficiencias en el plano de la 
política económica: “Una fue la limitada preocupación por el manejo de las variables macroeconómicas de corto plazo: el análisis sobre la definición de los espacios de maniobra en lo referente a los déficit fiscales, la liquidez monetaria y regulación de la balanza de pagos ocupó un lugar secundario en el pensamiento estructuralista. No se pasó de manera sistemática de diagnosticar el origen de los desequilibrios al terreno de las políticas adecuadas de regulación de los mercados. La otra limitación se ubicó en la debilidad de la reflexión en las políticas de mediano plazo, que relaciona el corto plazo con los objetivos nacionales de desarrollo y la planeación". Por esta razón, para los neoestructuralistas, sus antecesores de la CEPAL tenían una visión analítica insuficiente e incompleta de los problemas a corto plazo y de su articulación con la dinámica a largo plazo.

Claramente, en el centro de la nueva estrategia propuesta por los neoestructuralistas se encuentra la acción del Estado. No se trata de que la intervención estatal sustituya a las fuerzas del mercado con un exceso de acción sino, más bien, que intervenga de forma selectiva para sostener y fortalecer la actividad del mercado. Como se mencionó en la introducción, el debate ya no se basa en tener más Estado o más mercado, sino en procurar un mejor Estado y un mercado más eficaz y equitativo.

\section{Una aproximación al aporte de Prebisch al debate actual}

En el presente ensayo se han examinado en una apretada síntesis los principales conceptos sobre el Estado y el desarrollo y, en particular, sobre los principales paradigmas de desarrollo latinoamericano, destacando de paso algunos de los rasgos esenciales de la evolución del propio paradigma de la CEPAL. A lo largo de las diferentes concepciones sobre desarrollo o subdesarrollo, se entremezclan las ideas fundacionales de Prebisch, que se forjaron a partir de sus propias experiencias al frente del Banco Central de la Argentina durante la Gran Depresión y la Segunda Guerra Mundial y a lo largo del tiempo en cinco etapas (más la etapa final al frente de la Revista de la CEPAL).

Como revelara Prebisch (1983) en "Cinco etapas de mi pensamiento sobre el desarrollo":

"Cuando inicié mi carrera como joven economista y profesor durante los años veinte, creía firmemente en las teorías neoclásicas. Sin embargo, la tremenda depresión de la primera gran crisis del capitalismo (la depresión mundial) generó en mí graves dudas acerca de estas creencias. En retrospectiva, me parece que fue el inicio de un largo período de herejías cuando traté de explorar nuevas 
concepciones en el campo del desarrollo económico. La segunda gran crisis del capitalismo, que todos estamos padeciendo ahora, ha fortalecido mi actitud. En el largo período transcurrido entre estas dos grandes crisis, mi pensamiento sobre el desarrollo ha atravesado por etapas sucesivas bajo la influencia de una realidad cambiante y del ensanchamiento de mi propia experiencia. Durante aquellos años agitados de la Depresión, ejercí cierta influencia sobre la política económica de mi país, la Argentina, primero como Subsecretario de Finanzas y luego como banquero central. En los años treinta recomendé medidas antinflacionarias ortodoxas para eliminar el déficit fiscal y reprimir las tendencias inflacionarias, pero al mismo tiempo me alejé de la ortodoxia cuando hube de afrontar un grave desequilibrio de balanza de pagos y aconsejé una resuelta política de industrialización y otras medidas orientadas a ese fin".

La vitalidad actual de las ideas de Prebisch puede expresarse mediante los mensajes centrales identificados por Aldo Ferrer y Edgar J. Dosman o mediante la visión que Prebisch tuvo del desarrollo latinoamericano, que ha sido desarrollada e interpretada por ilustres académicos e investigadores a partir de sus contribuciones analíticas más importantes. Algunos de ellos son Edgar J. Dosman, Octavio Rodríguez, Hans Singer, Joseph Love, Carlos Mallorquín, David H. Pollock, José Antonio Ocampo y Ricardo Bielschowsky. También hubo otros que colaboraron directamente con Prebisch e influyeron en su pensamiento o profundizaron y complementaron sus ideas, tales como Celso Furtado, Adolfo Gurrieri, Enrique V. Iglesias, Osvaldo Sunkel, Víctor Urquidi, José Medina Echeverría, Aníbal Pinto, Gert Rosenthal, Enzo Faletto, Jorge Ahumada, José Serra, Maria da Conceição Tavares y Fernando Henrique Cardoso, entre tantos otros. Ambas aproximaciones no son excluyentes, sino que permiten conocer mejor el "Prebisch esencial" y definir por qué sus ideas siguen siendo más vigentes que nunca.

Según la interpretación de Ferrer (2010), Prebisch dejó tres mensajes que a la postre se convertirían en su legado más importante. El primero es que los países del "centro" confeccionan un pensamiento "céntrico" que es funcional a sus intereses. El centro racionaliza el orden internacional, muchas veces a partir de formulaciones ideológicas o ideologizadas, donde la "periferia" ocupa un lugar residual y "pasivo", incapaz de desplegar sus propias capacidades. Para superar esa perspectiva, Prebisch propuso un pensamiento crítico autónomo, una rebelión intelectual contra la corriente dominante y los preceptos económicos ortodoxos. Inspiró a otros a concebir el desarrollo desde América Latina, a partir de las propias fortalezas, obstáculos y herencias históricas y estructurales de la región. Puso de manifiesto que la sustitución de importaciones era igualmente válida cuando se trataba de adoptar paradigmas de desarrollo provenientes 
del centro desarrollado. El segundo mensaje se desprende del anterior y se refiere a la necesidad de la periferia de mantener una relación simétrica y no subordinada con el Norte y el resto del mundo. Instaba a discutir con el Norte, no a tener una ruptura con él. El tercer mensaje, posiblemente el más importante de todos, es la idea de transformar la estructura productiva a fin de incorporar el conocimiento y el cambio técnico, como instrumentos fundamentales del desarrollo ${ }^{23}$.

Prebisch entendió que el principal problema del desarrollo entrañaba la necesidad de elevar el nivel de productividad de toda la fuerza de trabajo. Por esa razón, el subdesarrollo no podía interpretarse como un simple estado de atraso, explicado por factores extraeconómicos vinculados a la estructura social. Prebisch lo visualizó como un patrón de funcionamiento y de evolución específica de ciertas economías, que requería un esfuerzo de elaboración propio y específico (Rodríguez, 2001).

En la concepción de Prebisch sobre el subdesarrollo, existen cuatro hechos estilizados claramente diferenciados. El primero es la brecha creciente de ingreso entre los países del centro y los de la periferia. El segundo, el desempleo persistente en la periferia. El tercero, los continuos desequilibrios en la balanza de pagos de los países de la periferia, que imponen restricciones importantes al proceso de crecimiento económico. El cuarto, la tendencia al deterioro secular de los términos de intercambio. De ahí surgió la concepción del subdesarrollo en Prebisch, sobre la que Furtado (1993) destaca con profunda elegancia: "Desde el punto de vista teórico, el mayor aporte de Prebisch fue la idea de una ruptura estructural de la economía internacional, causada por la lenta difusión del progreso técnico y mantenida por el sistema de división internacional del trabajo establecido al comienzo de la Revolución Industrial. En esta concepción, el comercio exterior no era considerado como una simple extensión de la economía interna, sino que se creía que poseía una dinámica propia". Esta ruptura estructural se constituyó en la piedra angular que dio inicio a la teoría del subdesarrollo y que, con el tiempo, ocuparía un lugar preponderante en la historia del pensamiento desarrollista latinoamericano después de la Segunda Guerra Mundial.

El propio Prebisch (1983), en una recapitulación sobre la evolución de su pensamiento, revela que la estructura de relaciones económicas internacionales que él denominó "sistema centro-periferia" fue en realidad un subproducto de sus aproximaciones analíticas sobre el ciclo económico, como se evidencia en la siguiente afirmación: “Los países que producían

23 El "joven" Prebisch propuso un patrón de desarrollo cuyo principal objetivo sería la industrialización, con el fin de promover cambios en la estructura productiva en respuesta a la elevada elasticidad de la demanda de manufacturas. Así, la industrialización y el aumento de la productividad en la producción primaria se volvían complementarios (Pérez Caldentey y Vernengo, 2012). 
y exportaban materias primas quedaban vinculados así con el centro como función de sus recursos naturales, con lo cual formaban una vasta y heterogénea periferia, incorporada al sistema en diferentes modos y en diferente medida". Termina concluyendo que el subdesarrollo se origina en "la concentración del progreso técnico y sus frutos en actividades económicas orientadas hacia la exportación [que] se volvió característica de una estructura social heterogénea donde gran parte de la población permanecía al margen del desarrollo".

La concepción fundacional de Prebisch puede entenderse, como sugiere Rodríguez (2001), a partir de tres conceptos clave: heterogeneidad estructural, especialización y desarrollo desigual (véase la sección B.1). Sobre esa base se pueden hacer inferencias acerca de la relevancia de sus aportes para el debate actual y a lo largo de los paradigmas de desarrollo experimentados en la región. Sin embargo, para capturar al "Prebisch esencial" y al "pionero del desarrollo" se optó por una aproximación que no se limitara al ámbito de sus aportes teóricos, sino que incluyera la óptica del diplomático, el creador de instituciones, el formulador de políticas económicas, el hombre de acción abierto a nuevas ideas y dispuesto a romper con paradigmas vigentes.

A la hora de referirse a los aportes de Prebisch y su relevancia para el debate actual, más allá de sus contribuciones seminales a la teoría del subdesarrollo latinoamericano, se deben considerar al menos cinco elementos esenciales. En primer lugar, su insistencia en que los economistas de América Latina, y luego los pensadores y científicos sociales en general, mantuvieran la autonomía intelectual. Esto surgió probablemente debido al impacto que tuvieron sobre su forma de pensar la Gran Depresión y la Segunda Guerra Mundial. Además, todo parece indicar que se nutrió de la crítica de Keynes a los modelos neoclásicos que habían dominado el debate económico de la época. En segundo lugar, su vocación permanente por los problemas de desarrollo. Desde esa óptica, es uno de los grandes pioneros del desarrollo y sin duda, padre intelectual de la teoría del subdesarrollo latinoamericano. En tercer lugar, su incansable esfuerzo por forjar instituciones con vocación desarrollista, el Banco Central de la Argentina, la CEPAL, los organismos de integración latinoamericana, la Conferencia de las Naciones Unidas sobre Comercio y Desarrollo (UNCTAD) y la Revista CEPAL. En cuarto lugar, su insistencia en relacionar el análisis teórico con el diseño de políticas y observar la realidad antes de pensar, actuar y formular propuestas. En quinto lugar, su elevada dosis de pragmatismo para buscar soluciones sin ideologismos, exaltando y valorando en su justa dimensión el papel del Estado en el proceso de desarrollo. 
Es evidente que esos mensajes siguen teniendo vitalidad en nuestros días. Las ideas asociadas a la transformación productiva con equidad, el papel vital del Estado en el proceso de desarrollo, el crecimiento sostenido con inclusión social, la sostenibilidad ambiental y una distribución del ingreso más equitativa, la heterogeneidad estructural, la especialización productiva, el desarrollo desigual, el cambio estructural, la relación entre innovación y desarrollo inclusivo y la concepción misma de desarrollo como proceso de aprendizaje, generación y difusión de capacidades tecnológicas endógenas, están enraizados en el pensamiento de Prebisch, que hoy en día adquiere mayor pertinencia en el debate sobre crecimiento y desarrollo.

Como conclusión, valga citar a Joseph Love (1980), cuando subrayó que "...la tesis de Prebisch es la idea de mayor influencia en lo referente a la economía y la sociedad de América Latina del siglo XX, y posiblemente de la historia de la región".

\section{Conclusiones}

El papel del Estado en la economía y en el progreso económico y social de los países en desarrollo, y de los latinoamericanos en particular, ha sido siempre controversial. Es un debate que se ha manifestado a lo largo de los distintos paradigmas de desarrollo y tecnoeconómicos que se han aplicado en la región desde la independencia. Se empieza por definir al Estado y contextualizar el debate reciente en América Latina. Asimismo, se procura desmitificar el falso dilema de las concepciones que contraponen de forma excluyente la función del Estado con el papel del mercado en la actividad económica. En ese esfuerzo, se intenta esclarecer que cualquier paradigma y estrategia de desarrollo supone en última instancia decidir y adoptar una postura sobre los límites del Estado y la política pública.

El concepto de Estado se esclarece desde los preceptos weberianos y sus funciones se plantean a partir de una teoría institucionalista de intervención estatal en un contexto de cambio estructural. Se elaboran tres proposiciones básicas. La primera consiste en reconocer que el Estado y su economía política son variables determinantes del desarrollo económico y social. La segunda sugiere que el Estado en su concepción más amplia es una construcción institucional y, por ende, una variable explicativa fundamental de por qué unos países son más ricos que otros. La tercera es que el Estado en América Latina tiende a ser social-liberal y cada vez más democrático, con diversas interpretaciones del capitalismo globalizado y una integración comercial y regional creciente ${ }^{24}$.

24 Existen dos "variedades" de economías de mercado que recientemente se han propuesto como alternativas que podrían dar mejor resultado que el modelo anglosajón de mínima intervención o laissez-faire. La primera es la de los "Estados de política industrial" de Asia oriental (Japón, 
Se concluye que la idea del mercado equilibrado y eficiente de los neoclásicos ha sido cuestionada desde la Gran Depresión de los años treinta, luego con la crisis de la deuda de los años ochenta y, más recientemente, con la crisis financiera internacional de 2008. Incluso los neoliberales más vehementes aceptan como inevitables algunas formas de intervención estatal, debido no solo a la presencia de externalidades, sino a la ubicuidad de los mercados incompletos, la información asimétrica y el incipiente desarrollo institucional. Por consiguiente, el falso dilema entre Estado y mercado debe sustituirse por la relación correcta de estudio: el papel del Estado en el mercado. Por último, se afirma que un enfoque institucionalista de intervención estatal permite comprender la relación entre el mercado, el Estado y las instituciones en un marco unificado y analíticamente consistente.

Por otra parte, se plantea el concepto de desarrollo sobre la base de tres metateorías y se concluye que cualquier "desarrollo" puede ser concebido a partir de sus factores estratégicos o estructurales, y cualquier política pública, independiente de su origen o concepción, tiene una dimensión estratégica y otra estructural. Una vez establecidos los conceptos centrales sobre Estado y desarrollo, se analiza esa relación mediante un recorrido por los principales documentos institucionales de la CEPAL.

Se muestra por medio de esos documentos que el pensamiento de la CEPAL se caracteriza por aplicar un método histórico-estructural y desarrollar tres ejes analíticos que han permanecido a lo largo de su producción intelectual: i) el análisis de la inserción internacional; ii) el análisis de las condicionantes estructurales internas del crecimiento y del progreso técnico, así como de las relaciones entre ellos, el empleo y la distribución del ingreso, y iii) el análisis de las posibilidades de acción estatal.

Sobre esas bases se plantean los principales paradigmas de desarrollo latinoamericano. Se comienza por el debate entre desarrollo y subdesarrollo en el contexto latinoamericano y se concluye que dicho debate se relaciona directamente con el proceso de acumulación capitalista. Tanto las corrientes estructuralistas como las de la teoría de la dependencia basaron conceptualmente su formulación en dicho proceso. De esa manera, se emprende la búsqueda del Prebisch esencial y de las ideas fundacionales que a la postre se constituyeron en los fundamentos de la teoría del subdesarrollo latinoamericano.

República de Corea y provincia china de Taiwán) y Francia; la segunda es la de las economías escandinavas "corporativistas sociales" (Suecia, Noruega y Finlandia) (Chang, 2003; Hall y Soskice, 2001). 
La revisión sucinta de los paradigmas se realizó a partir de sus rasgos más sobresalientes. Primero, el modelo de desarrollo exportador o de "desarrollo hacia afuera" estuvo vinculado con el auge de las exportaciones de productos primarios y la idea de progreso. Esta última se concebía como resultado del proceso de integración de los países latinoamericanos en la economía mundial como productores de materias primas. Este período abarcó desde 1870 hasta 1929 y terminó con la Gran Depresión.

El segundo paradigma de "industrialización dirigida por el Estado" se aplicó desde 1930 y concluyó en la década de 1970. Se caracterizó por adoptar la industrialización como motor del desarrollo, promover la intervención estatal en diferentes ámbitos de la actividad económica y desarrollar una fuerte orientación al mercado interno. Según el precepto de la CEPAL, fue un patrón de "desarrollo hacia adentro" o, como se conoce internacional y secularmente, de "industrialización por sustitución de importaciones".

El tercer paradigma de "reformas estructurales y de mercado" adoptado desde los años setenta hasta los noventa, tuvo como "manifiesto" el decálogo prescrito en el Consenso de Washington y se caracterizó por promover la liberalización de las fuerzas del mercado mediante un sistema basado en permitir que los precios alcanzaran su debido nivel y una confianza desmedida en el mercado como medio más eficiente de asignar recursos (la supremacía del mercado). Con ese paradigma se relegó el papel del Estado en la actividad económica y, según esa visión, las instituciones distintas al mercado (incluido el Estado) son la "segunda" mejor solución y se consideran solamente cuando el orden "natural" del mercado no llega a producir el resultado esperado.

Se plantea que la corriente neoestructuralista se presentó no solo como el paradigma alternativo al modelo de reforma de mercado, sino como una superación del paradigma estructuralista original en que se inspiró. Se concluye argumentando que, según los neoestructuralistas, lo principales problemas económicos de América Latina no se deben en lo fundamental a distorsiones inducidas por la política económica, sino que son más bien de carácter endógeno, estructural e histórico.

Por último, se ha intentado rescatar un elemento de la "cosmovisión" de las ideas de Prebisch que parece muy pertinente a la situación actual de América Latina, a saber, su concepción balanceada entre las medidas intervencionistas y el respeto al mercado. Añádase a esto su elevado pragmatismo, con la insistencia en la necesidad de mantener la mirada atenta al cambiante orden internacional o al desarrollo del mundo en general. Sus palabras, mensajes, enseñanzas, teorías, intuiciones $\mathrm{y}$, sobre todo, su visión de un desarrollo posible para América Latina, siguen teniendo eco y plena validez en el debate actual sobre Estado y desarrollo. 


\section{Bibliografía}

Acemoglu, D. (2009), Introduction to Modern Economic Growth, Princeton University Press.

Acemoglu, D. y James Robinson (2012), Why Nations Fail: The Origins of Power, Prosperity, and Poverty, Crown Business.

Aguirre, Teresa (2010), "Estado y desarrollo: hacia una nueva agenda", Desarrollo y transformación: opciones para América Latina, México, D.F., Fondo de Cultura Económica.

Altimir, Oscar, Enrique V. Iglesias y José Luis Machinea (eds.) (2008), Hacia la revisión de los paradigmas del desarrollo en América Latina, Comisión Económica para América Latina y el Caribe (CEPAL)/Secretaría General Iberoamericana (SEGIB).

Bértola, Luis y José Antonio Ocampo (2013), El desarrollo económico de América Latina desde la Independencia, México, D.F., Fondo de Cultura Económica.

Bielschowsky, R. (comp.) (2010), Sesenta años de la CEPAL. Textos seleccionados del decenio 1998-2008, Buenos Aires, Siglo XXI.

(1998a), "Evolución de las ideas de la CEPAL", Revista de la CEPAL, número extraordinario (LC/G.2037-P), Santiago de Chile, Comisión Económica para América Latina y el Caribe (CEPAL), octubre.

(1998b), "Cincuenta años del pensamiento de la CEPAL: una reseña", Cincuenta años de pensamiento en la CEPAL. Textos seleccionados, vol. 1, Santiago de Chile, Fondo de Cultura Económica.

Bresser Pereira, Luiz Carlos (1998), "La reconstrucción del Estado en América Latina", Revista de la CEPAL, número extraordinario (LC/G. 2037-P), Santiago de Chile, Comisión Económica para América Latina y el Caribe (CEPAL), octubre.

Bulmer-Thomas, Víctor (2011), La historia económica de América Latina desde la Independencia, México, D.F., Fondo de Cultura Económica, segunda edición.

Cárdenas, Enrique, José Antonio Ocampo y Rosemary Thorp (comps.) (2003), Industrialización y Estado en la América Latina: la leyenda negra de la posguerra, México, D.F., Fondo de Cultura Económica.

Cardoso, Fernando Henrique y Enzo Faletto (1979), Dependencia y desarrollo en América Latina, México, D.F., Siglo XXI.

Cardoso, Fernando Henrique, Raúl Prebisch y R. Green (1982), En torno al Estado y el desarrollo, Editorial Nueva Imagen.

CEPAL (Comisión Económica para América Latina y el Caribe) (2014), Pactos para la igualdad: hacia un futuro sostenible (LC/G.2586(SES.35/3)), Santiago de Chile. (2012), Cambio estructural para la igualdad: Una visión integrada del desarrollo (LC/G.2524(SES.34/3)), Santiago de Chile.

(2010), La hora de la igualdad: brechas por cerrar, caminos por abrir (LC/G.2432(SES.33/3)), Santiago de Chile.

(2000), Equidad, desarrollo y ciudadanía (LC/G.2071(SES.28/3)), Santiago de Chile.

(1998), Estudio Económicode América LatinayelCaribe1998-1999(LC/G.2056-P/E), Santiago de Chile. Publicación de las Naciones Unidas, $\mathrm{N}^{\mathrm{o}}$ de venta: S.99.II.G.2. (1992a), Equidad y transformación productiva: un enfoque integrado, Libros de la CEPAL N 32 (LC/G.1701/Rev.1-P), Santiago de Chile. (1992b), Población, equidad y transformación productiva (LC/G.1758/Rev.2-P; LC/DEM/G.131/Rev.2), Santiago de Chile. 
(1990), Transformación productiva con equidad: La tarea prioritaria del desarrollo de América Latina y el Caribe en los años noventa (LC/G.1601-P), Santiago de Chile, marzo. Publicación de las Naciones Unidas, $\mathrm{N}^{\mathrm{o}}$ de venta: S.90.II.G.6.

(1966), El proceso de desarrollo industrial en América Latina, Santiago de Chile. (1963), Hacia una dinámica política de desarrollo para América Latina, Santiago de Chile.

(1951), Estudio Económico de América Latina 1949 (E/CN.12/217/Rev.1), Nueva York.

(1949), Estudio Económico de América Latina 1948 (E/CN/.12/82), Nueva York.

Chang, Ha Joong (2005), "Entendiendo la relación entre las instituciones y el desarrollo económico: Algunos aspectos teóricos claves", documento presentado en la conferencia aniversario del Instituto Mundial de Investigaciones de Economía del Desarrollo (WIDER), Helsinki, 17 y 18 de junio.

(2003), Globalisation, Economic Development and the Role of the State, Zed Books and Third World Network.

Dossman, Edgar J. (2010), La vida y la época de Raúl Prebisch, 1901-1986, Colección Instituto de Estudios Latinoamericanos, Universidad de Alcalá, Madrid, Editorial Marcial Pons.

(ed.) (2006), Raúl Prebisch: Power, Principle and the Ethics of Development, Washington, D.C., Banco Interamericano de Desarrollo (BID)/Instituto para la Integración de América Latina y el Caribe (INTAL).

(2001), "Los mercados y el Estado en la evolución del "manifiesto" de Prebisch", Revista de la CEPAL, No 75 (LC/G.2150-P/E), Santiago de Chile, Comisión Económica para América Latina y el Caribe (CEPAL), diciembre.

Fajnzylber, F. (1983), La industrialización trunca de América Latina, México, D.F., Nueva Imagen.

Ferrer, A. (2013a), Historia de la globalización I: orígenes del orden económico mundial, México, D.F., Fondo de Cultura Económica.

(2013b), Historia de la globalización II: La revolución industrial y el segundo orden mundial, México, D.F., Fondo de Cultura Económica.

(2010), "Raúl Prebisch y el dilema del desarrollo en el mundo global", Revista CEPAL, N 101 (LC/G.2455-P/E), Santiago de Chile, Comisión Económica para América Latina y el Caribe (CEPAL), agosto.

Ffrench-Davis, Ricardo (2008), Chile entre el neoliberalismo y el crecimiento con equidad: Reformas y políticas económicas desde 1973, Santiago de Chile, Comunicaciones Noreste Ltda.

(2005), Reformas para América Latina: después del fundamentalismo neoliberal, Buenos Aires, Siglo XXI Editores.

(2001), "Formación de capital y marco macroeconómico: bases para un enfoque neoestructuralista", El desarrollo desde dentro: Un enfoque neoestructuralista para la América Latina, Osvaldo Sunkel (comp.), El Trimestre Económico, No 71, México, D.F., Fondo de Cultura Económica.

Ffrench-Davis, Ricardo, Oscar Muñoz y Gabriel Palma (1998), “The Latin American economies, 1959-1990", Latin America: Economy and Society Since 1930, Leslie Bethell (comp.), Cambridge, Cambridge University Press.

Fontaine, Jean-Marc y Mario Lanzarotti (2001), "Le néo-structuralisme. De la critique du Consensus de Washington à l'émergence d'un nouveau paradigme", Mondes en développement, vol. 29, No 113 y 114. 
Furtado, Celso (1993), “La cosmovisión de Prebisch”, El legado de Prebisch, Enrique V. Iglesias (ed.), Washington, D.C., Banco Interamericano de Desarrollo (BID). (1989), La fantasía organizada, Bogotá, Tercer Mundo Editores.

(1971), La economía latinoamericana desde la conquista ibérica hasta la revolución cubana, México, D.F., Siglo XXI Editores.

Ganuza, Enrique y otros (2004), ¿Quién se beneficia del libre comercio? Promoción de exportaciones y pobreza en América Latina y el Caribe en los 90, Bogotá, Programa de las Naciones Unidas para el Desarrollo (PNUD)/ Alfaomega Colombiana.

(eds.) (2001), Liberalización, desigualdad y pobreza: América Latina y el Caribe en los 90, Programa de las Naciones Unidas para el Desarrollo (PNUD), Comisión Económica para América Latina y el Caribe (CEPAL), Editorial Universitaria de Buenos Aires.

Glade, William (1992), "El Estado como capital organizativo en la industrialización", Los problemas del desarrollo en América Latina: Homenaje a Raúl Prebisch, Luisa Montuschi y Hans Singer (comps.), México, D.F., Fondo de Cultura Económica.

Guillén Romo, Héctor (2010), "Políticas y estrategias de desarrollo en América Latina y los países del sudeste asiático", Desarrollo y transformación: opciones para América Latina, Gregorio Vidal, Arturo Guillén y José Déniz (coords.), Madrid, Fondo de Cultura Económica.

(2007), "De la orden cepalina del desarrollo al neoestructuralismo en América Latina", Comercio Exterior, vol. 57, N 4, México, D.F., abril.

Gurrieri, Adolfo (comp.) (1982), "La obra de Prebisch en la CEPAL", Lecturas del Trimestre Económico, No 46, México, D.F., Fondo de Cultura Económica.

Hall, Peter A. y David Soskice (eds.) (2001), Varieties of Capitalism: The Institutional Foundations of Comparative Advantage, Nueva York, Oxford University Press.

Hirschman, A. (1980), "Orto y ocaso de la economía del desarrollo", Trimestre Económico, vol. XLVII, No 188 , octubre-diciembre.

(1971), "The political economy of import-substituting industrialization in Latin America", A Bias for Hope: Essays on Development and Latin America, New Haven, Yale University Press.

Iglesias, Enrique V. (2006), “El papel del Estado y los paradigmas económicos en América Latina", Revista de la CEPAL, No 90 (LC/G.2323-P/E), Santiago de Chile, Comisión Económica para América Latina y el Caribe (CEPAL), diciembre. (ed.) (1993), El legado de Raúl Prebisch, Washington, D.C., Banco Interamericano de Desarrollo (BID).

ILPES (Instituto Latinoamericano y del Caribe de Planificación Económica y Social) (1995), Reforma y modernización del Estado (LC/IP/L.107), Santiago de Chile, Comisión Económica para América Latina y el Caribe (CEPAL).

Kozul-Wright, R. y Paul Rayment (2008), The Resistible Rise of Market Fundamentalism: Rethinking Development Policy in an Unbalanced World, Zed Books.

Love, J. (1980), "Raúl Prebisch and the origins of the doctrine of unequal exchange", Latin American Research Review, vol.15, N³, Chapel Hill, Asociación de Estudios Latinoamericanos.

(1994), "Economic ideas and ideologies in Latin America since 1930", The Cambridge History of Latin America, vol. 6, N 1 , L. Bethel (comp.), Cambridge, Cambridge University Press.

Lustig, Nora (1998), "Del estructuralismo al neoestructuralismo: la búsqueda de un paradigma heterodoxo", Colección de Estudios CIEPLAN, $\mathrm{N}^{\mathrm{o}} 23$, Santiago de Chile, marzo. 
Morley, S., R. Machado y S. Pettinato (1999), "Indexes of structural reform in Latin America", serie Reformas Económicas, N 12 (LC/L.1166), Santiago de Chile, Comisión Económica para América Latina y el Caribe (CEPAL).

North, Douglass C. (1990), Institutions, Institutional Change and Economic Performance, Cambridge, Cambridge University Press.

Ocampo, José Antonio (2008), “Los paradigmas del desarrollo en la historia latinoamericana", Hacia la revisión de los paradigmas del desarrollo en América Latina, Óscar Altimir, Enrique V. Iglesias y José Luis Machinea (eds.), Santiago de Chile, Comisión Económica para América Latina y el Caribe (CEPAL)/ Secretaría General Iberoamericana (SEGIB).

Ocampo, José Antonio y Jaime Ros (2011), “Shifting paradigms in Latin America's economic development", The Oxford Handbook of Latin American Economics, Oxford University Press.

O'Donnell, Guillermo (2008a), "Hacia un Estado de y para la democracia", Democracia, Estado y ciudadanía. Hacia un Estado de y para la democracia en América Latina, Nueva York, Programa de las Naciones Unidas para el Desarrollo (PNUD).

(2008b), "Los desafíos actuales de la democracia y el desarrollo", Hacia la revisión de los paradigmas del desarrollo en América Latina, Oscar Altimir, Enrique V. Iglesias y José Luis Machinea (eds.), Santiago de Chile, Comisión Económica para América Latina y el Caribe (CEPAL)/Secretaría General Iberoamericana (SEGIB).

Pérez Caldentey E. y M. Vernengo (2012), "Retrato de un joven economista: La evolución de las opiniones de Raúl Prebisch sobre el ciclo económico y el dinero, 1919-1949", Revista CEPAL, No 106 (LC/G.2518-P-E), Santiago de Chile, Comisión Económica para América Latina y el Caribe (CEPAL), abril.

Pérez Caldentey, E., Osvaldo Sunkel y Miguel Torres (2013), Raúl Prebisch (1901-1986): Un recorrido por las etapas de su pensamiento sobre el desarrollo económico [en línea] http://prebisch.cepal.org/sites/default/files/Etapas_pensamiento_ Prebisch.pdf.

Pinto, A. (2008), "Nota sobre los estilos de desarrollo en América Latina", Revista de la CEPAL, No 96 (LC/G.2396-P/E), Santiago de Chile, Comisión Económica para América Latina y el Caribe (CEPAL), diciembre. (1973), "Inflación: Raíces estructurales", Ensayos de Aníbal Pinto, Lecturas del Trimestre Económico, N 3, México, D.F., Fondo de Cultura Económica. (1970), "Naturaleza e implicaciones de la "heterogeneidad estructural" de la América Latina", El Trimestre Económico, vol. 37, N 145, México, D.F., Fondo de Cultura Económica, enero-marzo.

Polanyi, Karl (1944), The Great Transformation: The political and economic origins of our time, Nueva York, Rinehart.

Prebisch, R. (1949), “El desarrollo económico de la América Latina y algunos de sus principales problemas", La obra de Prebisch en la CEPAL, A. Gurrieri, México, D.F., Fondo de Cultura Económica, 1982.

(1970), Transformación y desarrollo. La gran tarea de la América Latina, México, D.F., Fondo de Cultura Económica.

(1973), "Interpretación del proceso de desarrollo latinoamericano en 1949", serie Conmemorativa del XXV aniversario de la CEPAL, Santiago de Chile, Comisión Económica para América Latina y el Caribe (CEPAL).

(1976), "Crítica al capitalismo periférico", Revista de la CEPAL, No 1, Santiago de Chile, Comisión Económica para América Latina y el Caribe (CEPAL), primer semestre. 
(1979), "Las teorías neoclásicas del liberalismo económico", Revista de la CEPAL, N 7 (E/CEPAL/1084), Santiago de Chile, Comisión Económica para América Latina y el Caribe (CEPAL), abril.

(1983), "Cinco etapas de mi pensamiento sobre el desarrollo", El Trimestre Económico, vol. 50(2), N ${ }^{o}$ 198, México, D.F., Fondo de Cultura Económica, abril-junio.

Rodríguez, Octavio (2006), El estructuralismo latinoamericano, México, D.F., Comisión Económica para América Latina y el Caribe (CEPAL)/Siglo XXI Editores. (2001), "Prebisch: actualidad de sus ideas", Revista de la CEPAL, N 75 (LC/G.2150-P/E), Santiago de Chile, Comisión Económica para América Latina y el Caribe (CEPAL), diciembre.

Rodrik, Dani (ed.) (2002), In Search of Prosperity: Analytic Narratives on Economic Growth, Princeton, Princeton University Press.

(2004), "Getting institutions right", CESifo DICE Report, febrero.

(2007), One Economics, Many Recipes: Globalization, Institutions and Economic Growth, Princeton, Princeton University Press.

Rosenthal, Gert (2004), "ECLAC: a commitment to a Latin American way towards development", Unity and Diversity in Development Ideas: Perspectives from the UN Regional Commissions, Yves Berthelot (comp.), serie de Proyectos de historia intelectual de las Naciones Unidas, Bloomington, Indiana University Press.

(1998), "Pensamiento y políticas sobre el desarrollo en América Latina y el Caribe: pasado y futuro", El desarrollo económico y social en los umbrales del siglo XXI, Louis Emmerij y José Núñez del Arco (comps.), Washington, D.C., Banco Interamericano de Desarrollo (BID).

Sen, Amartya (1999), Development as Freedom, Oxford University Press.

Singer, Hans (1998), “¿Es aún relevante la economía del desarrollo?”, El desarrollo económico y social en los umbrales del siglo XXI, Louis Emmerij y José Núñez del Arco (comps.), Washington, D.C., Banco Interamericano de Desarrollo (BID).

Stallings, Barbara y Wilson Peres (2000), Growth, Employment and Equity: the Impact of the Economic Reforms in Latin America and the Caribbean, Washington, D.C., The Brookings Institution/Comisión Económica para América Latina y el Caribe (CEPAL)/Fondo de Cultura Económica.

Sunkel, Osvaldo (comp.) (1991), El desarrollo desde dentro: un enfoque neoestructuralista para la América Latina, Lecturas del Trimestre Económico, N 71, México, D.F.

Sunkel, O. y P. Paz (1970), "El subdesarrollo latinoamericano y la teoría del desarrollo", Textos del Instituto Latinoamericano y del Caribe de Planificación Económica y Social (ILPES), México, D.F., Siglo XXI Editores.

Thorp, Rosemary (1998), Progress, Poverty and Exclusion: An Economic History of Latin America in the 20th Century, Baltimore, Johns Hopkins University Press/Banco Interamericano de Desarrollo (BID).

Veltmeyer, Henry (2010), "Una sinopsis de la idea de desarrollo", Migración y Desarrollo, Nº 14. Universidad Autónoma de Zacatecas (UAZ).

Williamson, John (1990), "What Washington means by policy reform”, Latin American Adjustment. How Much Has Happened?, John Williamson (ed.), Washington, D.C., Instituto de Economía Internacional.

Williamson, Oliver (1985), The Economic Institutions of Capitalism, Free Press. 

Capítulo XII

\section{Sobre el Estado, la heterodoxia y el aporte del feminismo}

En este capítulo se presentan tres vertientes que fluyen del feminismo - en tanto filosofía política de la igualdad-, y se argumenta cómo el pensamiento feminista contribuye a mejorar la calidad de la economía y la política. La primera vertiente se refiere al pensamiento crítico en cuanto interpelación de ciertos dogmas sobre el Estado y el mercado; la segunda remite a la crítica de los supuestos que subyacen en las políticas públicas, y la tercera aborda las implicancias del pensamiento feminista en el papel del Estado.

El texto se ha estructurado en cuatro secciones. En la sección A se analizan los aportes de la teoría feminista y sus propuestas de política. En la sección B se analiza la relación del Estado, la democracia y la economía a la luz de la igualdad de género. En la sección C se examina la vinculación entre la economía y la igualdad de género y las aportaciones del pensamiento feminista en la materia. En la sección D se reflexiona sobre la perspectiva heterodoxa y sus retos en la economía y el papel del Estado. 


\section{A. Los aportes del feminismo}

Si se parte de la premisa que la reflexión heterodoxa se caracteriza principalmente por ser un pensamiento crítico que no acepta los dogmas, ciertamente la teoría feminista y las propuestas políticas que de esta se desprenden, forman parte de una de las corrientes innovadoras y vigentes de la modernidad en el debate global, con múltiples expresiones que, sin embargo, conservan un núcleo de ideas fundamentales que sustentan el concepto del sistema sexo género como marco analítico ${ }^{1}$. El feminismo ha resignificado los conceptos de la sexualidad, sus vínculos con la política y las leyes empujando hacia el mundo privado las fronteras del análisis de la democracia y el papel del Estado. En palabras de Amelia Valcarcel (1997), el feminismo es una filosofía política de la igualdad que simplemente, como claros y distintos son todos los principios, se plantea lo siguiente: admitida la igualdad entre todos los seres humanos, en su procuro de aquello que se consideren bienes, ¿qué razón hay para que la mitad de los seres humanos, el colectivo completo de las mujeres, no tenga los mismos derechos reconocidos a tales bienes que tiene el colectivo humano?

Mediante la identificación de los vínculos señalados anteriormente y analizando las relaciones de poder entre los sujetos, se ha posibilitado una ampliación del concepto de derechos humanos, que incluye el papel del Estado como garante de estos en la familia gracias a una comprensión de las interconexiones entre las esferas pública y privada.

La ampliación del concepto de igualdad ha sido uno de los aportes más importantes del pensamiento feminista al análisis de la desigualdad. La teoría feminista ha puesto en evidencia la distancia entre los discursos normativos sobre la igualdad y las interacciones cotidianas, esclareciendo los distintos procesos (construcción cultural) mediante los cuales se reproduce la desigualdad, y donde destacan los mecanismos sutiles de "creación" de los otros sujetos como inferiores. Al hacerlo, ha ampliado el concepto de universalismo y ha servido para argumentar las insuficiencias de los modelos económicos, políticos ${ }^{2}$ y el propio sistema de derechos humanos (Naciones Unidas, 1993). El universalismo, en sus orígenes, delimitó la comunidad de iguales mediante el estado conyugal, la propiedad, el sexo y otras características que se están transformando en beneficio de una mirada más amplia de los derechos humanos. La libertad del jefe de familia se sustentaba en la desigualdad y el dominio de los otros dentro del grupo familiar. Al poner en cuestión los límites del

Gayle Rubin define el sistema sexo género como el conjunto de disposiciones por el que una sociedad transforma la sexualidad biológica en productos de la actividad humana, y en el cual se satisfacen esas necesidades humanas transformadas. Véase Reiter (1975).

2 Según Carole Pateman (1995), todas las democracias son insuficientes desde el punto de vista de género. 
universalismo y extenderlos hasta las mujeres excluidas de los derechos o subordinadas a las relaciones conyugales para obtenerlos, la teoría feminista ha identificado las causas estructurales de la discriminación, explicando la subordinación de las mujeres conceptualizadas como sistema de sexo género (Lamas, 2002), y por extensión ha influido en el reconocimiento de los derechos individuales de todos los miembros de la familia, incluidos los niños, niñas y adolescentes como sujetos de derecho.

Al develar la articulación de los distintos sistemas de desigualdad en la organización de la vida social y la configuración de experiencias, se ha iluminado la singularidad y especificidad de las biografías de las personas durante el ciclo de vida en distintos contextos socioculturales (raza, género y etnia). Las desigualdades de género vividas de acuerdo a la procedencia social, el origen étnico racial, la edad y el territorio donde transcurre la vida de las mujeres interactúan con otras formas de discriminación configurando experiencias de vida distintas. Los modelos de opresión existentes en la sociedad no actúan de forma independiente unos de otros; más bien al contrario, se interrelacionan entre sí generando un sistema de opresión que refleja la "intersección" de múltiples formas de discriminación ${ }^{3}$.

La diferenciación y desagregación en el análisis ha contribuido a visibilizar la pluralidad de actores sociales y políticos que deberían participar en los debates de los que están excluidos a pesar de ser directamente concernidos y reconocidos como interlocutores de los distintos actores e instituciones, en especial del Estado. La paridad ha sido una de las estrategias para habilitar las voces de las mujeres al erigirlas como sujetos políticos reconocidos.

La perspectiva de la igualdad inscrita en el concepto de género trasciende el pensamiento liberal e ilustrado. Esta llega más allá de la concepción de la igualdad de oportunidades, al tornar explícitos los sesgos y las constelaciones de poder en las relaciones sociales que se expresan en diferentes dimensiones, desafiando en especial el poder privado asociado al ejercicio de la autoridad y a la lógica de los afectos, en contraposición al poder público con el que se asocia la democracia. El análisis feminista ha revelado cómo las formas de ejercicio del poder en distintos ámbitos se interrelacionan y contribuyen así a restringir los espacios, y por tanto actores y temas deben ser abordados en las esferas públicas donde se instalan las agendas. A la vez, ha ampliado y enriquecido la comprensión sobre las formas de hacer política desde posiciones de menor poder.

Al mostrar las relaciones de poder dentro de la familia, el feminismo ha contribuido a la definición política de fenómenos sociales invisibilizados

Esta es una de las razones por las que la integración de la perspectiva de género debería ser transversal. 
(feminicidio, economía del cuidado, paridad, entre otros) y a la cuantificación de su magnitud mediante nuevas estadísticas, contribuyendo de esta manera a precisar las dimensiones y objetivos del desarrollo. Tales aportaciones se han sustentado en la producción de información, de conocimientos y argumentaciones que cuestionan las representaciones y estereotipos dominantes con la realidad social. En el ámbito de la política, se han sustentado en la capacidad de formar redes y alianzas, así como de trazar escenarios políticos en torno a nuevos problemas y su capacidad de mantener las agendas en el tiempo ${ }^{4}$. Igualmente importante es la riqueza de sus aportes recogiendo las críticas de los movimientos sociales de mujeres indígenas, afroamericanas, lesbianas, gays, travestis y bisexuales (LGTB) y articulando y haciéndose cargo de las tensiones políticas e intelectuales que plantea el reconocimiento de todos los sujetos.

Diversas tensiones y desafíos conceptuales derivan del análisis de género sobre la igualdad. Entre estas, las tensiones de lo particular y lo universal, lo individual y lo colectivo, lo público y lo privado, así como los asuntos vinculados a la representación, la delegación de poder y las formas de liderazgo. La constitución del imaginario moderno de lo público y lo privado, así como la idea moderna de la diferencia radical entre hombres y mujeres fueron determinantes para la construcción de los criterios de inclusión, exclusión y clasificación que han sustentado las formas de ciudadanía contemporáneas. El Estado moderno se ha fundado en una tajante separación de las esferas pública y privada y en un orden jerárquico de géneros.

\section{B. El papel del Estado, la democracia y la economía}

Para referirse al Estado y su relación con la política económica y macroeconómica, es necesario ahondar en el papel de las instituciones (leyes, prácticas y mecanismos). Estas configuran un conjunto de relaciones y han dejado al Estado como el supervisor o regulador del mercado, sin abordar otros problemas relacionados con temas como el patriarcado, la democracia, la integración, la ciudadanía y la igualdad social.

La igualdad de género es un indicador de cuán democrático es un sistema político. Desde el feminismo se critica a la democracia porque no incluye a las mujeres en igualdad de condiciones, sobre todo en el ejercicio del poder, y no atiende a sus intereses específicos, restándole en consecuencia capacidades de actuación en el mercado, la sociedad y la política.

\footnotetext{
La agenda de desarrollo de Naciones Unidas durante la década de 1990 mostró la capacidad de innovación que ha tenido la agenda feminista y que se expresa en este momento en la agenda para el desarrollo después de 2015.
} 
De forma creciente se están desarrollando mecanismos de inclusión de las mujeres en cargos electivos y mandatos. Los instrumentos más importantes han sido las cuotas mínimas de representación, que corresponden a un mecanismo compensatorio eficaz. Durante los últimos años se ha comenzado a debatir y consagrar la democracia paritaria, consistente en revisar el concepto de una representación que atendía a la pluralidad ideológica y territorial. Solo después se consideró que como la ciudadanía está compuesta por hombres y por mujeres, ambos sexos deberían estar representados en porcentajes iguales en el sistema político. Sin duda, la conquista de la paridad entraña un proceso que necesita herramientas como el recurso de las cuotas, pero sobre todo precisa el reconocimiento de las mujeres como ciudadanas de pleno derecho.

América Latina ha mostrado en los últimos 30 años una capacidad en el manejo de las políticas macroeconómicas que ha concitado reconocimiento. La región también ha sido capaz de avanzar en el desarrollo de la democracia durante el último cuarto de siglo. Sin embargo, ambos procesos han ido acompañados de una creciente desigualdad social y de género, en particular. Está pendiente una agenda abocada a la desigualdad, la heterogeneidad y la constatación de brechas, cuya visibilidad ha dado lugar a nuevas críticas y desafíos a los dogmas persistentes.

A pesar de las diferencias fundamentales de los modelos inspirados en el Estado de bienestar y los modelos de desarrollo sustentados en el libre mercado, una constante se ha mantenido en los países: las mujeres, no obstante haber logrado altos niveles educativos y una amplia y veloz incorporación a la fuerza de trabajo, continúan siendo la parte menos beneficiada del progreso y del desarrollo. Esto se relaciona con la invisibilidad política de estas brechas y el desconocimiento de los efectos virtuosos que trae consigo la igualdad de género. La pregunta que surge es entonces, ¿por qué ocurre esto? La invisibilidad de las relaciones de género obscurece la subordinación de las mujeres y refuerza la percepción generalizada de economistas y políticos acerca de la irrelevancia de esta desigualdad para el diseño de políticas, lo que asegura la hegemonía masculina en las esferas de toma de decisiones. Belluzzo señala correctamente que uno de los desafíos que debe enfrentar la región es la captura del Estado por parte de intereses particulares, cuyos claros sesgos de género debilitan las instituciones públicas (Gonzaga Belluzzo, 2013).

Asimismo, desde la perspectiva de la igualdad social y ciudadana esta captura de intereses particulares se refiere tanto a los intereses económicos, financieros o a la corrupción, como a la captura de las instituciones públicas por parte del fundamentalismo religioso. El fortalecimiento del Estado laico es crucial para el desarrollo y devolver a las instituciones democráticas una institucionalidad que garantice 
efectivamente la libertad de culto, junto con el ejercicio de los derechos sexuales y reproductivos, sin cuyo goce no es posible pensar en la igualdad de oportunidades y mucho menos en sus resultados.

Estudios de la CEPAL (2013 y 2012a) han mostrado que las mujeres pobres son precisamente quienes enfrentan las consecuencias de la dificultad de acceso y goce de esos derechos y, a la vez, resultan las menos favorecidas por las oportunidades de empleo. Como se puede observar en el gráfico XII.1, todavía la mitad de las mujeres en edad de trabajar no tiene un vínculo laboral en la región.

\section{Gráfico XII.1 \\ América Latina (18 países): tasa de actividad económica ${ }^{a}$ por sexo, total nacional ${ }^{b}$, rondas de encuestas ${ }^{c}$}

(En porcentajes)

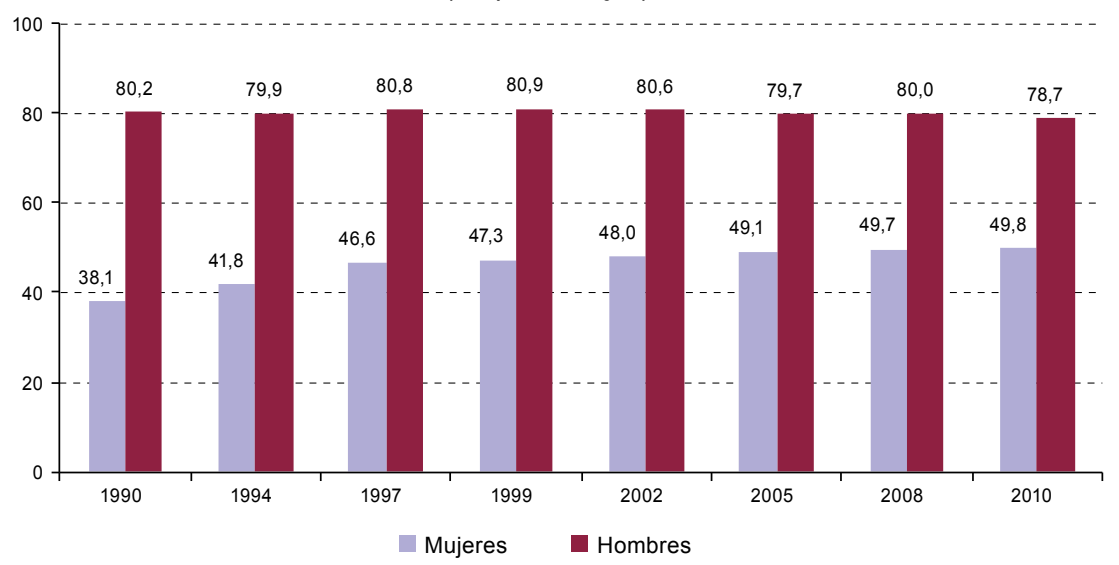

Fuente: Comisión Económica para América Latina y el Caribe (CEPAL), sobre la base de tabulaciones especiales de las encuestas de hogares de los respectivos países.

a Sobre la población de 15 años de edad y más.

b Datos nacionales. Salvo la Argentina, datos urbanos en todas las rondas de encuestas. Bolivia (Estado Plurinacional de), datos urbanos en rondas de 1990 y 1994. Ecuador, datos urbanos en rondas de 1990 a 2002. Panamá, datos urbanos en rondas de 1990 a 1999. El Paraguay, datos urbanos en rondas de 1990 a 1997. El Uruguay, datos urbanos en rondas de 1990 a 2005.

c América Latina, promedio simple calculado con 18 países salvo la ronda de encuestas de 1990 sin El Salvador, Nicaragua y la República Dominicana; ronda de 1994 sin Guatemala y la República Dominicana; ronda de 1997 sin Guatemala, Nicaragua y la República Dominicana; ronda de 1999 sin la República Dominicana; ronda de 2005 sin Guatemala; ronda de 2008 sin Nicaragua; ronda de 2010 sin Guatemala.

Uno de los debates críticos ha estado relacionado con el papel del Estado en la regulación del mercado. La respuesta ha surgido por la práctica de las políticas de salvataje que los Estados han ocupado frente a la crisis del sistema financiero. La contundencia de la respuesta frente a la crisis del Estado, permite que legítimamente se le pida al Estado atender las demandas de igualdad y redistribución. 


\section{Economía e igualdad}

El dogma neoliberal sobre el Estado en el sentido de que este solo cumple un papel de regulación se ha roto durante la última crisis en que los Estados han salido a rescatar el sistema. Al aceptar, legitimar y fomentar el salvataje del sistema financiero, se han traspasado no solo todas las barreras económicas aceptables, sino también las éticas y morales 5 .

La legitimidad de la intervención del Estado a favor de la redistribución y la igualdad es más compatible con la perspectiva que tiene la economía feminista. Dicho de otra manera, si los Estados pueden rescatar a la banca especuladora, con mayor razón pueden invertir en igualdad. La perspectiva de igualdad de género y los derechos humanos universales permiten abordar de forma más clara el debate sobre el tipo de desarrollo que se puede construir. Al abrirse una discusión sobre la ineficacia del neoliberalismo, es factible debatir entre diversas "heterodoxias" cuyo punto de convergencia es la revalorización del Estado. Entre estas persisten aún diferencias críticas respecto al concepto de desarrollo, una de cuyas dimensiones clave es para el feminismo la visibilidad, el reconocimiento y la valorización del trabajo de las mujeres y los sesgos con los que se aborda el tema desde la economía y la política. Todavía existen vínculos ideológicos entre ortodoxos y heterodoxos cuando de igualdad de género se trata.

Hoy en día, esta inquietud comienza a resolverse cuando se reconoce $^{6}$ que los aportes del pensamiento feminista están proporcionando una nueva visión del bienestar. Esta subraya, visibiliza y releva la importancia que tiene el trabajo no remunerado, el trabajo doméstico y el trabajo invisible de mujeres y hombres para el bienestar, a través de su visibilidad estadística, política y para enfrentar el paradigma tradicional del desarrollo, donde se lo asociaba con el crecimiento y, eventualmente, con una distribución de arriba hacia abajo7.

El principal aporte de la perspectiva de género en la economía ha sido el deshacer la confusión existente entre trabajo y empleo. No son sinónimos: tanto en las economías desarrolladas como, incluso más, en las economías de países en desarrollo, frecuentemente el empleo no absorbe ni siquiera la mitad del esfuerzo de trabajo de la economía. De

Un claro ejemplo al respecto se observa en Europa, con el problema de la vivienda y los desahucios, entre otros. Igualmente son ilustrativas las consecuencias del ajuste en Grecia, entre otros países.

6 La Comisión Sarkozy encargó al respecto la elaboración de un informe, elaborado por Stiglitz, Sen y Fitoussi (2009).

7 Una de las exponentes más notables de este pensamiento es María Ángeles Durán, cuyos aportes próximos a publicar por la Comisión Económica para América Latina y el Caribe (CEPAL) sintetizan el debate actual sobre la economía y el desarrollo (Durán, 2012 y 2007). 
aquí deriva el gran aporte de los estudios sobre otras formas de trabajo que no son empleo, como el trabajo no remunerado de los hogares y el trabajo de voluntariado.

En este largo tránsito de debate intelectual, el feminismo ha aportado no solo a la economía, sino también a la comprensión del Estado y a la importancia que tiene la visibilización de las condiciones estructurales que diferencian la ciudadanía de hombres y mujeres. Esto ha ocurrido hasta en el contexto de los estados de bienestar donde la ciudadanía femenina y sus derechos laborales estaban asociados a la titularidad laboral del hombre. Se ha tardado mucho tiempo $-\mathrm{y}$ todavía media distancia- para que las mujeres puedan tener el derecho legítimo a una participación laboral con autonomía.

Para avanzar hacia esta agenda de igualdad de derechos, el enfoque de género - a partir de la visualización y el reconocimiento de la operación de las relaciones de género en la variedad de ámbitos del desarrollo de las personas y las sociedades - ha identificado la división sexual del trabajo entre hombres y mujeres, y el uso diferente del tiempo como el fundamento de la subordinación económica, social y política de las mujeres. Para transformar esta situación, se requiere de la voluntad política de los gobiernos a fin de concretar cambios que apunten a lograr el desarrollo de capacidades, oportunidades y derechos para las mujeres.

Otra aportación importante que hizo el pensamiento feminista ${ }^{8}$ a la reflexión sobre la economía, la producción, el desarrollo y el desarrollo sostenible, es que no solo resulta pertinente valorizar y tomar en cuenta los costos y las contribuciones de la naturaleza y la explotación de recursos naturales en la economía, sino también el que tiene el trabajo no remunerado en tanto producción de un conjunto de bienes y servicios que, sobre todo en América Latina, recae enormemente en las mujeres pobres (véase el gráfico XII.2).

Emerge un nuevo desafío de investigación y documentación, para mostrar desde otra perspectiva dónde estriba el aporte, por ejemplo, de las mujeres en la agricultura, en las cadenas de servicios y de las mujeres migrantes en el envío de remesas. En suma, existe un conjunto de elementos que están protegiendo a la sociedad de la decadencia social y económica y, sin embargo, no forman parte del sistema de mecanismos que se consideran en las políticas económicas para atender la especificidad y los sesgos, no de un grupo minoritario de mujeres, sino de la mitad de la población.

Hazel Henderson es una de las principales exponentes del pensamiento feminista en los años sesenta y setenta. 


\section{Gráfico XII.2}

América Latina (promedio simple 17 países): desigualdad en la distribución de ingresos por quintiles de ingreso, según sexo, zonas urbanas, alrededor de 2012

(En porcentajes)

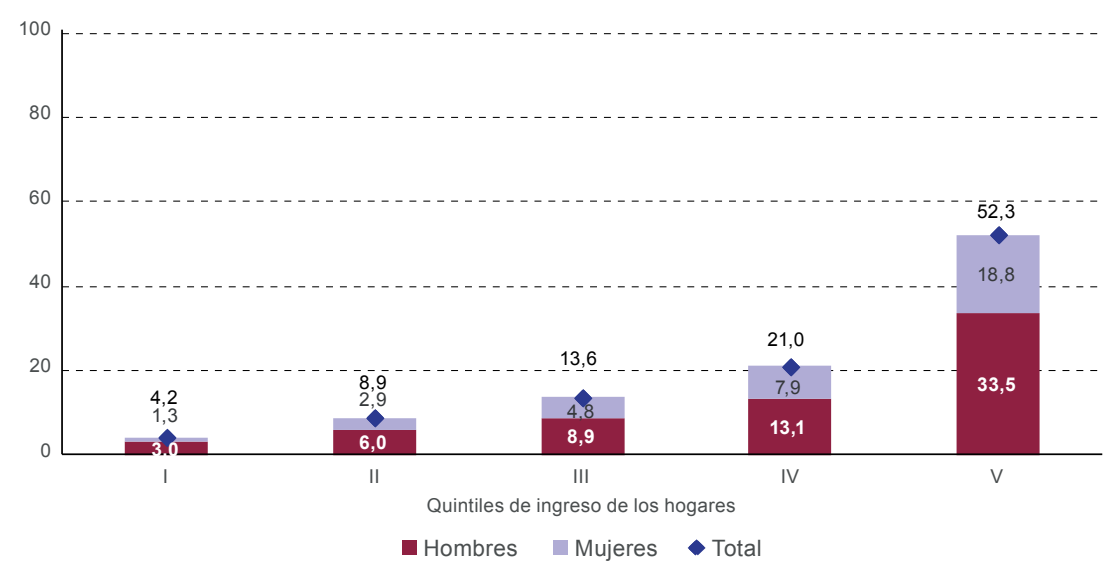

Fuente: Comisión Económica para América Latina y el Caribe (CEPAL).

Se precisa un abordaje que reconozca la diversidad, y que paralelamente admita que esta implica distinguir, visibilizar, valorizar, cuantificar y resignificar un conjunto de materias. ¿Por qué resignificar el tema del trabajo? Porque hasta ahora la noción de trabajo que asumen los países, la academia y la mayoría de los espacios de investigación es un concepto mercantil asociado al salario, según el cual no hay trabajo si no hay salario, cuando en realidad lo que se está tratando de reflejar, con abundante evidencia, es que existe una producción de bienes y servicios en los hogares que no es remunerada $y$, sin embargo, produce valor. Esto, asociado al hecho de que en la actualidad se entiende que la producción entre comillas, reproducción de seres humanos, constituye una tarea fundamental para el desarrollo de la productividad, compele a una reflexión sobre una política pública que no solo se preocupe de los aspectos laborales, ni únicamente busque la protección social, que de por sí ya son desafíos clave, y que extienda la concepción de igualdad desde el ámbito de lo no público y de lo no considerado como objeto en la política.

Es fundamental subrayar la aportación del feminismo al pensamiento crítico, en lo relativo al Estado y al ámbito de la economía. Al develar que lo personal es también político, se busca escapar del control estatal sobre los cuerpos de las mujeres, su tiempo y sus voces, cuestionando el papel accesorio asignado a su trabajo, sea como salario familiar complementario o trabajo no remunerado dentro de los hogares, 
y se desplaza la frontera de los derechos, extendiendo su protección a la dimensión familiar y demandando que el Estado garantice su pleno reconocimiento.

En el contexto de los cambios demográficos se ha tornado evidente la magnitud del cuidado y su valor económico. Como se sabe por las estadísticas, el cuidado se encuentra fundamentalmente entregado a manos de mujeres, en algunos casos mal remuneradas y en otros, no remuneradas. Las mujeres de los países en desarrollo hacen transnacional el trabajo doméstico al emigrar para cuidar a los ancianos, extendiendo la globalización al espacio privado, lo universal a lo local, y viceversa. Se afirma en este texto que es necesario superar el análisis del trabajo y la economía restringido a sus dimensiones macroeconómicas y mercantiles, para resignificar el trabajo del cuidado en comparación con otras actividades. Cabe preguntarse, por ejemplo, ¿por qué se debe poner en el producto interno bruto (PIB) el valor de las bombas atómicas y no asignar el valor del trabajo de cuidado?, ¿por qué conferir valor económico al crecimiento cuando se construyen bombas para destruir vidas y no medir el trabajo no remunerado de las mujeres, que crea seres humanos, valores y capacidades para aprender, producir y desarrollar?

\section{La heterodoxia en la economía y el papel del Estado}

Ciertamente, una de las grandes debilidades de esta perspectiva heterodoxa de la producción y del desarrollo es la ausencia de información y datos, aunque en América Latina varios países están realizando esfuerzos para medir y reconocer el valor del tiempo en estos procesos. El concepto de pobreza de tiempo también interpela la manera tradicional de medición de la pobreza, que es la pobreza de ingresos (véase el gráfico XII.3). En esta línea, la Comisión Económica para América Latina y el Caribe (CEPAL) está trabajando en una nueva metodología, distinta y multidimensional, de medición de la pobreza. Se busca incluir la dimensión del tiempo en la medición de la pobreza, no como algo adjetivo, sino que describiendo la relación conceptual entre los ingresos y el tiempo, lo que pondría en evidencia que la capacidad de generación de ingresos de las mujeres está asociada estructuralmente a sus ataduras domésticas; esto es, las mujeres carecen de los grados de libertad para escoger dónde trabajar, aunque estén educadas, si es que no se cuenta con una inversión en infraestructura, ni políticas activas que tiendan a la eliminación de los obstáculos que estas enfrentan para acceder al mercado de trabajo. Así, el factor tiempo y la medición, valorización e integración de tales consideraciones en la política pública son un reto de la nueva economía heterodoxa. 


\section{Gráfico XII.3}

América Latina (7 países): tiempo total ${ }^{\mathrm{a}}$ destinado al trabajo remunerado y no remunerado por sexo, según país, último dato disponible ${ }^{b}$

(En promedio de horas semanales)

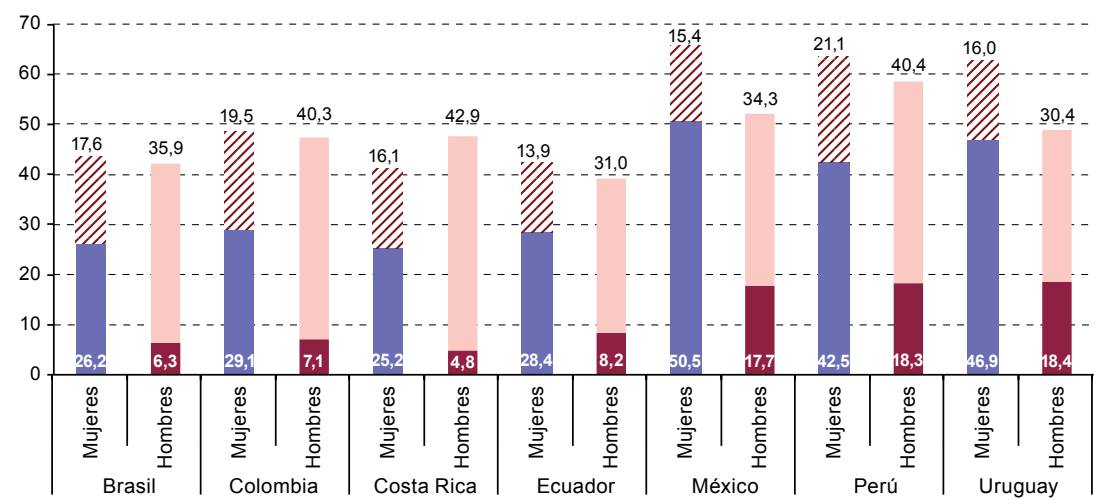

- Tiempo de trabajo no remunerado $\geqslant$ Tiempo de trabajo remunerado

Fuente: Comisión Económica para América Latina y el Caribe (CEPAL), sobre la base de tabulaciones especiales de las encuestas de hogares de los respectivos países.

a Población de 15 años de edad y más.

b Datos de 2011, salvo en los casos de México (2009), Perú (2010) y Uruguay (2007).

Un ejemplo sobresaliente es el caso de la reforma previsional de Chile en 2008. Esta rompió con aquello que para el dogma más tradicional no era posible reconocer: el trabajo de las mujeres. Debido a la reforma previsional, las mujeres a través del fondo solidario y del bono según el número de hijos nacidos vivos pueden superar sus lagunas previsionales y mejorar sus condiciones de jubilación en el futuro. En términos de economía política, es posible medir en comparación con lo que se quiere medir. Aquí primó la voluntad política: debió asumir una mujer Presidenta en Chile, Michelle Bachelet, que dijo "quiero", para que la reforma previsional fuera posible. Mientras ella no dijo "quiero integrar a estas mujeres", a quienes las administradoras de fondos previsionales (AFP) no daban respuestas, este era un tema invisible (Arenas, 2010).

Otro reto importante cuya superación requeriría de políticas de acción positiva, es el tema de los promedios. Si bien en América Latina se está registrando una reducción de la pobreza, no ha disminuido la brecha de la pobreza entre hombres y mujeres. Esto significa que hasta la pobreza está distribuida de acuerdo con patrones de género, por lo que el desafío consiste en que estas brechas no se incrementen mientras los promedios bajan (véase el gráfico XII.4). 


\section{Gráfico XII.4 \\ América Latina (18 países): índice de feminidad de la pobreza por país y región, alrededor de 2002 y 2012}

(En porcentajes)

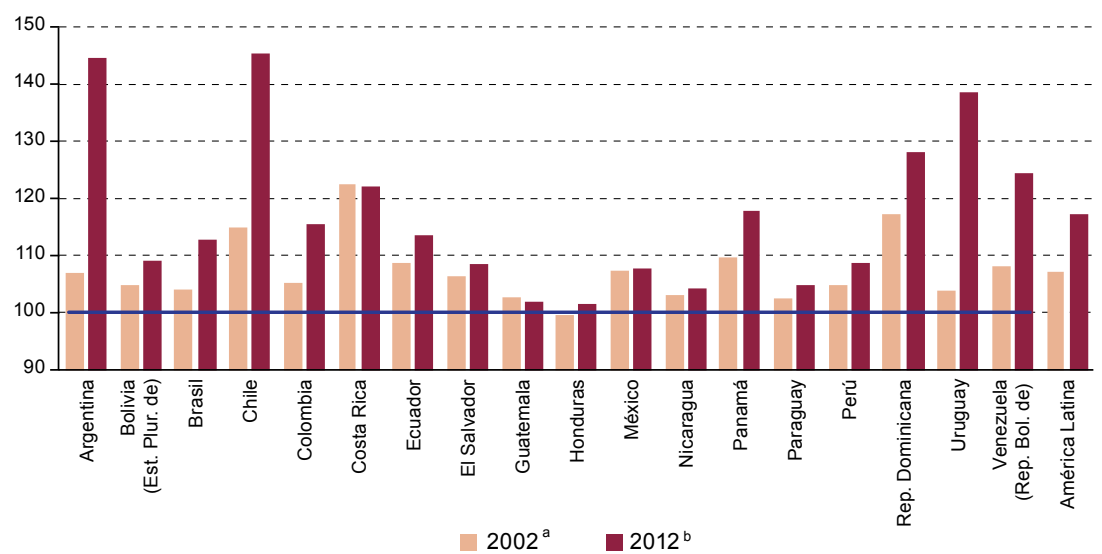

Fuente: Comisión Económica para América Latina y el Caribe (CEPAL), sobre la base de tabulaciones especiales de las encuestas de hogares de los respectivos países.

a Datos nacionales salvo en la Argentina, el Ecuador y el Uruguay, donde corresponden a áreas urbanas. Los datos nacionales de Chile corresponden a 2003; los de El Salvador, Nicaragua y el Paraguay, a 2001.

b Datos nacionales, salvo en la Argentina, donde corresponden a áreas urbanas. Los datos nacionales de Bolivia (Estado Plurinacional de), Chile, Panamá y el Paraguay corresponden a 2011; los de Honduras, a 2010; los de Nicaragua, a 2009, y los de Guatemala, a 2006.

En cuanto a la brecha salarial de género, resulta inaceptable que en una sociedad donde las mujeres son más educadas que los hombres y donde ambos padecen las debilidades del sistema educativo para la innovación y la producción, ellas terminen siendo penalizadas de forma inexplicable, dado que no son causantes de la discriminación que las afecta (véase el gráfico XII.5).

En consecuencia, constituye un desafío para el papel del Estado en la sociedad, poder garantizar los derechos y una política pública adecuada frente a un conjunto de medidas no relacionadas con la economía directamente, sino con la familia, la libertad, la sexualidad, la violencia contra la mujer, la fecundidad y otras materias. Frente a estas cuestiones deberían ponerse en marcha las políticas públicas estatales, y es hacia donde tendrían que orientarse también la política fiscal y los tributos. 
Gráfico XII.5

América Latina (promedio simple 18 países $^{a}$ ): ingreso medio laboral de las mujeres comparado con el de los hombres, según número de años de instrucción, total nacional, alrededor de 2012

(En porcentajes)

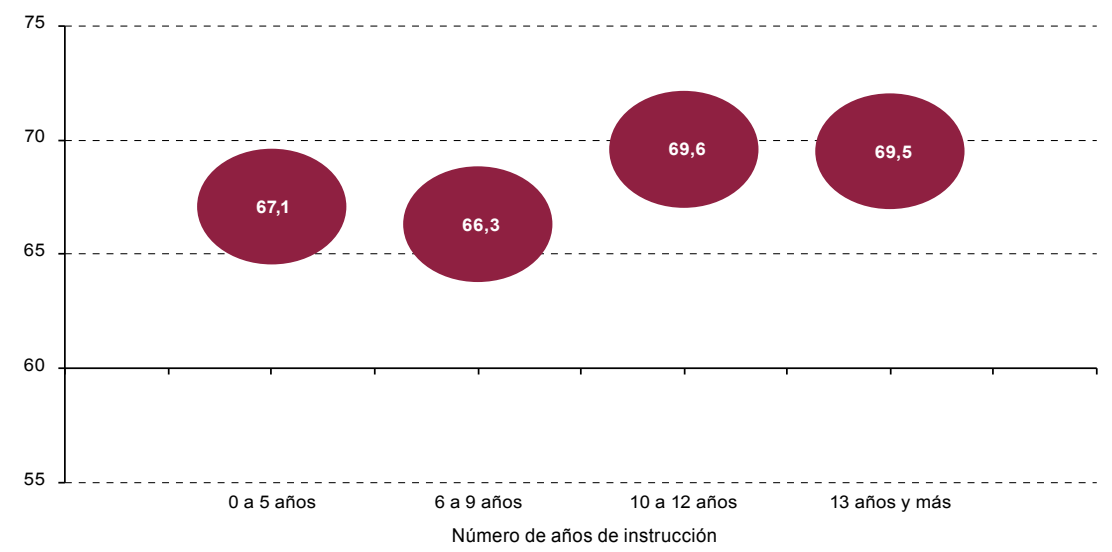

Fuente: Comisión Económica para América Latina y el Caribe (CEPAL), sobre la base de tabulaciones especiales de las encuestas de hogares de los respectivos países.

a Datos nacionales salvo en la Argentina, donde corresponden a áreas urbanas. Los datos de la Argentina, el Brasil, Colombia, Costa Rica, el Ecuador, El Salvador, México, el Perú, la República Dominicana, el Uruguay y Venezuela (República Boliviariana de) corresponden a 2012; los de Bolivia (Estado Plurinacional de), Chile, Panamá y el Paraguay, a 2011; los de Honduras, a 2010; los de Nicaragua, a 2009, y los de Guatemala, a 2006.

Es positivo que esté de regreso la perspectiva de que el Estado juegue un papel activo en la producción y en la redistribución y a partir de allí se busque una nueva ecuación con el mercado. Sin embargo, el Estado precisa además tener la capacidad de superar estos límites para comprometerse con la promoción de una ciudadanía activa, impulsar la democracia y propiciar la participación equitativa de hombres y mujeres en la toma de decisiones; estas y otras políticas requieren de la liberación de ataduras que están todavía invisibles en los ámbitos de la economía del cuidado y de la pobreza, así como de acciones específicas de los Estados que reconozcan que ha habido lo que Isabella Baker llama un olvido estratégico.

Tomando en cuenta lo expuesto, el análisis del desarrollo no puede restringirse a la inclusión de la mujer en cada materia que se trate, ni a una sección específica y tampoco al examen de los efectos de las desigualdades en sus vidas, sino que debe trascender y ampliarse a la comprensión de las relaciones desiguales de género como relaciones de poder y parte sustantiva del desarrollo, que afecta a la totalidad de los procesos económicos, políticos y culturales. De esta manera se estará avanzando hacia un análisis respetuoso de la complejidad del desarrollo y anticipándose a los fracasos de las políticas públicas, independientemente de las buenas intenciones que las animan. 


\section{Bibliografía}

Albelda, Randy, Mignon Duffy y Nancy Folbre (2009), Counting on Care Work. Human Infrastructure in Massachusetts, Universidad de Massachusetts.

Antonopoulos, Rania e Indira Hirway (eds.) (2010), Unpaid Work and the Economy: Gender, Time Use and Poverty in Developing Countries, Londres, Palgrave Macmillan.

Antonopoulos, Rania, Nilufer Cagatay y Sara Hsu (2012), Gender Perspectives and Gender Impacts of the Global Economic Crisis, Routledge.

Arenas, Alberto (2010), Historia de la reforma previsional chilena: una experiencia exitosa de política pública en democracia, Organización Internacional del Trabajo (OIT).

Arenas, Alberto y Pamela Gana (2001), "Reforma a los sistemas de pensiones y los desafíos de la dimensión de género", serie Población y Desarrollo, $\mathrm{N}^{\mathrm{o}} 18$ (LC/L.1614-P), Santiago de Chile, Comisión Económica para América Latina y el Caribe (CEPAL).

Bakker, Isabella (ed.) (1994), The Strategic Silence: Gender and Economic Policy, Londres, Zed Books.

Beck, Ulrich (2004), Poder y contrapoder en la era global: la nueva economía política mundial, Barcelona, Paidós.

Calderón, Coral (coord.) (2013), "Redistribuir el cuidado. El desafío de las políticas", Cuaderno de la CEPAL, No 101 (LC/G.2568-P), Santiago de Chile, Comisión Económica para América Latina y el Caribe (CEPAL). Publicación de las Naciones Unidas, $\mathrm{N}^{\mathrm{o}}$ de venta: S.13.II.G.9.

Carrasco, Cristina, Cristina Borderías y Teresa Torns (eds.), El trabajo de cuidados. Historia, teoría y políticas, Madrid Editorial Catarata.

CEPAL (Comisión Económica para América Latina y el Caribe) (2013), Mujeres en la economía digital: superar el umbral de la desigualdad (LC/L.3666(CRM.12/3), Santiago de Chile.

(2012a), Observatorio de Igualdad de Género de América Latina y el Caribe. Informe Anual 2012 (LC/G.2561/Rev.1), Santiago de Chile.

(2012b), Panorama Social de América Latina, 2012 (LC/G.2557-P), Santiago de Chile. Publicación de las Naciones Unidas, Nº de venta: S.13.II.G.6.

Durán, María Ángeles (2012), El trabajo no remunerado en la economía global, Fundación BBVA.

(2007), El valor del tiempo. ¿Cuántas horas te faltan al día?, Madrid, Espasa Calpe.

Espejo, A., F. Filgueira y N. Rico (2010), “Familias latinoamericanas: organización del trabajo no remunerado y de cuidado", Documentos de Proyecto, No 354 (LC/W.354), Santiago de Chile, Comisión Económica para América Latina y el Caribe (CEPAL).

Gammage, Sarah (2010), “Encuestas de uso de tiempo y las políticas de protección social" [en línea] http:/ / www.mujer.gov.py/userfiles/file/Ponencia\%20de \%20 Sarah\%20Gammage\%20-\%20Chile.pdf. (2009), Género, pobreza de tiempo y capacidades en Guatemala: un análisis multifactorial desde una perspectiva económica (LC/MEX/L955), México, D.F., sede subregional de la CEPAL en México. 
Gonzaga Belluzzo, Luiz (2013), “Algunos aspectos de los desafíos económicos de América Latina y el Caribe", Intervención en el Seminario sobre neoestructuralismo y economía heterodoxa, Santiago de Chile, Comisión Económica para América Latina y el Caribe (CEPAL), 22 y 23 de abril.

Henderson, Hazel (1996), Creating Alternative Futures: The End of Economics, Connecticut, Kumarian Press Books for a World that Works. (1991), Paradigms in Progress: Life beyond Economics, Indianapolis, Knowledge Systems.

Montaño, Sonia y Coral Calderón (coords.) (2010), "El cuidado en acción entre el derecho y el trabajo", Cuadernos de la CEPAL, No 94 (LC/G.2454-P), Santiago de Chile, Comisión Económica para América Latina y el Caribe (CEPAL). Publicación de las Naciones Unidas, $N^{o}$ de venta: S.10.II.G.35.

Naciones Unidas (1993), Declaración y Plan de Acción de Viena. Nota de la Secretaria (A/CONF.157/23), 12 de julio [en línea] http://www.unhchr.ch/huridocda/ huridoca.nsf/(Symbol)/A.CONF.157.23.Sp?Opendocument.

Lamas, Marta (2002), Cuerpo: diferencia sexual y género, México, D.F., Taurus.

Orozco, Mónica y Anitzel Merino (2011), "Pobreza de tiempo de las mujeres", documento presentado en la novena Reunión internacional política públicas, uso del tiempo y economía del cuidado: la importancia de las estadísticas nacionales, Instituto Nacional de las Mujeres (INMUJERES)/ONU-Mujeres, México, D.F., 29 y 30 de agosto.

Pateman, Carole (1995), El contrato sexual, Ed. Anthropos.

Reiter, Rayna (1075), "The traffic in women, Notes on the political economy of sex", Toward an Anthropology of Women, R. Reiter (comp.), Nueva York, Monthly Review Press.

Stiglitz,Joseph E., Amartya Sen y Jean-Paul Fitoussi (2009), "Report by the Commission on the Measurement of Economic Performance and Social Progress" [en línea] http:/ / www.stiglitz-sen-fitoussi.fr/documents/overview-eng.pdf.

Valcarcel, Amelia (1997), La política de las mujeres, Madrid Editorial, Cátedra. 

Parte V

Estudios de caso de las grandes economías de la región 

Capítulo XIII

\section{Desarrollo y macroeconomía: reflexiones a partir del caso mexicano}

Juan Carlos Moreno-Brid ${ }^{1}$

\section{Introducción}

El propósito de este artículo es señalar elementos fundamentales de la estructura de la economía que deben tenerse en cuenta en el diseño de una política macroeconómica para el desarrollo. Esta tarea se apoya en los aportes de la perspectiva neoestructuralista, en especial su énfasis en la importancia de la heterogeneidad productiva como determinante de la pauta de crecimiento económico. También se consideran algunas críticas a la política macroeconómica convencional realizadas, con diferentes enfoques, a raíz de la crisis financiera internacional que estalló en 2008 y 2009. Para ello, y a modo de ilustración, se ha tomado como referencia la política macroeconómica aplicada en México durante los últimos 30 años y su relación con el desempeño de la economía mexicana.

Se agradecen los comentarios de Esteban Pérez, Miguel Torres y Luis Ángel Monroy sobre una versión preliminar de este trabajo, presentada en el Seminario sobre Neoestructuralismo y Economía Heterodoxa, CEPAL, Santiago, 22 y 23 de abril de 2013. Asimismo, se reconoce la valiosa asistencia de Jesús Santamaría en la investigación. El presente capítulo se apoya en gran medida en una versión preliminar presentada a la Revista Problemas de Desarrollo de la UNAM. 
El lapso elegido como base de la referencia a la evolución de la economía mexicana comienza a mediados de la década de 1980, cuando el gobierno mexicano empezó a poner en marcha una serie de reformas radicales - en línea con el Consenso de Washington- en respuesta a la contracción económica que había sufrido el país en los años 1981 y 1982, incluida una moratoria de pagos externos que inauguró la crisis internacional de la deuda en América Latina. Las reformas tuvieron como objetivo cancelar la pauta de desarrollo tradicional seguida por el país desde los primeros años de la posguerra, que estaba basada en una industrialización liderada por el Estado y en la sustitución de importaciones. En efecto, el gobierno de De la Madrid (1982-88) inició el rápido desmantelamiento del sistema de protección comercial, la liberalización del mercado financiero, la clausura de la política industrial, la reducción del sector público mediante privatizaciones o cierres de gran parte de las más de 1.000 empresas paraestatales existentes en ese momento y la contracción del gasto público, fundamentalmente el destinado a la inversión.

En línea con la ideología dominante en aquella época, se consideró que una política de "menos Estado y más mercado" era indispensable para lograr un mejor desempeño de la economía, en un contexto de apertura comercial y financiera. Las autoridades económicas decidieron que el objetivo prioritario de la política macroeconómica era la estabilidad nominal, entendida como mantener baja la inflación. Con esa finalidad, la política macroeconómica se concentró en cimentar una marcada disciplina fiscal para cerrar el déficit, reduciendo los gastos más que fortaleciendo los ingresos fiscales. Un supuesto clave de esta nueva estrategia era que, al disminuir a su mínima expresión la injerencia del Estado en la economía y al eliminarse el déficit de las finanzas públicas, se aseguraría una tasa de inflación baja y estable. Esa situación, a su vez, se veía como la condición necesaria y, en gran medida, suficiente para conducir a la economía por una senda de expansión elevada y duradera, liderada por las exportaciones y con uso intensivo de la mano de obra, que constituía el recurso más abundante de la economía mexicana. Esta orientación de la política macroeconómica ha prevalecido desde entonces y, de hecho, se acentuó entre los años 2000 y 2012, es decir, los sexenios en los que el Partido de Acción Nacional ocupó la presidencia de la República.

Esta política macroeconómica logró resultados significativos de estabilización nominal y de orientación de la producción hacia las exportaciones. En efecto, México lleva años registrando valores mínimos de déficit fiscal y una baja inflación, que fluctúa en una banda estrecha 
fijada por las metas del Banco de México. El país ha experimentado un impresionante auge en la exportación de manufacturas. Hasta el estallido de la crisis financiera internacional en 2008 y 2009, esas exportaciones se expandieron de forma continua, a tasas anuales superiores al $10 \%$. Además, se componen en gran medida por productos de alta tecnología. Así, desde hace tiempo, las manufacturas representan más del 80\% del total de las exportaciones del país, en contraste con el 10\% que suponían en 1980. A la vez, la incidencia de la pobreza hoy es inferior a la de 1990, al final de la década perdida.

Sin embargo, estos innegables logros distan de haberse traducido en un crecimiento elevado y duradero de la economía mexicana, libre de crisis financieras o de la balanza de pagos. En este período, la economía mexicana ha crecido a tasas muy bajas, al punto de que la brecha con respecto al PIB per cápita de los Estados Unidos es mayor en 2012 que en 1980. Si bien la pobreza ha bajado, en la actualidad sigue afectando a más del $50 \%$ de la población y más del $80 \%$ de los mexicanos vive en condiciones de pobreza o de vulnerabilidad. Este decepcionante desempeño de la economía mexicana durante tres décadas, en el marco de una política macroeconómica cuyo énfasis ha sido preservar la estabilidad nominal - baja inflación y un déficit fiscal reducido- en un contexto de retiro del Estado de la esfera económica, con todo lo que eso ha implicado en la orientación de la política fiscal, monetaria y cambiaria, comercial e industrial, sirve de base para una serie de reflexiones en torno a lo que debe ser una política macroeconómica para el desarrollo.

\section{A. Avances, cuestiones pendientes y retrocesos de política macroeconómica en México en los tres últimos decenios}

El primer punto a subrayar, quizás innecesario por ser de sobra conocido en la CEPAL, es lo errada que es la idea fundamental de la política macroeconómica convencional de que una inflación baja y estable, y unas finanzas públicas sanas, entendidas como un déficit fiscal nulo o muy bajo y con una mínima intervención del Estado en la economía y la asignación de recursos, constituyen condiciones necesarias y suficientes para asegurar un crecimiento económico elevado y duradero. Tal ha sido la orientación de la política fiscal y monetaria en México desde hace 30 años. El tipo de cambio se mantiene en un régimen de flotación administrada, que tiende más a apoyar el logro de la meta inflacionaria que a corregir el desequilibrio externo a mediano o largo plazo. Desde hace décadas, la política fiscal se integra en el marco de una normativa legal 
- la Ley Federal de Presupuesto y Responsabilidad Hacendariaque obliga a mantener en cero el balance fiscal nominal, excluida la inversión de Petróleos Mexicanos (PEMEX). Esta restricción legal, aplicada independientemente de la fase del ciclo en que se encuentre la actividad económica, imbuye una orientación procíclica a la política fiscal, profundizando las fases recesivas y agudizando las de expansión. La debilidad del impacto de los instrumentos fiscales se ve acentuada por la baja carga tributaria - de las menores de la región-y por su marcada dependencia de los recursos derivados de las exportaciones petroleras, que provoca que los desequilibrios de la balanza comercial petrolera repercutan directamente en desequilibrios fiscales. En consecuencia, la tasa de interés de referencia del Banco de México es el instrumento esencial para controlar la demanda agregada o, más bien, para incidir en la presión inflacionaria.

Esta orientación de la política macroeconómica, junto con la firme apertura del mercado interno a la competencia internacional y el acotamiento o restricción de la intervención del sector público de la esfera productiva, han cimentado desde la década de los noventa una inflación baja -alrededor del 3\% anual-y un déficit fiscal inferior al 3\% del PIB. Sin embargo, y no obstante el auge exportador en manufacturas ya mencionado, la economía mexicana permanece sumida en una senda de bajo crecimiento. Entre 1987 y 2012, el ritmo de expansión media anual del PIB fue de menos de la mitad que entre 1960 y 1981. Esta lentitud ha provocado que su participación en el producto interno bruto mundial haya caído de manera persistente desde los años ochenta hasta la actualidad. De esta forma, en 1990, México aportó el 2,68\% del PIB mundial, porcentaje que cayó al 2,13\% en 2013. El escaso dinamismo es aun más evidente en términos de la evolución del producto por habitante. En efecto, entre 1994 (cuando comienza a operar el Tratado de Libre Comercio de América del Norte) y 2012, el PIB per cápita real de México en dólares constantes creció a una tasa anual media de apenas un 1,1\%. Este escaso impulso de la actividad económica implica que la brecha de ingresos relativos entre México y los Estados Unidos se ha ampliado en vez de cerrarse. En 1980, el PIB per cápita real de México alcanzó un monto equivalente al 23\% del de los Estados Unidos, en 1994 el porcentaje ya era de solo el 17,7\% y en 2012 había disminuido hasta el 16,9\%. Es decir, la brecha actual es equiparable a la que se registró en la década de 1950 . 
Gráfico XIII.1

México y países seleccionados: PIB real per cápita como proporción del PIB per cápita de los Estados Unidos, 1980-2012 ${ }^{\text {a }}$

(En porcentajes)

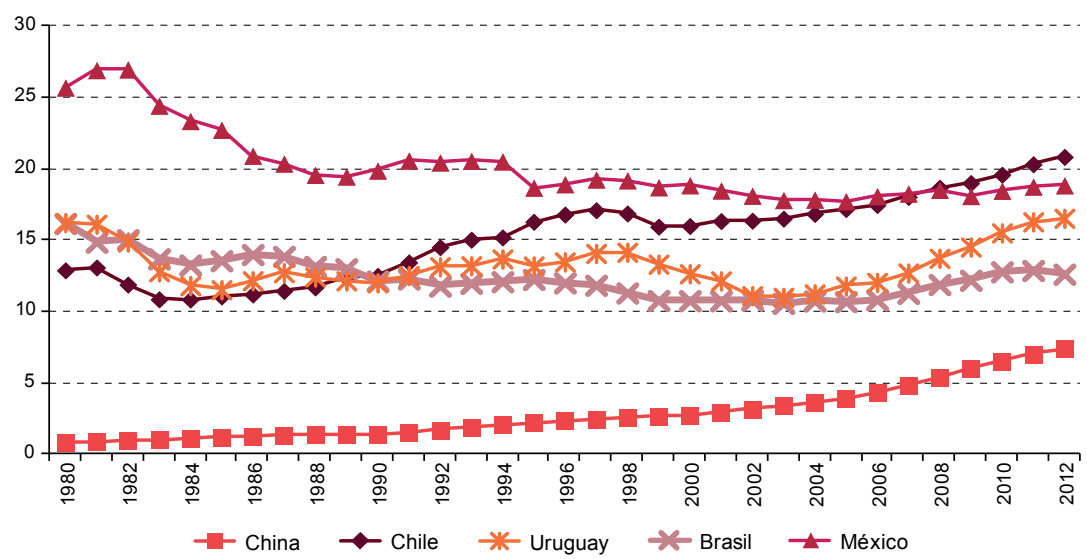

Fuente: Elaboración propia, sobre la base de datos de los Indicadores del Desarrollo Mundial del Banco Mundial.

a Brechas porcentuales calculadas a partir de datos expresados en dólares constantes de 2000. La evolución de las brechas relativas de los países considerados para este indicador es sensible al año base en que se mide el PIB per cápita en dólares reales.

Una vez que se ha establecido, en relación con la orientación de la política macroeconómica convencional, que una inflación baja y estable y unas finanzas públicas sustentables son condiciones necesarias pero no suficientes para un crecimiento económico elevado y duradero, conviene analizar cuáles son las restricciones que han bloqueado y siguen bloqueando el crecimiento a largo plazo de la economía mexicana por encima del 5\%. ¿En qué medida la política macroeconómica en México ha debilitado, ignorado o incluso reforzado estas restricciones?

Para responder a esta cuestión, se utilizará en este estudio una perspectiva no convencional, centrada en la demanda y no en los múltiples ejercicios de contabilidad del crecimiento (growth accounting). Desde esta óptica, la raíz de la falta persistente de dinamismo de la economía mexicana desde mediados de los años ochenta hasta la fecha se encuentra en dos factores íntimamente relacionados. El primer factor es el comportamiento de la inversión, tanto en lo que concierne a sus montos agregados como proporción del PIB como a su orientación relativa a actividades no transables. En efecto, en México, desde mediados de los años ochenta, la formación bruta de capital fijo permanece por debajo del $25 \%$ del PIB, umbral mínimo determinado por la CEPAL y la Conferencia de las Naciones Unidas sobre Comercio y Desarrollo (UNCTAD) para lograr tasas medias duraderas de crecimiento del PIB real por encima del $5 \%$ anual. 
El otro factor es el desmadejamiento de los encadenamientos internos de su estructura productiva, que se refleja en un alza muy significativa de la elasticidad ingreso de las importaciones desde mediados de los años ochenta, con una limitación notable de la capacidad de arrastre de la demanda y en especial de las exportaciones al resto del aparato productivo. El debilitamiento de los encadenamientos internos, tanto hacia atrás como hacia delante, que constituye, en efecto, una pérdida de densidad de la matriz de insumo producto de México, está asociado a la rapidez de la apertura comercial y sobre todo al desmantelamiento de la política industrial. Todo ello, junto con el surgimiento de una tendencia a la apreciación del tipo de cambio real, provoca una disminución considerable del multiplicador keynesiano de los gastos, hasta cierto punto exógenos, de la inversión y las exportaciones ${ }^{2}$. Como se indicó en las páginas anteriores, desde el punto de vista de la evolución de la demanda agregada, la fuerte desaceleración económica de México desde finales de los ochenta hasta la actualidad se explica por la caída del multiplicador keynesiano y la pérdida de dinamismo de la inversión.

\section{Gráfico XIII.2 \\ México: crecimiento económico y balanza comercial como proporción del PIB en períodos seleccionados, 1960-2012 \\ (En porcentajes)}

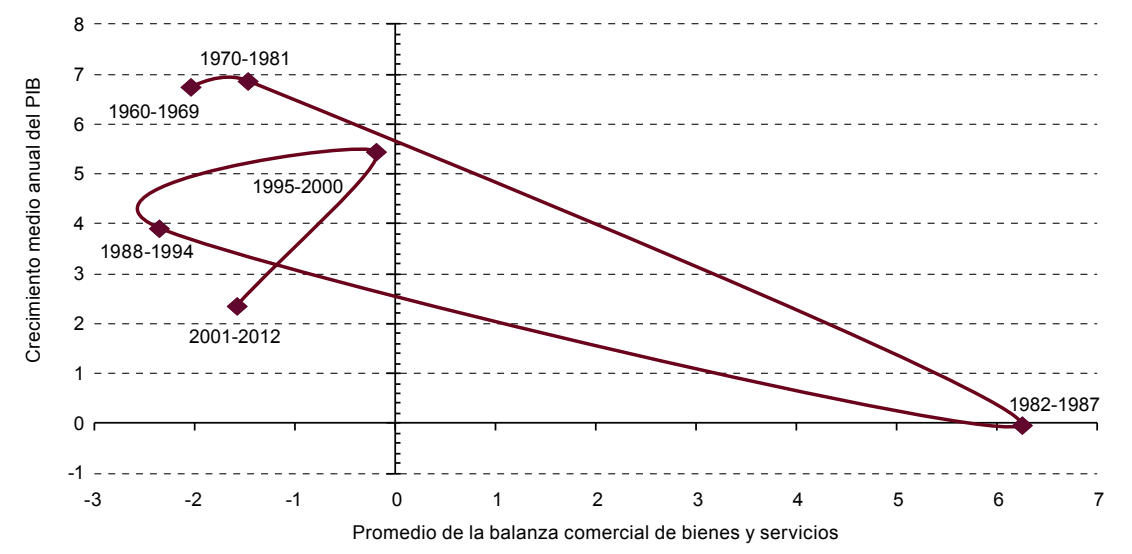

Fuente: Elaboración propia, sobre la base de cifras oficiales.

\footnotetext{
Desde el punto de vista de la demanda, hay que separar los efectos debidos a una disminución del multiplicador y los que se deben a una reducción del dinamismo de la inversión o de las exportaciones. El primer caso se debe a la contracción del multiplicador $\frac{1}{(1-c+m)}$, que puede producirse como consecuencia de un alza en la propensión a importar o a ahorrar. El segundo caso corresponde al decrecimiento del dinamismo de la inversión o de las exportaciones. En el resto del capítulo, solamente la primera situación se denota como una bajada del multiplicador.
} 
Como se muestra en el gráfico XIII.2, desde hace seis décadas la economía mexicana sigue una pauta de expansión marcada por una significativa restricción externa. Es decir, déficits comerciales de magnitud similar en cuanto a proporción del PIB tienden a aparecer asociados a tasas cada vez más bajas de crecimiento anual medio del PIB real. En efecto, en las décadas de 1960 y 1970, el PIB real experimentó una expansión media anual del $5 \%$ o $6 \%$ y se generó un déficit comercial equivalente al 2,5\% del PIB. Entre 1988 y 1994, primera etapa de la nueva estrategia de desarrollo con reformas de mercado, la tasa media anual de expansión del PIB real estuvo cerca del $4 \%$ y el déficit comercial mostró una magnitud ligeramente mayor como proporción del PIB. Entre 2001 y 2012, el ritmo medio de alza de la actividad productiva fue de poco más del $2 \%$ pero el déficit comercial fue similar al de los años setenta. Este comportamiento del déficit comercial refleja el alza de las importaciones como proporción del PIB, que ha subido cerca de 30 puntos porcentuales desde 1986, cuando apenas superaba el 5\% del PIB, hasta alcanzar el 35\% en 2012.

La intensa penetración de importaciones en el mercado interno ha estado acompañada por una trayectoria muy estable de la tasa de ahorro nacional, que se ha mantenido entre el $20 \%$ y el $25 \%$ del PIB en los últimos 30 años. Esta alza de la propensión a importar ha sido tan fuerte que, en el marco de una propensión a ahorrar prácticamente constante, ha dado lugar a una reducción de la magnitud del multiplicador keynesiano $\frac{1}{(1-c+m)}$, que determina el impacto que tienen la inversión y las exportaciones sobre el crecimiento del PIB. Según los cálculos del autor, el multiplicador bajó desde un nivel medio de 3,1 entre 1960 y 1981 hasta 1,13 entre 1987 y 2012 ${ }^{3}$. La contracción del multiplicador, unida al menor dinamismo de la inversión, no se compensó con el auge de las exportaciones. Por ello, la tasa media de expansión anual del PIB real cayó notablemente entre ambos períodos, ya que bajó del 6,9\% entre 1960 y 1981 al 2,7\% entre 1987 y 2012.

Recientemente, ha resurgido el debate sobre el peso o preponderancia relativa de la debilidad de la inversión frente a la caída del multiplicador keynesiano como determinantes del lento ritmo de crecimiento de la economía mexicana desde mediados de los años ochenta. Ambos factores son parcialmente responsables de la disminución del dinamismo económico en México. En efecto, por un lado y como ya se ha indicado, el multiplicador se desplomó después de 1987 hasta quedarse en un tercio de su valor medio anterior a 1981. Por otro lado, la inversión fija bruta sufrió una notable pérdida de impulso

El primer subperíodo abarca las décadas finales de la economía mexicana bajo la pauta de desarrollo de industrialización liderada por el Estado. El segundo refleja su desempeño bajo la nueva pauta neoliberal, tomando como año inicial 1987, cuando ya México estaba saliendo de la parte más difícil de la crisis de la deuda y de la crisis de la balanza de pagos de 1986. 
después de las reformas y se incrementó en términos reales un promedio del 9,1\% anual entre 1960 y 1981 y solo un 4,5\% entre 1987 y 2012.

Ambos elementos incidieron en el lento ritmo de expansión del PIB, pero según los cálculos del autor y dado el descenso que registró el multiplicador keynesiano, si se hubiera mantenido después de 1987 el mismo ritmo que había mostrado la inversión entre 1960 y 1981, la tasa media de crecimiento anual del PIB habría sido del $4 \%$, es decir, superior al 2,7\% que de hecho se registró, pero considerablemente por debajo del 6,9\% correspondiente al período entre 1960 y 1981. Por otra parte, los cálculos del autor revelan que, si el multiplicador keynesiano se hubiera mantenido en el mismo nivel, el alza media anual del PIB real entre 1987 y 2012 habría sido del 5\%, aunque la inversión hubiera aumentado al 4,5\%, como en efecto lo hizo. De hecho, dada la caída del multiplicador registrada, mantener entre 1987 y 2012 la tasa de crecimiento anual del PIB del 6,9\% habría requerido que el auge exportador ocurrido hubiera estado acompañado por un alza media anual de la inversión bruta real del $14 \%$, un ritmo jamás registrado de manera duradera en la economía mexicana a lo largo de varios años.

Los resultados anteriores indican que, a menos que se adopte una política para hacer más densos los encadenamientos internos del aparato productivo mexicano, reduciendo con ello la propensión media a importar para aumentar el multiplicador keynesiano, el crecimiento del PIB real a un ritmo del $5 \%$ o $6 \%$ anual llevaría irremediablemente a un alza insostenible del déficit comercial como proporción del PIB, que sería imposible de financiar. Este hecho se conoce en la literatura heterodoxa como la restricción de la balanza de pagos al crecimiento económico. En términos más generales, en el caso mexicano el predominio de la balanza de pagos, que caracteriza a muchas economías emergentes aún no totalmente industrializadas, constituye una significativa restricción para el crecimiento económico a largo plazo. Por lo tanto, a menos que se implemente una política industrial activa, lograr tasas de expansión de la actividad productiva de más del 5\% anual de manera duradera conllevaría un gran aumento del déficit comercial, que más temprano que tarde detonaría una crisis de divisas o de la balanza de pagos. No está de más subrayar que, hoy en día, la restricción de la balanza de pagos afecta al crecimiento a largo plazo, pero no necesariamente al crecimiento a corto plazo.

Ahora bien, enfatizar el peso del sector externo, de la balanza de pagos o, análogamente, de la creciente caída del multiplicador de la demanda como restricción fundamental para el crecimiento de la economía mexicana es una lección importante, que se desprende de una perspectiva neoestructuralista de la política macroeconómica. Esta lección dista de significar que la inversión sea poco importante. Por el contrario, la única manera de superar la restricción externa a largo plazo es mediante la 
puesta en marcha de un intenso proceso de inversión, orientado a lograr un cambio estructural de la economía de México. El cambio debe orientarse a fortalecer los sectores, actividades o eslabones con mayores rendimientos crecientes a escala y un nivel más alto de sofisticación tecnológica, con mayores probabilidades de insertarse en nichos de mercado con demanda dinámica y con mayor potencial de influir positivamente en el resto del aparato productivo. Las dos primeras características se han identificado como eficiencias keynesiana y schumpeteriana (CEPAL, 2012). Se complementan con la última, definida por el autor como eficiencia hirschmaniana, que hace que la matriz productiva sea más densa.

Los datos indican que la serie de reformas de corte neoliberal o de mercado emprendidas por México desde mediados de los ochenta logró llevar a cabo una modificación radical de la composición de las exportaciones, pero no de su destino. En efecto, de ser en su gran mayoría petroleras, pasaron en pocos años a estar compuestas en más de cuatro quintas partes por manufacturas, generalmente de productos de alto contenido tecnológico. Sin embargo, estas reformas y el cambio del perfil exportador no se vieron acompañados por una modificación importante de la estructura productiva del país. En efecto, teniendo en cuenta el indicador de cambio estructural inicialmente propuesto por la Conferencia de las Naciones Unidas sobre Comercio y Desarrollo (UNCTAD), Moreno-Brid y Ros (2010) señalan que la estructura productiva de la economía mexicana a nivel de dos dígitos modificó su composición en menos de un $20 \%$ al realizarse las reformas.

Además, esta limitada modificación estructural no logró reducir mucho la heterogeneidad sectorial en cuanto a, por ejemplo, la brecha de productividades laborales. Como muestra Monroy (2014), desde mediados de los ochenta hasta 2011 (último año para el que había información disponible), aumentó sistemáticamente el coeficiente de variación de la productividad laboral relativa en los 11 grandes sectores de actividad considerados en las cuentas nacionales de México: agropecuario; minería; manufacturas; electricidad, gas y agua; construcción; comercio, hoteles y restaurantes; comunicaciones y transportes; finanzas, y otros servicios. En efecto, el valor de ese coeficiente era 0,48 en 1986, 0,57 en 1994, 0,76 en 2000 y 0,81 en 2011. Durante este proceso, el sector de electricidad, gas y agua fue siempre el de mayor productividad laboral. Además, su brecha o divergencia se incrementó en el período. Mientras que en 1986 su productividad laboral relativa era 2,74 veces superior al promedio, en 2011 la cifra correspondiente era 4,76 veces superior al promedio. La divergencia estructural en la evolución de la productividad relativa se reflejó en diversos sectores y no solo en la creciente brecha a favor del sector de electricidad, gas y agua. Así, la productividad laboral relativa de los sectores de la minería, de las comunicaciones y transporte y, en menor grado, de las manufacturas se elevó por encima del promedio nacional. 
El desempeño de la productividad laboral relativa de las manufacturas resulta especialmente significativo en este proceso de muy limitado cambio estructural de la economía mexicana en el período. Si bien en 1986 la productividad laboral relativa de las manufacturas estaba un $3 \%$ por encima del promedio nacional, en 1994 la brecha era del $14 \%$, en 2000 del $20 \%$ y en 2011 del $30 \%$. Este proceso de aumento de la productividad laboral manufacturera se combinó con un descenso del empleo y una débil formación de capital fijo en el sector. Todo ello sugiere que el incremento de la productividad manufacturera es frágil y que se ha logrado mediante recortes de la plantilla laboral, casi sin modernizar los acervos de maquinaria y equipo. De esta forma, el sector de las manufacturas, probablemente el grupo de actividades con mayor potencial para crear externalidades productivas, apenas mantuvo su participación en el PIB y sufrió una notable caída de su peso en el empleo. La falta de dinamismo manufacturero impidió que la economía mexicana absorbiera mano de obra del campo y de servicios escasamente productivos, frenó la productividad global de la economía mexicana y con ello la encaminó por una senda de bajo crecimiento a largo plazo.

Así pues, la economía mexicana ha experimentado un cambio estructural que, en vez de eliminar las restricciones externas que afectan a su crecimiento a largo plazo, ha acentuado esas restricciones. Tal como señalaron los estructuralistas, el proceso de desarrollo es un proceso de cambio estructural, pero el cambio estructural también tiene consecuencias y costos. Esto tiene relación con la idea de que los estructuralistas en general y Raúl Prebisch en particular eran conscientes de que el cambio estructural podría causar o agudizar las restricciones externas e incluso conllevar un estrangulamiento externo. Es decir, el cambio estructural no siempre se da en un contexto de perfecta flexibilidad ni está exento de suponer costos importantes.

En consecuencia, toda estrategia de transformación estructural, para ser exitosa en la búsqueda del desarrollo, debe reducir las brechas de productividad intersectoriales, potenciar los encadenamientos hacia atrás y hacia adelante del aparato productivo y promover la inserción en mercados de demanda muy dinámica. Todo ello apunta a romper el círculo vicioso de lento crecimiento, baja inversión, insuficiente expansión de los sectores sujetos a rendimientos crecientes a escala, limitada productividad, sobredimensionamiento del mercado laboral informal y los consiguientes rezagos económicos y sociales de la población. Para lograrlo, como ha insistido la CEPAL, se requiere una fuerte inversión, tanto pública como privada, en el marco de una renovada y activa política industrial, comprometida precisamente con lograr la transformación de la estructura productiva nacional. 
La experiencia de la economía mexicana en las décadas analizadas indica que, como se subrayó anteriormente, para impulsar un proceso de crecimiento intenso y duradero del PIB, el monto de la inversión bruta fija es importante. Sin embargo, quizás lo sea todavía más su estructura o composición sectorial. En efecto, en la economía de México ha habido períodos relativamente largos con proporciones entre la inversión y el PIB muy similares, pero con resultados muy diversos en lo que se refiere al ritmo de crecimiento del PIB. Así, por ejemplo, entre 1960 y 1969 y entre 1988 y 1994, la proporción entre la inversión y el PIB rondó el 19\%, pero en el primer período el PIB creció a una tasa media anual de casi un 7\%, mientras que en el segundo creció a una tasa 3 puntos inferior. Entre 2001 y 2012, la proporción entre la inversión y el PIB fue, en promedio, del $21 \%$, pero el PIB real solo se elevó en promedio un poco menos de un 2,5\% anual.

Un análisis similar de la evolución de la inversión en la economía mexicana, distinguiendo por una parte sus componentes público y privado y, por otra, la inversión en infraestructura y en maquinaria y equipo, también muestra escasa correlación con los niveles de crecimiento del PIB real. Es decir, al parecer el impacto de la inversión sobre el crecimiento económico depende menos del monto de la inversión y más de su composición y orientación a diferentes sectores o actividades. Cuanto más se oriente a cambiar la estructura productiva en la dirección señalada anteriormente, de manera que se robustezcan las eficiencias keynesiana, schumpeteriana y hirschmanniana, mayor será su impacto para promover la senda de expansión a largo plazo de la actividad económica. Esto refuerza la relevancia de la estructura productiva como determinante del crecimiento económico. No es casualidad que el lento crecimiento de la economía mexicana de 1987 en adelante haya estado acompañado por una pauta de la inversión fija marcada por un menor dinamismo de la expansión de los acervos de capital fijo en las manufacturas que en el resto de los grandes sectores de actividad que componen la economía.

A este respecto, la CEPAL (2012), en su documento Cambio estructural para la igualdad, sostuvo que, en la reorientación del aparato industrial nacional, hay tres elementos fundamentales que deben guiar la política macroeconómica para asegurar no solo la estabilidad nominal, sino también la expansión fuerte y a largo plazo de la economía mexicana. A los efectos del presente estudio, estos tres elementos se identifican o asocian con Keynes, Schumpeter y Hirschman. El primero enfatiza la necesidad de que el aparato productivo se oriente a la búsqueda de mercados con fuerte demanda a corto y, sobre todo, a largo plazo. El segundo centra su atención en los procesos de producción y manufactura locales y recomienda que estos dependan cada vez más de la innovación y la sofisticación tecnológicas y no de bajos salarios. Esta transformación permitiría que las diferentes industrias y actividades del país ascendiesen 
o ganasen espacio en las cadenas globales de valor agregado. El tercero, que constituye el aporte del autor de este estudio, derivado de las contribuciones de Hirschman, indica que la política industrial tiene que adoptar como objetivo, además del cumplimiento de las recomendaciones keynesiana y schumpeteriana, la reconstrucción de encadenamientos hacia atrás y hacia delante, para densificar la matriz interindustrial de la economía de México. En la práctica, este factor ha estado lamentablemente ausente en las reflexiones o consideraciones sobre la nueva estrategia de desarrollo seguida por México desde mediados de los años ochenta. $\mathrm{Su}$ ausencia explica la paradoja del auge exportador, con sus fuertes rasgos keynesianos y schumpeterianos, pero con una dualidad creciente cimentada en la falta del marco hirschmaniano, que hubiese corregido la incapacidad del sector exportador para arrastrar al resto de la economía en un ámbito de expansión elevada y duradera a largo plazo.

La reconstrucción o transformación estructural, a medida que vaya avanzando, aumentará por sí misma el multiplicador de la inversión y de las exportaciones. Para que esto ocurra de manera sistemática, la economía nacional tendrá que abordar exitosamente el reto de su transformación estructural que quedó pendiente desde la etapa de protección comercial e industrialización liderada por el Estado. Este reto, que se consideró la fase más difícil e inconclusa de la sustitución de importaciones, es la creación o robustecimiento de una industria nacional de bienes de capital. Entre 2003 y 2012, las cifras del Instituto Nacional de Estadística y Geografía (INEGI) indican que, en México, casi un $70 \%$ de la demanda de maquinaria y equipo se satisfizo mediante importaciones. La presión que esa situación impone al balance de pagos resulta preocupante, pues implica que una estrategia de impulso fuerte y coordinado a la formación de capital, a menos que genere divisas rápidamente, tiende a ejercer presión sobre la balanza comercial y el mercado de divisas.

Finalmente, cabe destacar otro aspecto vinculado al tipo de cambio real como variable fundamental, tanto en la competitividad internacional a través de su efecto sobre los precios y costos unitarios y sobre los salarios reales, como en la orientación de la inversión hacia sectores transables o no transables. La historia económica moderna de América Latina, es decir, desde 1950 hasta la actualidad, muestra que los períodos de auge, entendidos como un mínimo de cinco años de expansión sostenida del PIB por encima del $3 \%$, tienden a estar asociados con una depreciación del tipo de cambio real, ya sea en el lapso durante el que persiste su impulso o bien antes del inicio del repunte. Son muy contados los episodios de auge en la región asociados a la apreciación del tipo de cambio real. Los escasos episodios de este tipo corresponden a economías cuyas exportaciones y estructuras productivas son altamente intensivas en recursos naturales. La aplicación de una política cambiaria como instrumento de una estrategia 
de transformación productiva para la igualdad requiere, en las condiciones actuales de apertura de los mercados financieros internacionales y de flujos de capital a corto plazo intensos y volátiles, incorporar el manejo de la cuenta de capitales de la balanza de pagos. Este manejo debe ser visto como un instrumento con uso legítimo también en períodos de relativa tranquilidad en los mercados internacionales y no solo para episodios de crisis o de fuerte presión sobre el mercado de divisas.

Una vez examinados los errores, aciertos y limitaciones de la aplicación de la política macroeconómica en México durante las últimas tres décadas, en la siguiente sección se estudian algunas de las lecciones derivadas de los datos internacionales - y no solo del caso mexicanode la reciente crisis financiera mundial de 2008 y 2009, tanto desde la perspectiva estructuralista como desde otros puntos de vista.

\section{B. Algunas lecciones de la crisis financiera internacional en la aplicación de una política macroeconómica para el desarrollo}

La debacle financiera internacional que explotó en 2008 y 2009, además de provocar el colapso de los flujos de crédito y comercio en el mundo y de la actividad productiva en las economías desarrolladas, puso gravemente en duda algunos de los cimientos analíticos de la política macroeconómica convencional. A la vez, las respuestas de las políticas públicas ante la crisis también han dado lugar a lecciones importantes sobre los objetivos y ámbitos de acción que debe tener la política macroeconómica en sus diferentes componentes: la política fiscal, la monetaria, la cambiaria y la macroeconómica prudencial, incluida en esta última la administración de las entradas y salidas de capitales. Como consecuencia de la crisis, suscitaron especial atención los aportes de la revolución keynesiana y su recomendación de usar políticas contracíclicas para aminorar los efectos adversos de choques externos, así como las indicaciones de Hyman Minsky sobre la inestabilidad intrínseca de los sistemas financieros en las economías desarrolladas. Sus contribuciones siguen teniendo relevancia para entender tanto la gestación de la crisis financiera como las ventajas y limitaciones de las diferentes opciones de política macroeconómica ante la crisis.

Paradójicamente, a la vez que el sector académico y diversos organismos internacionales reconocen la relevancia de los aportes mencionados para entender y enfrentar los retos que plantea la crisis financiera a la economía mundial, los gobiernos de la OCDE se han empecinado en aplicar políticas de contracción fiscal. Con ello, repitiendo los errores históricos de las respuestas de política macroeconómica a la Gran Depresión de la década de 1930, profundizan y prolongan 
innecesariamente el descenso del ritmo de expansión económica, que conlleva graves repercusiones para el empleo y la cohesión social; todo ello sin resolver la fragilidad fiscal. Por otra parte, a raíz de la crisis, los gobiernos de Alemania, los Estados Unidos, el Reino Unido y otros miembros de la Unión Europea han manifestado un renovado interés por la aplicación de políticas industriales activas que promuevan un cambio de sus estructuras productivas y patrones de exportación.

En primer lugar, cabe apuntar que, mucho tiempo antes de que estallase la crisis de 2008 y 2009 y de manera especial a raíz de la década perdida, economistas cercanos a corrientes heterodoxas realizaron críticas muy pertinentes a la política macroeconómica convencional. En América Latina, las políticas macroeconómicas llamadas neoliberales, en su versión más ortodoxa, conciben la apertura comercial y financiera, la desregulación y el retiro del Estado de la esfera económica como las únicas estrategias de desarrollo válidas para todos los países y para cualquier momento. Las reformas de mercado se abocaron a esto y generaron, más temprano que tarde, fuertes críticas, dado su evidente fracaso en impulsar un crecimiento elevado a largo plazo. También surgieron críticas por la incapacidad de dichas estrategias para aislar a la región de choques externos adversos y de sus graves impactos sociales. En la práctica, las reformas y políticas económicas aplicadas desde mediados de los ochenta y diseñadas en línea con el denominado Consenso de Washington abrieron los mercados locales a la competencia mundial, achicaron el sector público, redujeron el déficit fiscal y se orientaron a consolidar una inflación baja, como ocurrió en México. Sin embargo, hasta la etapa entre 2003 y 2008 y por razones muy distintas, fueron incapaces de elevar de forma sustancial y duradera el ritmo de crecimiento económico. Tampoco lograron evitar que América Latina siguiera sufriendo periódicas crisis financieras y de la balanza de pagos, como atestiguan, por ejemplo, la crisis de la economía mexicana en 1995 y la de la Argentina y países vecinos a inicios del siglo XXI.

El énfasis en la estabilización de precios y variables y la convicción de que la intervención del sector público en la economía tiende meramente a distorsionar el correcto y eficiente funcionamiento de los mercados son rasgos fundamentales de la política macroeconómica convencional en la región en general, así como en México en particular durante buena parte de su historia moderna. Un punto especial en el que ha insistido la CEPAL es la necesidad de orientar la política macroeconómica a conseguir la estabilidad real —y no solo nominal— de la economía. La Comisión insta a que la política macroeconómica actúe de manera contracíclica, a fin de reducir el impacto de choques externos y con ello lograr que la actividad productiva no esté por debajo de su potencial de expansión. Esta forma de intervención también permite generar ahorros en las arcas públicas en las épocas de bonanza de la actividad privada, que pueden servir para 
financiar la expansión adicional del gasto en las fases de menor impulso. En este empeño, la CEPAL recomienda, asimismo, que en la aplicación de la política macroeconómica se evite que la inversión pública se convierta en la variable de ajuste en los procesos de contracción o recorte fiscal. Otros elementos muy cuestionados de la perspectiva convencional de la política macroeconómica son su escasa o nula atención a los aspectos estructurales del desarrollo económico y a sus condicionantes históricos, geográficos o políticos en su diagnóstico y en la puesta en marcha de programas de estabilización o de reformas.

A raíz de la crisis reciente, surgieron una serie de cuestionamientos por parte de expertos del Fondo Monetario Internacional y del Banco de Pagos Internacionales, tradicionalmente ligados al pensamiento convencional. En este terreno, el cuestionamiento que quizás más atención ha recibido es el de Blanchard, Dell'Ariccia y Mauro (2010) que, haciéndose eco de objeciones fundamentales planteadas desde la perspectiva heterodoxa, critican el énfasis de la política macroeconómica en considerar una inflación baja y estable como su único objetivo. Este elemento es el mismo que se señaló en la primera sección como fuerte limitación, error u omisión en la conducción de la política macroeconómica en el caso mexicano. En particular, los autores mencionados afirman que una inflación baja y estable no es condición suficiente para que la economía se expanda al máximo. Subrayan que esta falencia de la política macroeconómica no se debe a que se cuente o no con un índice correcto o adecuado de la inflación, sea esta la subyacente, la central (core) o la corregida por precios de petróleo o de la construcción u otros. Al respecto, Blanchard y otros reconocen la existencia de limitaciones en los modelos convencionales:

Es claro que el comportamiento de la inflación es mucho más complejo de lo que suponen nuestros modelos sencillos ${ }^{4}$ y que es muy pobre nuestro conocimiento de la relación entre la actividad económica y la inflación, especialmente en condiciones de tasas bajas de inflación.

En segundo lugar, las nuevas críticas ponen en tela de juicio el limitado o nulo papel al que se ha ido restringiendo la política fiscal, en contraste con el que se ha otorgado a la política monetaria, en la búsqueda de la estabilización macroeconómica. Este tema ya había sido denunciado desde la corriente estructuralista. Por razones más bien ideológicas, en la política macroeconómica convencional ganó erróneamente peso la noción de que los instrumentos fiscales no deben ni pueden incidir en la conducción de la economía más allá de: i) su compromiso de mantener el equilibrio de las finanzas públicas - es decir, con un déficit lo más bajo posible-, y ii) asegurar un patrón sostenible de la deuda pública.

4 Es decir, los que guían la política macroeconómica convencional. 
En muchos países de la región, el rechazo del uso de la política fiscal como instrumento de estabilización se acompañó, en la práctica, de una creciente complejidad de trámites y barreras para una rápida ejecución del gasto público, sobre todo en inversión. El arranque oportuno de nuevos proyectos de obra pública se complicó aún más con la eliminación o disminución del peso político, dentro de los gobiernos nacionales de la región, de las entidades encargadas de la planificación económica y de los proyectos de inversión. En efecto, con el retraimiento del Estado de la esfera económica y el desencanto con la planificación, en parte asociados a la caída del bloque socialista, dichas entidades perdieron fuerza y fue mermando la capacidad del Estado de elaborar proyectos de inversión.

Paralelamente al ataque a la legitimidad del gasto público en fomento e inversión y a la capacidad redistributiva de los impuestos, la política monetaria ganó preponderancia en la gama de instrumentos de estabilización macroeconómica. En particular, el manejo de la tasa de interés a corto plazo por el banco central en un marco de metas de inflación (inflation targeting) se convirtió en el principal instrumento de las autoridades para lograr la estabilización macroeconómica.

La acción contracíclica, discrecional o contingente de la política fiscal quedó borrada del discurso de la política macroeconómica de las economías desarrolladas. Su relevancia fue restringida aun más en las economías emergentes, dada la tradicional debilidad de sus ingresos fiscales, que se vio agravada en diversos países por la dependencia de los ingresos fiscales de recursos provenientes de gravámenes o impuestos a las exportaciones. En tales circunstancias, como sucedió en el caso mexicano, ciertas crisis de la balanza comercial se traducen de manera automática en crisis fiscales y, por ende, no hay posibilidad de usar el gasto público para reducir el impacto adverso de choques en la demanda externa o en los términos de intercambio.

Entre las nuevas críticas a la política macroeconómica aplicada en los países desarrollados a raíz de la crisis de 2008 y 2009 que se han realizado o admitido y que desde la perspectiva ortodoxa quizás más han permeado, se encuentran las que se refieren a la falta de atención, hasta fecha reciente, al impacto macroeconómico que pueden tener la actividad, liquidez y solvencia de los intermediarios financieros, bancarios o no bancarios. Este impacto macroeconómico - independiente del microeconómico-, como demostró la crisis de 2008 y 2009, puede ser mayúsculo y de dimensiones sistémicas catastróficas. El desdén por el impacto o la relevancia macroeconómicos de la intermediación financiera fue permeando la política macroeconómica muchos años antes de la crisis internacional. La crítica - ahora también desde el campo de la ortodoxia- resucita, en general sin admitirlo, contribuciones centrales 
del trabajo de Minsky (2008) sobre la inestabilidad inherente de los mercados financieros y los patrones de creación sistemática de burbujas especulativas en mercados clave. Antes o después, estas burbujas explotan, con repercusiones macroeconómicas brutales.

Un área en la que esta inestabilidad de los mercados financieros se manifiesta con impacto mayúsculo en los países en desarrollo es el flujo de capitales a corto plazo. Con la liberalización financiera, las economías en desarrollo se vieron sujetas a abruptas entradas y salidas financieras a corto plazo, masivas y volátiles. Dichos movimientos, por su elevado volumen y rápido e inestable desplazamiento, pueden provocar fluctuaciones agudas en variables clave para el desempeño económico: los tipos de cambio, la liquidez monetaria y las tasas de interés, así como la disponibilidad de crédito. Rompiendo una larga tradición en contra, a raíz de la reciente crisis financiera internacional, el Fondo Monetario Internacional acepta ahora que la administración de los flujos de capital a corto plazo es un instrumento legítimo de la política macroeconómica. Tal aceptación va en línea con el pensamiento de la CEPAL, así como de diversos economistas de la corriente estructuralista. Estos, desde hace tiempo, han instado a las economías en desarrollo a monitorear los flujos de capital y a estar listas para aplicar medidas para desincentivar o imponer restricciones en casos de entradas masivas que puedan ser súbitamente revertidas. A diferencia del Fondo Monetario Internacional (FMI), que considera que este instrumento administrativo o regulatorio es una respuesta de última instancia, para la CEPAL su consideración o aplicación debe ser parte de la gama normal de instrumentos de estabilización macroeconómica ${ }^{5}$.

La política macroeconómica convencional centrada en la inflación ha prevalecido durante décadas $\mathrm{y}$, en buena medida, sigue siendo predominante. Sus méritos en bajar la inflación y focalizar la atención de los responsables de la política pública en mantener el equilibrio de las cuentas fiscales y preservar la estabilidad macroeconómica nominal son innegables. Sin embargo, igual o mayor relevancia tienen sus fallos y omisiones, como los mencionados anteriormente, tanto en esta sección como en la previa. Esos fallos restringen enormemente la capacidad de la política macroeconómica para intervenir de manera contracíclica en la esfera real de la economía y más bien tienden a introducir elementos procíclicos. Además, no consideran adecuadamente las implicaciones macroeconómicas de la intermediación financiera ni de la inherente inestabilidad de mercados financieros clave y minan las posibilidades de conseguir una expansión económica duradera y elevada.

Véanse Ocampo (2005 y 2011), Ffrench-Davis (1996 y 2010) y, con una perspectiva convencional, Ostry y otros (2010). 


\section{Reflexiones finales ${ }^{6}$}

Ahora bien, retomando el propósito del presente trabajo de identificar las características que debe tener hoy una política macroeconómica para el desarrollo, cabe concebir esta política en términos de las principales áreas del funcionamiento de la economía en las que incide. La primera es la de estabilización, entendida como la reducción de la volatilidad de variables o relaciones clave de la economía nacional. Esta volatilidad inherente se manifiesta en los mercados locales financieros, accionarios e incluso de inversión, de bienes raíces y de ciertos productos básicos, pero también puede tener su origen en el impacto de choques adversos surgidos en mercados internacionales de bienes, de servicios o de capitales y provocar cambios bruscos en los volúmenes demandados o en precios relativos clave, así como en las condiciones de acceso a nuevos créditos o a la renovación de financiamientos previos.

A este respecto, es prerrogativa y obligación fundamental de todo gobierno identificar un conjunto de indicadores o variables cuya estabilidad - sea en niveles o en pautas de crecimiento- pueda establecerse como objetivo de la política macroeconómica. En gran parte del período de posguerra la estabilización tuvo como meta mantener el equilibrio en dos flancos: el equilibrio interno, que incluía preservar la estabilidad de precios y mantener un ritmo elevado de actividad económica compatible con el pleno empleo, y el equilibrio externo, que se ceñía a evitar situaciones críticas en la balanza de pagos y en relación con la disponibilidad de divisas. Después, en parte debido a la crisis internacional de la deuda de la década de 1980 y al giro de la política económica en línea con el llamado Consenso de Washington, se generalizó la interpretación ortodoxa de la estabilización, como se señaló en la sección inicial del presente texto, circunscrita a preservar una baja inflación y un déficit fiscal acotado o nulo. Este cambio a favor de las variables nominales llevó, tarde o temprano, a excluir el pleno empleo y el crecimiento del producto interno bruto real del conjunto de objetivos directos de la política de estabilización.

La causa de dicho giro fue doble. Por una parte, comenzó a prevalecer la noción de que la estabilización de las variables nominales era condición suficiente —además de necesaria - para conseguir la estabilización de las variables reales, es decir, del empleo, del crecimiento de la actividad productiva y de la balanza de pagos ${ }^{7}$. Por otra parte, este razonamiento se

Esta sección se apoya en Moreno-Brid (2013).

Agradezco a Miguel Torres su comentario, con el que coincido, a los efectos de que es curioso que el paradigma dominante - al menos hasta la crisis financiera internacional de 2008 y 2009- tienda a sostener que la estabilidad nominal es condición necesaria y suficiente para el crecimiento económico y la estabilidad real, a la vez que, en sus modelos más formales, se reconoce que la neutralidad a largo y a veces a corto plazo hace que, con independencia de los factores nominales, las posiciones de equilibrio de la economía dependan más de las variables 
complementó con la afirmación de que la expansión del producto y de la ocupación era un mero reflejo de la evolución de las condiciones de oferta de la economía — acumulación de factores y productividad-, sobre las cuales la política de estabilización no tenía ninguna influencia. De hecho, durante algunos años y hasta la crisis de la economía mexicana en 1995, la política de estabilización dejó de preocuparse por la magnitud del déficit en cuenta corriente de la balanza de pagos en tanto que no estuviese asociado a un déficit fiscal o a inflaciones elevadas (véanse Corden (1977) ${ }^{8}$ y el Informe Anual del Banco de México de 1994). La crisis de la balanza de pagos de México en 1995, que estalló en un contexto de prudentes finanzas públicas pero con un gasto y un endeudamiento privado que crecían aceleradamente, demostró cuan errónea era dicha interpretación. En consecuencia, se ha vuelto a incorporar el desequilibrio externo a su esfera de monitoreo.

Como se subrayó en los párrafos iniciales, la CEPAL, junto con diversos analistas y académicos, ha urgido desde hace tiempo a que el diseño de la política macroeconómica se asiente sobre una concepción amplia de la estabilización macroeconómica, que vaya más allá de la esfera nominal y cubra la real. Esta nueva concepción, sin descuidar la evolución de variables nominales como la inflación, la sostenibilidad fiscal y la solvencia de instituciones financieras, debe tener como objetivos prioritarios el crecimiento de la actividad productiva y del empleo. Dicha posición ha adquirido creciente fuerza a raíz de la aún vigente crisis financiera internacional surgida en 2008 y 2009 y de la política macroeconómica aplicada en respuesta a la crisis, sobre la base de la consolidación fiscal como instrumento central.

En la práctica, esta estrategia tiende a profundizar la recesión, a retardar la recuperación y a agravar las condiciones del mercado de trabajo y de empleo. Además, no alivia de manera oportuna ni suficiente la restricción fiscal ni la de la balanza de pagos de las economías vulnerables. Este problema fue implícitamente reconocido por el Banco Central Europeo ya en abril de 2012, cuando anunció la puesta en marcha de un programa masivo de inversión para estimular la recuperación económica de la Unión Europea.

en términos reales y de ciertos precios clave. Sin embargo, dado que en la práctica la evolución de los precios no es estable ni perfectamente predecible, esta evolución incide en la toma de decisiones y puede introducir incertidumbres e inestabilidad que depriman la inversión e influyan en el poder adquisitivo de los salarios y en el empleo.

8 En el texto original de 1977, Corden escribió que, puesto que los diversos componentes de la balanza de pagos mostraban los resultados tanto de la oferta y demanda públicas como privadas, las cifras relativas a esa balanza no eran las que debían considerarse. Su posición cambió significativamente en los noventa a raíz de diversas crisis en América Latina y pasó a reconocer que, dada la existencia de riesgo país, el déficit en cuenta corriente de la balanza de pagos era relevante y debía monitorearse, independientemente de que en su origen estuviera un desequilibrio del gasto público o del sector privado. 
La segunda área en que la política macroeconómica tiene un impacto crucial sobre el desarrollo económico es la de transformación de la estructura productiva. En efecto, reconózcalo o no la perspectiva teórica convencional, la política macroeconómica crea incentivos para la orientación y uso de los recursos o factores productivos por parte del sector privado, a la vez que incide en la asignación correspondiente de recursos de y para el sector público - en particular para la formación bruta de capital fijo- en la actividad económica y sus distintas ramas o sectores. A través de diferentes instrumentos, la política macroeconómica tiene una capacidad significativa de orientar, incentivar o estimular la actividad económica en algunas actividades, en detrimento relativo de otras; por ejemplo, entre los productores de bienes y servicios transables y los de no transables 9 . Dicha asignación de recursos puede influir en la senda de expansión a largo plazo de la economía, en la medida en que estos sectores difieran en cuanto a la prevalencia de ramas o actividades con rendimiento creciente a escala en comparación con otras caracterizadas más bien por rendimientos constantes o decrecientes ${ }^{10}$.

Esta concepción del crecimiento económico duradero como resultante de un proceso o círculo virtuoso de transformación de la estructura productiva tiene una relevancia fundamental en el diseño de la política macroeconómica. Desde su punto de partida, reconoce que la composición actual o a corto plazo de la producción y el empleo, es decir, la estructura de la actividad productiva marca, para bien o para mal, su desempeño y ritmo de expansión a largo plazo. La perspectiva del desarrollo como proceso de cambio estructural resultante de la interdependencia entre el ritmo de expansión de la economía y su forma de inserción en los mercados internacionales, por un lado, y la composición del tejido productivo y el empleo, en particular en actividades sujetas a rendimientos crecientes a escala, por otro, está en el centro de la teoría estructuralista del desarrollo. Esta última se contrapone a la visión tradicional, que considera que la política macroeconómica tiene solo dos objetivos: i) colocar a la economía en su frontera de producción y ii) ampliar dicha frontera.

En este sentido, desde la óptica de una política macroeconómica para el desarrollo, la política fiscal y la monetaria tienen objetivos y funciones que rebasan las que se les asignaban en el consenso prevaleciente antes de la crisis. En particular la primera, a través de la composición y monto del gasto, especialmente la inversión pública en infraestructura, es un instrumento relevante para promover el cambio estructural y por ende el crecimiento económico y el empleo. Asimismo, en la medida en que tenga

Véanse Frenkel (2006); Frenkel y Taylor (2008), y Ros (2013).

10 Véase CEPAL (2012). 
éxito en su intervención contracíclica e induzca períodos sostenidos de uso elevado del acervo de capital y de la capacidad de producción, constituirá un estímulo para la inversión privada. La segunda debe ir más allá, en sus prelaciones, de cuidar la inflación. Conviene que también vigile la evolución del crédito, sus tasas de interés, condiciones de acceso y sectores de destino, además de regular en pro del adecuado funcionamiento de los intermediarios financieros, tanto bancarios como no bancarios ${ }^{11}$.

La tercera y última área que se considera de relevancia en una política macroeconómica para el desarrollo es la de distribución del ingreso ${ }^{12}$. Su efecto en este campo se manifiesta en parte a través de su incidencia en variables clave como la inflación, el desempeño fiscal y los ingresos tributarios y gastos corrientes o de inversión ${ }^{13}$. En particular, se muestra en diversos estudios de la Organización de Cooperación y Desarrollo Económicos (OCDE), el Banco Interamericano de Desarrollo (BID), y la CEPAL, entre otras instituciones, que la carga tributaria, incluidas su composición, incidencia y aplicabilidad legal con el menor número de regímenes especiales, es un determinante fundamental de la distribución del ingreso en las diferentes economías del mundo. Raya en lo dramático o patético que, en la vasta mayoría de países de América Latina y el Caribe, la distribución personal del ingreso medida por el coeficiente de Gini sea muy similar antes y después de impuestos. En contraste, en la Unión Europea y en el mundo industrializado en general, el coeficiente de Gini cae significativamente cuando se mide con respecto al ingreso después de impuestos. Lo mismo ocurre con el gasto público, cuya influencia sobre la distribución del ingreso también puede ser significativa en función del carácter progresivo o regresivo de la orientación de sus principales programas, así como de su eficiencia y eficacia en la promoción del crecimiento y el empleo.

Por otra parte, la política macroeconómica también incide en la distribución factorial del ingreso a través de su influencia en tres precios relativos cruciales: el tipo de cambio, el nivel del salario mínimo (incluido su efecto en el salario medio y las remuneraciones) y la tasa de interés. Dichos efectos a corto y largo plazo no necesariamente van en la misma dirección ni tienen la misma magnitud. Por ejemplo, una depreciación significativa del tipo de cambio puede provocar de forma inmediata o a corto plazo un deterioro del salario real. En cambio, su efecto a mediano y largo plazo puede ser totalmente contrario, en la medida en que, al

\footnotetext{
11 Véase Nayar (2011).

12 Véase Musgrave y Musgrave (1989), en el que se distinguen tres funciones esenciales de las políticas económicas: i) asignación de recursos, ii) estabilización macroeconómica frente a choques externos y iii) redistribución del ingreso.

13 Véase, como antecedente, Taylor (1991).
} 
evitar un proceso duradero de apreciación del tipo de cambio real, logre promover un cambio estructural proclive a una mayor inversión en actividades comerciables y una competitividad internacional e interna más alta, con innovación tecnológica y mayor capacidad de arrastre del sector exportador al resto de la economía. Así, la política macroeconómica condiciona la distribución del ingreso nacional entre las distintas clases, factores, sectores productivos, grupos, regiones, familias e individuos.

Como ha enfatizado la CEPAL (2010) desde la publicación de La hora de la igualdad, la búsqueda en América Latina de una distribución más equitativa del ingreso y de la riqueza y de un crecimiento económico elevado y duradero distan de estar en contradicción. Por el contrario, ambos objetivos tienen una interdependencia que les retroalimenta directamente y que vuelve indispensable avanzar concomitantemente en ambos, es decir, hacia una mayor igualdad en la distribución del ingreso y hacia un crecimiento económico robusto y estable a largo plazo ${ }^{14}$. El lema cepalino "crecer para igualar, e igualar para crecer" cobra especial relevancia en las condiciones actuales de escaso o menor impulso de la economía mundial. En efecto, la caída de la demanda externa asociada a la recesión de buena parte del mundo desarrollado obliga a diversas economías latinoamericanas de tamaño medio o grande a apoyarse más en el mercado interno para su expansión, ante la falta de dinamismo de la demanda externa.

Corresponde a los gobiernos especificar los objetivos prioritarios de la política macroeconómica en relación con sus tres áreas de influencia en el desempeño de la economía. Igualmente les concierne, según el contexto histórico de cada economía de la región, la selección de instrumentos y su uso - tanto a corto como a largo plazo-, en concordancia con los diversos objetivos fijados para la política macroeconómica. Este proceso de selección de instrumentos presupone un diagnóstico de los obstáculos o restricciones fundamentales (binding constraints ${ }^{15}$ ) que han impedido o siguen impidiendo la consecución de los objetivos prioritarios. Requisito ineludible en este empeño es que la especificación de objetivos e instrumentos de la política macroeconómica sea coordinada y con consideración explícita del marco institucional. Es decir, se requiere que el diseño y la aplicación de la política macroeconómica tomen muy en cuenta el conjunto de restricciones formales - legales, reglamentarias o de tipo- e informales —normas, costumbres, prácticas o códigos de comportamiento- en vigor, que condicionan las interacciones económicas en el momento histórico pertinente. Dicho de otra forma, los

Véanse CEPAL (2010 y 2012).

Véase, por ejemplo, Hausmann, Rodrik y Velasco (2005). 
distintos contextos institucionales obligan a reconocer que, en política macroeconómica, no hay recetas únicas aplicables uniformemente en cualquier país y en todo momento.

En cuanto a los objetivos y, como hemos dicho, en cuanto a la agenda de desarrollo $-\mathrm{y}$ como parte de ella, la política macroeconómica-, se fija como prioridad fundamental lograr un cambio estructural para encaminar a la economía por una senda de elevado crecimiento a largo plazo con igualdad. Concretar este objetivo de largo alcance en políticas que se apliquen día a día, a veces en situaciones de urgencia y ante choques externos en ocasiones sumamente adversos, obliga a los gobiernos a adoptar una perspectiva tanto a corto como a largo plazo en la selección y aplicación de instrumentos de política macroeconómica. Para ello, resulta esencial identificar los obstáculos fundamentales que, en lo inmediato así como en un horizonte temporal amplio, bloquean o impiden impulsar y sostener una expansión robusta de la actividad productiva y una distribución más progresiva de sus beneficios.

Finalmente, y por demás importante, en tanto que la política macroeconómica incide en distintas áreas de la dinámica de funcionamiento de la economía, es evidente que los diversos instrumentos utilizados pueden provocar efectos antagónicos, no necesariamente complementarios, sobre algunos de los objetivos fijados. Reconocer estas disyuntivas (trade-offs) y proponer formas de conciliarlas parcial o totalmente es el quehacer cotidiano de los responsables de la política macroeconómica y exige no solo la capacidad técnica de los diferentes gobiernos, sino también su capacidad política y su comprensión de los condicionantes derivados de la economía política y del contexto institucional que enmarca la acción de la política macroeconómica. ¿En qué medida la política macroeconómica utilizada y las reformas posibles o deseables impulsan o al menos son consistentes con una agenda de cambio estructural para el desarrollo que promueva la igualdad y un elevado crecimiento económico? Es una pregunta clave, de cuya respuesta depende en buena medida el futuro económico de gran parte de los latinoamericanos. 


\section{Bibliografía}

Arestis, P. y M. Sawyer (2009), Path Dependency and Macroeconomics, Basingstoke, Palgrave MacMilllan.

Arndt, H.W. (1985), "The origins of structuralism”, World Development, vol. 13, № 2. Banco de México (1994), Informe Anual, México, D.F.

Beteta,H.yJ.C.Moreno-Brid (2014), “Cambioestructural y crecimientoen Centroamérica y la República Dominicana: un balance de dos décadas, 1990-2011", Libros de la CEPAL, No 122 (LC/G.2600-P), Santiago de Chile, Comisión Económica para América Latina y el Caribe (CEPAL).

Blanchard, O., G. Dell'Ariccia y P.Mauro (2010), "Rethinking macroeconomic policy", IMF Position Note, N ${ }^{\circ}$ SPN/10/03, Washington, D.C., Fondo Monetario Internacional (FMI).

Botta, A. (2012), Is Latin American Structuralism Still Relevant? A Theoretical Dissertation on Structural Change and Economic Development, Berlín, Lambert Academic Publishing.

CEPAL (Comisión Económica para América Latina y el Caribe) (2012), Cambio estructural para la igualdad: una visión integrada del desarrollo (LC/G.2524(SES.34/3)), Santiago de Chile. (2010), Lahora dela igualdad:brechas porcerrar, caminos porabrir(LC/G.2432(SES.33/3)), Santiago de Chile.

Corden, Max (1994), Economic Policy, Exchange Rates, and the International System, Oxford, Oxford University Press. (1977), Inflation, Exchange Rates and the World Economy, Chicago, The University of Chicago Press: Chicago.

Ffrench-Davis, R. (2010), “Macroeconomía para el desarrollo, desde el financiarismo hasta el productivismo", Revista CEPAL, No 102 (LC/G.2468-P/E), Santiago de Chile, Comisión Económica para América Latina y el Caribe (CEPAL). (1996), "Políticas macroeconómicas para el desarrollo", Revista de la CEPAL, No 60 (LC/G.1943-P/E), Santiago de Chile, Comisión Económica para América Latina y el Caribe (CEPAL), diciembre.

Frenkel, R. (2006), "An alternative to inflation targeting in Latin America: macroeconomic policies focused on employment", Journal of Post Keynesian Economics, vol. 28, No 4 .

Frenkel, R. y L. Taylor (2008), "Real exchange rate, monetary policy and employment: economic development in a garden of forking paths", Beyond Inflation Targeting. Assessing the Impacts and Policy Alternatives, G. Epstein y Erinc Yeldan, Cheltelham, Edward Elgar.

Hausman, R., D. Rodrik y A.Velasco, (2005), "Growth Diagnostics", Documento de Trabajo, Cambridge, Universidad de Harvard.

Monroy, L.A. (2014), "La heterogeneidad de la economía mexicana", Paradigmas Economía, 6 de enero.

Moreno-Brid, J.C. (2013), "Política macroeconómica para el desarrollo", EconomíaUNAM, vol. 30, Universidad Nacional Autónoma de México (UNAM). (2001), "Essays on the balance of payments constraint, with special emphasis on the case of Mexico", disertación para optar al grado de doctor (Ph.D.), Facultad de Economía y Política, Universidad de Cambridge. 
Moreno-Brid, J.C. y J. Ros (2010), Desarrollo y crecimiento de la economía mexicana: una perspectiva histórica, México, D.F., Fondo de Cultura Económica.

Mynsky, H. (2008), Stabilizing an Unstable Economy, McGraw-Hill Professional.

Nayar, D. (2011), "Rethinking macroeconomic policies for development", Brazilian Journal of Political Economy, vol. 31, N 3 .

Ocampo, J.A. (2011), “Macroeconomía para el desarrollo: políticas anticíclicas y transformación productiva", Revista CEPAL, No 104 (LC/G.2498-P/E), Santiago de Chile, Comisión Económica para América Latina y el Caribe (CEPAL). (2005), "The quest for dynamic efficiency: structural dynamics and economic growth in developing economies", Beyond Reforms, Structural Dynamics and Macroeconomic Vulnerability, J.A Ocampo (ed.), Washington, D.C., Stanford University Press, Comisión Económica para América Latina y el Caribe (CEPAL) / Banco Mundial.

Ostry, J. y otros (2010), “Capital Inflows: The Role of Controls", IMF Staff Position Note, $\mathrm{N}^{\mathrm{o}}$ 04, Washington, D.C.

Pérez Caldentey, E., J.C. Moreno-Brid y P. Ruiz Nápoles (2004), “The Washington Consensus: A Latin American perspective fifteen years later", Journal of Post Keynesian Economics, vol. 27, N 2 .

Pinto, Á. (1973a), "Heterogeneidad estructural y el modelo de desarrollo reciente de América Latina", Inflación: raíces estructurales, México, D.F., Fondo de Cultura Económica.

(1973b), “Concentración del progreso técnico y sus frutos en el desarrollo latinoamericano" Inflación: raíces estructurales, México, D.F., Fondo de Cultura Económica.

Prebisch, R. (1949), “El desarrollo económico de la América Latina y algunos de sus principales problemas" (E/CN.12/89), Comisión Económica para América Latina y el Caribe (CEPAL).

(1963), Hacia una dinámica del desarrollo latinoamericano, México, D.F., Fondo de Cultura Económica.

(1984), "Five stages in my thinking on development", Pioneers in Development, G. Meier y D. Seers (eds.), Nueva York, Oxford University Press.

Rapetti, M. (2013), "Macroeconomic policy coordination in a competitive real exchange rate strategy for development", Journal of Globalization and Development, vol. 3, N $\mathrm{N}^{\mathrm{o}}$.

Razmi, A., M. Rapetti y P. Skott (2012), "The real exchange rate and economic development", Structural Change and Economic Dynamics, N 23.

Ros, J. (2013), Rethinking Economic Development, Growth and Institutions, Oxford, Oxford University Press.

Serra, J. y M.C. Tavares (1974), "Más allá del estancamiento. Una discusión sobre el estilo de desarrollo reciente en Brasil", Desarrollo latinoamericano. Ensayos críticos, J. Serra (ed.), México, D.F., Fondo de Cultura Económica.

Taylor, L. (1991), Income, Distribution, Inflation and Growth. Lectures on Structuralist Macroeconomic Theory, Cambridge, The MIT Press. 



\section{Capítulo XIV \\ ¿Quo vadis, desarrollo brasileño? ${ }^{1}$}

Francisco Eduardo Pires de Souza

João Carlos Ferraz

\section{Introducción}

Las crisis cambiarias y financieras que experimentaron las economías emergentes en la segunda mitad de la década de 1990 parecen haber enterrado las recetas de política económica conocidas como el Consenso de Washington. Es verdad que algunos de sus elementos lograron sobrevivir, pero solo como parte de nuevas estructuras de política económica, que se fueron construyendo y poniendo a prueba en lugares que abarcan desde Asia hasta América Latina para viabilizar un crecimiento más vigoroso y menos vulnerable de cara a las turbulencias internacionales, sobre todo las originadas en los mercados financieros (véase, por ejemplo, Frenkel (2010)).

Sin embargo, no fue solamente la crítica de las recetas pasadas lo que determinó los nuevos rumbos que siguieron las economías emergentes. La nueva realidad económica mundial de la década de 2000 desató una ola de prosperidad para las economías en desarrollo y, en particular, para América Latina, que influenció sus estrategias de desarrollo e inserción externa. Los países de la región se beneficiaron

Dedicamos este artículo a Antônio Barros de Castro, intelectual inigualable, siempre optimista y en constante búsqueda de la esencia del desarrollo brasileño. 
de la gran expansión de la demanda internacional de sus productos de exportación, gracias a la mejora de los términos de intercambio y un abundante flujo de recursos externos. Esta bonanza parecía ser el umbral de una nueva era, caracterizada por la supuesta "gran moderación" en las economías avanzadas y la considerable expansión de la economía china, con su insaciable hambre de productos básicos.

No obstante, en el momento de la publicación de este artículo, aquella gloriosa década de 2000 se parece más a un superciclo — que ya ha llegado a su fin- que a una tendencia de largo plazo. ¿Cuál es el legado del pasado reciente y qué hacer después del fin del "superciclo"?

A pesar de que en la década pasada las economías emergentes tuvieron en general un buen desempeño, los patrones de crecimiento y la forma en que se usaron los frutos de la bonanza variaron mucho de un país a otro. Estas diferencias produjeron situaciones dispares al contemplar posibles caminos para la reanudación de un proceso de desarrollo, en un nuevo contexto internacional. Asimismo, las diferencias estructurales y en la dotación de factores también influencian, entre otras cosas, la selección de las nuevas estrategias de desarrollo e inserción externa más adecuadas para el nuevo marco internacional. Si adherirse nuevamente al Consenso de Washington no parece tener sentido, tampoco puede ser viable proseguir con el modelo de la década de 2000. El desarrollo supone procesos de cambio que se dan en un tiempo y lugar específicos. Así, nos encontramos una vez más frente a una encrucijada, en la que los caminos alternativos por recorrer no están listos y deben construirse.

En el presente documento pretendemos reflexionar sobre los desafíos que encara el desarrollo brasileño, tomando como base el contexto internacional y los avances y las limitaciones del modelo implementado en la última década. En la sección A, que figura a continuación, examinamos brevemente los antecedentes de la situación actual, mostrando la forma específica como la bonanza externa de la década de 2000 afectó la economía brasileña. Posteriormente, discutimos las características del modelo de la década pasada, que denominamos "crecimiento inclusivo", destacando sus virtudes y limitaciones y el uso dado a las ganancias inesperadas derivadas de la coyuntura internacional. En la sección $C$, evaluamos algunos cambios que se están produciendo, incluso en la orientación de la política económica del gobierno de Dilma Roussef, argumentando que pueden estar señalando el surgimiento de un nuevo modelo que busca capitalizar los activos y reformar, uniformar y sostener el modelo de crecimiento inclusivo. En la sección D reflexionamos sobre los desafíos que enfrenta la consolidación 
de este nuevo modelo y, en el epílogo, concluimos con una reflexión sucinta sobre si algunos elementos del proceso brasileño pueden ser pertinentes para otros países de América Latina y el Caribe.

\section{A. Antecedentes: del Plan Real a la bonanza externa}

Se tornó común caracterizar a la economía brasileña como productora y exportadora de productos básicos. A pesar de la amplia disponibilidad de recursos naturales y de la competitividad que exhiben la agroindustria y la producción mineral en el Brasil, esta caracterización es una caricatura. Tomada al pie de la letra, produce una visión muy simplificada de la estructura productiva del país. Además, de esa visión se derivan análisis superficiales acerca del proceso de reanudación del crecimiento económico del país a partir de 2004, así como sobre la amplitud de la gama de frentes susceptibles de expansión y diversificación de su dinamismo.

Para no caer en el cliché del crecimiento determinado por factores exógenos, es necesario tener en cuenta, en primer lugar, que los diez años previos a la reanudación del crecimiento se caracterizaron por profundas transformaciones institucionales y a nivel de la conducción de la política económica del país, que atravesó diferentes gobiernos. Tales transformaciones pusieron fin a la elevada inflación y a otras innumerables anomalías que habían condenado al país al estancamiento. Comenzaron con la apertura económica y la estabilización, prosiguieron con el orden de las finanzas públicas (ley de responsabilidad fiscal), del régimen cambiario y monetario, así como con reformas en el sistema financiero que permitieron superar la escasez del crédito a las familias (tanto para el consumo como para la vivienda). Por último, mediante la consolidación de los fundamentos fiscales y externos - la deuda pública mostraba una clara tendencia a reducirse y la deuda externa neta se tornaba negativa - se sentaron las bases para poner fin al proceso de interrupciones constantes y liberar los motores de crecimiento que por tantos años se habían reprimido.

Cuando la bonanza externa rindió sus frutos en América Latina se estaba desencadenando un proceso endógeno de expansión. Además, en realidad, dicha bonanza llegó muy tarde al Brasil. De hecho, por lo menos en lo que se refiere a los logros en cuanto a los términos de intercambio, el beneficio que obtuvo el Brasil fue, hasta 2008, muy modesto, en comparación con el que registraron otros países de América Latina, según se muestra en el gráfico XIV.1 y el cuadro XIV.1, que figuran a continuación. 


\section{Gráfico XIV.1}

Brasil y América Latina: índice de los términos de intercambio, 2002-2012

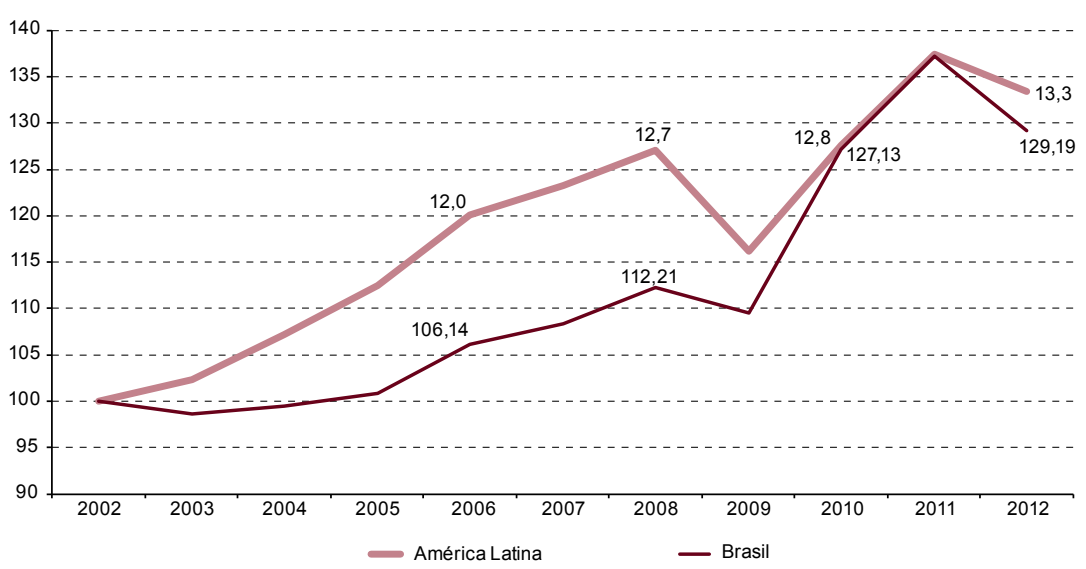

Fuente: Comisión Económica para América Latina y el Caribe (CEPAL).

Cuadro XIV.1

América Latina: términos de intercambio, años seleccionados (Índice, 2002=100)

\begin{tabular}{llll}
\hline País/región & 2002 & 2008 & 2011 \\
\hline Argentina & 100,0 & 134,9 & 136,8 \\
\hline Bolivia (Estado Plurinacional de) & 100,0 & 149,6 & 181,9 \\
\hline Brasil & $\mathbf{1 0 0 , 0}$ & $\mathbf{1 1 2 , 2}$ & $\mathbf{1 3 7 , 2}$ \\
\hline Chile & 100,0 & 169,6 & 211,3 \\
\hline Colombia & 100,0 & 149,3 & 162,4 \\
\hline Perú & 100,0 & 138,8 & 174,6 \\
\hline América Latina & $\mathbf{1 0 0 , 0}$ & $\mathbf{1 2 7 , 0}$ & $\mathbf{1 3 7 , 5}$ \\
\hline
\end{tabular}

Fuente: Comisión Económica para América Latina y el Caribe (CEPAL) - Bases de Datos y Publicaciones Estadísticas (CEPALSTAT).

El crecimiento económico brasileño registrado hasta la víspera de la crisis de 2008 fue impulsado por factores endógenos, como veremos a continuación, más que por los efectos benéficos de la coyuntura internacional. Habiendo hecho esta importante salvedad, que muchos analistas no han considerado, cabe ahora reconocer que a partir de 2009, los términos de intercambio de la economía brasileña efectivamente se incrementaron de forma vigorosa. Además, este aumento de los términos de intercambio tuvo un papel crucial a la hora de contener las presiones inflacionarias y el desequilibrio externo que comenzaron a surgir en una fase avanzada del ciclo expansivo iniciado en el segundo semestre de 2003. A fines de la década pasada, esta fue la principal contribución de la relación de intercambio favorable para el Brasil. 
De hecho, ante la falta de un aumento de los términos de intercambio observados en el período comprendido entre 2009 y 2011, el superávit comercial de 30.000 millones de dólares en 2011 (el mejor momento de los términos de intercambio) representaría, en las condiciones de 2009, un déficit de 18.000 millones de dólares, y el déficit en cuenta corriente del 2,1\% del producto interno bruto (PIB) alcanzaría el 4,1\% del PIB. Es decir, que el país se estaría dirigiendo de nuevo muy rápidamente a una situación de vulnerabilidad externa. Por otro lado, la fuerte apreciación del tipo de cambio viabilizada (e impulsada) por la mejora de los términos de intercambio contribuyó a mantener la inflación dentro de las metas del gobierno.

Por último, cabe destacar que, en el caso brasileño, uno de los ingredientes de la bonanza externa que tuvo una gran repercusión - con efectos positivos y negativos- sobre el desarrollo del país en el período, fue la cuantiosa afluencia de capitales externos. La voluminosa entrada de inversiones directas y de inversiones de cartera superó la necesidad de financiamiento, derivada del déficit en transacciones corrientes, por un monto medio anual equivalente al 2,5\% del PIB, de 2003 a 2012. Ello permitió una acumulación de reservas de 335.000 millones de dólares (de un nivel de 38.000 millones de dólares en diciembre de 2002 a uno de 373.000 millones de dólares en diciembre de 2012).

En resumen, las breves consideraciones expuestas sobre los antecedentes del nuevo modelo de crecimiento brasileño mostraron que, al contrario de lo que afirman muchos de sus críticos, el crecimiento con distribución, que lo caracterizó, no fue simplemente el subproducto de una coyuntura internacional extremamente favorable. Tampoco se puede concluir a partir de los datos que los frutos de la bonanza externa, que en el caso brasileño fue más importante a partir del final de la década pasada, fueron simplemente desperdiciados. Como se procurará mostrar a continuación, la oportunidad que ofrecieron las condiciones internacionales favorables se plasmó en el fortalecimiento de los fundamentos externos (reservas) y la aplicación de políticas que viabilizaron la transición hacia un modelo de crecimiento inclusivo.

\section{B. El modelo de crecimiento inclusivo: virtudes y limitaciones}

Después de dos décadas de cuasiestancamiento, la economía brasileña ingresó, a partir del segundo semestre de 2003, en un ciclo de crecimiento vigoroso y sostenido. Más importante aún, logró conciliar el crecimiento con la mejora sustancial de la distribución de ingresos, controlar la inflación y conseguir un equilibrio razonable de la balanza de pagos. Como parte 
de la estructura institucional y de políticas que sustentó este desempeño, se mantuvo la deuda pública neta en una trayectoria descendente y un nivel elevado de reservas internacionales y se consolidaron reglas y comportamientos (públicos y privados) que contribuyeron a garantizar la estabilidad y apalancar el crecimiento.

A pesar de su gran éxito, todavía no se ha llegado a un acuerdo en cuanto a los mecanismos de funcionamiento y la sostenibilidad del modelo económico de entonces. Para examinar sus principales puntos fuertes y sus fragilidades, centremos la atención sobre dos pilares del patrón de crecimiento de la economía en el período comprendido entre 2003 y 2012.

Por el lado de la demanda, el pilar principal que sostuvo el crecimiento de la economía fue el consumo de las familias que, a su vez, fue viabilizado e impulsado por dos factores: el aumento del ingreso real de las familias y el fuerte crecimiento del crédito personal.

El ingreso real de los consumidores aumentó en mayor medida en los estratos de la población de ingresos bajos. La tasa de crecimiento real del ingreso per cápita del 10\% más pobre de la población creció a un ritmo anualizado del 6,5\% de 2001 a 2011, en comparación con un aumento del 1,5\% anual en el caso del 10\% más rico (SAE, 2013). El aumento del ingreso de esos estratos de la población se derivó tanto de las políticas públicas (sobre todo del Programa Bolsa Família y la política de salario mínimo) como del progresivo agotamiento del excedente de oferta en el mercado de trabajo. Este último fenómeno, a su vez, se debió a fenómenos que afectaron la oferta y la demanda de mano de obra. Por el lado de la demanda de trabajo, el bajo crecimiento de la productividad condujo a un aumento de la absorción de trabajadores para un determinado crecimiento de la producción. Asimismo, el crecimiento de la oferta de trabajo, a su vez, perdió impulso debido a la rápida transición demográfica que ha estado teniendo lugar en el país: el ritmo de crecimiento de la población en edad activa bajó del $2 \%$ anual a comienzos de la década pasada a cerca del 1,1\% en los primeros años de la década actual.

El crecimiento del crédito personal se debió a la consolidación de la estabilidad y la creación de nuevos instrumentos y reglas (destacándose el crédito consignado) y apalancó la capacidad de consumir, que pasó de un nivel del 7\% del PIB a comienzos de 2005 al 16\% del PIB al final de 2012. A lo largo del mismo período, el endeudamiento de las familias como proporción de sus ingresos evolucionó, y pasó del 18\% al 43\%2.

Datos disponibles en las Series Temporales del Banco Central del Brasil (https://www3.bcb. gov.br/sgspub/localizarseries/localizarSeries.del?method=prepararTelaLocalizarSeries). 
Los dos determinantes mencionados permitieron que de 2005 a $2012^{3}$ el consumo de las familias creciese a un ritmo medio del 5,1\%, muy por encima del aumento anual medio del 3,6\% del PIB, lo que incrementó su participación en la economía, a precios constantes de 1995, del 60\% al 65,8\% en el mismo período. Además, al combinar el elevado peso del consumo en el PIB con su fuerte ritmo de expansión, se verifica que su incremento garantizó el 86\% del aumento del PIB real en el período.

En resumen, de 2005 a 2012 la economía experimentó un ciclo de expansión impulsado por el consumo de las familias. Sin embargo, es de prever que, en una economía cuya demanda comenzó a crecer de forma sostenida, la formación bruta de capital fijo también se recuperase y pasase a contribuir al propio crecimiento. Y, de hecho, la tasa de inversión aumentó de un mínimo del 15,3\% del PIB en 2003 al 19,1\% en 2008, y después osciló en torno a un nivel próximo al 19\% hasta 2012. No obstante, dado que el peso de esta variable es relativamente menor, su contribución positiva al aumento del PIB real fue de cerca de un tercio de aquella derivada del consumo ${ }^{4}$.

Al centrar ahora la atención en el lado de la oferta, se verifica que la expansión de la economía en la era de Lula (y comienzos del gobierno de Dilma) fue comandada crecientemente por los sectores de servicios y productores de productos básicos minerales y agrícolas. En lo que se refiere a estos dos últimos, se puede afirmar con certeza que su dinamismo fue fruto de la combinación entre la gran eficiencia brasileña en el ámbito de recursos naturales y el excepcional crecimiento de la demanda internacional liderada por la expansión de la economía china. Sin embargo, la selección de este motor del ciclo de expansión responde menos a una opción política y más a factores exógenos. No obstante, en cuanto a los servicios, su papel proviene de una combinación entre el crecimiento de la demanda agregada interna (en un sector que, por ser principalmente no comercializable, no sufrió la fuga de la demanda hacia el exterior) y una modificación de los precios relativos (debido al tipo de cambio) que favoreció la producción de servicios frente a la de productos industriales.

Por el contrario, el crecimiento de la demanda de productos industriales no creó estímulos semejantes a la producción manufacturera, porque una parte importante de aquel incremento "se filtró hacia el exterior" a través del aumento de las importaciones netas. Así, mientras

Utilizaremos datos correspondientes al período comprendido entre 2005 y 2012 para caracterizar el nuevo modelo porque el arranque inicial del crecimiento, entre mediados de 2003 y fines de 2004, se vio muy influenciado por el cambio altamente depreciado de aquel momento, lo que produjo una expansión basada (temporalmente) en inversión y exportaciones netas, desentonando con el patrón que enseguida se consolidaría.

4 Por su parte, las exportaciones netas contribuyeron de manera sumamente negativa. 
que el consumo aparente de bienes de consumo industriales registró un aumento real del $40 \%$ de 2004 a 2012, la producción interna de estos bienes creció tan solo el $20 \%{ }^{5}$.

En el cuadro XIV.2 que figura a continuación, se muestra el crecimiento medio anual por sectores en el período comprendido entre 2005 y 2012. En la segunda fila se presenta el crecimiento registrado hasta 2011, excluyéndose, por lo tanto, el crecimiento extremadamente bajo de 2012, cuando el sector agropecuario se vio particularmente afectado por una mala cosecha, lo que redunda en una subestimación del dinamismo del sector cuando se contemplan los datos medios hasta 2012. Los números muestran que la industria extractiva mineral, la de construcción, electricidad y el sector de servicios lideraron el crecimiento económico cuando se consideran tan solo las tasas de expansión. Sin embargo, cuando se toma en cuenta el peso de estos sectores, se concluye que la industria extractiva, por su pequeña participación en la economía (de tan solo el 2,5\% del valor agregado en 2005) representó apenas el 1\% de la expansión de la economía en el período, mientras que en el polo opuesto, el sector de servicios, con un peso del $65 \%$, representó el 63\% del aumento del PIB en esos ocho años.

El papel de pilar del crecimiento desempeñado por el sector de servicios, por el lado de la oferta, nos ayuda a comprender otras dos características del modelo de crecimiento de los últimos años: la baja productividad y el elevado ritmo de crecimiento del empleo, como se señaló anteriormente. A pesar de que el sector de servicios abarca segmentos de alta eficiencia, en promedio el sector todavía opera y crece con baja productividad. De esta manera, en el período comprendido entre 2005 y 2012 el sector de servicios fue responsable de la creación del 82\% de los nuevos empleos en las regiones metropolitanas del país.

\section{Cuadro XIV.2}

Brasil: crecimiento del PIB por el lado de la oferta, 2005-2012 (En porcentajes anualizados)

\begin{tabular}{lcccccc}
\hline Período & $\begin{array}{c}\text { Sector } \\
\text { agropecuario }\end{array}$ & $\begin{array}{c}\text { Industria } \\
\text { extractiva } \\
\text { mineral }\end{array}$ & $\begin{array}{c}\text { Industria de la } \\
\text { transformación }\end{array}$ & Construcción & $\begin{array}{c}\text { Electricidad, } \\
\text { agua y otros }\end{array}$ & Servicios \\
\hline $2005-2012$ & 2,6 & 4,1 & 1,1 & 4,3 & 4,1 & 3,9 \\
\hline $2005-2011$ & 3,3 & 4,8 & 1,6 & 4,8 & 4,2 & 4,2 \\
\hline
\end{tabular}

Fuente: Instituto Brasileño de Geografía y Estadística (IBGE), Cuentas Nacionales Trimestrales, segundo trimestre de 2013.

Cálculo realizado por los autores, tomando como base los valores en reales de la producción, exportación e importación de 2008 y calculando los valores de los demás años, a precios constantes, a través de la multiplicación por los respectivos índices de quantum de la Investigación Industrial Mensual del Instituto Brasileño de Geografía y Estadística (PIM/IBGE) y de la Fundación Centro de Estudios del Comercio Exterior (Funcex). 
Una consecuencia de este crecimiento intensivo de la mano de obra, impulsado por los servicios, junto con el mencionado cambio en la dinámica de la población, fue la caída sostenida de la tasa de desempleo, que pasó del 12,4\% en 2003 al 5,5\% en 2012. En este contexto de mercado de trabajo presionado (reforzado por la política salarial), los rendimientos reales del trabajo registraron un incremento acumulado del 38\% de 2005 a 2012, mientras que la productividad del trabajo experimentó un crecimiento del $10 \%{ }^{6}$.

La continua apreciación del tipo de cambio (y el aumento de las importaciones netas conexas) compensaron los efectos potencialmente inflacionarios de la expansión de la demanda interna a un ritmo superior al de la producción, y del crecimiento de los salarios por encima del aumento de la productividad. Se logró, así, mantener la inflación dentro de las metas propuestas por el gobierno.

Por último, los efectos negativos de la apreciación del tipo de cambio sobre la balanza comercial fueron parcialmente compensados por el alza de los precios internacionales de los productos básicos exportados por el país. Aun así, el saldo en transacciones corrientes presentó un deterioro equivalente a 4,2 puntos porcentuales del PIB: pasó de un superávit del 1,8\% del PIB en 2004 a un déficit del 2,4\% en 2012. Sin embargo, a precios de 2005, el déficit en cuenta corriente habría subido al 4,3\% del PIB en este último año.

Al observar el desarrollo reciente del Brasil desde la perspectiva de los pilares de la demanda (consumo de las familias) y la oferta (sector de servicios) podemos discernir, en verdad, los contornos de un modelo de crecimiento, sustentado por los mercados interno y externo - este último, exógeno, concentrado en productos básicos-que rompen, principalmente por el lado interno, con paradigmas históricos, al hacer extensivo para enormes contingentes de la población un patrón de consumo que anteriormente se restringía a la (antigua) clase media 7 .

En resumen, el modelo impulsado por la demanda, pero macroeconómicamente prudente, permitió que la economía brasileña volviera a crecer por un período prolongado, llevando el mercado de trabajo a la frontera del pleno empleo, además de promover una mejora considerable de la distribución del ingreso y sacar de la situación de pobreza absoluta a cerca de 8,4 millones de personas y de la situación de pobreza a 28,4 millones, de 2002 a 2012 (Instituto de Investigación Económica Aplicada (IPEA), 2013). Por todo eso, este modelo tiene mérito histórico.

Medidos por la evolución del rendimiento real del trabajo de la Encuesta Nacional por Muestra de Hogares (PNAD) y por el índice del PIB de las cuentas nacionales trimestrales dividido por el índice de ocupación total de la PNAD, respectivamente.

7 Antônio Barros de Castro (2011), a quien rendimos aquí un homenaje, en realidad ya había percibido en períodos anteriores la importancia del consumo de masas como motor del crecimiento en el Brasil. En el período en cuestión, el fenómeno adquirió una nueva escala. 
No obstante, se debe entender como un modelo obsoleto, adecuado para condiciones vigentes en un momento específico. Si no se transforma en el futuro, este modelo se torna insostenible, por lo menos por cuatro razones, a saber:

- el crecimiento del consumo a un ritmo superior al del PIB solo podría proseguir, sin deteriorar continuamente las transacciones corrientes (cuyo desenlace inevitable sería una crisis cambiaria), si la inversión creciese por debajo del PIB ${ }^{8}$. Pero si la inversión creciese por debajo del PIB (y se redujera la tasa de inversión), la tasa de crecimiento de la economía sería cada vez menor;

- la fuerte elevación de los términos de intercambio, que mitigó el crecimiento del déficit en cuenta corriente, era producto de una situación internacional única y no repetible que, al revertirse, provocaría un aumento considerable de aquel déficit;

- la apreciación del tipo de cambio, viabilizada por el ingreso de capitales y la mejora de los términos de intercambio, que garantizaba los bajos niveles de inflación en el contexto de ese modelo, venía minando la capacidad de crecimiento de la economía (sobre todo de los sectores comercializables distintos de los productos básicos), al tiempo que contribuía a un mayor deterioro de la balanza comercial,

- el crecimiento "extensivo" de la producción, basado en una gran absorción de mano de obra por parte del sector de servicios tiende a agotar el "ejército industrial de reserva", lo que redunda en crecientes aumentos del costo del trabajo.

Además de los factores mencionados, cada vez hay más pruebas de que el vigoroso crecimiento del consumo provocó un acentuado desequilibrio entre la disponibilidad de bienes privados y la oferta de bienes públicos, sobre todo de infraestructura, lo que comprometió la productividad y creó una fuerte insatisfacción social.

En resumen, si se mantienen intactas todas las características del modelo de crecimiento inclusivo, se produciría una reducción endógena del ritmo de crecimiento y un deterioro progresivo de las transacciones corrientes que en el futuro se traduciría en una crisis de la balanza

Dada la identidad macroeconómica básica, y sin considerar el consumo del gobierno, si $(\Delta C / C)>(\Delta Y / Y), C / Y$ es creciente, de forma que $(M-X) / Y$ debe aumentar, a no ser que $\mathrm{I} / \mathrm{Y}$ sea reducido. Se incorporamos la variable consumo del gobierno $(\mathrm{G})$, una alternativa, para evitar la caída de I/Y sería necesario elevar progresivamente el superávit primario como porcentaje del PIB. 
de pagos. Y la tentativa de compensar la caída endógena del crecimiento con un mayor estímulo al consumo acabaría por acelerar la crisis del tipo de cambio (o el proceso inflacionario ${ }^{9}$ ).

\section{C. (Primeras señales de) un modelo en gestación}

La caída de los precios internacionales de las productos básicos de 2011 a 2013 limitó la apreciación del tipo de cambio como mecanismo capaz de conciliar el fuerte crecimiento de la demanda y los costos con una inflación controlada. En realidad, beneficiándose de iniciativas que ya se habían puesto en marcha al final del gobierno de Lula, a partir de mediados de 2011 el gobierno de Dilma comenzó a corregir los rumbos de la política económica ${ }^{10}$.

La orientación más significativa se vincula a las políticas de apoyo a la inversión. En cuanto a la política industrial, después de que en el gobierno de Lula se reestableciera como política de Estado prioritaria (Kupfer, 2013) y una vez que culminó la etapa de instrumentalización de la industria de productos básicos para conquistar el liderazgo mundial, la atención se centró en reducir los costos industriales y estimular la productividad -que incluyó un marcado énfasis en la innovación-, con el objetivo de reestablecer la competitividad que la industria manufacturera había perdido y fomentar la inversión en el sector (Souza, 2013). Más pertinente aún, la inversión en infraestructura ocupó un lugar más preponderante en la escala de prioridades para acción del gobierno. Se dio continuidad a las inversiones en energía y se avanzó en dirección a la logística. Los cambios introducidos - aunque no sin dificultades- en el modelo de referencia para las inversiones en infraestructura revistieron el mismo nivel de importancia. Si en el gobierno de Cardoso la referencia era el valor de la concesión y en el período de Lula, la asequibilidad de las tarifas, en el modelo de la gestión de Dilma se mantiene este último criterio, pero se introduce la disposición a la inversión como factor decisivo en las licitaciones de concesiones.

Si una depreciación del tipo de cambio mitigara la crisis cambiaria, el problema se manifestaría en un aumento de la inflación impulsado por el incremento del tipo de cambio.

10 Cuando se anunció la modificación de la política monetaria de los Estados Unidos en mayo de 2013, se produjo una conmoción en los mercados financieros y cambiarios del mundo, con fuertes repercusiones en el Brasil, lo que dejó claro que las modificaciones en los "niveles de equilibrio" de los precios de los productos básicos y del tipo de cambio inviabilizaron las válvulas de escape del modelo económico anterior para contener la inflación y mantener las cuentas externas en niveles financiables. Dos años antes, cuando el gobierno comenzó a introducir nuevas políticas, los límites de este modelo estaban lejos de ser consensuados. 
El enfoque en políticas de apoyo a la inversión se correspondió con la política macroeconómica. Es decir, tal vez por primera vez se intentó formular políticas industrial, macroeconómica y de infraestructura, como partes de una misma estrategia ${ }^{11}$.

De hecho, la combinación de política macroeconómica se modificó, a través de la reducción de la tasa de interés que alcanzó su nivel más bajo desde la puesta en marcha del Plan Real, lo que disminuyó los costos financieros de las empresas. En materia de inversión, se mantuvieron las medidas introducidas en 2009 destinadas a reducir su costo a través de líneas del Banco Nacional de Desarrollo Económico y Social (BNDES), como el Programa de Sostenibilidad de la Inversión (PSI) ${ }^{12}$. La reducción de los intereses, junto con la imposición de impuestos sobre la entrada de capitales externos, produjo una depreciación del tipo de cambio del $28 \%$, entre su nivel mínimo de mediados de 2011 y el nivel medio cifrado en torno a 2,00 reales por dólar en que se situó de mediados de 2012 a mayo de 2013 (cuando, debido a conmociones externas, el tipo de cambio dejó de situarse en este nivel).

Estas medidas contribuyen a transformar el modelo precedente. Sin embargo, en la política macroeconómica siguen observándose dos puntos de fragilidad.

La primera fragilidad es que debido a la ausencia de un instrumento macroeconómico (sobre todo la política fiscal) para compensar los efectos inflacionarios de la nueva combinación de tipo de cambio (depreciado) e intereses (bajos), el gobierno recurrió a medios ad hoc, como el subsidio de bienes salario y la reducción de impuestos indirectos, cuyos efectos antiinflacionarios son, inevitablemente, limitados y temporales. La aceleración de la inflación en 2013 obligó al banco central a subir nuevamente los intereses (aunque en un ciclo de alza, cuyo pico deberá ser muy inferior al de los ciclos anteriores).

La segunda fragilidad es que las preocupaciones relativas a la inflación, junto con demandas en la esfera política, acabaron por fomentar una pérdida parcial del enfoque de las políticas de reducción de costos, con la extensión de las medidas hacia una amplia gama de sectores, muchos de ellos productores de no comercializables. De esta desvirtuación de las medidas originales se derivan dos problemas, a saber: a) como uno de los objetivos principales es la modificación de precios relativos entre comercializables

11 Este es un primer paso para que se puedan explorar plenamente las "tres poderosas fuentes de expansión" a las que se refirió Bielschowsky (2012), a saber: el consumo de masas (cuyos efectos, en ausencia de competitividad interna, se filtran hacia el exterior), la demanda nacional y mundial de abundantes recursos naturales y la demanda de inversiones en infraestructura.

12 Puesto en marcha a mediados de 2009 como parte de la respuesta del gobierno a la crisis, el PSI consistió en la creación de líneas de crédito en el BNDES, con tasas de interés reducidas y fijas, además de plazos dilatados, para la adquisición de bienes de capital en el mercado interno. 
y no comercializables, la ampliación de la gama de sectores afecta la funcionalidad dentro de la propia política, y b) el aumento del costo fiscal amplía la incongruencia macroeconómica a que se hace referencia en el párrafo anterior.

Las conmociones exógenas de mediados de 2013 —las amplias manifestaciones populares en el campo político y las fuertes variaciones en los precios de los activos (tipo de cambio, acciones e intereses futuros) que se derivaron del cambio en el contexto internacional- redundaron en una fuerte perturbación en la confianza de empresarios y consumidores, lo que puso en jaque la trayectoria rumbo a un nuevo crecimiento, conforme se describió anteriormente.

No obstante, desde la perspectiva de finales de 2013, la conmoción política y financiera de mediados de año parece surgir como una oportunidad única para ampliar la participación de la sociedad en los rumbos del país y el proprio significado y prioridad concedidos al término "inclusión". En el plano estrictamente económico, los impactos negativos probablemente no hayan sido más que un contratiempo coyuntural.

Admitiendo que sea así, el país podrá estar encaminándose rumbo a un nuevo desarrollo. Pero parte de las bases que sustentan este camino todavía se están por construir. En la sección siguiente reflexionaremos sobre esas bases.

\section{Bases y desafíos de un modelo de desarrollo inclusivo y productivo}

Al ampliar los términos de la reflexión, de un modelo de crecimiento económico a un ámbito más amplio, de un nuevo modelo de desarrollo, tenemos que conciliar la idea de un modelo consistente, dinámico y sostenido, en el frente estrictamente económico, con los imperativos de la sostenibilidad y la igualdad de oportunidades (CEPAL, 2012). En otras palabras, tenemos que tener en cuenta, simultáneamente, las dimensiones de la competitividad, la inclusión social y la sostenibilidad, en un marco político democrático. A continuación procuraremos abordar las dos primeras dimensiones (crecimiento e igualdad), teniendo clara la convicción de que no tendremos una visión completa del proceso de desarrollo sin incluir la cuestión socioambiental.

En las secciones anteriores afirmamos que, para ser sostenible a largo plazo, un nuevo modelo de crecimiento tendría que estar liderado por la inversión y, en menor medida - por lo menos hasta que la cuenta corriente alcance un nivel compatible con el equilibrio a largo plazo de la balanza de pagos-, por las exportaciones netas. Por otro lado, los 
salarios no podrían continuar creciendo por encima de la productividad, si no se quiere socavar la competitividad externa de la economía. Pero, ¿cómo lograrlo sin interrumpir el proceso de conquistas heredadas del modelo anterior?

La clave principal (aunque no exclusiva) para responder a este interrogante está en el desarrollo productivo, en la productividad. En primer lugar, porque solo es posible lograr un fuerte ritmo de crecimiento del consumo (que se deriva del aumento de los ingresos de los estratos más pobres de la población), sin inviabilizar el aumento de la tasa de inversión y reduciendo la vulnerabilidad externa, si la economía crece a un ritmo incluso más rápido que el del consumo. No obstante, el crecimiento rápido de la economía, en la medida que se va agotando el excedente de mano de obra desempleada, solo puede lograrse a través de un vigoroso aumento de la productividad. Como vimos anteriormente, tendría que ser muy superior al registrado en las décadas pasadas.

Pero eso no es todo. Para que el déficit en cuenta corriente no crezca como porcentaje del PIB y, sobre todo, para que la economía sea capaz de absorber la fuente de dinamismo proveniente de la demanda, sin que esta se filtre hacia el exterior, es fundamental aumentar la competitividad. A corto plazo, la competitividad depende casi exclusivamente del tipo de cambio. Un tipo de cambio depreciado (y estable) es, sin embargo, un activador indispensable del crecimiento. No obstante, la depreciación de la moneda nacional presenta inconvenientes y conlleva costos importantes para la economía interna, que dificultan la conciliación de los múltiples objetivos de un desarrollo inclusivo y sostenible. A modo de ejemplo podemos mencionar, como vimos anteriormente, que un tipo de cambio depreciado exige una política fiscal más austera de la que se requeriría en su ausencia, lo que reduce los grados de libertad de las políticas de gasto y tributación para alcanzar los demás objetivos.

Sin embargo, una vez que el tipo de cambio se sitúa en un nivel competitivo, en la medida que la economía del país logre aumentar la productividad a un ritmo superior a la media de sus competidores, es posible ir apreciando el tipo de cambio sin comprometer la competitividad de la economía, conforme se enuncia en el teorema de Balassa-Samuelson. A partir de este punto se entra en el umbral de un círculo virtuoso.

Fajnzylber (1992, pág. 24) utilizó la expresión "competitividad espuria" para referirse a aquella que se logra mediante la combinación de una renta geográfica o de recursos naturales y a expensas de las remuneraciones laborales y donde, además, los recursos generados en la fase inicial, en lugar de canalizarse hacia la incorporación del progreso técnico - a través de la inversión-, se desplazan hacia el consumo o 
hacia el exterior. En el presente contexto, podríamos redefinir la idea, denominando "apreciación cambiaria espuria" a aquella que es resultado de ingresos excesivos de capitales y de precios de productos básicos excepcionalmente altos $^{13}$, a diferencia de una apreciación cambiaria genuina, que se deriva del proceso de aumento de la productividad por encima de la internacional, como se señaló anteriormente.

La viabilidad del aumento de la productividad a un ritmo superior al de los socios comerciales es un objetivo más factible de lo que podría parecer al principio, si tuviéramos en cuenta la existencia de una brecha de productividad en relación con las economías avanzadas, que constituye una "ventaja del atraso". Sin embargo, resulta difícil crear instituciones y políticas que estimulen un crecimiento vigoroso de la productividad, para aprovechar esas ventajas del atraso.

Para crear tales instituciones y políticas para la productividad -cuestión que en el presente documento tan solo se enunciará, prestando especial atención al ámbito de la política- cabe observar como punto de partida que la productividad se localiza en tres frentes, a saber: a) productividad sistémica; b) productividad estructural, y c) productividad de la empresa.

En lo que se refiere al primer frente, la agenda de la política económica brasileña viene avanzando considerablemente, a pesar de los tropiezos y eventuales retrasos. Actualmente, el principal componente de esta agenda son las inversiones en infraestructura, sobre todo en logística, que incluye la logística urbana. El fuerte crecimiento del consumo y la producción en la década pasada dejó como legado un gran conjunto de obstáculos en materia de infraestructura, que comprometen la productividad y aumentan los costos sistémicos. Además, el aumento del nivel de calidad de vida "de la puerta de casa para adentro" comenzó a contrastar con un deterioro de los servicios públicos ("de la puerta para afuera") en las zonas urbanas, encontrándose ahí una de las insatisfacciones básicas que sustentaron las grandes manifestaciones populares de protesta en las calles brasileñas a mediados de 2013. La reforma y ampliación de la infraestructura tienen, pues, la función de enfrentar estos dos desafíos: el del aumento de la productividad y el de la atención a la creciente demanda social de nuevos y mejores servicios públicos, lo que confiere congruencia y sostenibilidad al proceso de inclusión.

13 Bresser-Pereira defendió la tesis de que existe una tendencia estructural a la apreciación del tipo de cambio (en el sentido que aquí denominamos espuria), causada por el síndrome holandés y por los flujos de capitales, y agravada por un conjunto de políticas equivocadas. A partir de este diagnóstico propone una política destinada a neutralizar esa tendencia a la sobreapreciación como uno de los pilares del nuevo desarrollismo. Véase, por ejemplo, Bresser-Pereira y Gala (2012). 
Además de las cuestiones relativas al financiamiento y el marco normativo - esenciales para desencadenar la inversión en infraestructura - surge una cuestión central, ausente en otras etapas de la historia brasileña, cuando tuvo lugar una gran expansión de las inversiones en este campo, a saber, la cuestión política. En una sociedad plenamente democrática, sobre todo en un contexto de representación política muy fragmentada, el riesgo de que demandas opuestas a nivel sectorial, regional o de diferentes fuerzas sociales paralicen, desvirtúen o tornen completamente disfuncional el proceso decisorio puede retrasar o incluso inviabilizar los avances. Las demandas de congelamientos o reducciones de los precios de los servicios de infraestructura, los grupos de presión contra nuevas reglas para preservar privilegios y las disputas políticas que afectan la mejor localización geográfica de determinadas inversiones son apenas algunos de los obstáculos a la expansión de la infraestructura con base en un marco normativo que combina asequibilidad de las tarifas e inversiones.

Un nuevo desarrollo, que presupone profundizar la democracia, requiere, por lo tanto, un sistema político que procese bien las diferentes demandas y conflictos inherentes a cualquier sociedad democrática, para no obstaculizar procesos decisorios y la implementación eficaz de políticas públicas. Esta tarea tiende a tornarse más factible en la medida que los gobiernos sean capaces de aunar las fuerzas políticas más pertinentes en torno a un proyecto claramente delineado y que aborde los requisitos de conciliar competitividad con equidad y sostenibilidad. En la medida que tal proyecto conquiste "corazones y mentes" y sea asumido por la sociedad, la tarea del gobierno de arbitrar entre diferentes fuerzas e intereses se torna más viable, tomando como criterio aquel proyecto.

Ese requisito político reviste igual importancia a la hora de lidiar con el segundo frente en el que se debe enfrentar la cuestión de la productividad. El enfoque estructural del aumento de la productividad consiste en diseñar e implementar una estrategia de desarrollo productivo dentro de la que se evolucione hacia actividades y competencias que tengan un fuerte potencial para aumentar la productividad, en relación con actividades más tradicionales. Aunque pocos discuerden con la idea de que la estructura de la economía deba desarrollarse apuntando a sectores más productivos, su implementación inevitablemente genera reacciones políticas de los posibles "perdedores". Ello se debe a que al privilegiarse competencias y etapas más avanzadas de las cadenas de generación de valor, puede ser que se eliminen o desaparezcan actividades más tradicionales -como, por ejemplo, aquellas que dependen de salarios bajos, cuya competencia con otros países de bajos 
ingresos sea insostenible - que pueden contar con un poder político considerable y muy arraigado.

Por último, el desafío de aumentar la productividad dentro de la empresa tal vez sea el más complejo, dado que el responsable de tomar las decisiones y el actor principal no es un actor público sino privado. La tarea supone la introducción de incentivos y reglamentaciones que induzcan capacitaciones funcionales para aumentar la productividad e innovación. Pero no solo eso. Se necesitan instituciones educativas, de capacitación y servicios técnicos especializados para desarrollar una cultura de eficiencia e innovación. A pesar de los considerables avances observados principalmente a nivel cuantitativo —-de 2001 a 2011 el número de matrículas en las universidades brasileñas creció de 3 a 6,7 millones-, el atraso en el Brasil, en el campo de las capacidades, es todavía muy marcado y los resultados surgen en el largo plazo. Sin embargo, el mayor desafío, de naturaleza política, se vincula a la movilización de agentes públicos y privados para inocular alto valor social en la sociedad, los gremios profesionales, las políticas públicas y privadas para la educación de calidad y para la meritocracia a fin de lograr un ambiente sistémico de igualdad de oportunidades.

Al comienzo de esta sección, afirmamos que la principal respuesta a los límites del modelo inclusivo radica en aumentar la inversión y la productividad. Un segundo requisito es incrementar la tasa de ahorro, en consonancia con el fuerte aumento de la tasa de inversión que un crecimiento vigoroso de la economía presupone. Esta cuestión tampoco podrá tratarse en el presente documento, pero cabe señalar que, sobre todo en países como el Brasil, donde el aumento de la tasa de inversión, que actualmente se cifra en torno al 19\% del PIB, deberá ser superior a 5 puntos porcentuales del PIB, y donde el déficit en cuenta corriente ya es muy elevado, se trata de una condición sine qua non para viabilizar el proceso de desarrollo que se pretende poner en marcha.

La cuestión aquí no es poner en tela de juicio el precepto keynesiano de que el aumento de la inversión generará su propio ahorro, sino que, si esta tarea se deja exclusivamente en manos de los mercados podrán dispararse procesos que se traducirán en un aumento de la inflación (y erosión de los salarios) o un incremento del déficit en las transacciones corrientes, o incluso en una combinación de ambos. En cualquier caso, se tendería a cuestionar la continuidad del desarrollo. La elevación de la tasa de ahorro público o el desarrollo de instituciones y políticas que estimulen el ahorro privado son caminos necesarios para ampliar la tasa de ahorro e inversión sin los mencionados efectos negativos sobre la estabilidad de los precios y las cuentas externas. 


\section{Reflexiones finales}

En el presente documento procuramos mostrar señales del surgimiento de un nuevo modelo de desarrollo -inclusivo y productivo- y reflexionamos sobre sus fundamentos y los desafíos - de naturaleza esencialmente política- que este enfrenta, partiendo del modelo de crecimiento inclusivo - con sus éxitos y limitaciones- observado en los últimos diez años.

Como se indicó al comienzo del documento, los procesos de desarrollo y las estrategias conexas se dan en un tiempo y lugar específicos, en función de las características estructurales, institucionales, históricas y hasta incluso del tamaño de cada país. Sin embargo, y teniendo presente esta advertencia, parece evidente que algunos de los elementos del modelo inclusivo y productivo, que discutimos sobre la base de la realidad brasileña, pueden ser pertinentes también para otros países de América Latina y el Caribe.

La diversidad de frentes de expansión de la economía es, en el mejor de los casos, algo que encuentra semejanzas tan solo en las economías más importantes de la región. Del mismo modo, no todos están vivenciando, en igual grado e intensidad, los efectos de la transición demográfica sobre el mercado de trabajo, por lo que aumentar la productividad del trabajo resulta esencial para lograr un crecimiento robusto del PIB. Estas son características estructurales que debemos tener en cuenta al discutir sobre la diversidad y el grado de libertad posibles para cada estrategia nacional.

No obstante, la inclusión, la eficiencia y el desarrollo productivo - que se darán sin dudas en función del grado de desarrollo de cada actividad económica en los distintos países - como modelo para superar el dilema que existe entre lograr una mejor calidad de vida de la población, un crecimiento económico con estabilidad macroeconómica y el mantenimiento de un bajo nivel de vulnerabilidad externa, son pilares que todos pueden compartir.

El énfasis en la inversión en infraestructura y, de forma más general, en la producción de bienes públicos, parece ser igualmente un rasgo común de casi todas las economías de América Latina, donde el desequilibrio entre la producción de bienes privados y bienes públicos genera elevada ineficiencia económica y gran descontento social.

Por último, financiar el incremento de la inversión, ya sea desde el punto de vista macroeconómico o microeconómico — de los instrumentos y canales de financiamiento- es por cierto un desafío común, sobre todo 
en un mundo en que no se podrá contar con términos de intercambio y financiamiento externos tan favorables como en la década pasada.

De la misma forma, tal vez podamos generalizar los factores de naturaleza política que impiden un desarrollo inclusivo y productivo. Debe preverse que los procesos de cambio estructural experimentarán resistencias por parte de intereses establecidos que habrá que entender muy bien para enfrentarlas mejor. En este caso, prevalecerán diferencias marcadas entre los países de la región, pues no existe nada más específico que la conformación y consolidación de grupos de interés.

Del mismo modo debemos tener claro que una diferencia central entre los países de la región radica en los distintos grados de capacidad de las instituciones públicas para formular e implementar políticas eficaces para la inclusión y el desarrollo productivo. Conocer estas diferencias resulta esencial si se pretende discutir estrategias nacionales de desarrollo consecuentes, como lo ha hecho la CEPAL a lo largo de su historia. Más importante aún: debemos reconocer y respetar las diferencias entre las decisiones políticas que toman democráticamente los ciudadanos de los países de la región. Es preciso reconocer que los caminos del desarrollo inclusivo y productivo nunca son únicos e invariables. 


\section{Bibliografía}

Bielschowsky, R., "Estratégia de desenvolvimento e as três frentes de expansão no Brasil: um desenho conceitual". En: Economia e Sociedade, vol. 21, número especial, diciembre de 2012.

Bresser-Pereira, L. C. y Gala, P., “O novo desenvolvimentismo e apontamentos para uma macroeconomia estruturalista do desenvolvimento". En: Oreiro, J.L., de Paul, L.F. y Basilio, F. (orgs.), Macroeconomia do Desenvolvimento. Editora Universitária UFPE, 2012.

Castro, A. B., "O Brasil a caminho do mercado de consumo de massa” y "Consumo de massa e retomada do crescimento". En: Velloso, J.P.R. (org.), O Desenvolvimento Brasileiro, da Era Geisel ao Nosso Tempo. Instituto Nacional de Altos Estudios INAE, 2011.

Comisión Económica para América Latina y el Caribe (CEPAL), Cambio estructural para la igualdad: una visión integrada del desarrollo, Santiago de Chile, 2012.

Fajnzylber, F., Industrialización en América Latina. De la "caja negra" al "casillero vacío". Nueva Sociedad No 118, marzo- abril de 1992, págs. 21-28.

Frenkel, R., Lecciones de política macroeconómica para el desarrollo, a la luz de la experiencia de la última década. CEDES, noviembre de 2010. Disponible en http:/ / www.itf.org.ar/ pdf/documentos/72-2010.pdf.

IPEA, Duas Décadas de Desigualdade e Pobreza no Brasil. Comunicado IPEA medidas pela PNAD/IBGE. Comunicado No 159, octubre de 2013.

Kupfer, D., Dez anos de política industrial. Valor Econômico, 08/07/2013.

SAE - Secretaría de Asuntos Estratégicos del Gobierno Federal, Determinantes da Produtividade do Trabalho para a Estratégia sobre Sustentabilidade e Promoção da Classe Média, septiembre de 2013.

Souza, F.E.P., A Macroeconomia da Reindustrialização. Disponible en http://www. ie. ufrj.br/images/conjuntura/A_Macroeconomia_da_Reindustrializao.pdf. 
Capítulo XV

\section{Trayectorias de cambio estructural y enfoques de política industrial: una propuesta a partir del caso argentino ${ }^{1}$}

Fernando Porta

\section{Introducción}

Desde principios de 2003 y hasta finales de 2011, la economía argentina recorrió una trayectoria uniforme de crecimiento acelerado, apenas interrumpida entre fines de 2008 y mediados de 2009, sobre todo, por los efectos de la crisis internacional. Este recorrido comprendió una primera fase de recuperación tras la crisis, que prologó y sucedió al colapso del régimen de convertibilidad, y una etapa posterior de crecimiento genuino e igualmente sólido. Recién hacia fines de 2005 y después de más de diez trimestres consecutivos de expansión generalizada, la economía alcanzó el mismo nivel de PIB que en 1998, indicio más que elocuente de la gravedad de la crisis interna de comienzos de siglo. Del mismo modo, ha llamado

Los temas abordados en este documento fueron el objeto de los debates del Seminario sobre neoestructuralismo y economía heterodoxa llevado a cabo en Santiago de Chile por la Comisión Económica para América Latina y el Caribe (CEPAL) los días 22 y 23 de abril de 2013. Para elaborar este trabajo, el autor se benefició notablemente de las reflexiones y los aportes de Fernando Peirano, Gustavo Baruj, Cecilia Fernández Bugna, Carlos Bianco, Patricia Gutti, Jésica De Ángelis, Pablo Sanches y Florencia Pizzarulli. Se agradecen especialmente los comentarios de un árbitro anónimo y las sugerencias de los editores de este volumen. Los errores remanentes son de exclusiva responsabilidad del autor. 
la atención que, después de haber igualado aquel máximo histórico, el nivel de actividad continuara logrando un vertiginoso crecimiento anual a tasas similares a las de China durante más de cinco años. Para propiciar tal desempeño convergieron varios factores: el modo en el que se resolvió la crisis de la convertibilidad instaló en un inicio condiciones favorables del lado de la oferta, mientras que la demanda se vio impulsada por excelentes condiciones internacionales y por deliberadas y eficaces políticas expansivas en el ámbito interno. En particular, estos dos últimos factores acompañaron buena parte del período y redundaron en una virtuosa dinámica de crecimiento.

El nuevo régimen macroeconómico que sucedió al colapso de la convertibilidad y que se consolidó a partir de 2003 tuvo como características principales, en una primera fase, el sostenimiento de un tipo de cambio relativamente depreciado (competitivo) y una política monetaria que convalidó la expansión de la demanda de dinero derivada de la recuperación y el crecimiento ${ }^{2}$. En un contexto de superávit fiscal, tanto primario como financiero, la política impositiva apuntaló el crecimiento constante del gasto público, resultante tanto del renovado papel de la inversión pública (en infraestructura y vivienda), como del aumento de los salarios, las jubilaciones, las prestaciones sociales y los subsidios generalizados al consumo de servicios públicos. La pesificación asimétrica de deudas nominadas en moneda extranjera, la renegociación explícita o implícita de los pasivos empresariales y la posterior reestructuración de la deuda externa permitieron el saneamiento de los balances privados y públicos. Así, tanto las expectativas privadas como la capacidad de intervención del sector público se vieron favorecidas por esta miríada de decisiones.

El principal objetivo de las políticas implementadas desde el comienzo de la gestión Kirchner consistió en sostener la demanda agregada. El diagnóstico, no siempre explícito, parece haber sido que, mientras se expandiera la demanda, se podría sostener el crecimiento y absorber así el desempleo y mejorar las condiciones distributivas. En gran medida, las acciones puestas en marcha con dicho propósito durante este período privilegiaron los grandes dispositivos macroeconómicos. En este contexto, la crisis internacional iniciada en 2008 tuvo un efecto paradójico en el caso argentino: si bien en los albores dio algunas señales de alarma relativas al sostenimiento de aquella dinámica, una vez que su efecto recesivo quedó pronto rezagado, se restableció la confianza y la preferencia oficial por las políticas macroeconómicas expansivas, con escasa selectividad en el nivel meso- y microeconómico.

A partir de 2008, el tipo de cambio real tendió a apreciarse en el marco de un proceso inflacionario paulatinamente creciente. 
Sin embargo, ya desde finales de 2007, había evidencia de que en esta trayectoria de crecimiento - y en parte por la forma en que se lo gestionaba - se habían acumulado algunos desequilibrios considerables, en su mayoría enraizados en la naturaleza de la estructura productiva argentina. El recrudecimiento de los efectos de la crisis internacional desde fines de 2011 y la posterior desaceleración del crecimiento hacen necesario volver a analizar si no hay algo más que meros problemas exógenos y de corto plazo. Al mismo tiempo, se ha tornado cada vez más evidente que las políticas de estabilidad macroeconómica y de tipo de cambio competitivo resultan una condición necesaria pero insuficiente: para superar las actuales restricciones a fin de crear ventajas competitivas dinámicas se requieren políticas productivas más diversificadas y con capacidad de sintonía fina.

Las consideraciones expuestas en este trabajo están organizadas en tres apartados. En el primero, se presentan unos breves comentarios sobre el desempeño de la economía argentina desde el cambio de régimen macroeconómico en 2002, con el énfasis puesto en el sector industrial. En el segundo se analiza la dinámica productiva de la Argentina desde una perspectiva neoestructuralista y en el tercero se evalúa una propuesta conceptual y metodológica para fundamentar la formulación de una política industrial correspondiente a una estrategia de desarrollo inclusivo. Ciertamente, el caso argentino reciente presenta algunas particularidades, sobre todo en lo atinente a la gestión de la política cambiaria, las restricciones de acceso al financiamiento externo y la virulencia del conflicto distributivo interno, que tornan muy difícil generalizar las hipótesis o conclusiones. De todas maneras, más allá del análisis de la especificidad argentina, este trabajo apunta a proponer algunos criterios metodológicos para llevar a la práctica el enfoque neoestructuralista y debatir sus consecuencias en términos de políticas de desarrollo productivo. Desde este objetivo principal se intentará efectuar alguna contribución al debate latinoamericano actual sobre el desarrollo.

\section{A. Características del desempeño industrial reciente}

La industria manufacturera fue uno de los sectores que lideró el crecimiento de la economía, apoyada en la expansión del consumo privado, mientras que la inversión bruta fija resultó ser el componente más dinámico de la demanda agregada y la demanda externa desempeñó un papel favorable y complementario. A diferencia de las tendencias de crecimiento agregado de los años noventa, el crecimiento industrial de este período se caracterizó por una expansión generalizada de las distintas ramas manufactureras, en 
especial de aquellas más agredidas por el contexto y la recesión previa, lo que produjo efectos favorables para la recuperación de las pequeñas y medianas empresas y para el crecimiento del empleo industrial. No obstante, no hubo un cambio en los contenidos unitarios del empleo, como podía esperarse del abaratamiento relativo de la mano de obra a causa de la fuerte devaluación real. La puesta en funcionamiento de los elevados niveles de capacidad ociosa, en un principio, y las ampliaciones posteriores facilitaron la creación de nuevos puestos de trabajo al tiempo que siguió en alza la productividad laboral media (véase el gráfico XV.1).

\section{Gráfico XV.1}

Argentina: evolución de la producción, el empleo y la productividad media de la industria manufacturera, 1992-2011 (Índice 1997=100)

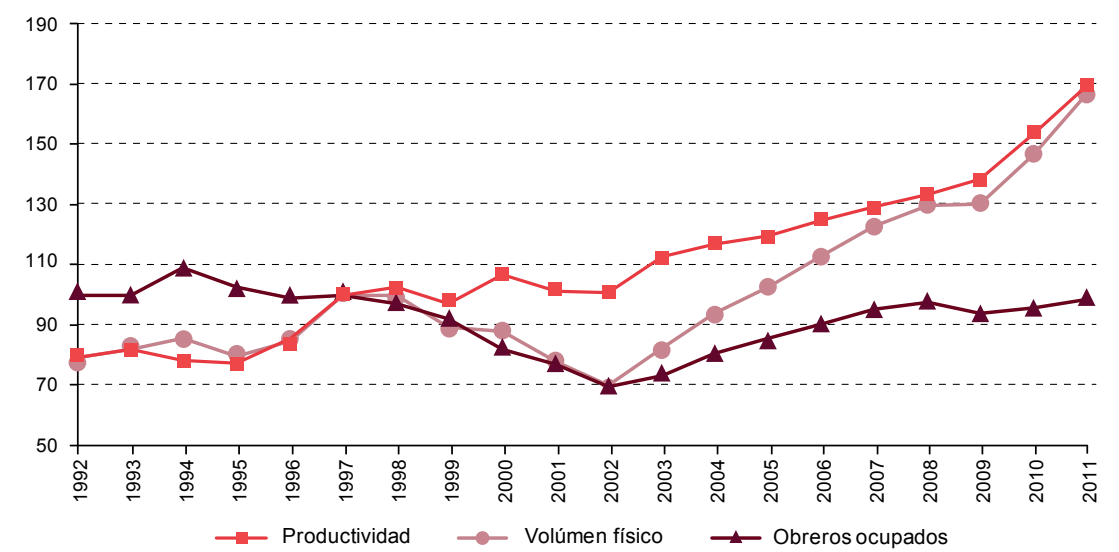

Fuente: Elaboración propia sobre la base del Instituto Nacional de Estadística y Censos (INDEC), Encuesta Industrial Mensual.

Si bien los nuevos incentivos macroeconómicos promovieron el crecimiento de las distintas ramas y agentes, en el aparato industrial de todas maneras se observaron diversas situaciones en función del mercado de destino de su producción y de la participación de los salarios y de los insumos importados o exportables en su estructura de costos, así como del tamaño, el grado de concentración de la oferta y su capacidad para fijar precios. Así, la participación en las ganancias de las industrias metálicas básicas y químicas, en primer lugar, y de

\footnotetext{
Datos de la Encuesta Industrial Mensual del Instituto Nacional de Estadísticas y Censos (INDEC). De acuerdo con los datos sobre empleo en blanco relevados por el Observatorio de Empleo y Dinámica Empresarial del Ministerio de Trabajo, Empleo y Seguridad Social (MTEySS), el empleo en empresas privadas de la industria manufacturera en el cuarto trimestre de 2005 ya era un $4,2 \%$ superior al registrado en el mismo trimestre de 1998 , aunque si se comparan los promedios de ambos años el valor es de solo un $0,2 \%$.
} 
las ramas con alto nivel de concentración, como la petroquímica y el cemento, en segundo lugar, resultó mayor a su peso en el valor agregado industrial, mientras que en las ramas intensivas en mano de obra e ingeniería se verificó la situación opuesta: aquellos sectores beneficiados por la convertibilidad registraron también las mayores ganancias en este período, basadas en ingresos extraordinarios en el marco de la devaluación (Tavosnaska, 2010).

En paralelo con la mejora de los márgenes de rentabilidad, repuntó y creció la inversión en todos los sectores industriales. En términos generales, la tasa de inversión de la economía se recuperó a gran velocidad y se convirtió en el elemento más dinámico de la demanda interna y en un factor determinante del ritmo de crecimiento. En 2008, la tasa de inversión alcanzó el 23,3\% del PIB, superior al máximo previamente registrado en 1998 (20\%). Si bien en un inicio la construcción fue el componente más dinámico, el gasto en equipo de producción duradero se recuperó sobre todo hacia 2007 hasta representar el 63\% y el 73\% del incremento de la inversión bruta interna fija en 2007 y 2008, respectivamente. Las pymes constituyeron el sector empresarial que logró el mejor desempeño relativo en materia de inversión y efectuaron desembolsos que crecieron a un promedio anual del $23 \%$, propiciados por una recomposición de la tesorería propia (Kulfas, 2009; Porta y otros, 2009). Asimismo, este proceso alentó la creación de nuevas empresas y el crecimiento de muchas de las ya existentes.

De todas maneras, si bien se produjo una cierta recomposición de los tejidos productivos muy agredidos por el anterior proceso de desindustrialización relativa, no alcanzó a modificarse en forma sustancial la baja articulación entre las grandes y las pequeñas empresas. La reestructuración de la industria manufacturera de las décadas previas no solo afectó de manera asimétrica a los distintos sectores, sino que también profundizó la heterogeneidad estructural de las firmas. Mientras que varias grandes empresas se habían consolidado en los sectores productivos y alcanzado niveles internacionales, el entramado de pymes padeció un marcado debilitamiento. Las grandes empresas suelen constituir en la economía argentina los nodos principales de redes muy jerárquicas, en las que quedan circunscritas sin trasladar efectos multiplicadores importantes a la cadena productiva en cuestión ${ }^{4}$. En este sentido, la tendencia al aprovisionamiento de partes, piezas y

\footnotetext{
El sector automotor brinda un ejemplo excelente, pues dado el elevadísimo porcentaje de componentes importados utilizados por las empresas terminales para las tareas de ensamblaje, el típico dinamismo de este segmento y del mercado se trasladó solo de manera acotada hacia la totalidad de la cadena. Tampoco se ha concretado una política explícita dirigida a articular los agentes de las tramas y modificar los nodos de acumulación.
} 
componentes importados de los años noventa no se modificó de modo generalizado en este último período, así como tampoco el reparto de rentas en las cadenas.

La expansión acelerada de las exportaciones manufactureras desde 2004 fue otro rasgo destacado del crecimiento industrial reciente y determinó un nuevo salto de nivel en el valor de las ventas externas y la virtual duplicación del coeficiente de apertura exportadora sectorial con respecto a la década de 1990. Este salto exportador se sustentó sobre todo en un aumento del volumen de ventas, tanto de las manufacturas de origen agropecuario como de origen industrial (véase el gráfico XV.2). Ahora bien, el patrón de exportaciones continúa concentrado en un conjunto acotado de productos basados en los recursos naturales - aceites y residuos de la industria alimenticia-, las industrias de proceso e intensivas en escala - el acero y el aluminio, la industria papelera y la petroquímica- y el sector automotor (promovido por un régimen sectorial especial establecido para el Mercado Común del Sur (MERCOSUR)). Al mismo tiempo, hay pruebas de que en el patrón de exportaciones industriales argentinas continúan predominando los bienes de bajo contenido tecnológico.

Gráfico XV.2

Argentina: exportaciones por rubro, 1991-2011

(En millones de dólares)

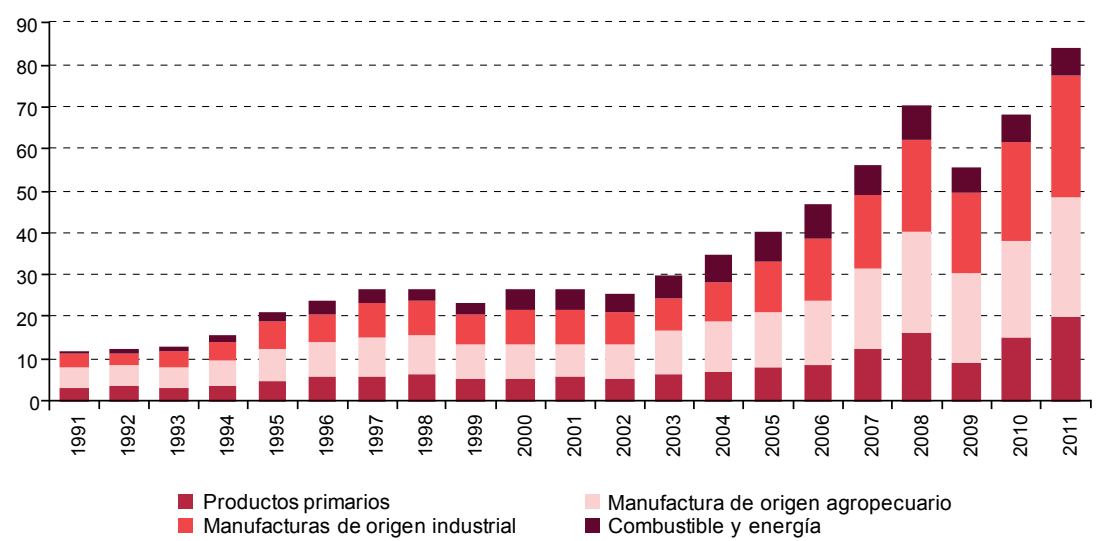

Fuente: Elaboración propia sobre la base de datos del Instituto Nacional de Estadística y Censos (INDEC).

De todas maneras, la mayor competitividad basada en los precios debida a la modificación radical del nivel de tipo de cambio y un contexto internacional favorable propiciaron la expansión de un nuevo conjunto de bienes, lo que posibilitó una muy incipiente diversificación de las 
exportaciones industriales (Bianco, Porta y Vismara, 2008; Herrera y Tavosnaska, 2009). Este resultado se relaciona también con el desempeño exportador de las pymes, que incrementaron sus despachos a un ritmo semejante al de los grandes exportadores. Entre estas empresas que comenzaron a exportar o profundizaron su inserción externa a partir del nuevo régimen macroeconómico predominan aquellas dedicadas a elaborar bienes de capital y otros productos metalmecánicos, maquinaria, artefactos eléctricos, manufacturas metálicas, instrumentos médicos y de precisión, y productos químicos y farmacéuticos.

Por otra parte y pese al cambio en los precios relativos, la relación entre las importaciones y el producto continuó en alza, asociada al crecimiento de la actividad económica interna, el proceso inversor y las rigideces remanentes en la estructura de aprovisionamiento debido a la ausencia de una trama local, dado que el patrón productivo no registró cambios sustanciales (véase el gráfico XV.3). Asimismo, para dar cuenta del crecimiento acelerado de las importaciones se suman otros factores, como el costo "hundido" del aprendizaje importador previo y no compensado por el nuevo régimen macroeconómico, el posicionamiento del Brasil como proveedor en el marco de la integración de las empresas transnacionales, la consolidación de hábitos de consumo centrados en productos de rápida obsolescencia de mercado y la preferencia por la flexibilidad de los agentes económicos.

\section{Gráfico XV.3}

Argentina: importaciones totales y su composición

según su uso económico, 1991-2011

(En millones de dólares)

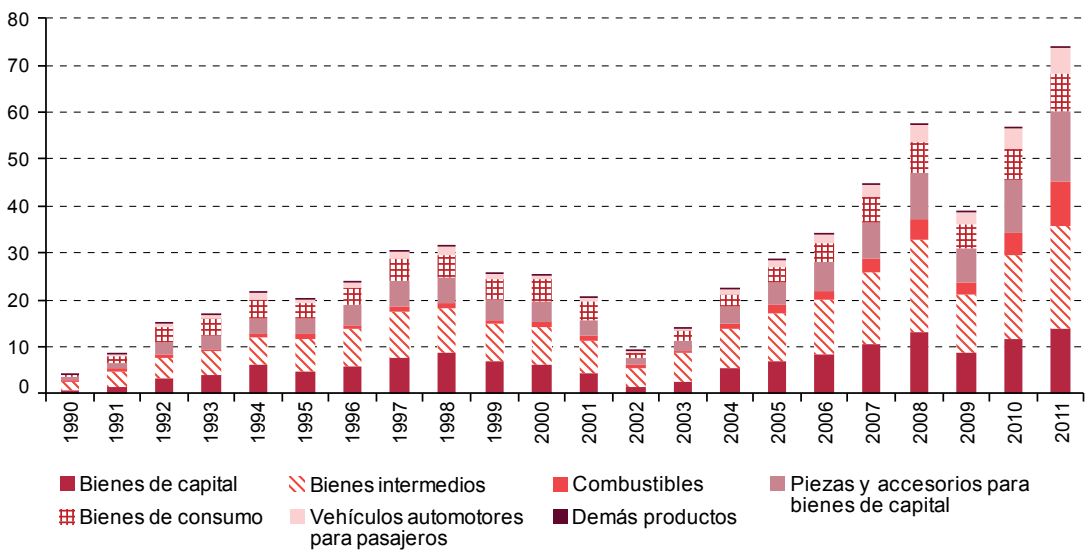

Fuente: Elaboración propia sobre la base de datos del Instituto Nacional de Estadística y Censos (INDEC). 
Pese al incremento de la producción, el empleo, las exportaciones y la inversión, la cuantía y la composición de las inversiones junto con la débil conducta tecnológica predominante en las empresas industriales se traducen en un insuficiente crecimiento de la productividad en términos internacionales. De acuerdo con la base de datos del Programa de Análisis de la Dinámica Industrial (PADI) de la Comisión Económica para América Latina y el Caribe (CEPAL), su ritmo de expansión continúa por debajo de los niveles registrados en las economías más avanzadas (con un crecimiento anual promedio de la productividad en la Argentina de un $3,7 \%$ y un $4,6 \%$ en el conjunto de las economías industrializadas entre 2002 y 2007). Como resultado de este proceso, en la Argentina el producto industrial por trabajador representaba el $45,1 \%$ del producto estadounidense en 1993, mientras que bajaba al $42,6 \%$ en 2001, se desplomaba al 37,7\% en 2002 y descendía incluso al 36,1\% en 2007 (véanse los gráficos XV.4 y XV.5). Si bien la Argentina comenzó a cerrar sus brechas internas en términos productivos y sociales, el incremento más marcado de la productividad de la industria estadounidense indica que se profundizó la brecha tecnológica externa de la economía argentina. En el ámbito sectorial, los desempeños resultan heterogéneos: mientras que en sectores como el de los automóviles y el de los alimentos, bebidas y tabaco se registra un cierto acortamiento de la brecha de productividad, las diferencias se acentuaron en las restantes ramas intensivas en ingeniería y en aquellas intensivas en mano de obra.

Gráfico XV.4

Argentina y Estados Unidos: producto industrial de sectores seleccionados, por trabajador, 1993-2007

(En miles de dólares de 1985)

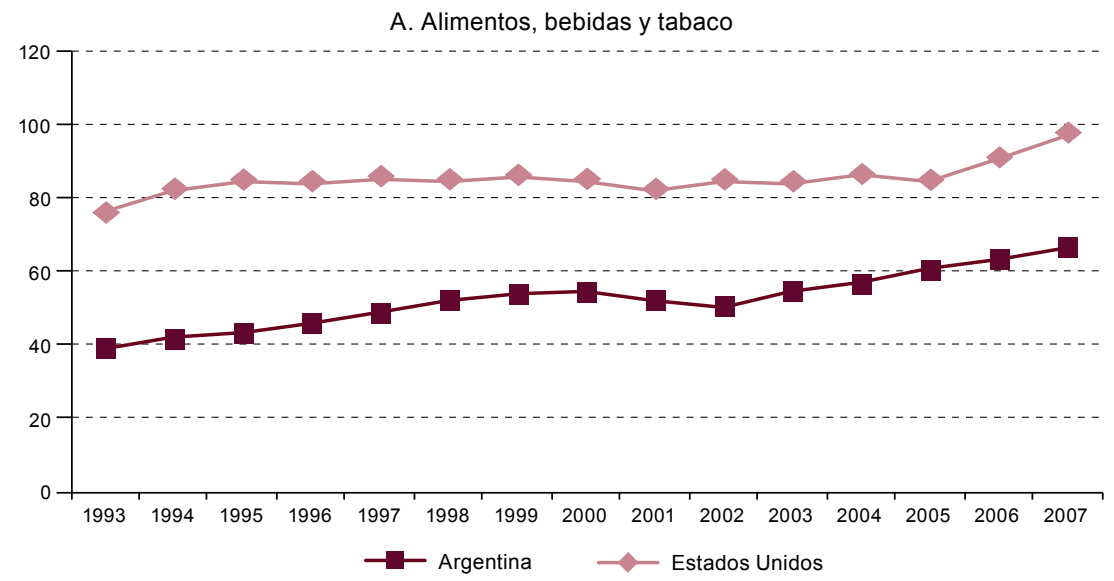


Gráfico XV.4 (conclusión)

\section{B. Automóviles}

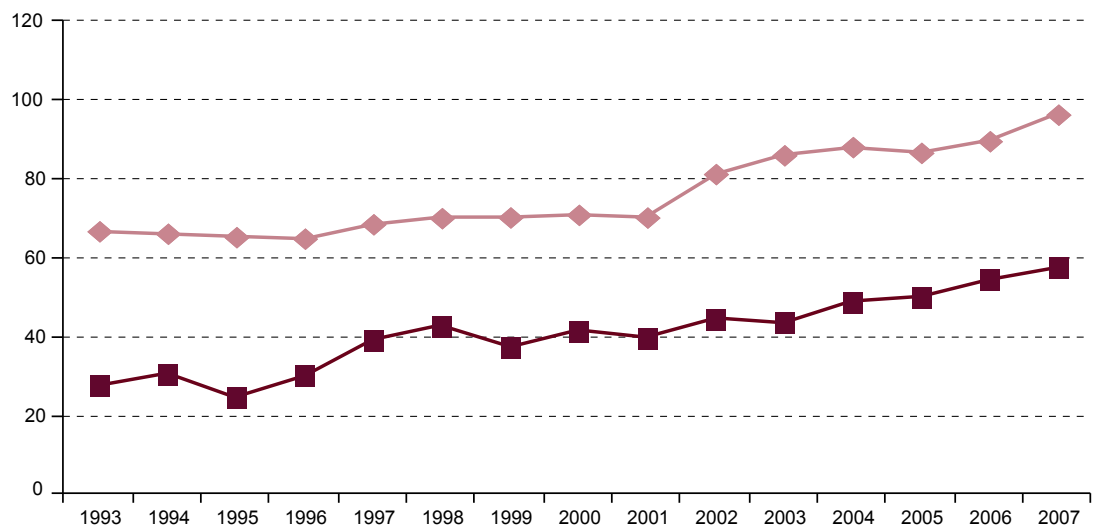

C. Ramas de la ingeniería, excluido el sector automotor
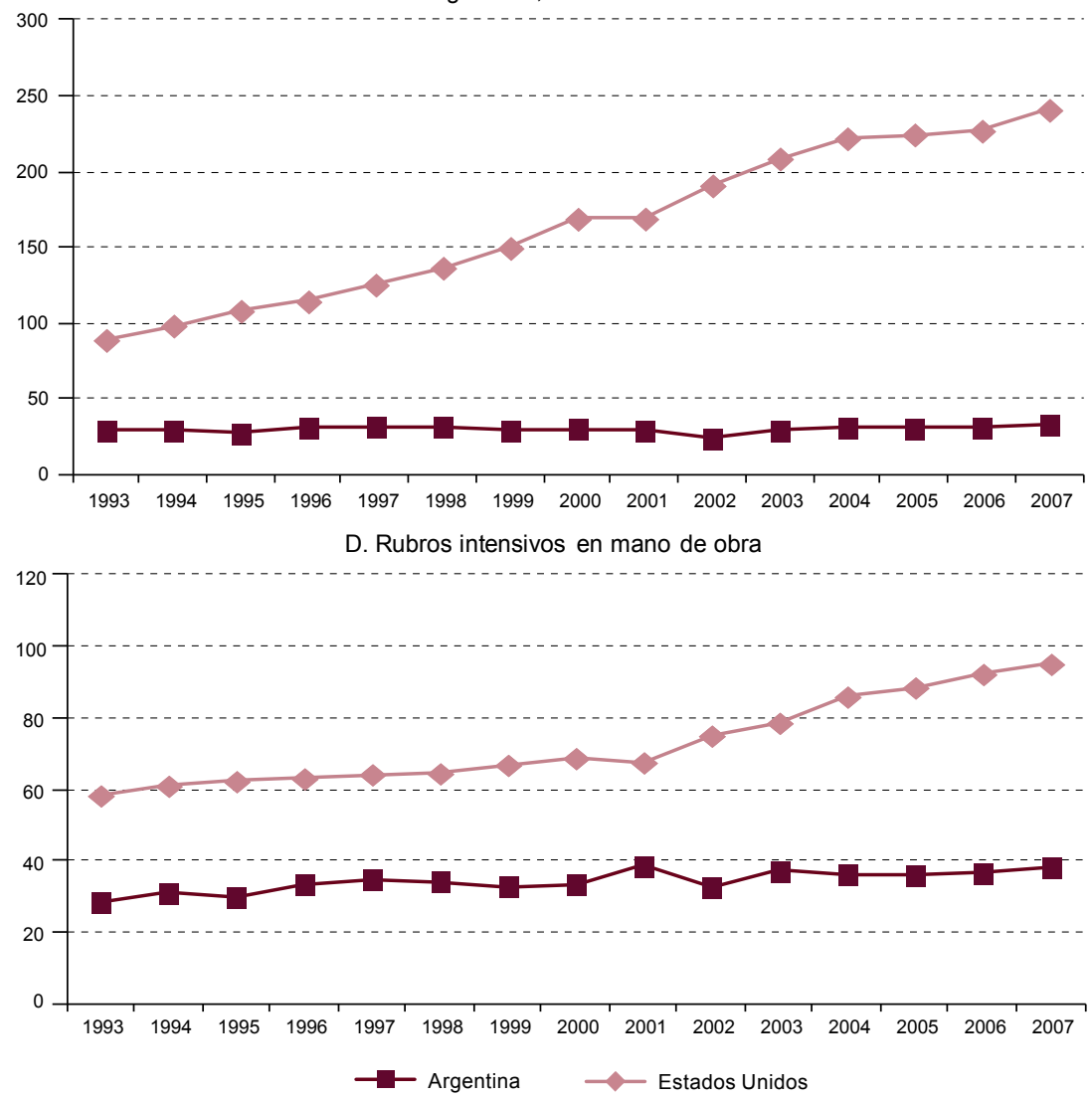

Fuente: Elaboración propia sobre la base de Comisión Económica para América Latina y el Caribe (CEPAL), Programa de Análisis de la Dinámica Industrial (PADI). 


\section{Gráfico XV.5 \\ Argentina: crecimiento de la productividad y comparación \\ con los Estados Unidos, 2000-2010 \\ (En porcentajes)}

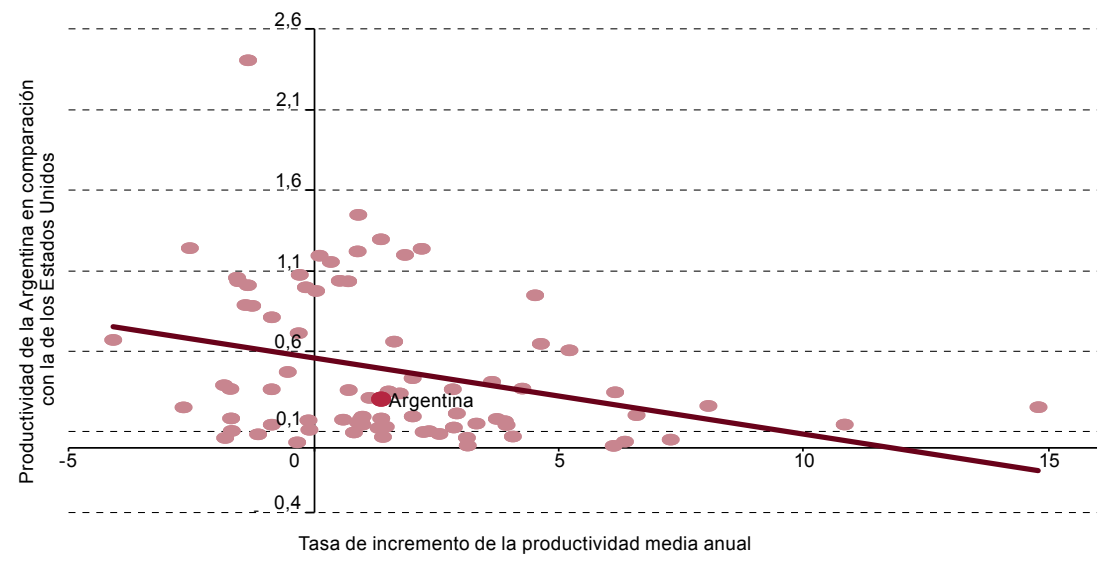

Fuente: Elaboración propia sobre la base de información del Banco Mundial.

En Coremberg (2012) se presentan estimaciones de la productividad total de factores (PTF) para la Argentina en el período 1990-2010 y se compara su comportamiento en las fases de auge registradas en cada década. De acuerdo con estas evidencias, el crecimiento en ambos períodos se debería más a la acumulación de factores — capital y trabajo- que a los incrementos de la PTF. La acumulación de capital da cuenta del $42 \%$ del crecimiento del PIB entre 2002 y 2010, y del 40\% entre 1990 y 1998. En ambos casos se trata fundamentalmente de capital no perteneciente al sector de las tecnologías de la información y las comunicaciones y de origen importado, aunque en la etapa posterior a la devaluación resulta algo más considerable la participación del equipamiento doméstico y de la inversión pública no residencial. A su vez, la incorporación del factor trabajo representa un $49 \%$ del crecimiento agregado a partir de 2002 y un $42 \%$ del registrado durante la convertibilidad hasta 1998, contribución que en general se basa más en la cantidad que en la calidad del empleo. En ambos períodos resulta también modesto el aporte de la mayor eficiencia en el uso de los factores.

\section{B. Limitaciones de la especialización productiva}

El nuevo esquema macroeconómico no parece haber representado un incentivo suficiente para alcanzar una producción más sofisticada o marcados cambios innovadores en los productos o procesos. En general, no alcanzan a alterar el panorama de la industria ni a lograr algunas mejoras, vinculadas a la búsqueda de una mayor inserción exportadora, o avances 
en los nuevos sectores del software y la biotecnología. Ya las primeras encuestas sobre innovación realizadas en la Argentina a finales de los años noventa mostraban que los gastos efectuados por las empresas en esta esfera eran significativamente menores a los estándares internacionales. Los resultados de las últimas mediciones ponen de manifiesto que la situación no ha experimentado modificaciones sustanciales. Esto sugiere que una gran parte de las empresas aprovecharon las nuevas condiciones para aumentar su nivel de actividad y de ventas sin proponerse una estrategia tendiente a desarrollar al mismo tiempo una plataforma de inserción competitiva, sostenible y acumulativa ${ }^{5}$.

Más que asociado a un cambio estructural, el proceso de reindustrialización relativa de los últimos años se caracterizó por un nuevo régimen de crecimiento, en el que la gran mayoría de las ramas industriales crecieron al mismo tiempo que la productividad laboral media y la ocupación de la mano de obra. La estructura productiva argentina presenta puntos flacos en su composición sectorial - centrada en actividades de bajo contenido tecnológico- $-\mathrm{y}$, a su vez, en las distintas ramas predomina una especialización en los rubros productivos de menor complejidad. Este tipo de especialización productiva se heredó del cambio estructural de los años noventa, en cuyo marco las actividades tecnológicamente menos dinámicas ganaron participación y el aparato industrial tendió a reemplazar el empleo y las capacidades locales mediante la incorporación de insumos, componentes y bienes de capital importados como una estrategia de modernización. Esta reestructuración tuvo como correlato el desaliento de las capacidades productivas y tecnológicas endógenas, el desmantelamiento de los encadenamientos locales y una mayor heterogeneidad productiva.

La composición sectorial de la estructura industrial no resulta un indicador suficiente de las características tecnológicas y el valor agregado de la producción local. Otros factores relevantes que se deben tener en cuenta son las clases de productos y actividades de cada industria, la complejidad de los procesos productivos y la aplicación de conocimientos en la producción, el valor agregado y la integración con el entramado productivo local así como los tipos de mercados o los eslabones de las cadenas de valor en los cuales se inserta. En este sentido, Ocampo (2005) recupera una larga tradición teórica de autores y de escuelas económicas heterodoxos al plantear que la dinámica de las estructuras productivas es el resultado de la interacción entre dos fuerzas distintas: por un lado, la innovación y, en

Solo unas pocas empresas industriales (menos del 10\%) muestran una estrategia continua de innovación, mientras que una cuarta parte realiza escasas o nulas actividades en este rubro (Lugones, Suarez y Moldovan, 2008), conducta que se observa en todos los sectores industriales. Del mismo modo, estos autores señalan que en todos estos sectores se observan ejemplos de empresas con comportamientos más dinámicos y auspiciosos, en cuyos casos el coeficiente respectivo se aproxima al promedio de las firmas europeas y excede el de la industria brasileña, pues el gasto en innovación supera el $3 \%$ de las ventas, un valor muy por encima del promedio $(1,12 \%)$. 
términos generales, los procesos de aprendizaje, y por el otro, la existencia de complementariedades, encadenamientos y redes entre empresas, actividades productivas e instituciones que sustentan externalidades dinámicas.

A partir de esta definición teórica, Porta (2006), Bianco y Fernández Bugna (2010), y Porta y Fernández Bugna (2011) han elaborado propuestas y metodologías para clasificar e identificar el posicionamiento relativo de las actividades productivas en función de los ejes planteados por Ocampo ${ }^{6}$. En el caso de la Argentina, los sectores que elaboran materiales para la construcción (269), automotores (341) y otros productos químicos (242) resultan ser los que combinan los mayores niveles relativos de aprendizaje y encadenamientos en el aparato industrial argentino (véase el gráfico XV.6). No se trata de actividades caracterizadas usualmente como de alto contenido tecnológico (con excepción de los fármacos, incluidos en la rama de productos químicos). La industria automotriz, en particular, ha mostrado un creciente avance hacia una mayor importación de partes y componentes con más contenido tecnológico, lo que redujo su integración con la economía local en términos cuantitativos y cualitativos.

\section{Gráfico XV.6 \\ Argentina: indicadores de innovación y aprendizaje y encadenamientos de las ramas manufactureras, $2005-2007^{\text {a }}$}

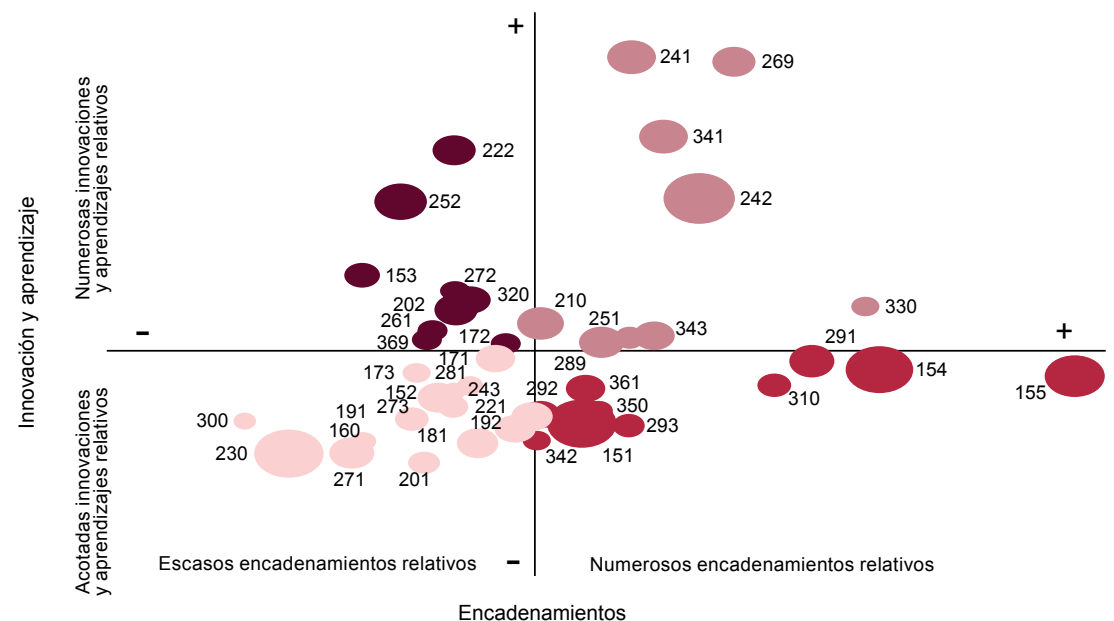

Fuente: Elaboración propia sobre la base de información del Centro de Estudios para la Producción (CEP), el Instituto Nacional de Estadística y Censos (INDEC) y la Matriz Insumo Producto 1997 (MIPAr-97).

a Las burbujas reflejan la importancia de cada una de las ramas manufactureras respecto del valor agregado de la industria.

$6 \quad$ Véanse las cuestiones metodológicas en Porta y Fernández Bugna (2011). Dado que las encuestas nacionales sobre innovación y conducta tecnológica se elaboran a partir de una muestra de empresas manufactureras, la falta de datos sobre las actividades de innovación en el sector primario y en el de los servicios no permite aplicar la presente metodología a las actividades productivas. 
A su vez, la mayoría de las ramas industriales se concentran en los cuadrantes de niveles medios y bajos de ambos indicadores: por ejemplo, la refinación de petróleo (230) y la industria procesadora de alimentos (151), ambas con fuerte participación en la estructura industrial, se ubican en los cuadrantes menos virtuosos. Esto indica que importantes actividades basadas en los recursos naturales todavía se sustentan fundamentalmente en ventajas estáticas, con acotados gastos en innovación y aprendizaje, así como un escaso desarrollo y diversificación de los eslabones con el resto de la economía.

Cabe señalar que, al utilizar esta metodología de cálculo, que hace uso de promedios agregados, se pueden llegar a pasar por alto considerables niveles de heterogeneidad intrasectorial (Bianco y Fernández Bugna, 2010). En diversos estudios se ha publicado información sobre sectores en los que empresas muy activas en el desarrollo de nuevos productos conviven con otras especializadas en bienes de baja calidad y diferenciación (por ejemplo, la industria láctea), así como el caso de empresas o segmentos que cuentan con reconocidos centros de investigación y desarrollo, por ejemplo, la industria siderúrgica o de maquinarias especializadas (véase, por ejemplo, Stumpo y Rivas, 2013). En este sentido, aunque según las encuestas tecnológicas en la Argentina el nivel de gasto privado en actividades de innovación sea acotado, también hay pruebas de la presencia en diversos sectores de agentes con comportamientos dinámicos y estrategias explícitas en términos de innovación e inserción externa (Lugones, Suárez y Moldovan, 2008; Suárez, 2013). De todos modos, en estos mismos trabajos se da cuenta del carácter minoritario de estos casos, lo que explica el desempeño promedio observado.

Si se aplican los postulados de Ocampo (2005), se pueden definir como procesos de transformación estructural virtuosos aquellos en los que ganan participación los sectores productivos intensivos en innovación y aprendizaje, y en complementariedades. Trayectorias de esta naturaleza determinan una eficiencia micro- y mesoecónomica, generan competitividad sistémica, reducen la heterogeneidad y mejoran los ingresos de la población. Por el contrario, los procesos en los que solo algunas empresas, actividades o sectores presentan altos contenidos de innovación y aprendizaje, pero con un débil desarrollo de complementariedades, constituyen casos con poco futuro. Las ventajas competitivas son específicas de ese conjunto de actividades o empresas. Dada su limitada integración con el resto del aparato productivo, el crecimiento de estas actividades requiere de significativos flujos de importaciones, genera filtraciones al crecimiento y anula los efectos multiplicadores, al tiempo que las convierte en actividades susceptibles de deslocalización. 
En el caso argentino, en la fase de crecimiento industrial reciente, han tendido a ganar cierta participación relativa aquellas ramas con mayores contenidos de innovación, aprendizaje o encadenamientos, lo que sugiere una tendencia interesante en términos de transformación estructural. No obstante, las actividades que combinan los indicadores más elevados en ambos ejes no superan el 15\% del producto industrial. Por otra parte, Porta y Fernández Bugna (2011) aplican una metodología similar y realizan una comparación de las estructuras productivas de la Argentina y el Brasil tomando a Alemania como referencia ${ }^{7}$. La mayor parte de las ramas manufactureras argentinas se ubican en los niveles relativamente más bajos de innovación y aprendizaje y de encadenamientos. Esta situación contrasta en parte con el caso brasileño, que presenta una mayor cantidad de sectores con características estructurales profundas y parece corroborar la hipótesis de Porta (2006), que plantea la existencia de un cuadrante ausente en la estructura productiva argentina (véase el gráfico XV.7).

\section{Gráfico XV.7}

Argentina y Brasil: diferencias entre los indicadores de innovación y aprendizaje y las complementariedades de las ramas manufactureras respecto de Alemania, $2005^{\text {a }}$ (En porcentajes)

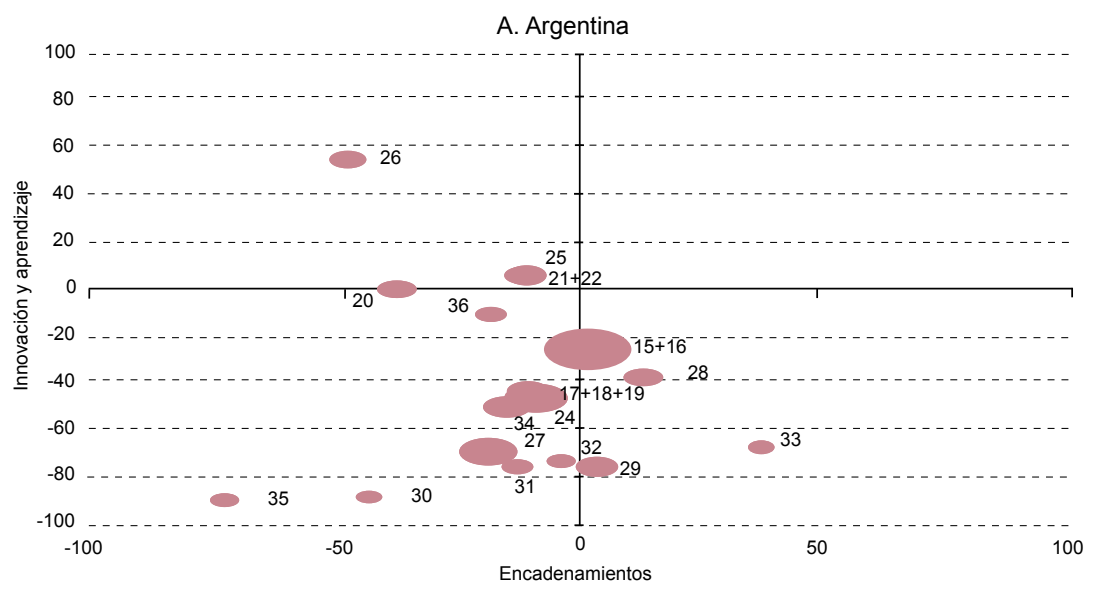

\footnotetext{
A partir de las matrices armonizadas de insumos y productos elaboradas por la Organización para la Cooperación y el Desarrollo Económicos (OCDE) y de las respectivas encuestas sobre innovación, se volvió a aplicar la metodología descrita para comparar la especialización industrial de la Argentina, el Brasil y Alemania. Se utilizó el caso de Alemania como patrón de referencia para definir los niveles absolutos de innovación, aprendizaje y encadenamientos con los cuales calificar la especialización productiva de economías como la argentina o la brasileña. Por su parte, se efectuó una comparación con el Brasil a fin de captar también las asimetrías tecnológicas con otra economía de desarrollo intermedio de la región. En función de estos indicadores, se calcularon para la Argentina y el Brasil las diferencias con los valores obtenidos en el caso de Alemania, teniendo en cuenta la intensidad de la innovación y el aprendizaje, el nivel de investigación y desarrollo, y los eslabonamientos de las ramas alemanas como un indicador indirecto de la frontera.
} 
Gráfico XV.7 (conclusión)

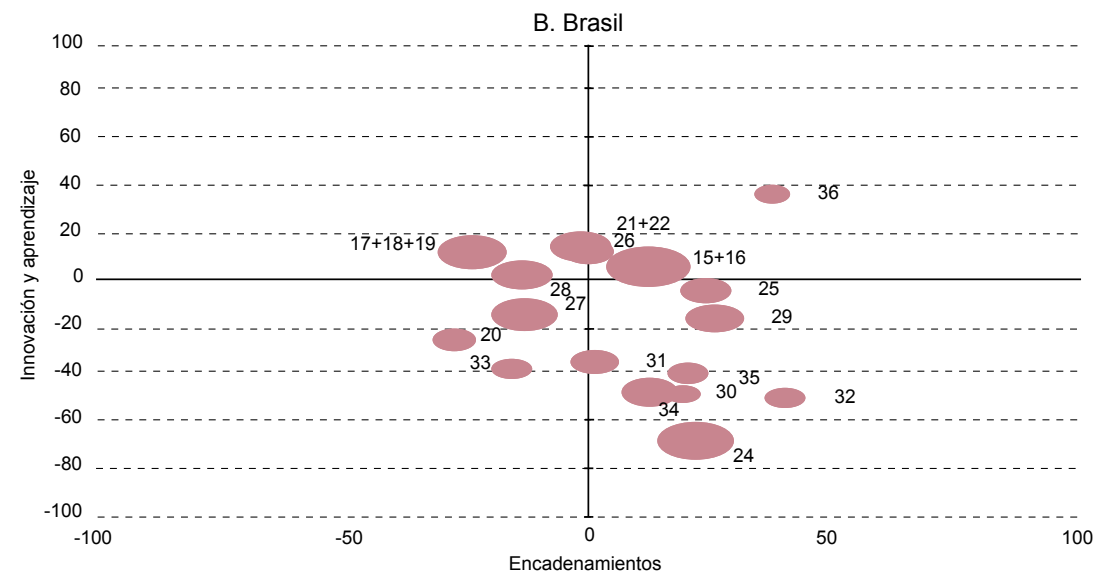

Fuente: Elaboración propia sobre la base de datos del Instituto Nacional de Estadística y Censos (INDEC), el Instituto Brasileño de Geografía y Estadística (IBGE), la Oficina de Estadística de las Comunidades Europeas (EUROSTAT) y la Organización de Cooperación y Desarrollo Económicos (OCDE).

Las burbujas representan la participación de cada rama en el producto industrial correspondiente a 2005 sobre la base de información de la Dirección Nacional de Cuentas Nacionales del INDEC, en el caso de la Argentina, y de la base de datos del Programa de Análisis de la Dinámica Industrial (PADI) de la CEPAL, en el caso del Brasil.

Según estos indicadores, cuando se considera la intensidad de la innovación y el aprendizaje, la distribución de las ramas confirma la amplitud de las brechas de innovación y aprendizaje en los distintos sectores industriales argentinos y brasileños respecto de la estructura alemana, con la sola excepción de cauchos y plásticos (25) y otros productos no metálicos (26), así como las distancias especialmente marcadas de las maquinarias y equipos (29), la maquinaria de oficina (29), los equipos y materiales eléctricos (31), y otros transportes (35). Estos datos demuestran que la diferencia tecnológica entre los sectores industriales de la Argentina, el Brasil y Alemania no se limita a una especialización sectorial, sino que se amplía de la mano de la debilidad de las capacidades endógenas de innovación y resulta aun más pronunciada cuando además se toman en cuenta los gastos absolutos en innovación y aprendizaje, y en investigación y desarrollo (Peirano, 2008).

En síntesis, los determinantes estructurales del crecimiento de la industria argentina tienden a ser débiles: su expansión suele requerir un flujo creciente de importaciones, sin redundar en mayores efectos multiplicadores por el lado de la demanda, a la vez que no crea necesariamente suficientes economías externas de escala como para sustentar avances de la competitividad sistémica. El proceso de crecimiento no se apoya en el desarrollo de actividades más intensivas en conocimiento y diferenciación, con demanda dinámica, altas tasas de inversión y efectos positivos en el 
resto del aparato productivo. Por lo tanto, el incremento de la productividad resulta insuficiente y la estructura productiva resulta ser en sí misma una limitante de los objetivos de crecimiento sostenible, el aumento de la calidad de vida y una mejor distribución de los ingresos. A su vez, tarde o temprano dependiendo de eventuales factores de coyuntura interna o externa, tiende a precipitar o agravar las condiciones de la restricción externa y fiscal, y a condicionar la política cambiaria.

Desde el punto de vista de las dimensiones estructurales que se examinan en este trabajo, el perfil de especialización exportadora de la economía argentina muestra una característica paradójica. Porta y Fernández Bugna (2011) analizaron cómo evolucionó la inserción comercial externa de los sectores industriales argentinos según el índice de ventajas comparativas reveladas propuesto por Lafay (1979 y 1980) ${ }^{8}$. Los resultados mostraron ventajas comparativas durante 1993-2008 en distintos rubros de alimentos y bebidas - alimentos, lácteos, molinería, bebidas- (15), productos de cuero (191), refinación de petróleo (23), hierro y acero (271), metales preciosos y no ferrosos (272) e impresión (222), este último explicado por los bajísimos niveles de importación (véase el gráfico XV.8). Se trata, sobre todo, de sectores basados en los recursos naturales o beneficiados por antiguos y permanentes regímenes de promoción industrial. En el gráfico puede observarse que ninguna de estas actividades se ubica en el cuadrante más virtuoso.

\section{Gráfico XV.8}

Argentina: sectores con ventajas comparativas según los indicadores de innovación y aprendizaje, y de encadenamientos, 2005-2007 a

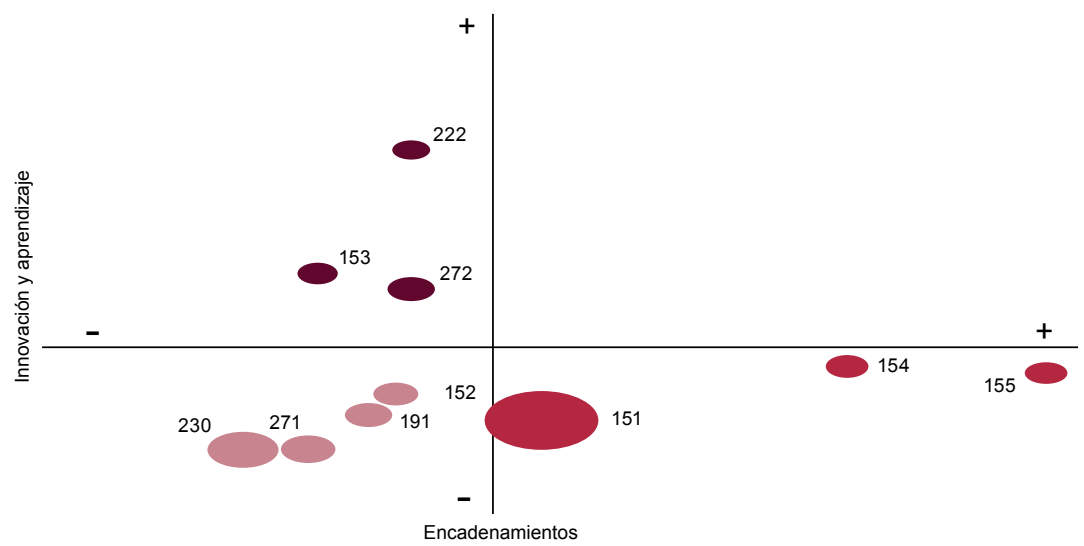

Fuente: Elaboración propia sobre la base de información del Centro de Estudios para la Producción (CEP), el Instituto Nacional de Estadística y Censos (INDEC) y la Matriz Insumo Producto 1997 (MIPAr-97).

a Las burbujas reflejan la importancia de cada una de las ramas manufactureras en el total de las exportaciones de este origen.

$8 \quad V C R_{i}=\frac{1000}{P B I}\left[\left(X_{i}-M_{i}\right)-\left(\frac{X_{i}+M_{i}}{X+M}\right)(X-M)\right.$ 
Ahora bien, se podría argüir que ciertos sectores gozan de ventajas comparativas potenciales, en el sentido de que han reducido en forma progresiva sus desventajas comparativas reveladas y presentan las características expuestas en este trabajo (Nassif, 2003; Briner, Sacroisky y Bustos Zavala, 2007). En general, se trata de ramas con elevados coeficientes de exportación y comercio intraindustrial, donde se incluyen algunos insumos industriales, como los productos químicos (241 y 242), los productos de papel (210) y el caucho (251), y algunas ramas basadas en economías de escala e intensivas en capital, que se cuentan entre las actividades con los mayores niveles de innovación y aprendizaje y desarrollo de encadenamientos de la industria argentina (véase el gráfico XV.9). Por otra parte, salvo contadas excepciones, las ventajas comparativas de las ramas con menores contenidos de innovación y aprendizaje y encadenamientos tienden a empeorar a lo largo del período.

\section{Gráfico XV.9}

Argentina: sectores con ventajas comparativas potenciales según los indicadores de innovación y aprendizaje y encadenamientos, 2005-2007 ${ }^{a}$

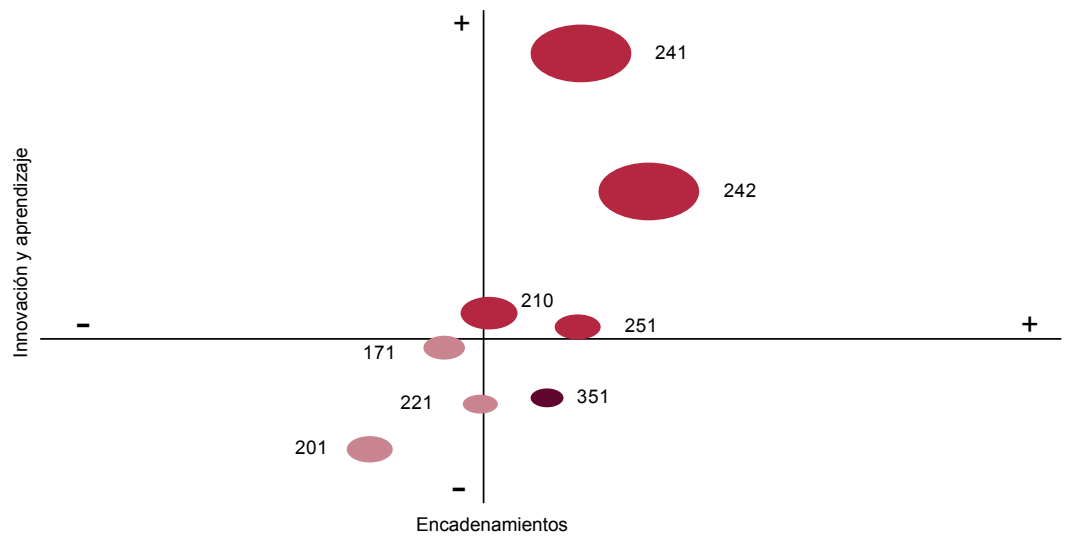

Fuente: Elaboración propia sobre la base de información del Centro de Estudios para la Producción (CEP), el Instituto Nacional de Estadística y Censos (INDEC) y la Matriz Insumo Producto 1997 (MIPAr-97).

a Las burbujas reflejan la importancia de cada una de las ramas manufactureras en el total de exportaciones de este origen.

Este patrón de inserción internacional —basado en actividades con un uso poco intensivo de la mano de obra y una limitada capacidad para crear encadenamientos productivos - determina una acotada elasticidad entre las exportaciones y el empleo (Stumpo, 2009). Así, la gran mayoría de los puestos de trabajo creados en la reciente etapa de crecimiento económico y exportador están relacionados con empresas cuya actividad se orienta exclusivamente hacia el mercado interno. Estos aspectos ponen en duda la eventual automaticidad de los efectos que podrían esperarse de una estrategia de crecimiento impulsado por las exportaciones, tal como 
se ha señalado con frecuencia en el debate corriente (Katz y Stumpo, 2001). Asimismo, sugieren la importancia de vincular con mayor eficacia una inserción internacional más profunda con la diversificación de la estructura productiva, al tiempo que se mejora su aptitud para originar eslabonamientos en ambos extremos de la cadena y para llevar adelante procesos más avanzados y complejos desde el punto de vista tecnológico.

\section{Enfoques de política industrial: hacia una agenda posneoliberal}

La clave para transformar un ciclo de expansión en un proceso de desarrollo económico radica en la dimensión mesoeconómica. La composición sectorial de la producción, las estructuras de mercado, el funcionamiento de los mercados de factores y las instituciones que encuadran el aparato productivo condicionan su evolución. Cualquier sendero de desarrollo se modelará en función de la dinámica de los cambios experimentados por la estructura de producción, que será el resultado de la interacción entre la secuencia de incorporación de innovaciones en los procesos, los productos, la organización o la institución - con la consecuente difusión de los procesos de aprendizaje- y la densidad de complementariedades presentes o inducidas en la estructura productiva. La capacidad de un sistema industrial para crear nuevas actividades constituye un componente fundamental de un crecimiento económico veloz, pero la transformación de la estructura productiva dependerá, sobre todo, de su difusión y la creación de encadenamientos productivos.

El reciente proceso de reindustrialización experimentado por la Argentina se vio impulsado por políticas activas que estimulaban la producción y, en particular, la expansión de la demanda. Sin embargo, las principales características tecnoproductivas y socioproductivas de la estructura económica no sufrieron modificaciones sustanciales y su funcionamiento tiende a producir desequilibrios que comprometen los objetivos de redistribución del ingreso y de recuperación de márgenes de acción para la política económica. La meta destinada a llevar adelante un cambio estructural requiere basarse en la definición explícita de una estrategia y las correspondientes políticas de desarrollo productivo que, en forma simultánea, alienten los procesos de escalamiento o actualización de los productos, procesos y funciones - donde resulta fundamental la dimensión intrasectorial - y promuevan un mayor grado de eslabonamiento entre las empresas, las actividades y los sectores. Se apunta a reconstruir un entramado de relaciones productivas que favorezcan el incremento sostenido de la productividad y de consolidar las instituciones sociolaborales que permitan lograr mejoras distributivas y la creación de nuevos mercados sin comprometer el crecimiento. 
Para consolidar un sendero de desarrollo inclusivo se necesita rediseñar la intervención estatal a nivel mesoeconómico. La Argentina cuenta con un sistema productivo muy diversificado, atravesado por intensos conflictos distributivos y caracterizado por una acotada capacidad para articular - de un modo inclusivo- los intereses de todos los actores involucrados en aras de un objetivo estratégico. El tamaño de su población y el acervo de capacidades acumuladas resultan incompatibles con una estrategia de tipo "nicho" y en extremo especializada, al tiempo que la administración de la puja distributiva requiere un alza sistemática y sustancial de la productividad media de la economía y evitar los abusos de las posiciones dominantes. La selectividad de toda intervención debería promover un escalamiento general de las actividades productivas y la definición de la política industrial en sentido amplio tendría que seguir aquellos criterios y atender las condiciones necesarias para maximizar su eficacia.

El desafío radica en avanzar hacia un tejido productivo más denso, complejo e integrado, transformación que no deriva automáticamente del crecimiento agregado. Por el contrario, se trata de un cambio estructural que necesita una intensa acción colectiva en un plano mesoeconómico, porque los obstáculos principales subyacen en los problemas de coordinación y en el tipo de gobernanza que rige las diferentes cadenas de valor. En este sentido, así como resulta evidente que las políticas productivas no tienen suficiente potencia como para compensar las incongruencias o los desequilibrios macroeconómicos, también salta a la vista que no se puede solo establecer un sistema de incentivos supuestamente favorables y apostar por la coordinación mediante un sistema de precios. La función primordial de las políticas de desarrollo productivo debe ser la intervención sobre la composición sectorial de la producción y la regulación de las relaciones interempresariales e intersectoriales, donde se define cómo se genera, se apropia y se distribuye el ingreso.

Es necesario formular las políticas a partir de objetivos que permitan identificar para cada cadena productiva la trayectoria de transformación requerida para concretar las opciones de escalamiento productivo y de desarrollo de complementariedades. No se trata de pensar la política industrial como una reacción ante fallas de mercado orientada a resolver los problemas de información o coordinación que causa un sistema de precios, ni como intervenciones meramente compensatorias. El corazón de las políticas productivas debe ser la definición del escenario estratégico factible — según las capacidades acumuladas y potenciales-y deseable en función del objetivo de desarrollo inclusivo. Esta es una tarea indelegable del Estado: supone explicitar la estrategia general y definir las metas y trayectorias del cambio estructural buscado. Al mismo tiempo, permite redefinir la relación entre el sector público y el sector privado: el tránsito 
desde la situación presente hacia la meta deseada requiere una interacción fluida con los sectores empresariales y sindicales a fin de asegurar una acertada implementación de las políticas específicas.

En términos más operativos, se propone elaborar una matriz de objetivos y estrategias de políticas, cuyo propósito específico sea establecer la trayectoria del cambio necesario en los sectores o las cadenas productivas que resulte más conveniente en términos sociales por las externalidades pecuniarias y no pecuniarias que puede traer aparejadas (véase el diagrama XV.1). El diagnóstico, organizado en función de los ejes de escalamiento y complementariedad planteados, debe identificar el posicionamiento sectorial (cualquiera de los Ai posibles), lo que supone tomar en cuenta el punto de partida de la intervención a los efectos de alcanzar una zona de mayor calidad dentro de los ejes del cambio estructural deseado (B) ${ }^{9}$. En términos generales, el paso de la situación actual de cada

$9 \quad$ El escalamiento puede plantear la exigencia de producir más eficientemente (escalamiento de los procesos), de orientarse hacia productos de mayor valor unitario (escalamiento de los productos) o de desplazarse hacia tareas que requieran mayores capacidades (escalamiento funcional). También debe tenerse en cuenta que toda destreza que se adquiera y permita desempeñar una función de forma sobresaliente se puede aplicar en distintos sectores (escalamiento intersectorial). En última instancia, el escalamiento procura alejarse de los sectores o las funciones donde la competitividad depende de los costos y las barreras de entrada son acotadas. En particular, el escalamiento funcional puede reducir la vulnerabilidad de la posición competitiva de una firma o sectores, ya que limitarse a cumplir solamente la fase de manufactura restringe la competencia a parámetros asociados con los costos de los factores y transforma el salario en la variable de ajuste. En pocas palabras, para los sectores productivos esta estrategia implica orientarse hacia aquellas actividades o funciones donde puedan demostrar ventajas competitivas no relacionadas con el precio. Los posibles indicadores que se pueden utilizar para analizar esta dimensión son de naturaleza tanto cuantitativa como cualitativa, a saber: i) variedad y diferenciación de las materias primas, insumos, partes y componentes; ii) calidad de las materias primas, insumos, partes y componentes; iii) costo de las materias primas, insumos, partes y componentes; iv) disponibilidad de los recursos humanos; v) aptitud y formación de los recursos humanos; vi) utilización de la capacidad instalada; vii) características del equipamiento tecnológico y las instalaciones; viii) conducta tecnológica de las empresas; ix) calidad de los productos, y $\mathrm{x}$ ) incorporación de actividades de ingeniería y diseño.

El desarrollo y fortalecimiento de complementariedades y encadenamientos productivos se encuentra en la base de la naturaleza sistémica de la competitividad. La creación de complementariedades resulta esencial para mejorar la competitividad de todo el sistema, pues están presentes en el desarrollo de encadenamientos verticales en ambos sentidos (hacia abajo y hacia arriba), así como en vinculaciones horizontales con otros sectores productivos. Constituyen el determinante estructural de los multiplicadores de los procesos de inversión y, por tanto, establecen un vínculo directo entre la estructura productiva y el desempeño macroeconómico. Un desarrollo profuso de los encadenamientos aumenta la densidad de la estructura productiva y evita las filtraciones que se producen en el crecimiento cuando este requiere mayores importaciones. Los posibles indicadores que se pueden utilizar para el diagnóstico de esta dimensión son de naturaleza tanto cuantitativa como cualitativa, a saber: i) cantidad y grado de aprovechamiento de las materias primas, insumos, partes y componentes nacionales; ii) desarrollo de eslabonamientos con proveedores de maquinaria y herramientas; iii) desarrollo de eslabonamientos con otros sectores proveedores de insumos y servicios; iv) grado de coordinación de las actividades a lo largo de la cadena; v) peso del sector dentro de la jerarquía o gobernanza; vi) asimetría de posiciones en la cadena; vii) creación de vínculos con cadenas comercializadoras y otros eslabones "hacia adelante"; viii) existencia de complejos productivos, y ix) grado de adecuación de la infraestructura física y tecnológica para el desarrollo del sector. 
uno de los sectores (Ai) al estado virtuoso adoptado como meta (B) se puede dar a partir de acciones en diferentes instancias tecnoproductivas y socioproductivas, y por medio de diferentes impulsos específicos.

Diagrama XV.1

Trayectorias de cambio estructural y acciones de política

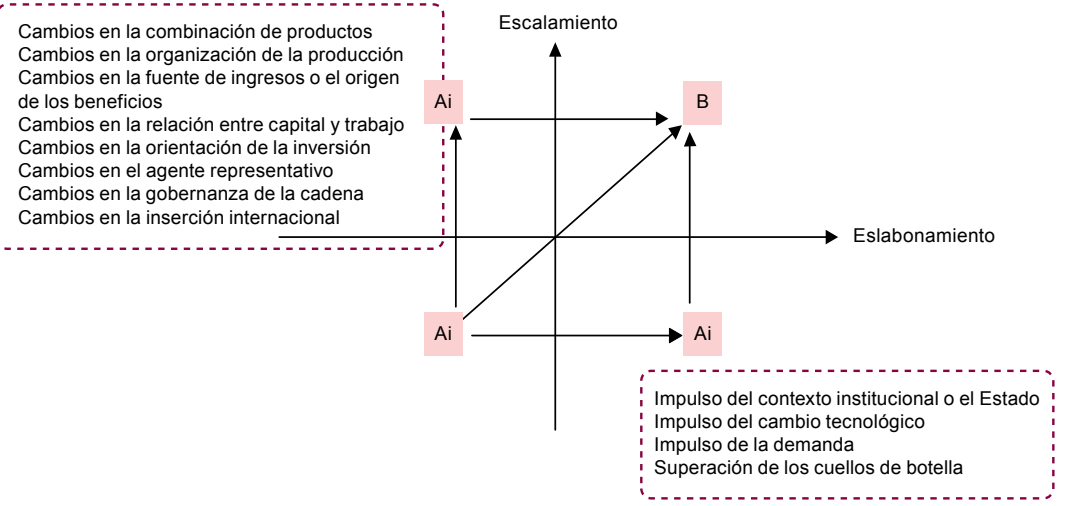

Fuente: Elaboración propia.

La matriz de objetivos y estrategias de política tiene como objeto proponer un sendero virtuoso destinado a incrementar la competitividad sectorial en función de las posibilidades reales de transformación, reconversión o cambio estructural del sector. La meta ideal (B) debe constituir una situación tanto deseable como posible, y responder a las potencialidades históricas del sector y a las necesidades específicas del contexto económico. En el marco de lo posible, se entiende que el desplazamiento desde la situación inicial al estado de mayor calidad está condicionado por una serie de factores. Al evaluar cada uno de estos factores se obtiene como resultado una combinación de rasgos y atributos que permiten delinear la trayectoria más conveniente para cada uno de los sectores.

Esta matriz ofrece un conjunto de iniciativas estratégicas que permiten seguir las mejores trayectorias de desarrollo de una competitividad genuina y señala de manera estilizada el menú de opciones (en términos de objetivos y estrategias de política) que se abren al momento de formular políticas de desarrollo orientadas al escalamiento y el eslabonamiento productivo (véase el diagrama XV.2). La tarea sugerida consiste en elaborar a partir del tablero de comando una estrategia de transformación, reconversión o cambio estructural para el sector. La implementación de políticas conforme a las trayectorias recomendadas en esta matriz debería arrojar resultados que apuntalen la competitividad 
sistémica de la economía. Así, una mejor estructura productiva se traducirá en un mayor número de innovaciones y de encadenamientos —que permitirán difundirlas-; un grado más elevado de escalamiento productivo; la elaboración de bienes y servicios más sofisticados; la incorporación de diseño, tecnología y procesos; una mayor proporción de valor agregado nacional; un mercado laboral de superior calidad y, por consiguiente, la reducción del empleo informal.

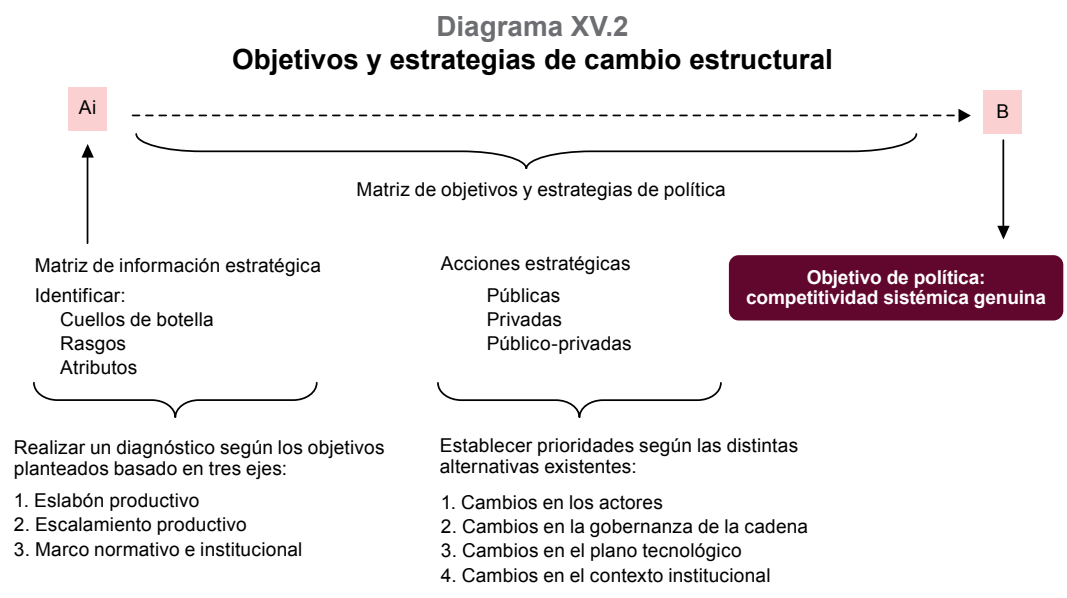

Fuente: Elaboración propia.

A continuación, se presenta una versión tentativa de la matriz de objetivos y estrategias de política (véase el cuadro XV.1). Las primeras dos filas componen lo que conformaría el diagnóstico sectorial, según los objetivos planteados. Dentro del diagnóstico, la primera fila explicita los distintos resultados y objetivos que se pueden esperar en términos de la modernización de los distintos sectores y que, de alguna manera, conforman el escenario deseable. La segunda fila, por su parte, identifica los principales cuellos de botella que pueden presentarse al momento de plantear la expansión del sector. Las restantes filas componen las acciones recomendadas, según los resultados del diagnóstico, para los objetivos deseados. En estas filas se muestran los distintos canales mediante los cuales se pueden impulsar las modificaciones en los sectores, a saber: i) los cambios en las fuentes del conocimiento y la tecnología; ii) los cambios en los actores; iii) los cambios en la gobernanza de la cadena, y iv) los cambios en el contexto institucional y normativo. 


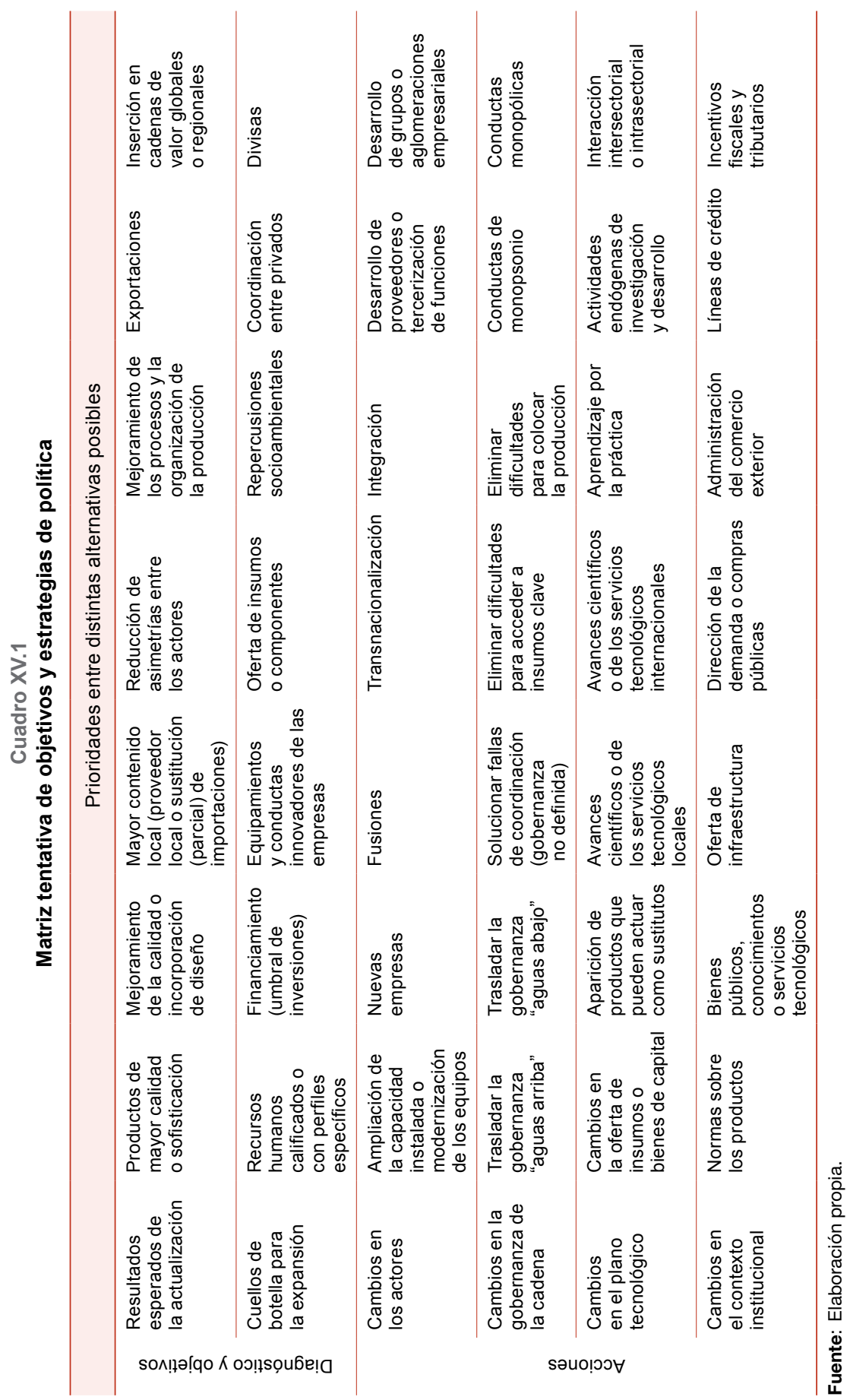


Cabe tener en cuenta que la herramienta metodológica que se desprende de esta matriz no establece prioridades para los sectores, sino que demarca los senderos que conducen a los objetivos específicos planteados. La matriz propone un número acotado de opciones para cada columna y brinda diferentes objetivos y estrategias de políticas, así como lineamientos de acción que exigen también fijar prioridades. Para ello, podrían identificarse las opciones principales y las secundarias tomando en cuenta el diagnóstico presentado anteriormente y el escenario deseable.

El diagnóstico inicial debe presentar y organizar a nivel de las cadenas, los sectores o las líneas de producción pertinentes un conjunto amplio de datos estratégicos, de modo tal que permita evaluar y fundamentar la intervención o política pública necesaria para alcanzar los objetivos perseguidos por la estrategia general. Este último es el propósito de las matrices de objetivos y estrategias de política. A este efecto, la información requerida se utilizará para evaluar las fortalezas y debilidades competitivas de cada segmento productivo y para identificar las trayectorias productivas más congruentes y convenientes. Las trayectorias de cambio estructural deseables y factibles para cada cadena o sector dependen de diversos factores propios de la actividad y de otros inherentes al entorno. Por ende, se deberán tomar en cuenta sus características tecnoproductivas generales, las formas de competencia en el plano internacional y la situación productiva. Según este enfoque metodológico, cada uno de los sectores o actividades tendrá una trayectoria específica de expansión, modernización o inclusión. La política pública debe adaptar sus instrumentos y sus modos de intervención a esa particularidad.

Esta redefinición conceptual de la política industrial exige también tomar en cuenta el papel de la demanda como un vector de la industrialización, lo que implica jerarquizar el papel del Estado en tanto que fuente de externalidades pecuniarias y reales. En algunos casos, para apalancar los procesos de eslabonamiento y escalamiento con la demanda tal vez se requiera dar prioridad al acceso a mercados externos, sobre todo a efectos de impulsar la incorporación de diseños sofisticados o materiales más nobles, o de sufragar de la mano de consumidores de ingresos elevados los costos que conllevan estos procesos productivos más complejos. En otros casos, el papel dinamizador de la demanda se puede canalizar por medio de las políticas de ingresos, que habilitan la expansión de la escala potencial mediante la incorporación de nuevos consumidores y la conformación de nuevos mercados. Por supuesto, el gasto público también resulta una potente herramienta para dinamizar los procesos productivos: los planes de viviendas, los gastos en equipamiento para la salud y las inversiones en trasporte o energía ofrecen magníficas oportunidades para que los sectores vinculados a la oferta gocen de condiciones aptas para avanzar en las opciones propuestas para canalizar el cambio estructural. 


\section{Conclusiones}

La resolución progresiva de los problemas de especialización entraña impulsar una trayectoria de los sectores, los segmentos o las actividades $y$, por ende, las empresas hacia un mayor contenido de conocimientos y complementariedades. Estas trayectorias han de ser específicas para cada sector, en el sentido de que permitan en diversos grados, tanto potenciales como factibles, producir efectos de aprendizaje, externalidades y vinculaciones. En la medida en que se recorran estas trayectorias (reconversión y reestructuración del aparato productivo existente) y en que las nuevas actividades tengan la capacidad de ejercer efectos dinámicos de escala, todo el sistema podrá adquirir mayor competitividad. Esta acción supone repensar la intervención pública y las políticas productivas desde otra perspectiva conceptual. De este enfoque se desprenden formas de intervención y modos de gestión y diseño de los instrumentos diferentes de los que predominaron hasta hoy en día. Para superar los problemas de heterogeneidad social de los que adolece la estructura económica argentina, se requiere de un Estado que, además de estimular el crecimiento, tenga la capacidad de intervenir activamente en la definición de un perfil productivo que haga frente de manera eficaz y sostenida al desafío de alcanzar la equidad. 


\section{Bibliografía}

Bianco, C. y C. Fernández Bugna (2010), “Transformación estructural: una aproximación cuantitativa de la industria argentina 1993-2007", Revista Iberoamericana de Ciencia, Tecnología y Sociedad, No 15, vol. 5, septiembre.

Bianco, C., F. Porta y F. Vismara (2008), “Evolución reciente de la balanza comercial argentina. El desplazamiento de la restricción externa", Documentos de Proyecto, No 165 (LC/W.165), Buenos Aires, oficina de la CEPAL en Buenos Aires.

Briner, M.A., A. Sacroisky y M. Bustos Zavala (2007), “Desafíos de la reconfiguración productiva en Argentina. Aportes para el debate actual", Documento de Trabajo, N ${ }^{\circ}$ 16, Centro de Economía y Finanzas para el Desarrollo de la Argentina (CEFID-AR), julio.

Coremberg, A. (2012), "Measuring productivity in unstable and natural resources dependent economies: Argentina", documento presentado en la segunda Conferencia mundial de KLEMS, Cambridge, Massachusetts, Universidad de Harvard, 9 y 10 de agosto.

Herrera, G. y A. Tavosnaska (2009), “La industria argentina a comienzos del siglo XXI. Aportes para una revisión de la experiencia reciente", primer Congreso anual de la Asociación de Economía para el Desarrollo de la Argentina (AEDA), Buenos Aires, 24 y 25 de agosto.

Katz, Jorge y Giovanni Stumpo (2001), "Regímenes sectoriales, productividad y competitividad internacional", Revista de la CEPAL, No 75 (LC/G.2150-P/E), Santiago de Chile, Comisión Económica para América Latina y el Caribe (CEPAL), diciembre.

Kulfas, M. (2009), “Cambio de régimen y dilemas del largo plazo. La economía argentina entre 2003 y 2007", primer Congreso anual de la Asociación de Economía para el Desarrollo de la Argentina (AEDA), Buenos Aires, 24 y 25 de agosto.

Lafay, R. (1990), “La mesure des avantages comparatifs révelés", Economie Prospective Internationale, París.

Lafay, G. y C. Herzog (1989), "Commerce international: la fin des avantages acquis", Economica, París, Centro de Estudios Prospectivos y de Información Internacional (CEPII).

Lugones, G., D. Suárez y P. Moldovan (2008), “Innovation, competitiveness and salaries: a model of combined growth at the firm level", ponencia presentada en la sexta Conferencia de Globelics, México D.F., 22 al 24 de noviembre.

Nassif, A. (2003), "Uma contribuição ao debate sobre a nova política industrial brasileira", Textos para Discussão, No 101, Río de Janeiro, Banco de Desarrollo del Brasil (BNDES), septiembre.

Ocampo, José Antonio (2005), "La búsqueda de la eficiencia dinámica: dinámica estructural y crecimiento económico en los países en desarrollo", Más allá de las reformas. Dinámica estructural y vulnerabilidad económica, José Antonio Ocampo (ed.), Bogotá, Comisión Económica para América Latina y el Caribe (CEPAL)/Alfaomega. 
Peirano, F. (2008), “La contribución del sector industrial al cambio tecnológico. Un análisis comparado de los casos de Argentina y de Brasil", Documento de Trabajo, No 28, Buenos Aires, Centro Redes, agosto.

Porta, Fernando (2006), "Especialización productiva e inserción internacional. Evidencias y reflexiones sobre el caso argentino", Enfoques y metodologías alternativas para la medición de las capacidades innovativas, G. Lugones y F. Porta (comps.), Proyecto PICT 02-09536, Buenos Aires, Fondo para la Investigación Científica y Tecnológica (FONCYT)/ Agencia Nacional de Promoción Científica y Tecnológica (ANPCYT).

Porta, F. y C. Fernández Bugna (2011), "La industria manufacturera: trayectoria reciente y cambio estructural", La Argentina del largo plazo: crecimiento, fluctuaciones y cambio estructural, R. Mercado, B. Kosacoff y F. Porta (eds.), Buenos Aires, Programa de las Naciones Unidas para el Desarrollo (PNUD).

Porta, F. y otros (coords.) (2009), Tendencias y determinantes del proceso de inversión en Argentina. 2002-2007, Buenos Aires, Programa de las Naciones Unidas para el Desarrollo (PNUD).

Stumpo, G. (comp.) (2009), "La especialización exportadora y sus efectos sobre la generación de empleos. Evidencia para Argentina y Brasil", Documentos de Proyecto, No 264 (LC/W.264), Giovanni Stumpo (comp.), Santiago de Chile, Comisión Económica para América Latina y el Caribe (CEPAL).

Stumpo, G. y D. Rivas (2013) (comps.), La industria argentina frente a los nuevos desafíos y oportunidades del siglo XXI (LC/R 3637), Santiago de Chile, Comisión Económica para América Latina y el Caribe (CEPAL).

Suárez, D. (2013), "Innovative strategies in unstable environments: the case of Argentinean firms", tesis para optar al grado de doctorado, Aalborg University/Universidad Nacional de Quilmes.

Tavosnaska, A. (2010), “Crisis, devaluación y después. Breve historia de la recomposición de las ganancias empresariales en la post-convertibilidad", segundo Congreso anual de la Asociación de Economía para el Desarrollo de la Argentina (AEDA), Buenos Aires, 20 y 21 de septiembre. 


\section{Reseña biográfica de los autores}

\section{Alicia Bárcena}

Asumió como Secretaria Ejecutiva de la Comisión Económica para América Latina y el Caribe (CEPAL) el 1 de julio de 2008. Previamente se desempeñó como Secretaria General Adjunta de Gestión en la Sede de las Naciones Unidas en Nueva York, y cumplió tareas como Jefa de Gabinete y anteriormente como Jefa Adjunta de Gabinete de Kofi Annan, entonces Secretario General de las Naciones Unidas. En la CEPAL ocupó el cargo de Secretaria Ejecutiva Adjunta y Directora de la División de Medio Ambiente y Asentamientos Humanos. En las Naciones Unidas fue Coordinadora del Programa de Desarrollo Sostenible de América Latina y el Caribe del Programa de las Naciones Unidas para el Desarrollo (PNUD) y Coordinadora del Proyecto Ciudadanía Ambiental del Programa de las Naciones Unidas para el Medio Ambiente (PNUMA). Además, fundó y dirigió el Consejo de la Tierra, organización no gubernamental con sede en Costa Rica, encargada del seguimiento de los acuerdos suscritos en la Conferencia de las Naciones Unidas sobre el Medio Ambiente y el Desarrollo (CNUMAD), celebrada en Río de Janeiro (Brasil) en 1992. Ha sido profesora e investigadora de la Universidad Nacional Autónoma de México y ha publicado numerosos artículos sobre desarrollo sostenible, políticas públicas, medio ambiente y participación pública. Tiene una licenciatura en Biología y obtuvo una maestría en Administración Pública en la Universidad de Harvard. Finalizó los cursos de la maestría en Ecología e inició estudios de doctorado en Economía en la Universidad Nacional Autónoma de México.

\section{Antonio Prado}

Economista brasileño especializado en el análisis de los cambios tecnológicos en la industria y su impacto en el desarrollo económico, el mercado laboral y las relaciones industriales del Brasil, que desde el 1 de noviembre de 2009 ocupa el cargo de Secretario Ejecutivo Adjunto de la Comisión Económica para América Latina y el Caribe (CEPAL). Previamente se desempeñó como Jefe de Asuntos Gubernamentales de la Presidencia del Banco Nacional de Desarrollo Económico y Social (BNDES) (2005-2009) y fue asesor del Jefe de Bancada del Gobierno en el Senado del Brasil (2003-2004). Ha sido también consejero de la Agencia Brasileña de Promoción de Exportaciones e Inversiones (APEX), la Agencia Brasileña de Desarrollo Industrial (ABDI) y el Centro Celso Furtado, entre otras instituciones, incluidas algunas organizaciones de la sociedad civil. Entre 1990 y 2000 fue miembro de la mesa directiva técnica y encargado de la división de investigación del Departamento Intersindical de Estadística 
y Estudios Socioeconómicos (DIEESE), un centro de investigación sobre temas laborales del Brasil. Allí elaboró encuestas estadísticas sobre el costo de la vida y el empleo y estudios sobre la distribución de ingresos, temas raciales y de género, planificación estratégica, cambios industriales y macroeconomía. En los años noventa coordinó trabajos de investigación con el Consejo Nacional de Desarrollo Científico y Tecnológico (CNPqBrasil) y realizó innovadores estudios sobre género y raza en el mercado laboral de las áreas metropolitanas del Brasil. Ha sido profesor en la Pontificia Universidad Católica de São Paulo y en el Instituto Rio Branco (IRBr) del Ministerio de Relaciones Exteriores del Brasil. Posee un magíster en Economía Industrial y un doctorado en Políticas Económicas para el Desarrollo de la Universidad Estatal de Campinas (UNICAMP). Asimismo, ha publicado libros y colaborado con artículos en la prensa especializada del Brasil.

\section{Esteban Pérez-Caldentey}

Actualmente se desempeña como Jefe de la Unidad de Financiamiento para el Desarrollo de la División de Desarrollo Económico de la Comisión Económica para América Latina y el Caribe (CEPAL). Anteriormente trabajó en la sede subregional de la CEPAL en México y la sede subregional de la CEPAL para el Caribe en Trinidad y Tabago, donde se desempeñó como Oficial de Asuntos Económicos y Coordinador de la Unidad de Economía. También ha trabajado para el Programa de las Naciones Unidas para el Desarrollo (PNUD) y el Fondo de las Naciones Unidas para la Infancia (UNICEF). Tiene una maestría y un doctorado de la New School for Social Research de Nueva York, donde se desempeñó como profesor auxiliar. Ha sido también docente de la Universidad de Santiago de Chile (USACH), la Universidad de Chile y la Universidad de Arte y Ciencias Sociales (ARCIS). Es miembro del Comité Editorial de la revista Investigación Económica de la Universidad Nacional Autónoma de México (UNAM), el International Journal of Political Economy y el Review of Keynesian Economics. Es además coeditor de la revista World Economic Review.

\section{José Antonio Ocampo}

En la actualidad es profesor de Práctica Profesional en Relaciones Internacionales y Públicas y Director del Programa de Desarrollo Económico y Político de la Escuela de Asuntos Públicos e Internacionales de la Universidad de Columbia. Anteriormente, trabajó como Secretario General Adjunto de las Naciones Unidas para Asuntos Económicos y Sociales del Departamento de Asuntos Económicos y Sociales (DESA), Secretario Ejecutivo de la Comisión Económica para América Latina y el Caribe (CEPAL) y Ministro de Hacienda y Crédito Público y Ministro de 
Agricultura y Desarrollo Rural del Gobierno de Colombia. Se especializó en Economía y Sociología en la Universidad de Notre Dame en 1972 y se doctoró en Ciencias Económicas por la Universidad de Yale en 1976. En el ámbito académico, se desempeñó como Director Ejecutivo de la Fundación para la Educación Superior y el Desarrollo (FEDESARROLLO), el principal centro de pensamiento de Colombia en temas económicos, Director del Centro de Estudios sobre Desarrollo Económico (CEDE) de la Universidad de los Andes, profesor de Economía en la Universidad de los Andes y profesor de Historia Económica en la Universidad Nacional de Colombia. También ha sido profesor visitante en Cambridge, Oxford y Yale y ha dado discursos en muchas otras instituciones durante su participación en diversas conferencias políticas y académicas en todo el mundo. José Antonio Ocampo es autor y editor de más de 40 libros y ha publicado más de 300 artículos académicos sobre la teoría y política macroeconómica, cuestiones financieras internacionales, desarrollo económico y social, comercio internacional, y la historia económica de Colombia y América Latina.

\section{Luis Gonzaga Belluzzo}

Licenciado en Derecho por la Universidad de São Paulo en 1965, estudió también Ciencias Sociales en la Facultad de Filosofía, Letras y Ciencias Humanas de esa misma universidad e hizo un posgrado en Desarrollo Económico en el Instituto Latinoamericano y del Caribe de Planificación Económica y Social (ILPES) de la Comisión Económica para América Latina y el Caribe (CEPAL). Fue colaborador docente de la Universidad Estadual de Campinas, donde se doctoró y se convirtió en profesor titular en 1986. Fue asesor económico del Partido del Movimiento Democrático Brasileño (PMDB) entre 1974 y 1992, Secretario de Política Económica del Ministerio de Hacienda del Gobierno del Brasil (1985-1987), Secretario de Ciencia y Tecnología del Estado de São Paulo (1988-1990) y jefe de la Secretaría Especial para Asuntos Económicos en el Ministerio de Hacienda durante el gobierno de José Sarney. Es uno de los fundadores de las Facultades de Campinas (FACAMP) y en 2005 recibió el Premio Juca Pato como intelectual del año en el Brasil. Es considerado el mejor economista heterodoxo del Brasil, debido a sus interpretaciones, sugerencias y críticas de la sociedad brasileña, desde la perspectiva de Karl Marx y John Maynard Keynes.

\section{Ricardo Ffrench-Davis Muñoz}

Economista chileno que obtuvo el Premio Nacional de Humanidades y Ciencias Sociales entregado por el Gobierno de Chile en 2005 y docente en la Facultad de Economía y Negocios de la Universidad de Chile. Es doctor (1971) y magíster (1961) en Economía por la Universidad de Chicago. Es también ingeniero comercial (1962) por la Pontifica Universidad Católica de Chile; 
titulado en las dos especialidades de economía y administración; coordinador docente durante 1963 y 1964 y profesor entre 1962 y 1974. Es además uno de los fundadores de la Corporación de Estudios para Latinoamérica (CIEPLAN), donde desarrolló su trabajo como investigador entre 1976 y 1990, cuando fue designado director de Estudios del Banco Central de Chile, cargo que ocupó hasta marzo de 1992, fecha en que ingresó en la Comisión Económica para América Latina y el Caribe (CEPAL) como asesor regional. Es reconocido por su contribución al estudio de los ciclos de entrada de capitales a los mercados emergentes, principalmente a América Latina. Es defensor de los mecanismos que evitan la fuerte entrada de capitales, como el encaje que funcionó en Chile durante buena parte de la década de 1990. Ha sido designado por los presidentes de Alemania, Argelia, el Brasil, Chile, España y Francia como representante en el Grupo Técnico para identificar fuentes de financiamiento innovador para combatir el hambre y la pobreza en el mundo. Junto al Premio Nobel de Economía de 2001, Joseph Stiglitz, codirige el Grupo de Macroeconomía de la Iniciativa para el Diálogo Político en la Universidad de Columbia. Ha sido también profesor visitante en las Universidades de Oxford, Boston, la Complutense de Madrid y la sede Chile de la Universidad de Stanford, así como en institutos de España, Francia, Italia y Suecia.

\section{Daniel Titelman}

Licenciado en economía por la Universidad de Los Andes en Colombia, es también doctor en Economía por la Universidad de California. Posee además una maestría en Ciencias Políticas de la Facultad Latinoamericana de Ciencias Sociales (FLACSO). En la actualidad se desempeña como Director de la División de Desarrollo Económico de la Comisión Económica para América Latina y el Caribe (CEPAL). Anteriormente fue Director de la División de Financiamiento para el Desarrollo, así como Experto en Políticas Monetarias y Financieras y Coordinador de la Unidad de Estudios Especiales de la CEPAL. Tiene una larga experiencia en temas macroeconómicos y financieros y ha publicado numerosos informes sobre la materia. También ha trabajado en temas relativos a financiamiento en seguridad social, particularmente en salud y reforma de pensiones. Ha participado en la elaboración de diversos informes institucionales de la CEPAL en ámbitos relacionados con la macroeconomía, el financiamiento para el desarrollo y la protección social y ha brindado asistencia técnica a diversos países de América Latina y el Caribe.

\section{Juan Alberto Fuentes Knight}

Economista y Ministro de Finanzas Públicas en Guatemala entre 2008 y 2010. Tiene un doctorado en Economía de la Universidad de Sussex y una maestría en la misma materia de la Universidad de Toronto. Fue Director de 
la División de Desarrollo Económico de la Comisión Económica de América Latina y el Caribe (CEPAL) entre 2012 y 2014. Trabajó previamente como coordinador de investigaciones y asesor regional en la sede subregional de la CEPAL en México. Anteriormente trabajó en la Secretaría General de Planificación y Programación de la Presidencia de Guatemala, el Centro de Estudios Monetarios Latinoamericanos (CEMLA) en México, la Secretaría de Integración Económica Centroamericana (SIECA) y el Programa de las Naciones para el Desarrollo (PNUD), donde coordinó el Informe de Desarrollo Humano de Guatemala durante varios años. También fue miembro del equipo de investigación que realizó el informe de la Comisión para el Esclarecimiento Histórico en Guatemala. Fundó y fue Director del Instituto Centroamericano de Estudios Fiscales (ICEFI). Es autor de diversas publicaciones sobre integración económica y política fiscal.

\section{Mario Cimoli}

Es Director de la División de Desarrollo Productivo y Empresarial de la Comisión Económica para América Latina y el Caribe (CEPAL) y profesor asociado de Economía en la Universidad Ca' Foscari de Venecia. Se doctoró en Economía por la Universidad de Sussex (1992) con una tesis en que analizó el efecto de las brechas tecnológicas y el comercio en el crecimiento de las economías en desarrollo. Junto a Giovanni Dosi y Joseph Stiglitz, es codirector desde 2004 de dos grupos de trabajo de la Iniciativa para el Diálogo Político de la Universidad de Columbia: política industrial y regímenes de derechos de propiedad intelectual para el desarrollo. También ha sido galardonado con el premio Philip Morris Chair in International Business (2004) en la Escuela de Estudios Avanzados Santa Ana de la Universidad de Pisa. Dicta conferencias y publica artículos y libros sobre temas vinculados con las políticas económicas para el desarrollo, tanto en el ámbito industrial como en de la ciencia, la innovación y la tecnología.

\section{Gabriel Porcile}

Es Oficial de Asuntos Económicos de la División de Desarrollo Productivo y Empresarial de la Comisión Económica para América Latina y el Caribe (CEPAL). Tiene una maestría en Ciencias Económicas por la Universidad Estadual de Campinas (UNICAMP) y un doctorado en Historia Económica por la Escuela de Economía y Ciencias Políticas de Londres. Es también profesor del Departamento de Economía de la Universidad Federal de Paraná e investigador del Consejo Nacional de Desarrollo Científico y Tecnológico (CNPq-Brasil). Ha publicado extensamente sobre temas de tecnología, crecimiento en América Latina y teorías heterodoxas del crecimiento. Sus dos últimos trabajos son "Technology, structural change 
and BOP-constrained growth: a structuralist toolbox", Cambridge Journal of Economics, y "Technological intensity of the export structure and the real exchange rate", Economics of Innovation and New Technology.

\section{Jorge Katz}

Licenciado en Economía por la Universidad de Buenos Aires en 1964 y doctor en Economía por el Nuffield College de Oxford en 1967. Su tesis de doctorado "Funciones de producción, inversión extranjera y crecimiento" fue publicada por North Holland Publishing Company en 1969. Después de volver a la Argentina, fue nombrado profesor de Economía en la Universidad de Buenos Aires, donde enseñó sobre organización industrial y desarrollo económico durante casi dos décadas. Durante ese período llevó a cabo un proyecto de investigación a largo plazo para la Comisión Económica para América Latina y el Caribe (CEPAL) y el Banco Interamericano de Desarrollo (BID) sobre el desarrollo de la capacidad tecnológica en América Latina. Los resultados de este proyecto han sido publicados en numerosos libros y artículos en español e inglés. En 1994 fue nombrado Director de la División de Desarrollo Productivo y Empresarial de la CEPAL, cargo que ocupó hasta su jubilación del sistema de las Naciones Unidas en 2003. Desde entonces, trabaja en la Universidad de Chile como profesor de desarrollo económico e innovación. Sus publicaciones incluyen 18 libros sobre cuestiones tecnológicas y el sector industrial de América Latina y cerca de 80 artículos en revistas científicas.

\section{Luis Bértola}

Doctor en Historia Económica por la Universidad de Gotemburgo, se desempeña como profesor de Historia Económica y Desarrollo en la Universidad de la República, Uruguay, donde es también jefe de la Comisión Académica del programa del doctorado. Dirige la Base de Datos de Historia Económica de América Latina Montevideo-Oxford y el proyecto Raúl Prebisch y los desafíos del siglo XXI de la Comisión Económica para América Latina y el Caribe (CEPAL). Es editor de la revista Journal of Iberian and Latin American Economic History y miembro del consejo editorial de muchas otras revistas científicas. Ha impartido cursos de posgrado y seminarios en varias universidades de todo el mundo. Sus publicaciones más recientes son dos libros sobre historia económica latinoamericana: Desarrollo, vaivenes y desigualdad: una historia económica de América Latina desde la independencia y Dos siglos de transformación productiva y social en América hispana. Sus temas principales de investigación son el desarrollo comparativo a largo plazo con enfoque en América Latina, las instituciones, los cambios técnicos e estructurales, la desigualdad, las condiciones de vida y las relaciones internacionales. 


\section{Robert Boyer}

Economista francés conocido por ser uno de los principales autores de la escuela de la regulación. Estudió en la Escuela Politécnica de París, el Instituto de Estudios Políticos y la Escuela Nacional de Puentes y Calzadas (ENPC). Actualmente, desempeña diversas actividades científicas y administrativas, entre ellas, investigador del Instituto Francés para América Latina (IFAL), socio de la Fundación Unión Europea-América Latina y el Caribe (Fundación EU-LAC), economista en el Centro para la Investigación Económica y sus Aplicaciones (CEPREMAP), director de investigaciones del Centro Nacional de Investigación Científica (CNRS) de la Escuela Normal Superior (ENS) y director de estudios en la Escuela de Estudios Superiores en Ciencias Sociales (EHESS). Es también miembro del Consejo de Análisis Económico, el Consejo Científico del Centro San Gobain para la Investigación en Economía, el Comité Ejecutivo de la Sociedad para el Avance de la Socioeconomía (SASE) y el Comité de Dirección de la Asociación Francesa de Ciencia Económica. Anteriormente trabajó como investigador asociado del Instituto de Estudios Avanzados (Wissenschaftskolleg) de Berlín y profesor visitante del Centro Internacional de Negocio y Política de Copenhague, el Departamento de posgrado de la Universidad Nacional Autónoma de México (UNAM) y la Facultad de Economía de la Universidad Nacional de Yokohama. En su libro La teoría de la regulación: un análisis crítico, desarrolla una alternativa al modelo neoclásico de equilibrio general. Busca comprender cómo se transforman las estructuras económicas y sociales en el largo plazo, adoptando una aproximación institucionalista: los fenómenos económicos solo pueden ser comprendidos a partir de la interdisciplinariedad.

\section{Sonia Montaño}

Socióloga boliviana que se desempeñó como Directora de la División de Asuntos de Género de la Comisión Económica para América Latina y el Caribe (CEPAL). Su carrera profesional comenzó en 1983 cuando fundó y dirigió el Centro de Información y Desarrollo de la Mujer (CIDEM) en el Estado Plurinacional de Bolivia, donde diseñó en 1989 la primera propuesta de políticas públicas en materia de género. Entre 1993 y 1995 fue Subsecretaria de Asuntos de Género del Ministerio de Desarrollo Humano de ese país y ha servido como asesora y consultora en varios países de América Latina. Ha publicado numerosos trabajos sobre políticas públicas, la ciudadanía y la participación política de las mujeres. La última publicación bajo su dirección es Objetivos de Desarrollo del Milenio. Informe 2006: una mirada a la igualdad entre los sexos y la autonomía de la mujer en América Latina y el Caribe. 


\section{René Hernández}

De nacionalidad mexicana, es doctor en Economía y magíster en Política Económica por la Universidad de Warwick, Reino Unido. Posee también una maestría en Desarrollo Económico de la Universidad de Vanderbilt, Estados Unidos. Actualmente se desempeña como Jefe de Capacitación y Educación del Instituto Latinoamericano y del Caribe de Planificación Económica y Social (ILPES) de la Comisión Económica para América Latina y el Caribe (CEPAL) y Coordinador del Comité Académico. Previamente fue Economista de la División de Desarrollo Productivo de la CEPAL, donde centró su actividad en temas de progreso técnico, heterogeneidad y cambio estructural en América Latina. Es además profesor de la Universidad de Chile y del Centro de investigación y capacitación económica y social sobre innovación y tecnología de la Universidad de las Naciones Unidas en Maastricht (UNU-MERIT) y Coordinador Académico de la Escuela de Verano sobre Economías Latinoamericanas de la CEPAL. Es autor y coautor de varios libros y ha realizado numerosas contribuciones a revistas científicas y académicas especializadas en economía latinoamericana; colabora también como dictaminador y editor en revistas de economía del desarrollo. Fue uno de los principales coautores del libro La transformación productiva 20 años después: viejos problemas, nuevas oportunidades, su más reciente publicación.

\section{Juan Carlos Moreno-Brid}

Es doctor por la Universidad de Cambridge y posee una maestría en Economía del Centro de Investigación y Docencia Económicas (CIDE) y una licenciatura en Matemáticas de la Universidad Nacional Autónoma de México (UNAM). Actualmente ocupa el cargo de Director Adjunto de la sede subregional de la Comisión Económica para América Latina y el Caribe (CEPAL) en México, donde ingresó en 2000 después de años como investigador asociado del David Rockefeller Center for Latin American Studies de la Universidad de Harvard. Especialista en temas de desarrollo económico, ha publicado múltiples artículos en revistas internacionales. Sus libros más recientes son Cambio estructural y crecimiento en Centroamérica y la República Dominicana: un balance de dos décadas, 1990-2011 y Desarrollo y crecimiento en la economía mexicana. Una perspectiva histórica. Participa como conferencista en foros especializados y es miembro del Comité Editorial de El Trimestre Económico, Revista CEPAL y ECONOMIAunam. Es también miembro fundador de la World Economics Association, agrupación con más de 14.000 afiliados. Pertenece además al grupo Nuevo Curso de Desarrollo de la UNAM. 


\section{João Carlos Ferraz}

Economista brasileño y experto en temas relacionados con la organización industrial y la competencia, la innovación y las estrategias de negocio, la financiación y las políticas de desarrollo productivo. Antes de incorporarse a la Junta del Banco Nacional de Desarrollo Económico y Social (BNDES), ocupó el cargo de Director de la División de Desarrollo Productivo y Empresarial de la Comisión Económica para América Latina y el Caribe (CEPAL). Se licenció en Ciencias Económicas en la Pontificia Universidad Católica de Minas Gerais en 1977 y en Periodismo en esa misma institución en 1978. Seis años más tarde obtuvo un doctorado en Economía de la Innovación y Políticas Públicas en la Universidad de Sussex. Es profesor de la Universidad Federal de Río de Janeiro, donde fue director del Instituto de Economía entre 1998 y 2003. También fue profesor visitante en la Universidad de Tsukuba, Japón. Tiene en su currículo la supervisión de tesis doctorales, disertaciones y monografías de graduación, artículos de revistas, libros y capítulos de libros.

\section{Fernando Porta}

Se licenció en Economía Política en la Universidad de Buenos Aires (1970) y realizó un posgrado en la Universidad de Sussex (1980). Es profesor titular de la Universidad Nacional de Quilmes y la Universidad de Buenos Aires e investigador principal del Centro de Estudios sobre Ciencia, Desarrollo y Educación Superior (Centro REDES). Es también profesor de posgrado en diversas universidades de la Argentina y del exterior. Especialista en economía internacional y economía industrial, trabaja como consultor para la Comisión Económica para América Latina y el Caribe (CEPAL), el Banco Interamericano de Desarrollo (BID), el Programa de las Naciones Unidas para el Desarrollo (PNUD) y la Conferencia de las Naciones Unidas sobre Comercio y Desarrollo (UNCTAD). Es además miembro del Comité Editorial de la revista Desarrollo Económico y la Revista Iberoamericana de Ciencia, Tecnología y Sociedad. Dirige también la colección Administración y Economía de la Universidad Nacional de Quilmes. Ha publicado diversos libros y artículos sobre patrones de especialización y desarrollo, competitividad internacional, integración económica, el MERCOSUR, la reestructuración industrial y las estrategias de empresas transnacionales. 


\section{Publicaciones recientes de la CEPAL ECLAC recent publications}

\section{www.cepal.org/publicaciones}

\section{Informes periódicos institucionales / Annual reports}

También disponibles para años anteriores / Issues for previous years also available

- Estudio Económico de América Latina y el Caribe 2014, 222 p. Economic Survey of Latin America and the Caribbean 2014, 214 p.

- La Inversión Extranjera Directa en América Latina y el Caribe 2013, 160 p. Foreign Direct Investment in Latin America and the Caribbean 2013, 152 p.

- Anuario Estadístico de América Latina y el Caribe 2013 / Statistical Yearbook for Latin America and the Caribbean 2013, 226 p.

- Balance Preliminar de las Economías de América Latina y el Caribe 2013, 92 p. Preliminary Overview of the Economies of Latin America and the Caribbean 2013, 92 p.

- Panorama Social de América Latina 2013, 226 p. Social Panorama of Latin America 2013, 220 p.

- Panorama de la Inserción Internacional de América Latina y el Caribe 2013, 128 p. Latin America and the Caribbean in the World Economy 2013, 122 p.

\section{Libros y documentos institucionales / Institutional books and documents}

- Pactos para la igualdad: hacia un futuro sostenible, 2014, 340 p. Covenants for Equality: Towards a sustainable future, 2014, 330 p.

- Integración regional: hacia una estrategia de cadenas de valor inclusivas, 2014, 226 p. Regional Integration: Towards an inclusive value chain strategy, 2014, 218 p. Integração regional: por uma estratégia de cadeias de valor inclusivas, 2014, 226 p.

- Reflexiones sobre el desarrollo en América Latina y el Caribe. Conferencias magistrales 2013-2014, Enrique Peña Nieto,

Marino Murillo, Luis Gonzaga Beluzzo, José Miguel Insulza, Winston Dookeran et al, 2014, 100 p.

- Prospectiva y desarrollo: el clima de la igualdad en América Latina y el Caribe a 2020, 2013, 72 p.

- Comercio internacional y desarrollo inclusivo: construyendo sinergias, 2013, 210 p. International trade and inclusive development: Building synergies, 2013, 200 p.

- Cambio estructural para la igualdad: una visión integrada del desarrollo, 2012, 330 p. Structural Change for Equality: an integrated approach to development, 2012, 308 p.

- La hora de la igualdad: brechas por cerrar, caminos por abrir, 2010, 290 p. Time for Equality: closing gaps, opening trails, 2010, 270 p. A Hora da Igualdade: Brechas por fechar, caminhos por abrir, 2010, 268 p.

\section{Libros de la CEPAL / ECLAC books}

129 Prospectiva y política pública para el cambio estructural en América Latina y el Caribe, Javier Medina Vásquez, Steven Becerra y Paola Castaño, 2014, 338 p.

128 Inestabilidad y desigualdad: la vulnerabilidad del crecimiento en América Latina y el Caribe, Juan Alberto Fuentes Knight (ed.), 2014, 304 p. 
127 Global value chains and world trade: Prospects and challenges for Latin America, René A. Hernández, Jorge Mario Martínez-Piva and Nanno Mulder (eds.), 2014, 282 p.

126 Planificación, prospectiva y gestión pública: reflexiones para la agenda del desarrollo, Jorge Máttar, Daniel E. Perrotti (eds.), 2014, 250 p.

125 La crisis latinoamericana de la deuda desde la perspectiva histórica, José Antonio Ocampo, Barbara Stallings, Inés Bustillo, Helvia Velloso, Roberto Frenkel, 2014, 174 p.

124 La integración de las tecnologías digitales en las escuelas de América Latina y el Caribe: una mirada multidimensional, Guillermo Sunkel, Daniela Trucco, Andrés Espejo, 2014, 170 p.

123 Fortalecimiento de las cadenas de valor como instrumento de la política industrial: metodología y experiencia de la CEPAL en Centroamérica, Ramón Padilla Pérez (ed.), 2014, 390 p.

Strengthening value chains as an industrial policy instrument: Methodology and experience of ECLAC in Central America, Ramón Padilla Pérez (ed.), 2014, 360 p.

\section{Copublicaciones / Co-publications}

- Decentralization and Reform in Latin America: Improving Intergovernmental Relations, Giorgio Brosio and Juan Pablo Jiménez (eds.), ECLAC / Edward Elgar Publishing, United Kingdom, 2012, 450 p.

- Sentido de pertenencia en sociedades fragmentadas: América Latina desde una perspectiva global, Martín Hopenhayn y Ana Sojo (comps.), CEPAL / Siglo Veintiuno, Argentina, 2011, 350 p.

- Las clases medias en América Latina: retrospectiva y nuevas tendencias, Rolando Franco, Martín Hopenhayn y Arturo León (eds.), CEPAL / Siglo XXI, México, 2010, 412 p.

- Innovation and Economic Development: The Impact of Information and Communication Technologies in Latin America, Mario Cimoli, André Hofman and Nanno Mulder, ECLAC / Edward Elgar Publishing, United Kingdom, 2010, 472 p.

\section{Coediciones / Co-editions}

- Regional Perspectives on Sustainable Development: Advancing Integration of its Three Dimensions through Regional Action, ECLAC-ECE-ESCAP-ESCWA, 2014, 114 p.

- Multi-dimensional Review of Uruguay, ECLAC-OECD, 2014, 190 p.

- Perspectivas de la agricultura y del desarrollo rural en las Américas: una mirada hacia América Latina y el Caribe 2014, CEPAL / FAO / IICA, 2013, 220 p.

- Perspectivas económicas de América Latina 2014: logística y competitividad para el desarrollo, CEPAL/OCDE, 2013, $170 p$.

Latin American Economic Outlook 2014: Logistics and Competitiveness for Development, ECLAC/ OECD, 2013, $164 p$.

\section{Cuadernos de la CEPAL}

101 Redistribuir el cuidado: el desafío de las políticas, Coral Calderón Magaña (coord.), 2013, 460 p.

101 Redistributing care: the policy challenge, Coral Calderón Magaña (coord.), 2013, 420 p.

100 Construyendo autonomía: compromiso e indicadores de género, Karina Batthyáni Dighiero, 2012, 338 p.

99 Si no se cuenta, no cuenta, Diane Alméras y Coral Calderón Magaña (coordinadoras), 2012, 394 p.

98 Macroeconomic cooperation for uncertain times: The REDIMA experience, Rodrigo Cárcamo-Díaz, $2012,164 p$.

\section{Documentos de proyecto / Project documents}

- La economía del cambio climático en la Argentina: primera aproximación, 2014, 240 p.

- La economía del cambio climático en el Ecuador 2012, 2012, 206 p. 
- Economía digital para el cambio estructural y la igualdad, 2013, 130 p

The digital economy for structural change and equality, 2014, 128 p.

- La cooperación entre América Latina y la Unión Europea: una asociación para el desarrollo, José E. Durán Lima, Ricardo Herrera, Pierre Lebret y Myriam Echeverría, 2013, 157 p.

\section{Cuadernos estadísticos de la CEPAL}

41 Los cuadros de oferta y utilización, las matrices de insumo-producto y las matrices de empleo. Solo disponible en CD, 2013.

40 América Latina y el Caribe: Índices de precios al consumidor. Serie enero de 1995 a junio de 2012. Solo disponible en CD, 2012.

\section{Series de la CEPAL / ECLAC Series}

Asuntos de Género / Comercio Internacional / Desarrollo Productivo / Desarrollo Territorial / Estudios Estadísticos / Estudios y Perspectivas (Bogotá, Brasilia, Buenos Aires, México, Montevideo) / Studies and Perspectives (The Caribbean, Washington) / Financiamiento del Desarrollo / Gestión Pública / Informes y Estudios Especiales / Macroeconomía del Desarrollo / Manuales / Medio Ambiente y Desarrollo / Población y Desarrollo / Política Fiscal / Políticas Sociales / Recursos Naturales e Infraestructura / Reformas Económicas / Seminarios y Conferencias.

\section{Revista CEPAL / CEPAL Review}

La Revista se inició en 1976, con el propósito de contribuir al examen de los problemas del desarrollo socioeconómico de la región. La Revista CEPAL se publica en español e inglés tres veces por año.

CEPAL Review first appeared in 1976, its aim being to make a contribution to the study of the economic and social development problems of the region. CEPAL Review is published in Spanish and English versions three times a year.

\section{Observatorio demográfico / Demographic Observatory}

Edición bilingüe (español e inglés) que proporciona información estadística actualizada, referente a estimaciones y proyecciones de población de los países de América Latina y el Caribe. Desde 2013 el Observatorio aparece una vez al año.

Bilingual publication (Spanish and English) proving up-to-date estimates and projections of the populations of the Latin American and Caribbean countries. Since 2013, the Observatory appears once a year.

\section{Notas de población}

Revista especializada que publica artículos e informes acerca de las investigaciones más recientes sobre la dinámica demográfica en la región. También incluye información sobre actividades científicas y profesionales en el campo de población.

La revista se publica desde 1973 y aparece dos veces al año, en junio y diciembre.

Specialized journal which publishes articles and reports on recent studies of demographic dynamics in the region. Also includes information on scientific and professional activities in the field of population. Published since 1973, the journal appears twice a year in June and December. 
Las publicaciones de la CEPAL están disponibles en:

ECLAC Publications are available in: www.cepal.org/publicaciones

También se pueden adquirir a través de:

They can also be ordered through:

\section{www.un.org/publications}

United Nations Publications

PO Box 960

Herndon, VA 20172

USA

Tel. (1-888)254-4286

Fax (1-800)338-4550

Contacto / Contact. publications@un.org

Pedidos / Orders: order@un.org 


\section{Neoestructuralismo y corrientes heterodoxas en América Latina y el Caribe a inicios del siglo XXI}

ALICIA BÁRCENA ANTONIO PRADO

Editores
El pensamiento que ha dominado unilateralmente la ciencia económica desde hace más de cinco décadas se ha constituido en el centro de un intenso

debate con respecto a su validez y coherencia conceptual y empírica, que ha puesto en evidencia las limitantes del paradigma dominante para enfrentar las principales falencias de las economías de libre mercado.

Para América Latina y el Caribe estas falencias tienen, como lo planteara en su momento el estructuralismo, un carácter estructural. El neoestructuralismo ha profundizado en los temas tratados en el estructuralismo, con el fin de mejorar la inserción externa, incrementar la generación del empleo productivo, reducir la heterogeneidad estructural y mejorar la distribución del ingreso manteniendo equilibrios financieros que sustenten estos cambios en la esfera productiva con un apoyo social y estatal.

Lejos de ser un sistema de pensamiento autocontenido, el neoestructuralismo es un sistema abierto que se presta a abrir espacios de diálogo con otras tradiciones de pensamiento que reconocen las limitaciones del paradigma dominante y se oponen a su monismo metodológico.

En este libro se propone una mirada renovada sobre el neoestructuralismo y las corrientes heterodoxas a inicios del siglo XXI. En un contexto marcado por los impactos de la mayor crisis económica y financiera desde la gran depresión y por los cambios paradigmáticos a nivel global, pretende abrir espacios para el debate entre corrientes de pensamiento alternativas, permitiendo sentar las bases de un desarrollo socioeconómico inclusivo y ambientalmente sostenible para la región. 